ORNL/TM-10804

\title{
SECOND REPORT ON THE OAK RIDGE NATIONAL LABORATORY BIOLOGICAL MONITORING AND ABATEMENT PROGRAM FOR WHITE OAK CREEK WATERSHED AND THE CLINCH RIVER
}

\author{
J. M. Loar \\ Editor \\ Environmental Sciences Division \\ Publication No. 3869
}

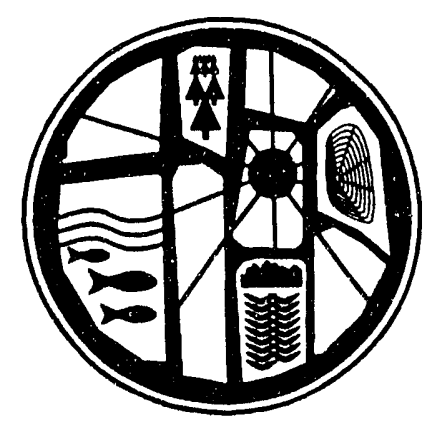

munetor

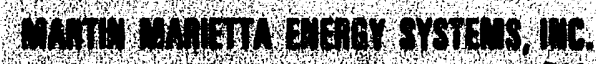

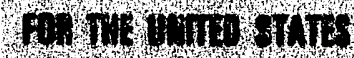

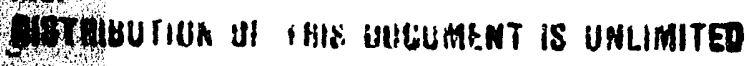

FFCEIVED

MAY 24993

OS TI 


\section{SECOND REPORT ON THE OAK RIDGE NATIONAL LABORATORY BIOLOGICAL MONITORING AND ABATEMENT PROGRAM FOR WHITE OAK CREEK WATERSHED AND THE CLINCH RIVER}

Editor

J. M. Loar

Contributors
S. M. Adams
S. M. Appellanis ${ }^{1}$
R. D. Bailey ${ }^{2}$
B. G. Blaylock
H. L. Boston
D. K. Cox
M. A. Huston
M. V. Huq $^{3}$

B. D. Jimenez ${ }^{1}$

B. L. Kimmel

L. R. Shugart

J. M. Loar

L. J. Meyers-Schone ${ }^{4}$

D. A. Mohrbacher ${ }^{5}$

J. B. Murphy ${ }^{6}$

C. R. Olsen ${ }^{7}$

M. G. Ryon

J. G. Smith

G. R. Southworth

A. J. Stewart

J. G. Stout ${ }^{8}$

S. S. Talmage ${ }^{9}$

C. K. Valentine ${ }^{6}$

B. T. Walton

\section{ENVIRONMENTAL SCIENCES DIVISION}

Publication No. 3869

\footnotetext{
${ }^{1}$ University of Puerto Rico, San Juan

${ }^{2}$ Environmental and Health Protection Division, ORNL

${ }^{3}$ Connecticut Department of Environmental Protection, Hamden, CT

4Frankfurter, STR 63A, 6080 Gross-Gerau, Germany

${ }^{5}$ Automated Sciences, Inc., Oak Ridge, TN

${ }^{6}$ Office of Environmental Compliance and Documentation

${ }^{7}$ Environmental Sciences Division, ER74 Office of Health and Environmental Research, U.S. DOE, Washington, DC

${ }^{8}$ University of Cincinnati, Cincinnati, $\mathrm{OH}$

${ }^{9}$ Health and Safety Research Division, ORNL
}

Date of Issue - December 1992

Prepared for

J. B. Murphy, Leader

Environmental Compliance Group

Department of Environmental Monitoring and Compliance

and

L. D. Bates, Manager

Remedial Action Program

Oak Ridge National Laboratory

Prepared by the

OAK RIDGE NATIONAL LABORATORY

Oak Ridge, Tennessee 37831-6285

managed by

MARTIN MARIETTA ENERGY SYSTEMS, INC. for the

U.S. DEPARTMENT OF ENERGY

under contract DE-AC05-84OK21400 


\section{CONTENTS}

Page

LIST OF FIGURES $\ldots \ldots \ldots \ldots \ldots \ldots \ldots \ldots \ldots \ldots \ldots \ldots \ldots \ldots \ldots$

LIST OF TABLES $\ldots \ldots \ldots \ldots \ldots \ldots \ldots \ldots \ldots \ldots \ldots \ldots \ldots \ldots$

LIST OF ACRONYMS $\ldots \ldots \ldots \ldots \ldots \ldots \ldots \ldots \ldots \ldots \ldots \ldots \ldots \ldots \ldots$

PREFACE $\ldots \ldots \ldots \ldots \ldots \ldots \ldots \ldots \ldots \ldots \ldots \ldots \ldots \ldots \ldots \ldots \ldots \ldots \ldots$

ACKNOWLEDGMENTS $\ldots \ldots \ldots \ldots \ldots \ldots \ldots \ldots \ldots \ldots \ldots \ldots \ldots \ldots$

EXECUTTVE SUMMMARY $\ldots \ldots \ldots \ldots \ldots \ldots \ldots \ldots \ldots \ldots \ldots \ldots \ldots$

1. INTRODUCTION (J. M. Loar) $\ldots \ldots \ldots \ldots \ldots \ldots \ldots \ldots \ldots \ldots \ldots$

2. DESCRIPTION OF WHITE OAK CREEK WATERSHED (J. M. Loar,

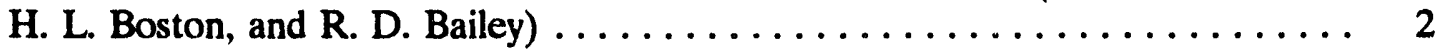

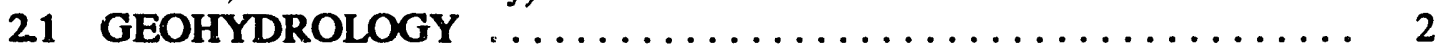

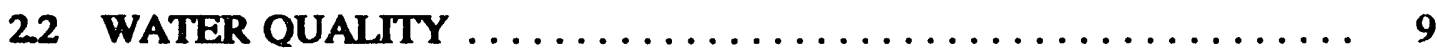

22.1 Description of ORNL Emuent Discharges ........... 10

222 Wastewater Modifications for Pollution Abatement .......... 13

223 NPDES Water Quality Monitoring Program .............. 13

22.4 BMAP Water Quality Sampling Program .............. 21

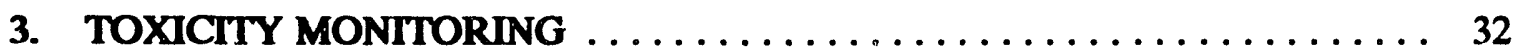

3.1 POINT-SOURCE AND AREA-SOURCE CONTRIBUTIONS TO

AMBIENT TOXICITY (A. J. Stewart) $\ldots \ldots \ldots \ldots \ldots \ldots \ldots \ldots \ldots$

3.1.1 Toxicity of Effluents from NPDES-Permitted Outfalls . . . . . . 35

3.1.2 Toxicity of Other Point-Source Discharges ............ 40

3.1.3 Toxicity of Area-Source Inputs to White Oak Creek ........ 43

3.1.4 Toxicological Problems Associated With Chlorine ........... 54

3.1.5 Summary of Results: Effluent and Ambient

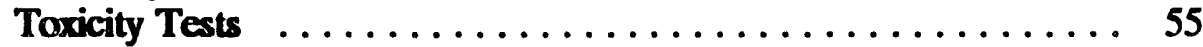

3.1.6 Future Studies .......................... 56

3.2 INSTREAM MONITORING OF THE PERIPHYTON

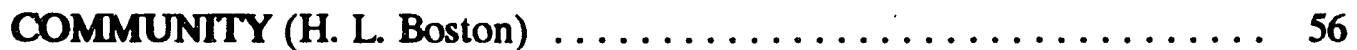

321 Methods .......................... 57

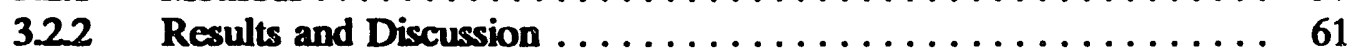

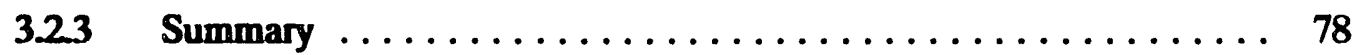

3.24 Future Studies $\ldots \ldots \ldots \ldots \ldots \ldots \ldots \ldots \ldots \ldots \ldots \ldots$

4. BIOACCUMULATION STUDIES (G. R. Southworth) $\ldots \ldots \ldots \ldots \ldots \ldots$

4.1 IDENTIFICATION OF CONTAMINANTS THAT
ACCUMULATE IN AQUATIC BIOTA $\ldots \ldots \ldots \ldots \ldots \ldots \ldots \ldots \ldots \ldots \ldots$

4.1.1 Introduction $\ldots \ldots \ldots \ldots \ldots \ldots \ldots \ldots \ldots \ldots \ldots \ldots \ldots \ldots$ 


\section{CONTENTS (continued)}

Page

4.1.2 Methods $\ldots \ldots \ldots \ldots \ldots \ldots \ldots \ldots \ldots \ldots \ldots \ldots \ldots \ldots$

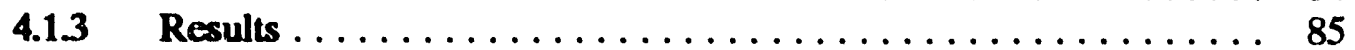

4.1 .4 Discussion $\ldots \ldots \ldots \ldots \ldots \ldots \ldots \ldots \ldots \ldots \ldots \ldots \ldots \ldots \ldots$

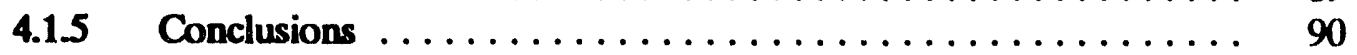

4.2 EVALUATION OF POLYCHLORINATED BIPHENYL CONTAMINATION IN WHITE OAK CREEK EMBAYMENT

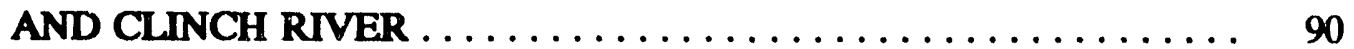

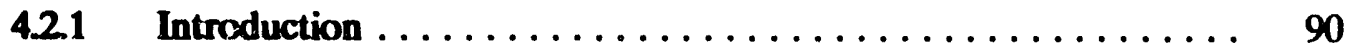

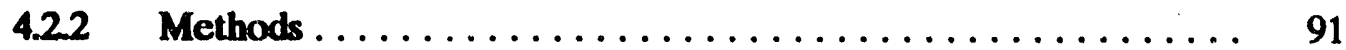

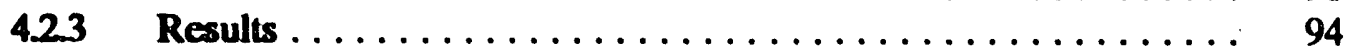

4.24 Discussion $\ldots \ldots \ldots \ldots \ldots \ldots \ldots \ldots \ldots \ldots \ldots \ldots \ldots \ldots \ldots$

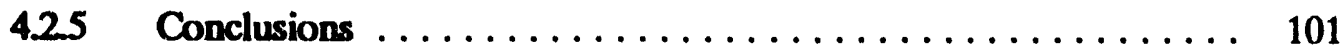

4.3 FUTURE STUDIES $\ldots \ldots \ldots \ldots \ldots \ldots \ldots \ldots \ldots \ldots \ldots \ldots \ldots \ldots$

5. BIOLOGICAL INDICATORS OF CONTAMINATED-RELATED

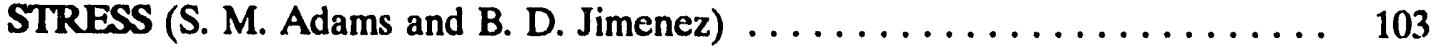

5.1 INTRODUCTION $\ldots \ldots \ldots \ldots \ldots \ldots \ldots \ldots \ldots \ldots \ldots \ldots \ldots \ldots$

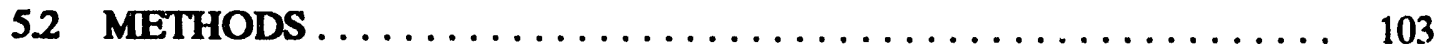

5.21 Analytical Procedures .................... 103

5.22 Statistical Procedures ... . . . . . . . . . . . . . . . . . 107

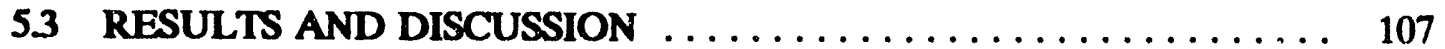

5.3.1 Individual Bioindicator Responses . . . . . . . . . . . . . . . . . . 107

5.2 Integrated Bioindicator Responses . . . . . . . . . . . 116

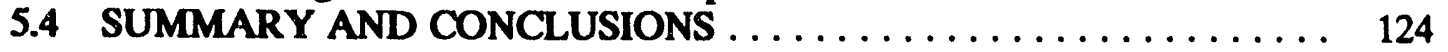

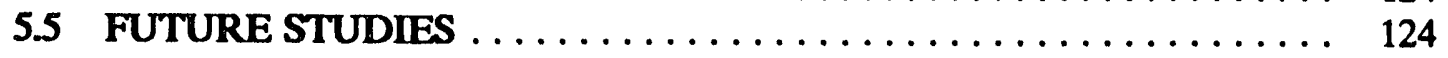

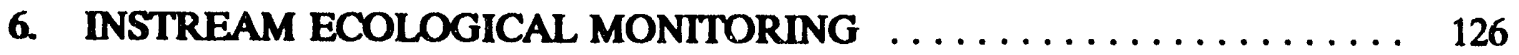

6.1 BENTHIC MACROINVERTEBRATES (J. G. Smith) . . . . . . . . 126

6.1.1 Introduction ........................ 126

6.1.2 Materials and Methods ..................... 126

$6.1 .3 \quad$ Results ............................ 128

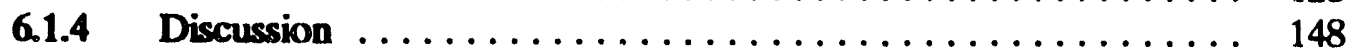

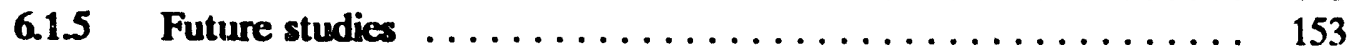

6.2 FISHES (M. G. Ryon) $\ldots \ldots \ldots \ldots \ldots \ldots \ldots \ldots \ldots \ldots \ldots \ldots \ldots \ldots \ldots \ldots$

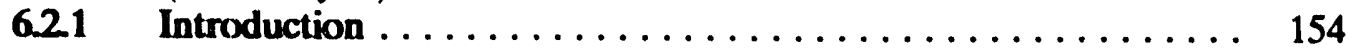

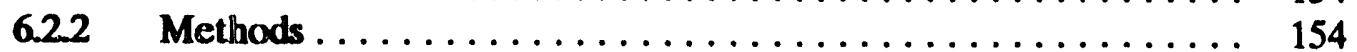

6.23 Results and Discussion ................... 158

6.2 .4 Fish Kills ............................... 174

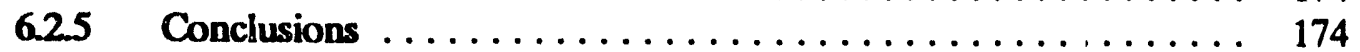

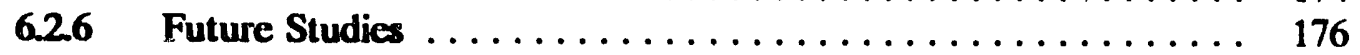

6.3 INTERPRETATION OF BIOTIC CHANGES (M. A. Huston) . . . . 177

6.3.1 Introduction . . . . . . . . . . . . . . . . . . 177

6.3 .2 Methods . . . . . . . . . . . . . . . . . . . . 177

6.3 .3 Results and Discussion ................... 178

6.3.4 Future Studies ......................... 185 
7. ASSESSMENT OF CONTAMINANTS IN THE TERRESTRIAL

ENVIRONMENT . . . . . . . . . . . . . . . . . . . . . . . . . 192

7.1 SMALL MAMMALS AS BIOLOGICAL MONITORS OF

ENVIRONMENTAL CONTAMINANTS (S. S. Talmage, J. G. Stout,

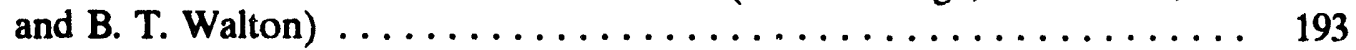

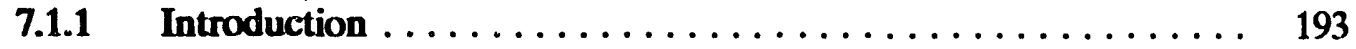

7.1.2 Materials and Methods ..................... 194

7.1.3 Results . . . . . . . . . . . . . . . . . . . . . . . . . . . 198

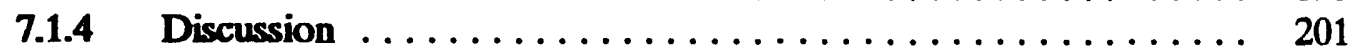

7.2 FRESHWATER TURTLES AS INDICATORS OF

CONTAMINATED ENVIRONMENTS (L. J. Meyers,

S. M. Appellanis, L. R. Shugart, and B. T. Walton) ... . . . . . . 205

7.21 Introduction ........................ 205

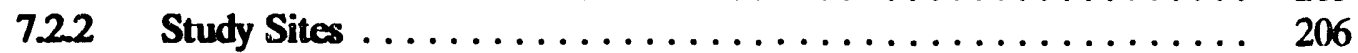

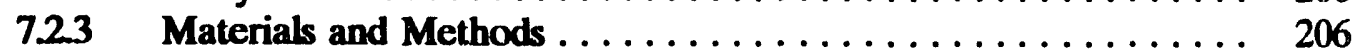

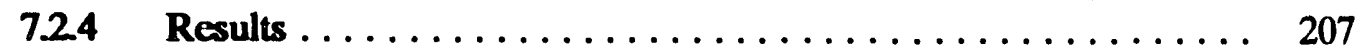

7.25 Discussion $\ldots \ldots \ldots \ldots \ldots \ldots \ldots \ldots \ldots \ldots \ldots \ldots \ldots \ldots \ldots \ldots$

7.3 FUTURE STUDIES (B. T. Walton, S. S. Talmage,

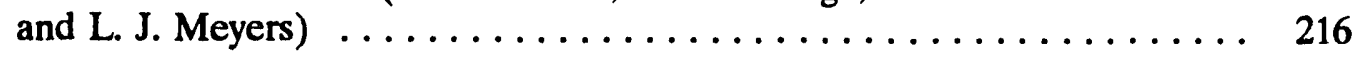

8. RADIOECOLOGY OF WHITE OAK LAKE $\ldots \ldots \ldots \ldots \ldots \ldots \ldots \ldots$

8.1 RADIONUCLIDES IN THE WHITE OAK LAKE ECOSYSTEM

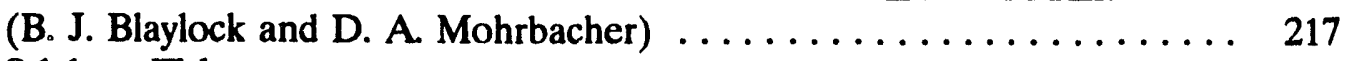

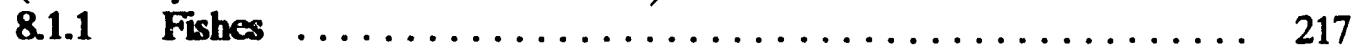

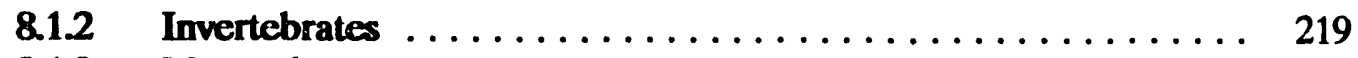

8.3 Macrophytes ........................ 219

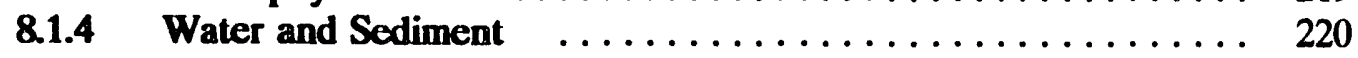

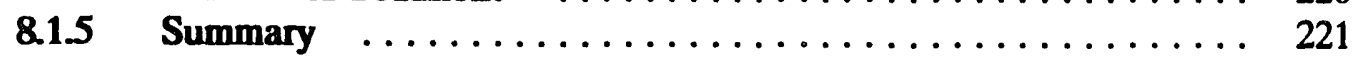

8.2 WATERFOWL POPULATIONS ASSOCIATED WITH ORNL

LAKES AND PONDS (B. G. Blaylock and D. K. Cox) . . . . . . . . 222

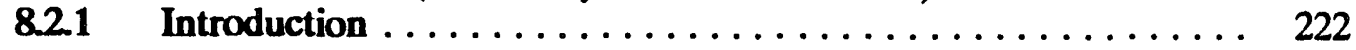

8.22 Materials and Methods ..................... 222

8.23 Results and Discussion . . . . . . . . . . . . . . . . 224

8.3 PRELIMINARY SCREENING OF NONRADIOLOGICAL

CONTAMINANTS IN WHITE OAK LAKE (B. G. Blaylock and

D. A. Mohrbacher) . . . . . . . . . . . . . . . . . . . . . 227

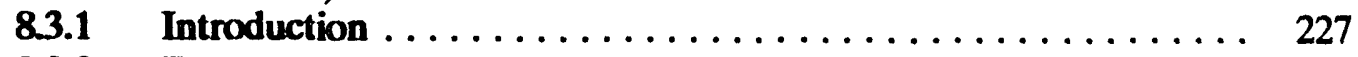

8.3.2 Exposure pathways ...................... 227

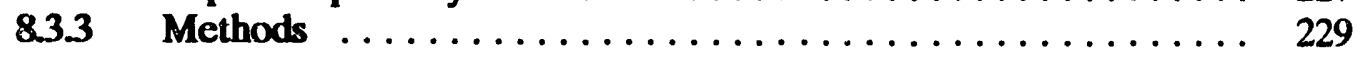

8.3.4 Results ........................ 233

8.4 ROLE OF AQUATIC MACROFLORA IN THE

RADIOECOLOGY OF WHITE OAK LAKE (H. L. Boston,

D. A. Mohrbacher, M. V. Hug,

and B. G. Blaylock) 
CONTENTS (continued)

Page

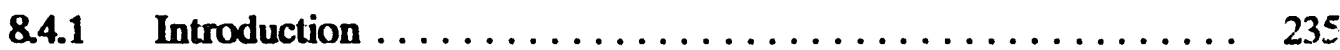

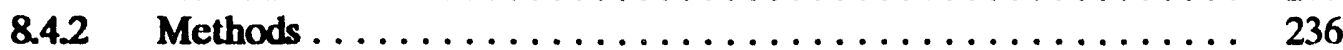

8.4.3 Results and Discussion .................... 238

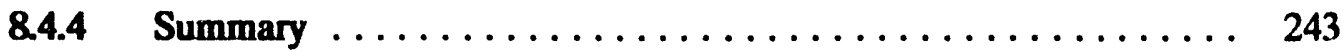

8.5 RADIONUCLIDES IN FISH IN WHITE OAK CREEK

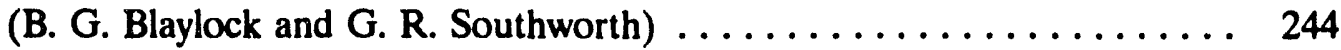

8.1 Introduction ......................... 244

852 Methods .......................... 244

$85.3 \quad$ Results ................................. 244

8.6 FUTURE STUDIES (B. G. Blaylock and D. A. Mohrbacher) . . . . . . . 244

8.6.1 Radionuclides in the White Oak Lake Ecosystem ......... 244

8.6.2 Waterfowl Populations Associated with ORNL

8.6.3 Preliminary Screening of Contaminants in

White Oak Lake . . . . . . . . . . . . . . . . . . . . 246

8.6.4 Role of Aquatic Macroflora in the Radioecology

of White Oak Lake . . . . . . . . . . . . . . . . 246

8.6.5 Radionuclides in Fish from White Oak Creek . . . . . . . . . . 247

9. CONTAMINANT TRANSPORT, DISTRIBUTION, AND FATE

IN THE CLINCH RIVER-WATTS BAR RESERVOIR SYSTEM

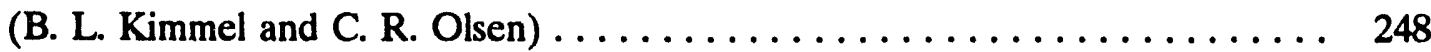

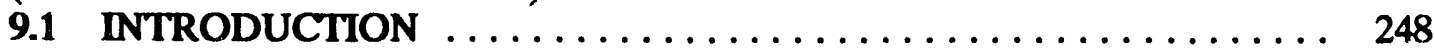

9.2 LITERATURE REVIEW AND SYNTHESIS $\ldots \ldots \ldots \ldots \ldots \ldots \ldots \ldots .248$

9.3 CONTAMINANT TRANSPORT AND FATE

SIMULATION MODEL . . . . . . . . . . . . . . . . . . . . . 248

9.4 BIOGEOCHEMICAL PROCESSES GOVERNING

9.5 CONTAMINANT ACCUMULATION IN BOTTOM

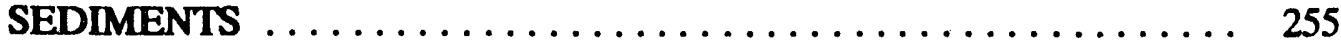

9.6 FUTURE STUDIES $\ldots \ldots \ldots \ldots \ldots \ldots \ldots \ldots \ldots \ldots \ldots \ldots \ldots$

10. ABATEMENT PROGRAM (J. P. Murphy and C. K. Valentine) . . . . . . . . 264

10.1 CHLORINE REDUCTION ........................ 264

10.2 ETHYLENE GLYCOL $\ldots \ldots \ldots \ldots \ldots \ldots \ldots \ldots \ldots \ldots \ldots \ldots$

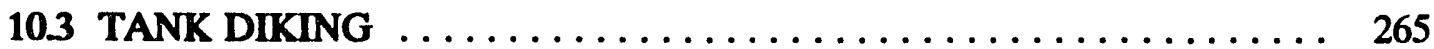

10.4 PCB/MERCURY MONITORING $\ldots \ldots \ldots \ldots \ldots \ldots \ldots \ldots \ldots \ldots \ldots . \ldots \ldots$

10.5 WASTEWATER PIPING $\ldots \ldots \ldots \ldots \ldots \ldots \ldots \ldots \ldots \ldots \ldots \ldots \ldots$

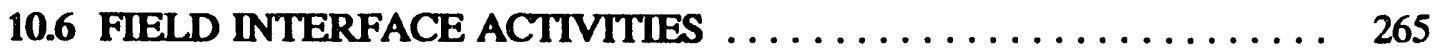

11. LITERATURE CITED $\ldots \ldots \ldots \ldots \ldots \ldots \ldots \ldots \ldots \ldots \ldots \ldots \ldots \ldots$ 


\section{CONTENTS (continued)}

APPENDIX A. MEAN CONCENTRATIONS OF SELECTED WATER QUALITY PARAMETERS MEASURED AT THE PERIPHYTON SAMPLING SITES, AUGUST-

APPENDIX B. MONTHLY ESTIMATES OF PERIPHYTON BIOMASS AND CARBON INCORPORATION RATES,

APRIL 1986-DECEMBER $1987 \ldots \ldots \ldots \ldots \ldots \ldots \ldots \ldots$

APPENDDX C. RESULTS OF QANC ANALYSES OF MERCURY, POLYCHLORINATED BIPHENYLS, AND ORGANICS

IN FISH SAMPLES

APPENDIX D. CONCENTRATIONS OF CONTAMINANTS IN AQUATIC BIOTA FROM WHITE OAK CREEK AND TRIBUTARIES, WHITE OAK LAKE, AND THE CLINCH RIVER, NOVEMBER 1986-AUGUST $1987 \ldots \ldots \ldots \ldots \ldots \ldots \ldots \ldots . \ldots . . . \ldots 01$

APPENDIX E CHECKLIST OF BENTHIC MACROINVERTEBRATE TAXA FROM WHITE OAK CREEK WATERSHED, MAY 1986-APRIL 1987

APPENDIX F. FISH POPULATION AND BIOMASS ESTIMATES IN WHITE OAK LAKE

APPENDIX G. FISH DENSITY, BIOMASS, AND CONDITION FACTOR DATA COLLECTED IN WHITE OAK CREEK WATERSHED, JANUARY-DECEMBER 1987

APPENDIX H. FISH COLLECTED IN SURVEYS OF WHTTE OAK LAKE DURING A WINTER DIE-OFF OF GIZZARD SHAD, 1987

APPENDIX I. MERCURY CONCENTRATIONS IN KIDNEYS OF SMALL MAMMALS

APPENDIX J. STRONTIUM-90 CONCENTRATIONS IN BONE OF

APPENDIX K. FOOD HABITS AND CONTAMINANT CONCENTRATIONS $\left({ }^{60} \mathrm{Co},{ }^{137} \mathrm{Cs}\right.$, and MERCURY) AND PERCENTAGE OF DOUBLE-STRANDED DNA LEVELS IN YELLOW-BELLIED SLIDER TURTLES FROM WHITE OAK LAKE AND BEARDEN CREEK EMBAYMENT $\ldots \ldots \ldots \ldots \ldots \ldots \ldots$ 


\section{LIST OF FIGURES}

$\begin{array}{ll}\text { Figure } & \text { Page }\end{array}$

2-1 Map of White Oak Creek watershed above White Oak Dam ......... 3

2-2 Map showing locations of (1) liquid and solid radioactive waste

disposal/storage areas; (2) National Pollutant Discharge Elimination System ambient monitoring stations on Melton Branch, White Oak Creek, and White Oak Dam; and three sampling sites for benthic invertebrates and fish in White Oak Creek watershed $\ldots \ldots \ldots \ldots \ldots \ldots \ldots \ldots \ldots \ldots \ldots$

2-3 Mean weekly streamflow in (1) Melton Branch at U.S. Geological Survey (USGS) gage 03537100 near Melton Branch kilometer (MEK) 1.9 and at National Pollutant Discharge Elimination System (NPDES) station X13 near MEK 0.16 and (2) White Oak Creek at NPDES station X14 near WCK 265 . . 7

2-4 Location of National Pollutant Discharge Elimination System (NPDES) effluent (Sites 1-9 and 13-14) and ambient (Sites 10-12) water quality

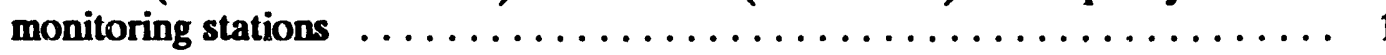

2-5 Mean weekly temperatures in White Oak Creek at sites above and below Oak Ridge National Laboratory [White Oak Creek kilometer (WCK) 6.8 and WCK 265 respectively], April-December 1987 . . . . . . . . . . . . . . 17

2-6 Mean weekly temperatures in four tributaries of White Oak Creek, June-December 1987 . . . . . . . . . . . . . . . . . . . . . . . . . 19

2-7 Water temperatures at National Pollutant Discharge Elimination System monitoring stations X13, on lower Melton Branch, and X14 on lower White Oak Creek for January-December 1985 and October 1986-December 1987 . . 20

2-8 Monthly data for hardness and conductivity from water samples collected at three periphyton monitoring stations, August 1986-December 1987 . . . . . . . 27

2-9 Monthly data for soluble reactive phosphorus and ammonia from water samples collected at three periphyton monitoring stations, August 1986-December 1987 . . . . . . . . . . . . . . . . . . . . . . . . . . . . . . . 28

3-1 Schematic showing the 15 ambient toxicity sampling sites on streams in White Oak Creek watershed

3-2 Plot of conductivity vs the ratio of alkalinity to hardness (A:H) for water samples from all ambient toxicity sampling sites $\ldots \ldots \ldots \ldots \ldots \ldots$

3-3 Ordination of the 15 ambient toxicity sampling sites on axes of conductivity and the ratio of alkalinity to hardness $(\mathrm{A}: \mathrm{H})$ 


\section{LIST OF FIGURES (continued)}

Figure

Page

3-4 Graph of hardness vs alkalinity for all samples from 15 ambient toxicity sampling sites in the White Oak Creek watershed $\ldots \ldots \ldots \ldots \ldots \ldots$

3-5 Graph of hardness vs alkalinity for all samples from the three ambient toxicity sampling sites on Melton Branch

3-6 Locations of the periphyton monitoring sites $\ldots \ldots \ldots \ldots \ldots \ldots \ldots$

3-7 Periphyton chlorophyll $a$ on small rocks in riflles in White Oak Creek above and below Oak Ridge National Laboratory (White Oak Creek kilometer 6.8 and White Oak Creek kilometer 3.4 respectively) during 1986 and 1987 . . . . .

3-8 Periphyton chlorophyll $a$ on small rocks in riflles in lower Melton Branch [Melton Branch kilometer (MEK) 0.6] during 1986 and 1987 . . . . . . . . . . .

3-9 Periphyton primary production as carbon incorporation rates on small rocks in riffles in White Oak Creek above and below Oak Ridge National Laboratory [White Oak Creek kilometer (WCK) 6.8 and WCK 29 respectively] during 1986 and $1987 \ldots \ldots \ldots \ldots \ldots \ldots \ldots \ldots \ldots$

3-10 Periphyton primary production as carbon incorporation rates on small rocks in riffles in lower Melton Branch [Melton Branch kilumeter (MEK) 0.6] during 1986 and 1987

3-11 Monthly values for chlorophyll-specific production (micrograms of carbon per milligram of chlorophyll a per hour) plotted as a function of chlorophyll $a$ (micrograms per square centimeter) for eight periphyton monitoring sites in the White Oak Creek watershed during 1987 . . . . . . . . . . . . . . . . .

3-12 Monthly data for the natural log of chlorophyll-specific production (micrograms of carbon per milligram of chlorophyll a per hour) plotted as a function of the natural log of chlorophyll a (micrograms per square centimeter) for eight periphyton monitoring sites in the White Oak Creek watershed during $1987 \ldots \ldots \ldots \ldots \ldots \ldots \ldots \ldots \ldots \ldots \ldots \ldots$

3-13 Periphyton adenosine triphosphate (ATP) concentrations at five periphyton monitoring sites on White Oak Creek

4-1 Location of catfish collection sites in White Oak Creek and the Clinch River 


\section{LIST OF FIGURES (continued)}

Figure

Page

5-1 Response of the carbohydrate-protein indicators in bluegill and redbreast sunfish at three sites in the White Oak Creek system, expressed as a percentage of the reference site (Brushy Fork) value . . . . . . . . . . .

5-2 Response of lipid metabolism indicators in bluegill and redbreast sunfish at three sites in the White Oak Creek system, expressed as a percentage of the reference site (Brushy Fork) value $\ldots \ldots \ldots \ldots \ldots \ldots \ldots \ldots \ldots$

5-3 Response of the histopathological indicators in bluegill and redbreast sunfish at three sites in the White Oak Creek system, expressed as a percentage of the reference site (Brushy Fork) value $\ldots \ldots \ldots \ldots \ldots \ldots \ldots \ldots$

5-4 Response of the condition index indicators in bluegill and redbreast sunfish at three sites in the White Oak Creek system, expressed as a percentage of the reference site (Brushy Fork) value $\ldots \ldots \ldots \ldots \ldots \ldots \ldots \ldots \ldots$

5-5 Response of the detoxification enzymes (P-450, EROD, NADPH) in male and female sunfish from three sites in the White Oak Creek system expressed as a percentage of the reference site (Brushy Fork) value .......

5-6 Segregation of integrated bioindicator responses (carbohydrate-protein metabolism, lipid metabolism, detoxification enzymes, and condition indices) for bluegill sunfish from White Oak Creek, White Oak Lake, and Brushy Fork (reference stream) in spring $1987 \ldots \ldots \ldots \ldots \ldots \ldots \ldots$

5-7 Segregation of integrated bioindicator responses (carbohydrate-protein metabolism, lipid metabolism, detoxification enzymes, and condition indices) for bluegill and redbreast sunfish from White Oak Creek, White Oak Lake, and Brushy Fork (reference stream) in spring $1987 \ldots \ldots \ldots \ldots \ldots \ldots$

5-8 Response of the U-ratio, a statistical measure of the ability to discriminate hetween site responses, to the number of variables in a subset $\ldots \ldots \ldots \ldots$

6-1 Monthly mean density of benthic macroinvertebrates in White Oak Creek watershed, May 1986-April $1987 \ldots \ldots \ldots \ldots \ldots \ldots \ldots \ldots \ldots \ldots$

6-2 Monthly mean biomass of benthic macroinvertebrates (excluding Decapoda and Mollusca) in White Oak Creek watershed, May 1986-April 1987 . . . . . .

6-3 Relative abundance (percentage of mean annual density) of selected benthic macroinvertebrate taxonomic groups in White Oak Creek watershed,

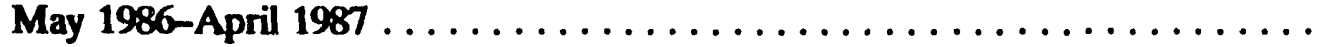




\section{LIST OF FIGURES (continued)}

Figure

Page

6-4 Relative biomass (percentage of mean annual biomass, excluding Decapoda and Mollusca) of selected benthic macroinvertebrate taxonomic groups in White Oak Creek watershed, May 1986-April 1987 . . . . . . . . . . . . . .

6-5 Total number of taxa collected per site from the White Oak Creek watershed, May 1986-April 1987 . . . . . . . . . . . . . . . . . . . .

6-6 Monthly mean number of benthic macroinvertebrate taxa per sample in White Oak Creek watershed, May 1986-April 1987 . . . . . . . . . . . . . . . . .

6-7 Monthly mean species diversity of benthic macroinvertebrates in White Oak Creek watershed, May 1986-April $1987 \ldots \ldots \ldots \ldots \ldots \ldots$. . . . . . . . .

$6-8$ Monthly mean density, biomass, number of taxa per sample, and diversity of benthic macroinvertebrates in White Oak Lake, May 1986-March 1987 . . . . .

6-9 Population growth rate (mean weight at age) of bluegill sunfish in White Oak Creek, White Oak Lake, two small ponds [Environmental Sciences Division (ESD) 2 and 5], and Brushy Fork, a reference stream, for 1987 . . . .

6-10 Population growth rate (mean weight at age) of redbreast sunfish in White Oak Creek, White Oak Lake, and Brushy Fork, a reference stream, during 1987

6-11 True rate of growth in weight of bluegill sunfish in White Oak Creek, White Oak Lake, a small pond, and Brushy Fork, a reference stream, during 1987 . .

6-12 True rate of growth in weight of redbreast sunfish in White Oak Creek, White Oak Lake, and Brushy Fork, a reference stream, during 1987

6-13 Relative rumber of fish species at sites in the Tennessee Valley regional data base and at White Oak Creek sites, August-September 1986

6-14 Relative fish wet weight at sites in the Tennessee Valley regional data base and at White Oak Creek (WOC) sites, August-September 1986 . . . . . .

6-15 Relative proportion of the periphyton scraper guild to total fish population at sites in the Tennessee Valley regional data base and at White Oak Creek sites, August-September 1986

6-16 Relative proportion of the midwater/surface insectivore guild at sites in the Tennessee Valley regional data base and at White Oak Creek sites, August-September 1986 


\section{LIST OF FIGURES (continued)}

Figure

Page

6-17 Relative proportion of the midwater/surface insectivore guild at sites in the Tennessee Valley regional data base and at White Oak Creek sites,

August-September 1986 (rescaled ares) . . . . . . . . . . . . . . .

6-18 Relative proportion of the periphyton scraper guild at sites in the Tennessee Valley regional data base and at White Oak Creek sites, August-September

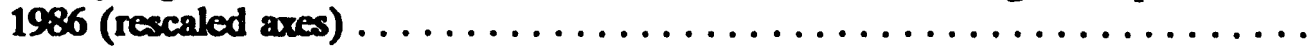

6-19 Relative proportion of the benthic insectivore guild at sites in the Tennessee Valley regional data base and at White Oak Creek sites, August-September 1986

6-20 Relative proportion of the benthic insectivore guild at sites in the Tennessee Valley regional data base and at White Oak Creek sites, August-September 1986 (rescaled axes) $\ldots \ldots \ldots \ldots \ldots \ldots \ldots \ldots \ldots \ldots \ldots \ldots$

6-21 Relative proportion of the detritivore guild at sites in the Tennessee Valley regional data base and at White Oak Creek sites, August-September 1986 ..

6-22 Relative proportion of the detritivore guild at sites in the Tennessee Valley regional data base and at White Oak Creek sites, August-September 1986 (rescaled axes) $\ldots \ldots \ldots \ldots \ldots \ldots \ldots \ldots \ldots \ldots \ldots \ldots \ldots \ldots \ldots \ldots \ldots$

7-1 Grid pattern for solid waste storage area 4, showing the bathtub seeps and the location of small mammal traps $\ldots \ldots \ldots \ldots \ldots \ldots \ldots \ldots \ldots$

7-2 Movement of the yellow-bellied slider turtle (Pseudemys scripta) in White Oak Lake as indicated by the recapture of individually marked turtles . . . . . .

8-1 Average number of waterfowl per site and total number of waterfowl observed at the White Oak Lake and Swan Pond sites, October 1987-January $1988 \ldots \ldots \ldots \ldots \ldots \ldots \ldots \ldots \ldots \ldots \ldots \ldots$

8-2 Map of White Oak Lake showing locations of emergent macrophyte bed and

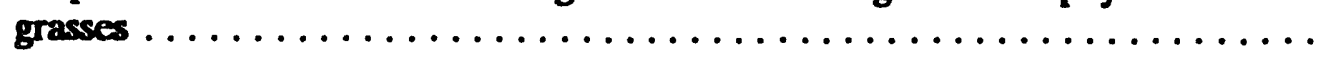

9.1 Linkages between subtasks and research products $\ldots \ldots \ldots \ldots \ldots \ldots$

9-2 Basic structure of the Clinch River-Watts Bar Reservoir contaminant transport simulation model $\ldots \ldots \ldots \ldots \ldots \ldots \ldots \ldots \ldots \ldots$

9-3 Simulation model output of "dye" concentrations in the Clinch River and in Watts Bar Reservoir displayed as longitudinal cross sections of the river and reservoir 


\section{LIST OF FIGURES (continued)}

Figure

Page

9-4 Surface water temperatures (a) and total suspended particle concentrations (b) in the lower Clinch River and Watts Bar Reservoir in the spring. summer, and winter .......................... 253

9-5 Dissolved 'Be concentrations measured in Melton Hill Reservoir samples collected in a time series after a major rainstorm ('Be-input) event . . . . . 256

$9-6$ A map illustrating the sedimentary characteristics in Watts Bar Reservoir ... 258

9-7 A map of the sediment core locations in Watts Bar Reservoir . . . . . . . . 259

$9-8$ A graph illustrating the discharge history of ${ }^{137} \mathrm{Cs}$ from White Oak Lake and a typical ${ }^{137} \mathrm{C}$ s profile in the sediments of Watts Bar Reservoir

9-9 A map showing the polygonal areas used by the Geographic Information System to determine the total burden of ${ }^{137} \mathrm{Cs}$ in Watts Bar Reservoir sediments 


\section{LIST OF TABLES}

Table

Page

2-1 Number of days of zero discharge (number of consecutive days in parentheses) in upper Melton Branch at Melton Branch kilometer (MEK) 1.93 (U.S. Geological Survey gaging station 03537100) . . . . . . . . 6

2-2 Comparison of the variability in mean daily discharge between streams with and without flow augmentation in $1987 \ldots \ldots \ldots \ldots \ldots \ldots \ldots \ldots$

2-3 Description of the ten major effluent discharges regulated under the Oak Ridge National Laboratory National Pollutant Discharge Elimination System permit issued on April 1, $1986 \ldots \ldots \ldots \ldots \ldots \ldots \ldots \ldots \ldots \ldots \ldots$

2-4 Number and location (receiving stream) of category I, I, and III outfalls that discharge to White Oak Creek and tributaries ................. 12

2-5 Median concentrations (range in parentheses) of 34 National Pollutant Discharge Elimination System (NPDES) water quality parameters that are routinely monitored below Oak Ridge National Laboratory in Melton Branch at NPDES site X13 (MEK 0.16), in White Oak Creek at NPDES site X14 (WCK 2.65), and at White Oak Dam (WOD) at NPDES site X15, January-December 1987

2-6 Mean ( \pm s.d.) monthly water temperatures $\left({ }^{\circ} \mathrm{C}\right.$ ) in White Oak Creek and tributaries, including First Creek, Fifth Creek, Melton Branch, and Northwest Tributary, May-November $1987 \ldots \ldots \ldots \ldots \ldots \ldots \ldots \ldots \ldots$

2-7 Water quality parameters determined for discrete samples collected monthly at ten sites in streams in White Oak Creek watershed $\ldots \ldots \ldots \ldots \ldots \ldots$

2-8 Water quality parameters (mean \pm s.d and range) determined from monthly water samples collected in Ish Creek and at the ten periphyton sampling stations in White Oak Creek watershed during $1987 \ldots \ldots \ldots \ldots \ldots \ldots$. . . .

2-9 Concentrations in parts per million (mean \pm s.d., and range) of dissolved elements in Ish Creek and at the ten periphyton sampling stations in White Oak Creek watershed based on inductively-coupled plasma analyses of discrete water samples collected quarterly during 1987

3-1 Summary of toxicity test results for the Oak Ridge National Laboratory Process Waste Treatment Plant (PWTP), Coal Yard Runoff Treatment Facility (CYRTF), and Sewage Treatment Plant (STP) $\ldots \ldots \ldots \ldots \ldots \ldots$

3-2 Chemical parameters of effluent from the Oak Ridge National Laboratory Process Waste Treatment Plant (PWTP), Coal Yard Runoff Treatment Facility (CYRTF), and Sewage Treatment Plant (STP) $\ldots \ldots \ldots \ldots \ldots$ 


\section{LIST OF TABLES (continued)}

Table

Page

3-3 Average no-observed-effect concentration (NOEC) of eflluent from the Oak Ridge National Laboratory Process Waste Treatment Plant (PWTP), Coal Yard Runoff Treatment Facility (CYRTF), and Sewage Treatment Plant (STP) in relation to ranges of water quality parameters characteristic of the

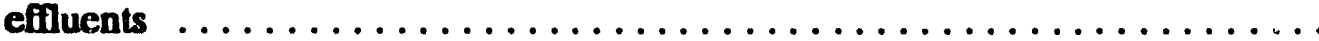

3-4 Survival (expression in percent) and growth (milligrams per fish, \pm 1 s.d.) of fathead minnow larvae, and survival (expressed in percent) and fecundity (offspring per female, \pm 1 s.d.) of Ceriodaphnia in full-strength process waste treatment plant (PWTP) effluent, and in full-strength PWTP effluent ..

3-5 Percent survival and growth (mean \pm 1 s.d.) of fathead minnows, and survival and fecundity (mean \pm 1 s.d.) of Ceriodaphnia in $7-d$ tests $\ldots \ldots \ldots \ldots \ldots$

3-6 Summary of water quality measurements in White Oak Creek abme Oak Ridge National Laboratory (WCK 6.8) and at National Pollutant Discharge Elimination System sites X13 on Melton Branch (MEK 0.16) and X14 on

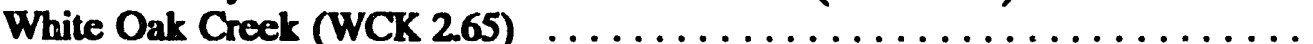

3-7 Conductivity, pH, alkalinity, total residual (TRC), and free chlorine (FC) of water samples collected from White Oak Creek just above the Materials Testing Laboratory (MTL) outfall (upstream), at the MTL outfall, and from White Oak Creek $20 \mathrm{~m}$ below the MTL outfall (downstream) ..........

3-8 Mean pH, total residual chlorine (TRC), and free chlorine (FC) concentrations (mean \pm 1 s.d.) in water from the Materials Testing Laboratory (MTL) outfall, from White Oak Creek (sites WCK 4.4, WCK 4.3, WCK 4.2, and WCK 3.8), and from Fifth Creek (FFK 0.0) $\ldots \ldots \ldots \ldots \ldots$

3-9 Mean survival (percent) and growth (in milligrams dry weight per fish, \pm 1 s.d.) of fathead minnow larvae (Pimephales promelas) and mean survival (percent) and fecundity of Ceriodaphnia in untreated and dechlorinated water samples from the Materials Testing Laboratory (MTL) outfall, from lower Fifth Creek, and from four sites in a midreach section of White Oak Creek ...................................

3-10 Correlation coefficients $(r)$ among water quality parameters measured in White Oak Creek ambient toxicity tests

3-11 Correlation coefficients among biological variables in ambient toxicity tests of water from White Oak Creek and tributaries 


\section{LIST OF TABLES (continued)}

Table

Page

3-12 Summary of correlative relationships among water chemistry parameters (chem), Ceriodaphnia (Cer) and fathead minnow (FHM) toxicity test data, and between these two (chemical, biological) data sets . . . . . . . . . . 52

3-13 Principal component factor patterns for 7-d means of water quality parameters measured during toxicity tests of water from 12 sites on 5 streams

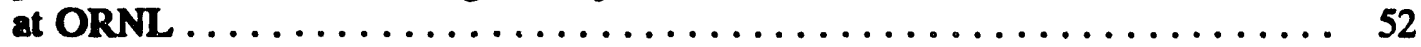

3-14 Results of multiple regression analyses of toxicity test response variables on chemical data used to generate principal components axes 1 and $2 \ldots \ldots \ldots$. 53

3-15 Mean annual periphyton chlorophyll $a$ and carbon incorporation rates in 1986 and $1987 \ldots \ldots \ldots \ldots \ldots \ldots \ldots \ldots \ldots \ldots \ldots \ldots \ldots \ldots \ldots \ldots \ldots$

3-16 Periphyton ATP concentrations and chlorophyll $a$ to ATP ratio (wt/wt) . . . . 74

3-17 Concentrations of selected elements (parts per million, dry weight) in periphyton collected in February $1987 \ldots \ldots \ldots \ldots \ldots \ldots \ldots$

3-18 Concentrations of selected elements (parts per million, dry weight) in periphyton collected in May $1987 \ldots \ldots \ldots \ldots \ldots \ldots \ldots \ldots \ldots$

3-19 Mercury concentrations in periphyton and filamentous algae $\ldots \ldots \ldots \ldots$

3-20 Characterization of the periphyton at ten study sites where periphyton was removed by brushing the rock surfaces $\ldots \ldots \ldots \ldots \ldots \ldots \ldots \ldots \ldots$

4-1 Mean metal concentrations in fish (parts per million, wet weight) from White Oak Creek and tributaries, White Oak Lake, and Hinds Creek (reference

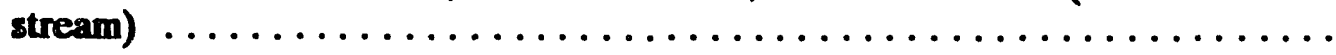

4-2 Concentrations of polychlorinated biphenyls and other organic priority pollutants (parts per million, wet weight) in sunfish (Lepomis macrochinus and $L$ auritus) from White Oak Creek and tributaries and White Oak Lake,

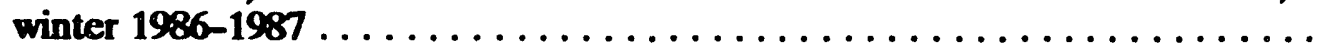

43 Concentrations of polychlorinated biphenyl (PCBs) (parts per million, wet weight) in composite samples of caged clams (Corbicula fluminea) held in White Oak Creek, Melton Branch, White Oak Lake (WOL), and East Fork Poplar Creek at the outfall of New Hope Pond near the Oak Ridge Y-12

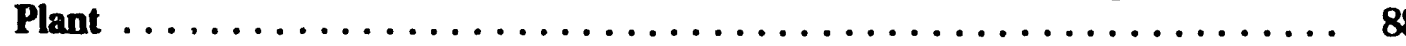




\section{LIST OF TABLES (continued)}

Table

Page

4-4 Concentrations of polychlorinated biphenyls and " $\mathrm{Sr}$ in channel catfish (Ictalunus punctatus) from lower White Oak Creek embayment, White Oak Lake, Clinch River, and other local sites $\ldots \ldots \ldots \ldots \ldots \ldots \ldots$

4-5 Changes between 1986 and 1987 in mean concentrations of polychlorinated biphenyls, ${ }^{9} \mathrm{Sr}$, and ratio of fish exceeding the Food and Drug Administration (FDA) limit to total number analyzed for channel catfish from White Oak Lake (WOL), White Oak Creek embayment, the Clinch River, and two local

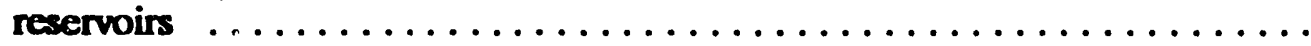

4-6 Concentrations of polychlorinated biphenyls (PCBs) and ${ }^{90} \mathrm{Sr}$ in gizzard shad (Dorosoma cepedianum) from White Oak Creek embayment (WCK 0.3), the Clinch River $\sim 1.3 \mathrm{~km}$ below White Oak Creek (CRK 32.2), and Melton Hill Reservoir ................................ 99

5-1 Statistical comparisons between sites for individual bioindicators $\ldots \ldots \ldots 109$

5-2 Statistical comparisons between sites for three liver detoxification enzymes in bluegill and redbreast sunfish $\ldots \ldots \ldots \ldots \ldots \ldots \ldots \ldots \ldots \ldots$

5-3 Relative importance ranking of the various bioindicators used to discriminate between the integrated responses of redbreast sunfish at three sites in the White Oak Creek system and Brushy Fork, a reference site . . . . . . . . .

6-1 Mean annual density (number per $0.1 \mathrm{~m}^{2}$ ) and biomass (milligrams wet weight per $0.1 \mathrm{~m}^{2}$ ) of benthic macroinvertebrates in White Oak Creek watershed, May 1986-April $1987 \ldots \ldots \ldots \ldots \ldots \ldots \ldots \ldots \ldots \ldots$

6-2 Comparisons of mean benthic macroinvertebrate density with and without Decapoda and Mollusca in tributaries of White Oak Creek ...........

6-3 Comparisons of mean benthic macroinvertebrate density with and without Decapoda and Mollusca in White Oak Creek $\ldots \ldots \ldots \ldots \ldots \ldots$

6-4 Comparisons of mean benthic macroinvertebrate biomass with and without Decapoda and Mollusca in White Oak Creek tributaries .............

6-5 Comparisons of mean benthic macroinvertebrate biomass with and without Decapoda and Mollusca in White Oak Creek ................

6-6 Mean annual richness (number of taxa per sample) and species diversity $\left(\mathrm{H}^{\prime}\right)$ of benthic macroinvertebrates in White Oak Creek watershed, May 1986-April 1987 


\section{LIST OF TABLES (continued)}

Table

Page

6-7 Comparisons of mean benthic macroinvertebrate richness (number of taxa per sample) in White Oak Creek watershed $\ldots \ldots \ldots \ldots \ldots \ldots \ldots \ldots \ldots$

6-8 Comparisons of mean benthic macroinvertebrate diversity $\left(\mathrm{H}^{\prime}\right)$ in White

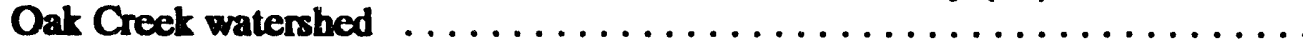

6-9 Mean annual density (number per $0.1 \mathrm{~m}^{2}$ ), biomass (milligrams wet weight per $0.1 \mathrm{~m}^{2}$ ), richness (number of taxa per sample), and diversity $\left(\mathrm{H}^{\prime}\right)$ of benthic macroinvertebrates in White Oak Lake (WCK 1.1), May

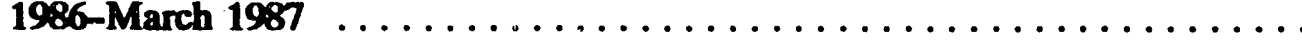

6-10 Mean lengths, widths, depths, and surface areas (ronge in parentheses) of fish sampling sites in White Oak Creek, First Creek, Fifth Creek, Melton Branch, and Northwest Tributary, January-December 1987 . . . . . . . . . .

6-11 Fish species composition in White Oak Creek, First Creek, Fifth Creek, Melton Branch, and Northwest Tributary, January-December 1987 . . . . . . .

6-12 Fish species composition in White Oak Lake (WOL) and Environmental Sciences Division (ESD) research ponds south of Building 1504, May-July 1987

6-13 Trophic structure and intolerance of fish communities in White Oak Creek, First Creek, Fifth Creek, Melton Branch, and Northwest Tributary, based on sampling conducted in 1987

6-14 Total fish density (individuals per square meter), total biomass (grams per square meter), and species richness (number of species) in White Oak Creek, First Creek, Fifth Creek, Melton Branch, and Northwest Tributary, January-December 1987

6-15 Data for calculation of true growth rates (after Ricker 1975) of bluegill sunfish in White Oak Creek, White Oak Lake, and a research pond [Environmental Sciences Division (ESD) 5] in comparison with the reference

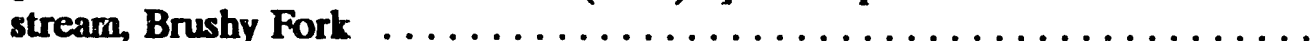

6-16 Data for calculation of true growth rates of redbreast sunfish in White Oak Creek and White Oak Lake in comparison with the reference stream, Brushy

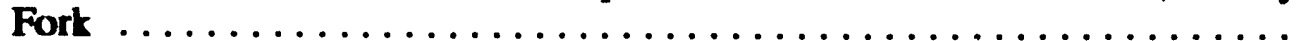

6-17 Functional classification of fish species collected from White Oak Creek in August-September ${ }^{4}$ 86 


\section{LIST OF TABLES (continued)}

Table

Page

7-1 Species and number of small mammals trapped at different study sites during 1986-1987 . . . . . . . . . . . . . . . . . . . . . . . . . . . . . . .

7-2 Benzo[ $[a]$ pyrene concentrations in soil at the East Fork Poplar Creek floodplain near EFK 17.4, White Oak Creek floodplain near WCK 2.1, and Solid Radioactive Waste Storage/Disposal Area 4 (SWSA 4) ..........

7-3 Mercury concentrations found in soil and kidney tissue of small mammals collected on the East Fork Poplar Creek floodplain near EFK 17.4, White Oak Creek floodplain, and Solid Radioactive Waste Storage/Disposal Area 4 (SWSA 4) $\ldots \ldots \ldots \ldots \ldots \ldots \ldots \ldots \ldots \ldots \ldots$

7-4 Strontium-90 concentrations (expressed as becquerels per gram dry wt) in bone of small mammals collected from Solid Radioactive Waste Storage/Disposal Area 4 (SWSA 4), the tloodplain of White Oak Creek, and the foodplain of East Fork Poplar Creek near EFK 17.4 . . . . . . . . .

7-5 PCB concentrations (expressed as micrograms per gram fresh wt) in brain and liver of laboratory control mice and Peromyscus leucopus trapped at the White Oak Creek floodplain (WCK 2.1) and Solid Radioactive Waste Storage/Disposal Area (SWSA 4) $\ldots \ldots \ldots \ldots \ldots \ldots \ldots \ldots$

7-6 Mark-recapture data for yellow-bellied slider turtles (Pseudemys scripta) from White Oak Lake

7-7 Mean percentage volume of different food types in the gastrointestinal tract of yellow-bellied slider turtles (Pseudemys scripta) collected from July through September 1987 . . . . . . . . . . . . . . . . . . . . . . . . . .

7-8 Concentrations of ${ }^{137} \mathrm{Cs}$ and ${ }^{60} \mathrm{Co}$ (expressed as becquerels per gram wet weight) in muscle tissue of yellow-bellied slider turtles (Pseudemys scripta) . . .

7-9 Strontium-90 concentrations (expressed as becquerels per gram wet weight) in the bone and carapace of yellow-bellied slider turtles (Pseudemys scripta) from White Oak Lake . . . . . . . . . . . . . . . . . . . . . .

7-10 Strontium-90 concentrations (expressed as wequerels per gram wet weight) in bone of yellow-bellied slider turtles (Pseudemys scripta) from Bearden Creek embayment $\ldots \ldots \ldots \ldots \ldots \ldots \ldots \ldots \ldots \ldots \ldots \ldots \ldots \ldots$

7-11 Strontium-90 concentrations (expressed as becquerels per gram wet weight) in bone of yellow-bellied slider turtles (Pseudemys scripta) $\ldots \ldots \ldots \ldots \ldots$. . . . 


\section{LIST OF TABLES (continued)}

Table

Page

7-12 Total mercury concentrations (in micrograms per gram wet weight) in yellowbellied slider turtles (Pseudemys scripta) $\ldots \ldots \ldots \ldots \ldots \ldots \ldots \ldots \ldots$

7-13 PCB concentrations (expressed as micrograms per graru wet weight) in fat tissue of turtles from White Oak Lake $\ldots \ldots \ldots \ldots \ldots \ldots \ldots \ldots$

7-14 Percentage of double-stranded (ds) deoxyribonucleic acid in liver samples from yellow-bellied slider turtles (Pseudemys scripta)

8-1 Whole body concentrations of ${ }^{137} \mathrm{Cs}$, ${ }^{60} \mathrm{Co}$, and ${ }^{90} \mathrm{Sr}$ (expressed in becquerels per kilogram wet weight) in fish collected from White Oak Lake in May 1987

8-2 Estimated total number of each species, mean weight (expressed in grams), and quantity of ${ }^{137} \mathrm{Cs},{ }^{60} \mathrm{Co}$, and ${ }^{90} \mathrm{Sr}$ in the fish population of White Oak Lake

8-3 Estimated numbers, biomass, and inventories of ${ }^{137} \mathrm{Cs}$ and ${ }^{60} \mathrm{Co}$ in benthic invertebrates in White Oak Lake . . . . . . . . . . . . . . . .

8-4 Estimated biomass and inventories of radionuclides in the emergent macrophytes of White Oak Lake

8-5 Estimated inventories of ${ }^{137} \mathrm{Cs},{ }^{60} \mathrm{Co}$, and ${ }^{90} \mathrm{Sr}$ (expressed in becquerels) in the abiotic and biotic compartments of White Oak Lake $\ldots \ldots \ldots \ldots \ldots \ldots$

8-6 Location and approximate size of water bodies near Oak Ridge National Laboratory that are being censused to estimate resident and migratory populations of waterfowl

8-7 List of waterfowl and waterbirds that have been observed at various water bodies near Oak Ridge National Laboratory $\ldots \ldots \ldots \ldots \ldots \ldots \ldots$

8-8 Mean concentrations ( \pm 1 s. d) of ${ }^{137} \mathrm{Cs}$ and ${ }^{60} \mathrm{Co}$ (expressed as becquerels per kilogram wet weight) in mallard ducks collected from White Oak Lake in December 1987

8-9 Potential White Oak Lake sources of metals and organic contaminants to humans via the ingestion pathway $\ldots \ldots \ldots \ldots \ldots \ldots \ldots \ldots$

8-10 Estimates of consumption rates of aquatic and terrestrial foods used in screening White Oak Lake contaminants

8-11 Comparison of the average intake (AI) of metals and organic compounds from drinking water with the allowable daily intake (ADI) 


\section{LIST OF TABLES (continued)}

Table

Page

8-12 Comparison of the average intake (AI) of metals and polychlorinated biphenyls through the fish food-chain pathway with the allowable daily intake

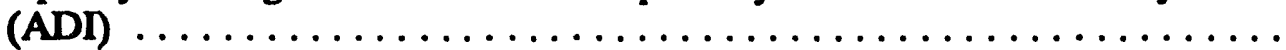

8-13 Comparison of the average intake (AI) of metals and polychlorinated biphenyls through the aquatic plant food-chain pathway with the allowable

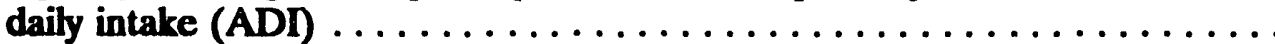

8-14 Comparison of the average intake (AI) of metals through the beef foodchain pathway with the allowable daily intake (ADI)

8-15 Comparison of the average intake (AI) of metals through the milk food-chain pathway with the allowable daily intake (ADI)

8-16 Comparison of the average intake (AI) of metals through the vegetable food-chain pathway with the allowable daily intake (ADI) . . . . . . 232

8-17 Allowable daily intake of metals and organics used for screening analysis . . 233

8-18 Metals and organic compounds warranting further consideration . . . . . . 234

8-19 Biomass and radionuclide concentration for emergent Macrophytes collected from White Oak Lake during September 1987

8-20 Concentratiuns of selected elements in the stems of Typha and Scipus from White Oak Lake

8-21 Radionuclide concentrations (expressed as becquerels per gram dry weight) in submersed and floating aquatic macrophytes in While Oak Lake, White Oak Creek, and Melton Branch during 1987

8-22 Concentrations of selected elements in the aboveground parts of aquatic macrophytes from White Oak Creek and Melton Branch

8-23 Levels of ${ }^{137} \mathrm{Cs}$ (measured in becquerels per kilogram dry weight) in sunfish from the White Oak Creek system, December 1986 .

9-1 Surface water velocities (measured in centimeters per second) in the lower Clinch River, 1987

9-2 Cesium-137 inventories in Watts Bar Reservoir sediment 


\section{LIST OF ACRONYMS}
A alkalinity
ACD Analytical Chemistry Division
ADI allowable daily intake
AFDW ash-free dry weight
AI average intake
ANOVA analysis of variance
ATDL Atmospheric Turbulence and Diffusion Laboratory
ATP adenosine triphosphate
$\mathrm{B}[a] \mathrm{P}$ benzo[a]pyrene
BCK Bear Creek kilometer
BFK Brushy Fork kilometer
BMAP Biological Monitoring and Abatement Program
BOD biochemical oxygen demand
CFS cubic feet per second
CRK Clinch River kilometer
C.V. coefficient of variation
CYRTF Coal Yard Runoff Treatment Facility
DCMU dichlorophenyldimethylurea
DEM Department of Environmental Management (name changed in 1987 to DEMC, see below)
DEMC Department of Environmental Monitoring and Compliance
DOC dissolved organic carbon
DOE U.S. Department of Energy
DMSO dimethyl sulfoxide
DNA deoxyribonucleic acid
DTT dithiothreitol
EDTA ethylenediamine tetracetic acid
EFK East Fork Poplar Creek kilometer
EFPC East Fork Poplar Creek
EPA Environmental Protection Agency
EROD 7-ethoxyresorufin $O$-deethylase
ESD Environmental Sciences Division
FC free chlorine
FCK First Creek kilometer
FDA Food and Drug Administration
FFK Fifth Creek kilometer
FIS field interface staff
$g$ denotes the standard acceleration due to gravity $\left(-9.8 \mathrm{~m} \cdot \mathrm{s}^{-1} \cdot \mathrm{s}^{-1}\right)$
GC/MS gas chromatography/mass spectrometry
GC/ECD gas chromatography/electron capture detector
GI gastrointestinal
GIS Geographic Information System
GLM general linear models
GM Geiger-Muller
$\mathrm{H}$ hardness 
HFIR High Flux Isotope Reactor

HPLC high performance liquid chromatography

HSRD Health and Safety Research Division

HTML High Temperature Materials Laboratory

ICP inductively coupled plasma

ISK Ish Creek kilometer

IWC instream waste concentration

$\mathrm{KOH}$ potassium hydroxide

$M \quad$ molar

mM millimolar

MEK Melton Branch kilometer

mrem millirem(s)

MSL mean sea level

mSv milliseiverts

MTL Materials Testing Laboratory

$\mu \mathrm{g}$ microgram

N normal

NADH nicotinamide adenine dinucleotide, reduced form

NADPH nicotinamide adenine dinucleotide phosphate, reduced form

NBS National Bureau of Standards

NCRP National Committee on Radiation Protection

NOAA National Oceanic and Atmospheric Administration

NOEC no observed effect concentration

NPDES National Pollutant Discharge Elimination System

NRC National Research Council

NRWTF Nonradiological Wastewater Treatment Facility

NTK Northwest Tributary kilometer

NWTP Nonradiological Wastewater Treatment Plant

ORAU Oak Ridge Associated Universities

ORGDP Oak Ridge Gaseous Diffusion Plant

ORNL Oak Ridge National Laboratory

ORR Oak Ridge Reservation

PAH polycyclic aromatic hydrocarbon

PCB polychlorinated biphenyl

PGV preliminary guidance value

PPM parts per million $(=\mu \mathrm{g} / \mathrm{g})$

PROC proposed required operational capacility

PWTP Process Waste Treatment Plant

RAP Remedial Action Program

RCRA Resource Conservation Recovery Act

RFI RCRA facility investigation

RNA ribonucleic acid

SAS Statistical Analysis System

s.d. standard deviation

SGOT serum glutamate oxaloacetate transaminase

SP Swan Pond

SRP soluble reactive phosphorus

STP Sewage Treatment Plant 
SWSA solid waste storage area

TCMP Toxicity Control and Monitoring Program

TDHE Tennessee Department of Health and Environment

TRC total residual chlorine

TSP total suspended particle

TSS total suspended solids

TVA Tennessee Valley Authority

USGS U.S. Geological Survey

WCK White Oak Creek kilometer

WOC White Oak Creek

WOD White Oak Dam

WOL White Oak Lake

WPCP Water Pollution Control Program 


\section{PREFACE}

On April 1, 1986, a National Pollutant Discharge Elimination System (NPDES) permit was issued for the Oak Ridge National Laboratory (ORNL) (EPA 1986). As required in Part III: Special Conditions (item $\mathbf{H}$ ) of the permit, a plan for biological monitoring of the Clinch River, White Oak Creek, Northwest Tributary of White Oak Creek, Melton Branch, Fifth Creek, and First Creek was prepared and submitted for approval in July 1986 to the U.S. Environmental Protection Agency (EPA) and the Tennessee Department of Health and Environment (Loar et al. 1991). The plan is referred to as the ORNL Biological Monitoring and Abatement Program (BMAP) and describes biomonitoring activities and characterization studies to be conducted for the 5-year duration of the permit.

This report is structured around the seven major tasks that comprise the BMAP (see Table of Contents, Sects. 3-9). It is the second of a series of *reports and presents the results of BMAP studies conducted in 1987. These reports also address any significant modifications in the scope of work outlined in Loar et al. (1991). 


\section{ACKNOWLEDGMENTS}

We thank D. K. Cox, W. C. Kyker, L. M. Stubbs, W. M. Harris, H. Schoene, C. M. Morrissey, R. D. Bailey, G. J. Haynes, and L. F. Wicker for their assistance with the field sampling. Substantial support was provided by the staff of the toxicity testing laboratory, including L. A. Kszos, R. D. Bailey, P. W. Braden, L. S. Ewald, G. J. Haynes, G. P. Morris, J. Richmond, R. Thomas, and L. F. Wicker. We thank N. M. Ferguson, B. C. Grant, T. G. Scott, J. H. Stewart, and J. E. Caton of the ORNL Analytical Chemistry Division (ACD) at Oak Ridge National Laboratory (ORNL); and W. McDaniels, W. Loy, and T. Bennett of the Environmental Protection Agency (EPA) Environmental Services Laboratory, Athens, Georgia, for analyses of samples. We thank I. L. Larsen, J. S. Eldridge, and B. D. Keele of ACD for technical assistance with the radionuclide analyses, and N. T. Edwards, T. Tamura, and D. E. Todd for their guidance on the analysis of organics in soils. A. W. King graciously assisted in the identification of small mammals. We also thank K. Newman and L. D. Voorhees for analyses of the National Pollutant Discharge Elimination System (NPDES) data and K. L. Daniels (affiliated at the time of manuscript preparation with the ORNL Department of Environmental Monitoring and Compliance) for providing the data. Programming and statistical assistance was provided by J. J. Beauchamp and P. A. Lesslie of the ORNL Computing and Telecommunications Division and by B. C. Harvey of the ORNL Environmental Sciences Division. We thank T. W. Toole, K. Tennessen, L. Young, and J. Walden, and other staff of the Tennessee Valley Authority (TVA) Aquatic Biology Laboratory in Muscle Shoals, Alabama, for processing (taxonomic identification and enumeration) the benthic invertebrate samples. Finally, we are grateful to G. W. Suter, G. F. Cada, R. R. Turner, and J. R. Trabalka, who reviewed the draft report and provided many helpful comments and suggestions.

This work was jointly funded by the ORNL Department of Environmental Monitoring and Compliance in the Environmental and Occupational Safety Division and the ORNL Remedial Action Program. 


\section{EXECUTIVE SUMMARY}

As a condition of the National Pollutant Discharge Elimination System (NPDES) permit issued to Oak Ridge National Laboratory (ORNL) on April 1, 1986, a Biological Monitoring and Abatement Program (BMAP) was developed for White Oak Creek (WOC); selected tributeries of WOC, including Fifth Creek, First Creek, Melton Branch, and Northwest Tributary; and the Clinch River. BMAP consists of seven major tasks that address both radiological and nonradiological contaminants in the aquatic and terrestrial environs on-site and the aquatic environs off-site. These tasks are (1) toxicity monitoring; (2) bioaccumulation monitoring of nonradiological contaminants in aquatic biota;

(3) biological indicator studies; (4) instream ecological monitoring; (5) assessment of contaminants in the terrestrial environment; (6) radioecology of WOC and White Oak Lake (WOL); and (7) contaminant transport, distribution, and fate in the WOC embayment-Clinch River-Watts Bar Reservoir system. This document, the second of a series of annual reports, describes the results of BMAP studies conducted in 1987.

\section{TOXICITY TESTING AND COIMLUUNTYY STUDIES (TASKS 1, 3, AND 4)}

Ambien! (instream) toxicity $\mathrm{w}$ as evaluated in 12 monthly tests at 15 sites on 5 streams in WOC, and the toxicity of the effluent from 3 ORNL wastewater facilities was evaluated in 10-12 tests of each facility. The evaluations were based on 7-d static-renewal tests that utilized the survival and growth of fathead minnow (Pimephales promelas) larvae and the survival and reproduction of a small crustacean (Ceriodaphnia dubia/affinis) as toxicity endpoints. The periphyton, benthic invertebrate, and fish communities were also routinely sampled at ail (or most) of these 15 sites in 1987, and several biological indicators were measured to assess the healtt of individual redbreast sunfish (Lepomis auritus) from the populations in lower WOC, Melton Branch, WOL, and Brushy Fork, a reference stream located just north of Oak Ridge nuar Marlow.

Toxicity patterns in WOL watershed in 1987 were similar to those observed in 1986. The middle reaches of WOC adjacent to the main ORNL complex and lower Fifth Creek are consistently toxic due primarily to high concentrations of total residual chlorine (TRC) that are apparently associated with discharges of chlorinated tapwater. The toxicological effects of TRC discharges to these two streams are at least episodically evident at sites where average concentrations of TRC are as low as 0.10 to $0.15 \mathrm{mg} / \mathrm{L}$.

Surveys of the biological communities in strenms near ORNL also showed that the impact of plant operations was greatest on middle WOC and lower Fifth Creek. For example, the periphyton community in middle WOC at White Oak Creek Kilometer (WCK) 3.9 was in poor physiological condition, and the number of species of benthic invertebrates (species richness) was significantly lower at WCK 3.9 than at all other WOC sites. Benthos abundance and richness were also significantly lower at the downstream site on Fifth Creek than at the upstream referesce site. As in 1986, fish densities were very low at WCK 3.9, and no fish were cullected in lower Fifth Creek. For the first time, the unusually high fish densities that had been observed throughout BMAP at WCK 5.1 just above the main plant complex were not found in fali 1987. The cause of the 13-fold 
decrease in density that occurred at this site between April and November 1987 is not known.

Significant ecological recovery was observed in lower Melton Branch following the shutdown of the High Flux Isotope Reactor (HFIR) in November 1986. Water quality improved, as evidenced by the decreased conductivity and lower sulfate and phosphorus concentrations; water temperatures also decreased. In February 1987, periphyton at Melton Branch kilemeter (MEK) $0.6, \sim 800 \mathrm{~m}$ below the confluence with the tributary that received blowdown from the HFIR cooling tower, exhibited the most rapid response. A significant but slower response by the fish populations at MEK 0.6 was also observed. Total fish density in lower Melton Branch increased 50-fold between April and November 1987 and reflected successful spawning and recruitment.

Although all three communities showed substantial recovery with increasing distance below ORNL, little change was noted between 1986 and 1987, and impacts of plant operations were still evident at WCK 2.3 just above WOL. Individual redbreast sunfish from lower WOC were in better physiological condition in spring 1987 than they were in fall 1986, but the difference may in part reflect seasonal differences in nutritional status. The activities of several detoxification enzymes, which regulate the biotransformation or metabolism of organic compounds, were significantly different between redbreast sunfish from WOC and those from Brushy Fork (a reference stream for lower WOC) in 1986 but not in 1987. This trend may be important, but the data base currently available for assessing its importance is too limited. In contrast, very little change was noted in community-level impacts between 1986 and 1987. Many benthic invertebrate and fish taxa that inhabit upstream reference areas and are sensitive to water quality degradation and habitat alteration were absent at WCK 2.3. The richness of aquatic insect species of the orders Ephemeroptera and Plecoptera was very low, and no representatives of such pollution-intolerant groups of fishes as Notropis, Catostomidae, and Percidae were collected. By contrast, all of these intolerant taxa are well represented in Brushy Fork.

Future studies will emphasize (1) characterization of the physical environment at each monitoring site (or sampling reach), (2) additional characterization of the biological communities by using various measures of ecological disturbance, and (3) manipulative field experiments. To help evaluate the importance of natural factors as determinants of community structure and function, the abiotic characterization will include morphometric measurements (e.g., channel width and depth, current velocity), substrate composition, description of riparian vegetation, canopy cover, and light penetration. Additional biotic characterizations may include (1) assessment of periphyton species composition, (2) application of the index of biotic integrity (Karr et al. 1986), (3) use of similarity indices, and (4) calculation of secondary production for the fish and benthic macroinvertebrate communities. Manipulative field experiments will be used to further evaluate sources of toxicity in WOC and to identify ecologically safe concentrations of residual chlorine. As part of the biological indicator task, caging experiments will be conducted to evaluate the effects of chronic stress on fish under semi-controlled field conditions. 


\section{CONTAMINANT TRANSPORT AND BIOACCUMULATION (TASKS 2 AND 5-7)}

The bioaccumulation of polychlorinated biphenyls (PCBs) is the most significant problem in the WOC system caused by the accumulation of metals and organics in biota. Although no other organic priority prilutants were detected in biota, substantial levels of PCBs were observed in sunfish from WOC and WOL, indicating a source upstream of WCK 3.5. However, the accumulation of PCBs by caged Asiatic clams (Corbicula fluminea) placed at sites in WOC, Melton Branch, and WOL suggested a source between WCK 3.5 near the Melton Valley Drive bridge and WCK 2.65 at the lower weir on WOC (NPDES site X14), possibly from a tributary that drains solid radioactive waste disposal/storage area No. 4 (SWSA 4) and enters WOC between these two sites. Future studies will involve the use of caged clams at numerous sites throughout the WOC watershed in order to identify PCB sources. Routine quantitative measurement of PCB concentrations in fish from WOC will be initiated on a semi-annual basis if collection pressure is not significant.

In 1987, 25\% of the channel catfish collected from the Clinch River in the vicinity of WOC exceeded the FDA limit for PCBs of $2 \mathrm{ppm}$. This study provided additional evidence that the WOC discharge and/or WOC embayment is an active source of PCB contamination to resident aquatic organisms. However, the absence of a relationship between ${ }^{90} \mathrm{Sr}$ and PCBs in catfish, coupled with the presence of significant PCB contamination in channel catfish from sites upstream of Melton Hill Dam, suggests that ORNL might not be the major source of PCBs in fish at more remote sites in the Clinch River.

The levels of $\mathrm{As}, \mathrm{Sb}, \mathrm{Be}, \mathrm{Cd}, \mathrm{Cr}, \mathrm{Cu}, \mathrm{Pb}, \mathrm{Li}, \mathrm{Ni}, \mathrm{Se}, \mathrm{Ag}, \mathrm{Ti}$, and $\mathrm{Zn}$ in fish from WOC and WOL did not differ from the levels found in fish from reference sites. Only mercury was found in elevated levels in fish from WOC and WOL. However, the levels were well below the FDA action limit of $1 \mathrm{ppm}$ and were not elevated in fish from WOC embayment or the Clinch River. The pattern of mercury contamination in fish suggests a source upstream of WCK 3.5. The screening of metals and organics in fish from WOC will be conducted annually.

Monitoring of contaminants in the terrestrial environs at ORNL in 1987 was focused on (1) benzo[a]pyrene $(\mathrm{B}[a] \mathrm{P})$, a representative polycyclic aromatic hydrocarbon, mercury, ${ }^{90} \mathrm{Sr}$, and PCBs in small mammals from the WOC floodplain and SWSA 4 and $(2){ }^{137} \mathrm{Cs}$, ${ }^{60} \mathrm{Co}$, ${ }^{90} \mathrm{Sr}$, mercury, PCBs, and a DNA-damage assessment in yellow-bellied slider turtles (Pseudemys scripta) from WOL and Bearden Creek embayment, a nearby reference site. Results indicated that $\mathrm{B}[a] \mathrm{P}$ is not a contaminant of concern in SWSA 4 or the WOC floodplain. Mercury concentrations in small mammals from SWSA 4 were substantially below the concentrations observed in small mammals collected from the mercurycontaminated floodplain of East Fork Poplar Creek, and no individual collected from the ORNL environs had a concentration greater than $1.1 \mathrm{ppm}$, a level that may have an adverse effect on the individual. Concentrations of mercury in muscle thesue of turtles from WOL were below those reported in sunfish from the lake. The mean ${ }^{90} \mathrm{Sr}$ concentration was highest in the Eastern harvest mouse (Reithrodontomys humulus) at SWSA 4 and the cotton rat (Sigmodon hispidus) from the WOC floodplain $(71.5 \pm 117$ and $20.7 \pm 20.9 \mathrm{~Bq} / \mathrm{g}$, dry wt of bone respectively). Mean radionuclide concentrations in 
turtles from WOL were $7.29 \times 10^{4} \pm 2.36 \times 10^{6}$ and $51.4 \pm 162$ for ${ }^{137} \mathrm{Cs}$ and ${ }^{60} \mathrm{Co}$ in muscle, and $9.9 \times 10^{5} \pm 2.12 \times 10^{6}$ for ${ }^{90} \mathrm{Sr}$ in bone. Radionuclide concentrations in both small mammals and turtles were highly variable. The high concentration and presence of ${ }^{85} \mathrm{Sr}$ in two turtles suggests they had migrated to WOL from another contaminated impoundment (Old Hydrofracture Pond). Turtles from WOL also had a significantly greater amount of deoxyribonucleic acid (DNA) damage than turtles from the reference site, indicating that turtles from WOL had a potentially greater exposure to nonspecific genotoxic agents. To date, too few PCB analyses have been conducted to adequately evaluate levels of contamination in terrestrial biota. Future studies will include additional analysis of PCB residues in small mammals and turtles and the analysis of radionuclides and assessment of DNA damage in another turtle species (the common snapping turtle, Chelydra serpentina) from WOL and a reference site.

Studies of the radioecology of WOL are being conducted to evaluate potential remedial action alternatives and to identify where additional data or research is needed. During the past year, estimates were obtained of the quantity of radioactivity in the biotic and abiotic compartments of the WOL ecosystem. It was estimated that the lake contains a total of $1.2 \times 10^{13} \mathrm{~Bq}\left(94 \%\right.$ was $\left.{ }^{137} \mathrm{Cs}\right)$, of which $<1 \%$ is in the water and biotic compartments (fish, benthic invertebrates, and emergent macrophytes). The study indicated the potential importance of sediments as a contaminant source in WOL and the need for a more comprehensive sediment sampling program in the lake.

In response to data gaps identified in the 1986 radionuclide screening analysis, a study of the emergent macrophyte community in WOL was initiated in July 1987, and a weekly census of the resident and migratory waterfowl populations on ORNL impoundments was initiated in October 1987. A similar screening analysis for metals and organics was completed in 1987 and, like the radionuclide inventory analysis, it demonstrated the need for additional data on contaminant levels in the sediments of WOL and WOC floodplain. Future studies of the radioecology of WOL will focus on (1) examination of the role of macrophytes in the remobilization of radionuclides from sediments, (2) completion of the waterfowl census and measurement of radionuclides in resident and migratory waterfowl, and (3) annual monitoring of radionuclide concentrations in fish from WOC above WOL to assess the effectiveness of abatement projects in reducing radionuclide levels in WOC.

A preliminary budget for ${ }^{137} \mathrm{Cs}$ in the sediments of Watts Bar Reservoir was developed by using a Geographic Information System and ARC:INFO software package to produce a digitized map of the sediment characteristics and ${ }^{137} \mathrm{Cs}$ inventories in the reservoir. Preliminary results showed that Watts Bar Reservoir sediments contain $\sim 1.07 \times 10^{13} \mathrm{~Bq}$ of ${ }^{137} \mathrm{Cs}$ compared with a decay-corrected total of $1.24 \times 10^{13} \mathrm{~Bq}$ of ${ }^{137} \mathrm{Cs}$ that have been released to the Clinch River from WOL. These results indicate that about $85 \%$ of the ${ }^{137} \mathrm{Cs}$ released from White Oak Dam has been trapped within the sediments of Watts Bar Reservoir while the remaining $15 \%$ either has been trapped within floodplain areas of the Clinch River and WOC embayment or has been transported beyond Watts Bar Dam into Chickamauga Reservoir. The off-site studies were conducted as Task 7 of BMAP. This task will be incorporated into the broader scope of the off-site Resource Conservation and Recovery Act (RCRA) Facility Investigation beginning in FY 1989. 


\section{ABATEMENT PROGRAM}

Abatement efforts at ORNL are directed toward providing both short-term and longterm management and technical solut ons to water quality problems, including toxicity of some receiving streams. Abatement projects include chlorine reduction, substitution for ethylene glycol, tank diking, PCB and mercury monitoring plans, wastewater treatment for 1500 and 2000 areas, and enhanced environmental surveillance of construction projects by ORNL Department of Environmental Monitoring and Compliance staff. 


\section{INTRODUCTION}

As a condition of the National Pollutant Discharge Elimination System (NPDES) permit issued to Oak Ridge National Laboratory (ORNL) on April 1, 1986, a Biological Monitoring and Abatement Program (BMAP) was developed for White Oak Creek (WOC); selected tributaries of WOC, including Fifth Creek, First Creek, Melton Branch, and Northwest Tributary; and the Clinch River (Loar et al. 1991). BMAP consists of seven major tasks that address both radiological and nonradiological contaminants in the aquatic and terrestrial environs on-site and the aquatic environs off-site. These tasks are (1) toxicity monitoring; (2) bioaccumulation monitoring of nonradiological contaminants in aquatic biota; (3) biological indicator studies; (4) instream ecological monitoring;

(5) assessment of contaminants in the terrestrial environment; (6) radioecology of WOC and White Oak Lake (WOL); and (7) contaminant transport, distribution, and fate in the WOC embayment-Clinch River-Watts Bar Reservoir system.

BMAP was developed to meet several objectives. First, studies (tasks) were designed to provide sufficient data to demonstrate that the effluent limits established for ORNL protect and maintain the classified uses of WOC, Melton Branch, Northwest Tributary, First Creek, and Fifth Creek. These streams have been classified by the Tennessee Department of Health and Environment (TDHE) for (1) growth and propagation of fish and aquatic life, (2) irrigation, and (3) livestock watering and wildlife (EPA 1986).

Second, BMAP will provide ecological characterizations of WOC and tributaries and of WOL that can be used to (1) document ecological impacts of past and current operations and (2) identify contaminant sources that adversely affect stream biota. This ecological information will be important in the development of various Remedial Investigation/Feasibility Study plans and in the assessment of remedial action alternatives as part of the Resource Conservation and Recovery Act (RCRA) planning process within the ORNL Remedial Action Program (RAP).

Third, BMAP will document the effects on stream biota from implementation of RAP and the Water Pollution Control Program (WPCP) at ORNL. The major remedial action included in the latter program is completion of a new Nonradiological Wastewater Treatment Plant (NWTP) in 1989. The ecological characterization of WOC watershed will provide baseline data that can be used to document the ecological effects of WPCP and RAP and to determine the success of remedial actions implemented under these programs. The long-term nature of BMAP ensures that the effectiveness of remedial measures will be properly evaluated. 


\section{DESCRIPTION OF WHITE OAK CREEK WATERSHED}

The WOC watershed is located near the southern boundary of the $150-\mathrm{km}^{2}$ U.S. Department of Energy (DOE) Oak Ridge Reservation (ORR). With a drainage area of $16.9 \mathrm{~km}^{2}$ at its mouth at Clinch River kilometer (CRK) 33.5 ," WOC watershed is similar in size to Bear Creek watershed $\left(20.1 \mathrm{~km}^{2}\right)$ near the Oak Ridge Y-12 Plant (Evaldi 1986). Parallel northeast-trending ridges constitute the northern and southern borders of the watershed, and a third ridge (Haw Ridge) bisects the basin and separates Bethel Valley to the north from Melton Valley to the south (Fig. 2-1). Elevations in the watershed range from $226 \mathrm{~m}$ above mean sea level (MSL) at the mouth of WOC to $413 \mathrm{~m}$ MSL on Melton Hill at the crest of Copper Ridge, the highest point on the ORR (McMaster 1963, McMaster and Waller 1965).

Because of dam construction, three distinct environments can be identified within the WOC watershed: (1) WOL, (2) WOC embayment below the lake, and (3) WOC and tributaries above the lake. The lake was created in 1941 by construction of a small highway-fill dam $-1.0 \mathrm{~km}$ above the confluence of WOC and the Clinch River (Fig. 2-1). It is a shallow impoundment that extends $\sim 0.7 \mathrm{~km}$ upstream from the dam and has a surface area $\sim 6$ ha at a lake elevation of $227.1 \mathrm{~m}$ MSL.

The water level in WOC embayment is controlled by the operation of Melton Hill Dam at CRK 37.2 and Watts Bar Dam, which is located at Tennessee River kilometer (TRK) 852.6, $-61 \mathrm{~km}$ below the confluence of the Clinch and Tennessee rivers. When Watts Bar Reservoir is maintained at or near full pool (approximately April to October) and discharges occur at Melton Hill Dam, the subsequent rise in water level in the Clinch River creates an embayment extending from the mouth of the creek to White Oak Dam. Because of this regulated condition, the WOC watershed is generally considered to be limited to the $15.5-\mathrm{km}^{2}$ area above the dam (Edgar 1978).

The region of the watershed above WOL is emphasized in the discussion that follows. Further descriptions of the WOL, WOC embayment, and Clinch River environments are provided in Loar et al. (1981), Boyle et al. (1982), Oakes et al. (1982), and Sherwood and Loar (1987) and in Sects. 4 and 7-8 of this report.

\subsection{GEOHYDROLOGY}

The headwaters of WOC originate on the southeast slope of Chestnut Ridge (Fig. 2-1). The belt of Knox Dolomite underlying the ridge is the principal water-bearing formation, and the springs that occur along the base of Chestnut Ridge and in its valleys are the chief source of the base flow of upper WOC (McMaster and Waller 1965). The largest tributary of WOC is Melton Branch, which originates at the eastern end of Melton Valley and joins WOC at White Oak Creek kilometer (WCK) 2.49 (Fig. 2-2), $-500 \mathrm{~m}$ above WOL (at a lake elevation of $227.1 \mathrm{~m} \mathrm{MSL}$ ). Most of the Melton Branch drainage

"CRK 0.0 is located at the confluence of the Clinch and Tennessee rivers. 

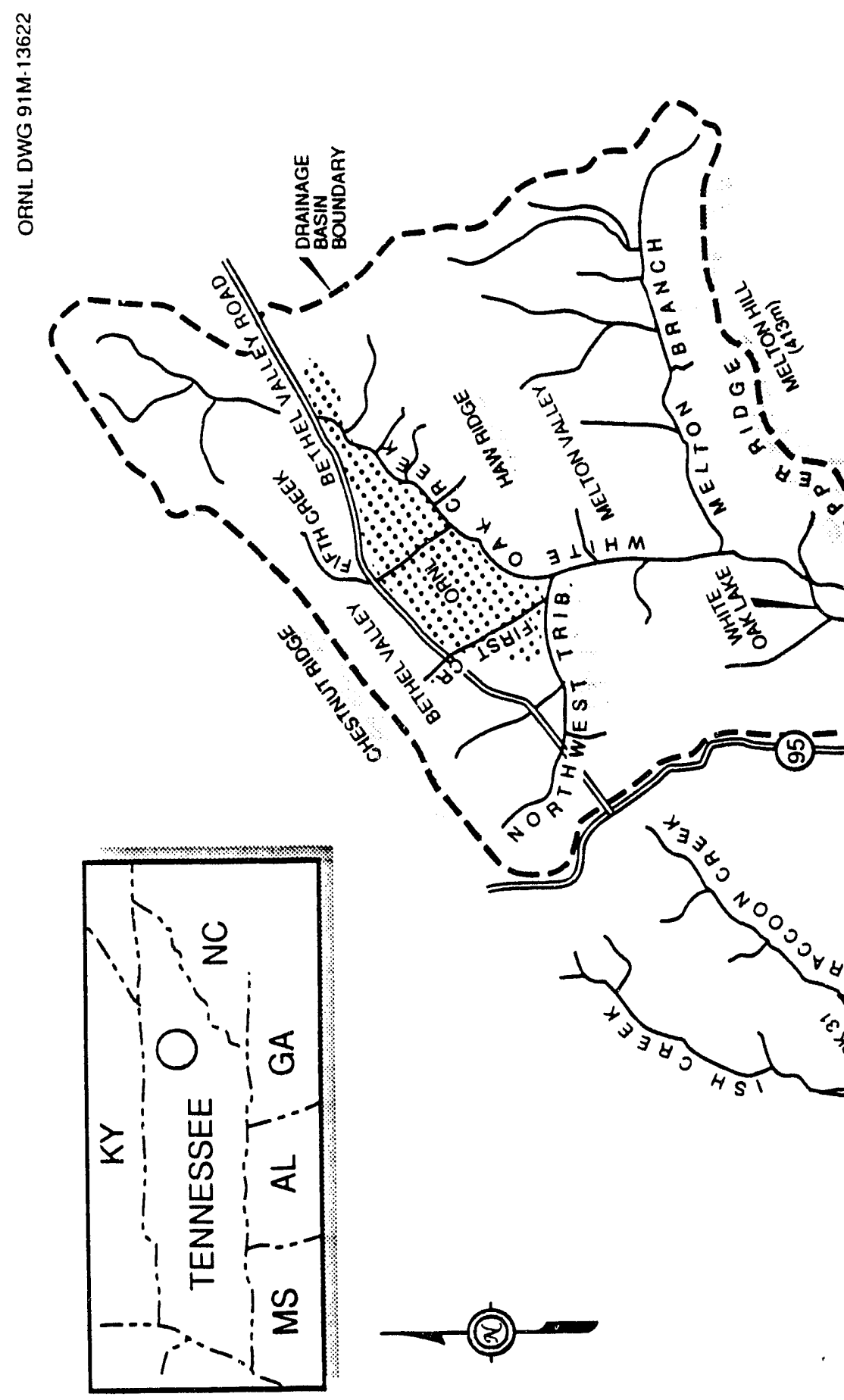
basin is underlain by the Rome Formation (Haw Ridge), which is composed principally of siltstone and shale, and by the Conasauga Group (Melton Valley), a primarily calcareous shale interlayered with limestone and siltstone (McMaster 1963, McMaster 1967); both are poor water-bearing formations (McMaster and Waller 1965). Together, the two formations compose $95 \%$ of the surface area of Melton Branch watershed, whereas all of upper WOC watershed north of Bethel Valley Road is underlain by Knox Dolomite (McMaster 1967, Table 10).

The hydrology of Melton Branch reflects the underlying geology of the watershed. Base-flow discharge is typically low, with periods of no flow at times (McMaster 1967). In each of the past 3 years, precipitation was below normal, and extended periods of zero discharge occurred in 1986 and 1987 at the U.S. Geological Survey (USGS) gaging station on upper Melton Branch at MEK 1.93. No flow was observed at this site on $14 \mathrm{~d}$ in 1985, $104 \mathrm{~d}$ in 1986, and $172 \mathrm{~d}$ in 1987 (Table 2-1). Excluding September 2, 3, and 6, when daily flow was $<0.5 \mathrm{~L} / \mathrm{s}$, there were 85 consecutive days of no flow in 1986 (July 17October 12) and 155 consecutive days of zero flow in 1987 (July 13-December 14). Zero discharge was also observed in both 1986 and 1987 in upper Northwest Tributary, where a portion of the watershed drains the north slope of Haw Ridge. Annual precipitation measured at the Atmospheric Turbulence and Diffusion Laboratory (ATDL) in Oak Ridge was $118.2 \mathrm{~cm}$ in 1985 , or $85 \%$ of normal, which is based on the 1951-1980 record period; $98.6 \mathrm{~cm}$ (71\% of normal) in 1986; and $102.4 \mathrm{~cm} \mathrm{(74 \% )} \mathrm{in} 1987$ (NOAA 1987a, 1987b).

Table 2-1. Number of days of zero discharge (number of consecutive days in parentheses) in upper Melton Branch at Melton Branch kilometer (MEK) 1.93

(U.S. Geological Survey gaging station 03537100)

\begin{tabular}{lllllllll}
\hline & June & July & August & September & October & November & December & Total \\
\hline 1985 & $4(2)$ & $8(6)$ & 0 & $2(2)$ & 0 & 0 & 0 & $14(6)$ \\
1986 & $10(10)$ & $15(15)$ & $31(31)$ & $27(24)$ & $20(12)$ & 0 & 0 & $103(47)$ \\
1987 & $11(8)$ & $21(19)$ & $31(31)$ & $30(30)$ & $31(31)$ & $30(30)$ & $18(14)$ & $172(155)$ \\
\hline
\end{tabular}

Source: J. F. Lowery, P. H. Counts, H. L. Edmiston, and F. D. Edwards. Water Resources Data for Tennessee, Water Year 1985, Report No. USGS/WRD/HD-86, U.S. Geological Survey, Nashville, Tennessee, 1986. J. F. Lowery, P. H. Counts, H. L. Edmiston, and F. D. Edwards. Water Resources Data for Tennessee, Water Year 1986, Report No. USGS/WRD/HD-87/225, U.S. Geological Survey, Nashville, Tennessee, 1987. Oak Ridge National Laboratory Department of Environmental Monitoring and Compliance, unpublished data.

Streamflow in lower Melton Branch, on the other hand, is augmented by periodic discharges of several process waste basins and cooling tower blowdown from the High Flux Isotope Reactor (HFIR) (see Sect. 2.2.1). The discharges, which enter the stream near Melton Branch kilometer (MEK) 1.4 via an unnamed tributary (Fig. 2-2), are a significant fraction of the flow in Melton Branch (Fig. 2-3). Extreme and possibly worse-case ambient conditions existed in lower Melton Branch in 1986 when upstream flows were at or near zero and dilution of plant discharges was minimal. Although upper Melton 


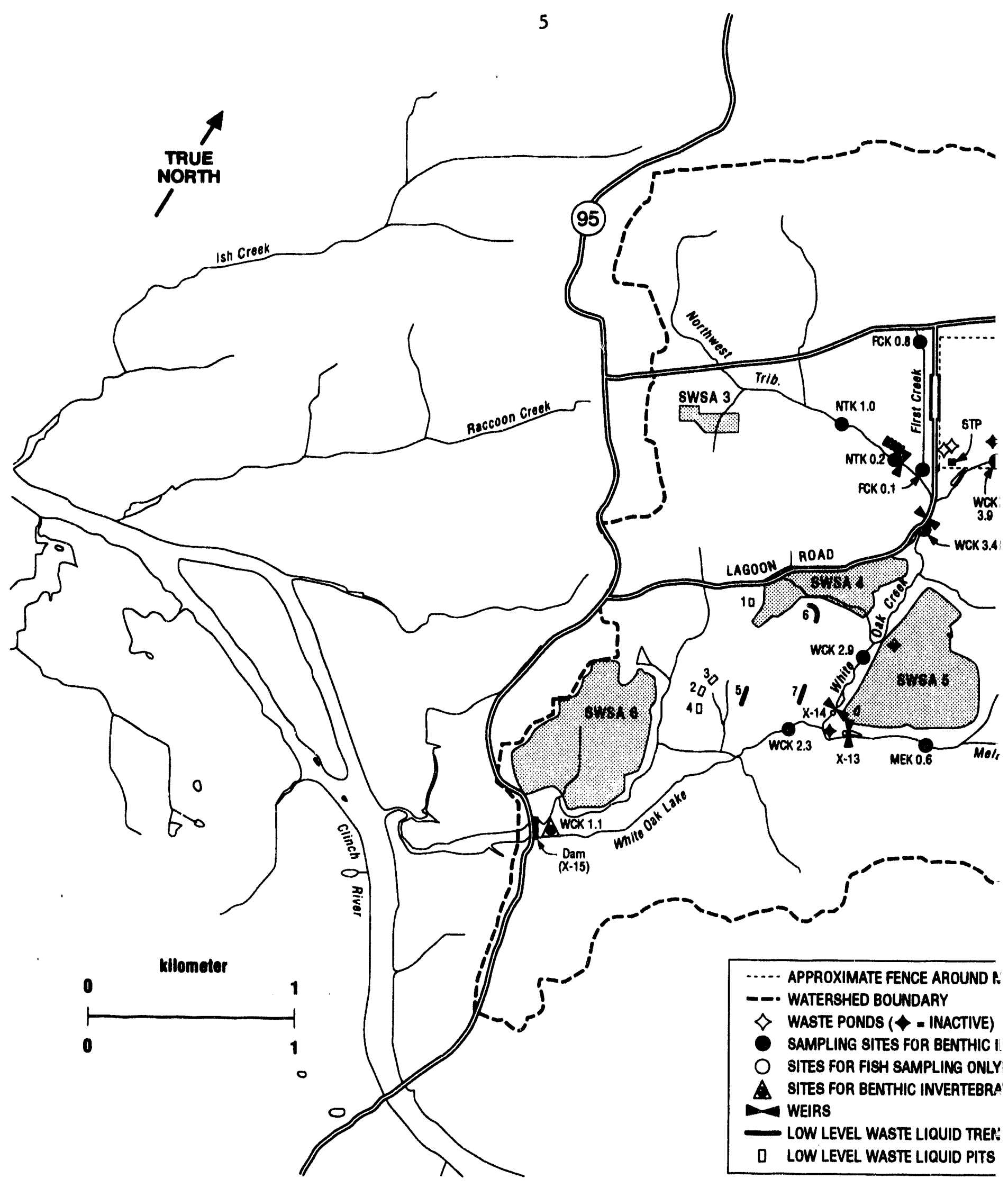

Fis 2-2. Map showing bentions of (1) liquid and solid redioactive waste disposalytorage areas; (2) National Pollutant DE: (X14), and Whic Oak Dam (X15); and (3) sampling sites for benthic invertebrates and fish in White Oak Creek watershed. - First Creek kilometer, FFK = Fifth Creek kilometer; HFIR = High Flux Isotope Reactor; LLW = low level waste; ME disposal/storage area; WCK = White Oak Creek kilometer. 

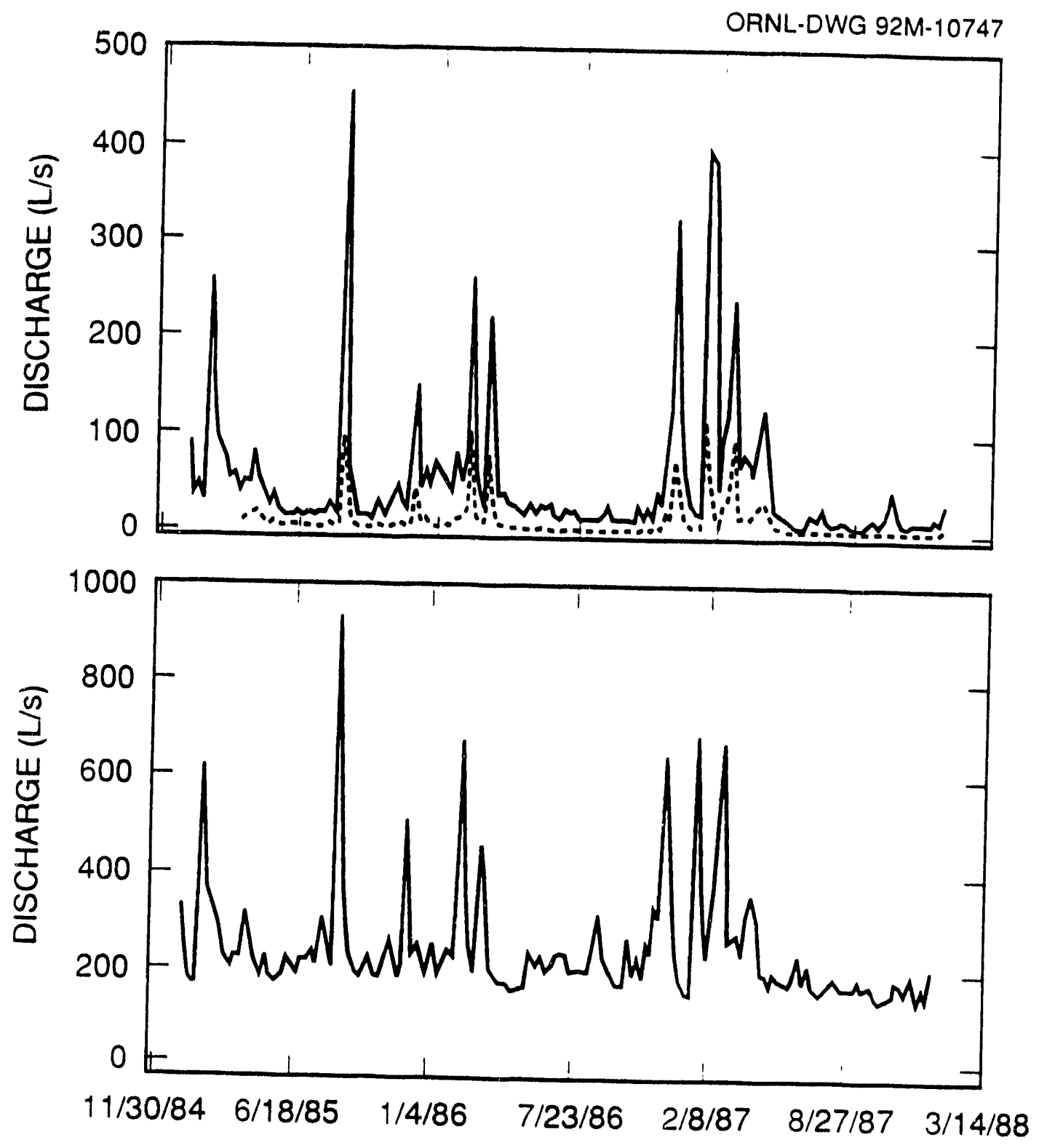

Fig 2-3. Mean wockly streamiow in (1) Meltern Branch (top) at U.S. Geological Survey (USGS) gas 0337100 near Melton Branch bilometer (MIEK) 1.9 (drahed line) and at National Pollutant Discharge Elimination System (NPDBS) station X13 near MEK 0.16 (solid line) and (2) White Oak Creek (bottom) at NPDES station X14 near WCK 265. Discharge at the NPDES site was measured once each day, excluding weekends and holidays. Source: Provisional data from the USGS, (L. D. Voorhees, Oak Ridge National Laboratory, unpublished data). J. F. Lowery, P. H. Counts, H. L. Edmiston, and F. D Edwards. Water Resources Data for Tennessee, Water Year 1985, Report No. USGS/WRD/HD-86, U.S. Geological Survey, Nashville, Tennessee, 1986. J. F. Lowery, P. H. Counts, H. L. Edmiston, and F. D. Edwards. Water Resounces Data for Tennessee, Wa er Year 1986, Report No. USGS/WRD/HD-87/225, U. S. Geological Survey, Nashville, Tennessee, 1987. Oak Ridge National Laboratory Department of Environmental Monitoring and Compliance, unpublished data. 
Branch was dry for an even longer period in 1987, discharges from the HFIR were substantially reduced following shutdown of the reactor in November 1987.

The hydrology of the headwater region of WOC above ORNL could be expected to differ from that of upper Melton Branch due to differences in the geologies of the two areas. For example, drainage basins underlain by limestone and dolomite generally have higher unit-area low-flow discharges than those underlain by sandstone and shale (McMaster 1967). Although extended periods of zero discharge occurred in upper Melton Branch and Northwest Tributary, no periods of zero flow have been observed at WCK 6.8 north of Bethel Valley Road or at sites near the headwaters of other tributaries, such as First Creek and Fifth Creek, which also originate in the Knox Dolomite of Chestnut Ridge. The watershed area of upper WOC at WCK 6.8 is $2.07 \mathrm{~km}^{2}$ and is similar in size to that of upper Melton Branch at the USGS gaging station $\left(1.35 \mathrm{~km}^{2}\right)$. Several extended periods of no flow occurred during the summer of 1979 in a reach of WOC just north of Bethel Valley Road near WCK 6.3 (Loar et al. 1981).

As in lower Melton Branch, streamflow in WOC below ORNL is augmented by discharges from various facilities (Sect. 2.2.1). Low-flow measurements have shown that $-90 \%$ of the dry-weather discharge of the creek originates as groundwater discharge from the Knox Dolomite of Chestnut Ridge, from the Chickamauga Limestone of Bethel Valley, and from ORNL plant effluent (McMaster 1967). Plant effluent provides a substantial portion of the flow in lower WOC, but the magnitude of this contribution cannot be accurately assessed without data on streamflows in upper WOC. (A USGS gaging station near WCK 6.8 is presently under construction.)

An indirect estimate of the relative importance of flow augmentation can be obtained from the coefficient of variation (C.V.) of stream discharge (Table 2-2). The C.V. is defined as the sample standard deviation (s.d.) expressed as a percentage of the sample

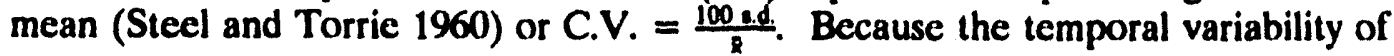
effluent discharges is usually much lower than that of natural streamflows, streams with substantial flow augmentation exhibit a much lower C.V. (or higher flow constancy) than streams without flow augmentation. For example, in natural streams, such as Bear Creek and upper Melton Branch, the C.V. usually ranges from 200 to $400 \%$, but streams that receive plant discharges generally have a C.V. of $<200 \%$ and usually $<100 \%$. For streams in WOC watershed, the C.V. in 1987 ranged from $25 \%$ in Northwest Tributary, where all the flow during much of the summer and early fall was due to discharges from the 1500 area (Sect. 2.2.1), to 105\% in First Creek. The high C.V. of the mean annual flow in lower Melton Branch (238\%), relative to that of other flow-augmented streams, probably reflects the intermittent or batch discharge of effluent from the process waste ponds and from the HFIR cooling towers (Sect. 2.2.1).

Low flow upstream and flow augmentation downstream dominated the hydrographs for Melton Branch and WOC in 1985-87, and high flows occurred infrequently (Fig. 2-3). There were eight major storms ( $>5 \mathrm{~cm}$ of precipitation in $24 \mathrm{~h}$ ) during this 3-year period, but only one had a recurrence interval greater than 1.5 years. The maximum $24-\mathrm{h}$ rainfall for the period 1985-87 occurred on August 16-17, 1985, when $10.9 \mathrm{~cm}$ of rain was recorded at the ATDL in Oak Ridge (NOAA 1985, 1986, 1987b). A storm of this magnitude has a recurrence interval of 3 years (Sheppard 1974, Fig. 2). 
Table 2-2. Comparison of the variability in mean daily discharge between streams with and without flow augmentation in 1987

Coefficient of variation (C.V.) $=100$ s.d./x

\begin{tabular}{|c|c|c|c|c|}
\hline Drainage/hite & $\begin{array}{l}\text { U.S. Geological Survey } \\
\text { site ID }\end{array}$ & $\begin{array}{l}\text { Drainage } \\
\text { area }\left(\mathrm{km}^{2}\right)\end{array}$ & $\begin{array}{l}\text { Mean annual } \\
\text { now }(L / s)^{b}\end{array}$ & C.V. \\
\hline $\begin{array}{l}\text { White Oak Creek } \\
\text { White Oak Creek kjlometer (WCK) } 3.9 \\
\text { WCK } 3.54 \\
\text { WCK } 2.65\end{array}$ & $\begin{array}{l}03536380 \\
03536550 \\
\times 14^{c}\end{array}$ & $\begin{array}{l}5.31 \\
8.50 \\
9.53\end{array}$ & $\begin{array}{l}116.4 \\
230.4 \\
227.7\end{array}$ & $\begin{array}{l}85.0 \\
73.0 \\
64.2\end{array}$ \\
\hline $\begin{array}{l}\text { Melton Branch } \\
\text { Melton Branch kilometer (MEK) } 1.93^{\circ} \\
\text { MEK } 0.16\end{array}$ & $\begin{array}{l}03537100 \\
\times 13^{c}\end{array}$ & $\begin{array}{l}1.35 \\
3.83\end{array}$ & $\begin{array}{l}10.1 \\
54.0^{d}\end{array}$ & $\begin{array}{l}398.5 \\
237.7\end{array}$ \\
\hline $\begin{array}{l}\text { First Creek } \\
\text { First Creek kilometer (FCK) } 0.2\end{array}$ & 03536450 & 0.85 & 15.2 & 105.4 \\
\hline $\begin{array}{l}\text { Northwest Tributary } \\
\text { Northwest Tributary kilometer (NTK) } 0.2\end{array}$ & 03536440 & 1.74 & 18.9 & 24.6 \\
\hline $\begin{array}{l}\text { East Fork Poplar Creek } \\
\text { East Fork Poplar Creek kilometer (EFK) } 5.3\end{array}$ & 03538250 & 50.5 & 991.8 & 109.3 \\
\hline $\begin{array}{l}\text { Bear Creeke } \\
\text { Bear Creek kilometer (BCK) } 6.24 \\
\text { BCK } 4.55 \\
\text { BCK } 3.88\end{array}$ & $\begin{array}{l}035382673 \\
03538270 \\
03538273\end{array}$ & $\begin{array}{r}8.29 \\
11.03 \\
12.95\end{array}$ & $\begin{array}{r}63.8 \\
110.6 \\
119.3\end{array}$ & $\begin{array}{l}300.2 \\
209.1 \\
292.6\end{array}$ \\
\hline $\begin{array}{l}\text { Bear Creek tributariesef } \\
\text { North Tributary } 14(6.24) \\
\text { North Tributary } 15(5.32) \\
\text { East Tributary } 1 \text { (4.07) }\end{array}$ & $\begin{array}{l}035382672 \\
035382677 \\
03538272\end{array}$ & $\begin{array}{l}0.78 \\
0.36 \\
0.36\end{array}$ & $\begin{array}{l}5.3 \\
2.6 \\
2.2\end{array}$ & $\begin{array}{l}368.0 \\
345.3 \\
309.8\end{array}$ \\
\hline
\end{tabular}

-Site designations refer to the distance in kjlometers $(\mathrm{km})$ above the mouth of the stream.

based on mean discharge for $249 \mathrm{~d}$ at WCK 2.65 and MEK 0.16; $254 \mathrm{~d}$ at NTK 0.2; $334 \mathrm{~d}$ at FCK 0.2; $364 \mathrm{~d}$ at

NT 14; and $365 \mathrm{~d}$ at WCK 3.9, EFK 5.3, and BCK 6.24; and $360 \mathrm{~d}$ at the remaining nine sites.

'Discharge data at this site are collected by the ORNL Department of Environmental Monitoring and Compliance.

Value is based on one discharge measurement each day, excluding weekends and holidays.

eStream has no flow augmentation at this location.

focation of the confluence with Bear creek (in kilometers) is given in parentheses.

Note: East Fork Poplar Creek and Bear Creek are located just north of Chestnut Ridge at the east and west end, respectively, of the Oak Ridge Y-12 Plant.

\section{WATER QUALTY}

ORNL is centrally located in upper WOC watershed (Fig. 2-1). Although most of the ORNL complex is situated in Bethel Valley, some facilities are located in Melton Valley (Fig. 2-3). Both WOC and several tributaries (First Creek, Fifth Creek, and Northwest Tributary) are located within or adjacent to the main plant area and receive effluents from various ORNL operations. 


\subsubsection{Description of ORNL Effluent Discharges}

Wastewater discharges at ORNL are generated by the operation of nuclear reactors, chemical pilot plants, research laboratories, iddioisotope production laboratories, and various support facilities. Such discharges include sanitary wastewater, coal yard runoff and ash washwater, process wastewaters, cocling system wastewaters (once-through cooling water and cooling tower blowdown), and storm drainage (EPA 1986). Approximately 30\% and $36 \%$ of the estimated total effluent discharge volume are contributed by the cooling and process systems respectively; discharges from the sewage treatment plant (STP), the steam plant, and leakage constitute the remainder of the discharges in approximately equal proportions (Kasten 1986, Table 5).

There are ten major effluent discharges that enter WOC either directly or indirectly via several tributaries (Table 2-3). Direct discharges to WOC, as listed in Table 2-3 and shown in Fig. 2-4, are largely restricted to a $1.5-\mathrm{km}$ reach of the creek that flows west along the southern peririster of ORNL (Fig. 2-2). Effluents are discharged to Melton

Table 2-3. Description of the ten major effivent discharges regulated under the Oak Ridge National Laboratory National Pollutant Discharge Elimination System permit issued on April 1, 1986

\begin{tabular}{|c|c|c|c|}
\hline $\begin{array}{l}\text { Receiving } \\
\text { stream }\end{array}$ & $\begin{array}{c}\text { Source of } \\
\text { effluent discharge }\end{array}$ & $\begin{array}{c}\text { NPDES } \\
\text { outfall No. }^{b}\end{array}$ & $\begin{array}{l}\text { Average flow } \\
\text { rate }(\mathrm{L} / \mathrm{s})^{c}\end{array}$ \\
\hline Fifth Creek & $O R^{d}$ resin regeneration facility & $\mathbf{X} 10$ & $0.4(0.01)^{e}$ \\
\hline Melton Branch & $\begin{array}{l}\text { TRU }^{d} \text { process waste basins } \\
\text { HRIR }{ }^{d} \text { proce:s waste basins }\end{array}$ & $\begin{array}{l}\text { X08 } \\
\text { X09 }\end{array}$ & $\begin{array}{l}2.2(0.08)^{e} \\
7.0(0.25)^{d}\end{array}$ \\
\hline Northwest Tributary & 1500 area & X03 & $0.3(0.01)$ \\
\hline White Oak Creek & $\begin{array}{l}\text { Sewage Treatment Plant } \\
\text { Coal Yard Runoff Treatment Facility } \\
2000 \text { area } \\
3539 \text { and } 3540 \text { ponds } \\
354 \text { Process Waste Treatment Plant } \\
3519 \text { Acid Neutralization Facility }\end{array}$ & $\begin{array}{l}\text { X01 } \\
\text { X02 } \\
\text { X04 } \\
\text { X06 } \\
\text { X07 } \\
\text { X11 }\end{array}$ & $\begin{array}{c}10.1(0.36)^{\gamma} \\
1.0(0.04)^{f} \\
0.6(0.02) \\
5.9(0.21)^{e} \\
7.9(0.28)^{f} \\
1.8(0.06)^{e}\end{array}$ \\
\hline
\end{tabular}

Discharge locations are illustrated in Fig. 2-4 of this document (ORNL/TM-10804).

${ }^{b}$ No outfall X05 exists. Outfall X12 is the planned discharge from the Nonradiological Wastewater Treatment Facility scheduled for completion in 1989 with a March 1990 date for compliance and an estimated average flow rate of $22 \mathrm{~L} / \mathrm{s}\left(0.8 \mathrm{ft}^{3} / \mathrm{s}\right)$.

'Discharge in cubic feet per second in parentheses. For batch ojerations, average flow rate is based on days when waste is discharged. Reactor.

${ }^{d}$ ORR = Oak Ridge Reactor; TRU = Transuranium Processing Facility; HFIR = High Flux Isotope

${ }^{\text {E}}$ Batch discharge with frequencies of once ev'ry $5 \mathrm{~d}$ (X08), three times per month (X09), once every 5-8 d (X10), and three batches per day (X11). Discharge X06 is batch if radioactivity is below predetermined levels.

Maximum flow rates are $32.9 \mathrm{~L} / \mathrm{s}\left(1.16 \mathrm{ft}^{3} / \mathrm{s}\right)$ at X01, $9.6 \mathrm{~L} / \mathrm{s}\left(0.34 \mathrm{ft}^{3} / \mathrm{s}\right)$ at X02, and $18.8 \mathrm{~L} / \mathrm{s}\left(0.67 \mathrm{ft}^{3} / \mathrm{s}\right)$ at X07.

Source: Authorization to Discharge Under the National Pollusant Discharge Elimination System, Permit No. TN0002941, Oak Ridge National Leboratory, Fact Sheet, U.S. Environmental Protection Agency, Region IV, Atlanta, April 1, 1986. 

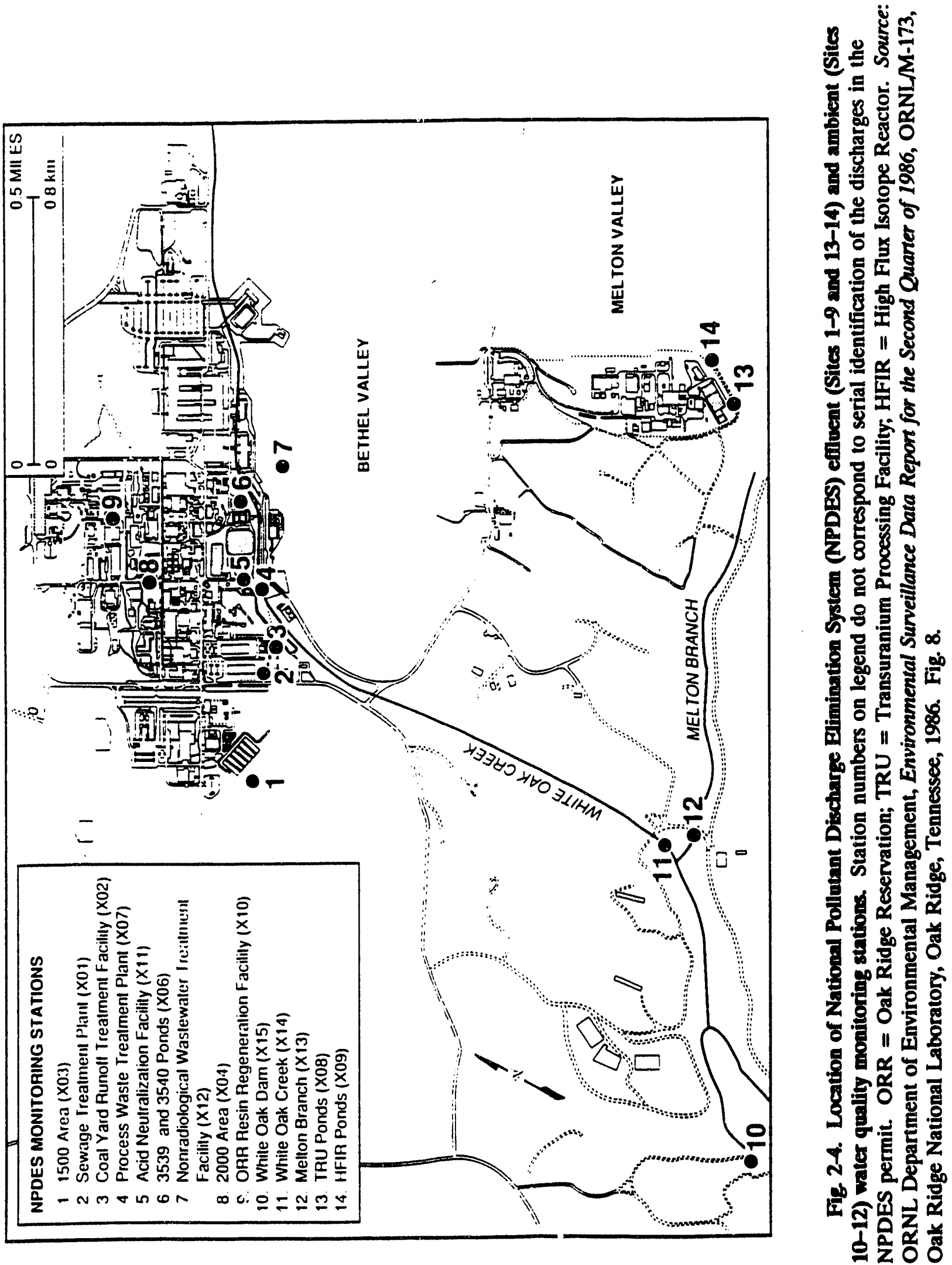
Branch via a small tributary near MEK 1.4, whereas discharges to Northwest Tributary from the $\mathbf{1 5 0 0}$ area and to Fifth Creek from the Oak Ridge Reactor are located above Northwest Tributary kilometer (NTK) 0.3 and just below Fifth Creek kilometer (FFK) 0.4 respectively (Figs. 2-2 and 2-4).

In addition to these major waste streams, there are 127 outfalls that also discharge to streams in WOC watershed, including Fifth Creek, First Creek, Melton Branch, and WOC (Table 2-4). These include (1) 34 noncontaminated storm drains (identified as Category 1 outfalls in the NPDES permit); (2) 61 drains that have been contaminated by ORNL

Table 2-4. Number and location (receiving stream) of category I, II, and III outfalls that discharge to White Oak Creek and tributaries

See text for complete description of each category

\begin{tabular}{lccccc}
\hline \multicolumn{1}{c}{ Type } & White Oak Creek & Fifth Creek & First Creek & Melton Branch & Total \\
\hline $\begin{array}{l}\text { Category I } \\
\text { Storm drains }\end{array}$ & 16 & 13 & 4 & 1 & 34 \\
Category II & & & & & \\
$\quad$ Parking lot drains & 27 & 6 & 8 & 3 & 44 \\
Storage area drains & 0 & 0 & 2 & 0 & 2 \\
Spill area drains & 1 & 0 & 0 & 0 & 1 \\
$\quad$ Cooling tower blowdown & 2 & 3 & 0 & 1 & 6 \\
$\quad$ Condensate & 4 & 4 & 0 & 0 & 8 \\
Category III & & & & & \\
$\quad$ Process drains & 14 & 8 & 4 & 6 & 32 \\
\hline
\end{tabular}

asettling ponds.

Source: DEM [(Department of Environmental Management), name changed in 1987 to DEMC (Department of Environmental Monitoring and Compliance)]. 1986. Environmental surveillance data report for the second quarter of 1986. ORNL/M-173. Oak Ridge National Laboratory, Oak Ridge, Tennessee.

operations (Catcgory II outfalls), including drains of roofs, parking lots, and storage/spill areas, once-through cooling water, cooling tower blowdown and condensate; and (3) 32 untreated process drains (Category III outfalls) that are contaminated by pollutants because of inflow/infiltration, cross-connections, or improper disposal of chemicals (DEM 1986a, EPA 1986).

Cooling system wastewater, a Category II outfall, is a major component, by volume, of the total effluent discharged by ORNL operations. Waste heat from reactors, particle accelerators, evaporators, environmental control systems, process systems, research laboratories, engineering-scale development facilities, and space-heating condensates is treasferred to once-through cooling water or dissipated to the atmosphere via 26 wetevaporative, mechanical-draft cooling towers (Boyle et al. 1982, Kasten 1986). Seven mechanical-draft cooling towers discharge the principal heat burden generated by the 
operation of ORNL facilities, and an additional 19 smaller towers operate intermittently to meet lesser demands (Boyle et al. 1982). Total blowdown from all cooling towers is $\sim 16.2 \mathrm{~L} / \mathrm{s}$ (Kasten 1986), of which an average of $\sim 6.9 \mathrm{~L} / \mathrm{s}$ is discharged to Melton Branch from operation of the HFIR, 3.3 L/s to Fifth Creek from operation of the Oak Ridge Reactor, and $3.8 \mathrm{~L} / \mathrm{s}$ to WOC from the Building 4500 cooling tower (Boyle et al. 1982, Table 2.12). Occasionally, the blowdown may contain radionuclides, thus requiring diversion to the diversion to the Process Waste Treatment Plant (PWTP) prior to discharge. Normally, however, cooling tower blowdown is discharged directly or indirectly via the storm sewer system to area streams.

\section{Wastewater Modifications for Pollution Abatement}

Several pollution abatement measures were implemented recently, and more are planned over the next several years as part of the ORNL WPCP (Sect. 10). The sewage treatment plant was upgraded in August 1985. A new coal yard runoff treatment facility became operational in early March 1986, and new demineralizer systems were installed at the HFIR and Oak Ridge Reactor in August 1986. One of the most significant components of the WPCP is construction of the Nonradiological Wastewater Treatment Facility (NRWTF). Scheduled for completion in 1989, the facility will treat effluents that are currently (1) untreated and discharged directly to area streams, (2) untreated but discharged to process waste basins prior to release, or (3) treated by existing facilities. The NRWTF will collect and treat NPDES serial discharges X03 through X10; discharge X11 will be treated by either NRWTF or the Coal Yard Runoff Treatment Facility (Table 2-3). Additional pollution abatement projects and programs are described in Sect. 10.

\subsection{NPDES Water Quality Monitoring Program}

Water quality in WOC and Melton Branch is influenced both by point-source discharges from ORNL facilities (Sect. 2.2.1) and by area-source discharges from waste disposal areas, such as the solid radioactive waste disposal/storage areas (SWSAs), former liquid radioactive waste disposal/storage areas (pits and trenches), and inactive process waste basins (Fig. 2-2). The discharge to area streams of leachates from waste disposal areas has been documented by Stueber et al. (1981) for Northwest Tributary (from SWSA 3) and by Cerling and Spalding (1982) for WOC (SWSA 4), Melton Branch (SWSA 5), and WOL (SWSA 6). A characterization of ambient water quality downstream of all point-source discharges and most major area sources is presented in Table 2-5. It is based on routine NPDES monitoring conducted in 1987 at sites MEK 0.16 and WCK 2.65 (NPDES sites X13 and X14 respectively), although data collected from sites on upper WOC and Melton Branch above ORNL and at White Oak Dam (X15) are included for comparative purposes. Routine radiological monitoring is also conducted at the three NPDES ambient stations and other sites on Melton Branch just below the HFIR, First Creek, Fifth Creek, Northwest Tributary, Raccoon Creek, and WOC at WCK 3.41 (Fig. 2-2). These data are collected either daily or weekly and are published quarterly by ORNL Department of Environmental Monitoring and Compliance (DEMC).

Water quality in lower WOC, as characterized by the NPDES monitoring program, consisted of (1) moderate levels of dissolved solids and occasionally high levels of turbidity, 


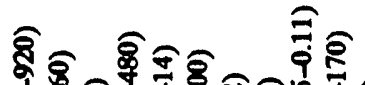
䓎

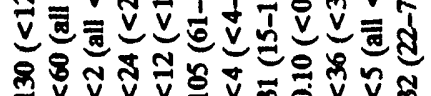

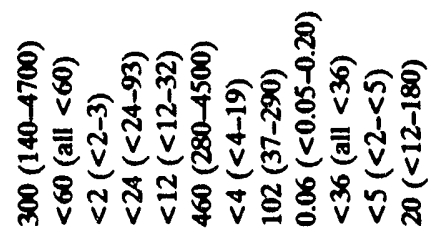

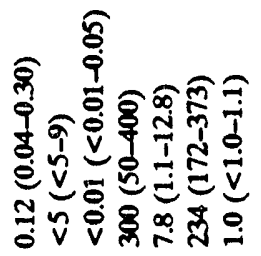

ง

v v v v

ฐิ

之全㖓呈

ริธิที่งิที่

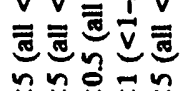
ทั่จิที่

จิ

항

z号守号文

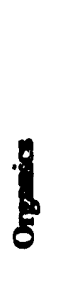

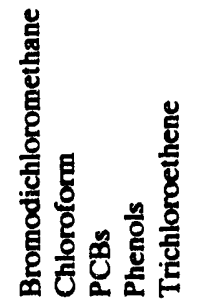

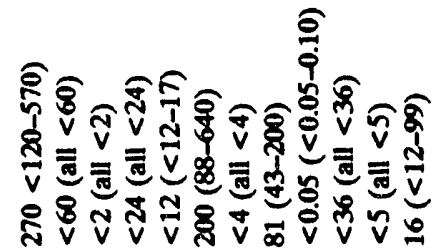

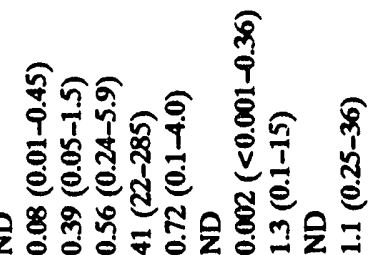

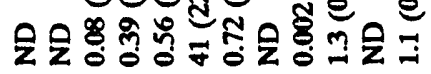

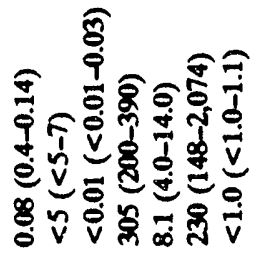

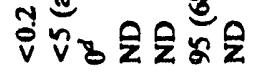

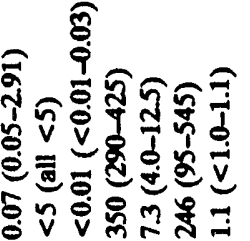

สู่<smiles>[Li]</smiles>

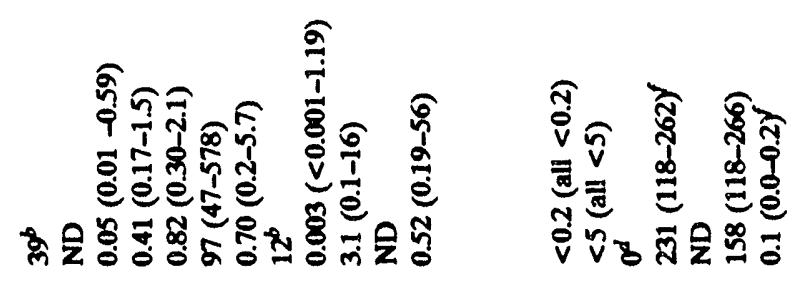

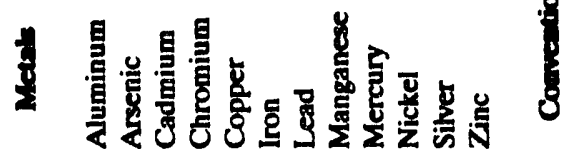

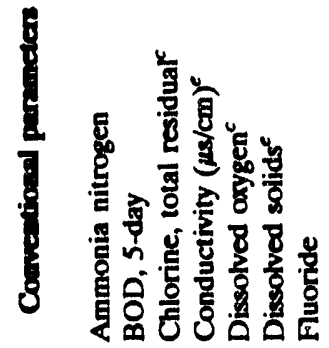




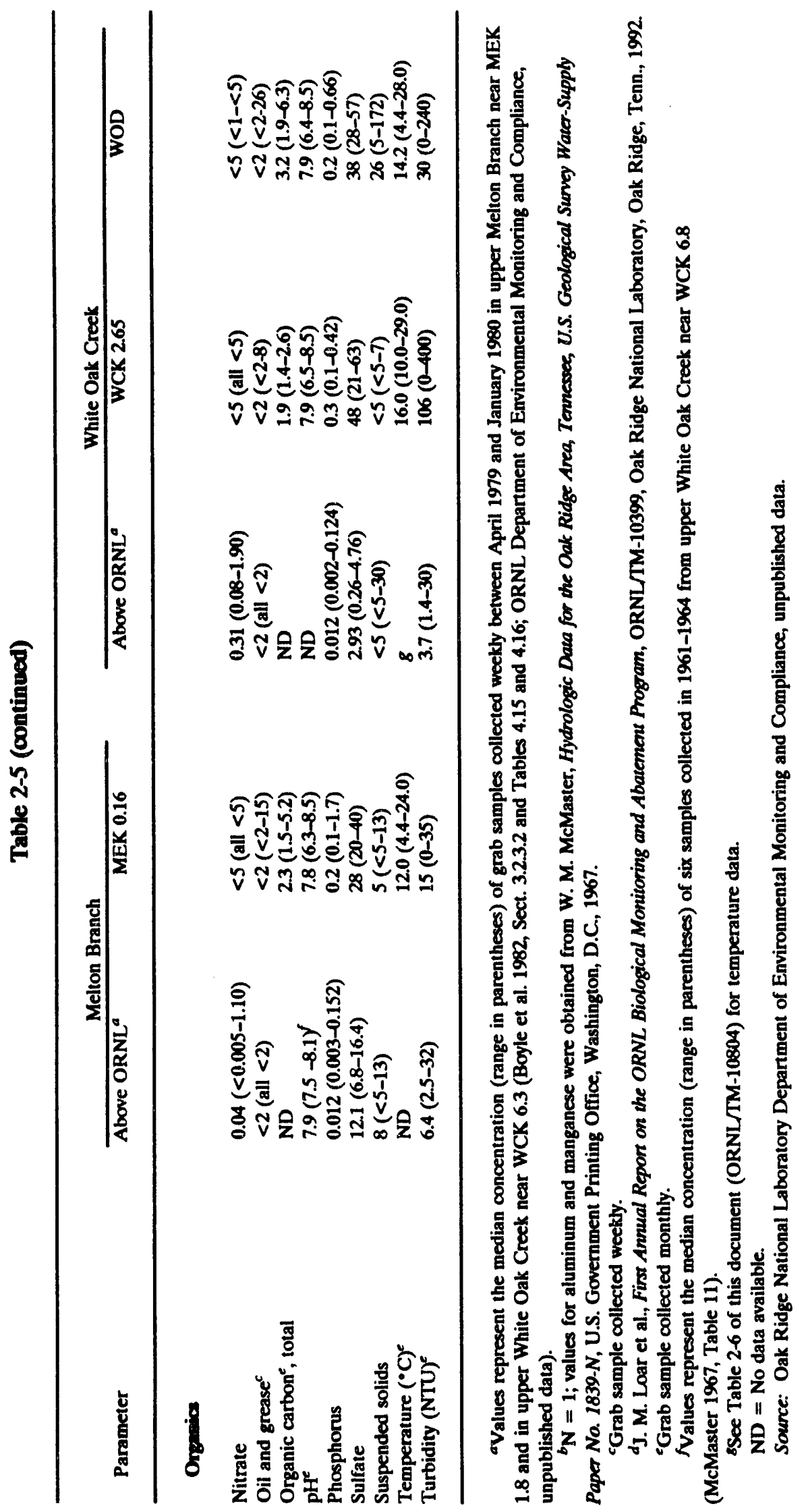


(2) elevated concentrations of most metals, (3) low concentrations of organics, (4) moderate phosphorus enrichment, (5) periods of low ( $<5 \mathrm{mg} / \mathrm{L}$ ) dissolved oxygen (Table 2-5), and (6) high temperatures (Fig. 2-5). Although concentrations of trace elements in WOC below ORNL exceeded the levels observed in the unimpacted upper reaches of the stream, most did not exceed EPA water quality criteria for freshwater aquatic life (EPA 1976, 1980a). Concentrations of iron in 1 of 12 samples from WCK 2.65 and 3 of 12 samples from White Oak Dam (WOD) exceeded the criterion of $1000 \mu \mathrm{g} / \mathrm{L}$ (EPA 1976). The maximum mercury concentration at WOD exceeded the criterion of $0.14 \mathrm{mg} / \mathrm{L}$ for protection of human health from ingestion of organisms and water (EPA 1980a). The detection limits for $\mathrm{Cd}, \mathrm{Cu}, \mathrm{Ni}, \mathrm{Ag}$, and PCBs exceeded the criteria either for average concentration or for protection of human health on most sampling dates. Based on the results of ambient toxicity testing (Sect. 3.1.2), however, it is unlikely that concentrations of these elements exceeded levels that would be toxic to biota.

The water quality of WOC in 1987 was much the same as in 1986 (Loar et al. 1992). Concentrations of iron and mercury exceeding EPA criteria were observed in both years in either WOC or at WOD. The greatest change between the 2 years was a tenfold increase in turbidity in 1987 . The greater turbidity probably reflects a general increase in construction activity associated with various WPCP and Remedial Action Program (RAP) projects. The only other parameter that exhibited a greater than twofold change between 1986 and 1987 was phosphorus, where the median concentration decreased from $0.63 \mathrm{mg} / \mathrm{L}$ in 1986 to $0.30 \mathrm{mg} / \mathrm{L}$ in 1987.

Temperatures in WOC below ORNL (WCK 2.65) are significantly higher than the temperatures in upper WOC north of Bethel Valley Road (Fig. 2-5). During the summer and fall of 1987 , temperatures at the downstream site were generally 7 to $10^{\circ} \mathrm{C}$ higher than those at WCK 6.8 (Table 2-6). Although some increase in downstream temperatures would be expected due to the absence of a riparian canopy in the $1.5-\mathrm{km}$ reach of stream adjacent to the plant complex, plant operations probably account for much of the longitudinal gradient in water temperature (average of $2^{\circ} \mathrm{C} / \mathrm{km}$ ). Cooling tower blowdown and condensate are discharged to WOC and several tributaries (Table 2-4), and most of the streams show higher temperatures downstream of these outfalls (Fig. 2-6).

Unlike WOC, a significant improvement in water quality occurred in Melton Branch between 1986 and 1987. The median sulfate concentration decreased from 306 to $28 \mathrm{mg} / \mathrm{L}$ (maximum levels declined from 1065 to $40 \mathrm{mg} / \mathrm{L}$ ), and phosphorus levels exhibited a fourfold decrease from 1986 to 1987 . Dissolved solids and conductivity also decreased by $-50 \%$. Reductions in stream temperatures were also evident; whereas temperatures in Melton Branch consistently exceeded those in WOC throughout the summer of 1985, the reverse was true in 1987 (Fig. 2-7). Maximum temperatures in Melton Branch at MEK 0.16 approached $38^{\circ} \mathrm{C}$ in 1986 (Loar et al. 1987, Fig. 2-6) but did not exceed $30^{\circ} \mathrm{C}$ in 1987 (Table 2-6).

The improvement in water quality was associated with shutdown of the HFIR in November 1986 and a subsequent reduction in cooling tower blowdown and in discharges from the HFIR process ponds (Fig. 2-2). The HFIR is the largest of the five ORNL 


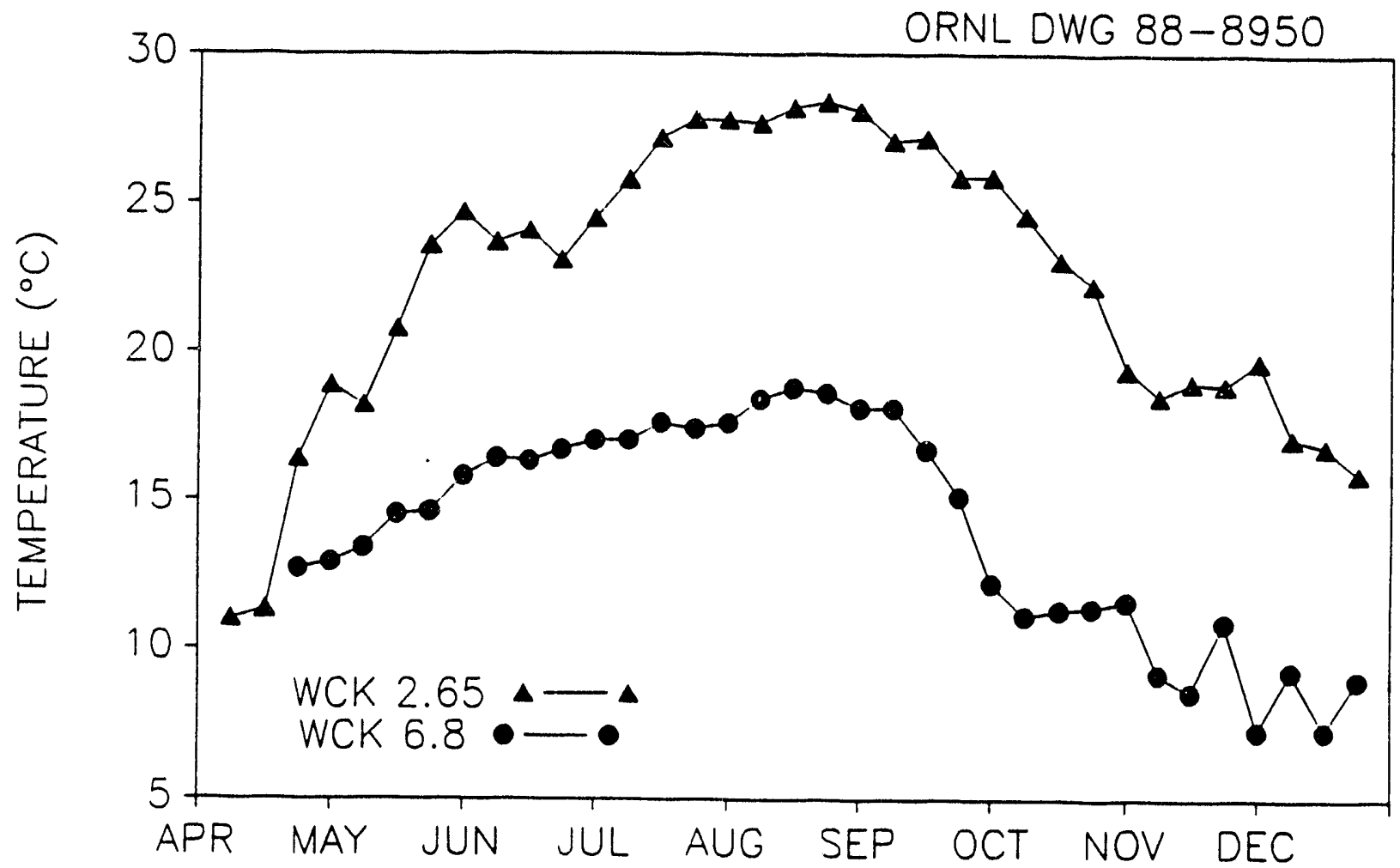

Fig. 2-5. Mean weekly temperatures in White Oak Creek at sices above and below Oak Ridge National Laboratory [White Oak Creet kilometer (WCK) 68 and WCK 265 respectiveby], Aprit-December 1987 . At WCK 6.8, temperature data were obtained hourly with a Ryan Tempmentor digital thermograph. At WCK 2.65 (National Pollutant Discharge Elimination System station X14), weekly values were based on average hourly temperatures computed from data collected at 10-min intervais with a real-time monitoring system. Source: Department of Environmental Monitoring and Compliance, unpublished data. 
Table 2-6. Mean ( \pm 8.d.) monthly water temperatures $\left({ }^{\circ} \mathrm{C}\right)$ in White Oak Creek and tributaries, including First Creek, Fifth Creek, Melton Branch, and Northwest Tributary, May-November 1987

Absolute maximum and minimum temperatures are given parentheses

\begin{tabular}{|c|c|c|c|c|c|c|c|}
\hline Site & May & June $^{b}$ & July & August & September & October & November \\
\hline FCK 0.1 & ND & $\begin{array}{l}20.5 \pm 1.5 \\
(17.1-24.8)\end{array}$ & $\begin{array}{l}22.1 \pm 1.6 \\
(19.0-26.7)\end{array}$ & $\begin{array}{l}21.3 \pm 1.7 \\
(17.5-25.0)\end{array}$ & $\begin{array}{l}19.9 \pm 1.8 \\
(16.0-24.0)\end{array}$ & $\begin{array}{l}15.5 \pm 1.8 \\
(11.9-19.6)\end{array}$ & $\begin{array}{l}14.1 \pm 2.1 \\
(10.0-19.5)\end{array}$ \\
\hline FCK 0.8 & ND & $\begin{array}{l}18.4 \pm 1.6 \\
(15.1-24.0)\end{array}$ & $\begin{array}{l}20.8 \pm 3.2 \\
(15.9-31.0)\end{array}$ & $\begin{array}{l}18.4 \pm 1.9 \\
(15.1-24.1)\end{array}$ & $\begin{array}{l}17.9 \pm 2.4 \\
(12.4-27.8)\end{array}$ & $\begin{array}{l}13.1 \pm 1.8 \\
(8.4-17.5)\end{array}$ & $\begin{array}{l}11.9 \pm 2.0 \\
(8.0-16.4)\end{array}$ \\
\hline FFK 0.2 & ND & $\begin{array}{l}20.2 \pm 2.1 \\
(16.2-35.0)\end{array}$ & $\begin{array}{l}22.8 \pm 2.9 \\
(17.9-35.0)\end{array}$ & $\begin{array}{l}23.0 \pm 1.9 \\
(19.8-31.0)\end{array}$ & $\begin{array}{l}20.0 \pm 1.0 \\
(17.7-23.2)\end{array}$ & $\begin{array}{l}17.4 \pm 1.3 \\
(14.5-20.9)\end{array}$ & $\begin{array}{l}16.5 \pm 1.4 \\
(14.0-21.0)\end{array}$ \\
\hline FFK 1.0 & ND & $\begin{array}{l}15.0 \pm 0.4 \\
(14.0-16.9)\end{array}$ & $\begin{array}{l}15.3 \pm 0.4 \\
(14.8-16.3)\end{array}$ & $\begin{array}{l}15.5 \pm 0.4 \\
(14.9-16.9)\end{array}$ & $\begin{array}{l}15.1 \pm 0.6 \\
(13.7-17.0)\end{array}$ & $\begin{array}{l}13.0 \pm 1.0 \\
(10.0-15.2)\end{array}$ & $\begin{array}{l}12.1 \pm 1.4 \\
(9.2-15.3)\end{array}$ \\
\hline NTK 0.3 & ND & $\begin{array}{l}22.9 \pm 1.1 \\
(20.0-25.6)\end{array}$ & $\begin{array}{l}23.9 \pm 1.0 \\
(21.5-26.1)\end{array}$ & $\begin{array}{l}23.7 \pm 0.9 \\
(21.3-25.9)\end{array}$ & $\begin{array}{l}20.4 \pm 2.4 \\
(14.9-25.7)\end{array}$ & $\begin{array}{l}13.8 \pm 2.5 \\
(7.3-21.1)\end{array}$ & $\begin{array}{l}12.7 \pm 2.7 \\
(7.1-17.6)\end{array}$ \\
\hline NTK 1.0 & ND & $\begin{array}{l}19.4 \pm 1.9 \\
(12.8-24.7)\end{array}$ & $\begin{array}{l}22.2 \pm 3.2 \\
(14.2-31.0)\end{array}$ & $\begin{array}{l}21.6 \pm 2.2 \\
(14.8-27.5)\end{array}$ & Dry & Dry & Dry \\
\hline MEK $0.16^{d}$ & $\begin{array}{l}21.8 \pm 1.1 \\
(17.4-25.8)\end{array}$ & ND & $\begin{array}{l}24.1 \pm 1.1 \\
(19.8-29.2)\end{array}$ & $\begin{array}{l}24.5 \pm 1.3 \\
(18.9-28.7)\end{array}$ & $\begin{array}{l}19.8 \pm 2.1 \\
(13.8-24.7)\end{array}$ & $\begin{array}{l}12.5 \pm 2.2 \\
(5.7-18.1)\end{array}$ & $\begin{array}{l}9.8 \pm 2.7 \\
(2.1-15.6)\end{array}$ \\
\hline MEK $1.4^{e}$ & ND & $\begin{array}{l}20.9 \pm 2.5 \\
(16.5-36.0)\end{array}$ & $\begin{array}{l}20.8 \pm 1.2 \\
(17.2-23.7)\end{array}$ & $\begin{array}{l}24.9 \pm 1.7 \\
(20.8-28.1)\end{array}$ & $\begin{array}{l}22.7 \pm 2.6 \\
(17.8-27.4)\end{array}$ & $\begin{array}{l}16.4 \pm 2.3 \\
(10.0-23.1)\end{array}$ & $\begin{array}{l}14.8 \pm 3.1 \\
(7.8-23.7)\end{array}$ \\
\hline WCK $2.65 f$ & $\begin{array}{l}22.6 \pm 1.9 \\
(15.6-29.0)\end{array}$ & $\begin{array}{l}26.1 \pm 1.0 \\
21.9-30.1)\end{array}$ & $\begin{array}{l}27.9 \pm 0.3 \\
(24.8-30.6)\end{array}$ & $\begin{array}{l}27.5 \pm 0.8 \\
(20.0-30.3)\end{array}$ & $\begin{array}{l}24.2 \pm 1.5 \\
(20.1-28.2)\end{array}$ & $\begin{array}{l}19.1 \pm 0.9 \\
(15.2-22.7)\end{array}$ & $\begin{array}{l}17.5 \pm 1.6 \\
(12.6-22.4)\end{array}$ \\
\hline WCK 6.8 & $\begin{array}{l}15.4 \pm 1.5 \\
(11.4-18.8)\end{array}$ & $\begin{array}{l}16.8 \pm 1.2 \\
(13.5-19.6)\end{array}$ & $\begin{array}{l}17.8 \pm 1.3 \\
(14.9-21.4)\end{array}$ & $\begin{array}{l}18.4 \pm 1.3 \\
(14.7-21.6)\end{array}$ & $\begin{array}{l}16.5 \pm 1.7 \\
(12.3-20.0)\end{array}$ & $\begin{array}{l}11.5 \pm 2.1 \\
(6.4-16.5)\end{array}$ & $\begin{array}{l}10.1 \pm 2.8 \\
(3.7-16.6)\end{array}$ \\
\hline
\end{tabular}

aData were obtained at 2-h intervals using a Ryan-Peabody thermograph (Model J 90), except sites White Oak Creek kilometer (WCK) 6.8 and Melton Branch kjlometer (MEK) 1.4, where data were collected hourty with a Ryan-Tempmentor digital thermograph and sites MEK 0.16 and WCK 2.65, where tabular values are based on average hourly temperatures computed from data collected at 10 -min intervals with a real-time monitoring system.

$b_{27} \mathrm{~d}$ of record at all sites except MEK 1.4 and WCK 6.8 (30 d), and WCK 2.65 (18 d).

'Sites with <30 d of record included Fifth Creek (17 d), FCK 0.1 (18 d), FCK 0.8 (16 d), NTK 0.3 (19 d), MEK 0.16 (28 d), and WCK 2.65 (27 d).

${ }^{d}$ Days of record were: May (18 d); June (6 d); July (20 d); August (30 d); September (30 d); October (29 d); and November (28 d).

'Site is located just below the confluence of the HFIR tributary with Melton Branch; temperatures could not be measured at the upstream reference site near MEK 2.1 due to zero discharge (see Table 2-1).

'Days of record were: May (30 d); June (18 d); July (21 d); August (30 d); September (29 d); October (29 d); and November (27 d).

ND $=$ No data available. FCK $=$ First Creek kilometer, FFK $=$ Fifth Creek kilometer, NTK = Northwest Tributary kilometer, MEK $=$ Melton Branch kilometer, WCK $=$ White Oak Creek kilometer. data.

Source: Oak Ridge National Laboratory Department of Environmental Monitoring and Compliance, unpublished 

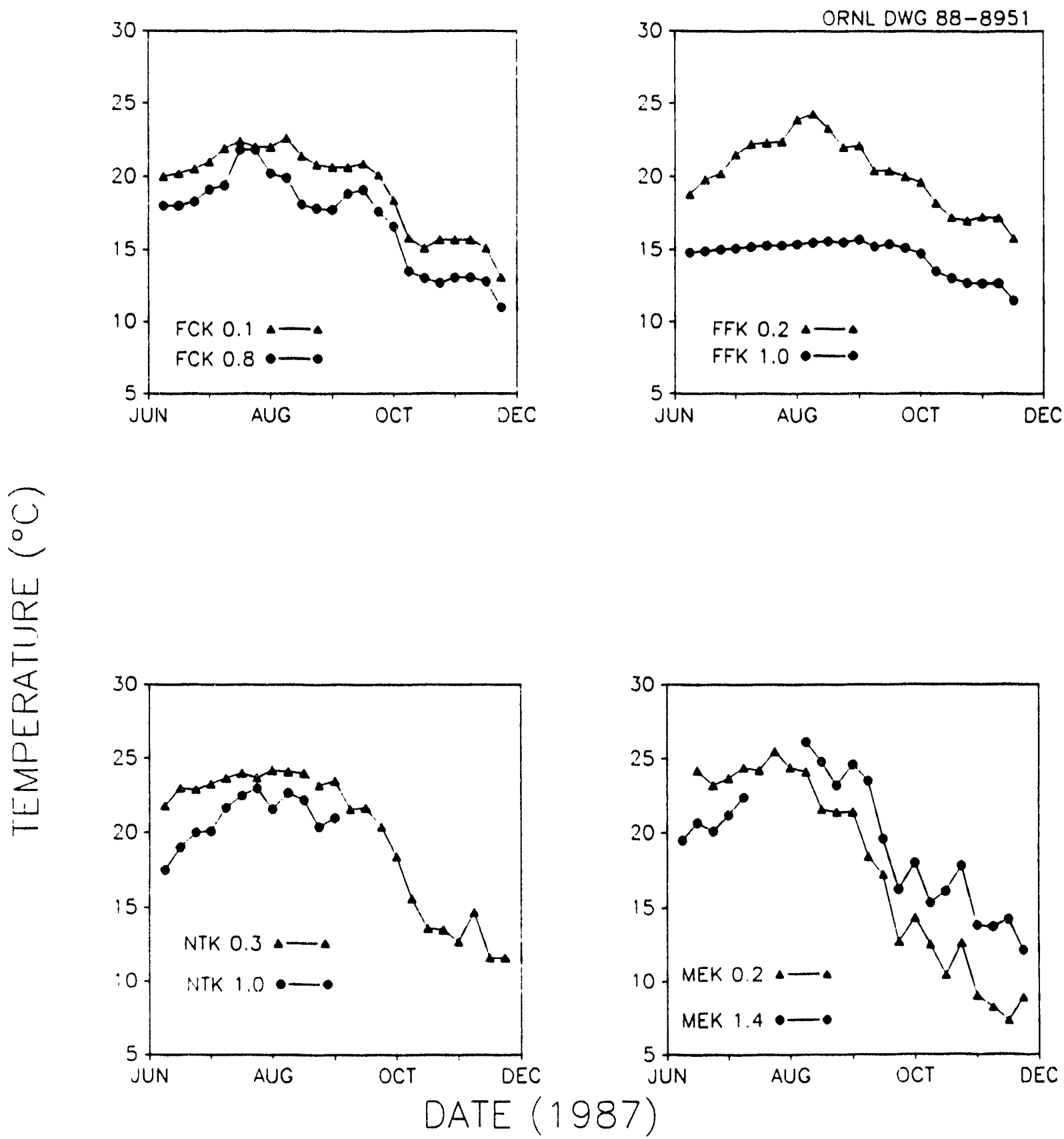

Fig. 2-6. Mean weekly temperatures in four tributaries of White Oak Creck, June-December 1987. Mean values were calculated from data obtained at 2-h intervals using a Ryan-Peabody thermograph (Mociel J90), except at site MEK 1.4, where data were collected hourly with a Ryan Tempmentor digital thermograph and at site MEK 0.2 (NPDES site X13), where weekly values were based on average hourly temperatures computed from data collected at 10 -min intervals with a real-time monitoring system. FCK = First Creek kilometer; FFK = Fifth Creek kilometer; NTK = Northwest Tributary kilometer, MEK = Melton Branch kilometer; NPDES = National Pollutant Discharge Elimination System.

Source: Department of Environmental Monitoring and Compliance, unpublished data. 

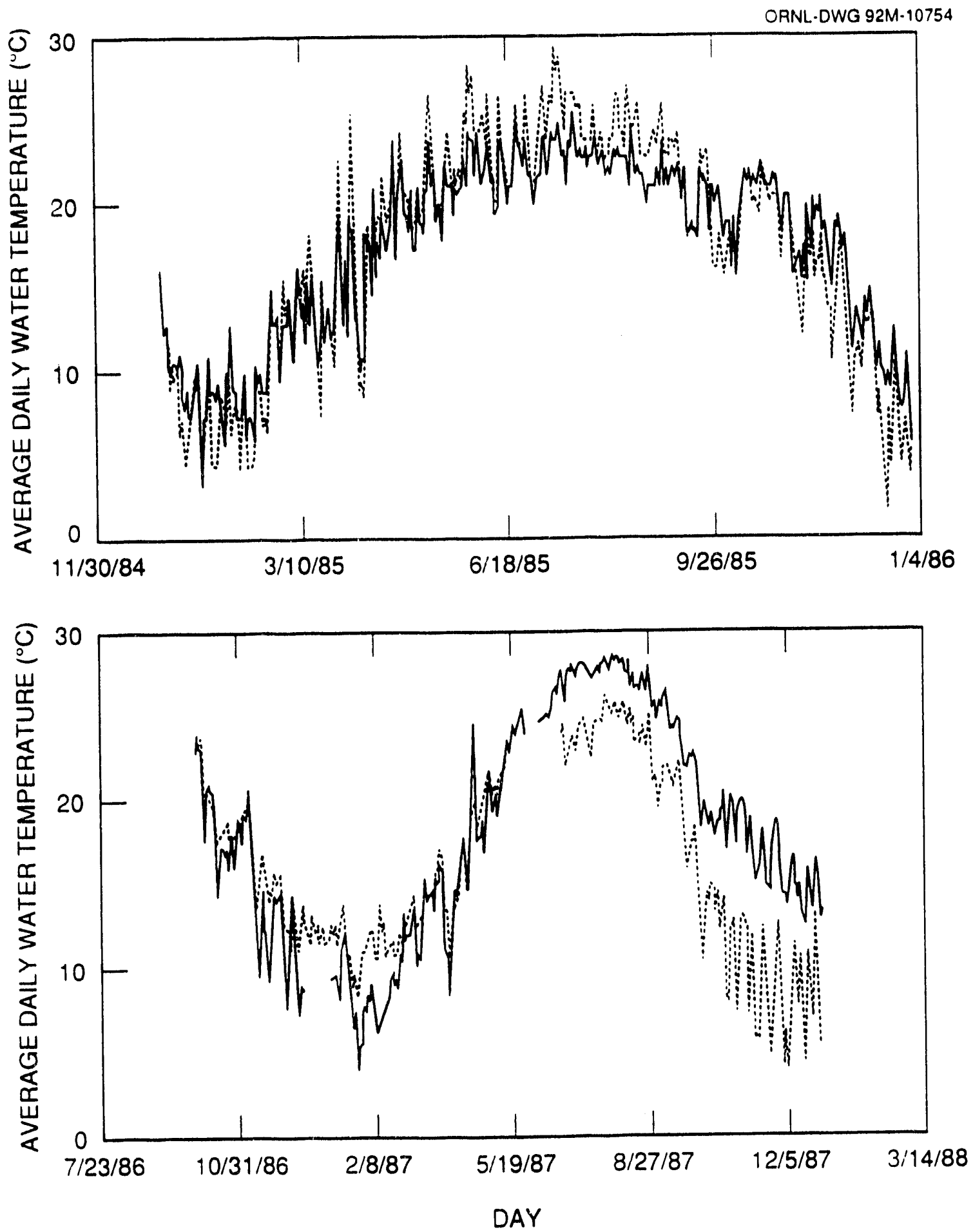

Fiz. 2-7. Water cemperatures at National Pollutant Discharge Elimination System monitoring stations X13, on lower Melton Branch (dashed line), and X14, on lower White Oak Creek (solid line) for January-December 1985 (top) and October 1986-December 1987 (bottom). Temperatures for 1985 represent a single daily measurement taken in the morning; temperatures in 1986-1987 represent a daily average computed from measurements taken at 10-min intervals with a real-time monitoring system. Source: Department of Environmental Monitoring and Compliance, unpublished data. 
reactors; the volume of blowdown from its cooling towers is twice that of any of the other four. Moreover, its chemical usage exceeds that of all the other cooling towers combined;the HFIR towers account for $77 \%$ of the sulfuric acid, $55 \%$ of the biocides, and $63 \%$ of the sodium phosphate used for cooling towers annually (Boyle et al. 1982, Table 2.2).

The dramatic shift in water quality in Melton Branch from 1986 to 1987 was due partly to the fact that most of the flow in lower Melton Branch in 1986 consisted of blowdown from the HFIR cooling towers. For much of the year, no flow occurred upstream of MEK 1.4 where HFIR discharges enter Melton Branch (Table 2-1). Although the four other ORNL reactors were eventually shut down in March 1987, no measurable effects on WOC water quality were observed. The average flow in WOC is four times greater than the flow in Melton Branch (Table 2-2), and the volume of the blowdown from all the cooling towers at the main ORNL complex is less than that of the HFIR. Moreover, the HFIR is the primary facility that discharges into Melton Branch. In contrast, there are numerous facilities producing a substantially greater volume of discharges to WOC. Consequently, a reduction in the HFIR discharges would be expected to have a greater impact on water quality recovery in Melton Branch than a similar reduction in the cooling tower discharges to WOC, which constitute a much smaller component of the total effluent discharges to the stream. Further assessment of the HFIR shutdown on water quality in Melton Branch is presented in the next section.

\subsection{BMAP Water Quality Sampling Program}

Aspects of water quality are an important component of the environment for aquatic organisms. Water quality parameters, such as $\mathrm{pH}$ and the concentrations of inorganic carbon, plant nutrients, and suspended solids, influence structural and functional aspects of attached algal and microbial communities (components of the "periphyton" on submersed surfaces). As an example, the rates of algal photosynthesis and accrual of primary-producer biomass are affected by the availability of nutrients, such as phosphorus and nitrogen, and the rate of sediment deposition on benthic surfaces. Other aspects of water quality, including the concentrations of potentially toxic metals and dissolved organic carbon, may affect the periphyton and so influence other biotic communities via food web connections.

Because such information is important for the evaluation of factors influencing biotic communities and for predicting the responses of these communities to remedial actions, a water quality monitoring program was initiated in August 1986 as a component of the periphyton community studies described in Subtask 1c of BMAP (see Sect. 3.2). This program consisted of the monthly collection of water samples (grab samples) at the ten periphyton sampling stations in WOC watershed (Sect. 3.2) and from nearby Ish Creek (Fig. 2-1). This program is intended to augment the continuous water quality monitoring conducted by the DEMC by providing information on water quality at additional sites of interest and on parameters not included in the NPDES monitoring program. The monthly "samples" of water quality provided by these discrete samples are useful in the interpretation of periphyton community function at the various study sites (see Sect. 3.2). 


\subsubsection{Methods}

Two 1-L grab samples of stream water were collected at each site at the time of collection of the monthly periphyton samples. The water samples were collected in acidwashed polyethylene bottles and taken to the laboratory within $1 \mathrm{~h}$ of collection. Samples for the determination of dissolved organic carbon (DOC) were collected in organic-free glass bottles with Teflon-sealed lids. The total amount of DOC was determined each month, and quarterly a subsample of this water was partitioned into hydrophilic and hydrophobic DOC fractions, which were again partitioned by molecular weight. One sample at each site was analyzed for several basic water quality parameters ( $\mathrm{pH}$, alkalinity, conductivity, hardness, and soluble metals). Analyses of the other parameters were performed on replicate samples. Analyses for $\mathrm{pH}$, alkalinity, hardness and conductivity were conducted within $2 \mathrm{~h}$ of collection. Samples for other analyses were preserved and/or frozen, according to approved methods (EPA 1983), until they could be analyzed. The methods for the parameters included in the BMAP water sampling program are listed in Table 2-7.

\section{2 .4 .2 Results}

Six sites served as reference sites, including five sites located upstream of ORNL operations (WCK 6.8, MEK 1.8, NTK 1.0, FCK 1.0, and FFK 1.1) and Ish Creek at the weir (Fig. 2-1). The five remaining sites were located downstream of ORNL. Upstream sites MEK 1.8, NTK 1.0, and Ish Creek were dry for several months during summer and fall of 1987 , but 12 months of data are available for all other sites. Water quality at all sites reflected the calcareous geology of this area, being moderately well buffered with a slightly alkaline $\mathrm{pH}$ (Table 2-8). The $\mathrm{pH}$, alkalinity, hardness, and conductivity were fairly similar for all sites; however, on a month to month basis, values for the upstream sites varied more than those at the downstream sites. An exception was downstream site MEK 0.6 , where ORNL discharges may have varied during the year.

Total suspended solids (TSS) concentrations were moderate (annual average of $3.71 \mathrm{mg}$ dry $w t / L)$, for upstream sites, decreased in the mid-reaches of WOC, and then increased at sites further downstream, averaging $4.49 \mathrm{mg}$ dry wt/L at WCK 2.4 (Table 2-8). Melton Branch sites had higher TSS concentrations than did the WOC sites, but TSS was highest for downstream sites in both systems. Upstream site NTK 1.0 and ISK had higher concentrations of TSS than did FCK 1.0 and FFK 1.1, which reflected the larger watershed areas of the former two streams. Concentrations of TSS at WCK 2.4, MEK 0.6, and NTK 1.0 are likely important influences on the biotic communities at those sites (Sect. 3.2).

Concentrations of DOC were higher at downstream sites than at upstream sites (Table 2-8), and concentrations at upstream sites seemed to reflect watershed area. Data from the quarterly DOC-fractionation procedures were incomplete at the time of this report and will be presented in the next annual report.

Concentrations of dissolved nitrogen $\left(\mathrm{NO}_{2}{ }^{-}+\mathrm{NO}_{3}{ }^{-}\right.$and $\left.\mathrm{NH}_{4}{ }^{+}\right)$were somewhat higher, and concentrations of phosphorus, including both soluble reactive phosphorus (SRP) and total soluble phosphorus, were greatly enriched at sites receiving ORNL 
Table 2-7. Water quality parameters deternined for discrete samples collected monthly at ten sites in streams in White Oak Creek watcrshed

\begin{tabular}{|c|c|c|}
\hline Parameter & Method & Reference $^{a}$ \\
\hline $\begin{array}{l}\text { pH } \\
\text { Alkalinity }\end{array}$ & $\begin{array}{l}\text { Glass electrode } \\
\text { Acid titration to pH } 4.7\end{array}$ & $\begin{array}{l}\text { APHA (1985) } \\
\text { APHA (1985) }\end{array}$ \\
\hline $\begin{array}{l}\text { Conductivity } \\
\text { Hardness } \\
\text { Phosphorus (P) } \\
\text { Total P } \\
\text { Total soluble } P \\
\text { Soluble reactive P }\end{array}$ & $\begin{array}{l}\text { Conductivity bridge } \\
\text { EDTA }{ }^{b} \text { titration } \\
\text { Ascorbic acid method } \\
\text { Persulfate digestion } \\
\text { Filter and digestion } \\
\text { Filter only }\end{array}$ & $\begin{array}{l}\text { APHA (1985) } \\
\text { APHA (1985) } \\
\text { APHA (1985) }\end{array}$ \\
\hline Nitrate and nitrite & Cadmium reduction & EPA (1983) \\
\hline Ammonia (ammonium) & Phenate method & EPA (1983) \\
\hline Suspended solids & Total filterable $\left(105^{\circ} \mathrm{C}\right)$ & APHA (1985) \\
\hline $\begin{array}{l}\text { Particulate carbon } \\
\text { and nitrogen }\end{array}$ & Elemental analyzer & \\
\hline Dissolved metals & $\begin{array}{l}\text { Filter and induction coupled } \\
\text { plasma (ICP) spectroscopy }\end{array}$ & APHA (1985) \\
\hline $\begin{array}{l}\text { Dissolved organic } \\
\text { carbon }\end{array}$ & $\begin{array}{l}\text { Persulfate oxidation and } \\
\text { infrared detection }\end{array}$ & Dohrman (1984) \\
\hline
\end{tabular}

aAPHA (American Public Health Association). Standard Methods for the Evaluation of Water and Wastewater, 16th ed. American Public Health Association, Washington, D.C., 1985. EPA (U.S. Environmental Protection Agency). Methods for chemical analysis of water and wastes, EPA-600/4-79-020. Environmental Monitoring and Support Laboratory, U.S. Environmental Protection Agency, Cincinnati, 1983. Dohrmann Company. Total Organic Carbon Systems Manual, Dohrmann Company, Santa Clara, California, 1984.

${ }^{b} \mathrm{EDTA}=$ ethylenediamine tetracetic acid.

effluent (Table 2-8). Concentrations of SRP were typically about 5 to 6 micrograms of phosphorus per liter for the upstream sites, with occasional peaks of 10 to 20 micrograms of phosphorus per liter. Reference site MEK 1.8 had SRP concentrations of about 1029 and 70 micrograms of phosphorus per liter in September and December respectively. These concentrations were much greater than for other reference sites; however, they both occurred in samples collected several days following the resumption of streamflow after several months of zero discharge. Concentrations of SRP in upper Melton Branch were similar to concentrations at other upstream sites for months during the highdischarge season. The low average SRP concentrations at upstream sites suggest that phosphorus availability may limit primary production there. Sites receiving ORNL discharges typically had concentrations of SRP in excess of 100 micrograms of phosphorus per liter. These sites also had higher algal biomass and rates of primary production than 


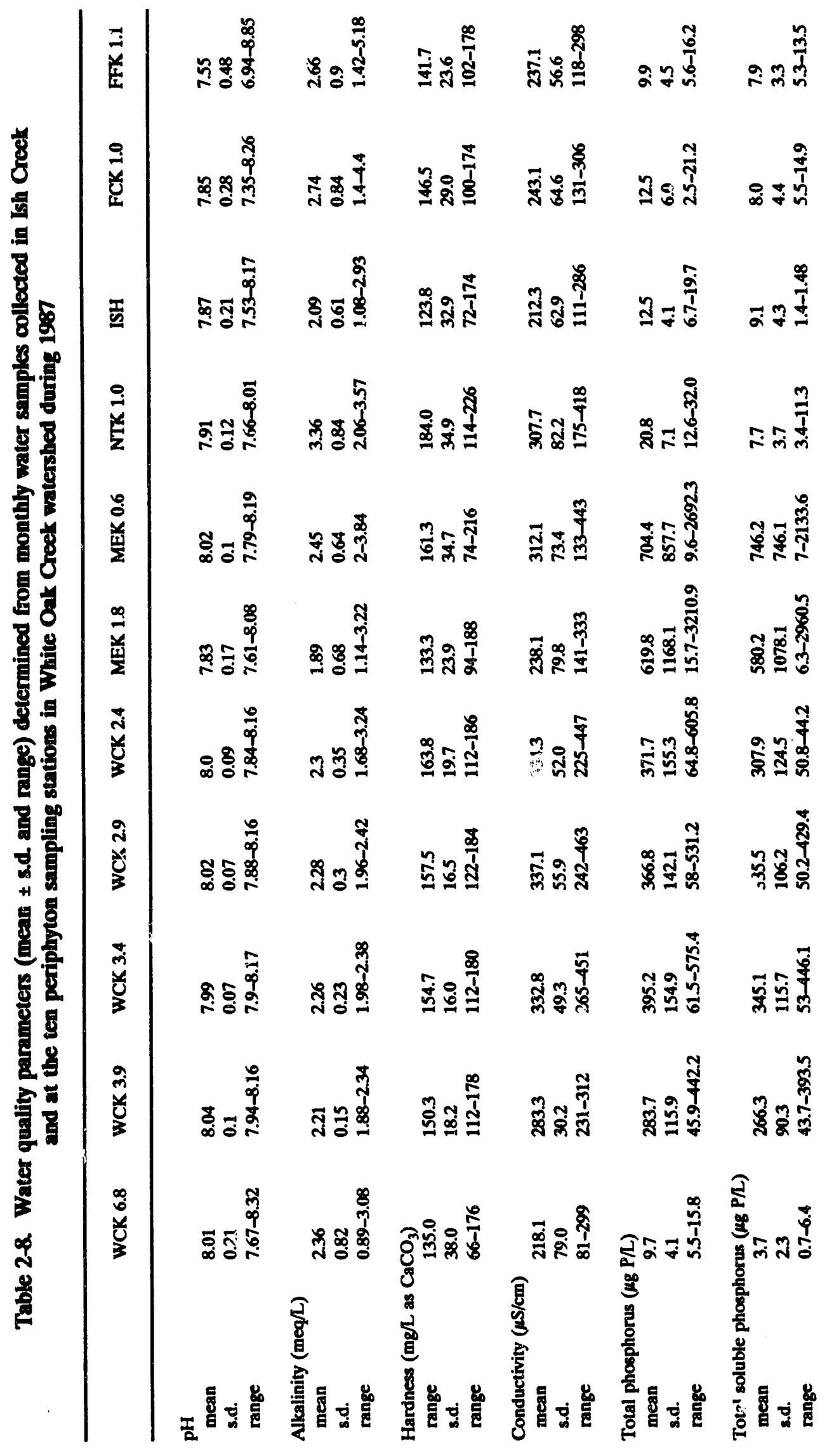




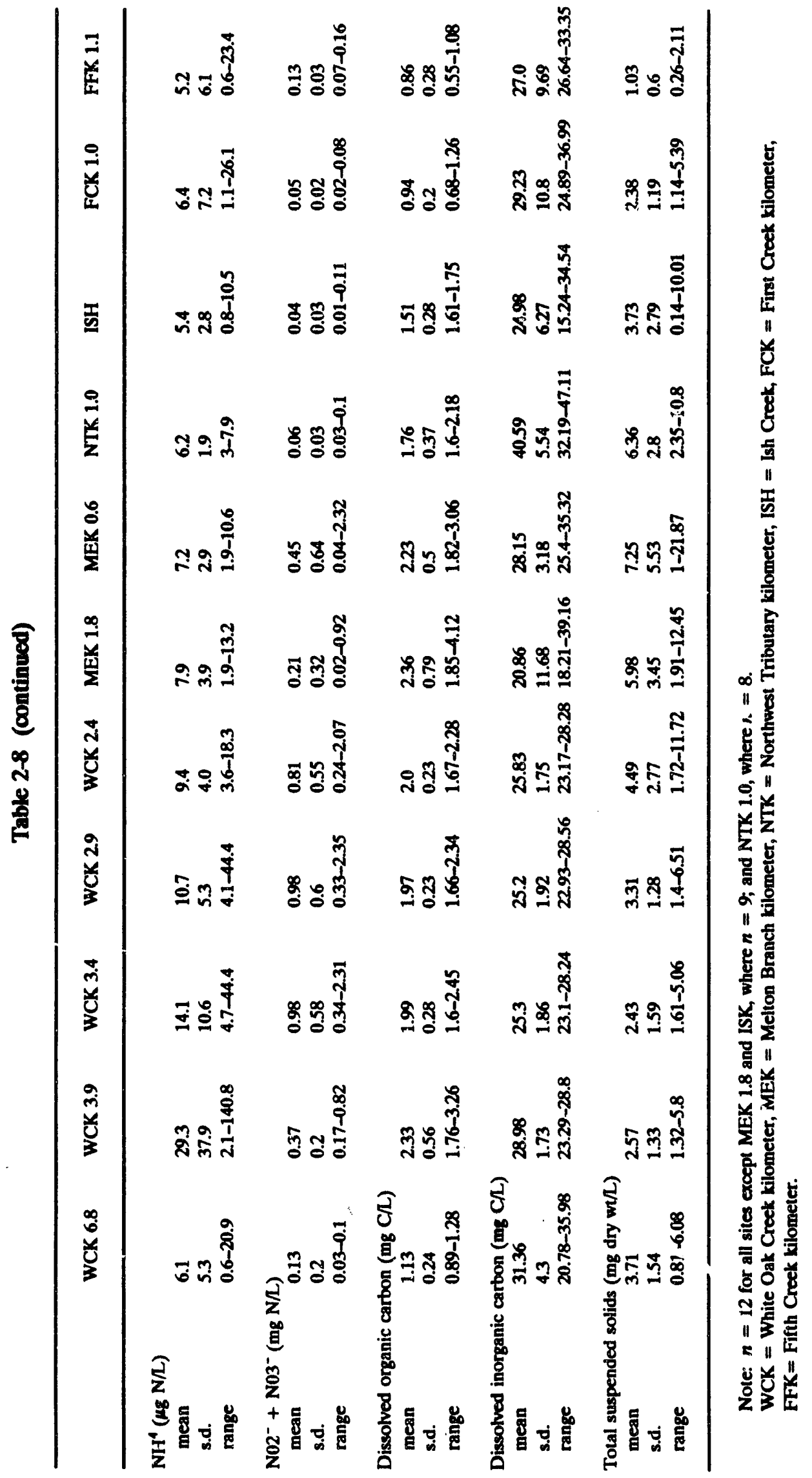


did upstream sites (see Sect. 3.2). Ammonia concentrations were low at all sites, averaging less than 30 micrograms of nitrogen per liter. Concentrations of $\mathrm{NO}_{2}{ }^{-}+\mathrm{NO}_{3}{ }^{-}$ nitrogen were also low at all sites but tended to be somewhat greater at the downstream sites.

In general, data from 1987 were similar to those collected for the same period during 1986 (Appendix A, Table A-1). The principal exception to this trend was site MEK 0.6, which is located $\sim 800 \mathrm{~m}$ below the HFIR/TRU discharge. The discharge from the HFIR contains cooling tower blowdown and so is high in sulfates, $\mathrm{Na}, \mathrm{P}, \mathrm{Cl}$, and other constituents that influence the biota. The HFIR was shut down in November 1986, and the subsequent reduction in discharges had significant effects on some water quality parameters and biotic communities at MEK 0.6 (see Sect. 3.2).

To illustrate some of the responses of water quality to the shutdown of the HFIR, data for hardness, conductivity, SRP, and $\mathrm{NH}_{4}^{+}$at MEK 0.6 and two sites on WOC above and below ORNL are presented in Figs. 2-8 and 2-9. A decrease in hardness and conductivity is apparent for MEK 0.6 following the HFIR shutdown (Fig. 2-8). High concentrations of SRP at MEK 0.6 in 1986 are believed to be largely due to discharges from the HFIR. Following a decrease in SRP concentrations at MEK 0.6 in early 1987, concentrations began rising in May 1987 and reached substantial concentrations during the summer, decreasing again with the onset of the wet season (Fig. 2-9). The high SRP concentrations at this site may be a residual effect of HFIR activities or a result of natural sources. The data for conductivity and hardness indicate that discharges from the HFIR facility were minimal in 1987 (Fig. 2-8). Interestingly, high SRP concentrations have occasionally been encountered at MEK 1.8 upstream of the HFIR discharge when Melton Branch flows intermittently during the summer (e.g., 1062 micrograms of phosphorus per liter during September 1987). During the wet season, when flow is continuous at MEK 1.8, SRP concentrations are typically low (10 micrograms of phosphorus per liter or less). The data may suggest a groundwater source of phosphorus in the Melton Branch system, although the extreme concentrations found at MEK 0.6 almost assuredly indicate an anthropogenic source of SRP. Because SRP may be an important determinant of biological activity in these streams, the source and influence of the SRP at MEK 0.6 will be further evaluated.

Ammonia provides an example of a biologically important water quality constituent that apparently was not influenced by the HFIR activity. Concentrations of ammonia at MEK 0.6 showed a similar relation to concentrations at the two WOC sites both before and after the HFIR shutdown (Fig. 2-9).

The quarterly analyses of stream water for dissolved elements [by means of inductively coupled plasma (ICP) spectroscopy] showed that only $\mathrm{Ba}, \mathrm{Ca}, \mathrm{Mg}, \mathrm{Mn}, \mathrm{Na}, \mathrm{Si}$, and $\mathrm{Sr}$ were consistently present at concentrations above the ICP detection limits (Table 2-9). Concentrations of $\mathrm{Fe}, \mathrm{P}$, and $\mathrm{Zn}$ were occasionally above the detection limits at some sites. Potassium concentrations were not determined. Because the detection limits of the ICP scans are relatively high in relation to the biologically significant concentrations of some elements (e.g., $\mathrm{Cd}, \mathrm{Cu}, \mathrm{Ni}$ ), these data only provide a screening for excessive concentrations of potentially toxic elements and a general characterization of the 

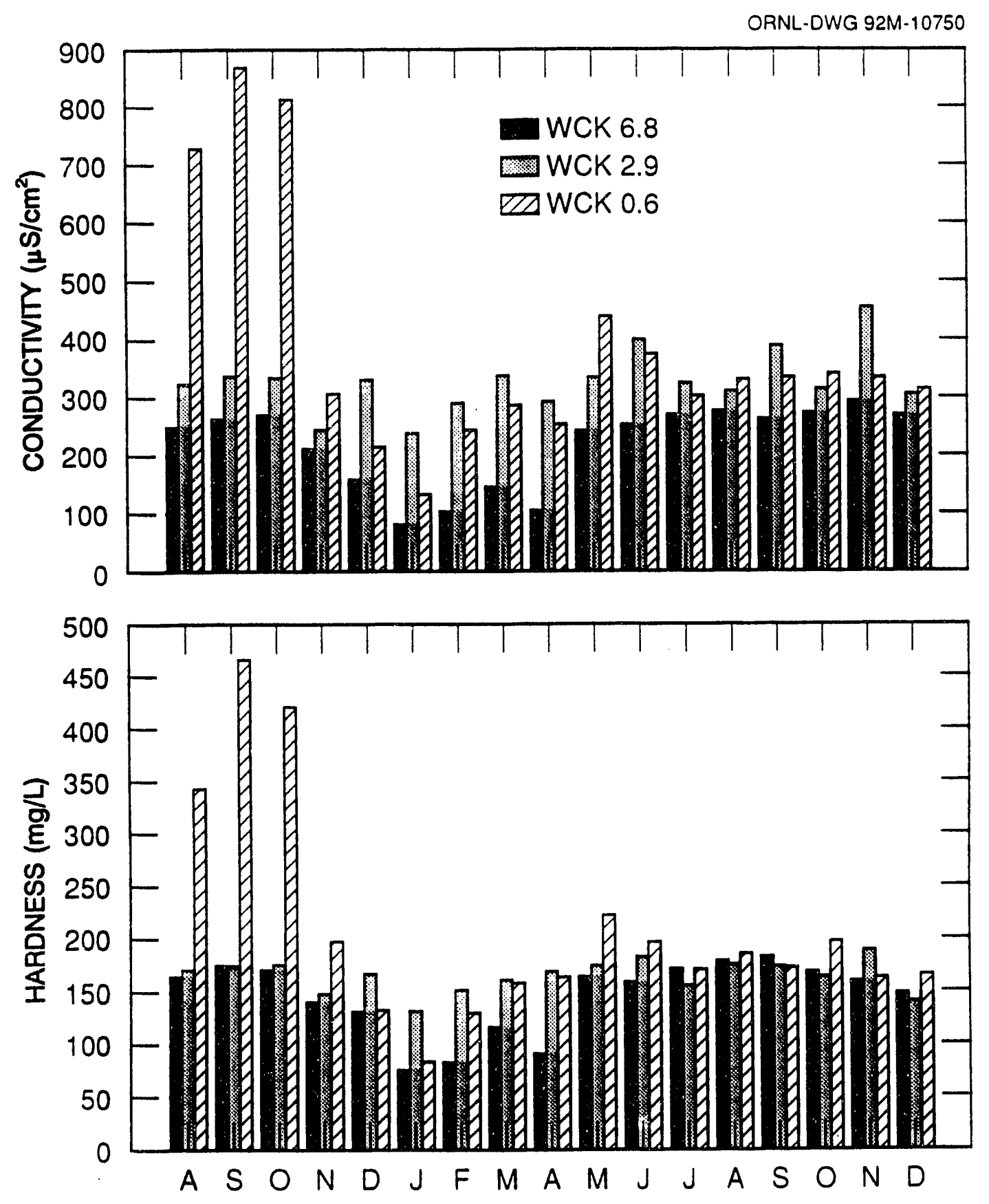

Fig 2-8. Monthly data for hardness and conductivity from water samples collocted at three periphyton monitoring stations, August 1986-December 1987. Sites on White Oak Creek include White Oai Creek kilometer (WCK) 6.8, an upstream reference site, and site WCK 2.9 located below ORNJL and above the confluence with Melton Branch. Site Melton Branch kilometer (MEK) 0.6 is located on Melton Branch approximately $800 \mathrm{~m}$ downstream from the HFIR facility discharge. Values are ine results of a single determination. The HFIR facility was shut down on November 14, 1986. 

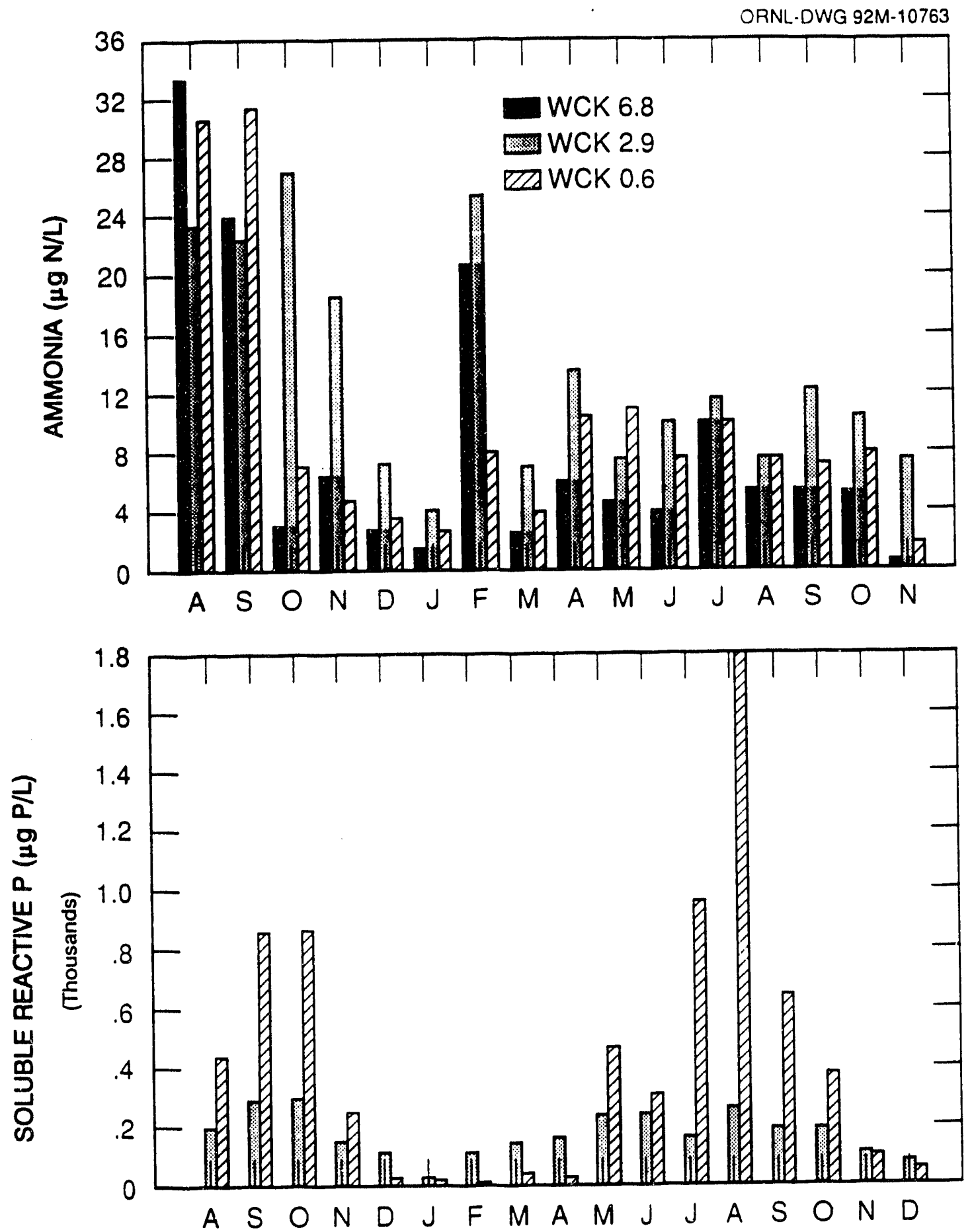

Fig. 2-9. Monthly data for soluble reactive phosphorus and ammonis from water samples collected at three periphyton monitoring stations, August 1986-December 1987. Sites on White Oak Creek include White Oak Creek kilometer (WCK) 6.8, and an upstream reference site, and site WCK 2.9, located below ORNL and above the confluence with Melton Branch. Site Melton Branch kilometer (MEK) 0.6 is located on Melton Branch approximately $800 \mathrm{~m}$ downstream of the discharge from the HFIR facility. Values are the average of two determinations. The HFIR facility was shut down on November $14,1986$. 


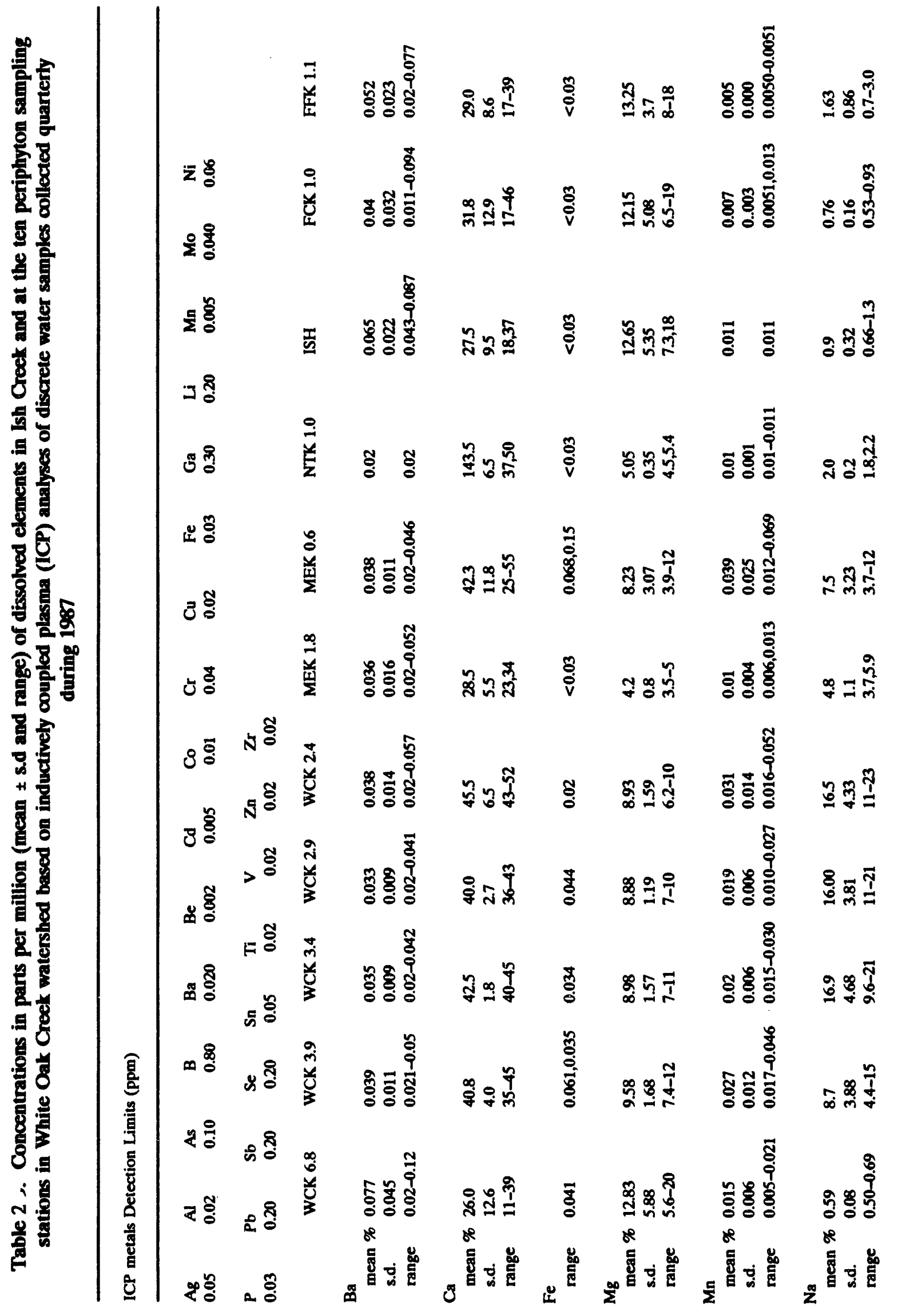




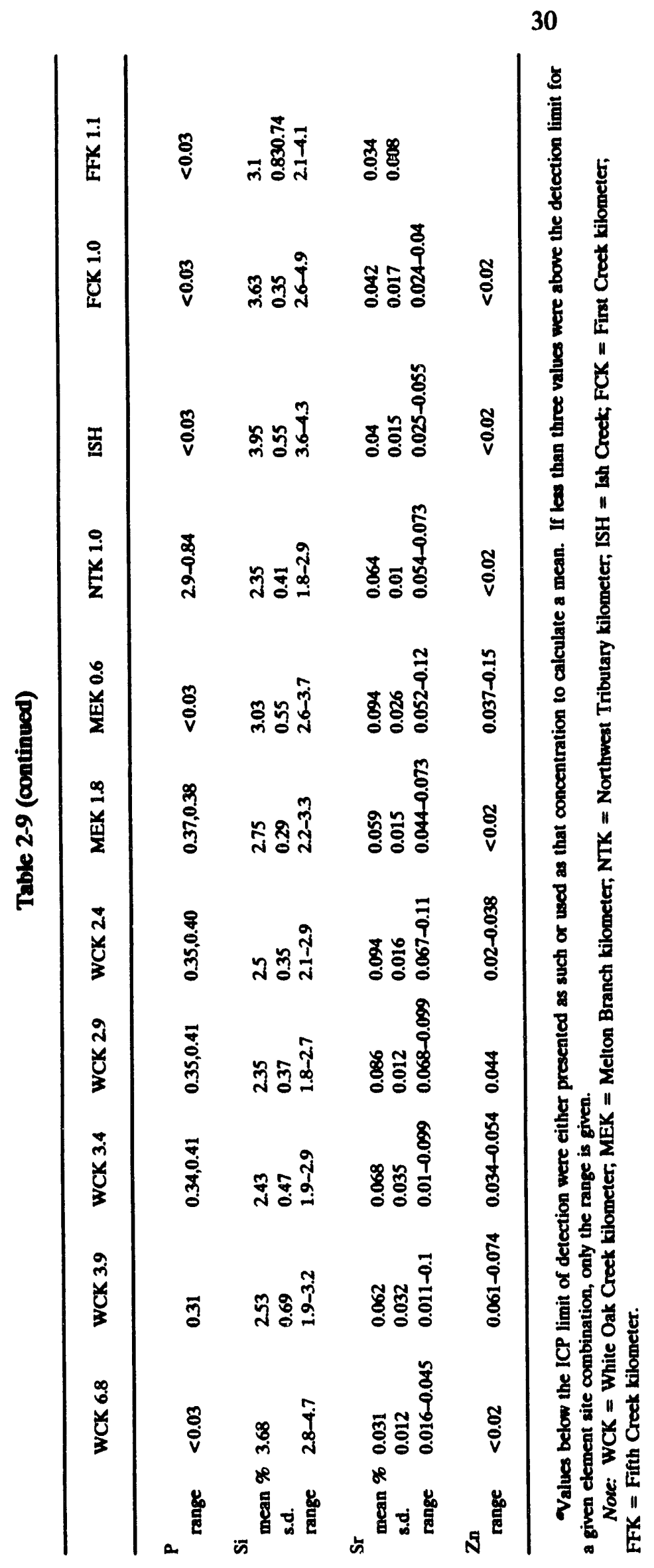


concentrations of the major cations at each site (excluding potassium). The concentrations of dissolved calcium were higher at downstream sites than at upstream sites, while magnesium followed an opposite trend (Table 2-9). The only major exception to this upstream-downstream trend was site NTK 1.0, which had relatively high calcium concentrations, high conductivity and hardness, and low magnesium concentrations relative to those at the other upstream reference sites (Tables 2-8 and 2-9). Sodium concentrations increased by about an order of magnitude at downstream sites relative to upstream sites, while silicon decreased slightly at downstream sites (Table 2-9). Strontium concentrations also increased somewhat at sites downstream of ORNL operations. Concentrations of other constituents showed little influence from ORNL discharges.

For those elements considered here, no evidence of continuous excessive inputs of potentially toxic materials was found. Data on the concentrations of metals in the periphyton matrix (see Sect. 3.2) showed accumulation of some metals at downstream sites; however, excessive concentrations were not found.

\subsection{Summary}

Water samples collected monthly as part of the periphyton monitoring program provide useful indicators of water quality at ten locations in the WOC drainage and at the weir on nearby Ish Creek and augment the information obtained from the NPDES monitoring program. Data on various water quality constituents are useful in (1) evaluating the behavior of some biological communities (Sect. 3.2), (2) documenting the influences of ORNL operations on water quality, and (3) screening for potentially toxic elements. With the exception of site MEK 0.6, where water quality improved as a result of the shutdown of the HFIR facility, water quality in WOC watershed in 1987 was similar to that observed in 1986. 


\section{TOXICITY MONITORING}

The toxicity monitoring task included in the ORNL BMAP (Loar et al. 1991) has three goals: (1) identify sources of toxicity in the WOC watershed (Subtask 1a); (2) monitor toxicity of water in WOC and its tributaries and assess the usefulness of the toxicity test systems in detecting ambient toxicity (Subtask 1b); and (3) monitor periphyton/microbial communities and test, by manipulative field experiments, relationships between ambient toxicity and periphyton-linked processes regulating energy flow in streams within the WOC watershed (Subtask 1c). Studies were conducted in each of these areas from February 1987 through February 1988.

\subsection{POINT-SOURCE AND AREA-SOURCE CONTRIBUTIONS TO AMBIENT TOXICTTY}

Point- and area-source contributions to ambient toxicity in streams in the WOC watershed were evaluated with 7-d static-renewal tests based on the survival and growth of fathead minnow (Pimephales promelas) larvae and on the survival and reproduction of the daphnid Ceriodaphnia dubia/affinis. These standard EPA-approved tests are described in Horning and Weber (1985), Norberg and Mount (1985), and Mount and Norberg (1984). Each fathead minnow test used four replicates, with ten larvae per replicate. Each Ceriodaphnia test used ten replicates, with one neonate per replicate.

Point-source discharges to WOC that were evaluated for toxicity under the ORNL Toxicity Control and Monitoring Program (TCMP), as stipulated in the NPDES permit (EPA 1986, Part V), included those from the STP, PWTP, and Coal Yard Runoff Treatment Facility (CYRTF) (Fig. 2-4). Effluents from these three facilities were evaluated every other month (Table 3-1).

Ambient toxicity of water from 15 sites on five streams (Fig. 3-1) was evaluated during February, March, and May 1987. In these tests, 4 of the 15 sites (uppermost sites on WOC, First Creek, Fifth Creek, and Melton Branch) served as reference sites because they were presumed to lack contaminants in toxic concentrations. Two ambient sites (X14 at WCK 2.65 and X13 at MEK 0.16, Fig. 2-2) were also evaluated under the TCMP section of the NPDES permit. Water from these two sites was evaluated every other month for toxicity with both species. Tests with the two species were always conducted concurrently. On each day of each test, subsamples of the effluent or water sample were analyzed for $\mathrm{pH}$, conductivity, alkalinity, and water hardness. Most samples collected for toxicity tests were also analyzed for free and total residual chlorine (TRC) by amperometric titrations with phenylarsen oxide. The temperature of the water at each site was recorded when the sample was collected.

Statistical computations were made with the use of SASe (SAS 1985a, 1985b) procedures on an IBM mainframe computer or with PC-SAS॰ on an IBM AT computer. Survival values for the minnows and the Ceriodaphnia were transformed (arcsine square root; Steel and Torrie, 1960) before statistical analysis. 
Table 3-1. Summary of toxicity test results for the Oak Ridge National Laboratory Process Waste Treatment Plant (PWTP), Coal Yard Runoff Treatment Facility (CYRTF), and Sewage Treatment Plant (STP)

\begin{tabular}{|c|c|c|c|}
\hline $\begin{array}{l}\text { ORNL } \\
\text { facility }\end{array}$ & Test date & $\begin{array}{l}\text { Fathead minnow } \\
\text { NOEC }\end{array}$ & $\begin{array}{l}\text { Ceriodaphnia } \\
\text { NOEC }\end{array}$ \\
\hline PWTP & July 1986 & $80 \%$ & $80 \%$ \\
\hline PWTP & September 1986 & $80 \%$ & $80 \%$ \\
\hline PWTP & November 1986 & $80 \%$ & $80 \%$ \\
\hline PWTP & January 1987 & $100 \%$ & $80 \%$ \\
\hline PWTP & March 1987 & $80 \%$ & $80 \%$ \\
\hline PWTP & May 1987 & $80 \%$ & $80 \%$ \\
\hline PWTP & July 1987 & $80 \%$ & $80 \%$ \\
\hline PWTP & September 1987 & $100 \%$ & $<80 \%$ \\
\hline PWTP & November 1987 & $80 \%$ & $100 \%$ \\
\hline PWTP & January 1988 & $80 \%$ & $\mathbf{8 0 \%}$ \\
\hline CYRTF & July 1986 & $20 \%$ & $<10 \%$ \\
\hline CYRTF & September 1986 & $>60 \%$ & $5 \%$ \\
\hline CYRTF & November 1986 & $>80 \%$ & NT \\
\hline CYRTF & January 1987 & $60 \%$ & $3 \%$ \\
\hline CYRTF & March 1987 & $60 \%$ & $10 \%$ \\
\hline CYRTF & June 1987 & $\geq 80 \%$ & $10 \%$ \\
\hline CYRTF & August 1987 & $\geq 80 \%$ & $25 \%$ \\
\hline CYRTF & September 1987 & $\geq 60 \%$ & NA \\
\hline CYRTF & November 1987 & $\geq 80 \%$ & $50 \%$ \\
\hline CYRTF & January 1988 & $\geq 80 \%$ & $25 \%(\mathrm{~W} / \mathrm{S})$ \\
\hline STP & May 1986 & $100 \%$ & $20 \%$ \\
\hline STP & June 1986 & NT & $100 \%$ \\
\hline STP & August 1986 & $100 \%$ & $100 \%$ \\
\hline STP & October 1986 & $100 \%$ & $100 \%$ \\
\hline STP & December 1986 & $100 \%$ & $75 \%$ \\
\hline STP & February 1987 & $100 \%$ & $<75 \%$ \\
\hline STP & March 1987 & $100 \%$ & $<50 \%$ \\
\hline STP & June 1987 & $100 \%$ & $<75 \%$ \\
\hline STP & August 1987 & $100 \%$ & $50 \%$ \\
\hline STP & October 1987 & $100 \%$ & $<80 \%$ \\
\hline STP & December 1987 & $100 \%$ & $100 \%$ \\
\hline STP & February 1988 & $100 \%$ & $<75 \%$ \\
\hline
\end{tabular}

${ }^{a}$ NOEC $=$ no-observed-effect concentration, or highest tested concentration (percentage) causing no statistically significant reduction $(p>0.05)$ in survival or growth of fathead minnow larvae or in survival or reproduction of Ceriodaphnia. W/S = Well/spring dilution water; NT $=$ not tested. 


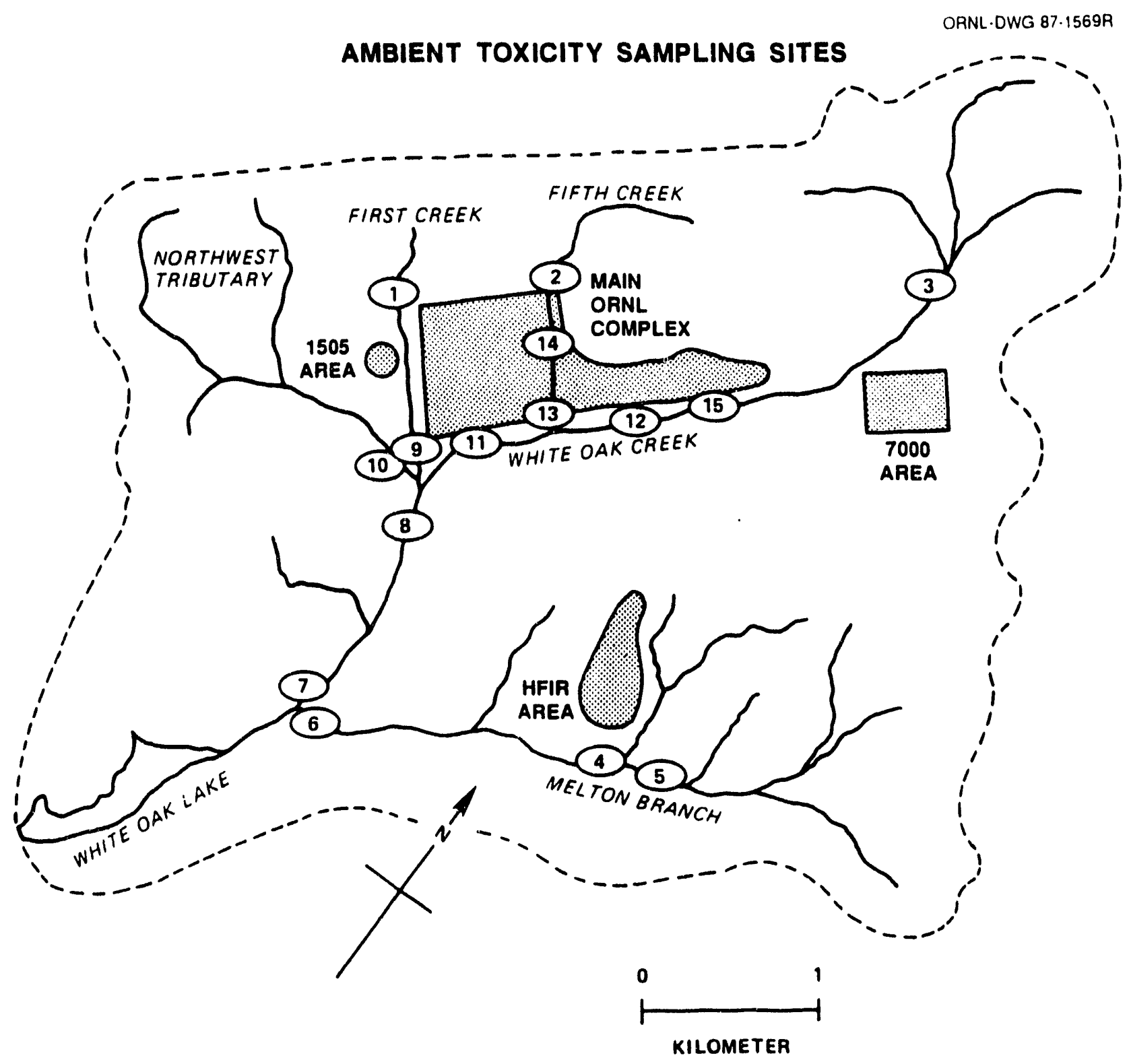

Fif 3-1. Schematic showing the 15 ambient toricity sampling sites on streams in White Oak Creek watershed. Stippling designates developed areas, which are major regions of point- and area-source discharges to streams. The dashed line shows the approximate boundary of the watershed. 


\subsubsection{Toxicity of Effluents from NPDES-Permitted Outfalls}

Discharges from PWTP were typically not very toxic to either test species, but effluent from CYRTF proved to be relatively toxic to both species in most tests, and effluent from the STP was sometimes toxic to Ceriodaphnia (Table 3-1). Each of the three facilities produced chemically distinct effluents (Table 3-2). The results of 10-12 chronic toxicity tests of effluents for the three facilities, summarized in relation to chemical parameters typical for effluents from the facilities, are given in Table 3-3.

Several toxicity tests were used to help identify the material(s) or conditions contributing to toxicity of the CYRTF and STP effluents. In these tests, the effluents were modified chemically in various ways before being tested. For example, PWTP effluent amended with calcium or magnesium sulfate was tested to determine if the low levels of hardness characteristic of this wastewater (Table 3-2) made it toxic to both species at full strength. Similarly, samples of wastewater from STP were dechlorinated with sodium thiosulfate before being tested to determine if total residual chlorine concentrations in this wastewater contributed to its toxicity. Additions of magnesium sulfate reduced survival and growth of fathead minnow larvae and survival and fecundity of Ceriodaphnia in PWTP effluent, while additions of calcium sulfate made little difference with respect to growth or survival of the fish but distinctly improved survival and fecundity of Ceriodaphnia (Table 3-4). The tests used to evaluate the possibility of improving the biological quality of STP effluent by dechlorination were inconclusive, and so are not detailed in this report; fish survival and growth were high even in nontreated effluent, and survival and fecundity of Ceriodaphnia in dechlorinated and nondechlorinated dilutions of STP effluent were similar.

Water from NPDES sites X13 at MEK 0.16 and X14 at WCK 2.65 was also tested with both species every other month. The results of these tests are given in Table 3-5. The results of chemical analyses of the water from these two sites, and from the reference site WCK 6.8, are summarized in Table 3-6.

Results of the fathead minnow and Ceriodaphnia tests shown in Tables 3-4 and 3-5 should be interpreted only with a clear understanding of the limitations of these two test systems. In the minnow test, for example, a control is considered to be acceptable if survival (based on $\mathbf{4 0}$ larvae distributed equally among 4 beakers) equals or exceeds $80 \%$ (W. Peltier, EPA, Athens, Georgia, personal communication). This consideration should indicate the general degree of sensitivity of the survival endpoint of the minnow test. Reductions in survival should be attributed to the presence of toxicants only when mean survival is less than $\mathbf{8 0 \%}$. Additionally, our experience has shown that among-replicate survival of the minnow larvae in samples of noncontaminated streamwater is sometimes quite variable. With four replicates, for example, survival of larvae in "good" water from upper WOC at WCK 6.8 was $90 \%, 40 \%, 40 \%$, and $100 \%$ during January 9-16, 1986. In the preceding month, survival of larvae in four replicates of "good" water from upper First Creek was $40 \%, 30 \%, 80 \%$, and $100 \%$. The results of subsequent and more highly replicated $(n=10)$ studies of survival of fathead minnow larvae reared in noncontaminated stream water containing different kinds and amounts of food, and at different temperatures, suggest that facultatively pathogenic fungi (such as Saprolegnia; $c f$. Alexopoulos 1962, pp. 138-49) common in pristine waters are, in part, responsible for this variability. In tests of effluents or of ambient water from less pristine sites, variability 
Table 3-2. Chemical parameters of efluent from the Oak Ridge National Laboratory Process Waste Treatment Plant (PWTP), Coal Yard Runoff Treatment Facility (CYRTF), and Sewage Treatment Plant (STP)

\begin{tabular}{|c|c|c|c|c|c|}
\hline & Test date & $\mathrm{pH}$ & Conductivity & Alkalinity & Hardness \\
\hline \multicolumn{6}{|c|}{ PWTP } \\
\hline & $\begin{array}{l}\text { Jul } 1986 \\
\text { Sep } 1986 \\
\text { Nov } 1986 \\
\text { Jan } 1987 \\
\text { Mar } 1987 \\
\text { May } 1987 \\
\text { Jul } 1987 \\
\text { Sep } 1987 \\
\text { Nov } 1987 \\
\text { Jan } 1988\end{array}$ & \begin{tabular}{l|}
7.81 \\
7.88 \\
7.47 \\
7.47 \\
7.67 \\
7.74 \\
7.59 \\
7.69 \\
7.89 \\
7.40
\end{tabular} & $\begin{array}{l}828 \\
827 \\
711 \\
544 \\
610 \\
680 \\
876 \\
731 \\
597 \\
665\end{array}$ & $\begin{array}{l}80.0 \\
65.3 \\
51.4 \\
40.9 \\
53.0 \\
54.7 \\
57.7 \\
61.3 \\
71.4 \\
40.4\end{array}$ & $\begin{array}{r}19.6 \\
20.3 \\
0.0 \\
2.6 \\
1.4 \\
32.3 \\
12.4 \\
43.1 \\
24.9 \\
4.4\end{array}$ \\
\hline Range of means: & & $7.4-7.9$ & $544-876$ & $40-80$ & $0-43$ \\
\hline \multicolumn{6}{|c|}{ CYRTF } \\
\hline & $\begin{array}{l}\text { Jul } 1986 \\
\text { Sep } 1986 \\
\text { Nov } 1986 \\
\text { Jan } 1987 \\
\text { Mar } 1987 \\
\text { Jun } 1987 \\
\text { Aug } 1987 \\
\text { Sep } 1987 \\
\text { Nov } 1987 \\
\text { Jan } 1988\end{array}$ & $\begin{array}{l}7.19 \\
7.19 \\
7.23 \\
6.70 \\
7.07 \\
7.22 \\
7.50 \\
7.33 \\
6.74 \\
6.84\end{array}$ & $\begin{array}{l}1,810 \\
2,883 \\
1,468 \\
1,404 \\
1,731 \\
2,580 \\
2,539 \\
2,624 \\
2,619 \\
1,703\end{array}$ & $\begin{array}{r}37.1 \\
9.0 \\
8.3 \\
5.6 \\
9.3 \\
9.3 \\
10.0 \\
16.5 \\
13.9 \\
8.3 \\
5.9\end{array}$ & $\begin{array}{r}1,160 \\
2,500 \\
1,023 \\
910 \\
1,080 \\
2,006 \\
1,740 \\
1,937 \\
1,569 \\
1,006\end{array}$ \\
\hline Range of means: & & $6.7-7.5$ & $1,404-2,883$ & $6-37$ & $910-2,500$ \\
\hline \multicolumn{6}{|c|}{ STP } \\
\hline & $\begin{array}{l}\text { May } 1986 \\
\text { Jun } 1986 \\
\text { Aug } 1986 \\
\text { Oct } 1986 \\
\text { Dec } 1986 \\
\text { Feb } 1987 \\
\text { Mar } 1987 \\
\text { Jun } 1987 \\
\text { Aug } 1987 \\
\text { Oct } 1987 \\
\text { Dec } 1987 \\
\text { Feb } 1988\end{array}$ & $\begin{array}{l}7.91 \\
8.02 \\
7.74 \\
8.13 \\
7.96 \\
7.82 \\
7.71 \\
7.68 \\
7.70 \\
7.79 \\
7.60 \\
7.66\end{array}$ & $\begin{array}{l}366 \\
385 \\
381 \\
403 \\
426 \\
470 \\
431 \\
391 \\
370 \\
421 \\
410 \\
483\end{array}$ & \begin{tabular}{|r|}
90.1 \\
82.9 \\
74.1 \\
108.7 \\
113.6 \\
111.6 \\
100.3 \\
82.6 \\
80.7 \\
91.4 \\
84.7 \\
88.3 \\
\end{tabular} & $\begin{array}{l}151.1 \\
152.7 \\
174.0 \\
166.1 \\
177.1 \\
175.1 \\
158.9 \\
176.3 \\
145.1 \\
155.1 \\
152.9 \\
169.4\end{array}$ \\
\hline Range of means: & & $7.6-8.1$ & $366-483$ & $74-114$ & $145-177$ \\
\hline
\end{tabular}

Values represent the mean of seven daily grab samples. Alkalinity and hardness are expressed as milligrams of $\mathrm{CaCO}_{3}$ per liter; conductivity (microseimens per centimeter) values are corrected to $25^{\circ} \mathrm{C}$. 
Table 3-3. Average no-observed-efiect concentration (NOEC) of efluent from the

Oak Ridge National Laboratory Process Waste Treatment Plant (PWTP), Coal

Yard Runoff Treatment Facility (CYRTF), and Sewage Treatment Plant

(STP) in relation to ranges of water quality parameters

characteristic of the efiluents

\begin{tabular}{lcccccc}
\hline & $\begin{array}{c}\text { Number of } \\
\text { toxicity } \\
\text { tests }\end{array}$ & $\begin{array}{c}\text { Minnow } \\
\text { NOEC }\end{array}$ & $\begin{array}{c}\text { Ceriodaphnia } \\
\text { NOEC }\end{array}$ & $\begin{array}{c}\text { Conductivity } \\
(\mu \mathrm{S} / \mathrm{cm})\end{array}$ & $\begin{array}{c}\text { Alkalinity } \\
(\mathrm{mg} / \mathrm{L} \text { as } \\
\left.\mathrm{CaCO}_{3}\right)\end{array}$ & $\begin{array}{c}\text { Hardness } \\
\left(\mathrm{mg}^{2} \mathrm{~L} \text { as }\right. \\
\left.\mathrm{CaCO}_{3}\right)\end{array}$ \\
\hline PWTP & 10 & $84 \%$ & $82 \%$ & $540-880$ & $40-80$ & $0-45$ \\
CRYTF & 10 & $>66 \%$ & $<15 \%$ & $1,400-2,880$ & $5-40$ & $900-2,500$ \\
STP & 12 & $100 \%$ & $<75 \%$ & $370-470$ & $75-115$ & $145-175$ \\
\hline
\end{tabular}

Table 3-4. Survival (expressed in percent) and growth (milligrams per fish, \pm 1 s.d.) of finthead

minnow larvae, and survival (expresced in percent) and fecundity (offspring per female,

\pm 1 s.d) of Ceriodaphnia in full-strength process waste treatment plant (PWTP) efluent, and in full-strength PWTP effluent

\begin{tabular}{lccccc}
\hline & \multicolumn{2}{c}{ Fathead minnow } & & \multicolumn{2}{c}{ Ceriodaphnia } \\
\cline { 2 - 3 } \cline { 5 - 6 } Treatment & $\begin{array}{c}\text { Survival } \\
(\%)\end{array}$ & $\begin{array}{c}\text { Growth } \\
\text { (milligrams per fish) }\end{array}$ & & $\begin{array}{c}\text { Survival } \\
(\%)\end{array}$ & $\begin{array}{c}\text { Fecundity } \\
\text { (offspring per female) }\end{array}$ \\
\hline Effluent only & 92.5 & $0.43 \pm 0.04$ & & 30 & $11.3 \pm 8.4$ \\
Effluent + MgSO & 60.0 & $0.32 \pm 0.07$ & & 30 & $7.0 \pm 6.1$ \\
Effluent + CaSO & 97.5 & $0.51 \pm 0.07$ & & 60 & $28.0 \pm 3.2$ \\
\hline
\end{tabular}

aFull strength PWTP effluent amended with $\mathrm{MgSO}_{4}$ (to $72-128 \mathrm{mg} / \mathrm{L}$ as $\mathrm{CaCO}_{3}$ ) or $\mathrm{CaSO}_{4}$ (to $48-98 \mathrm{mg} / \mathrm{L}$ as $\mathrm{CaCO}_{3}$ ). Tests were conducted November 5-12, 1987.

among replicates is much lower and mean survival values can be interpreted with much less difficulty.

In the Ceriodaphnia test, survival is based on ten replicates, each of which contains a single neonate. Each death, therefore, reduces mean survival by $10 \%$, and mean survival has no associated variability. Horning and Weber (1985) recommend that the survival endpoint of this test be assessed statistically using Fisher's Exact Test. The criterion for this test suggests that when ten replicates are used and controls have $100 \%$ survival, a sample in which the survival rate is $\leq 60 \%$ is significantly lower than the controls $(p<0.05)$. If the survival rate of the control declines to $90 \%$, the critical value for significance declines to $40 \%$. The fecundity endpoint of the Ceriodaphnia test is more tractable statistically because individuals are replicates (Haynes et al. 1989). However, when statistically comparing mean fecundity values among treatments for the purpose of identifying "toxic" sites, one should consider the fact that a healthy female Ceriodaphnia 
Table 3-5. Percent survival and growth (mein \pm 1 s.d.) of fathead minnows, and survival and fecundity (mean \pm 1 s.d.) of Ceriodaphnia in $7-d$ tests"

\begin{tabular}{|c|c|c|c|c|c|}
\hline \multirow[b]{2}{*}{ Date } & \multirow[b]{2}{*}{ Sampling site } & \multicolumn{2}{|c|}{ Fathead minnows } & \multicolumn{2}{|c|}{ Ceriodaphnial } \\
\hline & & $\begin{array}{l}\text { Survival } \\
(\%)\end{array}$ & $\begin{array}{c}\text { Growth } \\
\text { (milligrams per fish) }\end{array}$ & $\begin{array}{l}\text { Survival } \\
(\%)\end{array}$ & $\begin{array}{c}\text { Fecundity } \\
\text { (offspring/female) }\end{array}$ \\
\hline Jan 9, 1987 & $\begin{array}{l}\text { Control } \\
\text { WCK } 6.8 \\
\text { MEK } 0.16 \\
\text { WCK } 2.65\end{array}$ & $\begin{array}{l}98.0 \\
67.5 \\
67.5 \\
87.5\end{array}$ & $\begin{array}{l}0.42 \pm 0.06 \\
0.43 \pm 0.07 \\
0.41 \pm 0.03 \\
0.38 \pm 0.05\end{array}$ & $\begin{array}{l}100 \\
100 \\
100 \\
100\end{array}$ & $\begin{array}{l}26.8 \pm 2.8 \\
27.5 \pm 4.3 \\
29.2 \pm 4.1 \\
27.9 \pm 5.3\end{array}$ \\
\hline Feb 19,1987 & $\begin{array}{l}\text { Control } \\
\text { WCK } 6.8 \\
\text { MEK } 0.16 \\
\text { WCK } 2.65\end{array}$ & $\begin{array}{l}95.0 \\
95.0 \\
77.5 \\
80.0\end{array}$ & $\begin{array}{l}0.30 \neq 0.05 \\
0.18 \neq 0.03 \\
0.33 \pm 0.04 \\
0.26 \pm 0.05\end{array}$ & $\begin{array}{l}80 \\
90 \\
90 \\
70\end{array}$ & $\begin{array}{r}13.0 \pm 6.0 \\
23.1 \pm 5.5 \\
23.6 \pm 4.2 \\
15.7 \pm 10.0\end{array}$ \\
\hline Mar 19,1987 & $\begin{array}{l}\text { Control } \\
\text { WCK } 6.8 \\
\text { MEK } 0.16 \\
\text { WCK } 2.65\end{array}$ & $\begin{array}{l}95.0 \\
32.5 \\
15.0 \\
85.0\end{array}$ & $\begin{array}{l}0.34 \pm 0.03 \\
0.26 \pm 0.10 \\
0.42 \pm 0.15 \\
0.41 \pm 0.04\end{array}$ & $\begin{array}{l}80 \\
90 \\
80 \\
70\end{array}$ & $\begin{array}{r}6.6 \pm 7.7 \\
21.0 \pm 6.0 \\
19.3 \pm 6.4 \\
15.4 \pm 7.7\end{array}$ \\
\hline May 28, 1987 & $\begin{array}{l}\text { Control } \\
\text { WCK } 6.8 \\
\text { MEK 0.16 } \\
\text { WCK } 2.65\end{array}$ & $\begin{array}{l}97.5 \\
75.0 \\
95.0 \\
90.0\end{array}$ & $\begin{array}{l}0.28 \pm 0.02 \\
0.17 \div 0.02 \\
0.20 \pm 0.07 \\
0.17 \pm 0.04\end{array}$ & $\begin{array}{r}100 \\
90 \\
100 \\
100\end{array}$ & $\begin{array}{l}22.0 \pm 5.7 \\
20.9 \pm 6.2 \\
26.0 \pm 5.3 \\
19.2 \pm 4.8\end{array}$ \\
\hline Jul 9, 1987 & $\begin{array}{l}\text { Control } \\
\text { WCK } 6.8 \\
\text { MEK } 0.16 \\
\text { WCK } 2.65\end{array}$ & $\begin{array}{l}97.5 \\
\text { ND } \\
90.0 \\
85.0\end{array}$ & $\begin{array}{c}0.57 \pm 0.05 \\
\text { ND } \\
0.46 \pm 0.04 \\
0.44 \pm 0.04\end{array}$ & $\begin{array}{r}60 \\
\text { ND } \\
80 \\
100\end{array}$ & $\begin{array}{c}11.5 \pm 10.0 \\
\text { ND } \\
18.6 \pm 8.9 \\
20.9 \pm 5.3\end{array}$ \\
\hline 25,1987 & $\begin{array}{l}\text { Control } \\
\text { WCK } 6.8 \\
\text { MEK } 0.16 \\
\text { WCK 2.65 }\end{array}$ & $\begin{array}{c}100.0 \\
\text { ND } \\
97.5 \\
100.0\end{array}$ & $\begin{array}{c}0.91 \pm 0.04 \\
\text { N!n } \\
0.85 \pm 0.10 \\
0.83 \pm 0.07\end{array}$ & $\begin{array}{r}60 \\
\text { ND } \\
100 \\
90\end{array}$ & $\begin{array}{c}1.0 \pm 2.5 \\
\text { ND } \\
22.6 \pm 4.3 \\
19.9 \pm 2.3\end{array}$ \\
\hline Nov 5, 1987 & $\begin{array}{l}\text { Control } \\
\text { WCK } 6.8 \\
\text { MEK } 0.16 \\
\text { WCK } 2.65\end{array}$ & $\begin{array}{l}97.5 \\
\text { ND } \\
75.0 \\
92.5\end{array}$ & $\begin{array}{c}0.50 \pm 0.05 \\
\text { ND } \\
0.50 \pm 0.06 \\
0.50 \pm 0.09\end{array}$ & $\begin{array}{r}60 \\
\text { ND } \\
100 \\
100\end{array}$ & $\begin{array}{c}7.2 \pm 6.3 \\
\text { ND } \\
28.1 \pm 3.1 \\
23.4 \pm 3.1\end{array}$ \\
\hline Jan 14,1988 & $\begin{array}{l}\text { Control }^{b} \\
\text { WCK } 6.8 \\
\text { MEK } 0.16 \\
\text { WCK } 2.65\end{array}$ & $\begin{array}{l}97.5 \\
\text { ND } \\
82.5 \\
95.0\end{array}$ & $\begin{array}{c}0.94 \pm 0.07 \\
\text { ND } \\
0.88 \pm 0.05 \\
0.78 \pm 0.07\end{array}$ & $\begin{array}{r}100 \\
\text { ND } \\
100 \\
90\end{array}$ & $\begin{array}{c}27.4 \pm 2.3 \\
\text { ND } \\
27.8 \pm 1.9 \\
28.2 \pm 2.6\end{array}$ \\
\hline
\end{tabular}

${ }^{\circ}$ Bioassays were conducted with control water (dechlorinated tap water for the fish and reconstituted water for the Ceriodaphnia) and with water from White Oak Creek above Oak Ridge National Laboratory (WCK 6.8) and from National Pollutant Discharge Elimination System sites X13 (Melton Branch at MEK 0.16) and X.14 (White Oak Creek at WCK 2.65). Means for the fish were sased on four replicates, each with ten larvae. Mean fecundity was computed using only females that survived all 7 days. Date i.dicates initial day of test. WCK = White Oak cireek kilometer; MEK = Melton Branch kilometer.

Ceriodaphnia control water in this test was well/spring water.

Note: $\mathrm{ND}=$ no data. 
Table 3-6. Summary of water quality measurements in White Oak Creek above Oak Ridge National Laboratory (WCK 6.8) and at National Pollutant Discharge Elimination System sites X13 on Melton Branch (MEK 0.16) and X14 on White Oak Creek (WCK 265)

\begin{tabular}{|c|c|c|c|c|c|c|}
\hline Test date & Sampling/site & G/C & $\mathrm{pH}$ & Conductivity & Alkalinity & Hardness ${ }^{c}$ \\
\hline Jan $9-15,1987$ & $\begin{array}{l}\text { WCK } 6.8 \\
\text { MEK } 0.16 \\
\text { WCK } 2.65\end{array}$ & $\begin{array}{l}7 / 0 \\
7 / 0 \\
7 / 0\end{array}$ & $\begin{array}{l}8.23 \\
8.11 \\
8.12\end{array}$ & $\begin{array}{l}225 \\
314 \\
380\end{array}$ & $\begin{array}{l}124.3 \\
122.6 \\
115.3\end{array}$ & $\begin{array}{l}135 \\
158 \\
162\end{array}$ \\
\hline Feb 19-25, 1987 & $\begin{array}{l}\text { WCK } 6.8 \\
\text { MEK } 0.16 \\
\text { WCK } 2.65\end{array}$ & $\begin{array}{l}7 / 0 \\
7 / 0 \\
7 / 0\end{array}$ & $\begin{array}{l}7.74 \\
8.01 \\
8.06\end{array}$ & $\begin{array}{l}111 \\
224 \\
326\end{array}$ & $\begin{array}{r}54.1 \\
91.3 \\
109.4\end{array}$ & $\begin{array}{r}71 \\
117 \\
147\end{array}$ \\
\hline Mar 19-25, 1987 & $\begin{array}{l}\text { WCK } 6.8 \\
\text { MEK } 0.16 \\
\text { WCK } 2.65\end{array}$ & $\begin{array}{l}7 / 0 \\
4 / 3 \\
4 / 3\end{array}$ & $\begin{array}{l}7.80 \\
8.00 \\
8.12\end{array}$ & $\begin{array}{l}126 \\
234 \\
316\end{array}$ & $\begin{array}{r}64.9 \\
100.4 \\
111.3\end{array}$ & $\begin{array}{r}77 \\
119 \\
143\end{array}$ \\
\hline May 28-Jun 3, 1987 & $\begin{array}{l}\text { WCK } 6.8 \\
\text { MEK } 0.16 \\
\text { WCK } 2.65\end{array}$ & $\begin{array}{l}7 / 0 \\
2 / 5 \\
7 / 0\end{array}$ & $\begin{array}{l}8.15 \\
8.11 \\
8.17\end{array}$ & $\begin{array}{l}231 \\
366 \\
332\end{array}$ & $\begin{array}{l}133.9 \\
150.4 \\
116.3\end{array}$ & $\begin{array}{l}138 \\
183 \\
149\end{array}$ \\
\hline Jul 9-15, 1987 & $\begin{array}{l}\text { WCK } 6.8 \\
\text { MEK } 0.16 \\
\text { WCK } 2.65\end{array}$ & $\begin{array}{l}\text { ND } \\
7 / 0 \\
6 / 1\end{array}$ & $\begin{array}{l}\text { ND } \\
8.04 \\
8.07\end{array}$ & $\begin{array}{l}\text { ND } \\
322 \\
362\end{array}$ & $\begin{array}{l}\text { ND } \\
136.1 \\
113.3\end{array}$ & $\begin{array}{l}\text { ND } \\
169 \\
161\end{array}$ \\
\hline Sep 25-Oct 1, 1987 & $\begin{array}{l}\text { WCK } 6.8 \\
\text { MEK } 0.16 \\
\text { WCK } 2.65\end{array}$ & $\begin{array}{l}\text { ND } \\
5 / 2 \\
5 / 2\end{array}$ & $\begin{array}{l}\text { ND } \\
8.10 \\
8.17\end{array}$ & $\begin{array}{l}\text { ND } \\
339 \\
364\end{array}$ & $\begin{array}{l}\text { ND } \\
128.0 \\
110.3\end{array}$ & $\begin{array}{l}\text { ND } \\
169 \\
161\end{array}$ \\
\hline Nov 5-11, 1987 & $\begin{array}{l}\text { WCK } 6.8 \\
\text { MEK } 0.16 \\
\text { WCK } 2.65\end{array}$ & $\begin{array}{l}\text { ND } \\
7 / 0 \\
7 / 0\end{array}$ & $\begin{array}{r}\text { ND } \\
8.04 \\
8.06\end{array}$ & $\begin{array}{l}\text { ND } \\
332 \\
366\end{array}$ & $\begin{array}{l}\text { ND } \\
123.3 \\
101.8\end{array}$ & $\begin{array}{l}\text { ND } \\
163 \\
163\end{array}$ \\
\hline Jan $14-20,1988$ & $\begin{array}{l}\text { WCK } 6.8 \\
\text { MEK } 0.16 \\
\text { WCK } 2.65\end{array}$ & $\begin{array}{l}\text { ND } \\
7 / 0 \\
7 / 0\end{array}$ & $\begin{array}{r}\text { ND } \\
7.95 \\
8.05\end{array}$ & $\begin{array}{l}\text { ND } \\
323 \\
428\end{array}$ & $\begin{array}{c}\text { ND } \\
97.9 \\
107.1\end{array}$ & $\begin{array}{l}\text { ND } \\
148 \\
171\end{array}$ \\
\hline
\end{tabular}

${ }^{a}$ Da:a shown are means (each based on seven daily samples) collected during the indicated test period. $\mathrm{G} / \mathrm{C}=$ number of grab samples vs number of 24-h composite samples collected in each test. WCK $=$ White Oak Creek kilometer; $\mathrm{MEK}=$ Melton Branch kilometer.

${ }^{b}$ Conductivity in microseimens per centimeter, corrected to $25 \cdot \mathrm{C}$.

c. vkalinity or hardness, in milligrams per liter, expressed as $\mathrm{CaCO}_{3}$.

Note: $\mathrm{ND}=$ no data.

can produce $20-30$ offspring in a 7-d test period if food, water quality, and temperature conditions are adequate. Thus, a Ceriodaphnia control in which mean fecundity is less than about 15 offspring (cf. Table 3-5) should be considered biologically and, with respect to test interpretation, statistically suspect. Conversely, ambient water samples that permit high fecundity (i.e., $>20$ offspring per female) are evidence of low toxicity, regardless of the fecundity of the controls. 
With these considerations, the illusion of statistical objectivity (sensu Berger and Berry 1988) is less complete. Final interpretation of whether or not an ambient stream site shows evidence of toxicity should rely upon a general concordance of test endpoints (survival, growth, and fecundity responses) through repeated tests, taking into account the responses of the test animals in water from other sites and in controls.

\subsubsection{Toxicity of Other Point-Source Discharges}

The results of ambient toxicity tests described in the first annual report of BMAP (Loar et al. 1992) suggested that episodic excursions of chlorine in a midreach segment of WOC and in a lower reach of Fifth Creek tended to control overall ambient toxicity patterns. This suggestion was corroborated by results of ambient tests conducted during February, March and May of 1987 . To verify the importance of chlorine in controlling toxicity in WOC, toxicity tests were conducted (1) to evaluate a wastewater entering WOC from the Materials Testing Laboratory (MTL; also known as the Creep Laboratory) in Building 4500-S, and (2) to determine if materials other than chlorine contributed to toxicity in a midreach segment of WOC or the lower reach of Fifth Creek.

Once-through cooling water from MTL enters WOC from the north via a culvert located beneath the uppermost bridge to the High Temperature Materials Laboratory (HTML). The discharge of water from the MTL outfal! is continuous at $\sim 13-16 \mathrm{~L} / \mathrm{s}$ (200-250 gal/min) (L.R. Simmons, ORNL Operations Division, personal communication, 1987). On March 5, 1987, samples of water from the MTL outfall and from WOC just above and $20 \mathrm{~m}$ downstream from the outfall were analyzed for conductivity, $\mathrm{pH}$, alkalinity, TRC, and free chlorine. The concentration of TRC in the MTL outfall was also measured on March 11 and April 1, 1987. The results of these analyses (Table 3-7) suggested that (1) the MTL outfall contributes to instream chlorine levels in WOC and (2) other sources of TRC exist farther upstream.

On August 6-13, 1987, a test was conducted to determine if materials other than chlorine contributed to ambient toxicity in water from MTL and the midreach segment of WOC. For this test, water samples from MTL outfall (which enters WOC just below WCK 4.3) and from five ambient sites (WCK 4.4, WCK 4.3, WCK 4.2, WCK 3.8, and FFK 0.0) were collected daily. Each daily grab sample was divided into two equal portions, one of which was dechlorinated with sodium thiosulfate while the other was left untreated. The 12 samples were tested for chronic toxicity with Ceriodaphnia and fathead minnow larvae using standard static-renewal test procedures (Horning and Weber 1985). Water quality measurements made each day in conjunction with the test included $\mathrm{pH}$, conductivity, alkalinity, hardness, TRC and free chlorine.

Differences in $\mathrm{pH}$, conductivity, alkalinity, and hardness among the six sites were relatively minor. Water from lower Fifth Creek, for example, was on average only slightly more alkaline (by 0.2 standard $\mathrm{pH}$ units) than the other sites (where mean $\mathrm{pH}$ values ranged from 7.97 to 8.02) and had only slightly more alkalinity (0-16 milligrams of $\mathrm{CaCO}_{3}$ per liter). Differences in chlorine concentrations among the sites, however, were substantial (Table 3-8). The concentration of TRC in the MTL outfall, for example, averaged $0.83 \mathrm{mg} / \mathrm{L}$, whereas concentrations of TRC in WOC immediately upstream from the MTL outfall averaged only $0.08 \mathrm{mg} / \mathrm{L}$. Water from lower Fifth Creek contained an 
Table 3-7. Conductivity, pH, alkalinity, total residual (TRC), and free chlorine (FC) of water samples collected from White Oak Creek just above the Materials Testing Laboratory (MTL) outfall (upstream), at the MTL outfall, and from White Oak Creek $20 \mathrm{~m}$ below the MTL outfall (downstream)

\begin{tabular}{|c|c|c|c|c|c|c|}
\hline Date & Site & Conductivity $^{b}$ & $\mathrm{pH}$ & Alkalinity & $\operatorname{TRC}^{d}$ & $\mathbf{F C}^{d}$ \\
\hline \multirow[t]{3}{*}{ March 5} & Upstream & 188 & 8.11 & 103.0 & 0.03 & 0.00 \\
\hline & MTL outfall & 205 & 7.88 & 90.0 & 1.20 & 1.05 \\
\hline & Downstream & 167 & 8.01 & 103.0 & 0.20 & 0.06 \\
\hline \multirow[t]{3}{*}{ March 11} & Upstream & 267 & ND & ND & 1.38 & 1.29 \\
\hline & MTL outfall & 245 & ND & ND & 1.69 & 1.47 \\
\hline & Downstream & 229 & ND & ND & 0.79 & 0.38 \\
\hline April 1 & MTL outfall & 262 & ND & ND & 1.10 & ND \\
\hline
\end{tabular}

"Only conductivity and chlorine were measured in the samples collected on March 11 and April 1, 1987. ${ }^{b}$ Conductivity, microseimens per centimeter, corrected to $25^{\circ} \mathrm{C}$.

Milligrams per liter, expressed as $\mathrm{CaCO}_{3}$.

${ }^{d}$ Milligrams per liter, determined amperometrically.

Note: ND = no data available.

Table 3-8. Mean pH, total residual chlorine (TRC), and free chlorine (FC) concentrations (mean \pm 1 s.d.) in water from the Materials Testing Laboratory (MTL) outfall, from White Oak Creek (sites WCK 4.4, WCK 4.3, WCK 4.2, and WCK 3.8), and from Fifth Creek (FFK 0.0)

\begin{tabular}{llll}
\hline Sampling Site & $\mathrm{pH}$ & $\mathrm{TRC}^{b}$ & FC $^{b}$ \\
\hline WCK 4.4 & 8.00 & $0.13 \pm 0.12$ & $0.06 \pm 0.08$ \\
WCK 4.3 & 8.00 & $0.08 \pm 0.05$ & $0.04 \pm 0.04$ \\
MTL outfall & 8.02 & $0.83 \pm 0.59$ & $0.77 \pm 0.57$ \\
WCK 4.2 & 7.97 & $0.35 \pm 0.14$ & $0.17 \pm 0.15$ \\
FFK 0.0 & 8.23 & $0.32 \pm 0.05$ & $0.26 \pm 0.07$ \\
WCK 3.8 & 8.08 & $0.13 \pm 0.06$ & $0.03 \pm 0.04$ \\
\hline
\end{tabular}

${ }^{a}$ Grab samples were collected and analyzed daily during August 6-13, 1987.

${ }^{b}$ Milligrams per liter, determined amperometrically.

average TRC concentration of $0.32 \mathrm{mg} / \mathrm{L}$, and water in WOC just upstream from its confluence with Fifth Creek had an average concentration of $0.35 \mathrm{mg} / \mathrm{L}$. Concentrations of TRC at WCK 3.8 just downstream from the PWTP averaged $0.13 \mathrm{mg} / \mathrm{L}$. The chemical analyses showed that (1) the MTL outfall significantly increased TRC concentrations in WOC between HTML and Fifth Creek, (2) WOC received TRC from one or more 
sources upstream from the Building 4509 cooling tower, and (3) TRC levels in WOC declined fairly rapidly (by $\sim 50 \%$ over $\sim 0.6 \mathrm{~km}$ ) after joining with Fifth Creek.

Additions of sodium thiosulfate clearly reduced toxicity of water from the MTL outfall, WCK 4.2 (just upstream from Fifth Creek), and from Fifth Creek, based on responses of both test species (Table 3-9). This finding implied that chlorine or other oxidants were the primary toxicants at these sites. The data also suggested that toxicants other than chlorine were present at WCK 3.8. For example, growth of the fish and fecundity of Ceriodaphnia in water from this site were low and were not increased by treatment with sodium thiosulfate. Site WCK 4.2 is downstream of the outfall of PWTP, and effluent from this facility is toxic at high concentrations (Table 3-1). Materials in this effluent, or from as yet undetermined sources, may contribute to the chronic toxicity at WCK 3.8 that was identified in this test.

Table 3-9. Mean survival (percent) and growth (in milligrams dry weight per fish, \pm 1 s.d.) of fathead minnow larvae (Pimephales promelas) and mean survival (percent) and fecundity of Ceriodophria in untreated and dechlorinated water samples from the Materials Testing Laboratory (MTL) outfall, from lower Fifth Creek, and from four sites in a midreach section of White Oak Creels

\begin{tabular}{|c|c|c|c|c|c|}
\hline \multirow[b]{2}{*}{ Site } & \multirow[b]{2}{*}{ Treatment } & \multicolumn{2}{|c|}{ Fathead minnows } & \multicolumn{2}{|c|}{ Ceriodaphnia } \\
\hline & & $\begin{array}{c}\text { Survival } \\
\text { (\%) }\end{array}$ & $\begin{array}{l}\text { Growth } \\
\text { (mg/fish) }\end{array}$ & $\begin{array}{c}\text { Survival } \\
(\%)\end{array}$ & $\begin{array}{c}\text { Fecundity } \\
\text { (offspring/female) }\end{array}$ \\
\hline Control & None & 95.0 & $0.62 \pm 0.05$ & 80 & $18.1 \pm 5.6$ \\
\hline Control & $\mathrm{Na}_{2} \mathrm{~S}_{2} \mathrm{O}_{3}$ & 100.0 & $0.59 \pm 0.04$ & 60 & $13.7 \pm 4.2$ \\
\hline WCK 4.4 & None & 95.0 & $0.51 \pm 0.02$ & 70 & $17.4 \pm 5.3$ \\
\hline WCK 4.4 & $\mathrm{Na}_{2} \mathrm{~S}_{2} \mathrm{O}_{3}$ & 77.5 & $0.52 \pm 0.06$ & 90 & $19.2 \pm 4.7$ \\
\hline WCK 4.3 & None & 80.0 & $0.39 \pm 0.02$ & 100 & $18.4 \pm 4.5$ \\
\hline WCK 4.3 & $\mathrm{Na}_{2} \mathrm{~S}_{2} \mathrm{O}_{3}$ & 82.5 & $0.52 \pm 0.06$ & 100 & $18.5 \pm 3.3$ \\
\hline MTL outfall & None & 0.0 & ND & 0 & ND \\
\hline MTL outfall & $\mathrm{Na}_{2} \mathrm{~S}_{2} \mathrm{O}_{3}$ & 92.5 & $0.53 \pm 0.06$ & 90 & $9.7 \pm 3.4$ \\
\hline WCK 4.2 & None & 90.0 & $0.52 \pm 0.09$ & 0 & ND \\
\hline WCK 4.2 & $\mathrm{Na}_{2} \mathrm{~S}_{2} \mathrm{O}_{3}$ & 97.5 & $0.55 \pm 0.05$ & 90 & $14.4 \pm 5.4$ \\
\hline FFK 0.0 & None & 7.5 & $0.10 \pm 0.03$ & 50 & $8.0 \pm 6.5$ \\
\hline FFK 0.0 & $\mathrm{Na}_{2} \mathrm{~S}_{2} \mathrm{O}_{3}$ & 97.5 & $0.55 \pm 0.05$ & 90 & $14.9 \pm 3.4$ \\
\hline WCK 3.8 & None & 95.0 & $0.41 \pm 0.03$ & 90 & $11.0 \pm 9.6$ \\
\hline WCK 3.8 & $\mathrm{Na}_{2} \mathrm{~S}_{2} \mathrm{O}_{3}$ & 87.5 & $0.48 \pm 0.03$ & 90 & $11.8 \pm 5.5$ \\
\hline
\end{tabular}

'The tests were conducted on August 6-13, 1987. Samples were dechlorinated using sodium thiosulfate $\left(\mathrm{Na}_{2} \mathrm{~S}_{2} \mathrm{O}_{3}\right)$. FFK = Fifth Creek kilometer; $\mathbf{W C K}=$ White Oak Creek kilometer.

Note: $\mathrm{ND}=$ no data available. 


\subsubsection{Toxicity of Area-Source Inputs to White Oak Creek}

Ambient toxicity tests conducted during the first year of the ORNL BMAP suggested that inputs of tapwater levels of chlorine $(-1.5-1.8 \mathrm{mg} / \mathrm{L}$ as TRC) were at least intermittently problematic in lower reaches of Fifth Creek and in a midreach segment of WOC (Loar et al. 1992). The results of the ambient toxicity tests conducted in February and March 1987 were combined with the results of the previous year to address relationships among chemical parameters and spatiotemporal patterns of ambient toxicity. Toxicity test data were available for 139 to 167 site-test combinations, depending upon the test species (fathead minnows vs Ceriodaphnia) and the test endpoint (survival, growth, or fecundity). Water quality data (7-d mean and standard deviation) collected in association with the toxicity tests were available for 176 of the possible 180 (15 sites, 12 test periods; see Fig. 3-1) site-test combinations. A few sites were not sampled in every test period; upper Melton Branch, for example, was dry for much of the summer (Table 2-1).

Three kinds of statistical approaches were used to evaluate the biological and chemical data sets obtained during the ambient toxicity testing program. First, relationships among chemical parameters across all site-test combinations and between chemical parameters and sites were assessed by correlation and by graphical analysis. Second, the intensity and directions of the associations between the toxicity test data and the chemical data sets were evaluated by examination of the correlation structures. Finally, principal components analyses were used to detect and quantify relationships between the biological and chemical information available from the tests. The results of these three approaches are discussed in the following sections.

\subsubsection{Relationships among chemical water quality factors}

Three main points became evident by plotting and correlating results of chemical measurements of water quality. First, the values of conservative properties of water (conductivity, hardness, and alkalinity), when expressed in ratio form, provided useful information about the sites. Second, plots of alkalinity (A) vs hardness (H) for samples from the six sites on WOC and from the three sites on Melton Branch suggested that the ratio of alkalinity to hardness (A:H, both factors expressed as milligrams of $\mathrm{CaCO}_{3}$ per liter) could be used to distinguish two chemical regimes in each of these streams. Third, many of the physicochemical factors measured at the 15 ambient sites were highly correlated with one another. The implications of these findings are discussed below.

A plot of the A:H ratio vs conductivity using data for all site-date combinations produced a nonlinear curve with most points having A:H values between 0.6 and 1.1 (Fig. 3-2). Few samples had conductivity values $>400 \mu \mathrm{S} / \mathrm{cm}$. Water from three of the reference sites (upstream sites on First Creek, Fifth Creek, and WOC) never had A:H values of $<0.58$ nor $>1.14$; the mean $\mathrm{A}: \mathrm{H}$ values for water from these three sites were extremely similar $(0.94,0.93$, and 0.92$)$ and temporally constant. (C.V.s were only $7.4 \%$, $7.5 \%$, and $13.8 \%$ respectively.) These findings showed that the 15 sites were, on average, chemically distinct and that they could be ordinated along strictly chemically axes

(Fig. 3-3). 


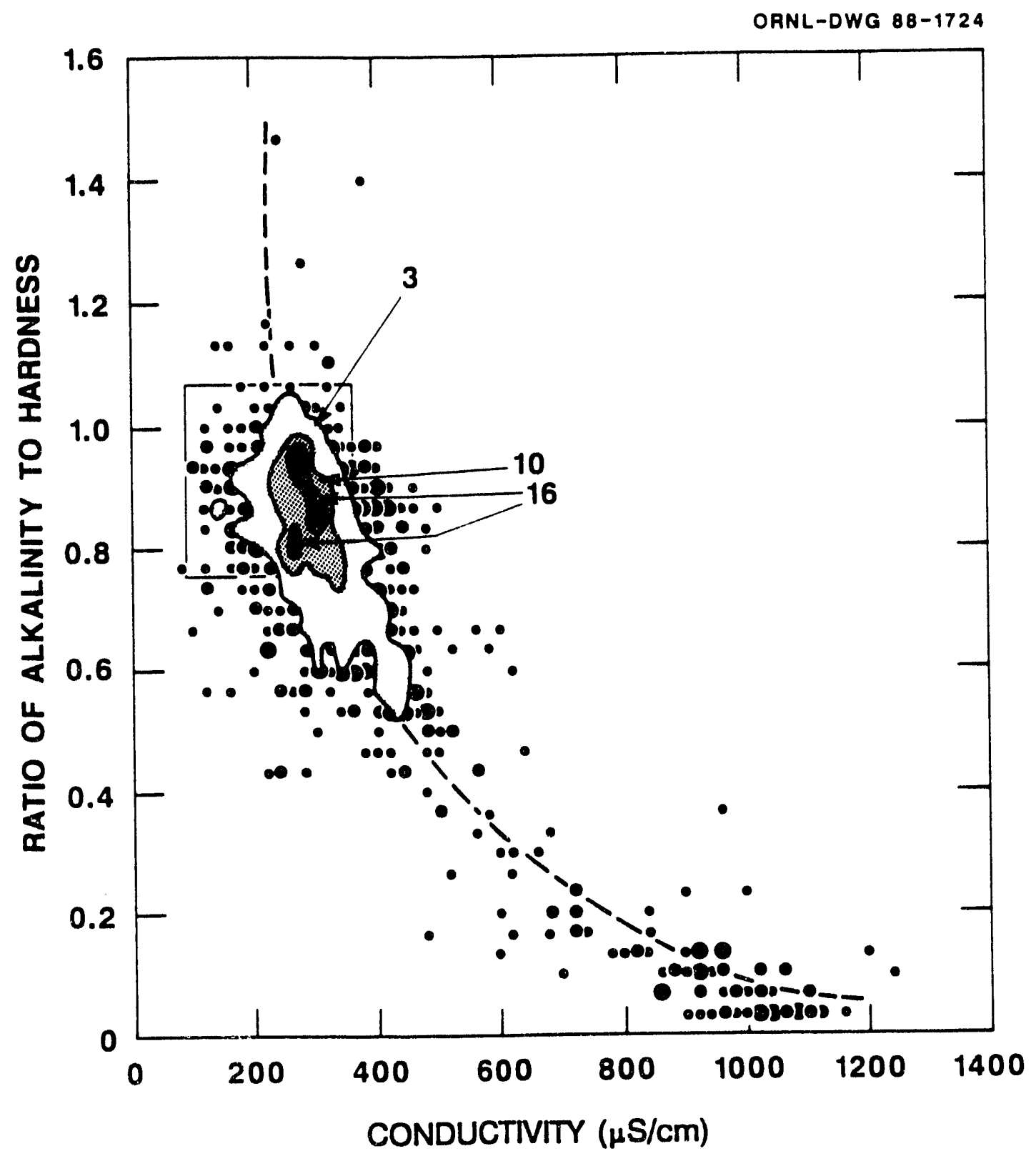

Fig 3-2. Plot of conductivity vs the ratio of allalinity to hardness (A:H) for water samples from all ambient toricity sampling sites. The area enciosed by the square shows the $95 \%$ confidence interval for conductivity and $\mathrm{A}: \mathrm{H}$ ranges for upstream reference sites on First Creek, Fifth Creek, and White Oak Creek. Two overplots are shown as progressively larger symbols. Regions of the graph where there are $3-10,11-16$, and $>16$ overplots per value are indicated by increasing degrees of shading within the isopleths. 


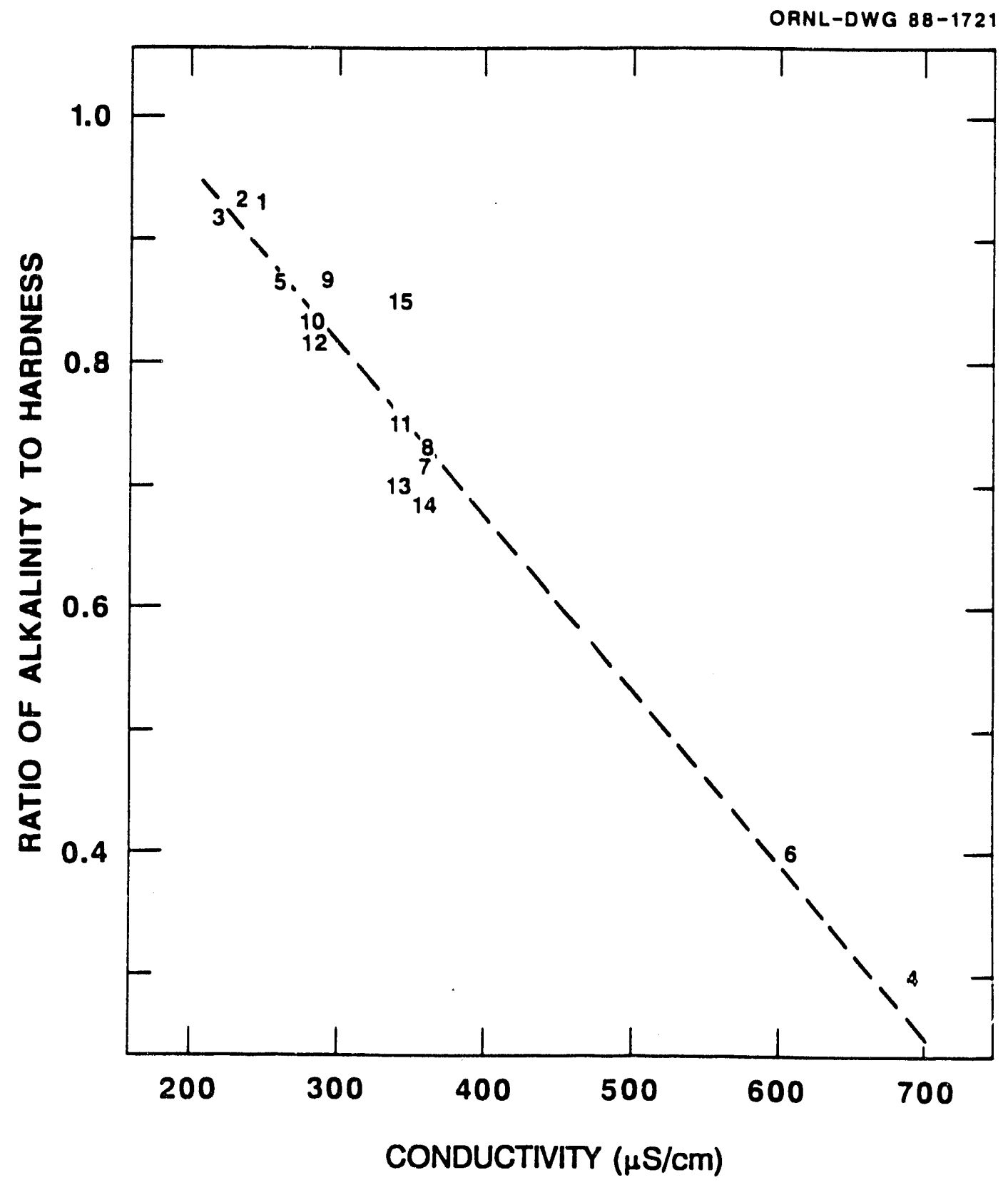

Fig 3-3. Ordination of the 15 ambient toxicity sampling sites on ares of conductivity and the ratio of alkalinity to hardness $(A: H)$. The values for each site are means for all dates, but A:H was computed from daily values before the means were computed. Sites 1,2 , and 3 (upper left) are upstream reference sites; sites 4 and 6 (lower right) are on Melton Branch downstream from the HFIR (see Fig. 3-1). 
Plots of alkalinity vs hardness for samples from the six sites on WOC and from the three sites on Melton Branch suggested that A:H could be used to distinguish two chemical regimes in each stream. In one regime, the relationship between $A$ and $H$ was linear and positive, and $\mathrm{A}: \mathrm{H}$ was close to 1.0 ; in the other, the relationship between $\mathrm{A}$ and $\mathrm{H}$ was zero to negative, and $\mathrm{A}: \mathrm{H}$ was well below unity (Figs. 3-4 and 3-5). Bicarbonaterich waters have an innate tendency to assume a positive near-unity relationship between alkalinity and hardness (Cole 1983, Stewart 1988). An A:H value close to 1.0 over a range of alkalinity and hardness concentrations is, therefore, indicative of a "natural" chemical regime. Deviations from this axis that generate the alternate regime may provide a measure of the degree of chemical perturbation at a site or over a stream reach.

In WOC, deviations from the expected A:H relationship are most easily explained by inputs of wastewaters, such as those produced by CYRTF. The wastewater from this facility is relatively concentrated and has little alkalinity but is high in hardness (Table 3-3). In lower Melton Branch (MEK 0.16), abnormal relationships between A and H (Fig. 3-4) were evident in every test conducted in 1986. Some improvement was noted between tests conducted during October 16-22 and November 13-20, 1986, when A:H increased from $0.16 \pm 0.05$ to $0.46 \pm 0.09$ (mean \pm 1 s.d.). In 1987, A:H at MEK 0.16 increased even more. For the eight test periods, $7-\mathrm{d} \mathrm{A}: \mathrm{H}$ averages ranged from 0.67 to 0.84. In each of these test periods, A:H averages at MEK 0.16 exceeded those at WCK 2.6 (Table 3-6).

The increases in A:H in lower Melton Branch suggest that beneficial changes in wastewater discharge patterns in Melton Valley occurred at about the same time as the shutdown of the HFIR in November 1986. Cooling towers that are used to dissipate heat generated by operation of the HFIR release blowdown high in conductivity and hardness. The blowdown is subsequently discharged to Melton Branch near MEK 1.4 via an unnamed tributary. As much as $95 \%$ of the heat dissipated by the HFIR cooling tower is from the HFIR. (C. W. Ayers, Plant and Equipment Division, ORNL, personal communication, 1986); hence, the shutdown of the HFIR resulted in less use of the cooling tower, and so reduced the average conductivity of water discharged to Melton Branch.

Silver recovery operations are also located at the HFIR site. The procedure used to recover silver from spent photographic wastes generates wastewaters that are high in hardness but low in alkalinity (i.e., a low A:H). Discharges to Melton Branch from this operation were terminated on June 17, 1986. Because the HFIR operations (and the associated high rates of cooling tower blowdown) were greatly reduced in mid-November, chemical conditions in Melton Branch from July to mid-November should reflect the effects of the HFIR operation alone. A:H values (7-d means) for water from MEK 0.16 over this 5-month period were 0.10 for June $19-26,0.08$ for July 25-August $1,0.12$ for August 22-28, 0.16 for September 25-October 1, and 0.17 for October 16-22. The persistently low A:H during the 5-month period when the HFIR was operating but the silver recovery operation was not, combined with the relatively rapid and complete recovery of A:H in Melton Branch after the HFIR was shut down, clearly implicates cooling tower blowdown as a factor controlling water quality parameters in this stream. Materials that could contribute to low A:H include calcium or magnesium sulfate, chloride, or nitrate. These substances result from neutralization of strong acids (e.g., sulfuric, hydrochloric, or nitric) with calcium or magnesium carbonates. 


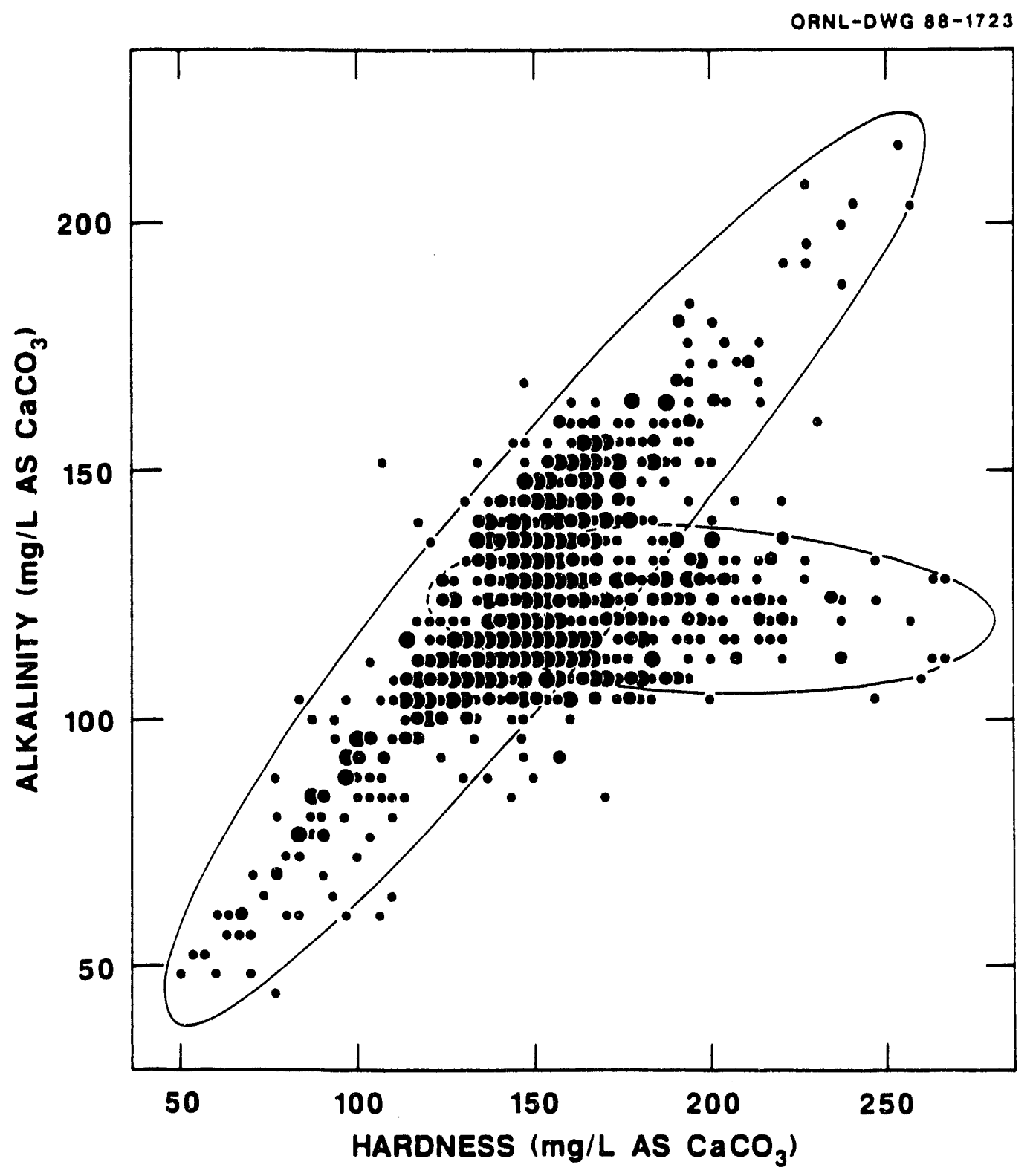

Fig. 3-4. Graph of hardness vs alkalinity for all sampies from 15 ambient toxicity sampling sites in the White Oak Creek watershed (see Fig. 3-1). The longer ellipsoid encompasses an alkalinity to hardness (A:H) ratio that is close to unity; the area outside of the larger ellipsoid but within the smaller, more horizontal ellipsoid encloses values that are not typical for undisturbed local streams. 


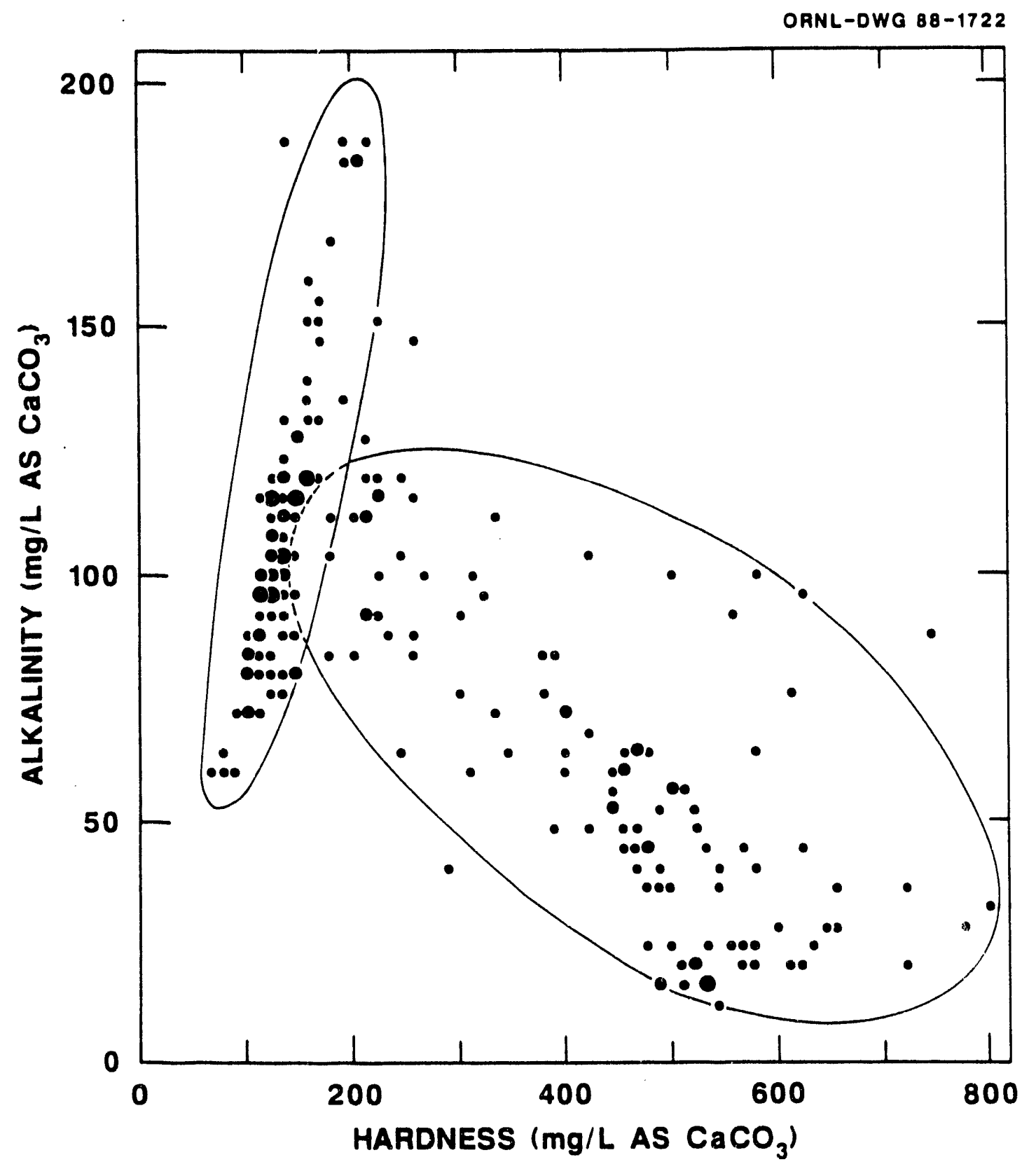

Fig. 3-5. Graph of hardness vs alkalinity for all samples from the three ambient toxicity sampling sites on Melton Branch (see Fig 3-1). The ellipsoid on the left defines an alkalinity to hardness $(\mathrm{A}: \mathrm{H})$ ratio that is close to unity; the area within the larger ellipsoid on the right encloses values that collectively form an $\mathrm{A}: \mathrm{H}$ axis that is markedly different from the $\mathrm{A}: \mathrm{H}$ axis for undisturbed local streams. 
Many of the physicochemical factors measured at the 15 ambient sites were significantly correlated with one another. For example, 42 of 66 possible pair-wise comparisons (64\%) had $p$ values of $\leq 0.03$ (Table $3-10$ ). (Because one would expect, at $p=0.05,5$ of 100 correlations to be "significant" by chance alone, only correlations whose probability of occurring by chance alone was $\leq \mathbf{0 . 0 3}$ were considered "significant".) The degree of redundancy found here suggested that, for the same effort, more information could be obtained either by measuring a smaller, more select suite of parameters either at more sites on a given date or at fewer sites on several dates.

\subsubsection{Correlative ascociations: Biological ve chemical data}

The biological data set contained seven variables: mean survival of the fish for each test [arcsine square root transformed percentage, (MFSURV)]; the among-replicate standard deviation in fish survival for each test (DFSURV); mean growth of fish for each test (MFGROW); the standard deviation associated with mean growth of the fish (DFGROW); survival of the Ceriodaphnia in each test [arcsine square root transformed percentage, (MCSURV)]; mean fecundity of Ceriodaphnia that survived all $7 \mathrm{~d}$ for each test at each site (MCREPRO); and the standard deviation of MCREPRO (DCREPRO). Degrees of freedom for correlations among the biological parameters ranged from 139 (DEREPRO vs MFGROW and DCREPRO vs DFGROW) to 175 (DFSURV vs MFSURV).

The proportion of statistically significant correlations $(\boldsymbol{p} \leq \mathbf{0 . 0 3 )}$ among all 7 biological variables was lower (only 8 of 21 possible comparisons or 38\%) than the proportion found among the chemical variables (64\%, cf. Table 3-10 vs Table 3-11). The acute (survival) endpoints of the tests for the two species were significantly correlated ( $p<0.0001$ ); the chronic endpoints for the two tests (MFGROW vs MCREPRO) were also correlated but less strongly $(p=0.0258)$. Among fish-test parameters, three of six possible correlations were significant; among Ceriodaphnia-test parameters, two of three possible correlations were significant. Only 3 of the 12 fish vs Ceriodaphnia correlations were significant.

Of the 84 possible correlations between the chemical and biological data sets, 17 were significant $(p<0.05)$; parameters associated with the Ceriodaphnia test accounted for 13 of the $17(76 \%)$. Only 4 of $48(8 \%)$ possible fish-test parameters correlated significantly with the chemical data, whereas $36 \%$ (13 of 36 possible) of all Ceriodaphniatest vs chemical parameter correlations were significant. In short, as might be expected, the proportion of significant relationships in each category declined according to the sequence: chemical-chemical > biological-biological $>$ chemical-biological. These correlative relationships are summarized in Table 3-12.

\subsubsection{Principal components analyses: Biological vs chemical data}

Principal components analyses were used to determine the kinds of chemical water quality factors that best explained the toxicity test outcomes for each species. Because these analyses were to identify chemical conditions related to ambient toxicity, they excluded chemical and biological data from reference sites on upper First Creek, Fifth Creek, and WOC where toxicity was not evident. Analyses of separate principal components were used to assess mean survival of the fish, mean growth of the fish, survival of the Ceriodaphnia, and mean fecundity of Ceriodaphnia. The 7-d mean water 
Table 3-10. Correlation coefificients (r) among water quality parameters measured in White Oak Creek ambient toxicity tests"

\begin{tabular}{|c|c|c|c|c|c|c|c|c|c|c|c|c|}
\hline & M-pH & M-cond & M-alk & M-hard & M-TRC & D-temp & D-pH & D-cond & D-alk & D-hard & D-TRC & \\
\hline M-temp & $\begin{array}{l}-0.264 \\
0.0004 \\
\end{array}$ & $\begin{array}{l}0.663 \\
0.0001 \\
\end{array}$ & $\begin{array}{l}-0.351 \\
0.0001 \\
\end{array}$ & $\begin{array}{l}0.660 \\
0.0001 \\
\end{array}$ & $\begin{array}{l}0.092 \\
0.2230\end{array}$ & $\begin{array}{l}0.089 \\
0.2398\end{array}$ & $\begin{array}{l}0.058 \\
0.4431\end{array}$ & $\begin{array}{l}0.304 \\
0.0001 \\
?\end{array}$ & $\begin{array}{l}0.009 \\
0.9068\end{array}$ & $\begin{array}{l}0.346 \\
0.0001\end{array}$ & $\begin{array}{l}0.180 \\
0.0170\end{array}$ & $\begin{array}{l}p \\
p\end{array}$ \\
\hline M-pH & & $\begin{array}{l}-0.430 \\
0.0001 \\
\end{array}$ & $\begin{array}{l}0.649 \\
0.0001\end{array}$ & $\begin{array}{l}-0.451 \\
0.0001\end{array}$ & $\begin{array}{l}0.248 \\
0.0009\end{array}$ & $\begin{array}{l}-0.131 \\
0.0832\end{array}$ & $\begin{array}{l}-0.282 \\
0.0001 \\
\end{array}$ & $\begin{array}{l}-0.196 \\
0.0092 \\
?\end{array}$ & $\begin{array}{l}-0.094 \\
0.2141\end{array}$ & $\begin{array}{l}-0.267 \\
0.0003\end{array}$ & $\begin{array}{l}0.243 \\
0.0011\end{array}$ & $\begin{array}{l}r \\
p\end{array}$ \\
\hline M-cond & & & $\begin{array}{l}-0.522 \\
0.0001 \\
?\end{array}$ & $\begin{array}{l}0.975 \\
0.0001 \\
\end{array}$ & $\begin{array}{l}-0.028 \\
0.7157\end{array}$ & $\begin{array}{l}0.342 \\
0.0001\end{array}$ & $\begin{array}{l}0.148 \\
0.0507\end{array}$ & $\begin{array}{l}0.587 \\
0.0001 \\
\end{array}$ & $\begin{array}{l}0.112 \\
0.1400\end{array}$ & $\begin{array}{l}0.621 \\
0.0001 \\
\end{array}$ & $\begin{array}{c}-0.559 \\
0.4610\end{array}$ & $\begin{array}{r}r \\
p\end{array}$ \\
\hline M-alk & & & & $\begin{array}{l}-0.514 \\
0.0001 \\
?\end{array}$ & $\begin{array}{l}0.014 \\
0.8491\end{array}$ & $\begin{array}{l}-0.181 \\
0.0159 \\
\end{array}$ & $\begin{array}{l}-0.248 \\
0.0009 \\
\end{array}$ & $\begin{array}{l}-0.403 \\
0.0001 \\
\end{array}$ & $\begin{array}{l}-0.128 \\
0.0908\end{array}$ & $\begin{array}{l}-0.459 \\
0.0001 \\
?\end{array}$ & $\begin{array}{l}0.010 \\
0.8951\end{array}$ & p \\
\hline M-hard & & & & & $\begin{array}{l}-0.081 \\
0.2852 \\
\end{array}$ & $\begin{array}{l}0.334 \\
0.0001\end{array}$ & $\begin{array}{l}0.172 \\
0.0224 \\
?\end{array}$ & $\begin{array}{l}0.528 \\
0.0001\end{array}$ & $\begin{array}{l}0.107 \\
0.1577 \\
\end{array}$ & $\begin{array}{l}0.654 \\
0.0001\end{array}$ & $\begin{array}{c}-0.119 \\
0.1164\end{array}$ & p \\
\hline M-TRC & & & & & & $\begin{array}{l}-0.147 \\
0.0508\end{array}$ & $\begin{array}{c}-0.047 \\
0.5298\end{array}$ & $\begin{array}{l}0.194 \\
0.0100\end{array}$ & $\begin{array}{l}-0.127 \\
0.0924\end{array}$ & $\begin{array}{l}0.047 \\
0.5370\end{array}$ & $\begin{array}{l}0.797 \\
0.0001 \\
\end{array}$ & $\begin{array}{l}r \\
p\end{array}$ \\
\hline D-temp & & & & & & & $\begin{array}{l}0.081 \\
0.2858\end{array}$ & $\begin{array}{l}0.300 \\
0.0001 \\
\end{array}$ & $\begin{array}{l}0.383 \\
0.0001 \\
\end{array}$ & $\begin{array}{l}0.405 \\
0.0001\end{array}$ & $\begin{array}{l}-0.164 \\
0.0298\end{array}$ & $\begin{array}{l}p \\
p\end{array}$ \\
\hline D.pH & & & & & & & & $\begin{array}{l}0.267 \\
0.0008\end{array}$ & $\begin{array}{l}0.282 \\
0.0002 \\
\end{array}$ & $\begin{array}{l}0.267 \\
0.0003\end{array}$ & $\begin{array}{c}-0.043 \\
0.5702\end{array}$ & $\stackrel{r}{p}$ \\
\hline D-cond & & & & & & & & & $\begin{array}{l}0.286 \\
0.0001\end{array}$ & $\begin{array}{l}0.796 \\
0.0001 \\
?\end{array}$ & $\begin{array}{l}0.204 \\
0.0068 \\
.\end{array}$ & $\begin{array}{l}p \\
p\end{array}$ \\
\hline D-alk & & & & & & & & & & $\begin{array}{l}0.355 \\
0.0001 \\
?\end{array}$ & $\begin{array}{c}-0.004 \\
0.9565\end{array}$ & $\begin{array}{l}r \\
p\end{array}$ \\
\hline D-hard & & & & & & & & & & & $\begin{array}{l}0.046 \\
0.5413\end{array}$ & p \\
\hline
\end{tabular}

The $M$ and $D$ preceding the parameter refer to the mean and standard deviation respectively. The probability of obtaining a greater absolute value for $r$ under the null hypothesis $H_{0}: R=0$ is given for each value of $r$, the number of observations used to compute $r$ is 176 in all cases. Temp = temperature, cond = condition, alk $=$ alkalinity, hard = hardness, $T R C=$ total residual chlorine.

-Significant at $p=0.05$. 
Table 3-11. Correlation coefificients among biological variables in ambient toxicity tests of water from White Oak Creek and tributaries

\begin{tabular}{|c|c|c|c|c|c|c|}
\hline & DFSURV & MFGROW & DFGKOW & MCSURV & MCREPRO & DCKEPRO \\
\hline & -0.087 & 0.080 & -0.484 & 0.293 & -0.016 & -0.100 \\
\hline MFSURV & $\begin{array}{l}0.2507 \\
(175)\end{array}$ & $\begin{array}{c}0.3210 \\
(157)\end{array}$ & $\begin{array}{c}0.0001^{b} \\
(155)\end{array}$ & $\begin{array}{c}0.0001^{b} \\
(167)\end{array}$ & $\begin{array}{c}0.8421 \\
(155)\end{array}$ & $\begin{array}{c}0.2214 \\
(152)\end{array}$ \\
\hline DFSURV & & $\begin{array}{c}0.034 \\
0.6724 \\
(157)\end{array}$ & $\begin{array}{c}0.342 \\
0.0001^{b} \\
(155)\end{array}$ & $\begin{array}{c}0.150 \\
0.0530 \\
(167)\end{array}$ & $\begin{array}{c}0.048 \\
0.5525 \\
(155)\end{array}$ & $\begin{array}{c}0.053 \\
0.5187 \\
(152)\end{array}$ \\
\hline MFGROW & & & $\begin{array}{c}0.249 \\
0.0018^{b} \\
(155)\end{array}$ & $\begin{array}{c}-0.072 \\
0.3837 \\
(149)\end{array}$ & $\begin{array}{c}-0.185 \\
0.0285^{b} \\
(141)\end{array}$ & $\begin{array}{c}-0.204 \\
0.0158^{b} \\
(139)\end{array}$ \\
\hline DFGROW & & & & $\begin{array}{c}-0.030 \\
0.7210 \\
(147)\end{array}$ & $\begin{array}{l}-0.096 \\
0.2577 \\
(140)\end{array}$ & $\begin{array}{l}0.014 \\
0.8696 \\
(139)\end{array}$ \\
\hline MCSURV & & & & & $\begin{array}{c}0.348 \\
0.0001^{b} \\
(155)\end{array}$ & $\begin{array}{c}-0.010 \\
0.9067 \\
(152)\end{array}$ \\
\hline MCREPRO & & & & & & $\begin{array}{c}0.390 \\
0.0001^{b} \\
(152)\end{array}$ \\
\hline
\end{tabular}

${ }^{4}$ MFSURV = mean transformed survival of the fish in each test; DFSURV = among-replicate standard deviation in fish survival for each teat; MFGROW = mean growth of fish for each teat; DFGROW = standard deviation of MFGROW; CARCSUR = transformed survival of Ceriodaphnia; MCREPRO = mean fecundity of Ceriodaphnia that survived all 7 days for each teat at each site; and DCREPRO = standard deviation of MCREPRO. The probability of obtaining a greater

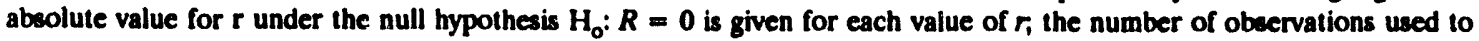
compute $r$ is given in parentheses.

'Indicates $p<0.05$.

temperature, $\mathrm{pH}$, conductivity, hardness, alkalinity, and TRC for each site-test combination were first used to generate principal components axes. These axes were in turn used as independent variables in separate regression models with MFSURV, MCSURV, MFGROW, and MCREPRO as dependent variables.

Results of the principal components analyses are shown in Table 3-13, and results of the SAS• general linear model (GLM) tests of the relationships of MFSURV, MFGROW, MCSURV, and MCREPRO to the two principal component factors are shown in Table 3-14. The loading values indicated that factor 1 represented an axis dominated by hardness, conductivity, and $\mathrm{pH}$; factor 2 correlated highly with chlorine, and secondarily with water temperature and $\mathrm{pH}$. Relationships of the two factors to the toxicity test data were similar to those suggested by the correlation analyses described earlier: the fish test results did not correspond well to any combination of the chemical data, but the Ceriodaphnia test results did. The chlorine-related axis (factor 2) strongly 
- Table 3-12. Summary of correlative relationships among water chemistry parameters (chem), Ceriodaphnia $(\mathrm{Car})$ and inthead minnow (FHM) toxicity test dats, and between these two (chemical, biologicai) data sets"

\begin{tabular}{|c|c|c|}
\hline Parameter sets analyzed & Number of correlations & $\begin{array}{l}\text { Number of } \\
\text { significant correlations }\end{array}$ \\
\hline Chemical & 66 & $41 / 66(62.1 \%)$ \\
\hline Biological & 21 & $8 / 21(38.1 \%)$ \\
\hline $\begin{array}{l}\text { Cer vs Cer } \\
\text { Cer us FHM } \\
\text { FHM vs FHM }\end{array}$ & $\begin{array}{r}3 \\
12 \\
6\end{array}$ & $\begin{array}{r}2 / 3(66.7 \%) \\
3 / 12(25.0 \%) \\
3 / 6(50.0 \%)\end{array}$ \\
\hline $\begin{array}{l}\text { Chemical } \\
\text { vs } \\
\text { Wiological (all) }\end{array}$ & 84 & $17 / 84(20.2 \%)$ \\
\hline $\begin{array}{l}\text { Cer vs Chem } \\
\text { FHM vs Chem }\end{array}$ & $\begin{array}{l}36 \\
48\end{array}$ & $\begin{array}{r}13 / 36(36.1 \%) \\
4 / 48(8.3 \%)\end{array}$ \\
\hline
\end{tabular}

${ }^{a}$ Data are based on 12 monthly tests with both species at 15 sites on 5 streams in the White Oak Creek watershed. Significance level is $p<0.05$.

Table 3-13. Principal component factor patterns for 7-d means of water quality parameters measured during toxicity tests of water from 12 sites on 5 streams at ORNL"

\begin{tabular}{lrr}
\hline Parameter & Factor 1 & Factor 2 \\
\hline & & \\
Mean water temperature & 0.71956 & 0.35307 \\
Mean pH & -0.82505 & 0.22678 \\
Mean conductivity & 0.93728 & 0.06768 \\
Mean alkalinity & -0.79663 & -0.02068 \\
Mean hardness & 0.93610 & 0.04857 \\
Mean total residual chlorine & -0.20577 & 0.93470 \\
\hline
\end{tabular}

${ }^{a}$ Chemical data from 12 monthly tests were used to compute the loadings for 6 orthogonal factors. The first two (factors 1 and 2) accounted for $60.5 \%$ and $17.6 \%$, respectively, of the total variance. 
Table 3-14. Results of multiple regression analyses of toricity test response variables on chemical data used to generate principal components ares 1 and 2

\begin{tabular}{|c|c|c|c|c|c|}
\hline Source & DF & Type III SS & Mean Square & F value & $\operatorname{Pr}>\mathrm{F}$ \\
\hline \multicolumn{6}{|c|}{ MFSURV } \\
\hline $\begin{array}{l}\text { Model } \\
\text { Error } \\
\text { Total }\end{array}$ & $\begin{array}{r}179.063 \\
136 \\
138\end{array}$ & $\begin{array}{r}89.532 \\
55445.470 \\
55624.533\end{array}$ & $\begin{array}{r}0.22 \\
407.687\end{array}$ & 0.8031 & \\
\hline \multicolumn{6}{|c|}{ MFGROW } \\
\hline $\begin{array}{l}\text { Model } \\
\text { Error } \\
\text { Total }\end{array}$ & $\begin{array}{r}2 \\
121 \\
123\end{array}$ & $\begin{array}{l}0.01614 \\
2.39697 \\
2.41311\end{array}$ & $\begin{array}{l}0.00807 \\
0.01981\end{array}$ & 0.41 & 0.6663 \\
\hline \multicolumn{6}{|c|}{ MCSURV } \\
\hline $\begin{array}{l}\text { Model } \\
\text { Axis } 1 \\
\text { Axis } 2 \\
\text { Error } \\
\text { Total }\end{array}$ & $\begin{array}{r}2 \\
1 \\
1 \\
130 \\
132\end{array}$ & $\begin{array}{r}16947.75 \\
1681.60 \\
15497.19 \\
80100.15 \\
97047.90\end{array}$ & $\begin{array}{r}8473.88 \\
1681.60 \\
15497.19 \\
616.16\end{array}$ & $\begin{array}{r}13.75 \\
2.35 \\
25.15\end{array}$ & $\begin{array}{l}0.0001 \\
0.1009 \\
0.0001\end{array}$ \\
\hline \multicolumn{6}{|c|}{ MCREPRO } \\
\hline $\begin{array}{l}\text { Model } \\
\text { Axis } 1 \\
\text { Axis } 2 \\
\text { Error } \\
\text { Total }\end{array}$ & $\begin{array}{r}2 \\
1 \\
1 \\
118 \\
120\end{array}$ & $\begin{array}{r}649.884 \\
352.556 \\
300.422 \\
6253.086 \\
6902.969\end{array}$ & $\begin{array}{r}324.942 \\
352.556 \\
300.422 \\
52.992\end{array}$ & $\begin{array}{l}6.13 \\
6.65 \\
5.67\end{array}$ & $\begin{array}{l}0.0029 \\
0.0111 \\
0.0189\end{array}$ \\
\hline
\end{tabular}

aSums of squares for each axis are given if the overall model was significant $(p<0.05)$. Variables are defined in Table 3-11.

influenced Ceriodaphnia survival, while factors 1 and 2 affected more equally, and to only a slightly smaller extent, Ceriodaphnia fecundity.

The results of the principal components analyses indicate that Ceriodaphnia may bo more sensitive than fathead minnow larvae to the presence of low levels of TRC and moderate to high levels of hardness and/or conductivity. The results of tests of various high-conductivity effluents [e.g., those from CYRTF at ORNL, the S-3 Liquid Treatment Facility and West Fnd Treatment Facility at the Y-12 Plant, and the K-1407-B pond at the 
Oak Ridge Gaseous Diffusion Plant (ORGDP)], with fathead minnow larvae and Ceriodaphnia tend to substantiate this finding. Support for the hypothesis that Ceriodaphnia may be more susceptible than fathead minnow larvae to TRC is also found in the results of toxicity tests of TRC-contaminated water from East Fork Poplar Creek above New Hope Pond at the east end of the Y-12 Plant (Loar 1992) and from Mitchell Branch at ORGDP (Smith et al. 1988).

\subsubsection{Toxicological Problems Aseociated with Chlorine}

The analyses of the biological and chemical data sets discussed in the preceding section and the results of the dechlorination experiments described in Sect. 3.1.1 repeatedly showed that concentrations of TRC in midreach sections of WOC and throughout most of Fifth Creek are at least episodically high enough to be acutely toxic (i.e., kill the test animals in less than $7 \mathrm{~d}$ ). Ultimately, changes in chlorine discharge patterns will be required if ambient toxicity in these reaches of stream is to be eliminated. Toxicity, however, is defined in terms of the responses of organisms (death, behavioral changes, reductions in growth or fecundity) to a material in the context of a particular exposure regime. The intensity (or rapidity) of the biological response of an organism or population of organisms to a material is generally assumed to be linearly or log-linearly related to toxicant concentration (i.e., responses increase with dose) and, for disruptive substances at least one can identify a concentration below which responses do not occur (Mackay 1988). The point at which concentrations of TRC in WOC and Fifth Creek are so low that toxicity is no longer evident is determined by two factors. Due to the doseresponse aspects inherent in the concept of toxicity, its measure is dependent upon (1) the innate sensitivity of the organisms for which protection is desired and (2) the fluctuations in concentration of TRC and ancillary factors influencing TRC speciation, such as $\mathrm{pH}$ and water temperature, that collectively define the organisms' exposure regime.

Results of the ambient toxicity tests indicate that the Ceriodaphnia test systems could, on average, reveal toxicity in water from WCK 4.4 where the mean TRC concentration was only $0.03 \mathrm{mg} / \mathrm{L}$. This mean value, however, included TRC concentrations ranging from nondetectable $(<0.01)$ to $0.38 \mathrm{mg} / \mathrm{L}$. Results of Ceriodaphnia static-renewal tests suggest that a test water with an initial TRC concentration of about $0.15 \mathrm{mg} / \mathrm{L}$ is likely to show evidence of toxicity. Studies presently underway show that Elimia, an operculate snail common in headwater reaches of First Crcek, WOC, Walker Branch, and Ish Creek changes its behavior almost immediately when exposed in flow-through test systems to tapwater with a TRC concentration of $0.09-0.10 \mathrm{mg} / \mathrm{L}$. Mortality of the snails exposed to this concentration of TRC for $2-4 \mathrm{~h}$ exceeds $70 \%$. In the same flow-through systems, fathead minnow larvae exposed to $0.09-0.10 \mathrm{mg} / \mathrm{L}$ of TRC died within $90 \mathrm{~min}$. To protect aquatic biota in ORNL streams, these findings suggest that average concentrations of TRC should be lower than $0.03 \mathrm{mg} / \mathrm{l}$, and that no site should have TRC concentrations that exceed $0.1 \mathrm{mg} / \mathrm{L}$ for more than $60-90 \mathrm{~min}$. The data do not allow much insight into how frequently stream organisms could be subjected to a maximum TRC level of $0.10 \mathrm{mg} / \mathrm{L}$ before ecological effects became evident. The data also do not provide insight into whether or not a hypothetical maximum concentration of $0.10 \mathrm{mg} / \mathrm{L}$ TRC would actually protect aquatic communities that include animals other than Elimia, fathead minnow larvae, and Ceriodaphnia. Assessment of community-ievel responses to continuous or 
intermittent exposures to known concentrations of TRC concentrations in flow-through test systems are required to address these questions.

\subsubsection{Summary of Results: Effluent and Ambient Toxicity Tests}

Based on (1) 10 to 12 toxicity tests of effluents from 3 ORNL wastewater treatment facilities, (2) 12 monthly tests of water from 15 stream sites, (3) tests with ambient water samples from WOC and Fifth Creek that were dechlorinated before testing, and (4) experiments on chlorine toxicity in flow-through systems, the following 6 conclusions seem warranted:

1. Chlorine and/or chlorine-like oxidants measurable as TRC and/or short-lived degradation products of such oxidants control the overall patterns of toxicity in WOC and Fifth Creek. Evidence for toxicity due to materials other than chlorine was found at WCK 3.8, based on responses of both test species. The evidence for toxicity at WCK 3.8, however, came from one test only and so should be interpreted cautiously.

2. The toxicological effects of discharges of TRC to these two streams are at least episodically evident at sites where average concentrations of TRC are as low as $0.10-0.15 \mathrm{mg} / \mathrm{L}$. Concentrations of TRC $\geq 0.15 \mathrm{mg} / \mathrm{L}$ occur at least intermittently throughout Fifth Creek below Bethel Valley Road; in WOC, TRC concentrations $\geq 0.15$ $\mathrm{mg} / \mathrm{L}$ occur at least occasionally throughout a 1.0 - to $1.7-\mathrm{km}$ reach extending upstream from the weir at Melton Valley Drive (WCK 3.41).

3. Much or most of the TRC in WOC and Fifth Creek appears to be associated with releases of chlorinated tapwater, notably through outfalls such as that from MTL.

4. Sampling sites used for evaluating toxicity patterns in the WOC watershed could be distinguished chemically, using conservative properties of natural waters (hardness:alkalinity and conductivity; Fig. 3-3) as descriptors.

5. Chemical analyses of water samples from reference sites on upper Fifth Creek, First Creek, and WOC, and from Ish Creek and Brushy Fork, indicate that local streams unaffected by DOE operations typically have a linear, positive relationship between alkalinity $(A)$ and hardness $(H)$. The value for $A: H$ in such cases ranges from about 0.83 to 0.94 and varies little seasonally. Deviations in A:H in the receiving streams can in some cases be linked to specific wastewater discharge processes; $\mathrm{A}: \mathrm{H}$ can then serve as a useful fingerprint for temporal and spatial changes in wastewater discharge patterns. CYRTF, for example, generates a chemically distinct wastewater that could contribute to reductions in A:H in WOC. In Melton Branch, cooling tower blowdown associated with operation of the HFIR appeared to be important to low instream values of A:H. A:H values in Melton Branch recovered rapidly after the HFIR was shut down in November 1986.

6. Correlation analyses and principal components analyses betwcen water quality data and ambient toxicity test data were in good general agreement in two areas. First, the Ceriodaphnia test system appears to be distinctly more sensitive than the fish test system and tracked measured ambient water quality factors fairly closely. This conclusion was supported by the results of the effluent tests (Table 3-1), where Ceriodaphnia were 
more sensitive than the fish in 18 of 29 side-by-side tests and just as sensitive as the fish in 10 of the 29 tests. Second, the degree of redundancy among the kinds of water quality factors included in the chemical data set and the general lack of concordance between fish-test and water chemistry data sets indicate that chemical factors other than those measured warrant toxicological consideration. Both statistical approaches also implicate TRC as an important factor controlling Ceriodaphnia test outcomes for midreach sites in WOC and in mid and lower Fifth Creek.

\subsubsection{Future Studies}

During the next year, studies are planned to address the following questions:

1. What outfalls, other than that associated with MTL, contribute significantly to TRC levels in WOC and Fifth Creek?

2. Is there evidence of chronic toxicity in the midreaches of WOC and in lower Fifth Creek after TRC is eliminated?

3. What concentrations and exposures of TRC can be considered to be ecologically safe? What kinds of test organisms and/or groups of organisms are most suited to provide answers to this question?

Finally, many wastewaters are treated to remove contaminants by adding chemicals. For example, acidic wastes are neutralized by additions of lime; basic wastes are typically neutralized by adding sulfuric acid; metals may be removed by $\mathrm{pH}$ adjustments made through the addition of acid or base; materials may be coagulated and/or precipitated by adding polymers or by $\mathrm{pH}$ adjustments after flocculating agents, such as Ferrifloc, have been added. In some cases, the removal of undesirable chemicals by means of adding other chemicals may leave the treated water more toxic than it was prior to treatment. Effluent from CYRTF is consistently toxic to Ceriodaphnia and ironically is concentrated with respect to conductivity and hardness. Is this toxicity due to the presence of toxic contaminants (such as metals or organics), or are reductions in Ceriodaphnia survival and fecundity reflections of more fundamental water quality factors (conductivity, hardness, $\mathrm{A}: \mathrm{H})$ that are altered by the processes used to remove the contaminants? Diagnostic tests will be used to distinguish between these two possibilities and to evaluate the biological effects of changes in alkalinity, hardness, and their ratio.

\subsection{INSTREAM MONITORING OF THE PERIPHYTON COMMUNETY}

Periphyton, a complex matrix of algae and heterotrophic microbes attached to submersed surfaces, serves as a major food source for many stream invertebrates (Minshall 1978) and herbivorous fishes (Power et al. 1985). The biotic activity and organic content of periphyton can result in concentrations of certain contaminants (e.g., mercury and cadmium within the periphyton matrix (Huckabee and Blaylock 1973, Selby et al. 1985). Thus, periphyton becomes important to both the natural functioning of aquatic systems and to the food-chain transfer of contaminants entering these systems. Turnover rates on the order of days for the biotic components of the periphyton make this community 
especially useful for detecting short-term environmental changes (e.g., infrequent puises of toxicants that might be difficult to detect when considering organisms with longer life spans). In summary, periphyton can be used to (1) characterize biological communities, (2) evaluate contaminant transport and food-chain accumulation, (3) identify sources and frequencies of toxicant entry into the system, and (4) predict and evaluate biotic responses to remedial actions.

Monitoring of the periphyton communities was initiated in April 1986 and, to date, has focused largely on the biomass and productivity of the algal component of the periphyton matrix. During 1987, additional parameters were included in the monitoring program, and several studies were conducted to evaluate conditions for algal periphyton growth at the study sites. Work continued on the development of metrics to evaluate the physiological state or "health" of the algal periphyton. Adenosine triphosphate (ATP) concentrations in the periphyton were determined as an indicator of both algal and heterotrophic biomass. Short-term laboratory algal bioassays were conducted to evaluate the influence of water quality on photosynthesis by the algal component of the periphyton. Recently initiated studies are evaluating biotic interactions and the influen re of various aspects of the physicochemical environment on the composition and process rates of the periphyton community. Periphyton samples were collected and analyzed to screen for metal contamination and to identify (1) sources of contaminant entry to the WOC system, (2) stresses on the periphyton community, and (3) the potential for food-chain transfer of contaminants via the periphyton.

Evaluating the role of the periphyton in the food-chain transfer of contaminants and utilizing the periphyton as sensitive bioindicators are viewed as important components of the periphyton monitoring task of BMAP. These areas received some attention during 1987 and will be more intensively evaluated in 1988.

\subsection{Methods}

Small rocks with their associated periphyton were collected monthly from ten sites in the WOC watershed (Fig. 3-6) to monitor algal periphyton biomass and photosynthetic rates. The periphyton sampling sites largely coincided with fish and invertebrate sampling stations (Fig. 2-3). Five sites receive drainage or are downstream from ORNL effluent discharges, including four on WOC (WCK 3.9, WCK 3.4, WCK 2.9, and WCK 2.3) and one on Melton Branch (MEK 0.6). The remaining five reference sites are all located above ORNL on WOC (WCK 6.8), Melton Branch (MEK 1.8), Northwest Tributary (NTK 1.0), First Creek (FCK 1.0), and Fifth Creek (FFK 1.1).

\subsubsection{Periphyton chlorophyll and carbon incorporation}

To determine algal periphyton biomass and production, four small (10- to $\left.60-\mathrm{cm}^{2}\right)$ relatively flat rocks were collected monthly from shallow $(<25-\mathrm{cm}$-deep) riffle areas at each site. The rocks were taken to the laboratory in water from the collection site. In the laboratory, rocks from each site were incubated for $2 \mathrm{~h}$ in $-1 \mathrm{~L}$ of water from the collection site containing $10 \mathrm{Ci} \mathrm{NaH}{ }^{14} \mathrm{CO}_{3}$. During the incubation, the water temperature 
was maintained within $2^{\circ} \mathrm{C}$ of ambient stream temperature. Approximately $400 \mu \mathrm{mol} \cdot \mathrm{m}^{-2} \cdot \mathrm{s}^{-1}$ of photosynthetically active radiation $(\sim 16 \%$ full sun) was provided by a $1000-\mathrm{W}$ metal halide lamp, and the water was circulated by a submersible pump to simulate natural conditions. After incubation, the rocks were rinsed twice in distilled water to remove residual inorganic ${ }^{14} \mathrm{C}$. They were then placed in $30 \mathrm{~mL}$ of dimethyl sulfoxide (DMSO) and kept in darkness for $24 \mathrm{~h}$ to extract soluble organic compounds and chlorophyll (Filbin and Hough 1984). Five milliliters of extract was diluted 1:1 with 90\% acetone, and the chlorophyll $a$ content was determined spectrophotometrically by using the equations of Jeffrey and Humphrey (1975). Corrections were made for phaeopigments (Strickland and Parsons 1972). A 500- $\mu \mathrm{L}$ aliquot of the extract was added to $10 \mathrm{~mL}$ of Aquasol (scintillation cocktail), and the ${ }^{14} \mathrm{C}$ content of the aliquot was determined by liquid scintillation spectrometry.

The surface area of each rock was determined by covering the upper surface with aluminum foil, determining the weight of the foil, and converting to surface area based on a known weight per unit area of foil. This procedure was repeated twice for each rock. Chlorophyll $a$, the rate of carbon incorporation, and ATP were then expressed on a surface-area basis.

\subsubsection{Periphyton ATP}

ATP was determined by assaying an aliquot of DMSO extract (Shoaf and Lium 1976) using Lumac reagents and a Lumac Biocounter integrating photometer. Phosphate was added to the DMSO to $\sim 20 \mathrm{mM}$ prior to extraction in order to prevent loss of ATP to phosphatase activity (Palumbo et al. 1987).

\subsubsection{Algal bioassay of water quality}

To evaluate the influence of water quality on the growth and photosynthesis of the algal periphyton, short-term laboratory bioassays were performed at each site using the green alga Haematococcus (modified from Giddings et al. 1983). In these studies, the photosynthetic rates of the laboratory-grown alga provide a relative measure of the potential influence of water quality on the photosynthesis of the algal periphyton in the stream. For these assays, water was collected from each of the nine study sites that were flowing on three dates in June and July 1987. (MEK 1.8 was dry on all three dates.) The water was taken to the laboratory, where an inoculum of the laboratory-grown green alga Haematococcus was added to an aliquot of the water from each site and to dechlorinated tap water as a control medium. Following a 2-h preincubation, the cells in each aliquot were concentrated by centrifugation, and a $500-\mathrm{L}$ inoculum from this concentrated solution was introduced to a fresh $4.5-\mathrm{mL}$ aliquot of water from the same site in a glass 20-mL scintillation vial. A solution of $\mathrm{NaH}^{14} \mathrm{CO}_{3}$ was added to each aliquot, and these were then incubated on a gently rotating shaker table for $2 \mathrm{~h}$ at $25^{\circ} \mathrm{C}$ and $\sim 150 \mu \mathrm{mol}$ of photosynthetically active radiation. At the end of the experimental period, $30 \mathrm{~mL}$ of $1 \mathrm{~N}$ $\mathrm{HCl}$ was added to each vial to stop carbon uptake and to lower the $\mathrm{pH}$ to $\sim 4$. The solutions were then purged for $20 \mathrm{~min}$ with an air stream to remove unincorporated inorganic ${ }^{14} \mathrm{C}$. Fifteen milliliters of Aquasol liquid scintillation cocktail was then added to each vial, and the ${ }^{14} \mathrm{C}$ content was determined by liquid scintillation counting. Photosynthesis was determined based on the fraction of the added carbon incorporated 


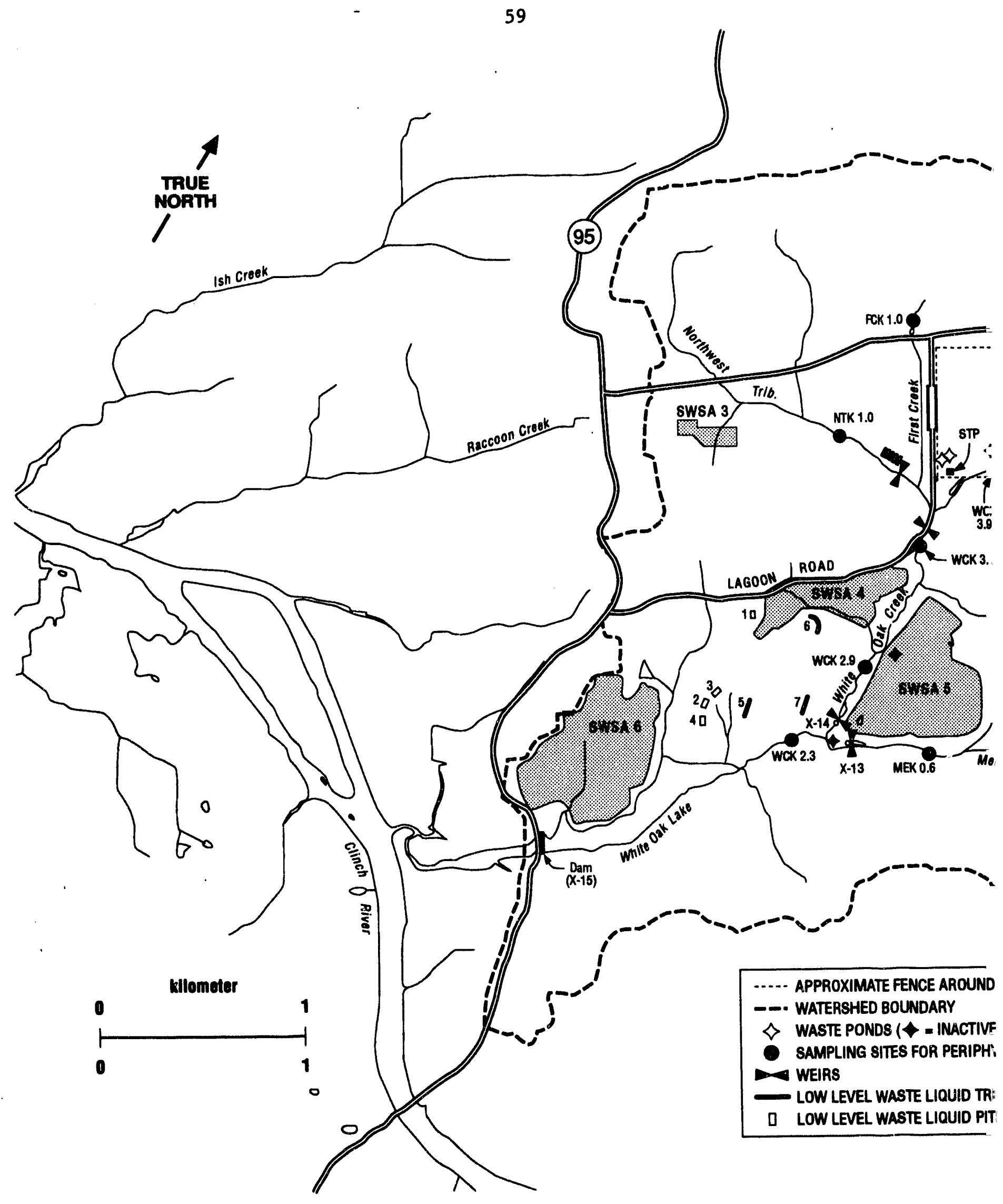

Fig 3-a Locations of the periphyton = 


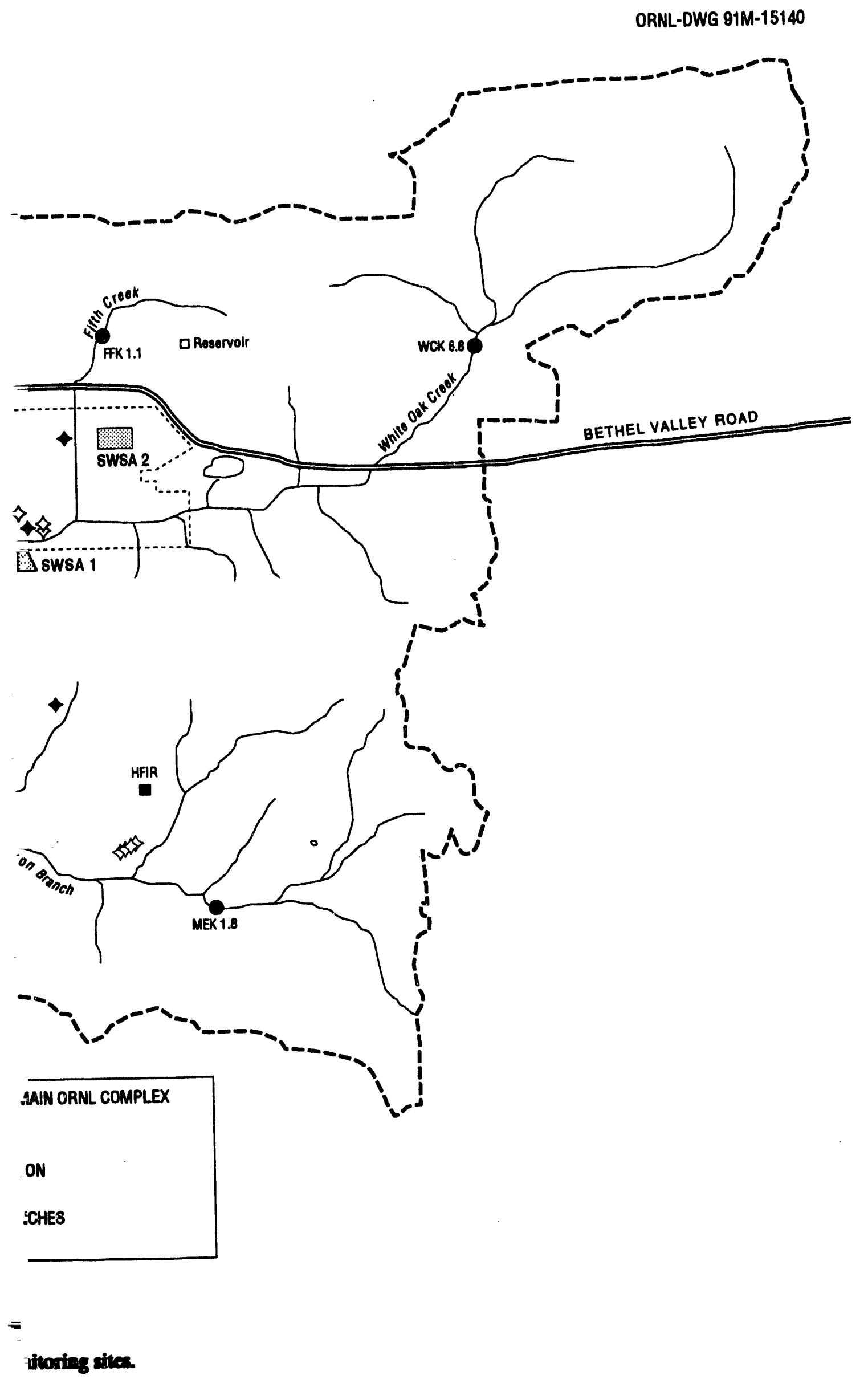


and the inorganic carbon content of the water from each site (determined from $\mathrm{pH}$, alkalinity, conductivity, and temperature), and then corrected for background uptake by photoautotrophs in the water sample and nonphotosynthetic carbon incorporation. Background uptake in the water sample was determined by adding the ${ }^{14} \mathrm{C}$ solution and incubating the water sample without adding the Haematococcus inoculum.

Nonphotosynthetic carbon uptake was determined by adding dichlorophenyl dimethyl urea (DCMU, an inhibitor of photosynthesis) to the Haematococcus in one of the scintillation vials from each site prior to the addition of the ${ }^{14} \mathrm{C}$ solution. For each site and date, three replicate samples, one background sample, and one control sample for nonphotosynthetic uptake were analyzed. The carbon uptake determined for the background and control vials was subtracted from each of the test vials; this was typically less than 5\% of the carbon incorporation determined for the test vials.

\subsubsection{Contaminant Transfer}

Periphyton samples were brushed (using a toothbrush) from rocks collected from each study site in February and May 1987 to determine the concentration of metals in the periphyton. Samples were analyzed by inductively coupled plasma (ICP) spectroscony. Periphyton samples collected on February 10, 1987, were analyzed for total mercury by cold vapor atomic absorption. Samples were not collected from several upstream sites due to the lack of sufficient periphyton biomass. On May 5, 1987, samples of filamentous algae were collected from several reference sites (WCK 6.8, NTK 1.0, and MEK 1.8) and submitted to the ORNL Analytical Chemistry Division for analysis. Standard reference material (NBS SRM-1645, River Sediment) was submitted along with the periphyton samples for ICP and mercury analyses.

\subsubsection{Results and Discussion}

\subsubsection{Algal periphyton biomass and productivity}

Recognizing the rapid turnover rates of the algal and microbial components of the periphyton, the monthly sampling frequency is a compromise between that frequency necessary to detect and follow episodic events (e.g., toxic pulses, scouring during high discharge) and a lower frequency needed to characterize seasonal changes in biomass and production. Therefore, the data should provide good estimates of seasonal conditions but will likely underestimate the frequency of episodic events. The importance of such events may depend on their frequency and severity, in relation to other biotic and abiotic factors. Evaluation of the influences of episodic events on the structure and function of the periphyton community at the study sites will be considered in future /studies.

Periphyton chlorophyll $a$ per unit rock surface area provided a measure of algal biomass at each of the monitoring sites. (Data from all sites are presented in Appendix B, Table B-1.) The seasonal patterns in periphyton chlorophyll a concentrations were similar the upstream and downstream sites, as shown for WCK 6.8 and WCK 3.4 (Fig 3-7). Chlorophyll $a$ showed peak concentrations for 1 or 2 months during early summer to midsummer (May through July) and again in the fall (September through November) in both 1986 and 1987 (Fig. 3-7 and Table B-1). Minimum values of periphyton chlorophyll $a$ occurred during midwinter (January through March). The rise in periphyton 
ORNL-DWG 92M-10738
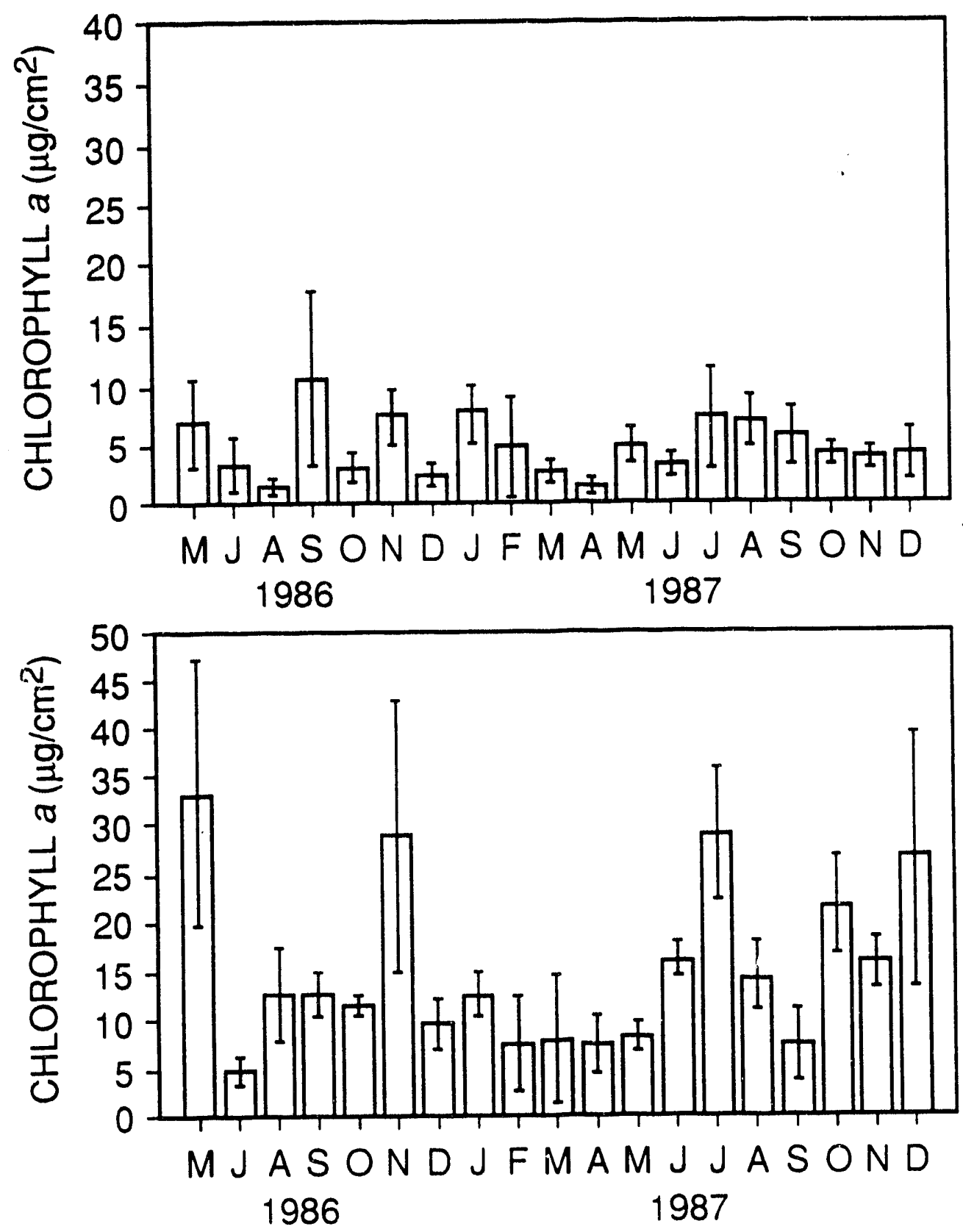

Fig. 3-7. Periphyton chlorophyll $a$ on small rocts in rifiles in White Oak Creek above and below Oak Ridge National Laboratory (White Oar Creek kilometer 6.8 and White Oak Creek kilometer 3.4, respectively) during 1986 and 1987 . Values are the mean \pm 1 s.d. $(n=4)$. 
chlorophyll $a$ in the fall also occurs in other streams in the Oak Ridge area and seems to be related to (1) increased light as the canopy thins, (2) periodic increases in discharge (and increased nutrient input for some sites), and (3) perhaps a decrease in grazing pressure. The cause for the midsummer chlorophyll peak is not clear. For the winter months, low light, low temperature, high turbidity, and frequent periods of scouring and sediment accumulation likely account for periods of low periphyton biomass.

Mean annual chlorophyll $a$ concentrations in 1987 were generally similar to values measured in 1986 (Table 3-15). As noted for the 1986 data (Loar et al. 1987), chlorophyll a concentrations at the upstream sites $\left(2.0-9.8 \mathrm{mg} / \mathrm{cm}^{2}\right)$ were fairly typical of small forested streams and were generally lower than the downstream sites $\left(7.9-28.8 \mu \mathrm{g} / \mathrm{cm}^{2}\right)$. The highest average chlorophyll concentration among the upstream reference sites occurred at FFK 1.1. Because this site is closer to its groundwater source than are the other upstream sites, there is less variability in nutrient concentrations (Table 2-8) and elevated water column $\mathrm{CO}_{2}$ (see data for $\mathrm{pH}$ and alkalinity in Table 2-8) than at other reference sites. Grazing pressure may also be lower at this site because snails are absent (Sect. 6.1). The downstream sites are enriched in phosphorus (Table 2-8) and receive chlorine inputs from various sources, including STP, which discharges to WOC above WCK 3.4. Site WCK 3.9 is nutrient-rich, open (no tree canopy shading the stream), and seldom has grazing invertebrates (Sect. 6.1); thus, the chlorophyll $a$ per unit area was generally quite high (Table 3-15) and reached a maximum of $69 \mu \mathrm{g} / \mathrm{cm}^{2}$ during July. Site MEK 0.6 had the lowest average concentration among the downstream sites (7.9 micrograms of chlorophyll a per cubic centimeter).

There were also some notable differences in the periphyton chlorophyll in 1987 compared with those in 1986 (Table 3-15). First, an increase in chlorophyll $a$ at FCK 1.0 likely resulted from the movement of the sampling site to a point $\sim 50 \mathrm{~m}$ upstream; rocks are now collected from the reach above Target Range Pond. This move was necessitated by construction in the pond and altered conditions downstream. Second, chlorophyll $a$ increased at MEK 0.6 (below the HFIR discharge) and at WCK 2.3 (below the confluence of WOC and Melton Branch). These increased concentrations occurred shortly after the shutdown of operations at the HFIR. This facility discharges materials used to prevent biofouling of the cooling system, and these materials may be toxic to the periphyton. The recovery of periphyton chlorophyll at MEK 0.6, following the shutdown of the HFIR in November 1986, is shown in Fig. 3-8. Third, the average chlorophyll $a$ concentration at WCK 3.9, an enriched, contaminated, and unshaded site, was substantially lower in 1987 than in 1986; however, this difference largely reflected the absence in 1987 of two largechlorophyll peaks that occurred during 1986. The reason for the absence of such peaks during 1987 is not known.

Periphyton primary production (inorganic carbon incorporation rates) followed a similar seasonal pattern at both the upstream and downstream sites. (Data for all sites are presented in Appendix B, Table B-2.) These similarities are illustrated in Fig. 3-9 for WCK 6.8 and WCK 2.9, which are located above and below ORNL respectively. The dominant feature for all sites was the relatively high rates of carbon incorporation during summer and fall as compared with the rates during winter and spring. The generally high rates of periphyton carbon incorporation during summer were noteworthy, since only moderate levels of periphyton chlorophyll $a$ were preser ${ }^{\star}$ during that time. In other local 
Table 3-15. Mean annual periphyton chlorophyll $a$ and carbon incorporation rates in 1986 and $1987^{\circ}$

\begin{tabular}{|c|c|c|c|c|c|c|c|c|c|c|}
\hline Year & $\begin{array}{c}\text { MEK }^{b, c} \\
1.8\end{array}$ & $\begin{array}{c}\text { WCK }^{b} \\
6.8\end{array}$ & $\begin{array}{c}\text { NTK }^{b, d} \\
1.0\end{array}$ & $\begin{array}{c}\text { FCK }^{b} \\
1.0\end{array}$ & $\begin{array}{c}\text { MEK } \\
0.6\end{array}$ & $\begin{array}{c}\text { FFK }^{b} \\
1.1\end{array}$ & $\begin{array}{c}\text { WCK } \\
2.3\end{array}$ & $\begin{array}{c}\text { WCK } \\
3.4\end{array}$ & $\begin{array}{c}\text { WCK } \\
2.9\end{array}$ & $\begin{array}{c}\text { WCK } \\
3.9\end{array}$ \\
\hline \multicolumn{11}{|c|}{ Chlorophyll a $\left(\mu \mathrm{g} / \mathrm{cm}^{2}\right)$} \\
\hline $\begin{array}{l}1987 \\
\text { Mean } \\
\text { s.d. } \\
\text { Range }\end{array}$ & $\begin{array}{c}2.0 \\
\pm 1.3 \\
0.5-4.3\end{array}$ & $\begin{array}{c}5.0 \\
\pm 1.8 \\
1.5-7.8\end{array}$ & $\begin{array}{r}5.1 \\
\pm 3.2 \\
1.7-11\end{array}$ & $\begin{array}{r}6.2 \\
\pm 4.1 \\
2.7-17\end{array}$ & $\begin{array}{c}7.9 \\
\pm 4.4 \\
1.2-19\end{array}$ & $\begin{array}{c}9.8 \\
\pm 5.6 \\
1.2-22\end{array}$ & $\begin{array}{c}11.5 \\
\pm 6.7 \\
2.0-26\end{array}$ & $\begin{array}{c}15.0 \\
\pm 7.5 \\
7.7-29\end{array}$ & $\begin{array}{c}16.4 \\
\pm 10.1 \\
4.2-33\end{array}$ & $\begin{array}{c}28.8 \\
\pm 18.3 \\
11-69\end{array}$ \\
\hline $\begin{array}{l}1986 \\
\text { Mean }\end{array}$ & 2.9 & 5.0 & 4.0 & 3.1 & 4.6 & 10.8 & 7.1 & 16.0 & 15.0 & 64 \\
\hline \multicolumn{11}{|c|}{ Production (mg $\left.C \cdot m^{-2} \cdot h^{-1}\right)$} \\
\hline Year & $\begin{array}{c}\text { MEK } \\
1.8\end{array}$ & $\begin{array}{c}\text { WCK } \\
6.8\end{array}$ & $\begin{array}{c}\text { NTK } \\
1.0\end{array}$ & $\begin{array}{c}\text { FCK } \\
1.0\end{array}$ & $\begin{array}{c}\text { MEK } \\
0.6\end{array}$ & $\begin{array}{c}\text { WCK } \\
3.4\end{array}$ & $\begin{array}{c}\text { FFK } \\
1.1\end{array}$ & $\begin{array}{c}\text { WCK } \\
2.9\end{array}$ & $\begin{array}{c}\text { WCK } \\
2.3\end{array}$ & $\begin{array}{c}\text { WCK } \\
3.9\end{array}$ \\
\hline 1987 & & & & & & & & & & \\
\hline $\begin{array}{l}\text { Mean } \\
\text { s.d. } \\
\text { Range }\end{array}$ & $\begin{array}{c}6.8 \\
\pm 4.4 \\
0.8-15\end{array}$ & $\begin{array}{l}16.3 \\
\pm 8.1 \\
5.3-30\end{array}$ & $\begin{array}{c}19.2 \\
+12.7 \\
5.8-43\end{array}$ & $\begin{array}{c}22.5 \\
\pm 11.8 \\
11-48\end{array}$ & $\begin{array}{c}38.5 \\
\pm 17.1 \\
3.4-74\end{array}$ & $\begin{array}{c}40.9 \\
\pm 18.3 \\
7.8-65\end{array}$ & $\begin{array}{c}42.3 \\
\pm 10.3 \\
25-61\end{array}$ & $\begin{array}{c}43.1 \\
\pm 21.7 \\
14-83\end{array}$ & $\begin{array}{c}47.4 \\
\pm 28.6 \\
13-123\end{array}$ & $\begin{array}{c}65.4 \\
\pm 43.6 \\
16-156\end{array}$ \\
\hline $\begin{array}{l}1986 \\
\text { Mean }\end{array}$ & & 11 & 14.5 & 7.5 & 12 & 26 & 35 & 26 & 19 & 69 \\
\hline
\end{tabular}

${ }^{a}$ Data for 1986 are based on eight monthly samples collected from April through December, except where noted. Values for 1987 are based on 12 monthly samples.

bUpstream reference site.

'Sampled in Jan., Feb., Mar., Apr., May, Sept., and Dec.

${ }^{d}$ Sampled in Jan., Feb., Mar., Apr., May, and June.

Note: FCK $=$ First Creek kilometer; FFK = Fifth Creek kilometer; MEK = Melton Branch kilometer; WCK $=$ White Oak Creek kilometer; NTK $=$ Northwest Tributary kilometer.

nutrient-rich streams, periphyton primary production largely follows chlorophyll $a$ and is high during the winter chlorophyll peak (H. L. Boston and A. J. Stewart, ORNL, unpublished data). A comparison of environmental conditions leading to the divergence in periphyton chlorophyll concentration and production, and the implications of such, will be considered during 1988 .

Average periphyton carbon incorporation rates generally followed the trends in algal periphyton biomass and so were typically greater for the downstream sites (Table 3-15). Annual average carbon incorporation rates at FFK 1.1, however, were similar to those of several downstream sites, in part, because of the high chlorophyll $a$ per unit area. The 


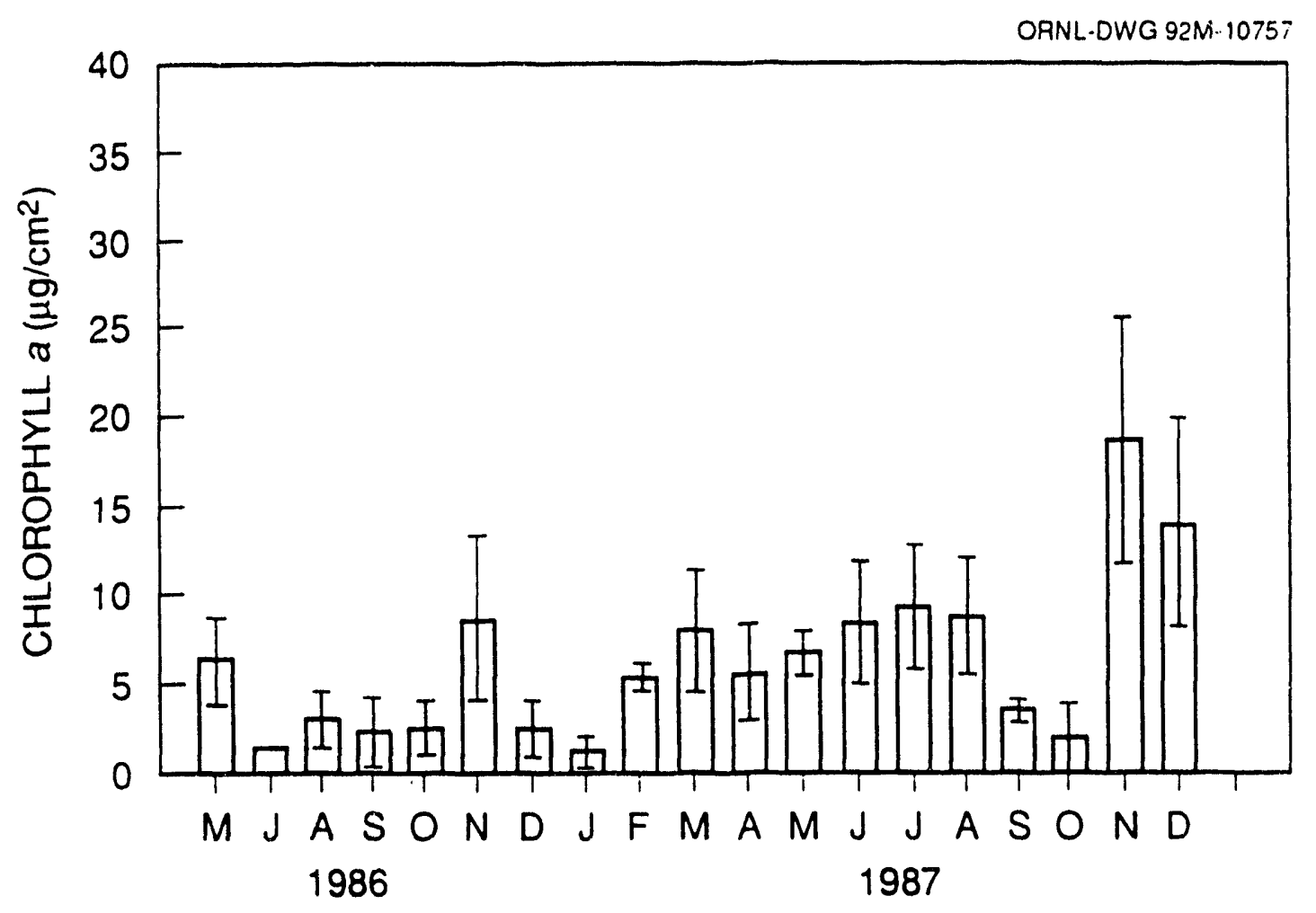

Fig. 3-8. Periphyion chlorophyll a on small rocks in rifiles in lower Melion Branch Melton Branch kilometer (MEK) 0.6] during 1986 and 1987. Values are the mean \pm 1 s.d. $(n=4)$. The High Flux Isotope Reactor, which discharges to the stream near MEK 1.4, was shut down in November 1986. 

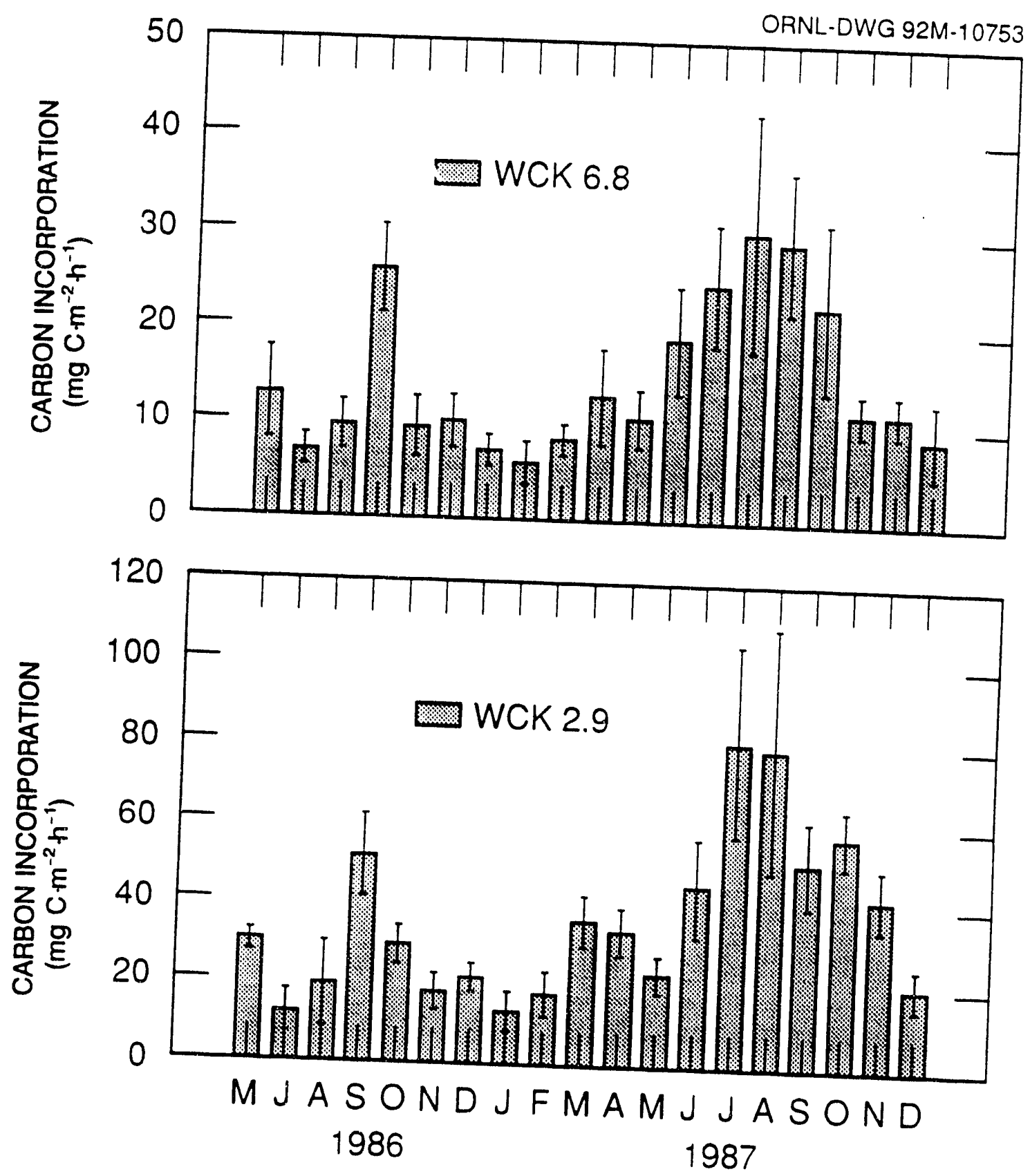

Fig. 3-9. Periphyton primary production as carbon incorporation rates on small rocks in riffles in White Oak Creek, above and below Oak Ridge National Laboratory [White Oak Creek s.d. $(n=4)$. 
annual average periphyton carbon incorporation rates in 1987 were generally greater than those observed in 1986 (Table 3-15). No general explanation for the higher primary production rates in 1987, compared with those in 1986, is offered at this time. The increased rates of primary production at FCK 1.0, MEK 0.6, and WCK 2.3 are likely the result of the higher algal periphyton biomass at these sites in 1987, as previously discussed. The sites tend to align along a nutrient gradient; those with higher water column nutrients have higher rates of primary production. Thus, downstream sites have higher rates of primary production than upstream sites. Site FFK 1.1 on upper Fifth Creek was an excertion to this pattern, having fairly high rates of carbon incorporation at fairly low concentrations of water column nutrients. As noted earlier, the higher-than-expected rates of primary production at FFK 1.1 may be related to the proximity of its groundwater source.

Following the cessation of discharges from the HFIR facility, algal periphyton production as well as biomass seems to have recovered at both MEK 0.6 and WCK 2.3. This recovery is evidenced by the increased rates of primary production at MEK 0.6 after November 1986 (Fig. 3-10). The periphyton at WCK 3.4 and WCK 2.9 had lower rates of primary production than would be expected based on water chemistry and periphyton chlorophyll $a$. This observation suggests the presence of unfavorable factors at those sites, perhaps related to the operation of STP. The rate of periphyton primary production at WCK 3.9 is also lower than would be expected based on biomass or water chemistry. As noted during 1986 (Loar et al. 1992b), the absence of invertebrates and the patchy distribution of the periphyton at WCK 3.9 (some rocks had thick coatings while nearby rocks were totally barren) suggest frequent exposures to transient toxicants, such as chlorine (Sect. 3.1.4). Results of toxicity tests (Sect. 3.1) and indicators of stress to other biotic components at this site (Sects. 6.1 and 6.2) support these inferences. Of the downstream sites, WCK 2.3 was most like the upstream reference sites. Datal on the benthic invertebrate and fish communities (Sects. 6.1 and 6.2, respectively) also suggest that environmental quality at this downstream site had recovered to conditions similar to those above ORNL.

Temporal (month-to-month) variability in algal periphyton biomass was least at WCK 3.4 (below STP) and at WCK 6.8 (above ORNL). Temporal variation in periphyton production was least at FFK 1.1, MEK 0.6, and WCK 3.4. The sites with the maximum variation in these parameters were MEK 1.8 and NTK 1.0, both of which flow only during the wet season, and WCK 3.9, which receives toxic inputs. During 1988, the potential factors determining the variability in biomass and production at the study sites will be investigated, and the implication for stream system structure and function resulting from such variation will be assessed.

\subsubsection{Physiological status}

Chlorophyll concentrations and carbon incorporation are positively correlated but not linearly related, because self-shading and diffusion limitation cause carbon incorporation to rise more slowly than chlorophyll as additional layers of cells are added to the periphyton matrix. Chlorophyll-specific production values (data for carbon uptake per unit chlorophyll per unit time) provide a means to assess the relative physiological state of the algal component of the periphyton. Chlorophyll-specific production normalizes the 


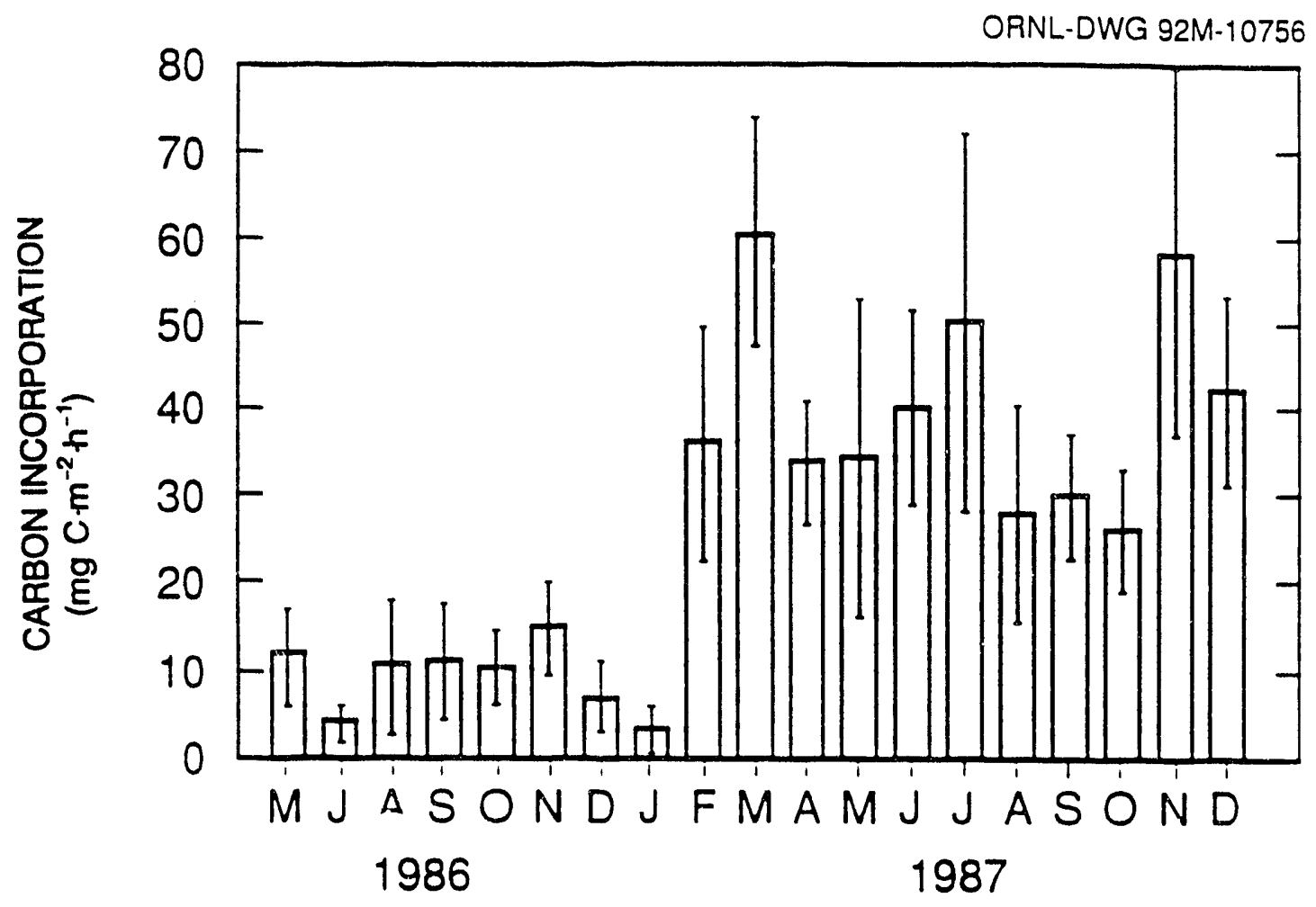

Fig 3-10. Periphyton primary production as carbon incorporation rates on small rocks in rifiles in lower Melion Branch [Melton Branch kilometer (MEK) 0.6] during 1986 and 1987. Values are the mean +1 s.d. $(n=4)$. The High Flux Isotope Reactor, which discharges to the stream near MEK 1.4, was shut down in November 1986. 
production data for the amount of biomass present and thus provides more insight into the variations in conditions controlling photosynthesis and the physiological state of the periphytic algae. Monthly data for chlorophyll-specific production rates were plotted as a function of periphyton chlorophyll for each site (Fig. 3-11). The decline in chlorophyllspecific production with increasing chlorophyll is to be expected based on the mathematical formulation; however, the location of points above or below the mean value for any given chlorophyll level suggests better-than- or worse-than-average performance respectively.

This point is illustrated more clearly in Fig. 3-12, where the data were transformed by natural logarithms. The resulting relationship can be described by a simple linear regression. When data for a given site consistently lie above the regression line (i.e., higher-than-predicted chlorophyll-specific production), the periphyton are in better-thanaverage physiological condition. The converse is true for sites where data consistently fall below the line. Ideally, only data from the reference sites would be used to establish such a relationship; however, using all of the available information allows a relative comparison of the performance of the algal periphyton at each site.

The residuals from the regression equation were used to determine the average deviation for each site. The results indicated that the algal periphyton at sites FFK 1.1, MEK 0.6, and WCK 2.3 were in the best condition, while those at WCK 6.8 and WCK 3.9 were in the worst condition. These results seem intuitively reasonable based on the characteristics of the sites. Sites MEK 0.6 and WCK 2.3 are nutrient-rich downstream sites with little toxic stress. As noted previously, FFK 1.1 has moderate nutrient levels, is enriched in $\mathrm{CO}_{2}$, and has low siltation and moderate to low grazing pressure.

Consequently, the good performance of the algal periphyton at these three sites was to be expected. Site WCK 6.8 is a nutrient-poor, heavily grazed reference site, where the algal periphyton would not be expected to be in very good physiological condition. Site WCK 3.9 is enriched in nutrients, and the periphyton are under little grazing pressure because grazer species are usually absent due to frequent episodes of chlorine toxicity. However, this episodic exposure to chlorine also clearly stresses the algal periphyton; and, thus, poor performance was to be expected. In general, the condition of the algal periphyton improved with distance downstream of ORNL (WCK 3.9 through WCK 2.3).

The approach described previously provides an objective means of quantifying the performance of the algal periphyton at sites that differ greatly in both biomass and production. Of the three reference sites included in this analysis, the algal periphyton at WCK 6.8 had the poorest performance of any site (probably due to low levels of nutrients and intensive grazing), those at FFK 1.1 performed among the best of all sites (moderate nutrient levels, little grazing, and low suspended loads), and the performance of the algal periphyton at FCK 1.0 was about average for all sites. Although these results were largely as expected, they illustrate that poor performance may result either from natural factors (e.g., few nutrients and intensive grazing at WCK 6.8) or from toxic stress (e.g., chlorine inputs at WCK 3.9). Further, these results suggest that increased nutrient loading may ameliorate the effects of other stresses. 


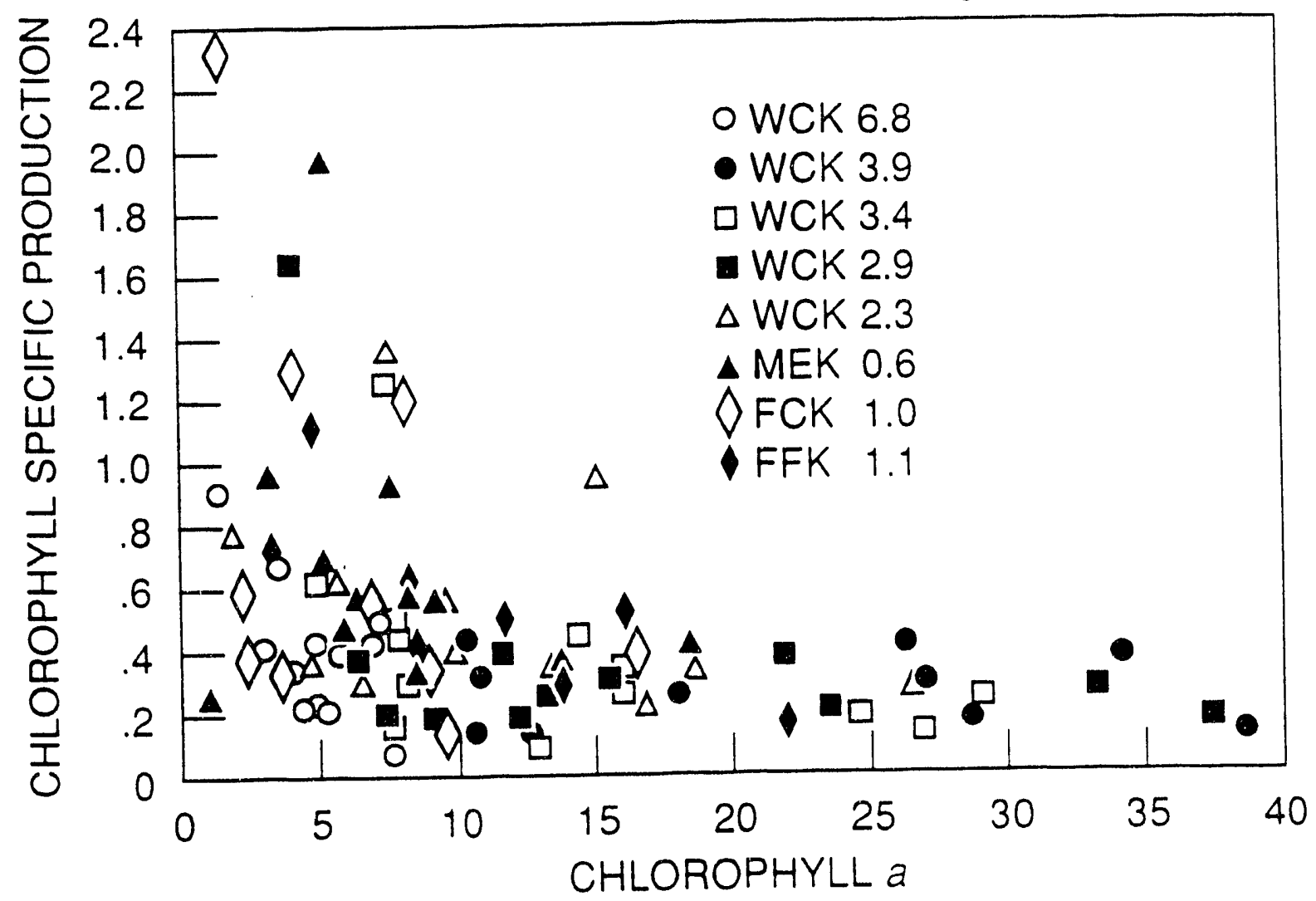

Fig. 3-11. Monthly values for chlorophyll-specific production (micrograms of carbon per milligram of chlorophyll $a$ per hour) plotted as a function of chlorophyll a (micrograms per square centimeter) for eight periphyton monitoring sites in the White Oak Creek watershed during 1987. Values are the mean of four determinations for each date. Site codes are $A=W C K 6.8 ; B=$ WCK 3.9; $C=$ WCK 3.4; D = WCK 2.9; $E=$ WCK 2.3; F = MEK 0.6; G = FCK 1.0; and H = FFK 1.1. 
ORNL-DWG 92M-10748

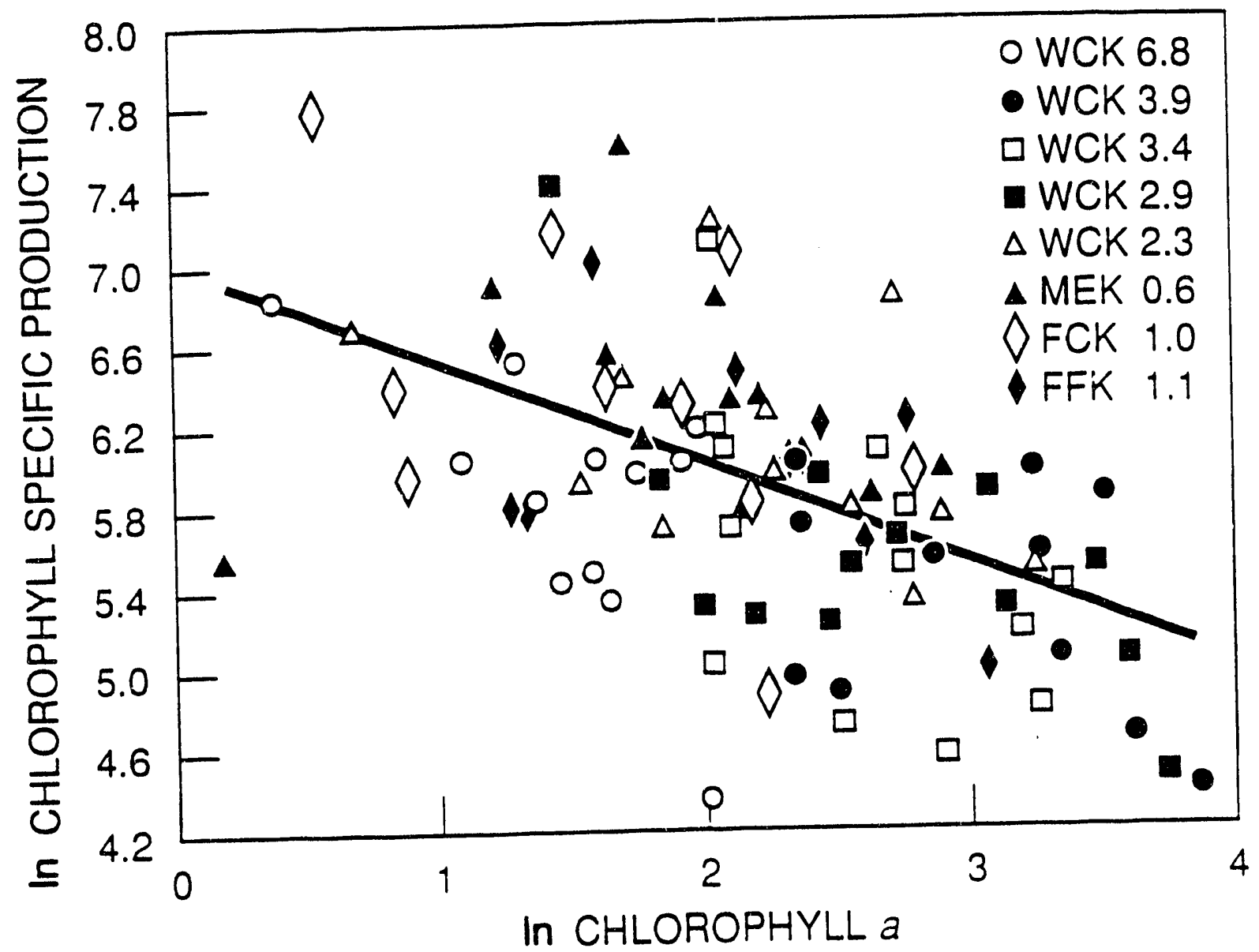

Fig 3-12 Monthly data for the natural log of chlorophyll-specific production (micrograms of carbon per milligram of chlorophyll a per hour) plotted as a function of the natural log of chlorophyll a (micrograms per square centimeter) for eight periphyton monitoring sites in the White Oak Creek watershed during 1987. Values are the mean of four determinations for each date. Site codes are $A=$ WCK $6.8 ; B=$ WCK 3.9; $C=$ WCK 3.4; D = WCK 2.9; E = WCK 2.3; $\mathrm{F}=$ MEK 0.6; $\mathrm{G}=$ FCK 1.0; and $\mathrm{H}=$ FFK 1.1. 


\subsubsection{Periphyton ATP}

ATP is present in all living cells, and so both algae and heterotrophic microbes contribute to the periphyton ATP pool. Thus, ATP serves as an additional indictor of live periphyton biomass, much like chlorophyll $a$; however, ATP reflects both autotrophic and heterotrophic contributions. Concentrations of ATP may be inherently more variable than chlorophyll concentrations because of the rapid turnover of microbes and their rapid responses to organic enrichment and toxicants. Further, while chlorophyll $a$ may persist in algal cells having low metabolic activity, the ATP pools of algal and microbial cells are more dynamic. As discussed below, chlorophyll $a$ in algal cells is usually present in a 3:1 to 10:1 ratio with ATP; therefore, data on periphyton ATP concentrations can be used together with data on periphyton chlorophyll $a$ to evaluate the relative contribution of heterotrophs to periphyton biomass at a given site. For such evaluations, sites with ratios of chlorophyll $a: A T P<1$ (wt/wt) likely receive excess organic loading and have relatively high heterotrophic activity; while sites with a ratio of chlorophyll:ATP $>10$ may have excess inactive chlorophyll, are phosphorus limited, or are exposed to toxicants that decrease microbial activity without decreasing algal chlorophyll $a$ concentrations. Consequently, periphyton ATP concentrations, in conjunction with data on other parameters, can be useful in characterizing and evaluating periphyton communities.

Periphyton ATP was measured four times between November 1986 and October 1987, with additional data collected from two sites in December 1987. Periphyton ATP ranged seasonally from $<1$ to $>40$ micrograms of ATP per square centimeter for several sites. The data for the WOC sites (Fig. 3-13) were similar to those for other sites and showed high ATP concentration during the fall (when biomass is high and nutrient and allochthonous organic carbon inputs increase), low ATP concentrations during the winter and spring, and moderate levels during the summer. As expected, downstream sites with high algal biomass and nutrient levels have high ATP concentrations compared with those at upstream sites (Table 3-16).

The ATP concentrations in January 1987 were especially low. However, data collected during January 1988 were similar to those for April 1987, suggesting that the data for January 1987 underestimated ATP by about an order of magnitude. This inference was corroborated by evaluating the chlorophyll $a$ :ATP ratio (Table 3-16). Data for January 1987 were well outside of the normal range of behavior as described in the literature and determined for these sites. Analytical error was likely responsible.

The ratio of periphyton chlorophyll $a$ to ATP provides another means of characterizing the periphyton community. The chlorophyll $a$ :ATP (wt/wt) ratio is typically on the order of $3: 1$ to 10:1 in algal cultures and varies with nitrogen or phosphorus availability, becoming larger with increasing phosphorus limitation. Under field conditions, ratios much larger than 10:1 usually indicate the presence of detrital chlorophyll (Healey and Hendzel 1980). The ratio decreases with increasing nitrogen limitation; however, ratios much lower than 3:1 suggest significant organic enrichment and substantial microbial populations. The periphyton chlorophyll $a$ :ATP varied seasonally at all sites (Table 3-16). Interpretation of these data remains difficult because low values during November 1986 and October 1987 likely reflect organic enrichment rather than nitrogen limitation. Interpreting the data for other months requires additional information on other parameters (see Sect. 3.2.4). 


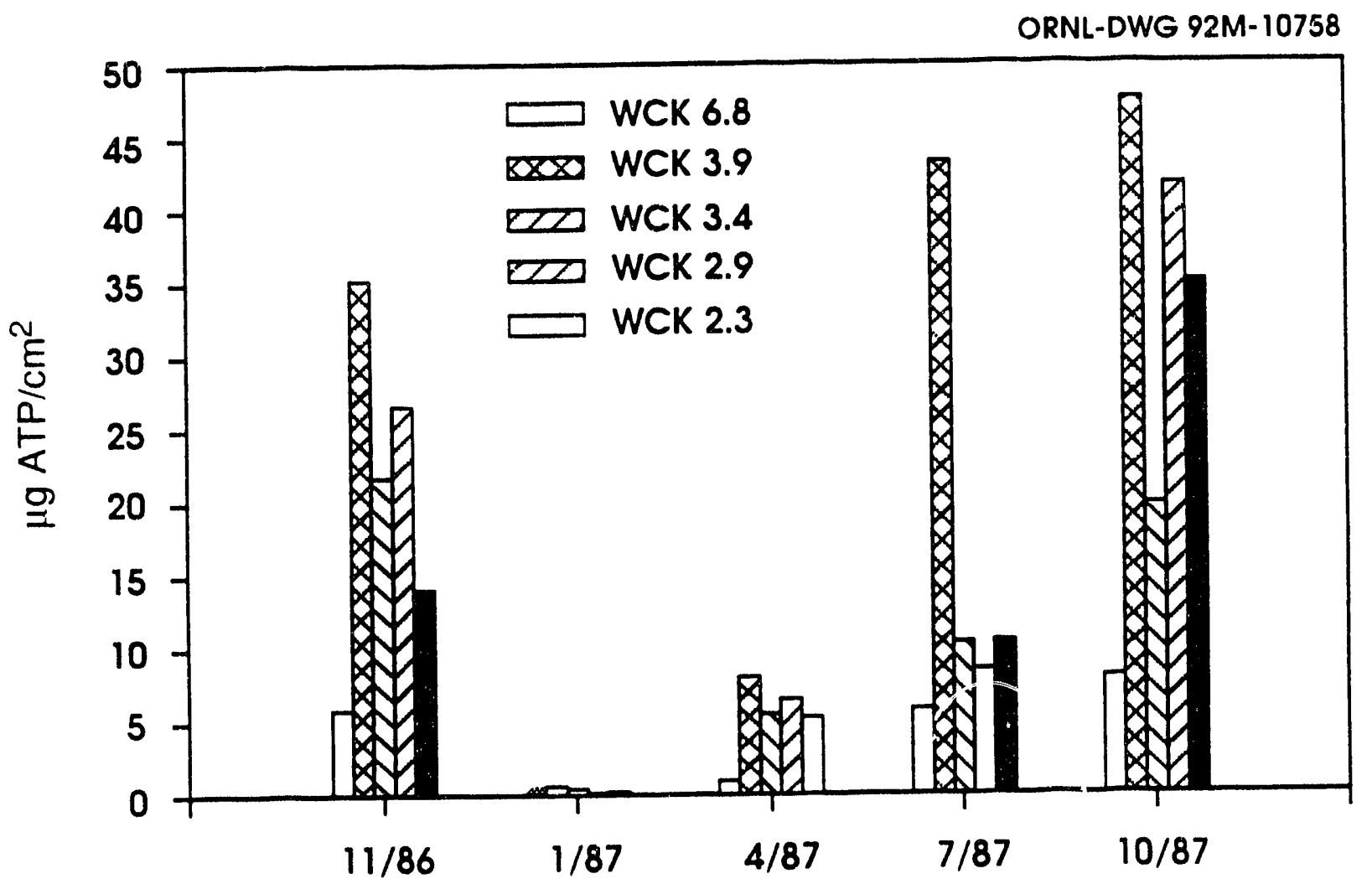

Fig 3-13. Periphyton adenosine triphosphate (ATP) concentrations at five periphyton monitoring sites on White Oak Creek. Values are the mean of tour replicates. $\mathrm{WCK}=$ White Oak Creek kilometer. 
Table 3-16. Periphyton ATP concentrations and chlorophyll a to ATP ratio (wt/wt)

Values are the mean of four replicates

\begin{tabular}{|c|c|c|c|c|c|c|c|}
\hline \multirow[t]{2}{*}{ Location } & \multicolumn{6}{|c|}{ Sampling period } & \multirow[b]{2}{*}{ Dec. 1987} \\
\hline & Nov. 1986 & Jan. 1987 & Apr. 1987 & July 1987 & Oct. 1987 & Nov. 1987 & \\
\hline \multicolumn{8}{|c|}{ Periphyton ATP (ng/cm²) } \\
\hline WCK 6.8 & 5351 & 114.2 & 1226 & 1532 & 8319 & $a$ & \\
\hline WCK 3.9 & 34,959 & 719.8 & 7508 & 43,739 & 48,246 & $a$ & \\
\hline WCK 3.4 & 21,435 & 493.9 & 5505 & 10,875 & 20,416 & $a$ & \\
\hline WCK 2.9 & 26,488 & 84.3 & 6356 & 8,984 & 42,575 & $a$ & \\
\hline WCK 2.3 & 13,632 & 375.9 & 5423 & 11,213 & 35,928 & $a$ & \\
\hline MEK 1.8 & 4,858 & 271.4 & 1130 & Dry & Dry & $a$ & \\
\hline MEK 0.6 & 9,966 & 203.8 & 5796 & 3,686 & 8,956 & $a$ & \\
\hline FCK 1.0 & 2,456 & 90.2 & 830.5 & 880.7 & 1577 & $a$ & 4909 \\
\hline FFK 1.1 & 1,3000 & 270.9 & 3515 & 2,114 & 26,246 & $\circ$ & 2918 \\
\hline NTK 1.0 & 5,142 & 474.5 & 1458 & Dry & Dry & $a$ & \\
\hline \multicolumn{8}{|c|}{ Chlorophyll a:ATP (wt/wt) } \\
\hline WCK 6.8 & 1.40 & 68.80 & 1.20 & 4.56 & 0.53 & & $a$ \\
\hline WCK 3.9 & 4.49 & 18.75 & 1.86 & 1.80 & 0.46 & & $a$ \\
\hline WCK 3.4 & 1.35 & 28.42 & 1.41 & 2.75 & 1.08 & & $a$ \\
\hline WCK 2.9 & 0.86 & 131.45 & 2.24 & 4.39 & 0.86 & & 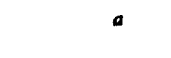 \\
\hline WCK 2.3 & 1.26 & 6.02 & 2.55 & 2.15 & 0.34 & & $a$ \\
\hline MEK 1.8 & 0.79 & 11.37 & 4.80 & Dry & Dry & & $a$ \\
\hline MEK 0.6 & 0.87 & 6.42 & 1.02 & 2.66 & 0.67 & & $a$ \\
\hline FCK 1.0 & 0.81 & 45.26 & 2.24 & 18.20 & 1.10 & 4.88 & $a$ \\
\hline FFK 1.1 & 1.11 & 12.37 & 0.30 & 7.07 & 1.03 & 1.36 & $a$ \\
\hline NTK 1.0 & 0.83 & 7.56 & 2.08 & Dry & Dry & & $a$ \\
\hline
\end{tabular}

"Value for this parameter not determined for this period.

Note: WCK $=$ White Oak Creek kilometer; MEK $=$ Melton Branch kilometer; FCK $=$ First Creek kilometer; FFK = Fifth Creek kilometer; NTK $=$ Northwest Tributary kilometer. 


\subsubsection{Algal bioassay of water quality}

Algal bioassays were conducted on June 26, July 9, and July 17, 1987. Results were inconsistent between dates. On June 26, for example, water collected from WCK 3.4 below STP completely inhibited carbon uptake by the laboratory-grown algae (possibly due to chlorine). On that date, the algal cells placed in water from WCK 6.8 had the best performance (highest rates of carbon uptake), and algae in water from MEK 0.6 performed only half as well as cells placed in the water from other sites. However, on the second date, carbon uptake by algae placed in water from WCK 3.4 and MEK 0.6 was about average, and uptake in water from WCK 6.8 was poor. On the third date, carbon uptake by the laboratory-grown algae was highest in water from WCK 2.3 and lowest in water from FCK 1.1 and FFK 1.0. With the exception of possible incidents of chlorine toxicity at WCK 3.4, the cause for the changes in the apparent water quality necessary for algal photosynthesis are unknown. Overall, the results of an analysis of variance (ANOVA) on these data found water from WCK 2.3 to be the best for short-term photosynthesis. However, water from sites WCK 6.8 and WCK 3.9 was similar to water from WCK 2.3, a result contrary to expectations.

In summary, the results confirmed the presence of acute toxicity at some sites; however, these assays were unable to account for observed differences in periphyton biomass, photosynthesis, and physiological status among the sampling sites. The results suggested that stresses are either intermittent, cumulative, or due to physical factors (e.g., siltation) or biological interactions (e.g., grazing) not included in this laboratory procedure. Even though the laboratory bioassay was generally a useful tool in identifying short-term toxicity and in comparing water quality for photosynthesis, the lack of consistent results (i.e., consistently good or poor water quality) reemphasizes the need for additional information concerning the abiotic and biotic environment.

\subsection{Contaminant transfer}

Compared with the upstream reference sites, levels of $\mathrm{Cu}, \mathrm{Cr}, \mathrm{Ni}, \mathrm{P}, \mathrm{Pb}, \mathrm{Ti}, \mathrm{Zn}$ and $\mathrm{Zr}$ were elevated in the periphyton collected on February 12, 1987 at WCK 3.9 (the uppermost site influenced by ORNL operations) and sites farther downstream (Table 3-17). Cadmium and cobalt were elevated at site WCK 3.4, which is located below STP and downstream of the confluence of First Creek and Northwest Tributary with WOC, and at sites on WOC farther downstream. The same elements were elevated relative to reference sites in May, except that (1) cadmium was also elevated at WCK 3.9 and downstream and (2) titanium was not detected at the downstream sites (Table 3-18).

In Melton Branch, $\mathrm{Co}, \mathrm{Cr}, \mathrm{Cu}$, and $\mathrm{P}$ were elevated in the periphyton at MEK 0.6 relative to MEK 1.8 during February (Table 3-17). In May, titanium and zinc were also elevated in periphyton from MEK 0.6 (Table 3-18).

Periphyton samples collected in WOC in February 1987 contained elevated levels of mercury relative to periphyton at NTK 1.0 and MEK 0.6 (Table 3-19). The single sample from WCK 6.8 had a higher mercury concentration than other upstream reference sites for unknown reasons. The analysis of filamentous algae samples collected from the 
Table 3-17. Concentrations of selected elements (parts per million, dry weight) in periphyton collected in February 1987

Values are the mean of three replicates

$\begin{array}{lllllllll}\text { WCK 6.8 } & \text { WCK 3.9 } & \text { WCK 3.4 } & \text { WCK 2.9 } & \text { WCK 2.3 } & \text { MEK } 1.8 & \text { MEK } 0.6 & \text { NTK } 1.0 & \text { FFK } 1.1\end{array}$

\begin{tabular}{|c|c|c|c|c|c|c|c|c|c|}
\hline Ag & $<16$ & 37 & 27 & 28 & 15 & $<45$ & $<9.6$ & $<9.6$ & $<10$ \\
\hline$A \bar{l}$ & 7,000 & 12,933 & 9,933 & 11,667 & 15,333 & 46,000 & 15,000 & 10,367 & 3,633 \\
\hline As & $<32$ & $<19$ & $<19$ & $<20$ & $<19$ & $<19$ & $<19$ & $<19$ & 160 \\
\hline $\mathbf{B}$ & 38 & 21 & 17 & 18 & $<1: j$ & $<73$ & $<16$ & 22 & 38 \\
\hline $\mathrm{Ba}$ & 227 & 280 & 293 & 220 & 157 & 240 & 357 & 160 & 34 \\
\hline $\begin{array}{l}\mathrm{Be} \\
0.59\end{array}$ & $<0.66$ & 0.74 & 0.63 & 0.53 & 1.1 & $<1.80$ & 0.8 & 9.4 & \\
\hline $\mathrm{Ca}$ & 49,700 & 49,667 & 24,000 & 15,667 & 8,933 & 17,000 & 6,933 & 86,333 & 104,000 \\
\hline $\mathrm{Cd}$ & $<1.6$ & 2.3 & 4.4 & 2.6 & 2.3 & $<4.5$ & 2 & 1.2 & $<1.0$ \\
\hline Co & 17 & 18 & 32 & 18 & 16 & $<9.1$ & 17 & 14 & 7.7 \\
\hline $\mathrm{Cr}$ & 13 & 54 & 41 & 48 & 98 & $<36$ & 45 & 14 & 11 \\
\hline $\mathrm{Cu}$ & $<6.3$ & 207 & 240 & 157 & 87 & $<18$ & 70 & 5 & $<4$ \\
\hline $\mathrm{Fe}$ & 11,367 & 17,667 & 15,000 & 19,667 & 33,000 & 11,000 & 19,667 & 13,667 & 5,067 \\
\hline $\mathrm{Ga}$ & $<94$ & $<57$ & $<58$ & $<60$ & $<59$ & $<270$ & $<58$ & $<57$ & $<60$ \\
\hline $\mathbf{L i}$ & $<63$ & $<38$ & $<38$ & $<40$ & $<39$ & $<180$ & $<39$ & $<30$ & $<40$ \\
\hline $\mathbf{M g}$ & 18,600 & 5,333 & 4,733 & 3,533 & 3,933 & 7,600 & 3,233 & 1,567 & 53,333 \\
\hline$M n$ & 3,633 & 3,167 & 9,167 & 4,000 & 2,733 & 3,900 & 7,933 & 4,067 & 213 \\
\hline Mo & 15 & $<8$ & $<8$ & $<8$ & $<8$ & $<36$ & $<8$ & $<8$ & $<8$ \\
\hline $\mathrm{Na}$ & 237 & 953 & 1,467 & 1,240 & 573 & $<450$ & 357 & 287 & 273 \\
\hline $\mathrm{Ni}$ & $<19$ & 32 & 40 & 22 & 22 & $<55$ & 25 & 12 & $<12$ \\
\hline $\mathbf{P}$ & 490 & 4,700 & 7,067 & 5,100 & 2,967 & 730 & 1,267 & 433 & 593 \\
\hline $\mathbf{P b}$ & $<63$ & 63 & 75 & 54 & 40 & $<180$ & $<39$ & $<39$ & $<40$ \\
\hline $\mathrm{Sb}$ & $<63$ & $<38$ & $<38$ & $<40$ & $<39$ & $<180$ & $<38$ & $<39$ & $<40$ \\
\hline $\mathrm{Se}$ & $<6$ & $<38$ & $<38$ & $<40$ & $<39$ & $<180$ & $<39$ & $<39$ & $<40$ \\
\hline $\mathbf{S i}$ & 1,867 & 3,000 & 2,600 & 3,600 & 4,600 & 4,300 & 3,900 & 2,300 & 2,200 \\
\hline Sn & $<16.0$ & $<9.5$ & $<9.6$ & $<9.9$ & $<9.8$ & $<45$ & $<9.6$ & $<9.6$ & $<10.0$ \\
\hline $\mathrm{Sr}$ & 36 & 67 & 47 & 33 & 26 & 23 & 27 & 41 & 35 \\
\hline $\mathrm{Ti}$ & 51 & 138 & 84 & 85 & 136 & 120 & 90 & 57 & 47 \\
\hline V & 17 & 16 & 14 & 19 & 32 & 21 & 18 & 15 & 13 \\
\hline $\mathrm{Zn}$ & 217 & 2,567 & 2,967 & 1,733 & 1,010 & 690 & 670 & 75 & 57 \\
\hline $\mathbf{Z r}$ & 7 & 13 & 13 & 15 & 18 & $<18$ & 10 & 9 & 6 \\
\hline
\end{tabular}

Note: WCK $=$ White Oak Creek kilometer; MEK $=$ Melton Branch kilometer; NTK $=$ Northwest Tributary kilometer; FFK $=$ Fifth Creek kilometer.

reference sites (WCK 6.8, MEK 1.8 and NTK 1.0) in May 1987 approximated what may be considered background levels.

The elevated levels of several metals found in periphyton from the downstream sites relative to the upstream reference sites reflect ORNL operations. However, none of the concentrations were in the range typically associated with "contaminated" areas. Based on the relatively low levels of these constituents, no attempt was made to evaluate the form (ionic species, organic vs inorganic) or type of association (adsorption, coagulation, matrix bound) of any of these elements within the periphyton matrix. Current investigations in 
Table 3-18. Concentrations of selected elements (parts per million, dry weight) in periphyton collected in May 1987

Values are the mean of three replicates

\begin{tabular}{|c|c|c|c|c|c|c|c|c|}
\hline & WCK 3.9 & WCK 3.4 & WCK 2.9 & WCK 2.3 & MEK 1.8 & MEK 0.6 & ISK 1.1 & STD \\
\hline Ag & 35 & 13.7 & $<11.8$ & $<11.1$ & $<8.0$ & $<9.3$ & $<8.0$ & $<60.0$ \\
\hline $\mathbf{A}$ & 9,233 & 15,333 & 16,333 & 15,666 & 14,333 & 16,666 & 11,566 & 4,100 \\
\hline As & $<30.7$ & $<19.3$ & $<18.8$ & $<21.7$ & $<16.3$ & $<19.0$ & $<16.0$ & $<120.0$ \\
\hline B & $<24.3$ & $<15.7$ & $<14.8$ & $<17.3$ & $<16.3$ & $<15.3$ & $<12.8$ & $<96.0$ \\
\hline $\mathrm{Ba}$ & 246.7 & 203.3 & 230 & 193.3 & 956.7 & 440 & 173.3 & 65 \\
\hline $\mathrm{Be}$ & 0.87 & 0.95 & 1 & 0.93 & 0.79 & 0.84 & 1 & $<2.4$ \\
\hline $\mathrm{Ca}$ & 57,000 & 41,666 & 28,333 & 21,666 & 8,933 & 73,666 & 52,000 & 29,000 \\
\hline $\mathrm{Cd}$ & 2.5 & 2.4 & 1.9 & 1.1 & $<0.8$ & 1.3 & $<0.8$ & 6.6 \\
\hline Co & 18.7 & 27.3 & 22.3 & 19.7 & 12.5 & 24.7 & 13.3 & 13 \\
\hline $\mathrm{Cr}$ & 173.3 & 47 & 46.3 & 75.7 & 18.3 & 55.7 & 15.7 & 25,000 \\
\hline $\mathrm{Cu}$ & 410 & 266.7 & 210.7 & 83.7 & 14.3 & 53.3 & 10.7 & 93 \\
\hline $\mathrm{Fe}$ & 24,666 & 23,000 & 24,333 & 26,666 & 19,000 & 17,000 & 16,000 & 86,000 \\
\hline $\mathrm{Ga}$ & $<92$ & $<58$ & $<56$ & $<65$ & $<49$ & $<57$ & $<48$ & $<360$ \\
\hline $\mathrm{Li}$ & $<61$ & $<41$ & $<41$ & $<44$ & $<43$ & 1925 & $<33$ & $<240$ \\
\hline $\mathbf{M g}$ & 7,266 & 6,866 & 5,233 & 6,166 & 3,433 & 3,700 & 5,033 & 5,700 \\
\hline $\mathbf{M n}$ & 4,066 & 5,300 & 4,433 & 4,400 & 2,100 & 12,000 & 4,000 & 590 \\
\hline Mo & $<12$ & $<7.7$ & $<7.3$ & $<8.7$ & $<6.4$ & $<7.6$ & $<6.4$ & $<48.0$ \\
\hline $\mathrm{Na}$ & $<793.3$ & $4,433.3$ & 1,390 & 1,346 & $<155.0$ & 3,170 & 257.7 & 920 \\
\hline $\mathrm{Ni}$ & 25 & 41 & 35.7 & 27.3 & 22.3 & 25.7 & 12 & $<72.0$ \\
\hline $\mathbf{P}$ & 3,100 & 4,466 & 3,833 & 2,200 & 770 & 2,100 & 520 & 520 \\
\hline $\mathrm{Pb}$ & 156.7 & 70 & 55.3 & $<43.3$ & $<33.0$ & $<37.7$ & $<32.0$ & 630 \\
\hline $\mathrm{Sb}$ & 61 & $<38.3$ & $<37.3$ & $<43.3$ & $<33.0$ & $<37.7$ & $<32.0$ & $<240.0$ \\
\hline $\mathrm{Se}$ & $<61.0$ & $<38.3$ & $<37.3$ & $<43.3$ & $<33.0$ & $<37.7$ & $<32.0$ & $<240.0$ \\
\hline $\mathbf{S i}$ & $2,666.7$ & 3,100 & 2,800 & 1,500 & $1,243.3$ & 4,933 & 4,666 & 1,700 \\
\hline $\mathrm{Sn}$ & $<15.2$ & $<9.8$ & $<9.2$ & $<11.1$ & $<8.3$ & $<9.3$ & $<8.0$ & 120 \\
\hline $\mathrm{Sr}$ & 59 & 56 & 40.6 & 32.7 & 81 & 58.7 & 33.3 & 690 \\
\hline $\mathrm{Ti}$ & $<6.1$ & $<13.9$ & $<11.8$ & $<22.5$ & $<21.7$ & 43 & 12.2 & 160 \\
\hline V & 20 & 19.7 & 21 & 22.7 & 18 & 15 & 16.7 & $<24.0$ \\
\hline $\mathrm{Zn}$ & 2,166 & 1,933 & 1,586 & 896 & 55 & 780 & 196.7 & 1,400 \\
\hline$Z_{r}$ & 15.7 & 17.3 & 16 & 11.7 & 8.9 & 8.5 & 6.2 & $<24.0$ \\
\hline
\end{tabular}

Note: STD = Standard Reference Material (River sediment from National Bureau of Standards, SRM-1645). WCK = White Oak Creek kilometer; MEK = Melton Branch kilometer; ISK = Ish Creek kilometer.

other local systems that are more highly contaminated by these elements (A. J. Stewart and H. L. Boston, ORNL, unpublished data) will provide information that can be used to evaluate the potential ecological role of these elements in the WOC system (e.g., direct effects on periphyton, food-chain transfer). Screening for organic contaminants and radionuclides will be conducted during 1988. 
Table 3-19. Mercury concentrations in periphyton and filamentous algae

Values are the mean \pm 1 s.d. $(n=3)$, expressed per unit dry weight

\begin{tabular}{|c|c|c|c|}
\hline Date & Site & Sample type ${ }^{a}$ & $\mathrm{Hg}$ \\
\hline February 10,1987 & $\begin{array}{l}\text { WCK } 6.8^{b} \\
\text { WCK } 3.4 \\
\text { WCK } 2.9 \\
\text { WCK } 2.3 \\
\text { MEK } 0.6 \\
\text { NTK } 1.0^{b}\end{array}$ & $\begin{array}{l}P \\
P \\
P \\
P \\
P \\
P\end{array}$ & $\begin{array}{l}3.81^{c} \\
5.00 \pm 1.74 \\
7.21 \pm 0.70 \\
3.72 \pm 0.32 \\
0.60 \pm 0.04 \\
0.09 \pm 0.03\end{array}$ \\
\hline May 5, 1987 & $\begin{array}{l}\text { WCK } 6.8^{b} \\
\text { MEK } 1.8^{b} \\
\text { NTK } 1.0^{b}\end{array}$ & $\begin{array}{l}\text { FA } \\
\text { FA } \\
\text { FA }\end{array}$ & $\begin{array}{l}0.20 \pm 0.03 \\
0.08 \pm 0.01 \\
0.23 \pm 0.03\end{array}$ \\
\hline
\end{tabular}

${ }^{a} \mathbf{P}=$ periphyton scraped from rock surfaces. $F \mathbf{A}=$ filamentous algae.

bUpstream reference site.

'Single determination.

Note: WCK $=$ White Oak Creek kilometer; MEK $=$ Melton Branch kilometer; NTK $=$ Northwest Tributary kilometer.

\subsection{Summary}

Efforts to date have focused on characterization of the rates of primary production and algal periphyton biomass at ten study sites in WOC watershed. Metrics were developed to evaluate the physiological performance of the algal periphyton and the heterotrophic component of the periphyton matrix. Studies were directed toward (1) documentation of the current condition of the biotic community at selected sites in the WOC system, (2) identification of the various effects of ORNL discharges on algal periphyton, (3) evaluation of responses to changes in toxicant input (e.g., at MEK 0.6), and (4) corroboration of results obtained from monitoring other communities.

The major conclusions at this stage of the investigations are as follows:

1. The downstream sites had higher algal periphyton biomass, which likely reflected the increased nutrient loading due to ORNL operations. Algal biomass on rocks in riffle zones averaged from 2 to 29 micrograms of chlorophyll a per square centimeter for 10 study sites during 1987. Values at the upstream reference sites were on the lower end of this range and were fairly typical for natural woodland streams.

2. Average periphyton primary production rates ranged from 6.8 to 65 milligrams of carbon per square meter per hour and followed a pattern similar to that for chlorophyll, again presumably reflecting nutrient enrichment at the downstream sites. 
3. Despite higher biomass, the periphyton at the downstream sites were apparently less efficient in photosynthesis, possibly as a result of toxic stresses. Periphyton physiological condition improved with increased distance downstream from ORNL discharges.

4. Results obtained in 1987 were similar to those reported for April through December 1986. Increased biomass and improved performance at several sites could be explained by the reduction in toxicant input or a change in sampling site location. For example, algal periphyton biomass and primary production rates increased and physiological condition improved at MEK 0.6 ( $800 \mathrm{~m}$ below the HFIR discharge) following the shutdown of the HFIR in November 1986 and the subsequent reduction in discharges.

5. Differences in the performance of the periphyton at the ten study sites could not be explained by differences in water quality based on short-term bioassays. These differences may be the result of intermittent toxic exposures or physical factors and biotic interactions not examined thus far. For example, siltation and grazing appeared to be important influences on periphyton biomass and performance at several sites.

6. Analyses of the metals associated with the periphyton reflected the impact of discharges from ORNL operations; concentrations of several elements (e.g., $\mathrm{Cr}, \mathrm{Cu}, \mathrm{Hg}$, $\mathrm{Pb}$, and $\mathrm{Zn}$ ) increased at the downstream sites. However, none of these compounds were present in what would be considered excessive or physiologically damaging concentrations.

\subsection{Future Studies}

Efforts during 1988 will emphasize the characterization of the physical environment and the biotic components at each site in order to evaluate the influences of natural vs toxic influences on community structure and function and to better assess the role of internal vs external regulation of system dynamics. This information will then contribute to the characterization of the various study reaches, permit an assessment of the influence of ORNL operations on the structure and dynamics of these systems, and provide the information needed to predict responses to proposed remedial actions.

Characterization of the physical environment will consist of the determination of the morphometry (width, depth, current velocity); substrate type; canopy cover; and light penetration at each of the sampling sites. These data will help to evaluate the factors influencing the periphyton (e.g., light and current) and the contribution of the periphyton to system dynamics for each site.

Characterization of the biological communities will consist of determining the presence and levels of several additional physical parameters useful for describing the periphyton at each site and for evaluating the population structure of the algal periphyton, the rates of colonization of algal and microbial components, and the influence of grazing pressure on the structure and dynamics of the periphyton communities. As part of this characterization, rocks will be collected from each site and taken to the laboratory where the periphyton matrix will be removed by abrasion (brushing with a toothbrush) rather than by DMSO extraction. A slurry of the periphyton matrix is produced that is then subsampled for algal species composition, filtered for the determination of dry weight and 
ash-free dry weight (AFDW), and extracted in DMSO for ATP and chlorophyll determinations.

A preliminary evaluation of this method was conducted by collecting three rocks from each sampling site on January 5,1988 . The periphyton was renoved by scraping, and chlorophyll a, ATP, dry weight, and AFDW were determined and expressed per unit rock surface area (Table 3-20). In addition to the data for chlorophyll and ATP, the ability to consider chlorophyll and ATP per unit AFDW is useful in evaluating site characteristics and the composition of the periphyton community. Although the species composition of the algal periphyton was not determined for these samples, such information will be useful for site characterization and for the evaluation of systam dynamics. Data on percentage of AFDW in conjunction with the other parameters showed the large contribution of inorganic material to periphyton weight at downstream sites WCK 2.3 and MEK 0.6 and upstream sites NTK 1.0 and WCK 6.8. Although the periphyton at the two downstream sites are generally in good condition, the accumulation of an unstable silt layer on the surface is likely a major influence on the composition and process rates for the algal periphyton at these sites. The high level of AFDW (>50\%) at WCK 3.9, WCK 3.4 and WCK 2.9 is similar to that at other local sites characterized by nutrient enrichment and reduced grazing pressure. When considered together with ther information, the percentage of AFDW in the periphyton matrix is correlated with site characteristics (e.g., nutrient-rich sites with occasional toxic stress; sites where siltation may be important) and may serve as a useful diagnostic parameter.

During 1988, ceramic tiles will be placed at each site and retrieved at 1- or 2-week intervals to evaluate the rate of colonization by algae and microbes and the accumulation of inorganic matter. These data will aid in identifying key factors influencing the dynamics of the periphyton community at each study site.

Although the brushing method tends to underestimate periphyton chlorophyll $a$ and ATP when low levels are present and difficult to remove from rock surfaces, the data for chlorophyll and ATP collected by brushing generally compare well with data collected using the DMSO extraction. The direct DMSO extraction method will continue to be used for routine monitoring of chlorophyll and carbon incorporation becausc of the ease of performing those extractions. The brushing method will be used several times annually to provide a more complete characterization of the periphyton community and to measure colonization rates. 
Table 3-20. Characterization of the periphyton at ten study sites where periphyton was removed by brushing the rock surfaces

\begin{tabular}{lccccc}
\hline Site & $\begin{array}{c}\text { Chlorophyll } a \\
\left(\mathrm{mg} / \mathrm{cm}^{2}\right)\end{array}$ & $\begin{array}{c}\text { ATP } \\
\left(\mathrm{mg} / \mathrm{cm}^{2}\right)\end{array}$ & $\begin{array}{c}\text { Dry weight } \\
\left(\mathrm{mg} / \mathrm{cm}^{2}\right)\end{array}$ & $\begin{array}{c}\text { AFDW } \\
\left(\mathrm{mg} / \mathrm{cm}^{2}\right)\end{array}$ & $\begin{array}{c}\text { AFDW } \\
(\%)\end{array}$ \\
\hline WCK 6.8 & 1.22 & 2.53 & & & \\
WCK 3.9 & 20.3 & 2.23 & 0.95 & 0.30 & 27 \\
WCK 3.4 & 18.8 & 6.23 & 1.47 & 0.97 & 69 \\
WCK 2.9 & 8.6 & 6.21 & 1.26 & 0.92 & 71 \\
WCK 2.3 & 13.0 & 4.99 & 0.94 & 0.62 & 56 \\
MEK 1.8 & 1.8 & 5.49 & 6.20 & 1.04 & 24 \\
MEK 0.6 & 5.3 & 4.36 & 1.21 & 0.28 & 36 \\
FCK 1.0 & 0.4 & 0.76 & 2.75 & 0.65 & 23 \\
FFK 1.1 & 13.7 & 9.75 & 0.18 & 0.07 & 38 \\
NTK 1.0 & 0.9 & 3.03 & 3.75 & 2.06 & 37 \\
& & & 1.56 & 0.34 & 23 \\
\hline
\end{tabular}

aSamples were collected on January 5, 1988. WCK $=$ White Oak Creek kilometer; MEK $=$ Melton Branch kilometer; FCK $=$ First Creek kilometer; FFK $=$ Fifth Creek kilometer; NTK $=$ Northwest Tributary kilometer.

bdenosine triphosphate.

'Values represent the mean of three replicates. AFDW $=$ Ash free dry weight determined after combustion at $550^{\circ} \cdot \mathrm{C}$. 


\section{BIOACCUMULATION STUDIES}

\subsection{IDENTIFICATION OF CONTAMINANTS THAT ACCUMULATE IN AQUATIC BIOTA}

The bioaccumulation monitoring task of the ORNL BMAP (Loar et al. 1991) has five subtasks with the following objectives:

1. to determine what materials present in the WOC system accumulate to unacceptable levels in aquatic biota (Subtask 2a);

2. to identify specific sources of any observed contamination (Subtask 2b);

3. to calibrate water quality monitoring data against contaminant levels in biota (Subtask 2c);

4. to determine the source and scope of polychlorinated biphenyl (PCB) contamination of channel catfish in WOC embayment and the Clinch River (Subtask 2d); and

5. to develop the capability to forecast future levels of biotic contamination under various remedial action alternatives (Subtask 2e).

Results of studies relating to Subtasks $2 a, 2 b$, and $2 c$ are reported in Sect. 4.1 of this report; results relating to Subtasks $2 b$ and $2 \mathrm{~d}$ are reported in Sect. 4.2. Data from all five subtasks will be applicable to Subtask 2 e.

\subsubsection{Introduction}

Prior to the implementation of BMAP for WOC watershed and the Clinch River (Loar et al. 1991), no data had been collected on levels of contaminants in biota in WOC and tributaries upstream from WOL. However, historical data on levels of metals and organics in water and sediment indicated that streams in the WOC watershed above WOL contained elevated levels of some contaminants. Elevated levels of mercury were observed in sediments of WOC between ORNL and WOL and also in WOL and WOC embayment in 1974-1975 (ERDA 1975). Sediments in WOC embayment contained elevated levels of mercury in 1984 (TVA 1985a, 1985b). An extensive water quality survey conducted by the ORNL Department of Environmental Management at ORNL in 1979-1980 (Boyle et al. 1982, DEM unpublished data) found an increase in total aqueous mercury concentrations as WOC flowed past ORNL.

In a 1985-86 streambed gravel survey, $\mathrm{Cu}, \mathrm{Zn}$, and Mo were found at elevated levels in reaches of WOC and Melton Branch downstream from cooling tower discharges (S. J. Morrison and T. E. Cerling, University of Utah, personal communication, March 1988). The 1979-80 water quality survey (Boyle et al. 1982, DEMC unpublished data) showed a severalfold increase in copper and zinc in WOC and Melton Branch downstream of ORNL facilities. Chromium was also elevated in the sediments of WOC and tributaries (S. J. Morrison and T. E. Cerling, University of Utah, personal communication, March 1988 ) and in the sediments of WOL and WOC embayment (ERDA 1975; Elwood et al. 
1980; TVA 1985a, 1985b) as a result of the past use of corrosion inhibitors containing chromate (discontinued in 1976) in cooling towers at ORNL. Silver appeared to be somewhat elevated in WOC embayment sediments in 1984 (TVA 1985a, 1985b), but elevated levels of silver were not observed in the 1985-86 gravel survey of the WOC watershed. Concentrations of $\mathrm{Fe}, \mathrm{Pb}, \mathrm{Mn}, \mathrm{Na}, \mathrm{K}$, and $\mathrm{Ni}$ increased substantially in WOC and Melton Branch downstream from ORNL (Boyle et al. 1982, DEMC unpublished data), as did total dissolved solids and major ions, such as calcium, magnesium, and sulfate.

Measurements of metals in fish from WOL and WOC embayment were made in 1979 (Loar et al. 1981) and in 1984 (TVA 1985c). Although elevated ( $\sim 0.6 \mathrm{ppm})$, mercury levels were below the Food and Drug Administration (FDA) action level of 1 ppm (FDA $1984 a)$ at both sites in 1979 . Mercury was still slightly elevated $(\sim 0.2 \mathrm{ppm})$ at these sites in 1984 , but levels were considerably lower than those observed in 1979. Other metals were not elevated in fish from these sites in either study.

PCBs were detected in sediments from WOC above WOL in 1974-75 (ERDA 1975) and in 1979 (Boyle et al. 1982, DEMC unpublished data); levels of about 3-5 ppm were typical of the most contaminated site (several hundred meters downstream from ORNL). PCBs were not found in sediments from Melton Branch, WOL, or WOC embayment in the 1979 survey (Boyle et al 1982, DEMC unpublished data), but PCB contamination of sediments in WOL and WOC embayment was observed in 1974-75 (ERDA 1975) and 1984 (TVA 1985a, 1985b).

Sediment samples from WOC between ORNL and WOL were analyzed for organic priority pollutants in 1985-86 (S. J. Morrison and T. E. Cerling, University of Utah, personal communication, March 1988). Several phthalate esters (bis-2-ethylhexylphthalate, di- $\boldsymbol{n}$-butylphthalate, and benzylbutylphthalate) were detected in some samples in concentrations of several parts per million, but they were found in similar concentration levels in control samples from upper WOC (above ORNL), suggesting that the results may be an artifact or the result of sample contamination. High molecular weight polycyclic aromatic hydrocarbons (PAHs) were found in low levels (total PAHs $<1 \mathrm{ppm}$ ) at a single site in WOC (Third Street Bridge) within the main ORNL plant area. The composition of the PAH mixture indicated the presence of a highly weathered aromatic oil, creosote, or asphaltic solid, such as blacktop or roofing tar. The low levels, localized occurrence, and absence of more soluble, low molecular weight PAHs suggest the absence of a chronic source of biologically available PAHs to this reach of WOC.

Sediment cores from WOL were analyzed for priority pollutants in 1984 (TVA 1985a, 1985b) and 1985 (T. W. Doyle and F. G. Taylor, ORNL, personal communication, June 1986), but no compounds were detected. Surface sediments from WOC embayment were analyzed for priority pollutants in 1984 (TVA 1985a, 1985b), but only bis-2-ethylhexylphthalate was detected in one of two samples.

Polychlorinated biphenyls have been found in fish from WOL and WOC embayment in recent samplings (TVA 1985c, Loar et al. 1992). No other organics were detected in fish from thes- sites in 1984 (TVA 1985c) with the exception of chloroform, which was reported in two samples from WOC embayment. Because chloroform has very little 
bioaccumulation potential (Callahan et al. 1979), it is unlikely that these results actually reflect environmental exposure to this chemical.

Recent data suggest that only two nonradioactive contaminants, mercury and PCBs, accumulate in fish from WOL and WOC embayment to levels substantially higher than those expected in local uncontaminated sites. Information is needed on the bioaccumulation of contaminants in biota in reaches of WOC and tributaries upstream from WOL, where the combination of lower dilution and the absence of contaminant scavenging by macrophytes and suspended particulates in WOL may result in substantially higher exposures.

\subsubsection{Methods}

Fish were collected by electrofishing at three sites on WOC and at single sites on WOL, WOC embayment, Northwest Tributary, and Melton Branch in winter 1986-87 (Table D-1). Sites on WOC, Melton Branch, and Northwest Tributary corresponded closely to the benthos and fish community sampling sites (Fig. 2-2). At each site, fish were generally concentrated in one or two large pools; only at WCK 2.9 was it necessary to electrofish a larger reach of stream $(\sim 150 \mathrm{~m})$.

Twelve fish were collected at each site to provide samples for analysis of metals, organics, radionuclides, and archival storage. Samples were taken from eight fish for each purpose (except at MEK 0.2, where fish numbers were inadequate). Bluegill (Lepomis macrochirus) and redbreast sunfish (Lepomis auritus) were collected in equal numbers where possible; however, redbreast sunfish were restricted to those portions of the WOC watershed downstream of the weir at WCK 3.41 (Fig. 2-2). Although an attempt was made to restrict the collections to individuals of a size likely to be taken by sport fishermen, it was impossible to meet this requirement at all sites. Fish were collected from Hinds Creek (Anderson County, Tennessee) in order to estimate background levels of contaminants and to provide analytical controls.

Fish collected at each site were placed on ice in a labeled ice chest and returned to the laboratory for processing. Upon return to the laboratory, fish were tagged with a unique four-digit tag wired to the lower jaw. Each fish was then weighed and measured, and scales were taken for age determination. The fish was fileted, and the skin was removed from the filet. A 1 - to 2-g sample of the anterior dorsal portion of the axial muscle filet was excised for the determination of mercury; the remainder of the filet was retained for analysis of other metals and radionuclides. Samples to be analyzed for metals and radionuclides were freeze-dried, wrapped in aluminum foil, and stored at room temperature until analyzed. The remaining filet was either used for a duplicate sample, archived, or analyzed for organic contaminants. Samples to be analyzed for organics or maintained in archival storage were wrapped in heavy-duty aluminum foil, labeled, and stored at $-20^{\circ} \mathrm{C}$ in a locked freezer in Building 1504 until delivered to the ORNL Analytical Chemistry Division (ACD) for analysis.

Asiatic clams (Corbicula fluminea) were placed in the streams to monitor for PCBs and organic contaminants. Clams were obtained in July 1987 from upper Bull Run near Maynardville in Union County, Tennessee. Results from a comparison of several area 
reference (or control) streams conducted in June 1987 as part of the Y-12 Plant BMAP showed that Corbicula from this site had the lowest background levels of PCBs of any specimen tested in the four streams that were evaluated (G. R. Southworth, ORNL, unpublished data). After the clams were held for $24 \mathrm{~h}$ in clean flowing water, they were put into polypropylene cages and placed in WOL, WCK 3.4, WCK 2.6 and MEK 0.2. One set of clams collected from Bull Run was frozen immediately for analysis as a control. Each cage held approximately 50 clams, which contained $0.5-2 \mathrm{~g}$ (wet wt) of soft tissue each. The clams were suspended in the stream for 4 weeks, at which time they were removed and processed prior to delivery to the ACD laboratory at ORNL. After freezing the clams, the shells were removed, and the frozen soft tissue was placed in a 20-mL glass vial. Composite samples weighing -5 and $10 \mathrm{~g}$ were taken for PCB analysis and gas chromatographic/mass spectrometric (GC/MS) analysis respectively.

Mercury determinations were conducted using the ACD procedure EC 420 (Martin Marietta Energy Systems 1983). Samples were digested in a mixture of nitric acid, perchloric acid, and potassium dichromate, after which the mercury was reduced with stannous chloride and determined by cold vapor atomic adsorption spectrophotometry. Other metals were determined using graphite furnace atomic absorption spectrophotometry following digestion with concentrated nitric acid (EPA 1980b). Organic priority pollutants were analyzed by procedure PPB 12/83 (EPA 1983), in which the homogenized sample is extracted in methylene chloride, cleaned up using column chromatography, and analyzed using GC/MS or electron capture detectors (GC/ECD) and high-performance liquid chromatography (HPLC) with fluorimetric detection.

Quality assurance was maintained using a combination of blind duplicate analyses; split sample analyses between the EPA Environmental Services Laboratory in Athens, Georgia, and ORNL; and the analysis of biological reference standards and uncontaminated fish. Recoveries of representative organics were verified by spiking uncontaminated fish or clam samples with known amounts of PCBs and analyzing them. Details and results of these procedures are summarized in Appendix C.

\subsubsection{Results}

\subsubsection{Metaks}

Mercury contamination in fish from the WOC system (WOC, Northwest Tributary, Melton Branch, WOL, and WOC embayment) was described in the first annual BMAP report (Loar et al. 1992). Levels were elevated above those found in fish from Hinds Creek, a reference stream, but they were well below the FDA tolerance level (1 ppm) in all fish (Table 4-1). Early results from the December 1987 collections indicate no change in this situation and will be reported fully in the next annual report.

Despite the presence of abnormal levels of some metals in sediments, levels of all other metals in fish collected from the WOC system were similar to those found in fish from the reference stream (Table 4-1; Appendix D, Table D-1). Levels of copper and zinc were ten times higher than background in periphyton (Table 3-17) but were not elevated at all in fish. The levels of metals in fish from the WOC system were also quite similar to those reported by Tennessee Valley Authority (TVA) researchers for Melton 
Table 4-1. Mean metal concentrations in fish (parts per million, wet weight) from White Oak Creek and tributaries, White Oak Lake (WOL), and Hinds Creek (reference stream)

Fish are bluegill (Lepomis macrochirus) and redbreast sunfish (Lepomis auritus) collected in winter 1986-1987; $n=8$ except where noted; \pm 1 s.d. in parentheses

\begin{tabular}{|c|c|c|c|c|c|c|c|c|c|c|c|}
\hline \multirow[b]{2}{*}{ Metal } & \multicolumn{8}{|c|}{ Levels by sampling site } & \multirow[b]{2}{*}{$\begin{array}{l}\text { TVA }^{c} \\
\text { levels }\end{array}$} & \multirow[b]{2}{*}{$\begin{array}{c}\text { USFWS }^{d} \\
\text { levels }\end{array}$} & \multirow[b]{2}{*}{${ }^{d}$ PGV } \\
\hline & NTK 0.2 & WCK 3.5 & WCK 2.9 & WCK 2.3 & MEK $0.2^{a}$ & WOL $v$ & WCK 0.9 & Hinds $\mathrm{Cr}^{b}$ & & & \\
\hline Antimony & $<0.12$ & $<0.12$ & $<0.12$ & $<0.12$ & $<0.12$ & $<0.12$ & $<0.12$ & $<0.3$ & & & 5.2 \\
\hline Arsenic & $<0.06$ & $<0.06$ & $<0.06$ & $<0.06$ & $<0.06$ & $<0.06$ & $<0.06$ & $<0.10$ & $<0.03$ & 0.16 & 0.0007 \\
\hline Beryllium & $<0.04$ & $<0.04$ & $<0.04$ & $<0.04$ & $<0.04$ & $<0.04$ & $<0.04$ & $<0.05$ & $<1$ & & 0.004 \\
\hline Cadmium & $\begin{array}{c}0.026 \\
(0.019)\end{array}$ & $\begin{array}{c}0.024 \\
(0.029)\end{array}$ & $\begin{array}{c}0.008 \\
(0.004)\end{array}$ & $\begin{array}{c}0.018 \\
(0.012)\end{array}$ & $\begin{array}{c}0.035 \\
(10.015)\end{array}$ & $\begin{array}{c}0.031 \\
(0.016)\end{array}$ & $\begin{array}{c}0.019 \\
(0.016)\end{array}$ & $\begin{array}{c}0.015 \\
(0.014)\end{array}$ & $\begin{array}{c}0.007 \\
(0.003)\end{array}$ & 0.04 & 1.0 \\
\hline Chromium & $<0.1$ & $<0.1$ & $<0.1$ & $<0.1$ & $<0.1$ & $<0.1$ & $<0.1$ & $<0.1$ & 0.06 & & 1.8 \\
\hline Copper & $<0.4$ & $\begin{array}{l}<0.4 \\
(0.56)\end{array}$ & $\begin{array}{c}<0.4 \\
(0.3)\end{array}$ & $<0.4$ & $<0.4$ & $<0.4$ & $<0.4$ & 0.45 & 0.4 & 0.86 & 36 \\
\hline Lead & $\begin{array}{c}<0.04 \\
(0.04)\end{array}$ & $\begin{array}{c}0.04 \\
(0.02)\end{array}$ & $\begin{array}{c}0.03 \\
(0.01)\end{array}$ & 0.03 & $\begin{array}{c}<0.04 \\
(0.11)\end{array}$ & $\begin{array}{c}0.10 \\
(0.01)\end{array}$ & 0.03 & $\begin{array}{c}<0.02 \\
(0.33)\end{array}$ & 0.21 & 0.19 & 1.8 \\
\hline Lithium & $<0.4$ & $<0.4$ & $<0.4$ & $<0.4$ & $<0.4$ & $<0.4$ & $<0.4$ & $<0.5$ & & & \\
\hline Mercury & $\begin{array}{c}0.26 \\
(0.05)\end{array}$ & $\begin{array}{c}0.25 \\
(0.12)\end{array}$ & $\begin{array}{c}0.44 \\
(0.09)\end{array}$ & $\begin{array}{c}0.49 \\
(0.18)\end{array}$ & $\begin{array}{c}0.13^{f} \\
(0.03)\end{array}$ & $\begin{array}{c}0.16 \\
(0.10)\end{array}$ & $\begin{array}{c}0.07 \\
(0.01)\end{array}$ & $\begin{array}{r}0.098 \\
(0.03)\end{array}$ & $<0.1$ & 0.11 & $0.42^{h}$ \\
\hline Nickel & $<1.0$ & $<1.0$ & $<1.0$ & $<1.0$ & $<1.0$ & $<1.0$ & $<1.0$ & $<1.0$ & $<1.0$ & & 5.2 \\
\hline Selenium & $\begin{array}{c}0.41 \\
(0.10)\end{array}$ & $\begin{array}{c}0.36 \\
(0.10)\end{array}$ & $\begin{array}{c}0.51 \\
(0.16)\end{array}$ & $\begin{array}{c}0.18 \\
(0.06)\end{array}$ & $\begin{array}{c}0.34 \\
(0.07)\end{array}$ & $\begin{array}{c}0.30 \\
(0.08)\end{array}$ & $\begin{array}{c}0.21 \\
(0.07)\end{array}$ & $\begin{array}{c}0.55 \\
(0.12)\end{array}$ & $\begin{array}{c}0.7 \\
(0.2)\end{array}$ & 0.46 & 12 \\
\hline Silver & $<0.06$ & $<0.06$ & $<0.06$ & $<0.06$ & $<0.06$ & $<0.06$ & $<0.06$ & $<0.10$ & $<0.3$ & & 0.29 \\
\hline Thallium & $<0.1$ & $<0.1$ & $<0.1$ & $<0.1$ & $<0.1$ & $<0.1$ & $<0.1$ & $<0.2$ & $<1$ & & 0.66 \\
\hline Zinc & $\begin{array}{c}5.2 \\
(1.1)\end{array}$ & $\begin{array}{c}6.4 \\
(1.2)\end{array}$ & $\begin{array}{c}6.4 \\
(1.3)\end{array}$ & $\begin{array}{c}7.2 \\
(2.4)\end{array}$ & $\begin{array}{c}6.4 \\
(0.8)\end{array}$ & $\begin{array}{c}5.1 \\
(0.7)\end{array}$ & $\begin{array}{c}5.6 \\
(0.6)\end{array}$ & $\begin{array}{c}6.2 \\
(1.0)\end{array}$ & $\begin{array}{c}8.4 \\
(2.6)\end{array}$ & 25.6 & 180 \\
\hline
\end{tabular}

$a_{n}=5$.

$t_{n}=4$.

TVA (Tennessee Valley Authority). 1985. Instream Contaminant Study, Task 4: Fish sampling and analysis. Report to the U.S. Department of Enerzy, Oak Ridge Operations Office. Tennessee Valley Authority, Office of Natural Reaources and Economic Development, Knoxville, Tenn. [Note: TVA reference site was Melton Hill Reservoir ( $n=9$ for $\mathrm{Cr}, \mathrm{As}, \mathrm{Ni}$; $n=4$ for others)]

'T. P. Lowe et al. 1985. National Contaminant Biomonisoring Program: Concentrations of seven elements in freshwater fish, 1978-1981. Arch. Environ. Contam. Toxicol. 14:363-388.

'Preliminary guidance values (Sources: F.O. Hoffman, et al. 1984. Preliminary screening of contaminants in sediments. ORNLTM-9370, Oak Ridge National Laboratory, Oak Ridge, Tenn.; and C. C. Travis et al. 1986. Preliminary review of TVA fish sampling and analysis repor. Report of Task Group Five to Oak Ridge Task Force. Mimeo.

$f_{n}=11$.

Adult redbreast sunfish, $n=20$.

hFDA action level is $1.0 \mathrm{ppm}$ wet wt.

Nove: NTK $=$ Northwest Tributary kilometer; WCK $=$ White Oak Creek kilometer, MEK $=$ Melton Branch kilometer. 
Hill Reservoir (Table 4-1; TVA 1985c, 1986) and, except for mercury, were similar to the geometric mean levels of metals ( $\mathrm{Pb}, \mathrm{Cd}, \mathrm{As}, \mathrm{Se}, \mathrm{Cu}, \mathrm{Zn}$ ) observed in fish in the National Contaminant Biomonitoring Program (Table 4-1, Lowe et al. 1985). A comparison of the levels of metals in fish from the WOC system with preliminary guidance values (PGVs) derived to screen for levels of contamination that potentially threaten human health (Hoffman et al. 1984, Travis et al. 1986) indicates that only $\mathrm{As}, \mathrm{Be}$, and $\mathrm{Hg}$ approach this threshold (Table 4-1). Neither arsenic nor beryllium was elevated in WOC fish; however, the PGV is set at a level below background die to the carcinogenicity of these two metals. The PGV screening approach is very conservative and is designed to eliminate from concern any substances not exceeding a specific PGV (Hoffman et al. 1984).

\subsubsection{Organics}

The only organic contaminants found to accumulate in fish from the WOC system were FCBs (Table 4-2 and D-2), and they were detected in fish at all sites except Northwest Tributary. Virtually all PCBs detected in sunfish from WOC and tributaries were quantified as PCB-1254. Very high levels of PCBs were reported in some sunfish at each of the sites sampled in WOC upstream from WOL, ranging up to $5.8 \mathrm{ppm}$ in one fish. The highest mean concentration of PCBs was $2.4 \mathrm{ppm}$ in fish collected at WCK 2.3, but mean levels $\geq 1 \mathrm{ppm}$ were also found at WCK 3.5, WCK 2.9, and MEK 0.2. A substantial proportion of the fish (8 of 51) exceeded the FDA tolerance level for PCBs in fish and shellfish of 2 ppm (FDA 1984b). Sunfish (Lepomis macrochirus and L.auritus) are relatively shortlived fish that do not have high levels of intramuscular lipids; thus, they do not accumulate hydrophobic contaminants to the extent that older, fattier fish do (e.g., channel catfish). PCB levels of $1 \mathrm{ppm}$ or more in sunfish imply a level of contamination in an aquatic system that would result in many larger game and food fishes exceeding the 2-ppm FDA limit.

Although the dual capillary column system used in these analyses of fish from WOC is a powerful confirmatory tool, lower detection limits and better quantitative results are possible using a packed column GC/ECD analysis. This latter procedure was used for investigating PCB contamination in fish in WOC embayment, where previous studies (TVA 1985a, Loar et al. 1992) had demonstrated that PCB contamination was a concern. In order to gain a better insight into the degree of PCB exposure to WOC and WOL biota, caged clams (Corbicula fluminea) were placed at several sites in the WOC system and allowed to accumulate contaminants for 1 month. These clams were then analyzed for PCBs by packed-column GC/ECD and for other organics by GC/ECD and GC/MS.

The results of these exposures (Table 4-3) were in general agreement with those of the fish collections; WOC above WOL contained a significant source of PCB contamination. No other organics exceeded detection limits (Tables D-3 and D-4). Clams maintained at WCK 3.5 did not accumulate high levels of PCBs, but those held at the two sites farther downstream (WCK 2.6 and WOL) accumulated substantial quantities of PCBs. Like those found in the fish from the WOC system, virtually all PCBs in clams were quantified as PCB-1254. Melton Branch did not appear to be a source of PCB contamination during this exposure. This result contrasts with that from the fish collections made 8 months earlier in which elevated PCB levels were found in sunfish from Melton Branch. 
Table 4-2. Concentrations of polychlorirated biphenyls (PCBs) and other organic priority pollutants (parts per million, wet wreight) in sunfish (Lepomis macnochirus and

L. auritus) from White Oak Creuk and tributaries and White Oak Lake

(WOL), winter 1986-87

\begin{tabular}{lcccc}
\hline Site & Mean \pm 1 s.d. & Range & Occurrence $^{\circ}$ & Other organics $^{b}$ \\
\hline WCK 3.5 & $1.0 \pm 1.9$ & $<0.2-4.8$ & $2 / 8$ & BLD $^{c}$ \\
WCK 2.9 & $1.4 \pm 1.3$ & $<0.2-3.9$ & $6 / 8$ & BLD \\
WCK 2.3 & $2.4 \pm 1.9$ & $<0.2-5.8$ & $8 / 8$ & BLD \\
WOL & $0.4 \pm 0.7$ & $<0.2-1.5$ & $2 / 8$ & BLD \\
WCK 0.9 & $0.6 \pm 0.4$ & $<0.4-1.0$ & $7 / 8$ & BLD \\
MEK 0.2 & $1.1 \pm 1.2$ & $<0.2-2.8$ & $2 / 3$ & BLD \\
NTK 0.2 & $<0.2$ & $<0.2-<0.4$ & $0 / 8$ & BLD \\
\hline
\end{tabular}

a Number of samples exceeding detection limit/total number of samples.

bNames and detection limits of organics that were screened for but not detected are listed in Appendix D, Table D-4.

'Below limit of detection.

Note: WCK $=$ White Oak Creek kilometer; MEK = Melton Branch kilometer; NTK $=$ Northwest Tributary kilometer.

Table 43. Concentrations of polychlorinated biphenyl (PCBs) (parts per million, wet weight) in composite samples of caged clams (Corbicula fluminea) held in White Oak Creek, Melton Branch, White Oak Lake (WOL), and East Fork Poplar Creek at the outfall of New Hope Pond near the Oak Ridge Y-12 Plant

\begin{tabular}{lcccc} 
Site & Exposure period & Mean \pm 1 s.d. & $N$ & Control \\
\hline WCK 3.5 & July 15-August 17, 1987 & $0.17 \pm 0.02$ & 2 & 0.05 \\
WCK 2.6 & July 15-August 17, 1987 & $1.5 \pm 0.0$ & 2 & 0.05 \\
MEK 0.2 & July 15-August 17, 1987 & $0.11 \pm 0.04$ & 2 & 0.05 \\
WOL & July 15-August 17, 1987 & $1.4 \pm 0.1$ & 2 & 0.05 \\
EFK 23.4 & July 7-August 6,1986 & $0.45 \pm 0.07$ & 3 & 0.07 \\
EFK 23.4 & April 28-May 26,1987 & $0.57 \pm 0.19$ & 3 & 0.08 \\
EFK 23.4 & September 1-29, 1987 & $0.40 \pm 0.10$ & 3 & 0.03 \\
\hline
\end{tabular}

Nore: WCK $=$ White Oak Creek kilometer; MEK $=$ Melton Hill kilometer; EFK = East Fork Poplar Creek kilometer. 
If the level of PCBs in WOC and WOL clams is compared with levcls attained in clams held for similar periods in East Fork Poplar Creek (EFPC), where levels of PCBs in fish have been monitored for several years (Table 4-3), it is possible to place the degree of contamination observed in the WOC system in perspective. Near East Fork kilometer (EFK) 23.4, where clams generally accumulate about $0.5 \mathrm{ppm}$ PCBs in a 4-week exposure, sunfish typically contain $0.5-1 \mathrm{ppm}$ PCBs, and carp collected at sites farther downstream often contain $>2 \mathrm{ppm}$ (G. R. Southworth, ORNL, unpublished data). The concentration of PCBs accumulated by clams placed in WOC and WOL was about three times that found in clams placed in EFPC. In addition, PCB levels in sunfish averaged $2.4 \mathrm{ppm}$ at the WOC site exhibiting the highest mean concentration of PCBs (Table 4-2). Thus, the degree of biotic PCB exposure in the WOC system above WOL would almost certainly result in levels of PCBs in excess of 2 ppm if long-lived fish, such as carp and channel catfish, which contain higher levels of intramuscular lipids, were residents of WOC.

\subsubsection{Discussion}

\subsubsection{Metak}

Excluding mercury, which was discussed as a contaminant ir. WOC fish in the previous annual report (Loar et al. 1992), the accumulation of metals in fish does not appear to be a problem in the WOC system. Levels of trace metals in fish were typical of those found in fish from a reference stream and similar to levels observed in previous surveys of this system (Loar et al. 1981, TVA 1985c). The comparison of levels of metals in WOC fish with levels assumed for screening purposes to represent a possibility of posing a health hazard to humans ingesting fish on a regular basis indicated no cause for concern.

\subsubsection{Organics}

The accumulation of PCBs was clearly evident in fish samples collected in November and December 1986 and in caged clams exposed in July and August 1987. The level of PCB accumulation in biota indicates a serious problem of PCB contamination within the WOC system. The clam samples suggest a source of contamination between WCK 3.5 and WCK 2.9, possibly in drainage from SWSA 4. Fish samples suggest PCB contamination in both WOC and Melton Branch, with the highest contamination occurring in the lower reaches of WOC. While the clam and fish data may appear contradictory, it should be noted that (1) these are the first data obtained on PCB contamination in biota from WOC and tributaries above WOL and (2) very little is known of the nature of PCB inputs to the WOC system. If the biotic contamination is a result of episodic discharges at different points, then site-by-site contamination patterns could differ between sampling periods. The finding of significant PCB-1254 contamination in biota of WOC is consistent with a conclusion in the previous annual report that the discharge of WOL is a source of PCB contamination (predorninantly PCB-1254) to channel catfish in WOC embayment (Loar et al. 1992, Sect.4.2.4.2). Much of the PCB-1260 noted in catfish from WOL, WOC embayment, and the Clinch River may represent accumulation via the food-chain pathway, which would tend to accentuate the accumulation of more highly chlorinated PCB congeners. 


\subsubsection{Conclusions}

The bioaccumulation of PCBs is the most significant problem in the WOC system caused by the accumulation of metals and organics in biota. High levels of PCBs are found above WOL in fish from stream reaches that are isolated by weirs and thus prevent the upstream movement of fish. Consequently, the source of the problem is upstream from the lower weir at WCK 2.65. Fish data, including incomplete results from the December 1987 sampling, suggest that the source is upstream from WCK 3.5. The levels of PCB contamination in some sunfish from WOC exceed the FDA tolerance level, and both clam and sunfish data indicate that the degree of PCB exposure to biota in WOC is at least as severe as that in EFPC. The PCB contamination of WOC also has the potential to act as a source of PCB contamination to upper Watts Bar Reservoir. There is a need to determine the source(s) of PCB contamination in fish in WOC and to evaluate the importance of the WOC discharge as a source of PCB contamination in biota of the Clinch River and Watts Bar Reservoir.

Mercury bioaccumulation in WOC fish is of interest because it indicates that ORNL is a source of biologically available mercury. However, the levels are well below the FDA action limit, and the elevated levels found in biota are confined to the WOC system upstream from White Oak Dam. The primary need is to determine the source of the mercury that is accumulating in WOC biota.

\subsection{EVALUATION OF PCB CONTAMINATION IN WHITE OAK CREEK EMBAYMENT AND CLINCH RIVER}

\subsection{Introduction}

The 1986 survey of PCB contamination in channel catfish (Ictalurus punctatus) from WOC embayment and nearby reaches of the Clinch River found significant levels of PCBs in many of the fish collected (Loar et al. 1992). That study concluded that recent or ongoing releases of PCBs from sources upstream or within the embayment (WOL or WOC) contributed to the observed contamination, especially in fish collected from WOC embayment and adjacent reaches of the Clinch River (Loar et al. 1992). Nevertheless, little of the PCB contamination in catfish from other sites in the Clinch River could be directly attributed to this source. Levels of PCBs in channel catfish from WOC embayment in 1986 were substantially lower than those observed in 1984 (TVA 1985c), when all fish collected at the site exceeded the FDA tolerance limit (FDA 1984b).

The 1986 survey also found a relatively strong association between ${ }^{90} \mathrm{Sr}$ content of channel catfish bone and the proximity of the collection site to WOC (Loar et al. 1992). Such a finding indicated that catfish resided in specific locations long enough to acquire burdens of contaminants that had long turnover times and thus were representative of exposure conditions at that site. This study also detected evidence of movement of catfish between WOC embayment and nearby reaches of the Clinch River, thus making fish that were residents of the embayment, which is closed to public access, vulnerable to capture by fishermen. 
The basic objectives of this task of BMAP in 1987 were the same as those in 1986: (1) to determine the likelihood that channel catfish caught by fishermen in the tailwaters of Melton Hill Dam and upper Clinch River and Watts Bar Reservoir might contain PCBs in excess of the FDA tolerance limit and (2) to establish the extent to which ORNL, via WOC, WOL, and WOC embayment, is the source of PCB contamination in channel catfish in public waters downstream.

Monitoring conducted in 1986 indicated that fish collected from the Clinch River within $300 \mathrm{~m}$ of the mouth of WOC (CRK 33.2 and CRK 33.8) contained PCB and ${ }^{90} \mathrm{Sr}$ levels identical to those of fish collected from within WOC embayment. The monitoring program, therefore, was modified in 1987 to exclude sites CRK 33.8, CRK 33.2, and CRK 30.2 (the most remote site sampled in 1986).

The 1986 study used levels of ${ }^{90} \mathrm{Sr}$ in catfish vertebrae to estimate the extent of exposure of fish to the WOC discharge. By comparing levels of ${ }^{90} \mathrm{Sr}$ and PCBs in fish at different sites, it was possible to estimate the extent to which PCB levels in fish were associated with exposure to the WOC discharge.

A key question in the investigation of PCB contamination downstream of the WOC system is how a localized source of PCBs subject to large-scale dilution could result in a broad geographic pattern of contamination in fishes that are not directly associated with the source. One mechanism assumes that the predominant uptake pathway is the ingestion of PCB-contaminated forage fish which, due to their wide-ranging movements, act to distribute the contamination to locations far removed from the source. If so, then a strong relationship between PCB levels and exposure to the local source (WOC) would not be expected. To investigate this question, gizzard shad (Dorosoma cepedianum), an abundant forage fish, were collected from WOC embayment, the Clinch River, and Melton Hill Reservoir and analyzed for PCBs and ${ }^{90} \mathrm{Sr}$.

\subsubsection{Methods}

Catfish were collected in July and August 1987 by trotline and gill net at five sites: WOL, WOC embayment (WCK 0.3), Clinch River $1.3 \mathrm{~km}$ above and below the mouth of WOC (CRK 34.8 and CRK 32.2, respectively) and Melton Hill Reservoir (Fig. 4-1). All five sites were also sampled in 1986 with one exception: channel catfish were collected from Hope Creek embayment of Melton Hill Reservoir in 1986, but in 1987 they were collected from the main channel of the reservoir so they would be more representative of contamination in the bulk flow of the Clinch River. The sampling program attempted to capture eight channel catfish (Ictalurus punctatus) weighing $440 \mathrm{~g}$ or more at each site. This objective was not met at CRK 34.8 and Melton Hill Reservoir, where fewer than eight fish were collected, or in WOL, where no channel catfish were found and yellow bullhead (Ictalurus natalis) were substituted.

Two other sites served as controls. Uncontaminated channel catfish were purchased from a local commercial fish farm to serve as analytical controls and to provide a basis for estimating background levels of PCBs likely to be reported by the analytical procedure. Fort Loudoun Reservoir at Lenoir City, Tennessee, served as a positive control, thus 


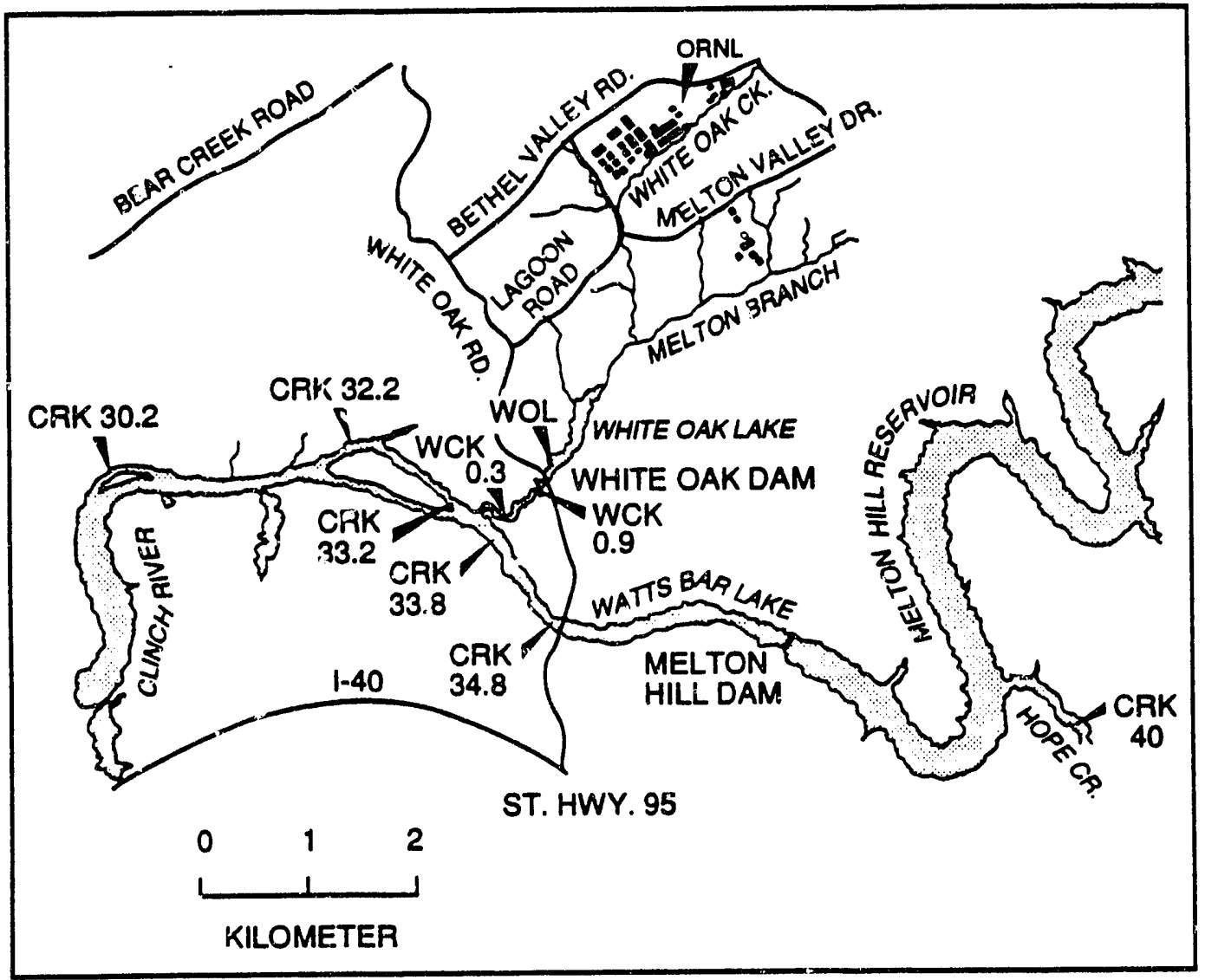

Fig 4-1. Location of catfish collection sites in White Oak Creek and the Clinch River. Site $1=$ WOL . Site $2=$ WCK 0.3, Site $3=$ CRK 34.8, Site $4=$ CRK 32.2, Site $5=$ Melton Hill Reservoir. 
enabling results of PCB analyses of Clinch River fish to be placed in perspective by comparing them with PCB levels in fish from a site of known contamination.

Fish collected at each site were placed on ice in a labeled ice chest and returned to the laboratory for processing. Individual ice chests were used to contain fish from each site when more than one station was sampled on a given date. Upon return to the laboratory, fish were tagged with a unique four-digit tag wired to the lower jaw. Each fish was then weighed, measured, and the dorsal fin removed for possible age determination. The fish was fileted, and the skin was removed from the filet. Filets were rinsed in running water, and one filet was wrapped in heavy-duty aluminum foil and stored in a locked freezer at $-20^{\circ} \mathrm{C}$ for archival purposes. The remaining filet was frozen and then ground three times in a hand-operated meat grinder. A 10- to 20-g sample of ground fish was wrapped in heavy-duty aluminum foil, labeled by writing directly on the aluminum foil with a permanent marker, and stored in a locked freezer until submitted to the ORNL $A C D$ laboratory for analysis.

Gizzard shad were collected from WCK 0.3, CRK 32.2, and Melton Hill Reservoir by electrofishing and analyzed for PCBs in order to estimate levels in a likely food of channel catfish. Three composite samples of five fish each (22-29 cm total length) were taken from each site. The fish were ground whole, frozen, and submitted for analysis.

A 4- to 5-cm portion of the vertebral column was removed from the tail of each catfish, air dried, wrapped and labeled, and sent to ACD for ${ }^{90} \mathrm{Sr}$ analysis. For gizzard shad, portions of the backbone of each fish were removed and submitted as composite samples (from the same five fish) for ${ }^{90} \mathrm{Sr}$ analysis.

Fish were analyzed for PCBs through the use of procedure EPA 600/4-81-055 (EPA $1980 \mathrm{~b})$. This procedure utilizes extraction with methylene chloride followed by adsorption column cleanup, solvent exchange, and evaporative concentration prior to analysis by packed column GC/ECD. Strontium-90 was determined by beta counting with the use of a low-background proportional counter. Prior to counting, the fish vertebrae were ashed, dissolved in nitric acid, and subjected to a chemical purification procedure in which a strontium oxalate precipitate is ultimately isolated for counting (Volchok and Planque 1982).

Statistical evaluations of the data were made by using SAS procedures and software (SAS 1985b) for ANOVA; Duncan's multiple range test; linear regression analysis; $t$-test with assumption of unequal variances; and the calculation of means, standard deviations, standard errors, and coefficients of variation.

Quality assurance was maintained using a combination of blind duplicate analyses; split sample analyses between the EPA Environmental Services Laboratory in Athens, Georgia, and the ORNL ACD laboratory; and the analysis of fish reference standards and uncontaminated fish spiked with PCBs. Details and results of these procedures are summarized in Appendix C. 


\subsection{Results}

\subsubsection{PCBs in catfish from WOC embayment-Clinch River}

PCB contamination was evident in channel catfish from WOC embayment, the Clinch River, and in yellow bullheads from WOL (Tables 4-4 and D-5). Channel catfish collected from Melton Hill Reservoir (upstream from any possible inputs from WOC) also contained significant levels of PCBs. The PCB mixtures recovered from fish contained predominantly pentachlorobiphenyl and hexachlorobiphenyl congeners characteristic of Arochlor 1254 and 1260 commercial mixtures; PCB-1260 was somewhat more abundant than PCB-1254. Total PCBs (PCB-1254 + PCB-1260) in individual fish ranged from a high of $5.0 \mathrm{ppm}$ in Fort Loudoun Reservoir, the positive control site, to $0.03 \mathrm{ppm}$ in a commercial catfish farm. The highest level observed in fish from WOC or the Clinch River was $4.7 \mathrm{ppm}$ in the Clinch River (CRK 32.2), while the lowest noncontrol level was 0.23 ppm in Melton Hill Reservoir. The minimum PCB level observed in Clinch RiverWOC embayment fish was $0.51 \mathrm{ppm}$. The fraction of fish containing PCBs in excess of the FDA tolerance limit of $2 \mathrm{ppm}$ was approximately $25 \%$ in both WOC embayment and the Clinch River (Table 4-5).

Contaminants witi long biological half-lives tend to accumulate in a fish to everhigher levels throughout much of its lifespan. Thus, larger, older fish may contain higher contaminant levels than smaller, younger fish. The effects of such a bias can be significant if fish collected from some sites are predominantly small while those from other sites are predominantly large. Such effects can often be avoided by collecting adult fish of similar size. Therefore, channel catfish weighing $<440 \mathrm{~g}$ were not included in this study if adequate numbers of larger fish were collected at a site. Mean weights of fish comprising collections varied somewhat among sites (893-1577 $\mathrm{g}$ ), and the range of weights and overall mean were larger than in the 1986 collections. Regressions of ${ }^{90} \mathrm{Sr}$, total PCBs, PCB-1254, and PCB-1260 vs fish weight at each site showed no significant relationship (slope not different from zero, $p>0.05$ ) in 17 of 19 possible comparisons. Therefore, comparisons of mean contaminant levels among sites were made without normalizing for variations in fish weight.

Mean levels of PCBs in catfish collected from sites in the Clinch River-WOC embayment were similar, ranging from $1.59 \mathrm{ppm}$ in WOC embayment to $1.69 \mathrm{ppm}$ at the upstream river site (Table 4-4). The mean PCB concentration in fish from Melton Hill Reservoir was about half that found in fish downstream from Melton Hill Dam. Channel catfish collected from Fort Loudoun Reservoir, a nearby lake for which an advisory was issued by TDHE warning the public against consuming catfish because of PCB contamination, averaged $1.9 \mathrm{ppm}$. However, ANOVA and Duncan's multiple range test indicated no significant differences in mean PCB levels among any of these sampling sites. In the 1986 survey of PCBs (Loar et al. 1992), Melton Hill Reservoir was used as a reference (control) site. The finding of substantial PCB contamination in fish from that site in 1986, which was corroborated the following year (Table 4-4), necessitated the selection of another control site. Consequently, in 1987, control fish were obtained from a commercial catfish farm near ORNL. Sampling at this site was used to evaluate whether or not high background levels of PCBs would be found in any channel catfish samples 
Table 4-4. Concentrations of polychlorinated biphenyls and $\mathrm{Sr}$ in channel catfish (Ictalunus punctatus) from lower White Oak Creek embayment, White Oak Lake (WOL), Clinch River, and other local sites

Values are mean \pm 1 s.d., range, and number of samples (in parentheses)

\begin{tabular}{|c|c|c|c|c|c|}
\hline \multirow[t]{2}{*}{ Site } & \multirow[t]{2}{*}{ Location $^{a}$} & PCB total & PCB-1254 & PCB-1260 & \multirow{2}{*}{$\begin{array}{c}{ }^{90} \mathrm{Sr} \\
(\mathrm{Bq} / \mathrm{kg} \mathrm{dry} \mathrm{wt})\end{array}$} \\
\hline & & \multicolumn{3}{|c|}{ (ppm, wet wt) } & \\
\hline 1 & WOL $^{b}$ & $\begin{array}{l}1.00 \pm 0.86 \\
0.41-2.50 \\
(5)\end{array}$ & $\begin{array}{l}0.30 \pm 0.30 \\
0.06-0.80 \\
(5)\end{array}$ & $\begin{array}{l}0.70 \pm 0.57 \\
0.35-1.70 \\
(5)\end{array}$ & $\begin{array}{l}4800 \pm 1107 \\
3700-6600 \\
(5)\end{array}$ \\
\hline 2 & WCK 0.3 & $\begin{array}{l}1.59 \pm 0.87 \\
0.57-3.28 \\
(8)\end{array}$ & $\begin{array}{l}0.52 \pm 0.50 \\
0.03-1.40 \\
(8)\end{array}$ & $\begin{array}{l}1.07 \pm 0.78 \\
0.43-2.6 \\
(8)\end{array}$ & $\begin{array}{l}351 \pm 326 \\
24-1100 \\
(8)\end{array}$ \\
\hline 3 & CRK 34.8 & $\begin{array}{l}1.69 \pm 1.16 \\
0.83-3.0 \\
(3)\end{array}$ & $\begin{array}{l}0.61 \pm 0.49 \\
0.13-1.10 \\
(3)\end{array}$ & $\begin{array}{l}1.08 \pm 0.84 \\
0.23-1.9 \\
(3)\end{array}$ & $\begin{array}{l}359 \pm 372 \\
47-770 \\
(3)\end{array}$ \\
\hline 4 & CRK 32.2 & $\begin{array}{l}1.61 \pm 1.55 \\
0.51-4.7 \\
(8)\end{array}$ & $\begin{array}{l}0.46 \pm 0.60 \\
0.01-1.9 \\
(8)\end{array}$ & $\begin{array}{l}1.15 \pm 1.22 \\
0.26-3.4 \\
(8)\end{array}$ & $\begin{array}{l}158 \pm 270 \\
13-800 \\
(8)\end{array}$ \\
\hline MHR & $\begin{array}{r}\text { Melton Hill } \\
\text { Reservoir }\end{array}$ & $\begin{array}{l}0.81 \pm 0.61 \\
0.23-2.0 \\
(7)\end{array}$ & $\begin{array}{l}0.37 \pm 0.34 \\
0.01-1.0 \\
(7)\end{array}$ & $\begin{array}{l}0.43 \pm 0.28 \\
0.19-1.0 \\
(7)\end{array}$ & $\begin{array}{l}11 \pm 10 \\
1-27 \\
(6)\end{array}$ \\
\hline FLD & $\begin{array}{l}\text { Fort Loudoun } \\
\text { Reservoir at } \\
\text { Lenoir City, } \\
\text { Tenn. }\end{array}$ & $\begin{array}{l}1.90 \pm 1.54 \\
0.42-5.0 \\
(8)\end{array}$ & $\begin{array}{l}0.57 \pm 0.64 \\
0.04-2.1 \\
(8)\end{array}$ & $\begin{array}{l}1.32 \pm 1.02 \\
0.35-2.9 \\
(8)\end{array}$ & $\begin{array}{l}\text { ND } \\
\text { ND } \\
\text { ND }\end{array}$ \\
\hline CEC & $\begin{array}{l}\text { Commercial } \\
\text { catfish farm }\end{array}$ & $\begin{array}{l}0.03 \pm 0.01 \\
0.03-0.04 \\
(4)\end{array}$ & $\begin{array}{l}0.02 \pm 0.01 \\
0.02-0.03 \\
(4)\end{array}$ & $\begin{array}{l}0.01 \pm 0.01 \\
0.01-0.01 \\
(4)\end{array}$ & $\begin{array}{l}\text { ND } \\
\text { ND }\end{array}$ \\
\hline
\end{tabular}

"The confluence of White Oak Creek and the Clinch River is located at White Oak Creek kilometer (WCK) 0.0 and Clinch River kilometer (CRK) 33.5. (CRK 0.0 is located at the confluence of the Clinch and Tennessee rivers.)

${ }^{b}$ Only yellow bullhead (Ictalurus natalis) were collected in WOL.

Note: $\mathrm{ND}=$ no data available. 
Table 4-5. Changes between 1986 and 1987 in mean concentrations of polychlorinated biphenyls (PCBs), Nr, and ratio of fish exceeding the Food and Drug Administration (FDA) limit to total number analyzed (for channcl catish)

Sampling from White Oak Lake (WOL), White Oak Creek embayment, the Clinch River, and two local reservoirs

\begin{tabular}{|c|c|c|c|c|c|c|}
\hline \multirow[b]{2}{*}{ Site } & \multicolumn{2}{|c|}{$\begin{array}{l}\text { PCB total } \\
\text { (ppm, wet wt) }\end{array}$} & \multicolumn{2}{|c|}{$\begin{array}{c}{ }^{90} \mathrm{Sr} \\
(\mathrm{Bq} / \mathrm{kg}, \mathrm{dry} \text { wt bone })\end{array}$} & \multicolumn{2}{|c|}{$\begin{array}{l}\text { No. of fish exceeding } \\
\text { FDA limit per } \\
\text { No. analyzed }\end{array}$} \\
\hline & 1986 & 1987 & $1 \overline{986}$ & 1987 & 1986 & 1987 \\
\hline WOL & 0.97 & 1.00 & 4420 & 4800 & $0: 5$ & $1: 5$ \\
\hline WCK 0.3 & 1.30 & 1.59 & $741^{\circ}$ & $351^{a}$ & $3: 12$ & $2: 8$ \\
\hline CRK 34.8 & 1.07 & 1.69 & 295 & 359 & $0: 8$ & $1: 3$ \\
\hline CRK 32.2 & 1.01 & 1.61 & 57 & 158 & $0: 8$ & $2: 8$ \\
\hline $\begin{array}{c}\text { Melton Hill } \\
\text { Reservoir }\end{array}$ & 0.46 & 0.81 & 14 & 11 & $0: 6$ & $1: 7$ \\
\hline $\begin{array}{l}\text { Fort Loudoun } \\
\text { Reservoir at } \\
\text { Lenoir City, Tenn. }\end{array}$ & $1.7^{b}$ & 1.90 & ND & ND & $3: 10^{b}$ & $3: 8$ \\
\hline
\end{tabular}

${ }^{a}$ Statistically significant difference at $0.1>p>0.05$.

'Fish collected and analyzed by Tennessee Valley Authority in 1985 (D. L. Dycus and G. D. Hickman. 1987. PCB Levels in Fish from Fort Loudon Reservoir-1985. TVAVONRED/AWR-88/8. Tennessee Valley Authority, Office of Natural Resources and Economic Development, Knoxville, Tenn.).

Note: $\mathbf{W C K}=$ White Oak Creek kilometer; CRK = Clinch River kilometer; $\mathbf{N D}=$ no data available.

analyzed by the analytical procedure used in this study. Results of those analyses, which showed a mean PCB concentration of $0.03 \mathrm{ppm}$ (Table 4-4), clearly disproved the hypothesis that PCB analyses of channel catfish routinely report high background levels, even in fish expected to be uncontaminated. The mean level of PCBs in the control fish was significantly lower than the mean level $(p<0.05)$ in Melton Hill Reservoir (the site with the next lowest level of PCBs) and the remaining sites (t-test with assumption of unequal variances and Duncan's multiple range test applied to the natural logarithm of the PCB concentration). 
Like total PCBs, levels of PCB-1254 and PCB-1260 were not significantly different among the noncontrol sites (Duncan's multiple range test, $p>0.05$ ). When levels of total PCBs, PCB-1254, and PCB-1260 were compared after logarithmic transformation of the data (a procedure that makes variances among sites more homogeneous and reduces the influence of very high and very low values), the results were unchanged.

The levels of ${ }^{90} \mathrm{Sr}$ in catfish vertebrae exhibited much greater differences among sampling sites than did PCBs (Table 4-4). The highest mean concentration of ${ }^{90} \mathrm{Sr}$ $(4800 \mathrm{~Bq} / \mathrm{kg}$ ) was found in fish from WOL, as expected, and the lowest level (11 Bq/kg) was observed in fish from Melton Hill Reservoir. The mean level of ${ }^{90} \mathrm{Sr}$ in catfish collected in WOC embayment $(351 \mathrm{Bg} / \mathrm{kg}$ ) was lower by about a factor of 14 than the level in WOL fish. The dilution factor for the flow of WOC in the embayment was estimated to be a factor of 5 (Loar et al. 1992); thus the ${ }^{90} \mathrm{Sr}$ concentration in catfish from this site was substantially lower than that expected if the fish were permanent residents of this site. The level of ${ }^{90} \mathrm{Sr}$ in fish collected from the two Clinch River sites did not differ greatly from that in fish from WOC embayment; fish from the downstream site (CRK 32.2) averaged about half as much ${ }^{90} \mathrm{Sr}$ as embayment fish, while fish from the upstream site (CRK 34.8) contained about the same amount as embayment fish. Results of statistical comparisons (Duncan's multiple range test using log-transformed data due to clearly nonhomogeneous variances) indicated no significant difference in ${ }^{90} \mathrm{Sr}$ among WOC embayment and Clinch River fish; fish from WOL and Melton Hill Reservoir had significantly higher and lower concentrations, respectively, than fish from other sites.

\subsubsection{2 ${ }^{90} \mathrm{Sr}$ vo PCB}

No close correspondence between mean $\mathrm{PCB}$ and ${ }^{90} \mathrm{Sr}$ concentrations in fish from WOC embayment and the Clinch River was evident (Table 4-4). Even less correspondence was noted when WOL fish were included, since these were lower in PCBs and much higher in ${ }^{90} \mathrm{Sr}$. The slopes of linear regressions of $[\mathrm{PCB}]$ vs $\left[{ }^{90} \mathrm{Sr}\right],[\mathrm{PCB}]$ vs $\left[\ln { }^{90} \mathrm{Sr}\right.$ ], and $[\ln \mathrm{PCB}]$ vs $\left[\ln { }^{90} \mathrm{Sr}\right]$ were not significantly different from zero $(p>0.05)$ for fish from the WOC embayment-Clinch River sites. Similar treatments of PCB-1254 and PCB-1260 were also not statistically significant. However, if the level of significance is reduced from 0.05 to 0.10 , a significant relationship was observed for PCB-1254 vs ${ }^{90} \mathrm{Sr}$ :

$$
[\mathrm{PCB}]=0.00069\left[{ }^{90} \mathrm{Sr}\right]+0.32, r^{2}=0.17
$$

suggesting rather inconclusively that WOC discharge and the WOC embayment may be the source of a significant fraction of the PCB burden of channel catfish in the embayment and nearby reaches of the Clinch River.

\subsubsection{PCB levels in fish in 1987 vs 1986}

PCB levels in fish collected in 1987 were somewhat higher than the levels found in fish from the same sites in 1986 (Table 4-5). Statistical comparisons between mean levels of total PCBs in fish at each site in 1987 vs 1986 indicated no significant differences (t-test with assumption of unequal variances, where appropriate, $p>0.05$ ). When fish from the WOC-Clinch River sites sampled in both years were pooled and compared, the difference was still not statistically significant. 
A probable explanation for the somewhat higher levels of PCBs observed in 1987 is that these collections tended to have a higher average weight per fish than the 1986 collections. While no statistically significant relationship was observed between PCB concentration and fish weight for specific sampling sites in either 1986 or 1987, a significant relationship was observed in 1987 (but not 1986) when all fish from the WOC embayment/Clinch River sites sampled in 1987 were pooled:

$$
[\mathrm{PCB}]=0.00075 \times \mathrm{wgt}(\text { grams })+0.67, r^{2}=0.24 .
$$

If the mean weight of channel catfish collected at these sites in 1986 (725 g) is inserted into Eq. 2, a predicted mean PCB concentration of $1.19 \mathrm{ppm}$ is obtained, which compares closely with the actual mean of $1.15 \mathrm{ppm}$ found in these fish in 1986.

The year-to-year difference in the mean weight per fish in the collections could also explain the higher level of PCBs in fish from Melton Hill Reservoir in 1987, although no statistically significant relationship between PCB concentration and fish weight was observed at this site. Fish collected from WOL differed very little in mean weight or PCB concentration between 1986 and 1987, and fish collected from WOC embayment in 1986 had virtually the same mean PCB concentration when reanalyzed in 1987 as they did in 1986 (Appendix C). The probable presence of a correlation between fish weight and PCB concentration underscores the need to ensure that fish are selected from a relatively narrow and consistent size range at all sites each year.

Similar levels of ${ }^{90} \mathrm{Sr}$ were observed in fish from WOL in 1986 and 1987 (Table 4-5), indicating little year-to-year variation in their exposure to ${ }^{90} \mathrm{Sr}$ and implying relatively constant year-to-year average ${ }^{90} \mathrm{Sr}$ concentrations in the discharge from WOL. Strontium-90 was lower in catfish collected in WOC embayment in 1987 than in 1986, but the difference ( 741 vs $351 \mathrm{~Bq} / \mathrm{kg}$ ) was significant only at $p=0.10$. The level of ${ }^{90} \mathrm{Sr}$ in fish at the downstream site on the Clinch River was higher (57 vs $158 \mathrm{~Bq} / \mathrm{kg}$ ) in 1987 than in 1986 , but the difference was not statistically significant $(p>0.05)$. The difference in geographic patterns of ${ }^{90} \mathrm{Sr}$ in fish between 1986 and 1987 could indicate a wider local-scale dispersal of fish in 1987. In 1986, fish at CRK 32.2 and CRK 34.8 contained significantly less ${ }^{90} \mathrm{Sr}$ than fish from WOC embayment; in 1987 they did not. The highest ${ }^{90} \mathrm{Sr}$ level found in fish at CRK 32.2 in 1986 was $120 \mathrm{~Bq} / \mathrm{kg}$; in 1987, it was $800 \mathrm{~Bq} / \mathrm{kg}$, a level typical of fish from WOC embayment. The mean ${ }^{90} \mathrm{Sr}$ concentration in WOC embayment fish was lower in 1987 than in 1986, despite similar inputs of ${ }^{90} \mathrm{Sr}$ to the WOC system in the 2 years (as inferred from the lack of change in ${ }^{90} \mathrm{Sr}$ in catfish from WOL between 1986 and 1987). Together, these data suggest that the fish comprising the 1987 collection had less association with the WOC discharge. In other words, the area within which one could assume to find a geographically homogeneous population sample was larger in 1987 than 1986.

The proportion of fish exceeding the FDA limit for PCBs was similar in 1986 and 1987 for the WOC embayment site. Although no fish exceeding 2 ppm PCBs were collected from CRK 32.2 and CRK 34.8 in 1986, 3 of 11 fish collected at those sites exceeded the FDA limit in 1987 (Table 4-5). Undoubtedly, some of this difference is due to the presence of larger fish in the 1987 collection; however, a wider dispersal of catfish, with more highly contaminated fish from WOC embayment moving to sites in the Clinch 
River, could also account for more fish exceeding the FDA limit at the Clinch River sites in 1987.

\subsubsection{PCBs in gizarard shad}

Gizzard shad, an important forage fish in most reservoirs in East Tennessee, were sampled and analyzed for PCBs in 1987 in order to evaluate the significance of PCB accumulation in channel catfish via the food chain. The results of these limited analyses were striking and unexpected.

Gizzard shad collected in WOC embayment contained very high levels of PCBs, averaging $3.0 \mathrm{ppm}$ (Tables 4-6 and D-5). Fish collected at CRK 32.2 (1.3 km downstream from WOC embayment) contained far lower levels, averaging $0.65 \mathrm{ppm}$ PCBs, while those collected in Melton Hill Reservoir averaged $0.44 \mathrm{ppm}$. The predominant mixture present in the WOC embayment fish was PCB-1254, but at the other two sites (CRK 32.2 and Melton Hill Reservoir), levels of PCB-1254 and PCB-1260 were similar. Results of ANOVA and Duncan's multiple range test indicated that mean PCB levels in WOC embayment fish were significantly higher than those at the other two sites $(p<0.05)$, which were not significantly different from each other.

Table 46. Concentrations of polychlorinated biphenyls (PCBs) and sr in gizard shad (Donosoma cepedianum) from White Oak Creek embayment (WCK 0.3), the Clinch River $-1.3 \mathrm{~km}$ below White Oak Creek (CRK 32.2), and Melton Hill Reservoir

Values are mean \pm 1 s.d. of composites of five fish, range, and number of samples (in parentheses)

\begin{tabular}{|c|c|c|c|c|}
\hline \multirow[t]{2}{*}{ Site } & PCB total & PCB-1254 & PCB-1260 & \multirow{2}{*}{$\frac{{ }^{90} \mathrm{Sr}}{(\mathrm{Bq} / \mathrm{kg}, \text { dry wt bone) }}$} \\
\hline & \multicolumn{3}{|c|}{ (parts per million, wet wt) } & \\
\hline WCK 0.3 & $\begin{array}{l}3.0 \pm 1.6 \\
1.8-4.8 \\
(3)\end{array}$ & $\begin{array}{l}1.9 \pm 1.1 \\
1.1-3.2 \\
(3)\end{array}$ & $\begin{array}{l}1.1 \pm 0.45 \\
0.71-1.6 \\
(3)\end{array}$ & $\begin{array}{l}397 \pm 108 \\
320-520 \\
(3)\end{array}$ \\
\hline CRK 32.2 & $\begin{array}{l}0.65 \pm 0.06 \\
0.60-0.71 \\
(3)\end{array}$ & $\begin{array}{l}0.34 \pm 0.17 \\
0.10-0.41 \\
(3)\end{array}$ & $\begin{array}{l}0.31 \pm 0.22 \\
0.19-0.25 \\
(3)\end{array}$ & $\begin{array}{l}91 \pm 112 \\
22-220 \\
(3)\end{array}$ \\
\hline $\begin{array}{l}\text { Melton Hill } \\
\text { Reservoir }\end{array}$ & $\begin{array}{l}0.44 \pm 0.19 \\
0.33-0.66 \\
(3)\end{array}$ & $\begin{array}{l}0.22 \pm 0.17 \\
0.10-0.41 \\
(3)\end{array}$ & $\begin{array}{l}0.22 \pm 0.03 \\
0.19-0.25 \\
(3)\end{array}$ & $\begin{array}{l}8 \pm 7 \\
1-14 \\
(3)\end{array}$ \\
\hline
\end{tabular}

Note: WCK $=$ White Oak Creek kilometer; CRK $=$ Clinch River kilometer. 
The mean concentration of ${ }^{90} \mathrm{Sr}$ in vertebrae of shad from WOC embayment (397 $\mathrm{Bq} / \mathrm{kg}$ ) was comparable to the concentration in channel catfish from that site (Tables 4-4 and D-5). Strontium-90 was significantly lower at the Clinch River site (Duncan's multiple range test and $t$-test with assumption of unequal variances, when necessary), but one of the composite samples from that site contained a relatively high level of ${ }^{90} \mathrm{Sr}(220$ $\mathrm{Bq} / \mathrm{kg}$ ). The sample that was high in ${ }^{90} \mathrm{Sr}$, however, did not contain $\mathrm{PCBs}$ at a level typical of those observed in WOC embayment fish.

\subsection{Diecussion}

\subsubsection{PCBs in Clinch River catfish}

Levels of PCBs in catfish in WOC embayment and nearby reaches of the Clinch River appear to have remained stable between 1986 and 1987, following a relatively large decrease between 1984 and 1986 (Loar et al. 1992). A substantial fraction (25\%) of the channel catfish collected in 1987 from WOC embayment and reaches of the Clinch River open to public fishing contained PCBs in excess of the 2-ppm FDA limit.

The levels of PCB contamination in channel catfish collected in 1986 in the Clinch River near ORNL were typical of those found by TVA in 1984 at sites farther downstream in Watts Bar Reservoir (Loar et al. 1992). Results of the 1987 sampling agree with this earlier finding. Because systematic differences may exist in quantitative determinations of complex mixtures, such as PCBs, among different analytical laboratories, a positive control, Fort Loudoun Reservoir, was added to the sampling program in 1987. A public health advisory warning against the consumption of catfish was issued by TDHE for this lake due to PCB contamination. Channel catfish collected from the lowermost reaches of Fort Loudoun Reservoir and analyzed by TVA in 1985 averaged 1.7 ppm PCBs; fish collected by ORNL at this site in 1987 averaged $1.9 \mathrm{ppm}$ PCBs (Table 4-5). Three of ten fish collected in 1985 at this site exceeded 2 ppm; three of eight fish in 1987 exceeded this level. The levels of PCB contamination in channel catfish from waters in the vicinity of ORNL appear to be somewhat lower (although differences are not statistically significant) than those in lower Fort Loudoun Reservoir. It should be noted, however, that substantially higher levels of PCB contamination occur in catfish in the upper reaches of Fort Loudoun Reservoir, especially Little River embayment, and that levels of contamination in the lower reaches of the lake did not necessarily result in the issuance of the advisory.

The levels of ${ }^{90} \mathrm{Sr}$ in catfish collected in the Clinch River corroborate the conclusion of the 1986 study (Loar et al. 1992) that there is substantial movement of fish between the embayment and the Clinch River. Strontium-90 levels in fish at sites $1.3 \mathrm{~km}$ upstream and downstream of the mouth of WOC were statistically indistinguishable from those in fish from WOC embayment, indicating substantial localized movement in and out of the embayment on a somewhat larger geographic scale than that observed in 1986.

\subsubsection{WOC as source of PCBs}

While a significant portion of the PCB burden of catfish collected in WOC embayment may result from recent or ongoing releases from sources within the 
embayment or upstream, the 1986 study concluded that little of the total PCB content of fish from other sites could be attributed to these sources (Loar et al. 1992). Although the 1987 data for $\left[{ }^{90} \mathrm{Sr}\right.$ ] vs [PCBs] in fish collected in the vicinity of ORNL support this earlier conclusion, they also suggest that the geographical scale of contamination traceable to ORNL may be larger than indicated by the 1986 data. The presence of high levels of PCBs in forage fish in WOC embayment and the high levels of PCBs accumulated by clams placed in WOC and WOL indicate that the role of ongoing or episodic contamination upstream from WOL may be more significant than previously thought. If small, widely ranging forage fish, such as gizzard shad, can accumulate high levels of PCBs during a relatively short residency in WOC embayment and then disperse to other portions of the Clinch River-Watts Bar Reservoir, an important pathway could exist for the spread of PCB contamination to higher trophic levels.

Ratios of PCB-1254 to PCB-1260 were higher in sunfish collected in WOC and WOL than in catfish collected in WOL and WOC embayment. Because more highly chlorinated PCB congeners have longer half-lives in fish (Niimi and Oliver 1983), PCB-1260 would tend to be higher in longer-lived fish. Similarly, the lower water solubility of PCB-1260 vs PCB-1254 (MacKay et al. 1983) and greater partitioning of PCB-1260 to particulates would act to enhance the relative importance of the food chain as an exposure pathway for PCB-1260 as compared with PCB-1254. Thus, it is not unlikely that the PCB-1254:PCB-1260 ratio would be lower in sunfish than in catfish. The use of PCB congener ratios may have value in elucidating the significance of specific sources of PCBs in larger systems, such as the Clinch River, but a thorough understanding of how environmental transport and transformation processes affect congener ratios, particularly among different fish species, is needed before this approach can be applied with confidence.

\subsection{Conclusions}

Some channel catfish caught by anglers in the Clinch River in the vicinity of WOC are likely to contain PCBs in excess of the 2-ppm FDA limit. In 1986, only 5\% of fish collected in the Clinch River exceeded that limit, but in 1987, 25\% did. The higher proportion of fish exceeding the FDA limit in 1987 is, in part, due to the larger average size of the fish collected and to the apparent wider range of movement of fish into and out of WOC embayment. It must also be noted that a smaller number of fish were collected from the Clinch River in 1987 and that the most distant site from WOC was not included in the 1987 sampling. Because there was no measurable change in mean PCB levels in channel catfish at these sites between 1986 and 1987, it is unlikely that the increased number of fish exceeding 2 ppm in PCBs in 1987 is a result of a change in PCB exposure. However, it is likely that fish residing for periods of time in WOC embayment are more susceptible to capture by anglers (due to movement into waters open to public fishing) than was concluded from the 1986 data.

The 1987 study provided more evidence that the WOC discharge and/or WOC embayment is an active source of PCB contamination to organisms that reside there. However, the lack of a relationship between ${ }^{90} \mathrm{Sr}$ and PCBs in catfish, coupled with the presence of significant PCB contamination in channel catfish from sites upstream from Melton Hill Dam, suggests that ORNL is not the major source of PCB contamination in 
fish at more remote sites in the Clinch River, unless a mechanism such as food-chain accumulation via widely ranging PCB-contaminated forage fish is dominant.

\subsection{FUTURE STUDIES}

The detection of significant levels of PCB accumulation in biota from WOC indicates the need to proceed to Subtask $2 b$ of BMAP: identification of contaminant sources (Loar et al. 1991). Further studies will be designed and implemented in this subtask, probably using caged clams at numerous sites within the watershed, after discussion with DEMC staff responsible for implementing the NPDES PCB Monitoring Plan. Routine quantitative measurement of PCB concentrations in fish from WOC will be initiated on a semiannual basis if other BMAP investigators agree that such collection pressure can be sustained without undue effects on fish populations or other tasks within BMAP. Routine quantitative evaluation of PCB contamination in WOC fish will provide a baseline for evaluating the effectiveness of any remedial actions that may be implemented.

Monitoring of PCB contamination in channel catfish in WOC embayment will continue annually to detect any change in PCB levels at this site. Additional studies of the role of the food-chain pathway in determining PCB levels in Clinch River catfish will also be initiated. These investigations will focus on the accumulation of PCBs in gizzard shad in WOC embayment and the dispersal of these fish to other sites in Watts Bar Reservoir. The possibility of using PCB congener ratios to evaluate the importance of ORNL as a source of PCBs in fish in Watts Bar Reservoir will be investigated.

The annual screening of fish in WOC for metals and organic contaminants as outlined in BMAP will be continued, with greater emphasis on the use of caged clams to monitor for organic contaminants. Further studies will be conducted to determine the source of mercury contamination in biota. Work will also continue on Subtask 2c: Integration of water quality and bioaccumulation data (Loar et al. 1991). 


\section{BIOLOGICAL INDICATORS OF CONTAMINATED- RELATED STRESS}

\subsection{INTRODUCTION}

This task of BMAP involves the development, screening, and application of biological indicators to evaluate the responses of fish populations in the WOC watershed to pointand area-sources of contamination (Loar et al. 1991). As used in BMAP, biological indicators (bioindicators) are those physiological variables of organisms that respond in biologically meaningful ways to changes in the environment. They have several advantages over other, more traditional approaches to biomonitoring that are focused on higher levels of biological organization (i.e., populations and communities). For example, bioindicators can provide an early warning of potential adverse ecological effects due to their sensitivity to water quality degradation and can be used to establish the relationship between water quality and important biological responses, such as growth. Because they are generally easy to measure and cost-effective, they can be used for long-term biomonitoring and for evaluating the effects of remedial actions on water quality.

Bioindicators selected after the first year of study were applied in long-term field investigations (Subtask 3b) initiated in 1987. The objectives of this phase of the study were (1) to measure a suite of indicators that represented a series of biological responses along a gradient of relatively short-term to long-term responses and (2) to evaluate the usefulness of these indicators for long-term monitoring of water quality. The basic approach involved a comparisen of buth individual and integrated biological responses of fish from various sites in the WOC watershed to the responses of fish from noncontaminated reference areas.

\subsection{METHODS}

Sampling was conducted during late April and early May 1987 at four sites: (1) WOC between WCK 3.2 and WCK 2.9; (2) Melton Branch near the weir at MEK 0.16; (3) WOL; and (4) Brushy Fork, a reference stream located north of Oak Ridge near Marlowe, Tennessee. At each site, 10-15 adult bluegill and reubreast sunfish were collected by electroshocking. Within 2 min after collection, blood samples were taken from each fish for various biochemical analyses. Blood was collected by puncturing the caudal vessels with a 20-gauge needle. Samples of $-0.7 \mathrm{~mL}$ were obtained from all fish with the use of heparinized (sodium heparin) and unheparinized 3-mL vacutainers (Becton, Dickson, \& Co.). Each tube was labeled with a fish identification number and placed in a container with ice for transport to the laboratory.

\subsubsection{Analytical Procedures}

Total lengths and weights of each fish were recorded before the liver, gonads, gills, and kidney were removed for analysis. The liver was removed from the body cavity and cut into three pieces that were used in three different analyses. A 100 -mg section for 
histopathological analysis was placed in a $20-\mathrm{mL}$ scintillation vial with $5 \mathrm{~mL}$ of Bouin's fixative. For analyses of detoxification enzymes, a $300-\mathrm{mg}$ sample was placed in a vial with $0.2 \mathrm{M}$ sucrose buffer. The remaining liver sample $(50-100 \mathrm{mg})$ was placed in a small plastic bag and immediately frozen in iiquid nitrogen for subsequent ribonucleic acid (RNA) and deoxyribonucleic acid (DNA) analysis.

The spleen was also removed from the body cavity and weighed to the nearest milligram; a section was placed in Bouin's fixative for subsequent histopathological analysis, and the remainder was used for immunological assays. A portion of the kidney was scraped off the interior dorsal body wall for histopathological analysis. Sections of the gill were also removed and placed in Bouin's fixative. For females, the ovary was removed, weighed to the nearest milligram, and placed in a separate vial with $10 \mathrm{~mL}$ of Bouin's fixative for future enumerations of egg numbers and size.

\subsubsection{Lipid Analysis}

Following dissection and removal of the critical organs, four individuals of each sex from each site were chosen for lipid analysis. These fish were frozen at $-120^{\circ} \mathrm{C}$ until shipment was made to the subcontractor. Lipid biochemical analysis was performed according to a modification of the Bligh and Dyer (1959) method and using the Iatroscan Analyzer System (Harvey and Patton 1981) for lipid class quantification. The Iatroscan system for lipid analysis combines the resolution capabilities of thin-layer chromatography with the quantitative sensitivity of a flame ionization detector. Lipid analysis for each fish included total lipids (percentage of body weight); triglycerides (percentage of total lipids); sterols, including cholesterol and/or sterol esters; phospholipids; and the two major fractions of phosphatidylethanolamine (PE) and phosphatidylcholine (PC).

\subsubsection{Serum Chemical Analysis}

Blood collected in the unheparinized tubes was allowed to clot, transferred with Pasteur pipettes to $1.5-\mathrm{mL}$ conical microcentrifuge tubes labeled with the fish identification number, and centrifuged for $2 \mathrm{~min}$ in a Beckman Microfuge. The clear supernatant (serum) was drawn off with clean pipettes and transferred to labeled 1-mL conical plastic tubes. Serum glucose, serum glutamate oxyaloacetate transaminase (SGOT), bilirubin, cholesterol, triglycerides, and serum electrolytes were analyzed by the ORNL Health Division and the ORNL Chemical Technology Division, using a Rotochem IIa 36-cuvette centrifugal analyzer. A centrifugal analyzer is a multicuvette device that uses centrifugal force to simultaneously transfer, mix, and initiate several reactions (36 with Rotochem IIa) and rotary motion to rapidly move these cuvettes through a stationary optical system (Burtis et al. 1973). This type of instrument is very versatile, has on-line data processing capabilities, and needs only microvolumes of sample and reagent.

Glucose analysis was performed according to the method of Peterson and Young (1968); SGOT was analyzed following the procedures of the Scandinavian Committee on Enzymes (1974); cholesterol was analyzed by the method of Allain et al.(1974); triglycerides were analyzed by the procedure of Bucolo and David (1973); and bilirubin was determined by the method of Tietz (1986). All of these methods are enzymatic assays, and the reagents for each assay were obtained from Smith Kline Beckman 
Instruments. Calibrations for all enzymatic assays are traceable to the National Bureau of Standards (NBS) reference materials. In addition, each batch of samples was run with quality control materials.

Total serum proteins were measured by the Biuret method (NCCLS 1979), where divalent copper reacts with the peptide bonds of proteins under alkaline conditions to form the characteristic biuret complex which absorbs at $540 \mathrm{~nm}$. The procedures for the assay are described in the Roche Diagnostic Systems (1986) information package. Assays were performed on an automated Centrifugal Fast Analyzer System (Cobas-Fara, Roche Inc.). Calibrations were performed using the Roche serum calibrator as the standard and monitrol Level 1 and 2 (American Dade, Miami, Florida) as internal controls.

\subsubsection{Enzyme Analysis}

Liver samples removed from fish were placed in a sucrose buffer and homogenized using a Tekmar tissue homogenizer and a motor-driven Potter-Elvenhem glass and Teflon homogenizer. The homogenates were centrifuged at $20,000 \times g$ for $30 \mathrm{~min}$ in a Beckman $\mathrm{J}-21 \mathrm{~B}$ centrifuge and the supernatants placed on ice while the resultant pellet was resuspended in buffer and again centrifuged at 10,000 $\times \mathrm{g}$ for $20 \mathrm{~min}$. "The supernatants from the two centrifugations were pooled and centrifuged at $105,000 \times g$ for $60 \mathrm{~min}$ in a Beckman L3-50 ultracentrifuge. Microsomal pellets were resuspended in $1 \mathrm{~mL}$ of Tris buffer [50 $\mathrm{mM}$ Tris, $1.0 \mathrm{mM}$ ethylenediaminetetraacetic acid (EDTA), 20\% glycerol, and $\mathrm{pH}$ 7.4] using a Braun Sonic 1510 sonicator at $50 \mathrm{~W}$ for $20 \mathrm{~s}$. Microsome suspensions were frozen in liquid nitrogen and stored at $-120^{\circ} \mathrm{C}$ until assayed.

Cytochrome P-450 and $b_{5}$. Cytochrome P-450 and $b_{5}$ were each assayed by their characteristic oxidized and reduced spectra (Omura and Sato 1964). For the $b_{5}$ assi $50 \mu \mathrm{L}$ of microsomes was added to $550 \mu \mathrm{L}$ of resuspension buffer (50 mM Tris, $1.0 \mathrm{~m}$.. EDTA, $\mathrm{mM}$ dithiothreitol (DTT), 20\% glycerol, and $\mathrm{pH}$ 7.4). These are mixed and divided between two cuvettes, one of which contained $5 \mu \mathrm{L}$ of $4 \mathrm{mg} / \mathrm{mL}$ nicotinamide adenine dinucleotide (NADH) while the other served as the reference. They were then scanned from 400 to $500 \mathrm{~nm}$, and the absorbance at 413 and $424 \mathrm{~nm}$ was recorded. The contents of the cuvettes were then combined, and carbon monoxide was gently bubbled through the mixture. A small amount of sodium dithionite was added to one cuvette. Nothing was added to the reference. These were again scanned from 400 to $500 \mathrm{~nm}$, and the absorbance at 450 and $490 \mathrm{~nm}$ was recorded. The difference between the two readings was used to calculate the quantity of each cytochrome. Activity was expressed as nanomoles per milligram.

Nicotinamide-adenine dinucleotide phosphate (NADPH) cytochrome $c$ reductase. The electron transfer enzyme, nicotinamide-adenine dinucleotide phosphate (NADPH)cytochrome $c$ reductase, was assayed spectrophotometrically by a modification of the Phillips and Langdon (1962) method, using cytochrome $c$ as an electron donor. This assay is a measure of the reduction of cytochrome P-450 by using NADPH cytochrome P-450 reductase. It spectrophotometrically monitors the reduction of the artificial electron

\footnotetext{
An italic, lower case $g$ denotes the standard acceleration due to gravity $\left(-9.8 \mathrm{~m} \cdot \mathrm{s}^{-1} \cdot \mathrm{s}^{-1}\right)$.
} 
acceptor cytochrome $c$ at $550 \mathrm{~nm}$. The assay mixture consisted of $0.36 \mathrm{mM}$ NADPH, $89 \mu M$ cytochrome $c, 1 \%$ glycerol, $2.5 \mathrm{mM}$ Tris, $50 \mu M$ EDTADTT, and $0.2 M$ phosphate buffer at pH 7.4 in a total volume of $450 \mu \mathrm{L}$. Either 5 or $10 \mu \mathrm{L}$ of sample was added to the assay mixture, and the solution was incubated at $30^{\circ} \mathrm{C}$ for $2 \mathrm{~min}$ prior to assay. To each of the cuvettes $10 \mu \mathrm{L}$ of NADPH was added. A third cuvette, the reference, contained cytochrome $c$ in $0.2 \mathrm{M}$ phosphate buffer. The assay was conducted at $30^{\circ} \mathrm{C}$ for 1.5 min. Activity was expressed as nanomoles per minute.

7-Ethoxyresorufin $O$-duethylase. The activity of 7-ethoxyresorufin- $O$-deethylase (EROD) was determined fluorometrically at $30^{\circ} \mathrm{C}$ by measuring the production of resorufin from 7-ethoxyresorufin (Molecular Probes, Oregon), using a Perkin-Elmer LS5B spectrofluorometer. The final reaction buffer contained $60 \mathrm{mM}$ Hepes $\mathrm{pH} 7.7,5 \mathrm{mM}$ magnesium acetate, $100 \mu M$ NADPH, and $1 \mu M$ 7-ethoxyresorufin (Egan et al. 1983). The mixture was preincubated at $30^{\circ} \mathrm{C}$ for $3 \mathrm{~min}$ before microsomes were added. The excitation wavelength was $574 \mathrm{~nm}$, and the emission wavelength was $583 \mathrm{~nm}$. Activity was expressed as picomoles of resorufin per minute per nanomole of P-450.

Microsomal protein was determined using a modification of the Bradford assay (Bradford 1976) that has been adapted to the Cobas-Fara system. This method is linear from 0.2 to $0.7 \mathrm{mg} / \mathrm{mJ}$ at $30^{\circ} \mathrm{C}$. It was modified to include $3 \mu \mathrm{L}$ of a $20 \times$ ailution of the microsomal protein suspension, $150 \mu \mathrm{L}$ of 4-volume dilution of the Bio-Rad reagent dye, and $27 \mu \mathrm{L}$ of diluent (distilled water). Six different protein concentration standards of bovine serum albumin were used in the test to establish the best linear regression (least squares fit), which was used to determine the unknown microsomal protein concentrations. Nine absorbance measurements at $595 \mathrm{~nm}$ were made during the first $90 \mathrm{~s}$ of the reaction, and the mean value wes used to calculate protein concentration.

\subsubsection{Histopathological Analysis}

The foliowing histopathological analyses were performed on three tissues from each fish: (1) liver (average hepatocyte number and volume; functional liver volume, including parasitic lesions and necrosis); (2) spleen (volume of germinal centers for white blood cells); and (3) kidney (relative intertubular cell volume and relative intertubular noncellular space). The analyses were performed according to the methods of Hinton and Couch (1984).

\subsection{RNADNA Analysis}

A 50- to 100-mg section of liver was homogenized in approximately $1 \mathrm{~mL}$ of distilled water for $1 \mathrm{~min}$ using a Teflon homogenizer while keeping the sample cold. After the homogenate was brought up to a final volume of $1.5 \mathrm{~mL}$ with distilled water, it was transferred to 1.5-mL microce'trifuge tubes and centrifuged for $2 \mathrm{~min}$ in a Beckman microfuge. The RNA content of each sample was analyzed in triplicate by adding to each of three $1.5-\mathrm{mL}$ centrifuge tubes $200 \mu \mathrm{L}$ of supernatant from the liver homogenate, $1.2 \mathrm{~mL}$ of $95 \%$ ethanol, $0.035 \mathrm{~mL}$ of $2 \mathrm{M}$ sodium acetate, and $0.015 \mathrm{~mL}$ of $1 M$ magnesium acetate. Samples were cooled for $20 \mathrm{~min}$ in a refrigerator before centrifuging in a Beckman microfuge for $2 \mathrm{~min}$. After the supernatant was decanted, $1 \mathrm{~mL}$ of $0.3 \mathrm{M}$ $\mathrm{KOH}$ was added to the tubes with the pellet and incubated at $37^{\circ} \mathrm{C}$ in a constant water 
bath until the pellet dissolved. Each tube then received $0.5 \mathrm{~mL}$ of $1.4 \mathrm{~N}$ perchloric acid before it was cooled for an additional $20 \mathrm{~min}$ in the refrigerator. The mixture was centrifuged for $2 \mathrm{~min}$, and the supernatant was recovered in $20-\mathrm{mL}$ scintillation vials. The precipitate was washed once with $1 \mathrm{~mL}$ of $0.2 \mathrm{~N}$ perchloric acid and centrifuged again, and the supernatant was combined with the previous supernatant. Standards were prepared using $1100 \mu \mathrm{g}$ of RNA and processed in exactly the same manner as the liver samples. Absorbance of the samples and standards was measured at $260 \mathrm{~nm}$ using a Gilford Response Spectrophotometer and a distilled water blank as a reference. Results were expressed as micrograms of RNA per milligram wet weight of liver tissue. For DNA analysis, duplicate samples were prepared by adding $3 \mathrm{~mL}$ of $0.2 \mathrm{M}$ phosphate buffer at pH 7.0 to $100 \mu \mathrm{L}$ of the original liver homogenate supernatant. Standards were prepared with $4.6 \mu \mathrm{g}$ of salmon sperm DNA. The fluorescence was measured using an excitation waveleng:h of $360 \mathrm{~nm}$ and an emission wavelength of $450 \mathrm{~nm}$ with a Beckman LS-5 spectrofluorometer. Results were expressed as micrograms of DNA per milligram of wet weight liver tissue.

\subsection{Statistical Procedures}

ANOVA procedures were used to test for differences in individual bioindicators among sites, between sexes, and between species (e.g., redbreast vs bluegill sunfish). Interaction effects between site, sex, and species were also included in the ANOVA model. If the ANOVA procedure rejected a multisample (site, sex, or species) null hypothesis of equal means, then the Tukey multiple range test was used to identify significant differences among pairs of variables (e.g., sites). The Tukey test was used because it is fairly robust with respect to departures of the data from normality and homogeneity and also because it is the most widely accepted and commonly used multiple comparison test (Zar 1984).

To determine the integrated response of fish to the environmental conditions at each sampling site, all the bioindicator variables were considered jointly within a multivariate context by using canonical discriminant analysis (Seal 1968). This method provides a graphical representation of the positions and orientations of the various integrated site responses relative to each other. In addition, the discriminant analysis variable selection technique of McCabe (1975) was used to identify and prioritize the variables that contributed most to discriminating between integrated site responses. This variable selection procedure considered all possible combinations of the observed values and, for any specified subset size, selected those var iables having the best discriminating power. The Melton Branch site was not included in the discriminant analysis because the minimum sample size requirement could not be met.

\subsection{RESULTS AND DISCUSSION}

\subsubsection{Individual Bioindicator Responses}

The individual indicator responses measured in this study can be grouped into five functional categories: (1) carbohydrate-prctein metabolism, (2) lipid metabolism, (3) liver detoxification enzymes, (4) histopathology, and (5) condition indices. Each of these 
categories is discussed below for both species. Except for the detoxification enzymes, there were no significant differences between sexes. Consequently, the indicators of carbohydrate-protein metabolism, lipid metabolism, histopathology, and condition represent the combined response of males and females for each species.

\subsubsection{Indicators of Carbohydrate-Protein Metabolism}

Total serum protein, SGOT, and bilirubin are indicators of protein metabolism, while glucose is an indicator of carbohydrate function. Both SGOT and bilirubin are involved in protein catabolism and, therefore, are indicative of tissue damage in organs such as the liver.

Bluegill. There were no significant differences between the reference site (Brushy Fork) and any of the three contaminated sites for bilirubin, SGOT, or total serum protein (Table 5-1). Even though they were not significantly different, the SGOT values appear to be higher for Melton Branch than for Brushy Fork and lower for WOL than for Brushy Fork (Fig. 5-1).

Serum glucose, an indicator of carbohydrate metabolism, was significantly higher in WOC than in Brushy Fork (Table 5-1); this response also appeared greater in fish from the other two sites (Fig. 5-1), but the differences were not statistically significant. Elevated serum glucose (hyperglycemia) is a generalized stress response in fish to a broad spectrum of environmental perturbations (Silbergeld 1974) and thus may reflect both direct (metabolic) and indirect (food chain) effects of contaminants.

Redbreast. Total serum protein and SGOT were significantly lower in WOL than in Brushy Fork (Table 5-1), whereas serum protein was lower in Melton Branch than in Brushy Fork. As in bluegill, serum glucose values in redbreast were slightly higher in Melton Branch and WOC than in Brushy Fork, and SGOT levels were higher in Brushy Fork than in WOL.

\subsubsection{Indicators of Lipid Metabolism}

Bluegill. Serum triglycerides and cholesterol can serve as indicators of both lipid metabolism and nutritional status in fish. The only serum lipid indicator that was significantly different among sites was cholesterol, which was lower in Brushy Fork than in WOL (Table 5-1). Both serum triglycerides and total body triglycerides appeared lower in Brushy Fork than in WOC (Fig. 5-2), but due to the high within-site variability, the means were not significantly different. Body lipids (diglycerides and triglycerides), which are indicators of overall physiological condition and, therefore, the vulnerability of an organism to stress, were significantly higher and lower, respectively, in Brushy Fork than in WOC (Table 5-1). Both the PC:PE ratio, which is an indicator of cell membrane integrity, and the levels of phospholipids were similar at Brushy Fork and each of the WOC sites (Fig. 5-2). Except for phospholipids, there was a lower response of all lipid indicators in fish from Brushy Fork than in those from sites in the WOC system. This pattern may indicate that bluegill in Brushy Fork are in poor nutritional condition, possibly because they must compete for food with the more abundant and possibly dominant redbreast sunfish. 


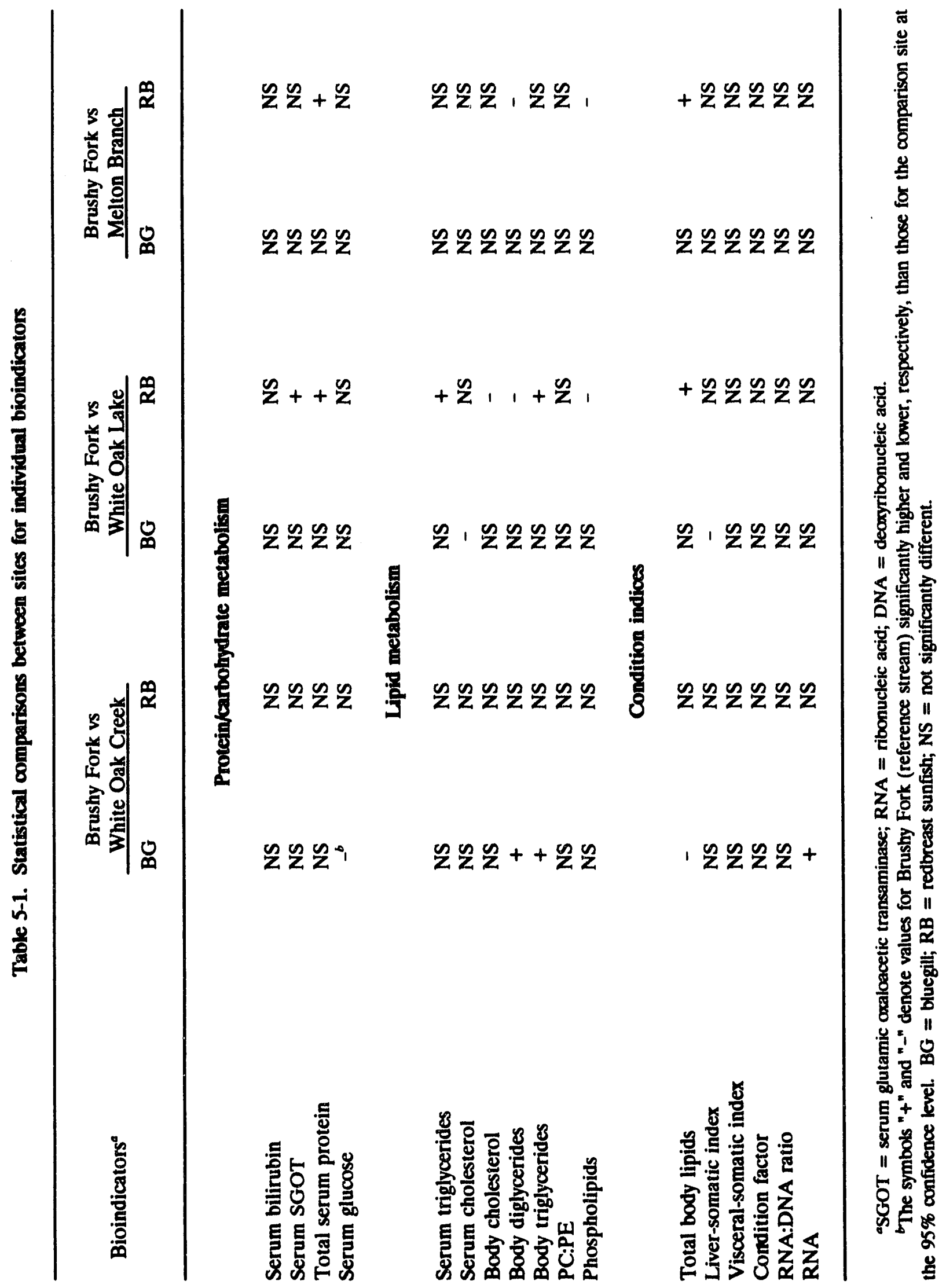




\section{BLUEGILL}

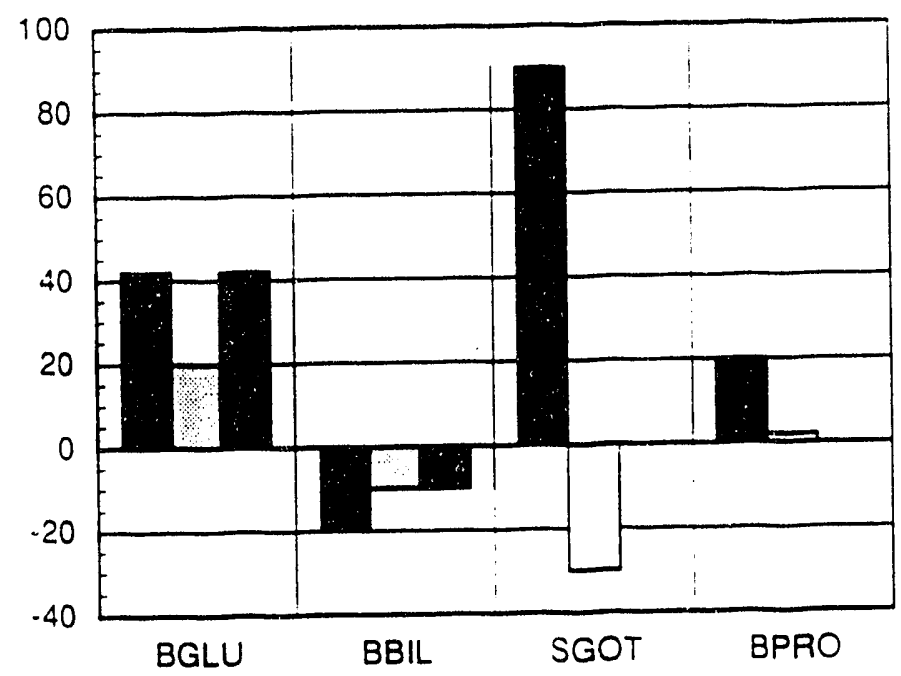

MELTON CREEK

$\square$ WHITE OAK LAKE

WHITE OAK CREEK

\section{REDBREAST}

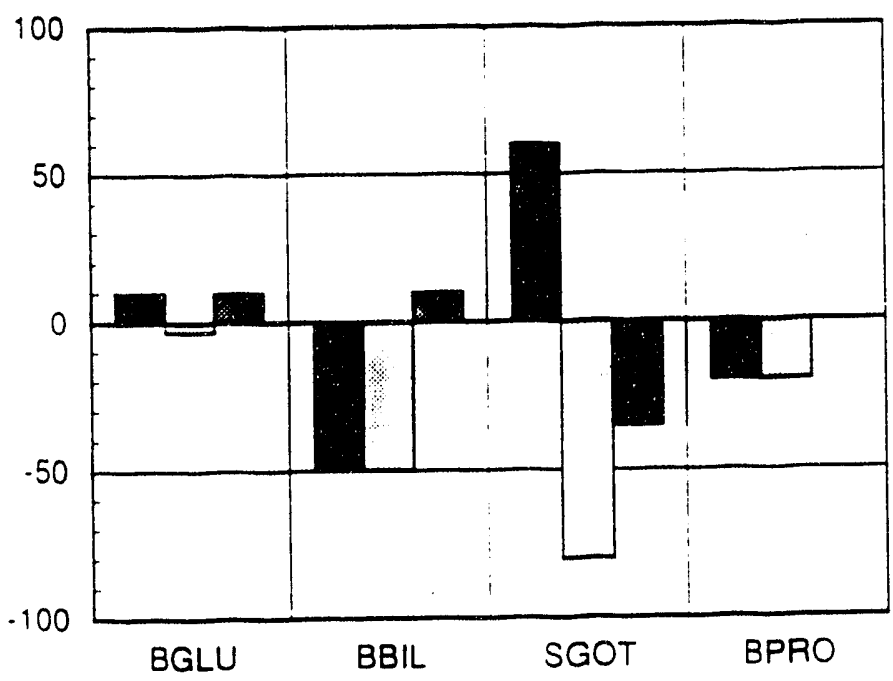
MELTON CREEK
WHITE OAK LAKE
WHITE OAK CREEK

Fig 5-1. Response of the carbohydrate-protein indicators in bluegill and redbreast sunfish at three sites in the White Oak Creek system, expressed as a percentage of the reference site (Brushy Fork) value. Bars with white tops indicate that the response of a particular parameter was greater in fish from the affected site than in those from the reference site, and bars with black tops indicate a greater response in fish from the reference site than in those from the affected site. BGLU = serum glucose; $\mathrm{BBIL}=$ serum bilirubin; SGOT = glutamate oxaloacetate transaminase; $B P R O=$ total sequm protein. 


\section{BLUEGILL}

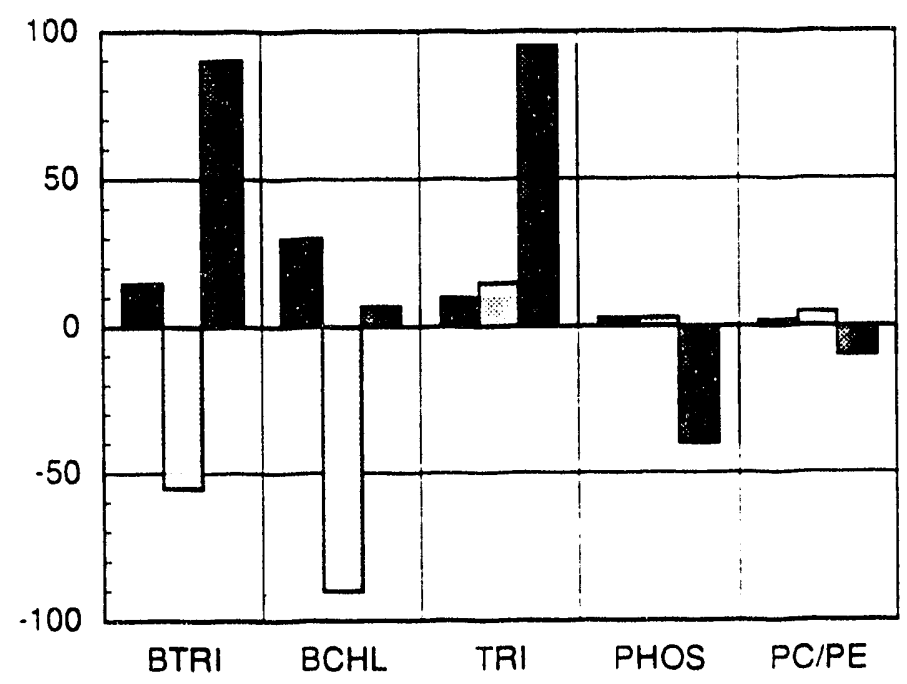

MELTON CREEK

WHITE OAK LAKE

WHITE OAK CREEK

\section{REDBREAST}

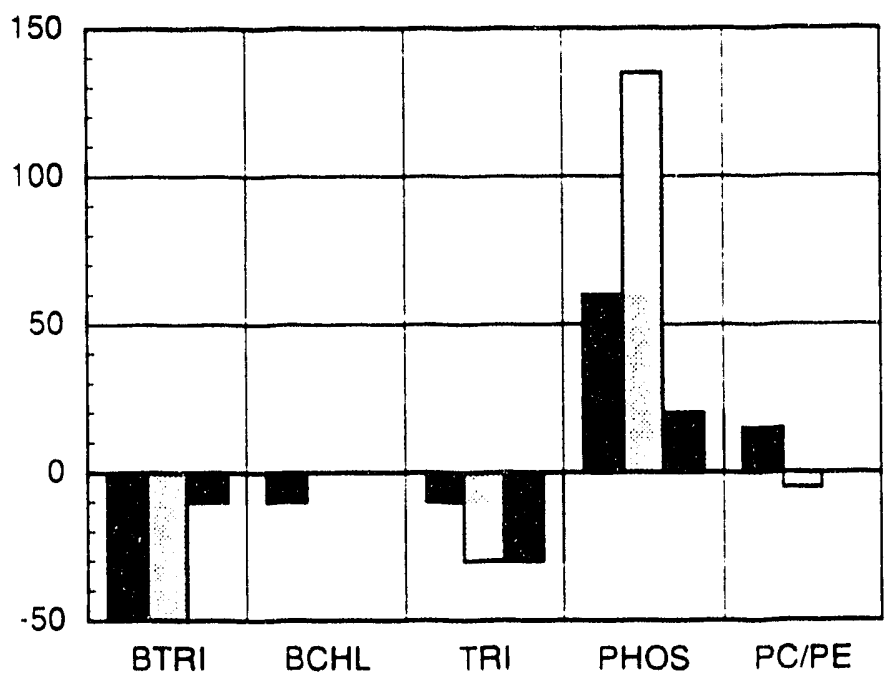

MELTON CREEK
WHITE OAK LAKE
WHITE OAK CREEK

Fig 5-2 Response of lipid metabolism indicators in bluegill and redbreast sunfish at three sites in the White Oak Creek system, expressed as a percentage of the reference site (Brushy Fork) value. Bars with white tops indicate that the response of a particular parameter was greater in fish from the affected site than in those from the reference site, and bars with black tops indicate a greater response in fish from the reference site than in those from the affected site.

BTRI = serum triglycerides; $\mathrm{BCHL}=$ serum cholesterol; TRI = body triglycerides; $\mathrm{PHOS}=$ total body phospholipids; $\mathrm{PC}: \mathrm{PE}=$ ratio of the two major types of phospholipids. 
Redbreast. The pattern of lipid metabolism in redbreast sunfish was dramatically different from that in bluegill at all sites. Even though phospholipids, which reflect the availability of nonenergy fats in the organism, were significantly lower in Brushy Fork than in both WOC and Melton Branch (Table 5-1), serum triglycerides were higher in the reference stream (Fig. 5-2). Such a pattern suggests that redbreast sunfish in Brushy Fork were in better nutritional condition and possibly experiencing less metabolic stress than redbreast sunfish in the WOC system. Like bluegill, this species had similar PC to PE ratios at all sites, indicating that the nature of contaminant stress in the WOC system was not of the type that interferes with the integrity of the cell membrane.

\subsubsection{Histopathological Indicators}

Indicators of liver pathology analyzed in this study included (1) the volume density of parasites, necrotic parenchyma, and macrophage aggregates and (2) the percentage of functional parenchyma in the liver. Indicators of spleen pathology included the volume density of parasites and macrophage aggregates, and the percentage of functional parenchyma in the spleen.

Bluegill Except for the density of liver parasites in WOL bluegill, all other indicators of liver pathology showed that bluegill in Brushy Fork had higher incidences of pathological conditions than bluegill from the WOC system (Fig. 5-3). The high value of the functional liver parenchyma, however, is indicative overall of healthier livers in fish from Brushy Fork than in fish from other sites.

Histopathological analyses of the spleen indicated higher levels of both macrophage aggregates and parasites in fish from Brushy Fork than in those from Melton Branch (Fig. 5-3). In contrast, both WOL and WOC fish had higher levels of these two parameters than fish from Brushy Fork. As observed from analysis of the functional parenchyma in the liver, fish from Brushy Fork exhibited somewhat lower levels of spleen pathologies than did the fish from the other three sites (Fig. 5-3).

Redbreast. The comparative histopathological response in redbreast and bluegill sunfish was very similar to the response pattern for lipid metabolism observed in the two species. Whereas the pathological condition of the liver and spleen was generally worse in bluegill from Brushy Fork, the condition of redbreast was much better. With the exception of Melton Branch fish, all the other fish from Brushy Fork had lower indicators of liver pathology than the fish from the WOC system (Fig. 5-3). The functional liver parenchyma was slightly higher in Brushy Fork fish, indicating healthier livers. The level of parasites in the spleen was higher in fish from the WOC system, but the volume density of macrophage aggregates was lower in WOL and WOC fish than in the Brushy Fork fish. The volume density of functional spleen tissue, which is the most important indicator of the pathological condition of the spleen, was very similar between fish from Brushy Fork and those from the WOC system.

Like the lipid metabolism indicators, the histopathological indicators also showed that bluegill in Brushy Fork were in poorer physiological condition than redbreast. This difference in condition between the two species may indicate (1) that, on a nutritional basis, bluegill are outcompeted for food and/or habitat by the more abundant redbreast in 


\section{BLUEGILL}

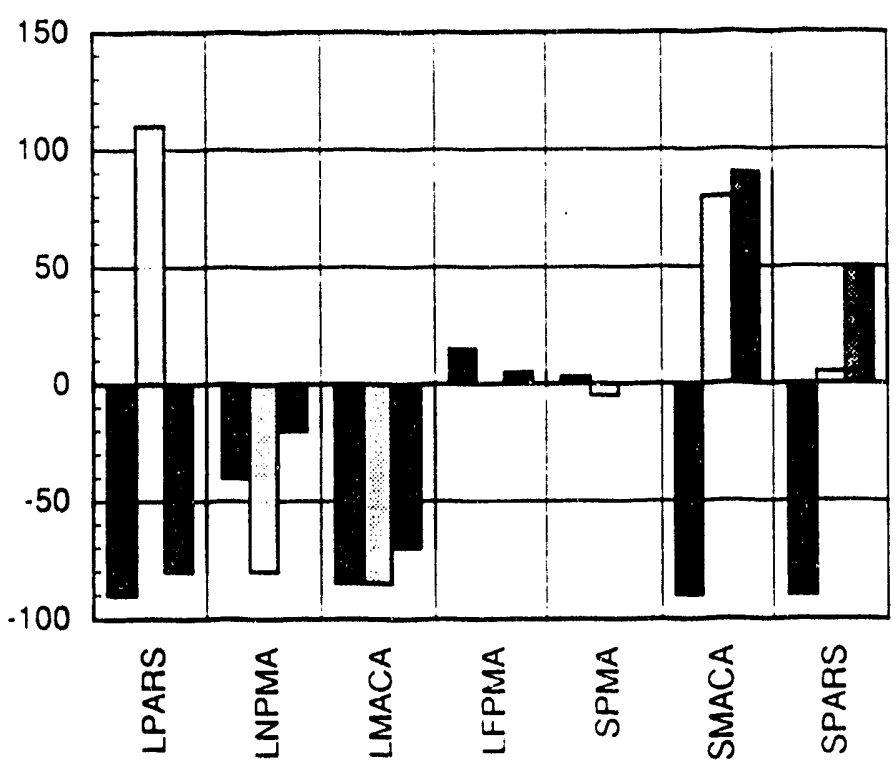

MELTON BRANCH

WHITE OAK LAKE

WHITE OAK CREEK

\section{REDBREAST}

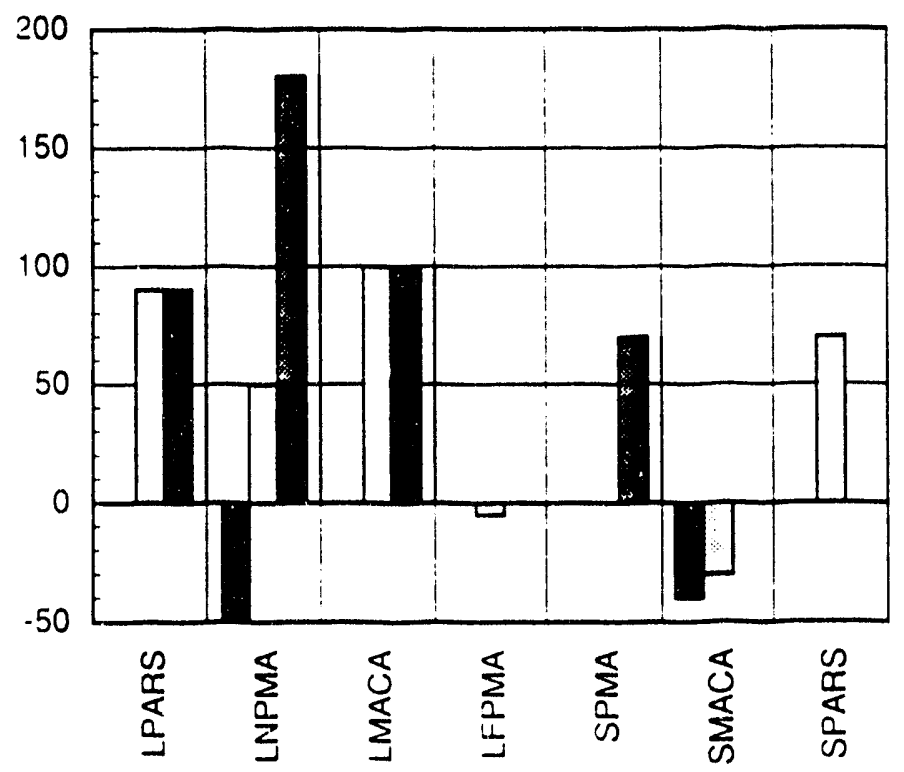

Fig. 5-3. Response of the histopathological indicators in bluegill and redbreast sunfish at three sites in the White Oak Creek system, expressed as a percentage of the reference site (Brushy Fort) value. Bars with white tops indicate that the response of a particular parameter was greater in fish from the affected sites than in those from the reference site, and bars with black tops indicate a greater response in fish from the reference site than in those from the affected site. LPARS = percent parasites in the liver; LNPMA = volume density of necrotic parenchyma in the liver; LMACA = percent macrophage aggregates in the liver; LFPMA = percent functional parenchyma in the liver; SPARS = percent parasites in the spleen; SMACA = percent macrophage aggregates in the spleen; SPMA = percent functional parenchyma in the spleen. 
Brushy Fork (although bluegill are much more abundant than redbreast at all WOC sites) and/or (2) redbreast in the contaminated WOC system are more sensitive and vulnerable to chronic stress than are bluegill, thus explaining, in part, the different bioindicator responses between the two species in both Brushy Fork and the WOC system.

\subsubsection{Condition Indicators}

Bluegill. Total body lipids and the liver-somatic index for bluegill were significantly lower for fish in Brushy Fork than those in WOC and WOL respectively (Table 5-1). The RNA levels in the liver were higher, however, in the fish from Brushy Fork than in those from WOC. Most condition indices, especially total body lipids, appeared higher in WOL and WOC fish, except for bluegill in Melton Branch, than in Brushy Fork fish (Fig. 5-4). Excluding total lipids, all condition indices in WOC fish were similar to those in Brushy Fork fish (Fig. 5-4).

Redbreast. The pattern of differences in lipid metabolism and histopathological responses between bluegill and redbreast sunfish was also reflected by the condition parameters. For example, total body lipids were higher for redbreast in Brushy Fork than in WOL and Melton Branch but were lower for bluegill (Table 5-1) in Brushy Fork than in WOC. In general, however, all condition parameters except total body lipids appeared slightly higher in fish from WOC than in those from Brushy Fork (Fig. 5-4).

\subsubsection{Detoxification Enzymes}

Because of significant differences in the levels of liver detoxification enzymes between sexes, males and females could not be combined for statistical comparisons. There were no significant differences, however, in the activity of P-450, EROD, and NADPH enzymes between the respective sexes of each species; thus, males of the two species were combined, as were females, for the statistical analyses of these particular enzymes. Because concentrations of the electron transport enzyme, cytochrome $b_{5}$, were significantly different between both species and sex, this parameter was analyzed separately from the other enzymes.

For both males and females, there were no significant differences in the levels of EROD, P-450, and NADPH between sunfish from Brushy Fork and both WOC and Melton Branch (Table 5-2). Activity of EROD (in males) appeared higher in WOC than in Brushy Fork (Fig. 5-5), but due to high within-site variability, no significant differences were detected.

In female sunfish from WOL, however, EROD activities exceeded the levels found in Brushy Fork fish, but P-450 and NADPH were significantly lower than levels found at the reference site (Table 5-2, Fig. 5-5). Male sunfish in WOL exhibited a pattern similar to that of females, but only NADPH was significantly different (lower) from levels in fish in Brushy Fork (Table 5-2, Fig. 5-5). Even though cytochrome $b_{5}$ levels were significantly different between redbreast and bluegill, and between sexes for both species, there were no significant differences between sites, primarily because of high within-site variability. 


\section{BLUEGILL}

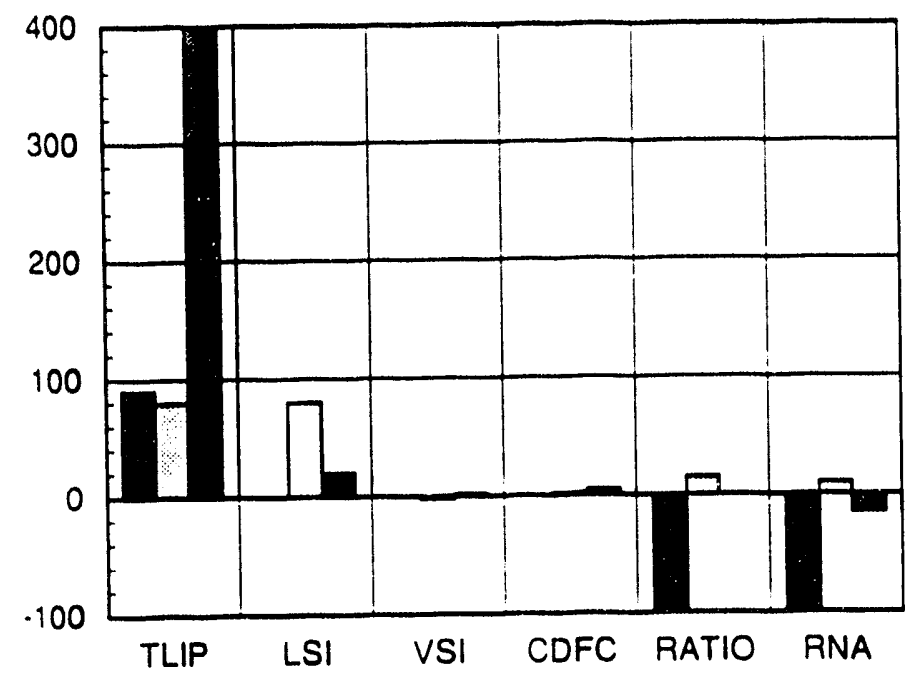

MELTON CREEK

WHITE OAK LAKE

WHITE OAK CREEK

\section{REDBREAST}

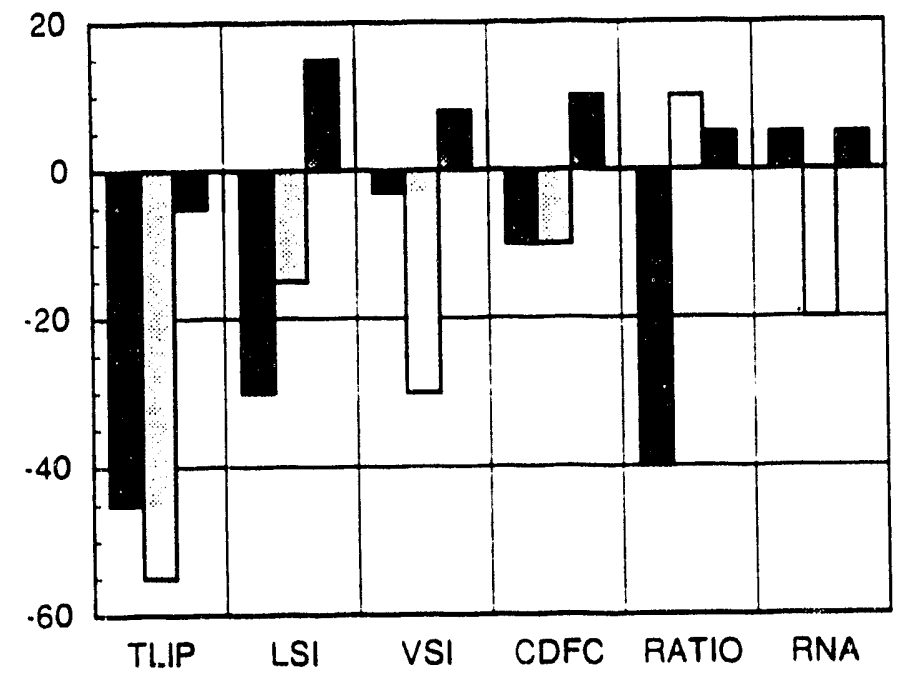

MELTON CREEK

WHITE OAK LAKE

WHITE OAK CREEK

Fif 5-4. Response of the condition indes indicators in bluegill and redbreast sunfish at three sites in the White Oak Creek system, expessed as a percentage of the reference site (Brushy Fork) value. Bars with white tops indicate that the response of a particular parameter was greater in fish from the affected sites than in those from the reference site, and bars with black tops indicate a greater response in fish from the reference site than in those from the affected site. TLIP = total body lipids; $L S I=$ liver-somatic index; VSI = visceral-somatic index; $C D F C=$ condition factor; ratio = RNA:DNA ratio; RNA = level of RNA in liver. 
Table 5-2. Statistical comparisons between sites for three liver detoxification enzymes in bluegill and redbreast sunfishe

\begin{tabular}{|c|c|c|c|c|c|c|}
\hline \multirow[t]{2}{*}{ Enzyme $^{b}$} & \multicolumn{2}{|c|}{$\begin{array}{l}\text { Brushy Fork vs } \\
\text { White Oak Creek }\end{array}$} & \multicolumn{2}{|c|}{$\begin{array}{l}\text { Brushy Fork vs } \\
\text { White Oak Lake }\end{array}$} & \multicolumn{2}{|c|}{$\begin{array}{l}\text { Brushy Fork vs } \\
\text { Melton Branch }\end{array}$} \\
\hline & $\mathrm{M}$ & $\mathrm{F}$ & $M$ & $\frac{F}{F}$ & $\mathbf{M}$ & $F$ \\
\hline EROD & NS & NS & NS & - & NS & NS \\
\hline P.450 & NS & NS & NS & + & NS & NS \\
\hline NADPH & NS & NS & + & + & NS & NS \\
\hline
\end{tabular}

"The symbols "+" and "-" denote values for Brushy Fork (reference stream) significantly higher and lower, respectively, than those for the comparison site at the $95 \%$ confidence level. $M=$ males; $F=$ females; NS = not significantly different.

${ }^{b} \mathrm{EROD}=7$-ethoxyresorufin $O$-deethylase; $\mathrm{NADPH}=$ nicotinamide adenine dinucleotide.

\subsubsection{Integrated Bioindicator Responses}

A canonical discriminant analysis procedure was used to examine the integrated physiological response of fish to environmental stress in the WOC system. This procedure evaluated blood biochemical parameters (protein, carbohydrate, and lipid metabolic responses), liver detoxification enzymes, nucleic acids (RNA and RNA:DNA ratio) and condition indices within a multivariate context. With canonical discriminant analysis, the mean values of the first two canonical variables (the two variables that account for most of the ability to separate integrated fish responses at each site) were plotted for fish from each site, along with the statistical confidence region (90\%). Sites were considered to be significantly different if the $90 \%$ confidence radii of the site means did not overlap. This integrated response analysis consisted of three components: (1) evaluation of differences between sites, and between species within sites, based on the total set of response variables; (2) variable selection/screening to determine the best subset of variables for evaluating the response of fish to environmental stress; and (3) evaluation of the selected response variables.

\subsubsection{Integrated Site Evaluation}

Multivariate analysis involving two different sets of variables was used to evaluate the integrated responses between all sites. The 17-variable set incorporated the carbohydrate-protein, lipid, liver enzyme, and condition index parameters. The second group set consisted of a 16-variable subset and incorporated all of the above parameters except that the growth indicators, RNA and RNA:DNA, were substituted for the lipid parameters. 


\section{MALES}

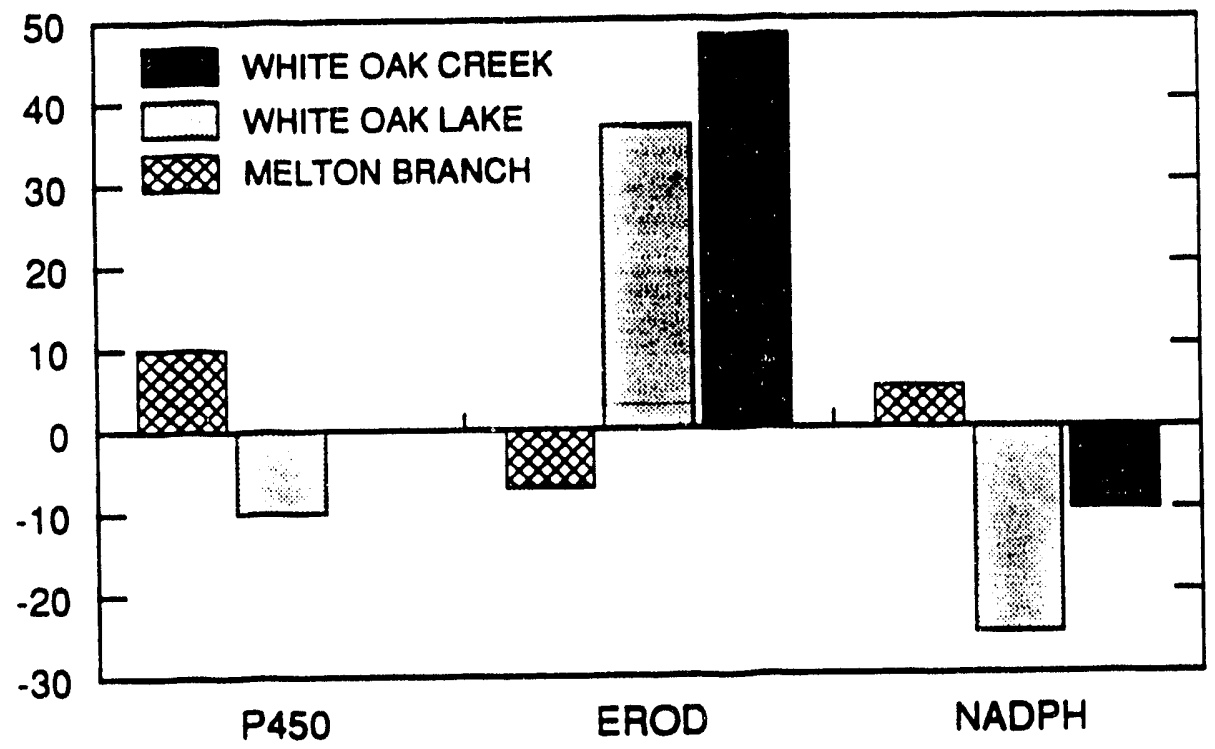

FEMALES

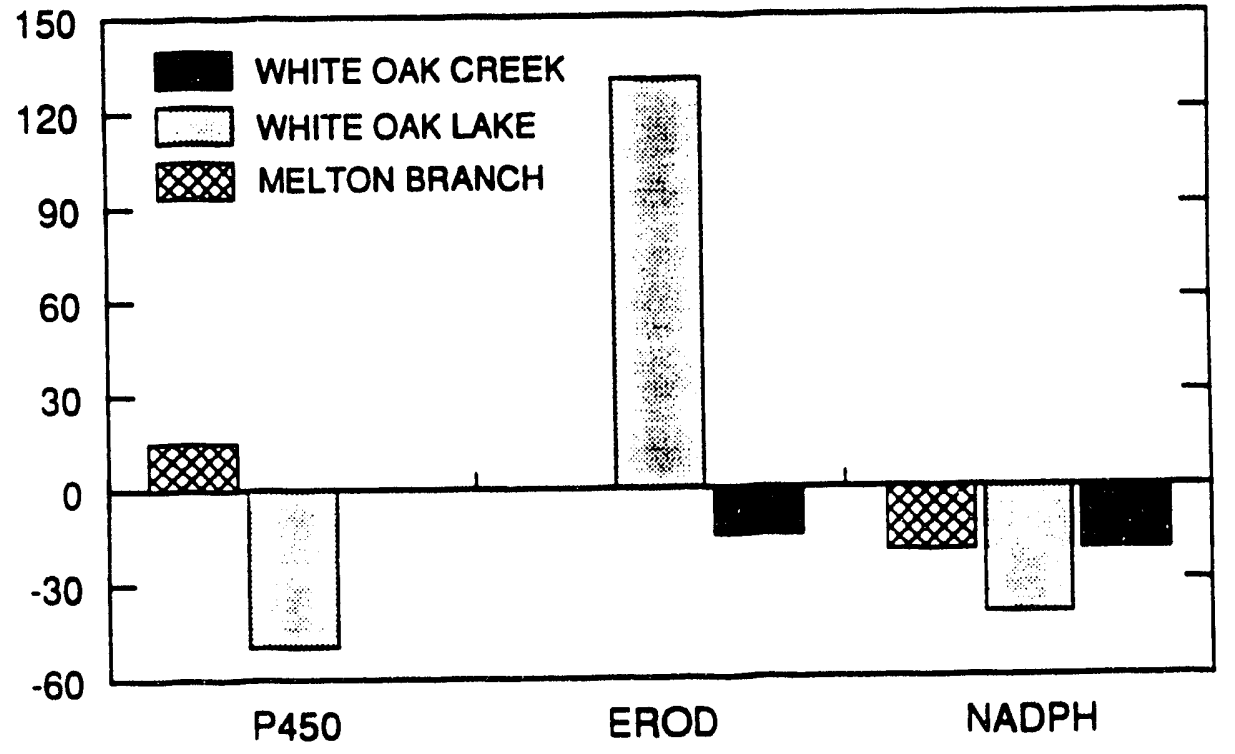

Fig 5-5. Response of the detorification enzymes (P-450, EROD, NADPH) in male and female sunfish from three sites in the White Oak Creek system expressed as a percentage of the reference site (Brushy Fork) value. Bars with white tops indicate that the response of a particular parameter was greater in fish from the affected sites than in those from the reference site, and bars with black tops indicate a greater response in fish from the reference site than in those from the affected site. EROD = 7-ethoxyresorufin $O$-deethylase; $N A D P H=$ nicotinamide adenine dinucleotide. 
Using both sets of variables, all sites were segregated and distinct in their integrated response (Fig. 5-6), demonstrating that Brushy Fork was significantly different from all

sites in the WOC system. With the 17-variable set that included the lipid parameters, sites were separated by larger linear distances than they were in the case where the RNA and the RNA:DNA variables were substituted for the lipid data. In the 17-variable set, the largest separation between sites occurred between Brushy Fork and WOC. With the 16-variable set, however, sites were closer together, indicating that the lipid parameters were relatively more important than the RNA and RNA:DNA parameters in discriminating between sites.

\subsubsection{Integrated Species Evaluation}

To determine the integrated responses of bluegill in relation to redbreast sunfish, the multivariate discriminant analysis procedure was performed by incorporating the same set of 17 variables that was used in the integrated site evaluation. The results showed that sites were significantly different for each species comparison and that redbreast and bluegill sunfish were significantly different from one another at each site (Fig. 5-7). For bluegill, all sites were widely separated from each other. Even though redbreast sunfish from Brushy Fork and WOC were significantly different, they were more similar to each other than were redbreast sunfish from Brushy Fork and WOL. Bluegill clustered as a group on the left side of the discriminant plot (Fig. 5-7), whereas redbreast clustered on the right side of the plot. Such a pattern indicated that there were fewer differences in the integrated response of a particular species between sites than in the integrated responses between species: that is, species effects appeared to be greater than site effects.

\subsubsection{Variable Selection/Screening}

Statistical procedures were used to identify subsets or combinations of variables that could discriminate as well between the three sites as could the full set of 17 variables. The U-ratio (McCabe 1975) is a statistical measure of the ability of variable subsets to discriminate between sites. The higher the ratio, the less discriminatory power a particular variable subset has. A plot of the U-ratio for subsets ranging from 1 to 17 variables (Fig. 5-8) indicated that beyond 10-11 variables (approximate break point in line), very little additional discriminating ability can be gained by the addition of more variables.

Using the variable selection process of McCabe (1975), the variables that were the most useful for discriminating between integrated site responses in the spring were the following (listed in order of importance): (1) serum triglycerides, (2) liver-somatic index, (3) bilirubin, (4) P-450, (5) cytochrome $b_{5}$ electron transport enzyme, (6) SGOT, (7) RNA:DNA, and (8) microsomal protein.

The variables selected for the highest discriminating ability between sites for the fall 1986 (Loar et al. 1992) and spring 1987 sampling periods are listed in Table 5-3. Of the ten most important variables, eight were common to both seasons, including four indicators of carbohydrate-protein metabolism, two detoxification enzymes, and two indicators of overall condition. However, the relative importance of these eight indicators was different between seasons. For example, serum triglyceride was the most important indicator in the spring but did not add to the discriminating ability for the fall sites. The 


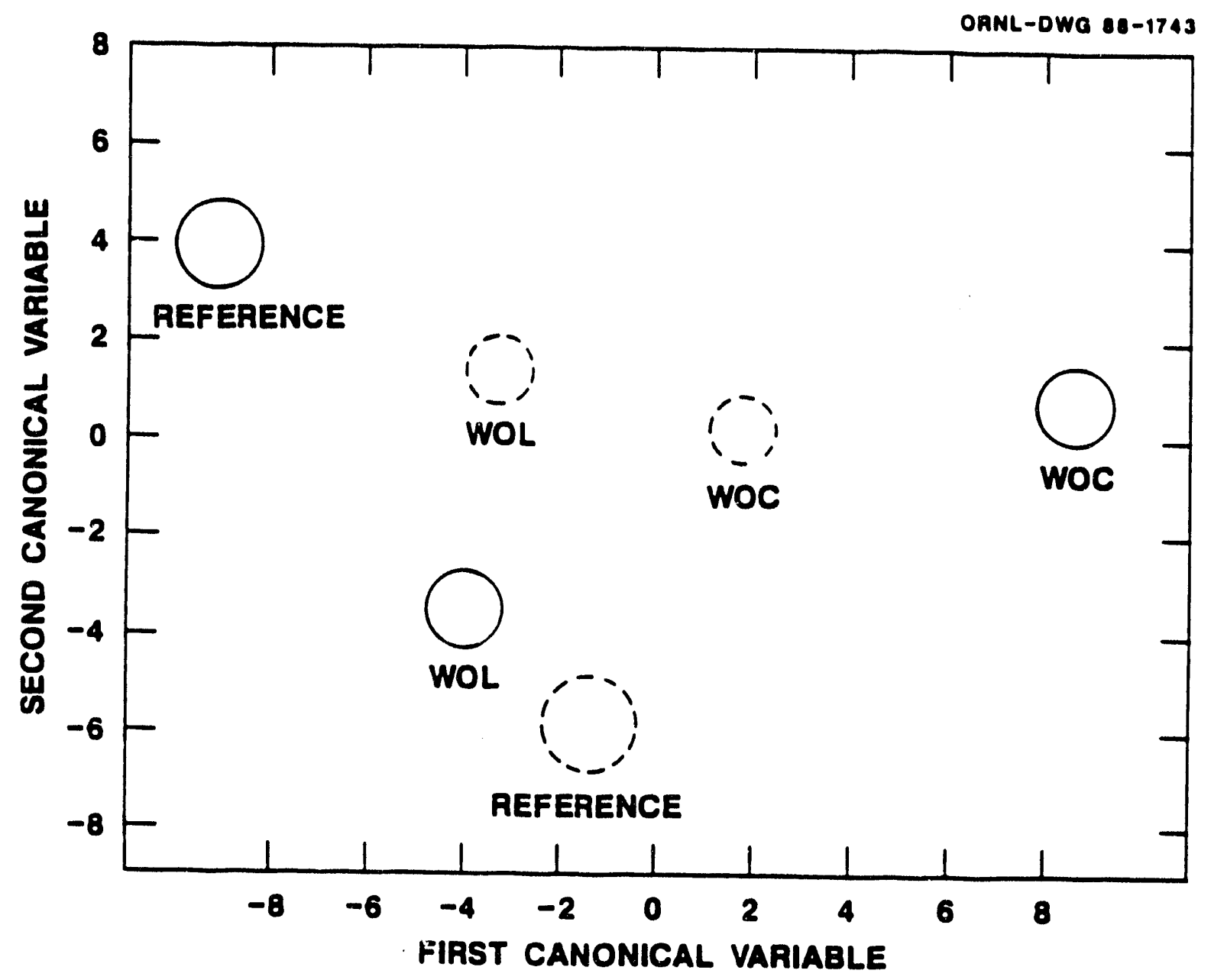

Fig. 5-6. Segregation of integrated bioindicator responses (carbobydrate-protein metabolism, lipid metabolism, detarification enzymer, and condition indices) for bluegill sunfish from White Oat Creet (WOC), White Oat Late (WOL), and Brwhy Fort (reference stream) in spring 1987. Circle represents the site mean of the integrated responses and the $90 \%$ confidence radii of the site mean. Solid circles represent a set of 17 variables that includes the lipid parameters; the broken circles represent a set of 16 variables that excludes the lipid parameters. 


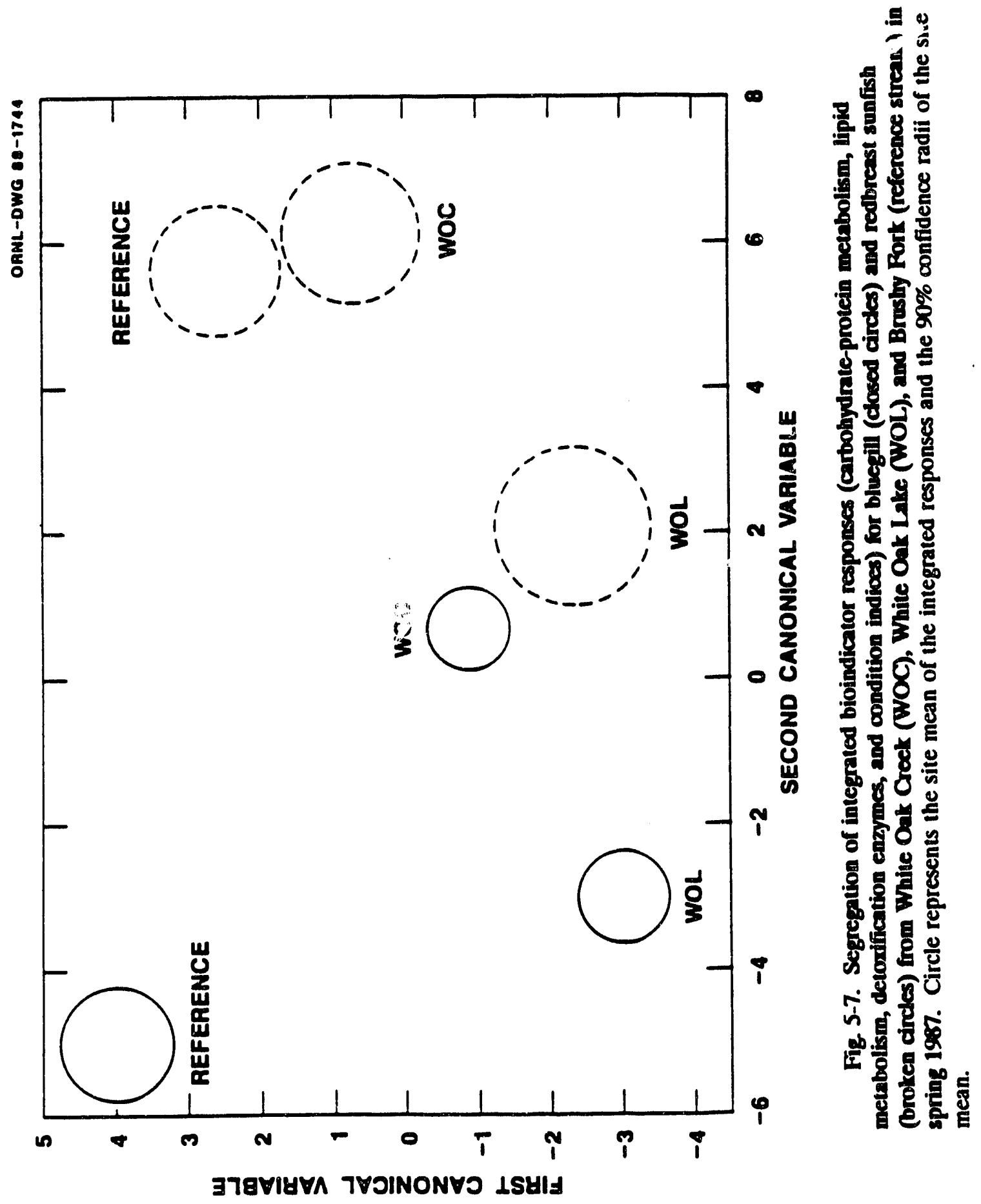




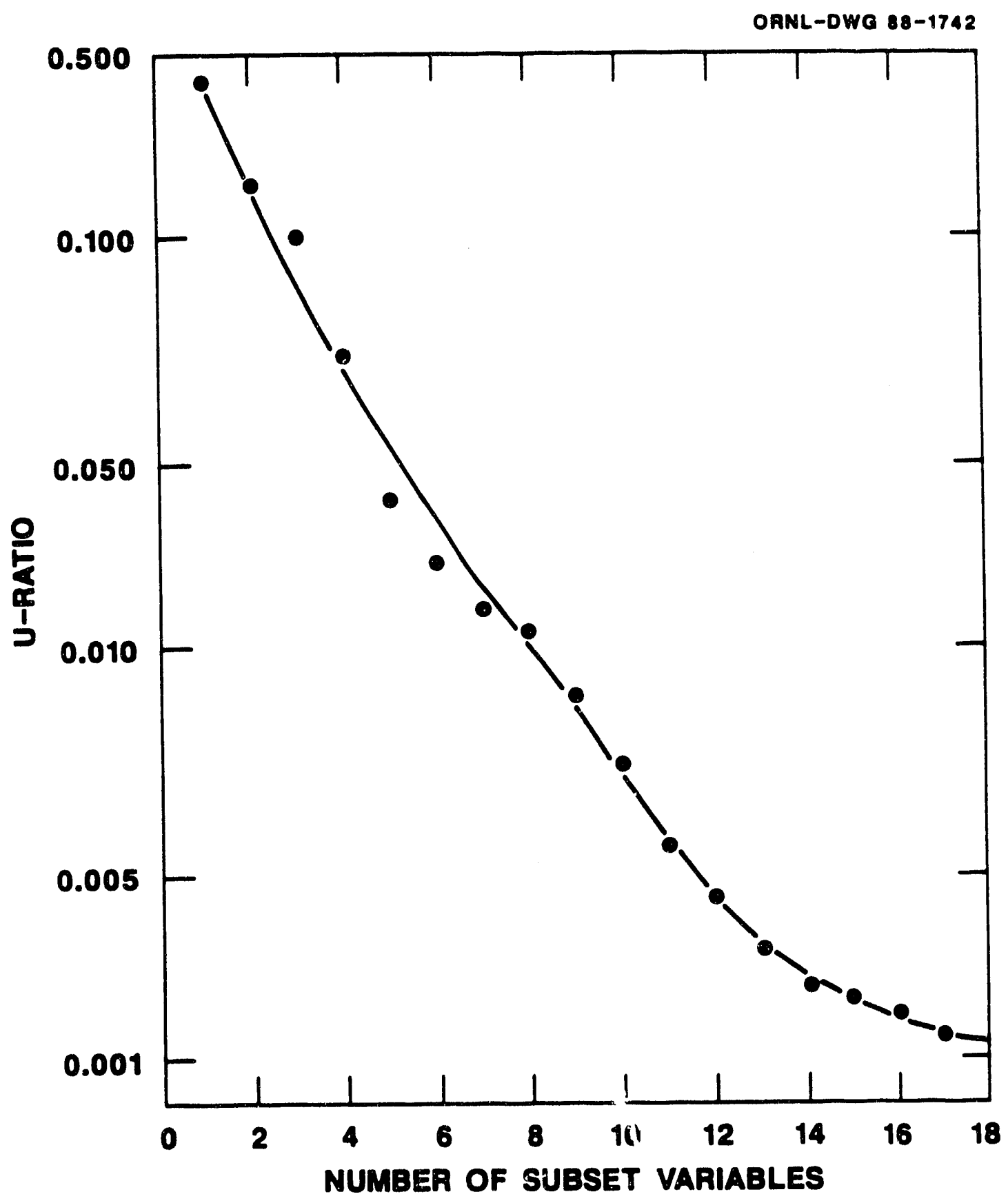

Fig 5-8. Response of the U-ratio, a statistical measure of the ability to discriminate between site responses, to the number of variables in a subset. 
Table 5-3. Relative importance ranking of the various bioindicators used to discriminate betwreen the integrated responses of redbreast sunfish at three sites in the White Oak Creek system and Brushy Fork, a reference site

The lower the rank, the higher the ability of the indicator to discriminate between sites

Relative rank

Fall 1986

Spring 1987

\section{Carbohydrate-Protein Metabolism}

Glucose

SGOT

Serum protein

Bilirubin

$\begin{array}{rr}7 & 10 \\ 2 & 6 \\ 4 & 9 \\ 8 & 3\end{array}$

Lipid Metabolism

Serum triglycerides

\section{Detorification Enzymes}

P-450

544

Cytochrome $b_{5}$

$\begin{array}{ll}6 & 5 \\ 6 & 8\end{array}$

Microsomal protein

8

\section{Condition Indices}

Liver-somatic index

RNA-DNA ratio

Condition factor

Visceral-somatic index

$\begin{array}{cc}3 & 2 \\ 1 & 7 \\ 9 & a \\ 10 & a\end{array}$

'Received a ranking greater than 10.

Note: SGOT = serum glutamate oxaloacetate transaminase; RNA = ribonucleic acid; DNA = decryribonucleic acid.

liver-somatic index and the P-450 and cytochrome $b_{5}$ enzymes were similar in importance in both seasons.

The existence of seasonal differences in the ability of indicators to discriminate between integrated site responses illustrates the importance of using a suite of response parameters for evaluating the effects of chronic stress on organisms. In both seasons, indicators representative of several physiological functions were necessary to distinguish site responses. Site responses or differences between sites cannot usually be detected based on only one (or even a few) individual indicators (Adams et al. 1988). 


\subsubsection{Evaluation of the Selected Response Variables}

The single most important variable for distinguishing between site responses in spring 1987 was serum triglycerides, a parameter that is more reflective of the level of nutritional status in fish than it is the degree of metabolic stress. In general, chronically low serum triglyceride levels indicate negative energy balance and nutritional deficiency. For fish inhabiting stressed environments, three situations could result in chronically low serum triglyceride levels: (1) inadequate food availability (quality and/or quantity) to maintain fish in a positive energy balance; (2) abnormal foraging behavior or reduced feeding ability due to contaminant effects; and (3) stress-related depletion of body lipid stores, resulting in reduced energy availability for metabolic pathways to maintain serum triglycerides at normal levels.

As observed for the fall 1986 data set (Loar et al. 1992), the liver-somatic index was one of the most important bioindicators for evaluating contaminant effect responses between sites. The index reflects both short-term nutritional status and metabolic energy demands (Heidinger and Crawford 1977, Adams and McLean 1985). In addition, the liver-somatic index is a sensitive indicator of toxicant stress; liver enlargement (hyperplasia) has been reported in fish exposed to various types of pollutants (Chambers 1979, Poels et al. 1980).

Increases in serum bilirubin levels are useful in the early detection of liver dysfunction. This indicator ranked third in importance in the spring but only eighth in the fall. Physiological and/or morphological liver impairment due to various types of stressors can result in increases in serum bilirubin or hyperbilirubinemia (Mattsoff and Oikari 1987). Elevated levels of bilirubin in bluegill from the WOC system (Fig. 5-1) could be associated with higher amounts of necrotic liver parenchyma (Fig. 5-3).

Indicators that ranked fourth and fifth in importance to site differentiation were the liver detoxification enzymes, P-450 and cytochrome $b_{5}$ respectively. These enzymes play a major role in the biotransformation or metabolism of xenobiotics, such as pesticides, hydrocarbons, chlorinated hydrocarbons, and numerous biological molecules, including steroid hormones (Payne and Penrose 1975, Stegeman 1981). High levels of these enzymes are generally associated with increased liver-somatic index values because with enzyme induction there is proliferation of hepatic endoplasmic reticulum that results in liver enlargement or hypertrophy (Sloof et al. 1983, Fabacher and Baumann 1985).

As a general indicator of protein metabolism/catabolism, SGOT can reflect tissue damage and impaired organ function (Freeman and Idler 1973, Rhodes et al. 1985). This indicator contributed a significant amount of statistical discriminating ability between sites (ranked sixth), even though levels of SGOT, as an individual response parameter, were not significantly different between sites.

In the fall 1986 collection, RNA:DNA was the single most important indicator for site segregation. In the spring 1987 collection, however, it ranked seventh in importance. This ratio is an indicator of immediate or short-term fish growth in natural systems (Bulow 1970, Haines 1973), as well as an indicator of exposure to sublethal concentrations of toxicants (Barron and Adelman 1984). It is generally considered a more accurate index of 
growth than RNA concentration alone, since the ratio is not affected by cell number or size in the tissue sampled (Hotchkiss 1955).

The relative importance of this ratio was less in the spring because fish were sampled in late March, when stream temperatures were still relatively low (Figs. 2-5 and 2-6) and before adequate levels of food were available for fish to realize any sustained growth. In the fall, however, food levels are typically high, and fish are growing at their maximum rate (Adams and McLean 1985).

Microsomal protein ranked eighth in importance for site segregation, even though it did not contribute to the variable selection procedure in the fall. Detoxification enzymes (fourth- and fifth-ranked variables), the liver-somatic index (ranked second), and microsomal protein are all related. Elevated levels of liver enzymes are due to increased microsomal protein production (endoplasmic reticulum), which results in hypertrophy in liver tissue (increased liver-somatic index).

\subsection{SUMMARY AND CONCLUSIONS}

Major findings of the bioindicator studies conducted in 1987 are listed below:

1. The integrated responses of fish from the reference site (Brushy Fork) were significantly different from the integrated responses of fish from both WOC and WOL. Also, there were significantly different integrated responses between fish from WOC and WOL. The pattern of responses observed between sites within the WOC system and between Brushy Fork and the WOC sites in the spring 1987 was the same as that observed in the fall 1986 (Loar et al. 1992, Fig. 5-6).

2. Of the ten most important variables for discriminating between sites in the spring, eight were also important for site discrimination in the fall sampling period. The relative importance of these ten variables in evaluating site responses during the two seasons varied, although the liver-somatic index was among the top three variables in both seasons.

3. In evaluating the effects of chronic stress on fish populations, indicators should be utilized that are representative of several physiological functions, such as carbohydrateprotein metabolism, lipid metabolism, enzyme response, and condition indices.

4. Investigations related to the effects of environmental stress on fish are more effectively evaluated using integrated responses (multiple bioindicators) instead of individual parameter responses (also see Adams et al. 1985).

\subsection{FUTURE STUDIES}

The results of this and previous studies (Loar et al. 1992) have provided a focus for the direction of future investigations, which fall into four major areas: 
1. Manipulative caging experiments. These experiments will be initiated in late spring 1988 to evaluate the effects of chronic stress under semicontrolled conditions. Healthy, uncontaminated fish will be placed in a large cage located in WOC between WCK 2.0 and WCK 2.5 and in a cage in Brushy Fork, the reference stream. Fish will be also released outside the cages at both sites. The response of these fish to environmental conditions in WOC will be determined by applying the suite of indicators selected in this and previous (Loar et al. 1992) studies. Differences in responses between caged (starved) and uncaged (well-fed) fish should indicate the relative importance of direct (waterborne) vs indirect (food chain) effects of chronic stress on fish in the WOC system.

2. Evaluation of Brushy Fork as an appropriate reference site. In 1987, fish from four reference (or control) sites were sampled to determine if Brushy Fork was, in fact, an appropriate and representative reference site for the WOC studies. In 1988 all the data from this study will be analyzed, and the results will be summarized in the next annual report.

3. Studies of reproductive success and competence. Preliminary studies will be initiated in spring and summer 1988 to evaluate the effects of chronic stress on the reproductive competence or success of fish in the WOC system. The initial studies will primarily involve the design, development, and screening of various bioindicators of reproductive success, such as steroid hormones, vitellogenin production, and egg quality and quantity.

4. Sampling strategy. The monitoring frequency for future bioindicator studies will be reduced to a single intensive seasonal survey because (1) the pattern of integrated responses between sites was similar in the fall and spring, thus eliminating the need for additional information on the seasonal differences in integrated site responses; (2) there is some evidence that multiseasonal sampling may exert an unacceptable collection pressure on the bluegill and redbreast sunfish populations, especially the females; and (3) new bioindicator studies will be initiated, including the caging experiments and investigations of reproductive success, and these studies will complement the seasonal bioindicator sampling. The main advantage of one intensive sampling period is that collection pressure on the fish populations can be reduced, and the sample size can be substantially increased. Such a change will improve both statistical reliability and ultimately the evaluation of effects of chronic stress on the integrity of fish populations in the WOC system. 


\section{INSTREAM ECOLOGICAL MONITORING}

The objectives of the instream ecological monitoring task (Task 4 of BMAP) are (1) to characterize spatial and temporal patterns in the distribution and abundance of the benthos and fish populations in WOC watershed; (2) to identify contaminant sources that adversely affect stream biota, including differentiation between point sources and nonpoint (or area) sources, wherever possible; and (3) to monitor these populations and evaluate the future effects on community structure and function from operation of new wastewater treatment facilities, from improvements in waste management operations, and from implementation of remedial actions directed at area source control. This task consists of three components: (1) benthic invertebrate studies (Subtask 6a), (2) fish population studies (Subtask 6b), and (3) evaluation of biotic changes (Subtask 6c); results to date of these studies are presented in Sects. 6.1-6.3 respectively.

\subsection{BENTHIC MACROINVERTEBRATES}

\subsubsection{Introduction}

Benthic macroinvertebrates are those organisms that are large enough to be seen without the aid of magnification and that live on or in the substrate of flowing and nonflowing bodies of water. Their limited mobility and relatively long life spans (a few weeks to more than 1 year) make them ideal for use in evaluating the ecological effects of effluents on streams (Platts et al. 1983). The composition and structure of the benthic community reflects the relatively recent past and can be considerably more informative than monitoring methods that rely solely on water quality analyses but ignore the potential synergistic effects often associated with complex effluents.

A preliminary characterization of the benthic macroinvertebrate communities of the WOC watershed based on sampling conducted during a 6-month period from May through October 1986 (Loar et al. 1992) was included in the first annual report of BMAP. To adequately evaluate the status of a benthic community and the effects of an environmental change (e.g., a perturbation or improvement in water quality), a complete understanding of both the seasonal and annual changes of a benthic community is needed. Thus, the present report includes analyses for an additional 6 months of data (November 1986-April 1987), and where appropriate, the data presented in the first annual BMAP report as well. The major objective of this study is to provide data on the benthic macroinvertebrate communities in WOC and tributaries and WOL in order to (1) document the ecological impacts of past and current operations and (2) identify contaminant sources that adversely impact these stream communities. The results of this study will also be used to provide a baseline from which the effects of remedial actions can be properly evaluated.

\subsubsection{Materials and Methods}

Benthic macroinvertebrate samples were taken, at approximately monthly intervals from November 1986 through April 1987, from 15 stream sites in the WOC watershed (Fig. 2-2); and a single transect was sampled in lower WOL at approximately bimonthly 
intervals. The sampling sites included all sites sampled during the May through October 1986 study (Loar et al. 1992). The uppermost site of each stream served as a reference site. In addition, a single site [Brushy Fork kilometer (BFK) 7.6], a stream located just north of Oak Ridge near Marlowe, was used as an additional reference site for WCK 2.3. Data for site BFK 7.6 included samples collected at monthly intervals from May 1986 through April 1987.

Three randomly selected benthic macroinvertebrate samples were collected from riffles at each stream site with a Surber bottom sampler $\left(0.09 \mathrm{~m}^{2}\right.$, or $1 \mathrm{ft}^{2} ; 363-\mu \mathrm{m}$-mesh net). In WOL, five samples were collected at $\sim 10-\mathrm{m}$ intervals across a single transect with a hand-operated Ponar dredge $(15 \times 15 \times 15 \mathrm{~cm})$. Five randomly selected samples were collected from a riffle in Brushy Fork with a modified Hess sampler $\left(0.1 \mathrm{~m}^{2}, 363-\mu \mathrm{m}-\mathrm{mesh}\right.$ net). Qualitative samples were collected from all stream sites and from WOL in March and April 198\%, with a D-frame aquatic dip net (mesh of $800 \times 900 \mu \mathrm{m})$. Qualitative samples were collected from riffle and nonriffle habitats (e.g., pools, leaf packs, detritus, snags) at the stream sites and from all identifiable habitats (e.g., emergent vegetation, leaf packs, snag,s, riprap) in WOL. Qualitative samples were washed in the field in a net (363- $\mu \mathrm{m}$-mesh net) and a white pan to concentrate the organisms. Both qiantititative and qualitative saniples were placed in prelabeled glass jars and preserve 1 in $80 \%$ ethanol; the ethanol was replaced with fresh ethanol within 1 week.

Various supplemental information was also recorded at the time of sampling. At each stream site, water temperature and specific conductance were measured with a ColeParmer Model R-1491-20 LCD temperature/conductivity meter. Recorded for each sample were water depth, location within the riffle area (distance from permanent headstakes on the stream bank); relative current velocity (visually determined as very slow, slow, moderate, or fast); and substrate type, which was determined with the use of a modified Wentworth particle-size scale (Loar et al. 1985). In WOL, a single measurement of water temperature and specific conductance was obtained at the surface, and water depth and substrate type were also recorded for each sample.

All samples were washed in the laboratory in a standard No. 60-mesh (250- $\mu \mathrm{m}$-mesh) sieve and then placed in a white tray. Organisms were removed from the debris with forceps and placed in labeled vials containing $70 \%$ ethanol. Organisms were identified to the lowest practical taxonomic level with the use of a stereoscopic dissecting microscope. Chironomid larvae were first sorted into groups based on morphological similarities, and then one or more representatives of each group was mounted on a slide in CMC-10 mounting media and identified using a compound microscope. The remaining larvae were then identified at a magnification of 80 to $120 \times$ with a dissecting microscope. A blotted wet weight (biomass) of all individuals in each taxon was determined to the nearest $0.01 \mathrm{mg}$ on a Mettler analytical balance.

Slides of mounted chironomid larvae were retained in slide boxes, and individuals of the remaining taxa from a given site and sampling date were preserved in separate vials in $80 \%$ ethanol. A reference collection, for which the identification of each taxon has been verified, will be maintained at ORNL. 
All data were analyzed using the Statistical Analysis System (SAS 1985a, 1985b). The Shannon-Wiener index $\left(H^{\prime}\right)$ was used to calculate the taxonomic diversity of benthic macroinvertebrates at each site (Pielou 1977):

$$
H^{\prime}=-\sum p_{j} \log _{2} p_{j},
$$

where $p_{j}$ is the proportion of the benthic invertebrate community made up by species $j$. For statistical comparisons, data were transformed $\left[\log _{10}(x+1)\right.$, where $x=$ individual values for density, biomass, richness, etc.] (Elliott 1977). Mean values for density, biomass, number of taxa per sample (species richness), and diversity of the reference sites and their respective downstream sites were compared, using a two-way ANOVA, with site and date as the main effects; only site effects are covered in this report. Significant site differences $(p<0.05)$ were identified with Tukey's studentized range test. The number of samples varied between sites because some upstream reference sites were dry or, in the case of First Creek kilometer (FCK) 0.8 , were initially sampled at a different frequency (see Sect. 2.1 and Loar et al. 1992, Table 6-1). Consequently, statistical analyses were limited to only those dates on which samples were collected from both the reference and downstream sites of each stream.

\subsubsection{Results}

\subsubsection{White Oak Creek and tributaries}

Taxonomic Composition. A total of 200 benthic macroinvertebrate taxa were identified in quantitative samples from WOC and its tributaries from May 1986 through April 1987 (Appendix E, Table E-1). Of these taxa, 174 were insects representing 12 orders. The most taxonomically rich group was Diptera (true flies) with 90 taxa, 71 of which were chironomids (nonbiting midges). The number of taxa in the other orders of insects were Collembola (spring tails), 3; Coleoptera (beetles), 10; Ephemeroptera (mayflies), 13; Hemiptera (true bugs), 3; Hymenoptera (wasps), 1; Megaloptera (alderflies, dobsonflies, and hellgrammites), 3; Neuroptera (spongillaflies), 1; Odonata (damselflies and dragonflies), 15; Plecoptera (stoneflies), 14; and Trichoptera (caddisflies), 21. The noninsect groups and the number of taxa in each included Amphipoda (sideswimmers), 2; Decapoda (crayfish), 2; Gastropoda (snails), 11; Hydracarina (water mites), 2; Isopoda (aquatic sowbugs), 2; Nematoda (roundworms), 1; Oligochaeta (aquatic earthworms), 2; Pelecypoda (mussels), 3; and Turbellaria (flatworms), 1 . In addition to the taxa collected during routine quantitative sampling, 13 additional taxa were collected during the spring of 1987 in qualitative samples, including 6 dragonflies/damselflies, 3 chironomids and 1 each mayfly, beetle, nonchironomid dipteran, and snail (Table E-1).

Relative to the nonreference sites (i.e., those sites located downstream of ORNL facilities), the reference sites (FCK 0.8, FFK 1.0, MEK 2.1, NTK 1.0, and WCK 6.8) generally had a greater variety of taxa within each of the major taxonomic groups (Table E-1). For example, the combined total of caddisfly, mayfly, and stonefly taxa was 21 or greater at each reference site, but exceeded 10 at only 2 nonreference sites (NTK 0.2 and MEK 0.6, each with 15). Additionally, some major taxonomic groups (orders) were totally absent at some sites or were collected in only qualitative samples. 
Table 6-1. Mean annual density (number per $0.1 \mathrm{~m}^{2}$ ) and biomass (milligrams wet weight per $0.1 \mathrm{~m}^{2}$ ) of benthic macroinvertebrates in White Oak Creek watershed, May 1986-April 1987

Standard error of the mean is given in parenthesis

\begin{tabular}{|c|c|c|c|c|c|}
\hline Site & $\mathbf{N}^{b}$ & Density & Density & Biomass $^{c}$ & Biomass $^{d}$ \\
\hline FCK 0.1 & 36 & $\begin{array}{l}142.3 \\
(69.5)\end{array}$ & $\begin{array}{c}1.1 \\
(0.3)\end{array}$ & $\begin{array}{l}179.2 \\
(29.9)\end{array}$ & $\begin{array}{l}147.2 \\
(71.4)\end{array}$ \\
\hline FCK 0.8 & 32 & $\begin{array}{l}207.3 \\
(24.8)\end{array}$ & $\begin{array}{l}33.4 \\
(4.6)\end{array}$ & $\begin{array}{l}289.5 \\
(25.5)\end{array}$ & $\begin{array}{l}2218.0 \\
(272.1)\end{array}$ \\
\hline FFK 0.2 & 36 & $\begin{array}{c}6.0 \\
(1.5)\end{array}$ & $\begin{array}{c}0.5 \\
(0.2)\end{array}$ & $\begin{array}{l}123.7 \\
(44.9)\end{array}$ & $\begin{array}{c}3.6 \\
(1.5)\end{array}$ \\
\hline FFK 1.0 & 36 & $\begin{array}{l}342.5 \\
(88.9)\end{array}$ & $\begin{array}{c}0.6 \\
(0.2)\end{array}$ & $\begin{array}{c}803.8 \\
(101.5)\end{array}$ & $\begin{array}{c}9.4 \\
(6.6)\end{array}$ \\
\hline MEK 0.6 & 35 & $\begin{array}{l}113.8 \\
(41.0)\end{array}$ & $\begin{array}{c}1.3 \\
(1.0)\end{array}$ & $\begin{array}{l}224.6 \\
(65.8)\end{array}$ & $\begin{array}{c}99.9 \\
(58.9)\end{array}$ \\
\hline MEK 1.2 & 35 & $\begin{array}{l}106.1 \\
(36.0)\end{array}$ & $\begin{array}{c}0.1 \\
(0.04)\end{array}$ & $\begin{array}{l}213.4 \\
(55.8)\end{array}$ & $\begin{array}{c}0.03 \\
(0.02)\end{array}$ \\
\hline MEK 2.1 & 24 & $\begin{array}{l}124.5 \\
(21.2)\end{array}$ & $\begin{array}{c}1.6 \\
(0.8)\end{array}$ & $\begin{array}{l}202.9 \\
(54.1)\end{array}$ & $\begin{array}{c}3.7 \\
(2.1)\end{array}$ \\
\hline NTK 0.2 & 36 & $\begin{array}{l}173.0 \\
(47.3)\end{array}$ & $\begin{array}{l}20.9 \\
(3.8)\end{array}$ & $\begin{array}{l}280.8 \\
(54.5)\end{array}$ & $\begin{array}{c}6528.8 \\
(1739.8)\end{array}$ \\
\hline NTK 1.0 & 30 & $\begin{array}{l}142.7 \\
(33.1)\end{array}$ & $\begin{array}{c}0.4 \\
(0.1)\end{array}$ & $\begin{array}{l}333.5 \\
(43.1)\end{array}$ & $\begin{array}{c}62.0 \\
(33.17)\end{array}$ \\
\hline WCK 2.3 & 36 & $\begin{array}{l}168.3 \\
(62.5)\end{array}$ & $\begin{array}{c}1.0 \\
(0.4)\end{array}$ & $\begin{array}{l}486.5 \\
(85.5)\end{array}$ & $\begin{array}{c}7.8 \\
(3.8)\end{array}$ \\
\hline WCK 2.9 & 36 & $\begin{array}{l}135.2 \\
(49.4)\end{array}$ & $\begin{array}{c}1.9 \\
(0.9)\end{array}$ & $\begin{array}{l}283.4 \\
(69.9)\end{array}$ & $\begin{array}{l}12.8 \\
(8.2)\end{array}$ \\
\hline WCK 3.4 & 36 & $\begin{array}{l}238.5 \\
(74.5)\end{array}$ & $\begin{array}{c}1.2 \\
(0.6)\end{array}$ & $\begin{array}{l}204.0 \\
(54.8)\end{array}$ & $\begin{array}{c}3.8 \\
(2.4)\end{array}$ \\
\hline WCK 3.9 & 36 & $\begin{array}{l}255.8 \\
(85.9)\end{array}$ & $\begin{array}{c}0.4 \\
(0.2)\end{array}$ & $\begin{array}{l}134.6 \\
(44.3)\end{array}$ & $\begin{array}{c}3.3 \\
(1.9)\end{array}$ \\
\hline
\end{tabular}


Table 6-1 (continued)

\begin{tabular}{lccccc}
\hline Site & $\mathbf{N}^{b}$ & Density & Densityd & Biomass $^{\mathrm{e}}$ & Biomass $^{d}$ \\
\hline \multirow{2}{*}{ WCK 5.1 } & 36 & 114.9 & 0.3 & 86.9 & 213.9 \\
& & $(44.6)$ & $(0.1)$ & $(21.3)$ & $(109.5)$ \\
WCK 6.8 & \multirow{2}{*}{36} & 136.5 & 27.6 & 266.3 & 2661.4 \\
& & $(27.9)$ & $(5.4)$ & $(57.9)$ & $(454.6)$ \\
BFK 7.6 & 60 & 182.0 & 83.9 & 252.6 & $17,550.2$ \\
& & $(28.1)$ & $(15.9)$ & $(50.6)$ & $(2275.0)$ \\
\hline
\end{tabular}

๑FCK = First Creek kilometer; FFK = Fifth Creek kilometer; MEK = Melton Branch kilometer;

NTK = Northwest Tributary kilometer; WCK $=$ White Oak Creek kilometer; BFK = Brushy Fork kilometer.

"Number of samples collected.

'All taxa except Mollusca and Decapoda.

Mollusca and Decapoda only.

Stoneflies were not collected at FFK 0.2, WCK 3.4, or WCK 5.1; and, at WCK 3.9, maytlies were not collected, and a single stonefly was collected in a qualitative sample.

Density and biomas. Mean annual density and biomass of the benthic macroinvertebrates at each sampling site in WOC watershed are presented in Table 6-1. Exclusive of Mollusca and Decapoda, densities of other taxa ranged from a low of 6.0 individuals per $0.1 \mathrm{~m}^{2}$ at FFK 0.2 to a high of 342.5 individuals per $0.1 \mathrm{~m}^{2}$ at FFK 1.0 . Densities tended to be higher in the upstream references sites, but this difference was significant in only First Creek and Fifth Creek (Tables 6-2 and 6-3) and in some WOC sites. For example, density was significantly lower at WCK 5.1 and WCK 2.9 than at their upstream reference site, WCK 6.8. Density at WCK 2.3 was also significantly lower than at BFK 7.6, a nearby reference stream similar in size to lower WOC (Table 6-3).

Mollusks and decapods added little to the total community density at any site except Brushy Fork (Table 6-1), and their exclusion from the comparison of density among sites did not alter the pattern of significant differences between sites (Tables 6-2 and 6-3). Abundance was highest in Brushy Fork (83.9 individuals per $0.1 \mathrm{~m}^{2}$ ) and at FCK 0.8 , NTK 0.2, and WCK 6.8, where their combined densities were 33.4, 20.9, and 27.6 individuals per $0.1 \mathrm{~m}^{2}$ respectively.

Excluding mollusks and decapods, biomass of the benthic invertebrates ranged from a low of $86.9 \mathrm{mg}$ wet wt/0.1 $\mathrm{m}^{2}$ at WCK 5.1 to a high of $803.8 \mathrm{mg}$ wet wt/0.1 $\mathrm{m}^{2}$ at FFK 1.0 (Table 6-1). As with density, biomass tended to be highest in the upstream reference sites; however, values were significantly higher only in upper First Creek and Fifth Creek. In WOC, values were significantly lower than those at the reference site (WCK 6.8) only at WCK 5.1 and WCK 3.9 (Tables 6-4 and 6-5). When mollusks and decapods were excluded, biomass at BFK 7.6 and WCK 2.3 was not significantly different (Table 6-5). 
Table 6-2 Comparisons of mean benthic macroinvertebrate density with and without Decapoda and Mollusca in tributaries of White Oak Creek

All taxa
All taxa except Decapoda and Mollusca

\section{First Creek}

$\frac{\text { FCK } 0.8}{n=32} \underset{n=33}{\text { FCK } 0.1}$

FFK 1.0 FFK 0.2

$n=36 \quad n=36$

MEK 2.1 MEK 0.6 MEK 1.2

$n=24 \quad n=23 \quad n=23$

MEK $0.6 \quad$ MEK 1.2

$n=35$

NTK 0.2 NTK 1.0

$n=30$ $\frac{\text { FCK } 0.8}{n=32} \underset{n=33}{\text { FCK } 0.1}$

Fith Croek

$\frac{\text { FFK } 1.0}{n=36} \frac{\text { FFK } 0.2}{n=36}$

$n=36 \quad n=36$

Melton Branch

$\frac{\text { MEK 2.1 MEK } 0.6 \quad \text { MEK } 1.1}{n=24 \quad n=23 \quad n=23}$

MEK 0.6 MEK 1.2

$n=35$

Northwest Tributary

NTK 0.2 NTK 1.0

${ }^{-} N=$ number of samples. Sites connected by the same line are not significantly different $(p>0.05)$, based on Tukey's studentized range (HSD) test. Sites are arranged in order of highest to lowest values from left to right. FCK $=$ First Creek kilometer; FFK $=$ Fifth Creek kilometer; MEK $=$ Melton Branch kilometer; NTK $=$ Northwest Tributary kilometer.

Mollusks and decapods contributed significantly to total biomass at some sites, especially at Brushy Fork $\left(17.6 \mathrm{~g} / 0.1 \mathrm{~m}^{2}\right)$ but also at FCK 0.8, NTK 0.2, and WCK 6.8, where their combined weights were $2218.0,6528.8$, and $2661.4 \mathrm{mg}$ wet wt/0.1 $\mathrm{m}^{2}$ respectively (Tables 6-1, 6-4, and 6-5). Although these groups made substantial contributions to the biomass at FCK 0.1 and WCK 5.1, their contributions were not significant compared with their reference sites. Compared with their contribution at MEK 1.2, mollusks and decapods contributed significantly to the biomass at MEK 0.6; and biomass at BFK 7.6, including decapods and mollusks, was significantly greater than at WCK 2.3. Except for NTK 0.2, most of the biomass of these two groups at nonreference sites consisted of a few crayfish. 
Table 6-3. Comparisons of mean benthic macroinvertebrate density with and without Decapoda and Mollusca in White Oak Creek

Site

All twa croept Decapoda and Mollusca

WCK 3.4 WCK 2.3 WCK 6.8 WCK 3.9 WCK 5.1 WCK 2.9

$n=36$

All tam

WCK 3.4 WCK 6.8 WCK 2.3 WCK 3.9 WCK 5.1 WCK 2.9

$n=36$

All $\tan$

BFK 7.6 WCK 2.3

$n=60 \quad n=36$

All tom except Decapoda and Mollusca

BFK 7.6 WCK 2.3

$n=60 \quad n=36$

$-N=$ number of samples. Sites connected by the same line are not significantly different $(p>0.05)$, based on Tukey's studentized range (HSD) test. Sites are arranged in order of highest to lowest values from left to right.

${ }^{b} \mathrm{BFK}=$ Brushy Fork kilometer; WCK $=$ White Oak Creek kilometer.

Considerable temporal variability occurred within and between sites in the density and biomass of benthic macroinvertebrates (excluding mollusks and decapods) ${ }^{\bullet}$ in WOC and tributaries (Figs. 6-1 and 6-2). Highest densities at all sites except MEK 1.2 and WCK 3.9 occurred during April, and some sites exhibited an additional but smaller peak during the late fall and early winter. Peak density at MEK 1.2 occurred in November; the most abundant taxonomic group was the chironomid, Polypedilum, whose numbers increased steadily after August. Density at WCK 3.9 increased dramatically after October before finally reaching a peak in January. The increase in density at this site during this time period was primarily associated with substantial increases in chironomids (primarily

The weights presented in Fig. 6-2 exclude Mollusca (snails and clams) and Decapoda (crayfish) in order to make the weight of benthic organisms at each site more comparable without the biasing effect of a few large organisms. However, these taxa are included in the estimates of mean monthly density shown in Fig. 6-1. 
Table 6-4. Comparisons of mean benthic mscroinvertebrate biomess with and without Decapoda and Mollusen in White Oak Creek tributaries
All taxa
All taxa except Decapoda and Mollusca

First Creek

FCK 0.8 FCK 0.1

$n=32 \quad n=33$

$\frac{\text { FFK } 1.0}{n=36} \underset{n=36}{\text { FFK } 0.2}$

MEK 0.6 MEK 2.1 MEK 1.2

$n=23 \quad n=24 \quad n=23$

MEK 0.6 MEK 1.2

$n=35 \quad n=35$

\section{- $\quad$ Northwest Tributary}

$\frac{\text { FCK } 0.8}{n=32} \underset{n=33}{\text { FCK } 0.1}$

Fith Creek

Melton Branch

MEK 0.6 MEK 2.1 MEK 1.2

$n=23 \quad n=24 \quad n=23$

MEK 0.6 MEK 1.2

$n=35 \quad n=35$

FFK 1.0 FFK 0.2

$n=36 \quad n=36$

NTK 0.2 NTK 1.0

NTK 1.0 NTK 0.2

$n=30 \quad n=30$

$n=30 \quad n=30$

${ }^{\top} \mathrm{N}=$ number of samples. Sites connected by the same line are not significantly different $(p>0.05)$, based on Tukey's studentized range (HSD) test. Sites are arranged in order of highest to lowest values from left to right. FCK = First Creek kilometer; FFK = Fifh Creek kilometer; $M E K=$ Melton Branch kilometer; NTK $=$ Northwest Tributary kilometer.

Cricotopus/Orthocladius group), oligochaetes, and the dipteran, Hemerodromia. The increase in density of these groups at WCK 3.9 most likely occurred as a result of a spill of $-29,500 \mathrm{~L}(7800 \mathrm{gal})$ of a $5 \%$ ethylene glycol solution into WOC near WCK 4.8 (6000 area) in September 1986. As this compound degraded, it most likely provided an ideal and abundant food supply (through increased microbial production) for these taxa. In combination with the ability of these taxa to reproduce rapidly, this spill allowed the populations to increase dramatically. Increases in density at sites in WOC downstream of WCK 3.9 during this time period were less dramatic.

Biomass was generally highest at most sites during the spring and early summer, although increases during early winter to midwinter and early summer to midsummer were also evident at most of the reference sites and at some nonreference sites (Fig. 6-2). As observed for density, biomass at WCK 3.9 showed a steady and dramatic increase after 
Table 6-5. Comparisons of mean benthic macroinvertebrate biomass with and without Decapoda and Mollusca in White Oak Creek

\section{Site $^{b}$}

All ton excluding Decapoda and Mollusca

$\begin{array}{llllll}\text { WCK } 2.3 & \text { WCK } 6.8 & \text { WCK } 2.9 & \text { WCK } 3.4 & \text { WCK } 5.1 & \text { WCK } 3.9\end{array}$

$$
n=36
$$

All tam

WCK 6.8 WCK 2.3 WCK 2.9 WCK 3.4 WCK 5.1 WCK 3.9

$$
n=36
$$

All tan

BFK 7.6 WCK 2.3

$n=60 \quad n=36$

All tara except Decapoda and Mollusca

$$
\begin{array}{cl}
\text { WCK 2.3 } & \text { BFK 7.6 } \\
\hline n=36 \quad n=60
\end{array}
$$

- $\mathrm{N}=$ number of samples. Sites connected by the same line are not significantly different $(p>0.05)$, based on Tukey's studentized range (HSD) test. Sites are arranged in order of highest to lowest values from left to right.

${ }^{b}$ WCK $=$ White Oak Creek kilometer; BFK = Brushy Fork kilometer.

October before peaking in January. Seasonal changes in biomass at WCK 2.3 and WCK 2.9 were very similar, most likely due to their similar taxonomic composition. The sites in Melton Branch, however, which had considerably different community compositions, exhibited little similarity in their seasonal biomass -hanges.

Dominant taxa. A majority of the within- and between-site differences in density and biomass of the benthic macroinvertebrate communities (exclusive of decapods and mollusks) can be accounted for with four major groups of organisms: the irue flies (Diptera), beetles (Coleoptera), caddisflies (Trichoptera), and aquatic worms (Oligochaeta). Additionally, dragonflies (Odonata), mayflies (Ephemeroptera), stoneflies (Plecoptera), and aquatic sowbugs (Isopoda) contributed considerably to the community biomass and/or density of some sites.

Dipterans, particularly the "nironomids, consistently represented the most abundant +- $\mathrm{xa}$ of benthic invertebrates throughout the WOC watershed (Figs. 6-3 and 6-4). Although densities of nonchironomid dipterans did not exceed $10 \%$ of the total 

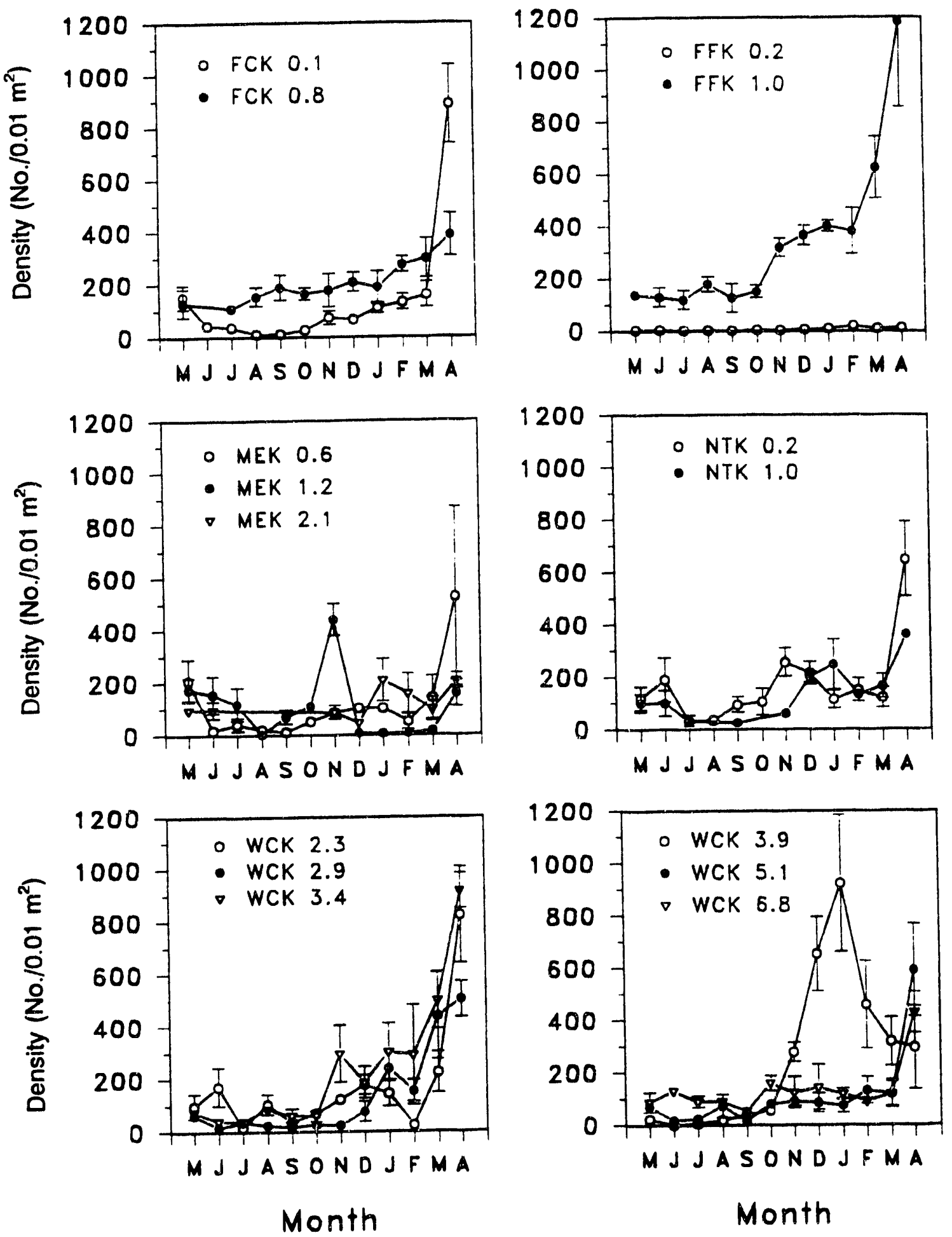

Fig 6-1. Monthly mean density of benthic macroinvertebrates in White Oal Croek watershed, May 1986-April 1987. FCK $=$ First Creek kilometer; MEK = Melton Branch kilometer; $\mathbf{W C K}=$ White Oak Creek kilometer, FFK = Fifth Creek kilometer; NTK = Northwest Tributary kilometer. 

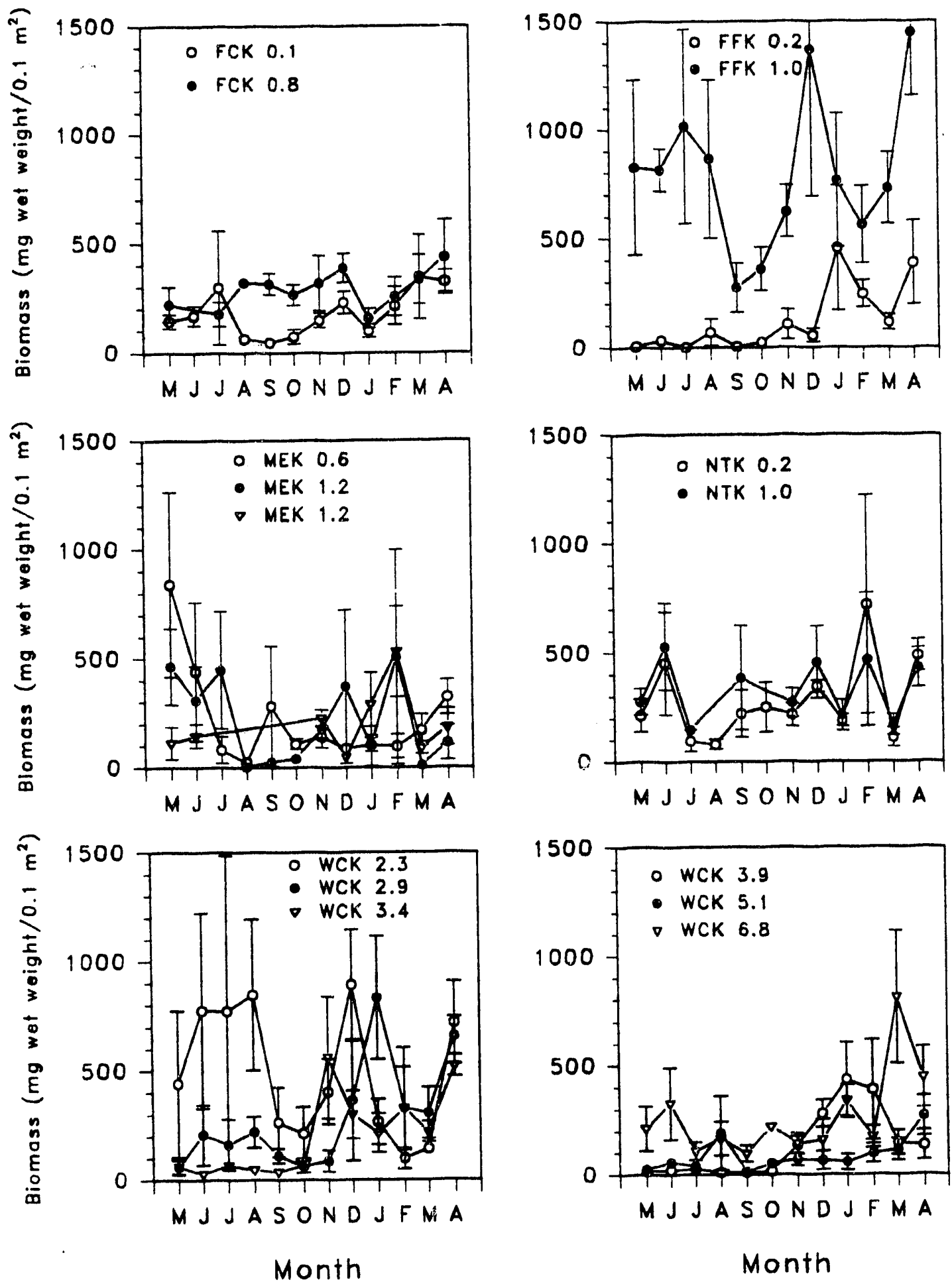

Fis 6-2. Monthly mean biomass of benthic macroinvertebrates (excluding Decapoda and Mollusca) in White Oak Creek watershed, Mry 1986-April 1987. FCK = First Creek kilometer; MEK = Melton Branch kilometer; WCK = White Oak Creek kilometer; FFK = Fifth Creek kilometer, NTK = Northwest Tributary kilometer. 

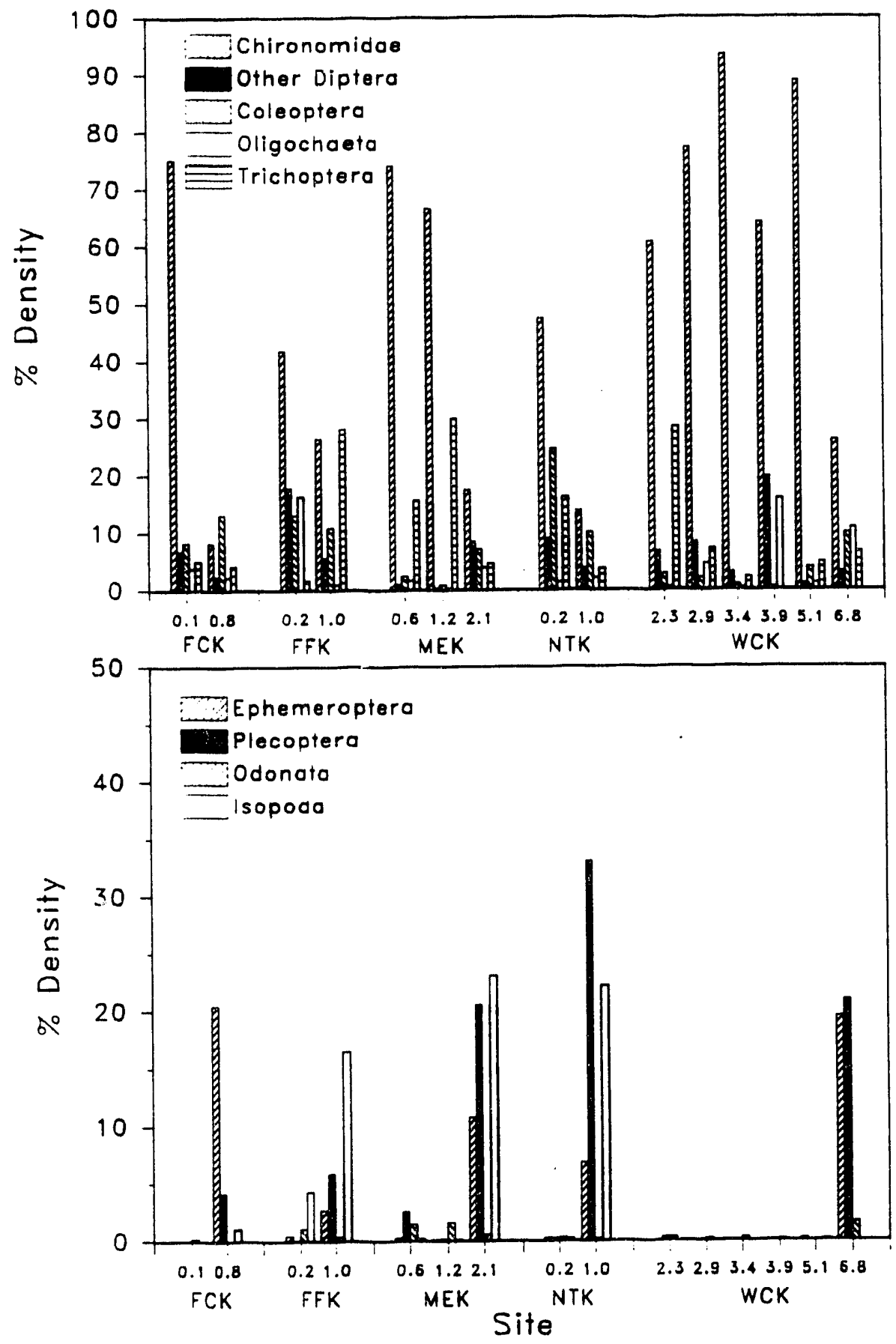

Fig 6-3. Relative abundance (percentage of mean annual density) of selected benthic macroinvertebrate trmonomic groups in White Oak Creek watershed, May 1986-April 1987. FCK = First Creek kilometer; FFK = Fifth Creek kilometer; MEK = Melton Branch kilometer; NTK $=$ Northwest Tributary kilometer; $W C K=$ White Oak Creek kilometer. 

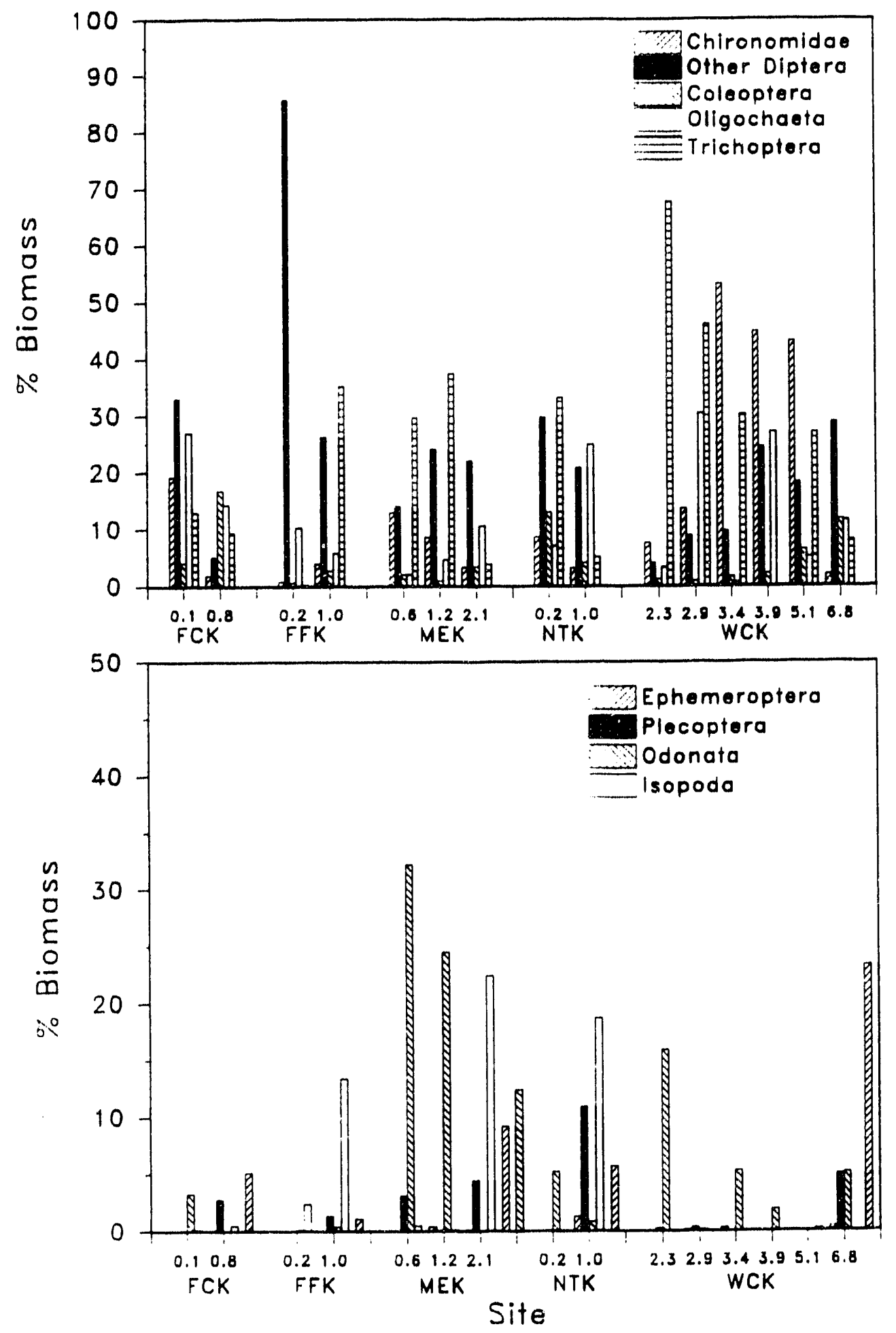

Fig. 6-4. Relative biomass (percentage of mean annual biomass, excloding Decapoda and Mollusca) of selected benthic macroinvertebrate tronomic groups in White Oak Creek watershed, May 1986-April 1987. FCK = First Creek kilometer; FFK = Fifth Creek kilometer; MEK = Meiton Branch kilometer; NTK = Northwest Tributary kilometer; WCK = White Oak Creek kilometer. 
community density at any site except FFK 0.2 and WCK 3.9, they did account for more than $10 \%$ of the total community biomass at all sites but FCK 0.8, WCK 2.3, WCK 2.9, and WCK 3.4. A few large-bodied craneflies (Tipulidae) accounted for the high relative biomass of this group. Although numerically dominant, the chironomids, which were generally very small, typically did not dominate community biomass. Their greatest relative contributions to biomass were at FCK 0.1, MEK 0.6, WCK 2.9, WCK 3.4, WCK 3.9, and WCK 5.1. The relative abundance of chironomids was greatest at nonreference sites, where they accounted for 42 to $93 \%$ of the total community density; their relative abundance at the reference sites did not exceed $27 \%$. Furthermore, as the relative abundance of chironomids increased, the relative abundance of the chironomids within the Cricotopus/Orthocladius group tended to also increase.

In general, caddisflies achieved their greatest relative abundance and biomass in the most downstream site(s) of each stream (Figs. 6-3 and 6-4). Caddisflies achieved their greatest relative abundance (30\%) and weight (68\%) at MEK 1.2 and WCK 2.3, respectively, and contributed little to either the biomass $(<1 \%)$ or abundance $(<2 \%)$ of benthic invertebrates at FFK 0.2 and WCK 3.9. With the exception of these latter two sites, the relative biomass of caddisflies at the nonreference sites tended to be high in comparison with their densities; whereas, at the reference sites, their relative biomass and numbers were very similar, suggesting more balance within the communities of the reference sites. Also, one or two taxa (Cheumatopsyche and Hydropsyche) accounted for a majority of the total caddisfly density and biomass at the nonreference sites; while at the reference sites, particularly FFK 1.0, several taxa contributed.

Oligochaetes were most likely represented by two or three families and several genera, but no identifications were made of this group. No consistent pattern in the distribution of oligochaetes was discernable within the streams of the WOC watershed (Figs. 6-3 and 6-4). Their highest relative abundance occurred at FFK 0.2 (16\%), WCK $3.9(16 \%)$, and WCK $6.8(11 \%)$, while their greatest relative biomass (24 to $30 \%$ ) occurred at FCK 0.1, NTK 1.0, WCK 2.9, and WCK 3.9.

With few exceptions, the highest relative abundance and biomass of beetles were generally found at the reference sites, ranging from 7 to $13 \%$ and 3 to $17 \%$, respectively (Figs. 6-3 and 6-4). Of the nonreference sites sampled, the greatest relative abundance and biomass of beetles occurred at NTK 0.2 (25 and 13\%, respectively); relative abundance and biomass at the remaining nonreference sites were considerably less.

Mayflies and stoneflies contributed little to either biomass or density at any nonreference sites, where, with the exception of stoneflies at MEK 0.6, the relative abundance and biomass of both groups never exceeded 0.5\% (Figs. 6-3 and 6-4). Relative to the nonreference sites, however, these groups contributed substantially to the density and/or biomass of the reference sites. The relative abundance and biomass of mayflies and stoneflies at the reference sites ranged from 3 to $20 \%$ and 4 to $33 \%$ respectively.

Odonates contributed little to the total community density ( $2 \%$ or less) at any site in WOC watershed, but because of their large and heavy bodies, their contributions to community biomass was considerable at some sites (Figs. 6-3 and 6-4). In terms of biomass, their greatest contributions were at MEK 0.6 (32\%) and MEK 1.2 (24\%), where 
the relative abundance of the small-bodied chironomids was very high (Figs. 6-3 and 6-4). The highest relative biomass of odonates at the reference sites occurred at MEK 2.1 (12\%), but was $5 \%$ or less at all other reference sites.

As was the case with mayflies and stoneflies, the highest relative abundance and biomass of isopods occurred at the reference sites, although at FCK 0.8 and WCK 6.8 they contributed little to either parameter (Figs. 6-3 and 6-4). Except for FFK 0.2 where the relative density and biomass of isopods were 4 and $2 \%$, respectively, the relative abundance and biomass of this group did not exceed $0.5 \%$.

Community structure. With the exception of samples from Melton Branch, more taxa were collected from the reference site of each stream than from their respective downstream site(s) (Fig 6-5); the total for the reference site on Melton Branch (MEK 2.1), however, included only 8 months of samples, since this site was dry from July through October of 1986. The greatest number of taxa (101) were collected at FFK 1.0, while the fewest taxa (31) were collected at FFK 0.2. In both Melton Branch and WOC, the fewest taxa were collected at the midstream sites.

The annual mean number of taxa collected per sample followed a trend similar to that of total number of taxa; the highest values generally occurred at the reference sites, and the lowest values occurred in the mid-reach sites of Melton Branch and WOC (Table 6-6). These trends were significant for First Creek, Fifth Creek, WOC, and Melton Branch (MEK 2.1 relative to MEK 1.2) (Table 6-7). Also, the mean number of taxa collected was significantly greater in Brushy Fork than in WCK 2.3 (Tables 6-6 and 6-7). As observed for the total number of taxa, FFK 1.0 exhibited the highest annual mean number of taxa (24.5 taxa per sample) in the watershed, while FFK 0.2 exhibited the lowest (3.4 taxa per sample).

Seasonal trends in the mean number of taxa per sample were not evident at most sites (Fig. 6-6). Four sites (FCK 0.1, NTK 0.2, NTK 1.0, and WCK 6.8) appeared to exhibit maximum depressions in the mean number of taxa/sample during the summer. The number of taxa appeared to increase each month after September at many sites, and, at MEK 0.6, the number of taxa increased dramatically after September and remained elevated for the remainder of the study period. This increase in density may be a seasonal phenomenon or it could be related to the shutdown of the HFIR in November 1986. Monthly benthos sampling is continuing in 1988 , so a larger data base will be available to assess recovery of the benthos in Melton Branch in the next annual report.

Spatial trends in taxonomic diversity were very similar to the spatial trends observed in taxonomic richness, with highest diversity generally occurring at the upstream reference site of each stream, and with maximum depression of diversity in the midreaches of Melton Branch and WOC (Table 6-6). Relative to their respective downstream sites, diversity was significantly greater at the reference sites on First Creek, Fifth Creek, and WOC; and, in Melton Branch, diversity at the reference site was greater relative to the middle site (MEK 1.2) (Table 6-8). Diversity was also significantly greater at BFK 7.6 than at WCK 2.3. Maximum diversity in the WOC watershed occurred at FFK $1.0\left(\mathrm{H}^{\prime}=\right.$ 3.3), while the lowest diversity occurred at WCK $3.9\left(\mathrm{H}^{\prime}=0.8\right)$. 
CRNL. DWG 88-8972

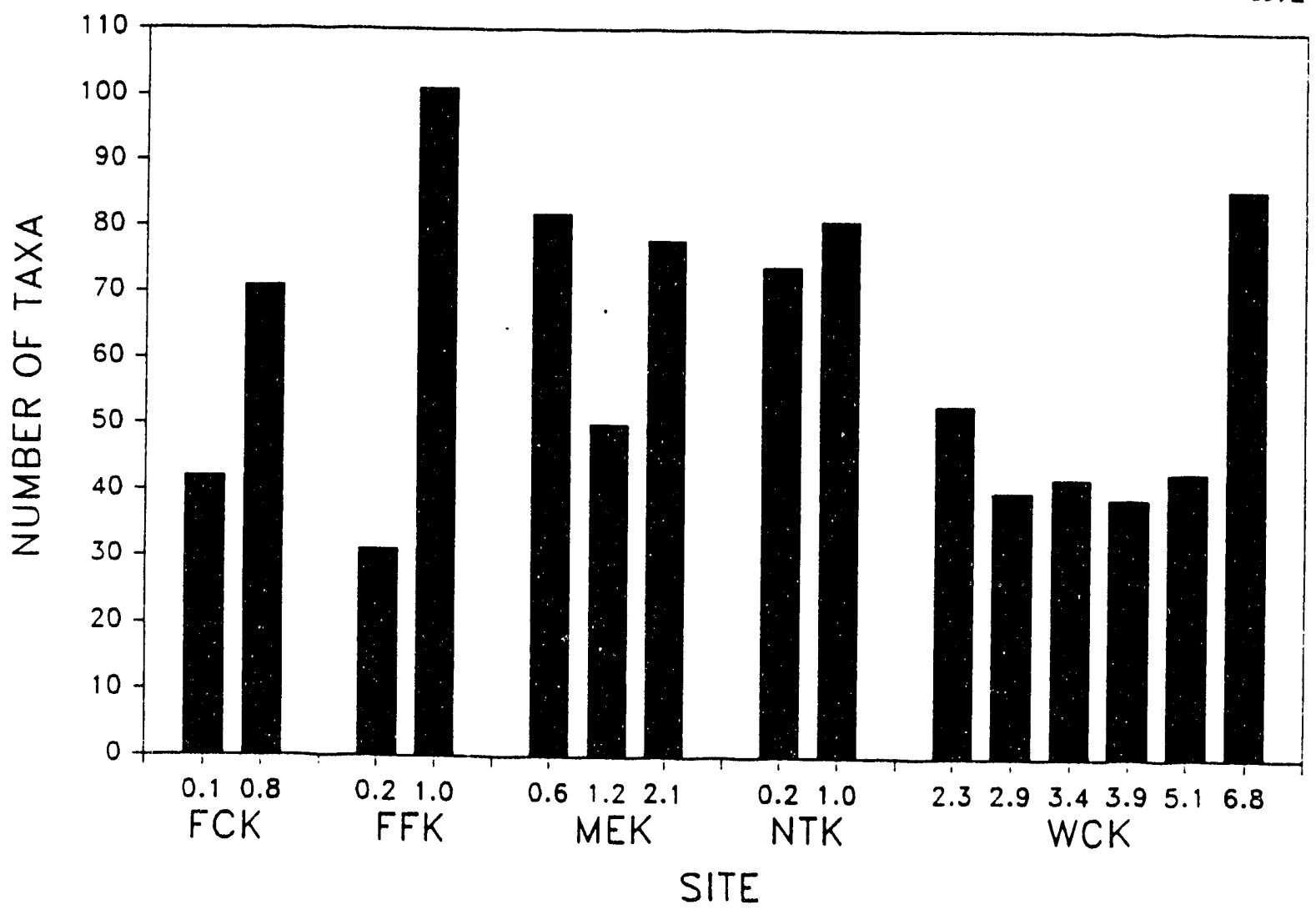

Fig 6-5. Total number of tam collected per site from the White Oak Creek watershod, May 1986-April 1987. FCK = First Creek kilometer, FFK = Fifth Creek kilometer; MEK = Melton Branch kilometer; NTK $=$ Northwest Tributary kilometer; WCK $=$ White Oak Creek kilometer. 
Table 6-6. Mean annual richneas (number of tom per sample) and species diversity $\left(\mathrm{H}^{\prime}\right)$ of benthic macroinvertebrates in White Oat Creek watershed, Mry 1986-April 1987

Standard error of the mean is given in parentheses

\begin{tabular}{|c|c|c|c|}
\hline Site & $\mathbf{N}^{\bullet}$ & Richness & Diversity \\
\hline FCK 0.1 & 36 & $\begin{array}{c}8.9 \\
(0.8)\end{array}$ & $\begin{array}{c}2.1 \\
(0.2)\end{array}$ \\
\hline FCK 0.8 & 32 & $\begin{array}{c}18.6 \\
(2.0)\end{array}$ & $\begin{array}{c}2.7 \\
(0.2)\end{array}$ \\
\hline FFK 0.2 & 36 & $\begin{array}{c}3.4 \\
(0.6)\end{array}$ & $\begin{array}{c}1.4 \\
(0.2)\end{array}$ \\
\hline FFK 1.0 & 36 & $\begin{array}{l}24.5 \\
(1.9)\end{array}$ & $\begin{array}{c}3.3 \\
(0.1)\end{array}$ \\
\hline MEK 0.6 & 35 & $\begin{array}{l}12.6 \\
(1.6)\end{array}$ & $\begin{array}{c}2.6 \\
(0.2)\end{array}$ \\
\hline MEK 1.2 & 35 & $\begin{array}{c}5.4 \\
(0.5)\end{array}$ & $\begin{array}{c}1.2 \\
(0.2)\end{array}$ \\
\hline MEK 2.1 & 24 & $\begin{array}{l}15.3 \\
(1.4)\end{array}$ & $\begin{array}{c}2.8 \\
(0.2)\end{array}$ \\
\hline NTK 0.2 & 36 & $\begin{array}{l}15.2 \\
(1.5)\end{array}$ & $\begin{array}{c}2.8 \\
(0.1)\end{array}$ \\
\hline NTK 1.0 & 30 & $\begin{array}{l}17.6 \\
(2.1)\end{array}$ & $\begin{array}{c}3.0 \\
(0.1)\end{array}$ \\
\hline WCK 2.3 & 36 & $\begin{array}{c}7.6 \\
(0.8)\end{array}$ & $\begin{array}{c}1.5 \\
(0.1)\end{array}$ \\
\hline WCK 2.9 & 36 & $\begin{array}{c}6.8 \\
(0.8)\end{array}$ & $\begin{array}{c}1.5 \\
(0.2)\end{array}$ \\
\hline WCK 3.4 & 36 & $\begin{array}{c}7.0 \\
(0.8)\end{array}$ & $\begin{array}{c}1.1 \\
(0.1)\end{array}$ \\
\hline WCK 3.9 & 36 & $\begin{array}{c}5.0 \\
(0.9)\end{array}$ & $\begin{array}{c}0.8 \\
(0.1)\end{array}$ \\
\hline
\end{tabular}


Table 6-6 (continued)

\begin{tabular}{lccc}
\hline Site & $\mathrm{N}^{\bullet}$ & Richness & Diversity \\
\hline WCK 5.1 & 36 & 8.2 & 1.7 \\
& & $(0.6)$ & $(0.2)$ \\
WCK 6.8 & 36 & 19.7 & 3.1 \\
& & $(1.6)$ & $(0.2)$ \\
BFK 7.6 & 60 & 20.9 & 2.7 \\
& & $(1.4)$ & $(0.1)$ \\
\hline
\end{tabular}

"Number of samples collected.

Note: FCK $=$ First Creek kilometer; FFK $=$ Fifth Creek kilometer; MEK $=$ Melton Branch kilometer; NTK $=$ Northwest Tributary kilometer; WCK $=$ White Oak Creek kilometer; BFK = Brushy Fork kilometer.

Diversity at many sites appeared to peak during the winter and spring months, while minima typically occurred during the summer and/or fall (Fig. 6-7). Diversity at most reference sites usually remained near 3.0 most of the year, and at FFK 1.0, diversity fell below 3.0 in only 2 months. Diversity at MEK 0.6 increased dramatically after September and remained near 3.0 through April of the following year. As observed for density, biomass, and mean number of taxa, diversity at WCK 3.9 also increased dramatically from October through January.

\subsubsection{White Oak Lake}

A total of 15 distinct taxa were collected in bimonthly quantitative samples in WOL (WCK 1.1) from May 1986 through April 1987 (Table E-1). Of these taxa, 12 were insects, 2 were oligochaetes (aquatic worms), and 1 was a snail (Gastropoda). Eleven of the insects were dipterans (true flies), of which nine were chironomids (midges); the only nondipteran insect was a caddisfly (Trichoptera). An additional eight taxa, including three chironomids, two beetles (Coleoptera), and one mayfly (Ephemeroptera), damselfly (Odonata), and true bug (Hemiptera), were collected in qualitative samples in March 1987.

Mean annual density and biomass, excluding snails, were 166.8 individuals per $0.1 \mathrm{~m}^{2}$ and $144.7 \mathrm{mg}$ wet wt per $0.1 \mathrm{~m}^{2}$ respectively (Table 6-9). Snails were not often collected in quantitative samples in WOL, where they contributed only 0.4 individuals per $0.1 \mathrm{~m}^{2}$ and $5.7 \mathrm{mg}$ wet wt per $0.1 \mathrm{~m}_{2}$ to the mean annual community density and biomass respectively. Chironomids and other dipterans (primarily Chaoborus) were numerically dominant in WOL, contributing 57 and $36 \%$, respectively, to the total community density. These two groups were also the major contributors to the community biomass, accounting for 57 and $22 \%$ respectively. 
Table 6-7. Comparisons of mean benthic macroinvertebrate richness (number of tan per sample) in White Oak Creek watersher

Site

First Creek

$\frac{\text { FCK } 0.8}{n=32} \frac{\text { FCK } 0.1}{n=33}$

Fifth Croek

EFK 1.0 FFK 0.2

$n=36 \quad n=36$

Melton Branch

$\frac{\text { MEK 2.1 }}{n=24 \quad n=23} \quad \frac{\text { MEK } 1.2}{n=23}$

MEK $0.6 \quad$ MEK 1.2

$n=35 \quad n=35$

Northwest Tributary

NTK $1.0 \quad$ NTK 0.2

$n=30 \quad n=30$

White Oak Croek

$\begin{array}{llllll}\text { WCK } 6.8 & \text { WCK } 5.1 & \text { WCK 2.3 } & \text { WCK 3.4 } & \text { WCK 2.9 } & \text { WCK 3.9 } \\ n=36 & n=36 & n=36 & n=36 & n=36 & n=36\end{array}$

BFK 7.6 WCK 2.3

$n=60 \quad n=36$

${ }^{a} N=$ number of samples. Sites connected by the same line are not significantly different $(p>0.05)$, based on Tukey's studentized range (HSD) test. Sites are arranged in order of highest to lowest values from left to right.

Note: FCK $=$ First Creek kilometer; FFK $=$ Fifth Creek kilometer; MEK $=$ Melton Branch kilometer; NTK $=$ Northwest Tributary kilometer; WCK $=$ White Oak Creek kilometer; BFK $=$ Brushy Fork kilometer.

On a seasonal basis, density of benthic macroinvertebrates in WOL exhibited peaks in July and January, while the lowest densities occurred in March and September (Fig. 6-8). Biomass (excluding snails) achieved its highest peak in July before dropping considerably in September (Fig 6-8). Biomass then reached a smaller peak in November before gradually dropping during January and March. 

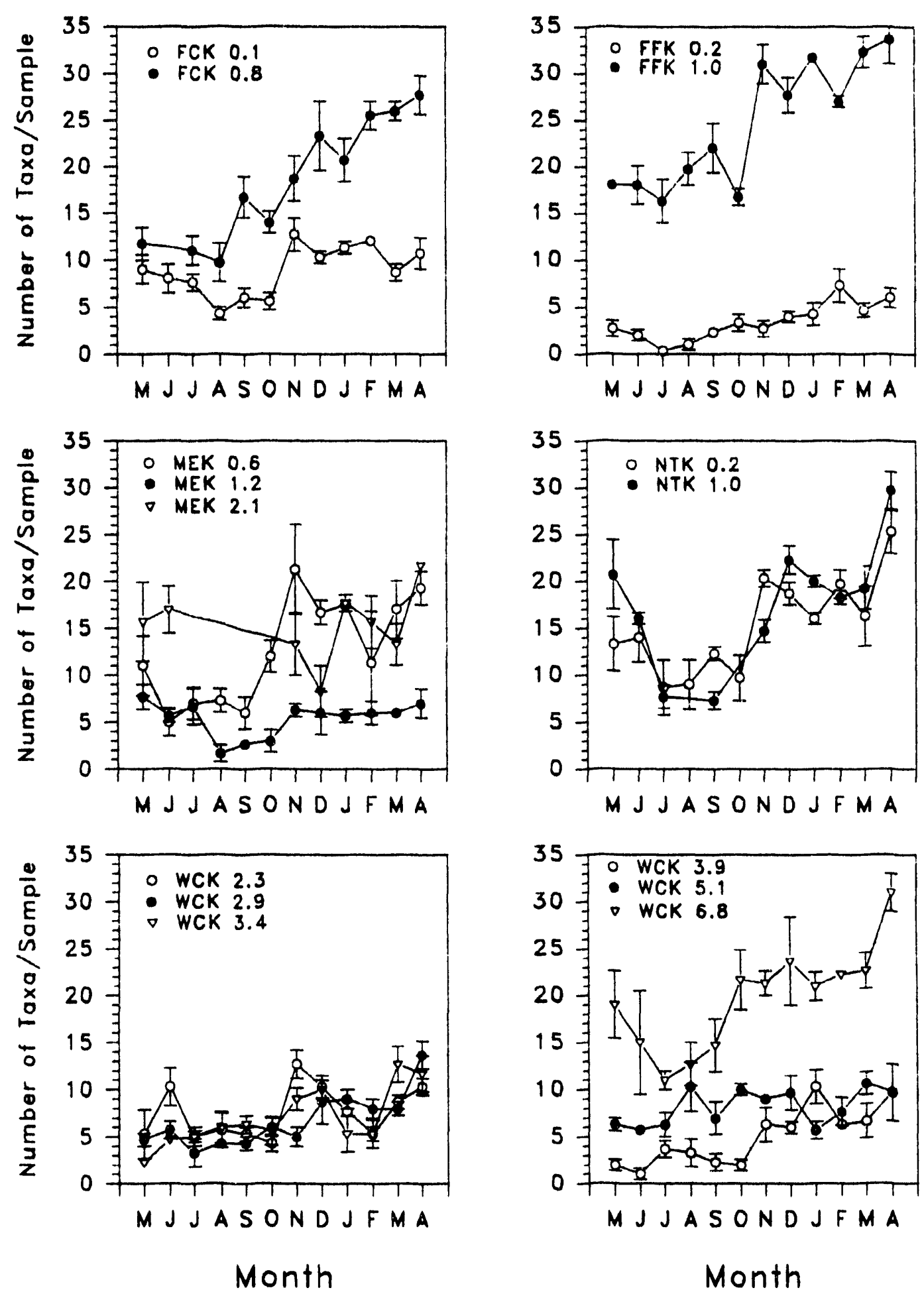

Fig. 6-6. Monthly mean number of benthic macroinvertebrate tan per sample in White Oak Creek watershed, May 1986-April 1987. FCK = First Creek kilometer; MEK = Melton Branch kilometer; WCK = White Oak Creek kilometer; FFK = Fifth Creek kilometer; NTK = Northwest Tributary kilometer; 
Table 6-8. Comparieons of mean benthic macroinvertcbrate diversity $\left(\mathrm{H}^{\prime}\right)$ in White Oak Creck watershor"

Site

\section{First Creek}

$\frac{\text { FCK } 0.8}{n=32} \quad \frac{\text { FCK } 0.1}{n=33}$

Fith Croek

$\begin{array}{ll}\text { EFK 1.0 } & \text { FFK } 0.2 \\ n=36 & n=36\end{array}$

Melton Branch

$\begin{array}{ll}\text { MEK } 2.1 & \text { MEK } 0.6 \\ n=24 \quad n=23\end{array}$

MEK 0.6

$n=35$

\section{MEK 1.2}

$n=23$

\section{Northwest Tributary

$\frac{\text { NTK } 1.0 \quad \text { NTK } 0.2}{n=30 \quad n=30}$

White Oak Creek

WCK 6.8 WCK 5.1 WCK 2.3 WCK 2.9 WCK 3.4 WCK 3.9

\begin{tabular}{|c|c|c|c|}
\hline$n=36$ & $n=36$ & $n=36 \quad n=36$ & $n=36$ \\
\hline & & $\frac{\text { BFK 7.6 }}{n=60}$ & $\frac{\text { WCK } 2.3}{n=36}$ \\
\hline
\end{tabular}

${ }^{a} N=$ number of samples. Sites connected by the same line are not significantly different $(p>0.05)$, based on Tukey's studentized range (HSD) test. Sites are arranged in order of highest to towest values from left to right. Sive: FCK = First Creek kilometer; FFK = Fifth Creek kilometer; MEK = Melton Branch kilometer; NTK $=$ Northwest Tributary kilometer; WCK $=$ White Oak Creek kilometer, BFK $=$ Brushy Fork kilometer.

The benthic fauna was neither very rich nor diverse in WOL. Mean annual richness per sample and diversity $\left(\mathrm{H}^{\prime}\right)$ were 5.5 and 1.7 respectively (Table 6-9), and neither parameter varied much between sampling periods (Fig. 6-8). The maximum (6.6) and minimum (4.2) richness per sample occurred in January and May, respectively, while maximum and minimum diversity occurred in November $\left(H^{\prime}=1.9\right)$ and January $\left(H^{\prime}=1.5\right)$ respectively. 
CRNL DWG 88-8974
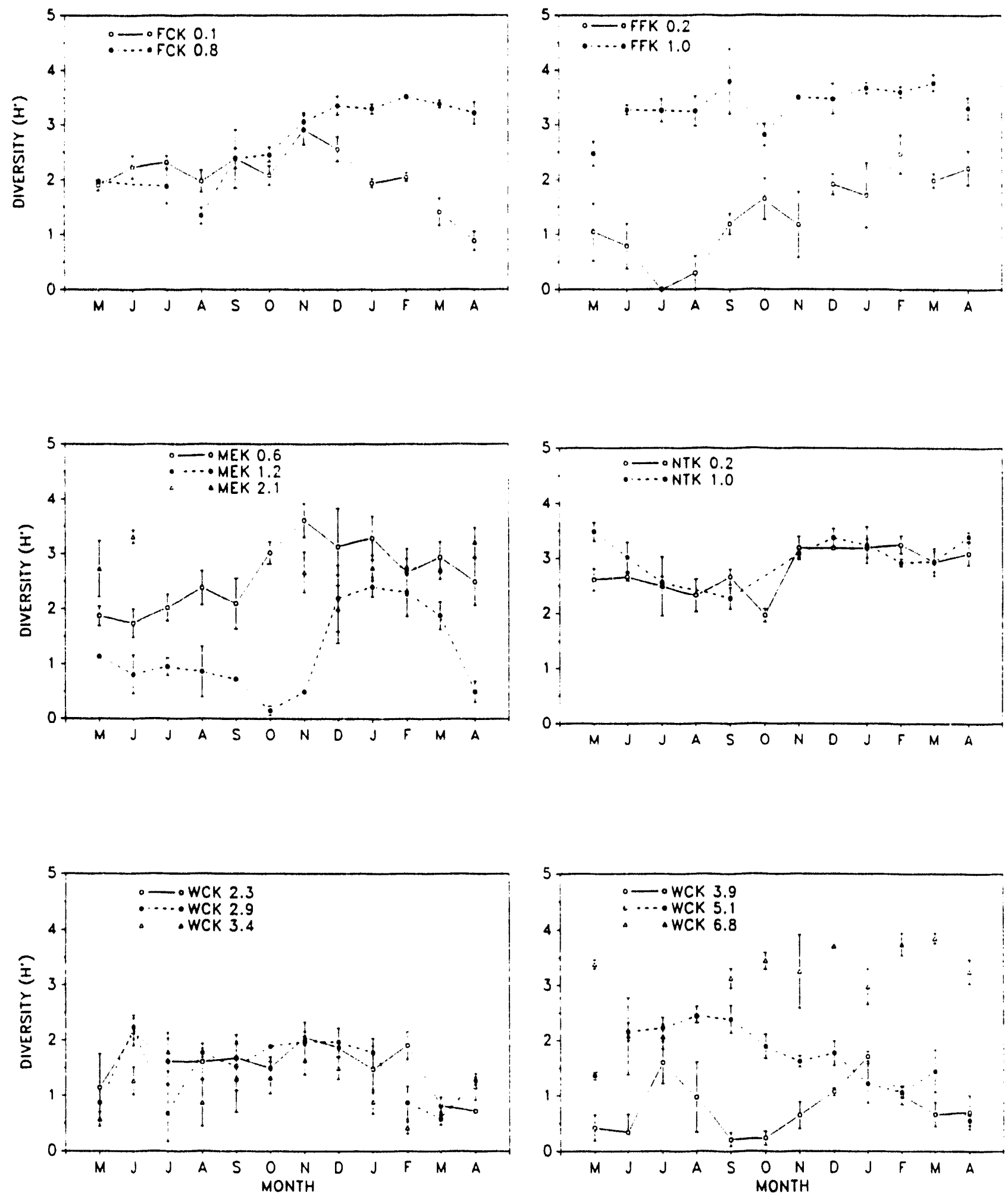

Fis 6-7. Monthly mean species diversity of benthic macroinveriebrates in White Oak Creek watershed, May 1986-April 1987. FCK = First Creek kilometer; FFK = Fifth Creek kilometer; MEK = Melton Branch kilometer; NTK $=$ Northwest Tributary kilometer; WCK $=$ White Oak Creek kilometer. 
Table 6-9. Mean annual density (number per $0.1 \mathrm{~m}^{2}$ ), biomass (milligrams wet weight per $0.1 \mathrm{~m}^{2}$ ), richness (number of tas per sample), and diversity $\left(\mathrm{H}^{\prime}\right)$ of benthic macroinvertebrates in White Oak Lake (WCK 1.1), May 1986-March 1987

Standard error of the mean is given in parentheses; $n=30$

\begin{tabular}{|c|c|}
\hline Parameter & Estimate \\
\hline Density" & $\begin{array}{l}166.8 \\
(27.4)\end{array}$ \\
\hline Densityb & $\begin{array}{c}0.4 \\
(0.3)\end{array}$ \\
\hline Biomass" & $\begin{array}{l}144.7 \\
(25.3)\end{array}$ \\
\hline Biomass $^{b}$ & $\begin{array}{c}5.7 \\
(5.2)\end{array}$ \\
\hline Richness & $\begin{array}{c}5.5 \\
(0.4)\end{array}$ \\
\hline Diversity & 1.7 \\
\hline
\end{tabular}

-All taxa except Mollusca and Decapoda.

'Mollusca and Decapoda only.

\subsubsection{Discussion}

\subsubsection{White Oak Creek and tributaries}

Continued studies on the benthic macroinve tebrate communities of the streams in WOC watershed confirmed the findings presented in the first annual report that varying degrees of impact have occurred on all study strean is (Loar et al. 1992). These studies also support the conclusions presented in Loar $\because:$ al. (1992) that, relative to past studies (Krumholz 1954; Blaylock, unpublished data, as :-ported in Loar et al. 1981; Loar et al. 1981), (1) WOC north of Bethel Valley Road appears "healthy" and unimpacted; (2) the benthic fauna of WOC south of Bethel Valley Road is sill impacted but some recovery has occurred in lower WOC; (3) the benthos in Melton Brisnch below the tributary draining the HFIR area are still adversely impacted; and (4) the benthic community in lower Northwest Tributary remains moderately impacied and has changed little since 1974.

All reference sites in the WOC watershed (FCK 0.8, FFK 1.0, MEK 2.1, NTK 1.0, and WCK 6.8) were characterized by rich and diverse benthic communities in which no one group of organisms was overwhelmingly numerically dominant. The nonreference sites 
ORNL DWG 88-8975
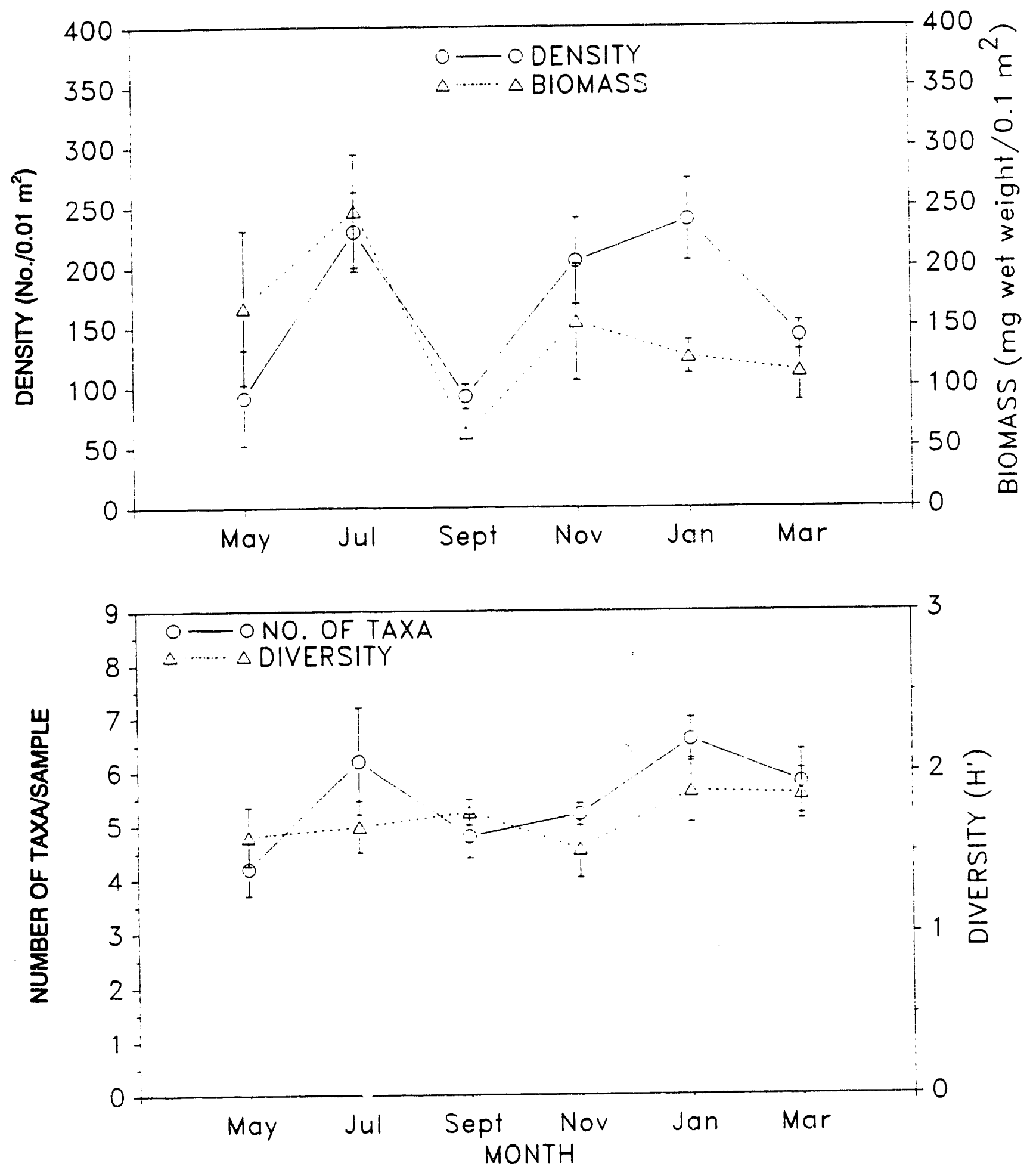

Fig. 6-8. Monthly mean density, biomass, number of tax per sample, and diversity of benthic macroinvertebrates in White Oał Lake, May 1986-March 1987. 
of each stream, however, were characterized, in general, by significantly lower richness and diversity; chironomids were usually the most abundant taxa (primarily taxa within the Cricotopus/Orthocladius group); and, at the less impacted sites, caddisfly densities (almost exclusively Cheumatopsyche and/or Hydropsyche) also tended to increase. This pattern has been observed in other polluted streams (e.g., Hynes 1960, Wiederholm 1984, Winner et al. 1980) and has also been observed in other streams on the DOE ORR [J. G. Smith, Environmental Sciences Division (ESD), ORNL unpublished data]. Conspicuously absent, or in very low numbers at the nonreference sites, were mayflies and stoneflies, groups of organisms which, with few exceptions, are generally intolerant to adverse environmental change (e.g., Hynes 1960, Wiederholm 1984).

The benthic community at a site in lower Fifth Creek (FFK 0.2) remained the most severely impacted, while the communities at MEK 1.2, WCK 3.4, and WCK 3.9 were also severely impacted but to a lesser extent than at FFK 0.2. These sites generally had the lowest richness and diversity of any site within the watershed, and FFK 0.2 had the lowest density. The composition and structure of the benthic communities at FCK 0.1, WCK 2.3, WCK 2.9, and WCK 5.1 continued to be indicative of moderately stressed conditions, as discussed in Loar et al. (1992). These sites all had communities numerically dominated by chironomids; however, the sites also, on either a consistent or periodic basis, had relatively high densities of caddisflies. Further evidence of impact in lower WOC at WCK 2.3 was the significantly lower density, richness, and diversity compared with Brushy Fork (BFK 7.6), a nearby reference stream of similar size.

The impact on the benthic communities at MEK 0.6 and NTK 0.2 was not as evident as it was at the other nonreference sites. These two sites did not differ significantly from their reference sites in either density, biomass, richness, or diversity; however, they differed considerably from the reference sites in taxonomic composition. Like other sites downstream of ORNL facilities, these sites were numerically dominated primarily by chironomids, especially MEK 0.6. With the exception of an increase in the numbers of a relatively pollution-tolerant stonefly (Amphinemura delosa) (J. G. Smith, ORNL, personal observations) at MEK 0.6 in March and April, mayflies and stoneflies were virtually absent from both sites. Thus, the absence of the kind of diverse community that is otherwise typical of the upstream reference sites, as well as the other reference sites, demonstrates the impacts on these benthic communities.

Several potential or known causes of stress occur within the WOC watershed, such as chlorine discharges (Sect. 3.1) and alterations in the natural flow and thermal regimes (Table 2-2 and Figs. 2-6 and 2-7). Most likely, the benthic communities are being impacted by a combination of factors rather than a single factor. In some cases, these factors may be acting synergistically and, therefore, increasing the level of stress that would be expecter solely on the basis of water quality or temperature alone. For example, it has been estimated that at a given concentration of a toxicant, survival is generally reduced by half with a temperature increase of $10^{\circ} \mathrm{C}$ (Hynes 1960).

Concentrations of residual chlorine have been reported at several sites, including FCK 0.1, FFK 0.2, NTK 0.2, WCK 2.9, WCK 3.4, and WCK 3.9 (Loar et al. 1992; Sect. 3.1 of this report). However, ambient toxicity tests have demonstrated that only water from FFK 0.2 and WCK 3.9 is periodically toxic (Loar et al. 1992; Sect. 3.1 of this ref rt). 
Benthic macroinvertebrate densities were consistently low at FFK 0.2, suggesting persistently toxic conditions. While densities of invertebrates at the other nonreference sites were sometimes low, densities at these sites were sometimes as high as or higher than those at the reference sites. As discussed previously, the benthic invertebrate communities at these nonreference sites were numerically dominated by chironomids and differed considerably in species composition from the reference sites. In addition to the high tolerance of some chironomid taxa to pollutants (e.g., Beck 1977), many have high turnover rates and are able to produce several generations a year (e.g., Mackay 1977). This suggests that episodic releases of toxicants could be a major factor controlling the structure as well as the composition of the benthic communities at the nonreference sites. Because chironomids have the capability of producing several generations a year, nonexposed (e.g., adult) and/or resistant (e.g., egg) stages are probably present much of each year, while taxa producing two or fewer generations a year (e.g., most mayflies, stoneflies and caddisflies) have nonexposed or resistant stages present at limited times during the year. Consequently, in the event of a release of a toxicant, chironomids could rapidly recolonize an area while other taxa might be eliminated. Continued monitoring of benthic macroinvertebrates will provide a valuable tool for assessing future recovery of the stream benthos in WOC watershed.

Another major source of anthropogenic stress to the benthic communities of the nonreference sites is the elevation of temperatures (Sect. 2.2.3). Temperatures exceeding $30^{\circ} \mathrm{C}$ were recorded at several sites, especially lower Fifth Creek and the middle reaches of Melton Branch (Table 2-6). Temperatures in excess of $20^{\circ} \mathrm{C}$ can be lethal to some invertebrates (e.g., mayflies and stoneflies), and even sublethal temperatures and altered daily and seasonal fluctuations can alter growth and development (e.g., Wiederholm 1984). This may partially explain why mayflies and stoneflies are absent from or contribute little to the benthic communities of the nonreference sites.

Many of the sites in the WOC watershed are highly enriched with nutrients (Table 2-8). A benthic community under enriched conditions is typically characterized by low taxonomic richness and sometimes high densities of a few taxa (Hynes 1960, Wiederholm 1984). These attributes were typical of the benthic communities at most of the nonreference sites. A good example of the effects of extreme nutrient enrichment occurred in WOC following an ethylene glycol spill on September 27, 1986. Within $\sim 5$ weeks after the spill occurred, large numbers of chironomids were observed inhabiting heavy microbial growths in the stream between the source of the spill (6000 area) and the downstream site, WCK 3.4 (J. G. Smith, ORNL, personal observation, November 3, 1986). Routine quantitative benthos samples collected in the months following the spill showed that both density and biomass dramatically increased at WCK 3.9 and, to a lesser extent, at sites farther downstream. From levels similar to those observed at FFK 0.2, densities increased to levels exceeding those of the reference site (WCK 6.8).

The benthic invertebrate communities in WOC watershed may also be impacted by flow augmentation (Sect. 2.1). Like other perturbations, altered flow regimes can affect the composition of a benthic community (Ward and Stanford 1979, Wiederholn 1984). Most likely, the major effects of flow augmentation in the WOC watershed are not caused directly, by increased discharge or velocity, but indirectly, from the pollutants that these additional discharges contain. This becomes particularly important to stream invertebrates 
during periods of low natural flow because dilution of the effluents is decreased. Both upper Melton Branch and Northwest Tributary experienced recent periods of zero discharge and very low discharge (Sect. 2.1 and Table 2-1); thus, streamflow downstream of these sites consisted of $100 \%$ effluent during extended periods in both 1986 and 1987. Periods of zero discharge appeared to have little lasting effect on the reference sites of these streams, which had communities of similar composition before and after these periods. Thus, although the discharges into these streams served to maintain flow in the downstream sites, the low quality of the water in these discharges does not support the development or establishment of healthy, well-balanced benthic communities.

Siltation resulting from past and current construction activities could also impact the benthic macroinvertebrate communities of the nonreference sites. Silt can affect invertebrates both directly (e.g., through the obstruction of food collection and respiration) and indirectly (e.g., by modification of habitat and changes in food quality) (Wiederholm 1984). Increased amounts of silt were evident at several nonreference sites, including FCK 0.1, WCK 3.9, and WCK 2.9 (J. G. Smith, ORNL, personal observation).

Once a perturbation is reduced or ceases, the ability of a benthic community to recover depends upon the duration, severity, and type of perturbation; dilution; the physical and chemical characteristics of the receiving body of water; and the source of the invertebrates that will recolonize the impacted region (Hynes 1960, Wiederholm 1984, Williams and Hynes 1976). One of the major sources of recolonization in streams is usually drift, although aerial and upstream migration may also contribute (Williams and Hynes 1976). Even after stresses are reduced or terminated, recovery may be slowed somewhat because of the long-term nature of the stress(es) to which the invertebrates in the WOC watershed have been exposed. However, recovery will be promoted because the unimpacted headwaters of the streams will serve as a good source of organisms for recolonization.

\subsubsection{White Oak Lake}

No notable major changes appeared to have occurred in WOL since preliminary data were presented in the first annual report of BMAP (Loar et al. 1992). Benthos diversity and richness values were similar to those reported previously (Loar et al. 1992), and the community continued to be dominated numerically by chironomids, as well as, at times, by the phantom midge (Chaoborus).

As was noted in the first annual report, several changes appear to have occurred in the benthic community of WOL since the study of Loar $e_{i}$ al. (1981), including (1) the appearance of Chaoborus as a major component of the invertebrate community, (2) a reduction in numbers of ceratopogonids and the snail Physella; and (3) the reduction or loss of mayflies (Loar et al. 1992). Based on the results of a complete year of sampling, the occurrence of Chaoborus as a major component of the community and the reductions in ceratopogonid and snail densities appear to be real changes.

The mayfly Caenis was collected in qualitative samples in the spring of 1987 , thus indicating that this mayfly still inhabits WOL but in unknown densities. However, another mayfly (Callibaetis) that was abundant in 1979-80 (Loar et al. 1981) was not collected in 
either qualitative or quantitative samples. The data of Loar et al. (1981) showed that Callibaetis was collected only during the summer and fall, indicating that if this mayfly occurs in WOL, it is only during certain seasons. Such a pattern may explain its absence in the spring qualitative samples, if indeed it still exists in WOL. The initiation of a sampling program in the spring of 1987 with artificial substrates (Loar et al. 1992, Sect. 6.1.6) should help resolve this question. Because the transect presently being sampled is approximately the same as that sampled by Loar et al. (1981) (L. M. Stubbs, ORNL, personal communication), it is assumed that a major change in either habitat or water quality or both may have occurred in WOL since 1980.

\subsection{Future studies}

Characterization of the benthic macroinvertebrate communities will continue through a second year of intensive sampling to provide a better understanding of the normal annual changes that occur in the streams near ORNL and in WOL. Sampling frequency will continue at monthly intervals in the stream sites and bimonthly in WOL. After April 1988 , sampling frequency will be reduced to once per quarter except for sampling of benthic invertebrates with artificial substrates in WOL, which will continue on a bimonthly basis through April 1989. Qualitative samples will again be collected at all sites during the spring of 1988, but in succeeding years will be taken only from downstream (nonreference) sites.

In conjunction with the periphyton and fish studies (Sects. 3.2 and 6.2, respectively), a characterization of physical habitat will be conducted at each site, and the effect of habitat differences on benthic community structure will be assessed. The characterization will include measurements of substrate type, current velocity, canopy cover, and other relevant parameters.

Additional in situ and/or laboratory studies will be designed and initiated during the third year to test the hypotheses that (1) elevated temperatures may exclude certain benthic macroinvertebrate taxa from some streams, (2) some sites are subjected to subacute or chronic exposures of toxicants, and (3) the composition of the benthic community at some sites is controlled by periodic releases of toxicants. Suitable species for testing these hypotheses will be obtained from reference streams within WOC watershed or off-site. Adult stages of aquatic insects will be collected at selected sites to assess the occurrence of recolonization. This evaluation could provide insight on the recolonization potential and habitability of impacted sites, as evidenced by the occurrence of new species in the vicinity of these sites.

Analyses in future reports will continue to incorporate data from reference sites used in other biological monitoring programs for the DOE Oak Ridge facilities. Additional analyses to be incorporated in future annual reports include secondary production and indices of similarity. 


\subsection{FISHES}

\section{2 .1 Introduction}

Fish population and community studies can be used to assess the ecological effects of water quality and habitat degradation. These studies offer several advantages over other indicators of environmental quality (see Karr et al. 1986, Karr 1987) and are especially relevant to assessment of the biotic integrity of WOC. Fish communities, for example, include several trophic levels, and species that compose the potential sport fishery in WOC [e.g., bluegill (Lepomis macrochirus), redbreast sunfish (L. auritus), and largemouth bass (Micropterus salmoides)] are at or near the end of food chains. Consequently, fish populations integrate the direct effects of water quality and habitat degradation on primary producers (periphyton) and consumers (benthic invertebrates) that are utilized for food. Because of these trophic interrelationships, the well-being of fish populations has often been used as an index of water quality (Weber 1973, Greeson et al. 1977, Karr et al. 1986). Moreover, statements about the condition of the fish community are better understood by the general public (Karr 1981).

The initial objectives of the instream fish monitoring task (Subtask $4 \mathrm{~b}$ of BMAP, as described in Loar et al. 1991) were (1) to characterize spatial and temporal patterns in the distribution and abundance of fishes in WOC and (2) to document any effects on fish community structure and function resulting from implementation of the ORNL Water Pollution Control Program and Remedial Action Program.

\subsection{Methods}

\subsubsection{Population Surveys}

Quantitative sampling of the fish populations at 16 sites in WOC watershed (Fig. 2-2) was conducted by electrofishing in January-February 1987, March-April 1987, and November-December 1987 to estimate population size (numbers and biomass per unit area). The mean length of the sampling reaches ranged from 26 to $69 \mathrm{~m}$ at the tributary sites and from 47 to $155 \mathrm{~m}$ at the WOC sites (Table 6-10). Fish sampling sites either overlapped or were within $100 \mathrm{~m}$ of the sites included in the instream benthic invertebrate monitoring task (Sect. 6.1), except for FFK 0.4, where benthos were not sampled. Lengths of the sampling reaches were similar to those used in 1985-86 (Loar et al. 1992, Table 6-6), except where the high density of fish required a reduction in length.

Qualitative sampling of WOC watershed was conducted from May to July 1987. Areas sampled included WOL (in conjunction with a population census, see Appendix F), impoundments of WOC behind two large weirs, and six research ponds located just south of Building 1504 and adjacent to Northwest Tributary.

Field Sampling Procedures. All stream sampling was conducted with the use of one or two Smith-Root Model 15A backpack electrofishers, depending on stream size. Each unit has a self-contained, gasoline-powered generator capable of delivering up to $1200 \mathrm{~V}$ of pulsed direct current. A pulse frequency of 90 to $120 \mathrm{~Hz}$ was used, and the output 
Table 6-10. Mean lengths, widths, depths, and surface areas (range in parentheses) of fish sampling sites in White Oak Creek, First Creek, Fifth Creek, Melton Branch, and

Northwest Tributary, January-December 1987

\begin{tabular}{|c|c|c|c|c|}
\hline Site $^{a}$ & Length (m) & Width (m) & Area $\left(m^{2}\right)$ & Depth $(\mathrm{cm})$ \\
\hline FCK 0.1 & $\begin{array}{c}63 \\
(60-68)\end{array}$ & $\begin{array}{c}1.2 \\
(1.0-1.4)\end{array}$ & $\begin{array}{c}75 \\
(68-82)\end{array}$ & $\begin{array}{c}9.9 \\
(7.5-11.6)\end{array}$ \\
\hline FCK 0.8 & $\begin{array}{c}32 \\
(29-35)\end{array}$ & $\begin{array}{c}1.5 \\
(1.4-1.7)\end{array}$ & $\begin{array}{c}48 \\
(48-49)\end{array}$ & $\begin{array}{c}9.8 \\
(7.2-12.5)\end{array}$ \\
\hline FFK 0.2 & $\begin{array}{c}69 \\
(63-73)\end{array}$ & $\begin{array}{c}1.1 \\
(1.0-1.2)\end{array}$ & $\begin{array}{c}76 \\
(61-87)\end{array}$ & $\begin{array}{c}11.9 \\
(11.4-12.4)\end{array}$ \\
\hline FFK 0.4 & $\begin{array}{c}26 \\
(25-28)\end{array}$ & $\begin{array}{c}1.5 \\
(1.2-1.7)\end{array}$ & $\begin{array}{c}41 \\
(31-49)\end{array}$ & $\begin{array}{c}12.4 \\
(9.7-14.0)\end{array}$ \\
\hline FFK 1.0 & $\begin{array}{c}30 \\
(29-30)\end{array}$ & $\begin{array}{c}0.9 \\
(0.8-1.0)\end{array}$ & $\begin{array}{c}27 \\
(25-29)\end{array}$ & $\begin{array}{c}7.7 \\
(6.4-8.6)\end{array}$ \\
\hline MEK 0.6 & $\begin{array}{c}53 \\
(50-55)\end{array}$ & $\begin{array}{c}3.0 \\
(2.7-3.2)\end{array}$ & $\begin{array}{c}155 \\
(142-164)\end{array}$ & $\begin{array}{c}17.1 \\
(14.0-22.5)\end{array}$ \\
\hline MEK 1.4 & $\begin{array}{c}51 \\
(50-52)\end{array}$ & $\begin{array}{c}2.4 \\
(2.3-2.6)\end{array}$ & $\begin{array}{c}122 \\
(119-128)\end{array}$ & $\begin{array}{c}11.9 \\
(9.1-14.9)\end{array}$ \\
\hline MEK 2.1 & $\begin{array}{c}48 \\
(46-49)\end{array}$ & $\begin{array}{c}1.4 \\
(0.7-1.8)\end{array}$ & $\begin{array}{c}69 \\
(31-88)\end{array}$ & $\begin{array}{c}5.1 \\
(2.7-7.2)\end{array}$ \\
\hline NTK 0.3 & $\begin{array}{c}65 \\
(62-69)\end{array}$ & $\begin{array}{c}2.4 \\
(2.3-2.5)\end{array}$ & $\begin{array}{c}155 \\
(141-175)\end{array}$ & $\begin{array}{c}6.5 \\
(6.1-6.8)\end{array}$ \\
\hline NTK 1.0 & $\begin{array}{c}37 \\
(35-39)\end{array}$ & $\begin{array}{c}2.2 \\
(1.4-2.7)\end{array}$ & $\begin{array}{c}85 \\
(48-107)\end{array}$ & $\begin{array}{c}7.3 \\
(4.4-9.1)\end{array}$ \\
\hline WCK 2.3 & $\begin{array}{c}88 \\
(85-92)\end{array}$ & $\begin{array}{c}5.6 \\
(5.4-5.8)\end{array}$ & $\begin{array}{c}497 \\
(457-533)\end{array}$ & $\begin{array}{c}27.7 \\
(25.4-28.8)\end{array}$ \\
\hline WCK 2.9 & $\begin{array}{c}92 \\
(88-97)\end{array}$ & $\begin{array}{c}5.0 \\
(4.9-5.2)\end{array}$ & $\begin{array}{c}464 \\
(438-504)\end{array}$ & $\begin{array}{c}36.2 \\
(34.7-39.5)\end{array}$ \\
\hline WCK 3.4 & $\begin{array}{c}60 \\
(58-63)\end{array}$ & $\begin{array}{c}3.2 \\
(3.2-3.2)\end{array}$ & $\begin{array}{c}192 \\
(185-201)\end{array}$ & $\begin{array}{c}33.8 \\
(28.1-39.6)\end{array}$ \\
\hline WCK 3.9 & $\begin{array}{c}155 \\
(150-161)\end{array}$ & $\begin{array}{c}2.8 \\
(2.6-3.0)\end{array}$ & $\begin{array}{c}434 \\
(410-463)\end{array}$ & $\begin{array}{c}17.6 \\
(13.9-21.5)\end{array}$ \\
\hline WCK 5.1 & $\begin{array}{c}47 \\
(45-48)\end{array}$ & $\begin{array}{c}1.8 \\
(1.5-2.1)\end{array}$ & $\begin{array}{c}82 \\
(68-99)\end{array}$ & $\begin{array}{c}10.7 \\
(9.2-12.1)\end{array}$ \\
\hline WCK 6.8 & $\begin{array}{c}54 \\
(53-55)\end{array}$ & $\begin{array}{c}2.4 \\
(2.2-2.7)\end{array}$ & $\begin{array}{c}130 \\
(123-141)\end{array}$ & $\begin{array}{c}7.6 \\
(6.1-10.0)\end{array}$ \\
\hline
\end{tabular}

${ }^{a}$ FCK $=$ First Creek kilometer; FFK = Fifth Creek kilometer; MEK = Melton Branch kilometer; NTK = Northwest Tributary kilometer; $\mathbf{W C K}=$ White Oak Creek kilometer. 
voltage was adjusted to the optimal value (generally $400 \mathrm{~V}$ or less) based on the specific conductance of the water. The circular (ring) electrode at the end of the fiberglass anodepole was fitted with a nylon net $(0.64-\mathrm{cm}$ mesh) to allow the electrofisher operator to collect stunned fish.

After a $0.64-\mathrm{cm}$-mesh seine was placed across the upper and lower boundaries of the fish sampling site to restrict fish movement, a two- to five-person sampling team electrofished the site in an upstream direction on three consecutive passes. If fish numbers captured during the first pass were extremely low or zero, then only one pass was made. Depending upon the turbidity of the water, the consecutive passes could not always be made immediately. Rather, fish were processed after each pass to allow sufficient time for the water to clear before another pass was initiated. Stunned fish were collected and stored, by pass, in wire mesh cages $(0.64-\mathrm{cm}$ diam) or in buckets with small holes during further sampling.

After electroshocking was completed, fish were anesthetized with MS-222 (tricaine methanesulfonate), identified, measured to the nearest $0.1 \mathrm{~cm}$ (total length), and weighed by using Pesola spring scales to the nearest $0.1 \mathrm{~g}$ (for fish less than $100 \mathrm{~g}$ ) or to the nearest gram (for fish greater than $100 \mathrm{~g}$ ). At sites with high fish densities, individuals were recorded by $1-\mathrm{cm}$ size classes and species. If 25 individuals of a species-size class were measured and weighed, additional members of that size class were only measured. Length-weight regressions (SAS 1985b) were later used to estimate missing weight data. Other data recorded included sex and reproductive state (if possible to determine), disposition (i.e., dead or kept for laboratory identification and reference collection), and presence of any abnormalities (e.g., external parasites and skeletal deformities).

After processing fish from all passes, the fish were allowed to fully recover from the anesthetic and were returned to the stream. Any additional mortality occurring as a result of processing was noted at that time. In addition to data on individual fish, conductivity, $\mathrm{pH}$, water temperature, turbidity, dissolved oxygen, cloud cover, and shocking time-as well as the length, width, and depth of the sampling reach-were recorded at each site.

Ponds and impoundments were qualitatively sampled using a Smith-Root Type IV, boat-mounted electrofisher with pulsed DC current and one or two booms. Because the purpose of this qualitative sampling was to identify additional species not collected in the routine quantitative sampling of WOC and tributaries, the time and effort expended at each impoundment was variable, depending on the variety of species encountered. At least $30 \mathrm{~min}$ of sampling was conducted at each site. Captured specimens were identified in the field, and only those species new to the WOC watershed or difficult to identify were preserved for identification in the laboratory and inclusion in the reference collection.

Data Analysis. After reviewing the information on the field data sheets for completeness and accuracy, the data were entered and stored on IBM 3033 computers and analyzed with the use of SAS procedures (SAS 1985a, 1985b).

Species population estimates were calculated by using the method of Carle and Strub (1978). Biomass was estimated by multiplying the population estimate by the mean weight 
per individual. To calculate density and biomass per unit area, total numbers and biomass were divided by the surface area (in square meters) of the study reach. For each sampling date, surface area was estimated by multiplying the length of the sampling reach by the mean width based on measurements taken at 5-m intervals (Table 6-10).

Condition factors (K) were calculated for individual fish by site and species by using the formula

$$
K=100\left(\text { weight/length }{ }^{3}\right),
$$

with weight in grams and total length in centimeters (Hile 1936). Fish without measured weights were not used in calculations of condition factors. Comparisons of condition factors between sites and between sampling periods were made using an analysis of variance procedure (PROC GLM) on untransformed data (SAS 1985b) because the condition factors exhibited homogeneity of variance as estimated with the UNIVARIATE procedure (SAS 1985a). If the GLM procedure indicated significant differences in condition factors between groups, the Tukey test was performed to identify those groups that were significantly different.

Analyses of growth were performed by using PROC GLM and PROC MEANS procedures (SAS 1985a, 1985b) with length, weight, and age data for redbreast and bluegill sunfish. Two different parameters, the population growth rate and the true growth rate, were estimated using t'.e procedures described by Ricker (1975). The population growth rate, which is the mean weight of surviving fish at successive age groups, was calculated for bluegill and redbreast sunfish at BFK 7.6, WCK 2.3, WCK 3.4, WOL, Environmental Sciences Division (ESD) 5 pond, and ESD 2 pond. Mean weights (calculated by the PROC MEANS procedure on untransformed data) were correlated with age classes to derive the population growth curves, as was done for these species in 1986 (Loar et al. 1992). Comparisons between sites of the mean weight of a given age class was performed using the Tukey test to evaluate site differences.

The true growth, which is the instantaneous rate of increase in weight for the most recent year of growth, was calculated for bluegill and redbreast sunfish at BFK 7.6, WCK 2.3, WCK 3.4, WOL, and ESD 5 pond. This latter analysis involved the following steps: (1) determine the age from scales (see Sect. 6.2.2.2) and measurement of successive annuli; (2) estimate the relationship between scale length and fish length; (3) backcalculate body length at the start and close of the last complete year contained on the scale at each age for each fish; (4) calculate the functional slope, $b$, of the length-weight regression for each fish population; (5) calculate the natural logarithm of lengths determined in (3) for each fish and subtract the logarithms (equals instantaneous rate of increase in length for each fish); and (6) average the instantaneous rates of increase for each age group and multiply by $b$ to obtain the instantaneous rate of increase in weight at each age (Ricker 1975). The formula for the backcalculation of length at each annulus (Carlander 1981) was

where,

$$
B C L=a+[(\Gamma L-a) / R L] A L,
$$

$$
\mathrm{BCL}=\text { backcalculated length at the time of annulus formation, }
$$




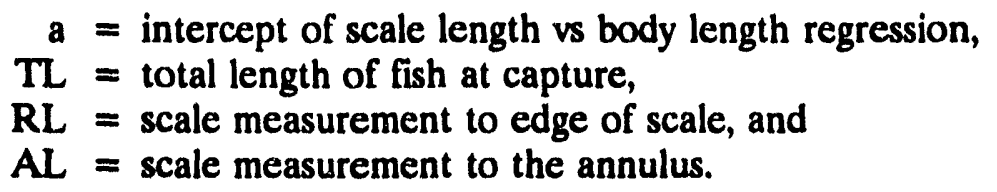

For these analyses, a common value of $20 \mathrm{~mm}$ was used for the constant a, as determined and recommended by Carlander (1982). The formula for the length-weight regression (Ricker 1975) was

$$
\log \text { weight }=\log a+b(\log \text { length })
$$

and was determined using PROC GLM (SAS 1985b) to estimate the slope, $b$.

\subsection{Age Determination}

Scales were taken for age determination from target species (redbreast and bluegill sunfish) collected during the fall 1987 population surveys. Because of the low densities of these species at the fish sampling sites in WOC, additional sampling above and/or below the site was necessary to obtain a larger sample size. Scale data for bluegill and redbreast sunfish collected in October 1987 from Brushy Fork, a reference stream, were used for comparison. Additionally, scale samples were taken during the population survey of WOL (see Appendix F) and during the qualitative sampling of the research ponds (ESD 2 and ESD 5).

Scales were taken from an area above the lateral line and slightly anterior to the insertion of the dorsal fin. Impressions of the scales were made by using a Wildco scale press and acetate slides. Enlarged images of the scales were projected on a screen by using an Bruning $\mathbf{4 0 2 0}$ microfiche reader with a $15-\mathrm{mm}$ lens. Where possible, at least ten scales from each fish were mounted and compared. For actual measurements of annuli, the best representative scale was used. Scales identified as regenerated (latinucleate) and those that were damaged or highly irregular in shape were not read. In some cases, no age data were obtained because all scales were unsuitable. In this analysis, ages were determined by one person; questionable scales were reviewed by a second observer and used for age analysis only if a consensus could be reached.

The following data were recorded for each scale examined: number of annuli, total length of scale radius (distance from focus to anterior margin), and length of radius to various annuli. The annulus was determined by examining (1) the intersection of the outermost margin of closely spaced (i.e., slow-growth) circuli with the innermost margin of widely spaced (i.e., rapid-growth) circuli, (2) the occurrence of cutting over of circuli at the lateral edges of the anterior field, (3) the increase in radii width or formation of holes in the radii, and (4) the termination or origin of radii.

\subsection{Results and Discussion}

\subsubsection{Species richness and composition}

A total of 15 species were collected in quantitative surveys of WOC during the 3 sampling periods in 1987 (Table 6-11). The lowermost site on WOC (WCK 2.3) had 
Table 6-11. Fish species composition in White Oak Creek, First Creek, Fifth Creek, Melton Branch, and Northwest Tributary, January-December 1987

\begin{tabular}{|c|c|c|c|c|c|c|c|c|c|c|c|c|c|c|c|c|}
\hline Species & $\begin{array}{l}\text { FCK } \\
0.1\end{array}$ & $\begin{array}{c}\text { FCK } \\
0.8\end{array}$ & $\begin{array}{c}\text { FFK } \\
0.2\end{array}$ & $\begin{array}{c}\text { FFK } \\
0.4\end{array}$ & $\begin{array}{c}\text { FFK } \\
1.0\end{array}$ & $\begin{array}{c}\text { MEK } \\
0.6\end{array}$ & $\begin{array}{c}\text { MEK } \\
1.4\end{array}$ & $\begin{array}{c}\text { MEK } \\
2.1\end{array}$ & $\begin{array}{c}\text { NTK } \\
0.5\end{array}$ & $\begin{array}{c}\text { NTK } \\
1.0\end{array}$ & $\begin{array}{l}\text { WCK } \\
2.3\end{array}$ & $\begin{array}{l}\text { WCK } \\
2.9\end{array}$ & $\begin{array}{c}\text { WCK } \\
3.4\end{array}$ & $\begin{array}{c}\text { WCK } \\
3.9\end{array}$ & $\begin{array}{c}\text { WCK } \\
5.1\end{array}$ & $\begin{array}{l}\text { WCK } \\
6.8\end{array}$ \\
\hline \multicolumn{17}{|l|}{ Centrarchidac } \\
\hline $\begin{array}{l}\text { Bluegill } \\
\text { (Lepomis macrochinus) }\end{array}$ & 2 & $\cdot$ & $\mathbf{N F}$ & - & - & - & - & - & 3 & 2 & 3 & 2 & 3 & 1 & - & $\cdot$ \\
\hline $\begin{array}{l}\text { Redbreast sunfish } \\
\text { (L. auritus) }\end{array}$ & . & - & - & - & $\cdot$ & 3 & - & $\cdot$ & - & - & 3 & 3 & 3 & - & - & $\cdot$ \\
\hline $\begin{array}{l}\text { Largemouth bass } \\
\text { (Micropterus salmoides }\end{array}$ & 1 & - & $\cdot$ & - & - & - & - & - & 1 & - & 1 & - & 1 & - & - & - \\
\hline $\begin{array}{l}\text { Spotted base } \\
\text { (M. punctulatus) }\end{array}$ & . & 2 & - & - & - & $\cdot$ & - & - & - & - & $\cdot$ & - & $\cdot$ & - & - & $\cdot$ \\
\hline $\begin{array}{l}\text { Warmouth } \\
\text { (L. gulosus) }\end{array}$ & $\cdot$ & - & $\cdot$ & - & - & - & - & - & - & - & 3 & - & - & - & - & - \\
\hline $\begin{array}{l}\text { Rock bass } \\
\text { (Ambloplities nupestris) }\end{array}$ & ) & - & - & - & - & - & - & - & - & 2 & - & - & - & - & - & \\
\hline \multicolumn{17}{|l|}{ Cottidae } \\
\hline $\begin{array}{l}\text { Banded sculpin } \\
\text { (Cottus carolinae) }\end{array}$ & $\cdot$ & - & - & 3 & 3 & - & - & - & - & - & - & - & - & - & 1 & 3 \\
\hline \multicolumn{17}{|l|}{ Cyprinidae } \\
\hline $\begin{array}{l}\text { Carp } \\
\text { (Cyprinus carpio) }\end{array}$ & $\cdot$ & - & - & - & - & - & - & - & - & - & 1 & - & - & - & - & - \\
\hline $\begin{array}{l}\text { Blacknowe dace } \\
\text { (Rhinicheloys atratulus) }\end{array}$ & 3 & 3 & - & 3 & 3 & 3 & 1 & 2 & 3 & 2 & 1 & 2 & 3 & 3 & 3 & 3 \\
\hline $\begin{array}{l}\text { Central stoneroller } \\
\text { (Campartoma anomah }\end{array}$ & (ium) & - & - & - & - & - & - & - & 1 & - & 3 & - & 1 & 1 & 3 & 1 \\
\hline $\begin{array}{l}\text { Creek chub } \\
\text { (Semotilus atromacular }\end{array}$ & $\begin{array}{l}1 \\
\text { zous) }\end{array}$ & 3 & - & - & - & 2 & 1 & 1 & 1 & 1 & - & 1 & 2 & 2 & 3 & 3 \\
\hline $\begin{array}{l}\text { Fathead minnow } \\
\text { (Pimephales promelas) }\end{array}$ & $2^{2}$ & - & - & - & - & - & - & - & 2 & 2 & 2 & 3 & 2 & 2 & 3 & - \\
\hline \multicolumn{17}{|l|}{ Gasterosteidae } \\
\hline $\begin{array}{l}\text { Brook stickleback } \\
\text { (Culaea inconrians) }\end{array}$ & - & - & - & - & - & - & - & - & - & - & 1 & 。 & - & - & - & - \\
\hline Ictaluridac & & & & & & & & & & & & & & & & \\
\hline $\begin{array}{l}\text { Yellow bullhead } \\
\text { (Ictalumus natalis) }\end{array}$ & $\cdot$ & - & $\cdot$ & - & - & - & - & - & - & - & 3 & - & - & - & - & - \\
\hline Poeciliidae & & & & & & & & & & & & & & & & \\
\hline $\begin{array}{l}\text { Mosquitofish } \\
\text { (Gambusia affinis) }\end{array}$ & 3 & - & - & - & - & - & - & - & 3 & - & 3 & 3 & 3 & 3 & - & - \\
\hline Number of species $(\mathrm{N})$ & 6 & 3 & $\mathbf{0}$ & 2 & 2 & 3 & 2 & 2 & 7 & 4 & 12 & 6 & 8 & 6 & 5 & 4 \\
\hline
\end{tabular}

aNumbers represent the number of sampling periods $(n=3)$ that a given species was collected at the site. WCK $=$ White Oak Creek kilometer, FCK $=$ First Creek kilometer, FFK $=$ Fifth Creek kilometer, MEK $=$ Melton Branch kilometer, NTK $=$ Northwest Tributary kilometer, BFK = Brushy Fork kilomeser.

${ }^{b} \mathrm{NF}=$ no fish taken in sample. 
12 species, of which 5 were centrarchids and 4 were cyprinids. Intermediate sites on WOC (WCK 2.9 to WCK 5.1) had five to eight species, while the uppermost reference site (WCK 6.8) had four species. The number of species in the WOC tributaries ranged from two to seven. No fish were collected in lower Fifth Creek (FFK 0.2).

An additional 13 species were collected in qualitative surveys of WOC, WOL, and the ESD research ponds (Table 6-12). Because the ESD ponds and WOL are directly linked to WOC, species in these impoundments can disperse throughout WOC and potentially affect the populations of endemic species. Consequently, information on the species composition of these ponds is important in evaluating changes in fish community composition in WOC. Several species in the ESD ponds were accidental introductions from ORNL research programs and occur only in these ponds, including the grass carp (Ctenophanygodon idella), smallmouth bass (Micropterus dolomieui), flathead catfish (Pylodictis olivaris), and striped bass (Morone saxatilis). Other species found in WOL were represented by only one specimen, including green sunfish (Lepomis cyanellus), freshwater drum (Aplodinotus grunniens), smallmouth buffalo (Ictiobus bubalus), and spotted sucker (Minytrema melanops).

In general, the number of species (species richness) increased as a function of stream size. In WOC, the barrier to fish movement represented by the lower weir on WOC (WCK 2.65) provided a sharp break in the richness between the lower site (WCK 2.3) and the upstream sites. Without this weir, the intermediate sites (at least up to WCK 3.4) would be expected to have a species richness similar to that of WCK 2.3. The tributaries represented two different conditions. First Creek and Northwest Tributary followed the pattern of WOC, with higher species richness at the downstream sites. This pattern indicated both larger area with more diverse habitat and greater exposure to species sources at the lower sites. However, Melton Branch and Fifth Creek both have barriers that isolate their headwaters from the remainder of the WOC system. For Melton Branch, the barrier is a large weir that restricts upstream movements and limits the species total to three. For Fifth Creek, the isolation is the result of unsuitable water quality in the lower section, which restricts the species list to only headwater inhabitants.

The patterns observed in species richness during 1987 were very similar to those found in 1985-86 (Loar et al. 1992). The additional species found at site WCK 2.3 originated primarily from access to WOL. Three species found at WCK 2.3 in 1987 that were not found in 1985-86, the fathead minnow (Pimephales promelas), blacknose dace (Rhinichthys atratulus), and brook stickleback (Culaea inconstans), had migrated downstream. Also, three species associated with WOL were found at WCK 2.3 in 1985-86 but were not collected in 1987.

The presence of the brook stickleback represents a dispersal pattern similar to that observed for the fathead minnow in 1986. Both were introductions from ESD research programs and have become well established in the ESD ponds near Building 1504. The stickleback is a species not known from the Tennessee area previously (Ryon and Loar 1988 ) and is normally a cold water species found in vegetated areas. Although it is not an 
Table 6-12 Fish species composition in White Oak Lake (WOL) and Environmental Sciences Division (BSD) rescarch ponds south of Building 1504, May-July 1987

\begin{tabular}{lcccccccc}
\hline Species & WOL & ESD & ESD & ESD & ESD & ESD & ESD \\
& & 1 & 2 & 3 & 4 & 5 & 6 \\
\hline
\end{tabular}

Lepisosteidae

Spotted gar

(Lepisosteus oculatus)

Clupeidae

Gizzard shad

(Dorosoma cepedianum)

Threadifin shad

(D. petenense)

Cyprinidae

Grass carp

(Ctenopharyngodon idella)

Carp

(Cyprinus carpio)

Golden shiner

(Notemigonus chrysoleucas)

Fathead minnow

(Pimephales promelas)

Blacknose dace

(Rhinichthys atratulus)

Catostomidae

Smallmouth buffalo

(Ictiobus bubalus)

Spotted sucker

(Minytrema melanops)

Ictaluridae

Yellow bullhead

(Icaturus natalis)

Flathead catfish

(Pylodictus olivaris)

Poeciliidae

Mosquitofish

(Gambusia affinis)

Gasterosteidae

Brook stickleback

(Culaea inconstans)
$\mathbf{X}$

$\mathbf{X}$

$\mathbf{X}$

$\mathbf{X}$

$\mathbf{X}$

$\mathbf{X}$

$\mathbf{X}$

$\mathbf{X}$

$\mathbf{X}$

$\mathbf{X}$

$\mathbf{x}$

$\mathbf{X}$

$\mathbf{X}$

$\mathbf{x} \quad \mathbf{x}$

$\mathbf{X}$
$\mathbf{X}$

$\mathbf{X}$

$\mathbf{X}$

$\mathbf{X}$

$\begin{array}{lll}\mathbf{X} & \mathbf{X}\end{array}$

$\mathbf{x} \quad \mathbf{x}$ 
Table 6-12 (continued)

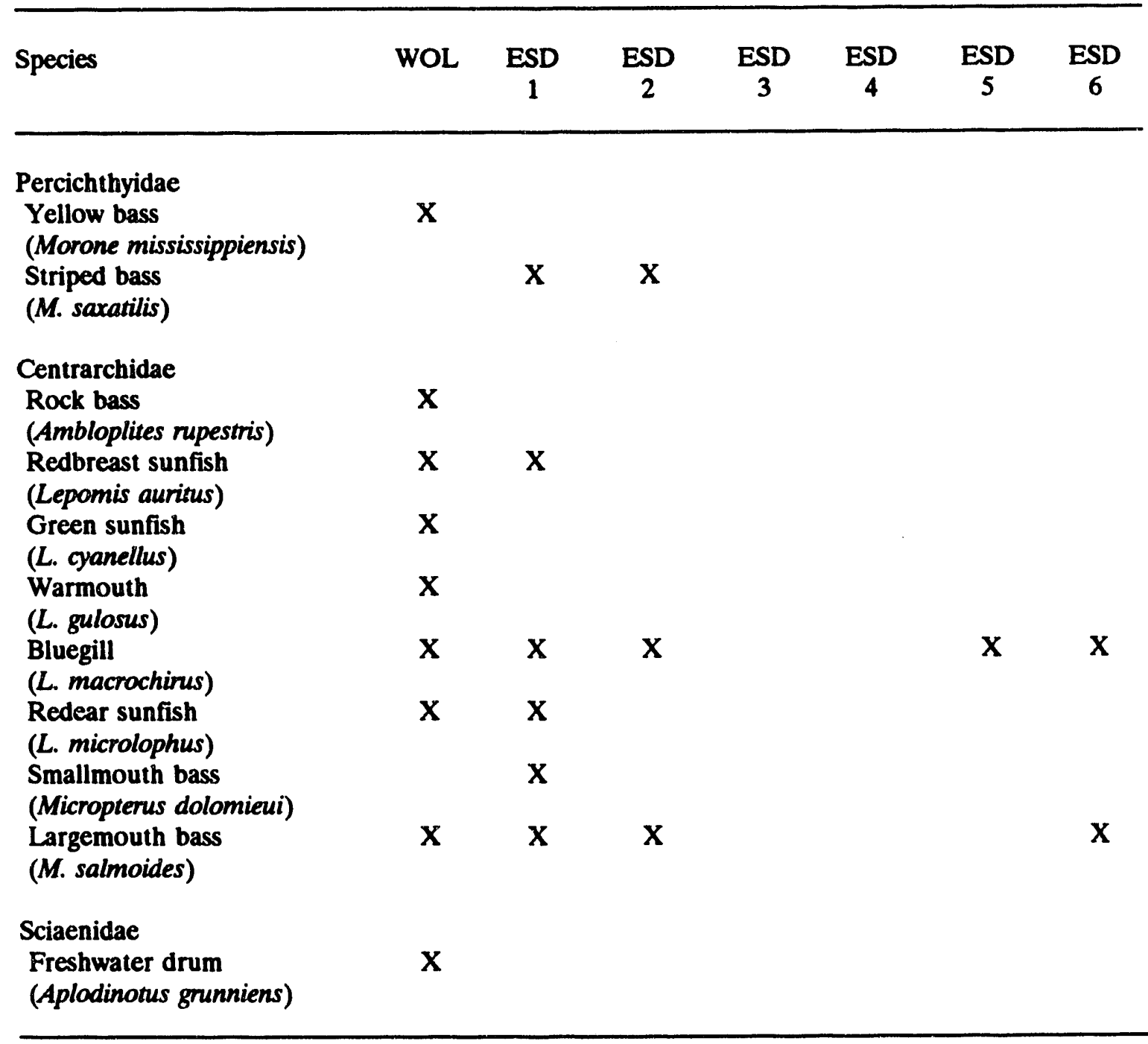

intolerant species, the establishment of a stickleback breeding population in the WOC stream system could provide additional information on the trophic structure and habitat quality of the system.

Sampling above the weir at WCK 2.65 in 1987 indicated a more equal species distribution, with wider distributions noted for the fathead minnow, the stoneroller (Campostoma anomalum), the banded sculpin (Cottus carolinae), and the spotted/largemouth bass (Micropterus punctulatus and $M$. salmoides); overall five sites above the weir had greater species richness in 1987 than in 1986.

Community structure in WOC indicated that most sites were dominated trophically by omnivores and insectivores (Table 6-13). Only six sites had a herbivore component, represented by the stoneroller. Piscivores, although represented by numerous species, 
Table 6-13. Trophic structure and intolerance of fish communities in White Oak Creak, First Creek, Fifth Creek, Melton Branch, and Northwest Tributary, based on sampling conducted in 1987

\begin{tabular}{|c|c|c|c|c|c|}
\hline \multirow[b]{2}{*}{$\operatorname{Sitc}^{c}$} & \multicolumn{5}{|c|}{ Trophic classifications $^{b}$} \\
\hline & Herbivore & Omnivore & Insectivore & Piscivore & Intolerant ${ }^{d}$ \\
\hline FCK 0.1 & 0 & 2 & 3 & 1 & 0 \\
\hline FCK 0.8 & 0 & 1 & 1 & 1 & 0 \\
\hline FFK 0.2 & NF & NF & NF & NF & NF \\
\hline FFK 0.4 & 0 & 1 & 1 & 0 & 1 \\
\hline FFK 1.0 & 0 & 1 & 1 & 0 & 1 \\
\hline MEK 0.6 & 0 & 1 & 2 & 0 & 0 \\
\hline MEK 1.4 & 0 & 1 & 1 & 0 & $\mathbf{0}$ \\
\hline MEK 2.1 & 0 & 1 & 1 & 0 & 0 \\
\hline NTK 0.3 & 1 & 2 & 3 & 1 & 0 \\
\hline NTK 1.0 & 0 & 2 & 2 & 0 & $\mathbf{0}$ \\
\hline WCK 2.3 & 1 & 4 & 4 & 3 & 1 \\
\hline WCK 2.9 & 0 & 2 & 4 & 0 & 0 \\
\hline WCK 3.4 & 1 & 2 & 4 & 1 & 0 \\
\hline WCK 3.9 & 1 & 2 & 3 & 0 & 0 \\
\hline WCK 5.1 & 1 & 2 & 2 & 0 & 1 \\
\hline WCK 6.8 & 1 & 1 & 2 & 0 & 1 \\
\hline
\end{tabular}

${ }^{a}$ Number of species in each category is shown; NF $=$ no fish collected.

bBased on information from the following sources: W.L. Pflieger, The Fishes of Missouri, Missouri Department of Conservation, Missouri, 1975; P.W. Smith, The Fishes of Illinois, University of Illinois Press, Urbana, Illinois, 1979; G.C. Becker, Fishes of Wisconsin, University of Wisconsin Press, Madison, Wisconsin, 1983; and E.L. Cooper, Fishes of Pennsylvania and the Northeastern United States, Pennsytvania State University Press, University Park, Pennsytvania, 1983. Classification represents major food component and, for carnivores, represents active ingestion of plant material.

${ }^{\text {'FCK }}=$ First Creek kilometer; FFK = Fifth Creek kilometer; MEK = Melton Branch kilometer; NTK = Northwest Tributary kilometer; WCK $=$ White Oak Creek kilometer.

${ }^{d}$ Number of species collected at the site that are intolerant of ecological disturbances, such as poor water quality or habitat degradation, as defined by Karr et al. (J.R. Karr et al., Assessing biological integrity in running waters: $A$ method and its rationale, Spec. Pub. 5. Illinois Natural History Survey, Champaign, 1986.

were found at only five sites. Species that are intolerant of habitat degradation and poor water quality, as defined by Karr et al. (1986), were restricted to five sites and represented only by the banded sculpin and the rock bass (Ambloplites rupestris). Sculpins were primarily restricted to the upstream reference sites that were spring-fed with cool, thermally stable environments. These sites receive little if any upstream disturbances. One sculpin was found at WCK 5.1, but most likely represented a migrant displaced from the upstream reference site. Rock bass were only found at WCK 2.3 and in WOL and never in abundance (Tables 6-13 and F-1). In their studies based on midwestern streams, 
Karr et al. (1986) classify the rock bass as an intolerant species, but that classification may be inappropriate for this study and region.

Comparisons with other stream communities in the Oak Ridge area indicate that the fauna of WOC is severely limited, even including the species represented by introductions. The fauna of East Fork Poplar Creek (EFPC) and Bear Creek are both more diverse, and species richness is higher compared with WOC proper (Ryon and Loar 1988). Nearly 40 species occur in EFPC and 19 species inhabit Bear Creek; species of Notropis, Percidae, and Catostomidae, which are indicative of higher water quality (Karr et al. 1986), inhabit both streams (Ryon and Loar 1988). The surveys of WOL and the ESD ponds suggest that such species could survive in the WOC system, but, as discussed in Loar et al. (1992), access for recolonization may be a limiting factor. The occurrence of a single adult spotted sucker and smallmouth buffalo in WOL indicates that these species probably cannot presently reproduce in the WOC system. Instead, they may represent either relicts from populations that existed when the system was still accessible through the WOD spillway (Krumholz 1956) or migrants that entered WOL during renovation of the dam in 1980 (Loar et al. 1981).

\subsubsection{Density and Biomass}

Population surveys of WOC were conducted during three separate sampling periods in 1987, and the data were used to determine species biomass and density for each period. The total biomass and densities at each site for each sampling period are presented in Table 6-14. Values for individual species are given in Appendix G, Tables G-1 through G-6. In 1985-86, fish densities decreased downstream, while biomass increased with increasing stream size. In contrast, the downstream (nonreference) sites often had higher densities in 1987, particularly in the tributaries. Like the earlier surveys, fish biomass in 1987 generally increased downstream.

In general, population densities were similar at most sites during the first two sampling periods, probably because the sampling periods were rather close together in time and young-of-the-year did not yet contribute significantly to the population size. However, sampling during the last period (November-December) indicated a decline in population densities at most sites, despite the presence of a new (1987) year class. In the tributaries, only MEK 0.6 and NTK 0.3 showed higher densities during the fall. This trend reflects some compression of the populations in these two streams due to the absence of flow at the upper sites. Also, the extremely large increase (35-fold) at MEK 0.6 reflects recovery and a successful reproductive season following the shutdown of the HFIR in November 1986 and the subsequent improvement in the adverse stream conditions, such as high temperatures, that existed in 1985-1986 (Fig. 2-7 and Loar et al. 1992).

In WOC, several interesting trends were observed over the three sampling periods. Abundance steadily declined at WCK 5.1, and the fall 1987 sample had a density more than 20 times lower than the previous winter sample (Table 6-14). The next site downstream (WCK 3.9) also showed a decline over this same period. In contrast, densities at WCK 3.4 and WCK 2.3 increased from the winter through the following spring and fall. At the three sites downstream of the main ORNL complex (WCK 3.4, WCK 2.9, and WCK 2.3), densities generally varied by less than a factor of 2 from January to December 1987. 


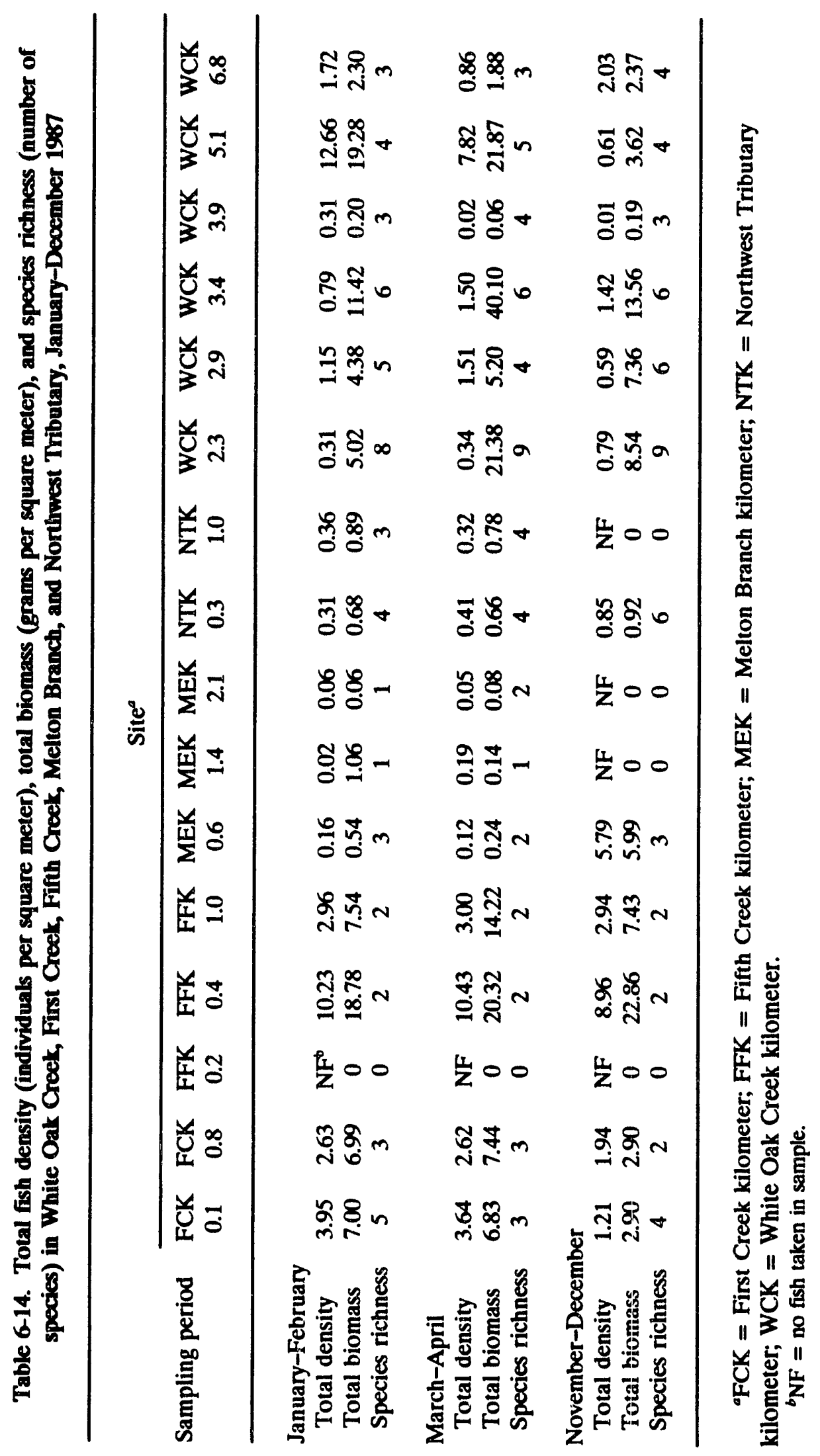


Biomass values for the individual sampling periods also showed a variety of trends. At FFK 0.4, NTK 0.3, and WCK 2.9, biomass gradually increased over the three sampling periods. In contrast, biomass decreased at FCK 0.1, FCK 0.8, MEK 1.4, and WCK 5.1, with large decreases (tenfold and fivefold, respectively) occurring at the latter two sites. At MEK 0.6, a substantial increase (tenfold) in biomass occurred in fall 1987, which paralleled the increase in density at that site.

Total fish densities were highest at WCK 5.1 and FFK $0.4\left(12.66\right.$ and $10.43 / \mathrm{m}^{2}$, respectively) and similar to the densities of 15.71 and 10.83 individuals per square meter observed at these sites in 1986 (Loar et al. 1992). The lowest total densities in 1987 were 0.01 and 0.02 individual per square meter at WCK 3.9 and MEK 1.4 respectively. The lowest fish density in 1986 also occurred at WCK 3.9 ( $<0.01$ individual per square meter). Maximum biomass values of 40.10 and $22.86 \mathrm{~g} / \mathrm{m}^{2}$ were observed at WCK 3.4 and FFK 0.4 , respectively, in 1987. The highest biomass in 1986 occurred at WCK 5.1 in the spring and late summer ( 33.56 and $25.16 \mathrm{~g} / \mathrm{m}^{2}$ respectively). The lowest biomass values in 1987 occurred at MEK 2.1 and WCK $3.9\left(0.02 \mathrm{~g} / \mathrm{m}^{2}\right)$; in 1986, the lowest biomass occurred at WCK 3.9 ( $<0.01$ and $0.34 \mathrm{~g} / \mathrm{m}^{2}$ in the spring and late summer respectively) (Loar et al. 1992).

In summary, the most significant changes in total density and biomass occurred at WCK 5.1 and MEK 0.6. Site WCK 5.1 has been an area of extremely high fish density and biomass, but a precipitous decline occurred in the fall of 1987 . The cause of this decline may be related to the drought conditions during this period or may represent a response to an undetected chemical perturbation. (The site is downstream of the $\mathbf{7 0 0 0}$ area.) Similarly, MEK 0.6 has generally had below-average biomass and density values since 1985 (Loar et al. 1992), but the most recent sampling showed a dramatic increase in both parameters. From the increase in abundance and the size range of the species observed in 1987, it was evident that successful reproduction and recovery from a prior fish kill in May 1986 (Loar et al. 1992) had occurred in Melton Branch. In 1985-86, biomass and density at WCK 2.9 were below the values at sites just upstream and downstream (WCK 3.4 and WCK 2.3 respectively). During the current sampling, values at WCK 2.9 were higher than or similar to those of the adjacent sites. Those sites that were shown to be significantly impacted by plant operations in the 1985-86 survey (FFK 0.2 and WCK 3.9) continued to have very low densities or no fish in 1987 and showed no evidence of recovery.

Contributions of individual species to total community density and biomass were comparable to those in 1985-86. The blacknose dace was the dominant species in terms of density and biomass at 23 and 22 sites, respectively, of 42 possible sampling date-site combinations. Other dominant species included redbreast sunfish (dominant in density at five sites and in biomass at seven sites), bluegill (three sites in density and three sites in biomass), and creek chub (three sites in density and four sites in biomass). One species, the fathead minnow, increased its distribution since 1985-86 and was the dominant species in terms of density at four sites. In particular, the fathead minnow showed a dramatic increase at WCK 2.9. At this site ripe males with spawning colors and tubercles were observed along with large numbers of young-of-the-year, indicating establishment of a successful spawning population in WOC. Their success is also reflected in the increased total density at WCK 2.9 during 1987. 


\subsubsection{Growth and Condition}

Growth and condition of fish in WOC watershed were evaluated by calculating condition factors for all species and by estimating the population growth rates and true growth rates of redbreast and bluegill sunfish.

The population growth rate is a comparison of mean weight of surviving fish at successive ages and is not always an accurate estimate of the true growth rate because of size-selective mortality. For comparisons of growth rates between sites, however, similar biases could be assumed, and the resulting curves would indicate site-specific growth differences. Data on the population growth rates of bluegill in 1987 (Fig. 6-9) suggested that WOL, WCK 3.4, and ESD 2 pond had better growth than the reference site BFK 7.6 and that ESD 5 pond and WCK 2.3 had lower growth than BFK 7.6. For redbreast sunfish, the population growth data indicated that all sites had better growth than the reference site, with WOL demonstrating the best growth (Fig. 6-10). However, a statistical comparison between sites of the mean weight at each age did not demonstrate a pattern of significant differences $(p>0.05)$ for either bluegill or redbreast sunfish. Although the slopes of the population growth curves were not tested in this analysis, these comparisons suggest that the slopes of the curves (i.e., the growth rate) will not be significantly different.

Analyses of true growth rates indicate slightly different trends and suggest an explanation for the low population growth at the reference site. For bluegill mean instantaneous growth appeared to be initially (for age-2 fish) greater at the WOC sites (Fig 6-11). However, as the fish got older, growth was greater at BFK 7.6, and the WOC and WOL sites showed a sharp decline in growth from the initial values (Table 6-15). For redbreast sunfish the trend in instantaneous growth was exactly opposite that shown by the population growth (Fig 6-12); fish at BFK 7.6 had higher initial growth that continued throughout the life span (Table 6-16). A potential explanation for the difference in growth patterns shown by the population and mean instantaneous growth analyses is the effect of size-selective mortality. Because calculation of the true growth rate restricts the growth evaluation to the most recent year of growth, problems with mortality biases that affect the population growth rate are avoided (Ricker 1975, Gutreuter 1987).

Condition factors were also calculated for the fish in WOC and the reference stream (BFK 7.6), and statistical comparisons were made to evaluate differences between sites and between sampling periods. Comparisons between sampling periods showed that the condition factors for the March-April period were significantly greater than for other periods (Appendix G, Tables G-7 and G-9). Of 21 comparisons where a significant difference was indicated, the spring period had the highest number (20). This trend was also observed in 1985-86 (Loar et al. 1992) and indicates the expected preparation for spawning. Of interest was the observed increase in condition factors in the spring at MEK 0.6 , where the fall sample had shown a substantial increase in density and biomass.

Comparisons between sites within a sampling period generally did not show any pattern of significant differences (Table G-10 through G-12). Sites that had been identified as being impacted, based on the biomass, density, and species richness data 
ORNL DWG 88-8976

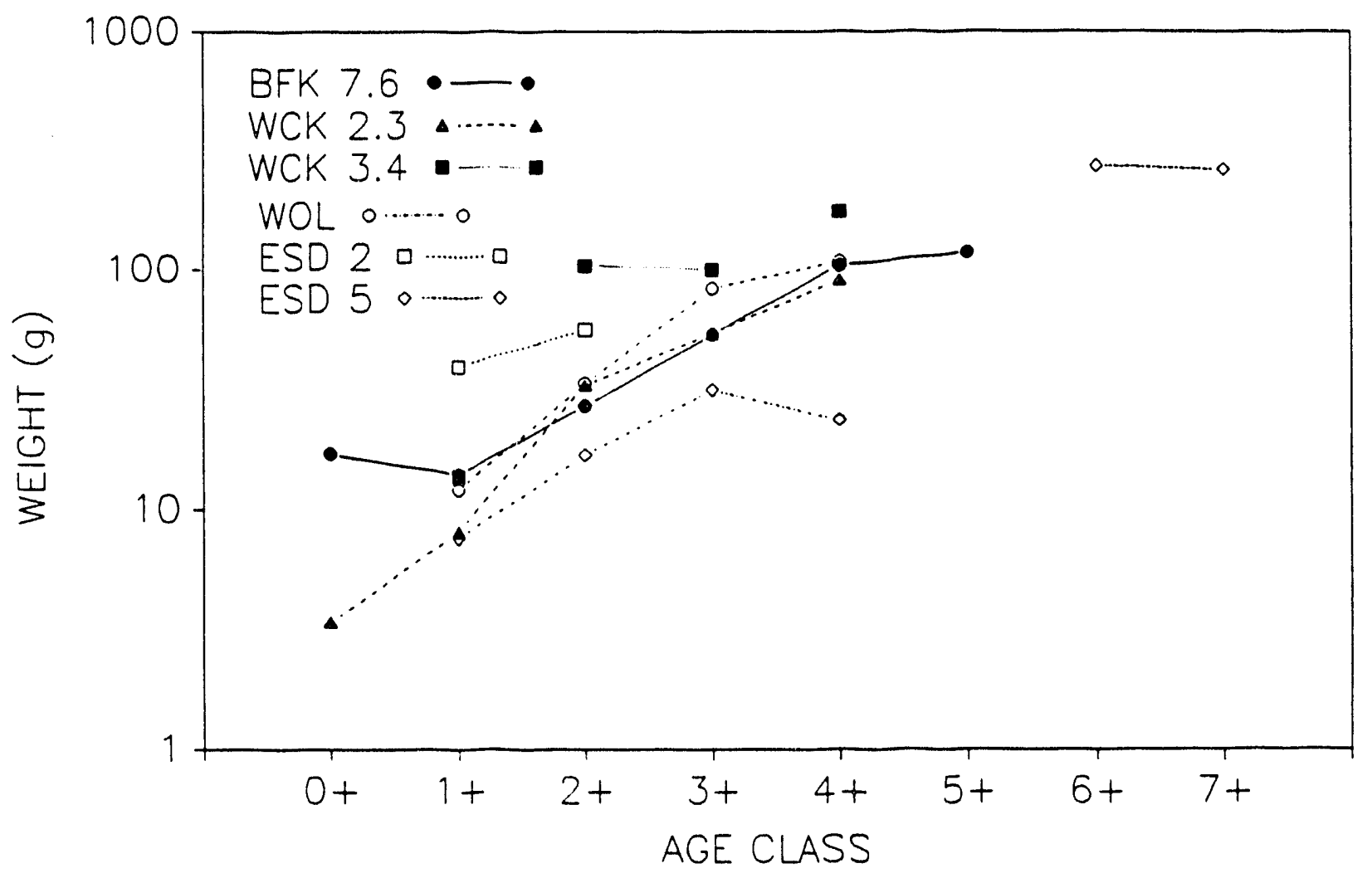

Fig 6-9. Population growth rate (mean weight at age) of bluegill sunfish in White Oak Creck, White Oak Lake, two small ponds [Environmental Sciences Division (ESD) 2 and 5], and Brushy Fort, a reference stream, for 1987 . BFK = Brushy Fork kilometer; WCK = White Oak Creek kilometer. 


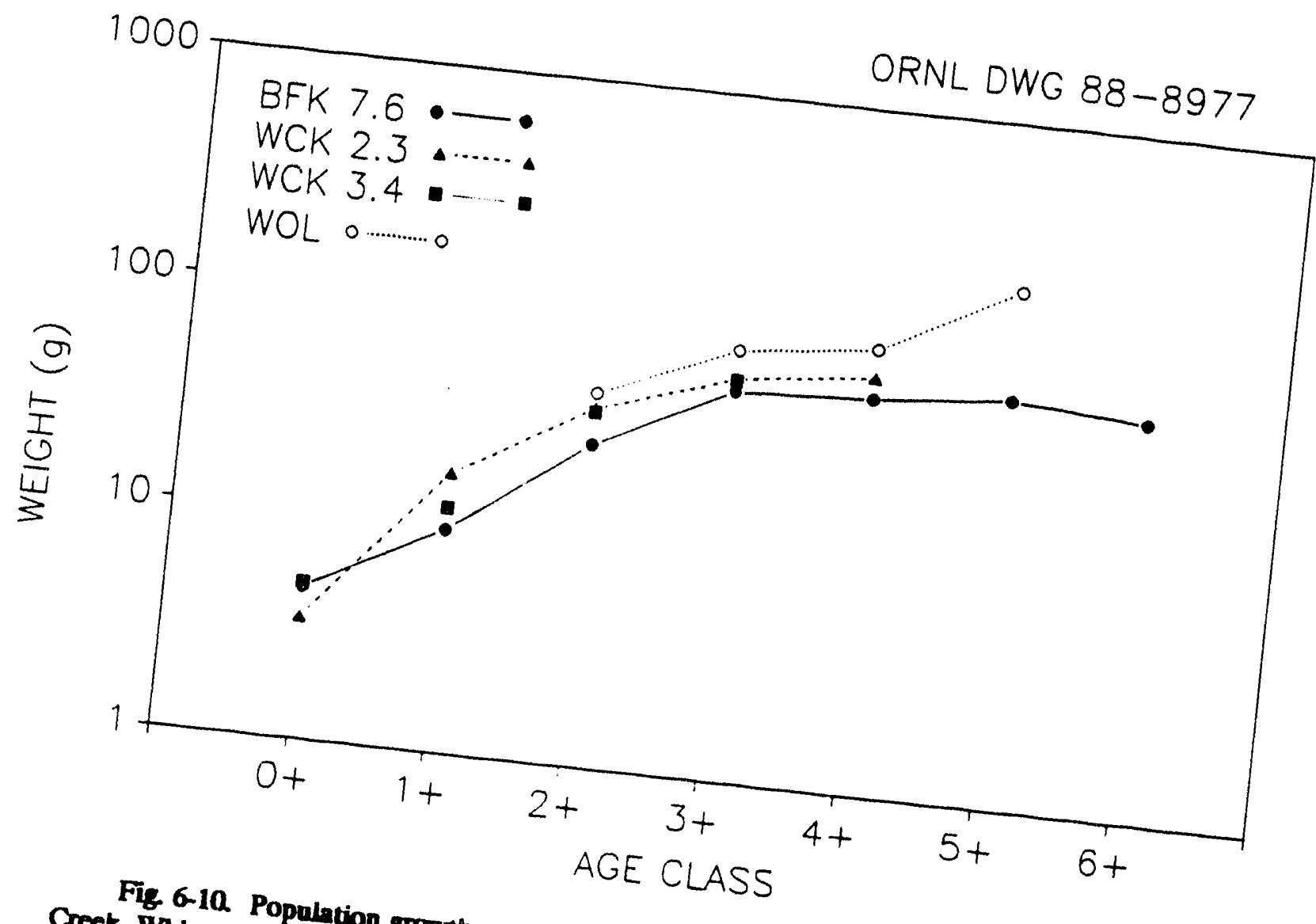

Creck, White Population gromth rate (man waigh age)

White Oak Creek kilome (WOL), and Brushy Fork a refere) of redbreast sunfight 


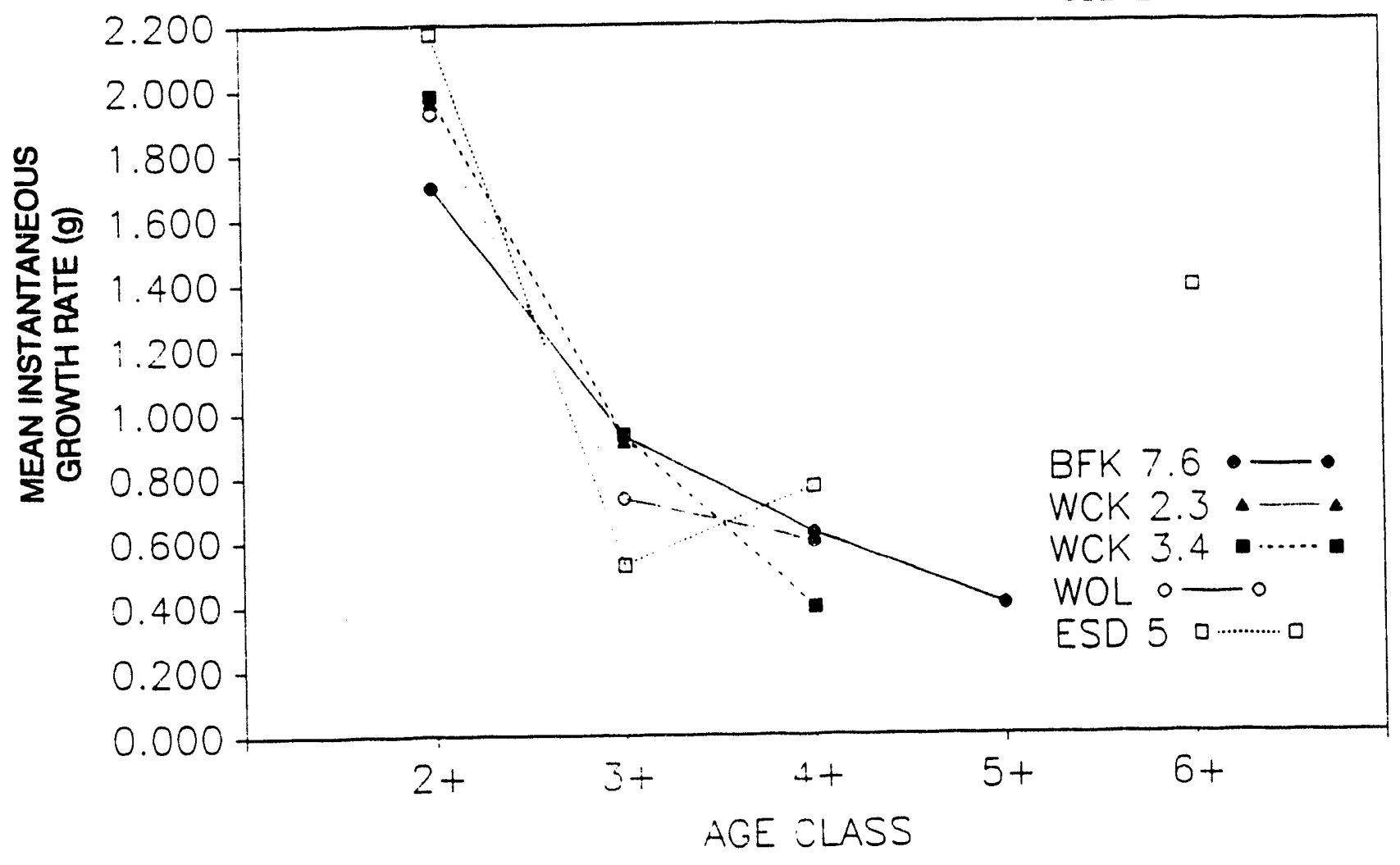

Fig 6-11. True rate of growth in weight (g) of bluegill sunfish in White Oak Creek, White Oak Lake (WOL), a small pond [Environmental Sciences Division (ESD) 5], and Brushy Fork, a reference stream, during 1987 . WCK $=$ White Oak Creek kilometer; BFK = Brush Fork kilometer. 
Table 6-15. Data for calculation of true growth rates (after Ricker 1975) of bluegill sunfish in White Oak Creek, White Oak Lake (WOL) and a research pond [Environmental Sciences Division (ESD) 5] in comparison with the reference stream, Brushy Fork

\begin{tabular}{|c|c|c|c|c|c|c|}
\hline Site $^{b}$ & $\begin{array}{l}\text { Year } \\
\text { class }^{c}\end{array}$ & $\mathbf{N}^{d}$ & $\begin{array}{l}\text { Incremental } \\
\text { growthe }\end{array}$ & s.d. $!^{\prime}$ & $\begin{array}{l}\text { Length-weight } \\
\text { regression } \\
(\mathrm{mm})\end{array}$ & $\begin{array}{l}\text { Age-class } \\
\text { growth }^{h}\end{array}$ \\
\hline \multirow[t]{4}{*}{ BFK 7.6} & 2 & 51 & 0.516 & 0.096 & 3.32 & 1.697 \\
\hline & 3 & 24 & 0.279 & 0.083 & 3.32 & 0.926 \\
\hline & 4 & 8 & 0.188 & 0.075 & 3.32 & 0.624 \\
\hline & 5 & 5 & 0.121 & 0.040 & 3.32 & 0.400 \\
\hline \multirow[t]{4}{*}{ WCK 2.3} & 2 & 18 & 0.622 & 0.168 & 3.15 & 1.959 \\
\hline & 3 & 3 & 0.288 & 0.143 & 3.15 & 0.907 \\
\hline & 4 & 1 & 0.192 & & 3.15 & 0.604 \\
\hline & 5 & 0 & & & & \\
\hline \multirow[t]{4}{*}{ WCK 3.4} & 2 & 7 & 0.594 & 0.144 & 3.33 & 1.978 \\
\hline & 3 & 5 & 0.279 & 0.067 & 3.33 & 0.929 \\
\hline & 4 & 3 & 0.118 & 0.011 & 3.33 & 0.393 \\
\hline & 5 & 0 & & & & \\
\hline \multirow[t]{4}{*}{ WOL } & 2 & 40 & 0.615 & 0.176 & 3.13 & 1.925 \\
\hline & 3 & 40 & 0.233 & 0.106 & 3.13 & 0.729 \\
\hline & 4 & 4 & 0.190 & 0.050 & 3.13 & 0.595 \\
\hline & 5 & 0 & & & & \\
\hline \multirow[t]{5}{*}{ ESD 5} & 2 & 6 & 0.646 & 0.083 & 3.36 & 2.171 \\
\hline & 3 & 3 & 0.156 & 0.028 & 3.36 & 0.524 \\
\hline & 4 & 1 & 0.228 & & 3.36 & 0.766 \\
\hline & 5 & 0 & & & & \\
\hline & 6 & 1 & 0.410 & & 3.36 & 1.378 \\
\hline
\end{tabular}

'Data derived from W.E. Ricker, "Growth in Length and Weight," Chap. 9, pp. 203-233, in Computation and Interpretation of Biological Statistics of Fish Populations, Bulletin 191, Department of the Environment, Fisheries and Marine Service, Ottowa, 1975.

${ }^{b}$ BFK = Brushy Fork kilometer; $\mathbf{W C K}=$ White Oak Creek kilometer.

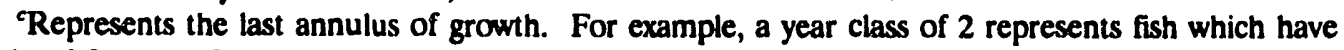
completed 2 years of growth.

${ }^{d} \mathrm{~N}=$ number of fish analyzed.

'Mean of the difference in the natural logarithm of the initial and final length (in millimeters) for the last complete year of growth. This is the instantaneous rate of increase in length.

$f_{\text {s.d. }}$ = standard deviation.

Slope of the linear regression between length and weight based on all fish at each site, as calculated by the PROC GLM procedure of SAS (SAS Institute, Inc. SAS User's Guide: Statistics, Version 5 Edition. SAS Institute, Inc., Cary, North Carolina, 1985).

${ }^{h}$ Product of the slope and instantaneous growth rate, which equals the true growth rate for the last year of growth for that age class. 


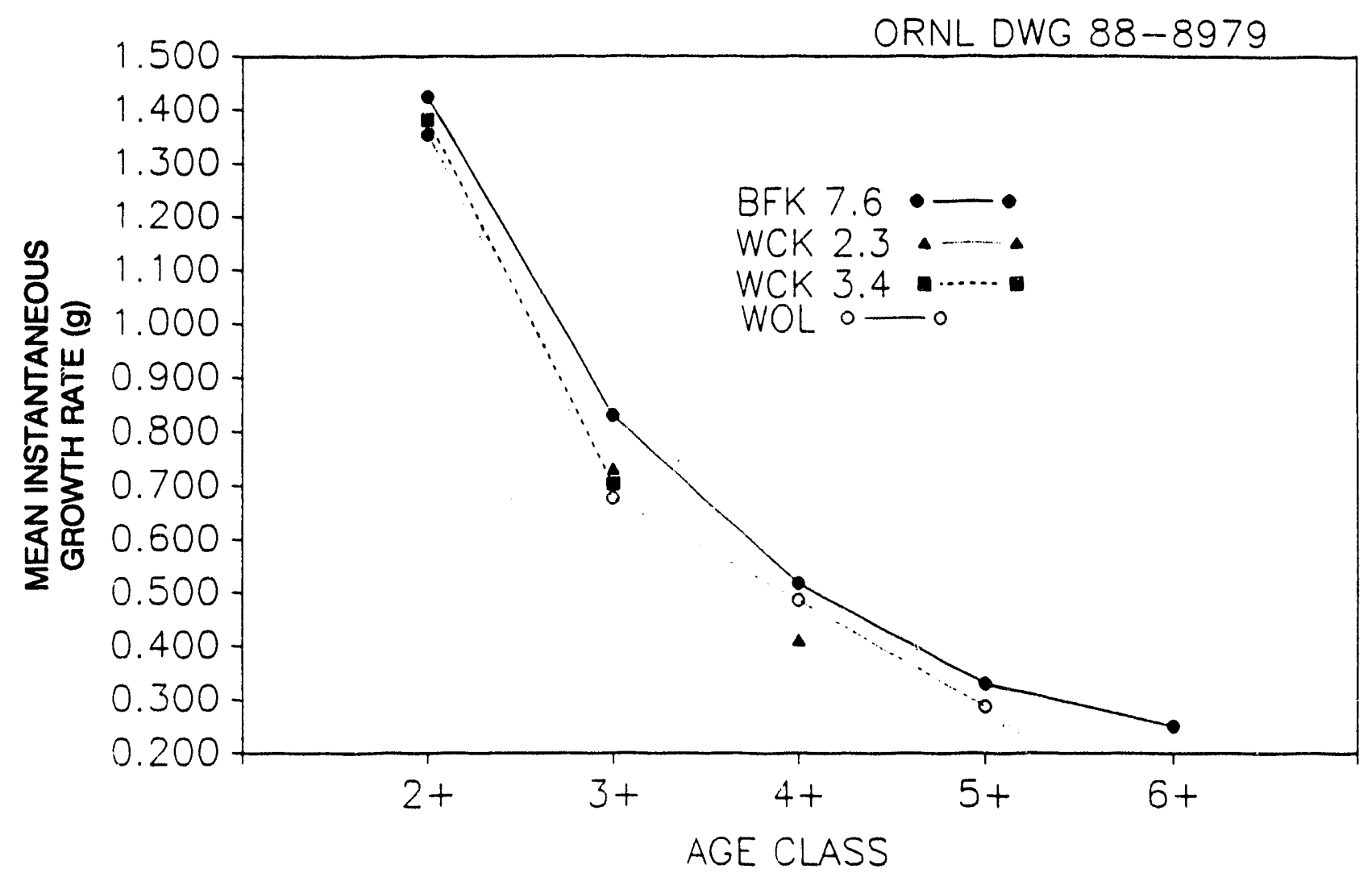

Fig 6-12 True rate of growth in weight (g) of redbreast sunfish in White Oak Creek, White Oak Lake (WOL), and Brushy Fort, a reference stream, during 1987. WCK = White Oak Creek kilometer; BFK = Brushy Fork kilometer. 
Table 6-16. Data for calculation of true growth rates of redbreast sunfish in White Oak Creek and White Oak Lake (WOL) in comparison with the reference stream, Brushy Fork

\begin{tabular}{|c|c|c|c|c|c|c|}
\hline Site $^{b}$ & $\begin{array}{l}\text { Year } \\
\text { class }^{c}\end{array}$ & $\mathbf{N}^{d}$ & $\begin{array}{l}\text { Incremental } \\
\text { growthe }\end{array}$ & s.d. ${ }^{f}$ & $\begin{array}{l}\text { Length-weight } \\
\text { regressions } \\
(\mathrm{mm})\end{array}$ & $\begin{array}{l}\text { Age class } \\
\text { growth }^{h}\end{array}$ \\
\hline \multirow[t]{5}{*}{ BFK 7.6} & 2 & 16 & 0.470 & 0.086 & 3.03 & 1.424 \\
\hline & 3 & 32 & 0.274 & 0.079 & 3.03 & 0.830 \\
\hline & 4 & 8 & 0.171 & 0.051 & 3.03 & 0.518 \\
\hline & 5 & 2 & 0.109 & 0.025 & 3.03 & 0.330 \\
\hline & 6 & 1 & 0.083 & & 3.03 & 0.251 \\
\hline \multirow[t]{4}{*}{ WCK 2.3} & & 14 & 0.472 & 0.085 & 2.88 & 1.359 \\
\hline & 3 & 18 & 0.254 & 0.087 & 2.88 & 0.732 \\
\hline & 4 & 3 & 0.143 & 0.069 & 2.88 & 0.412 \\
\hline & 5 & 0 & & & & \\
\hline \multirow[t]{4}{*}{ WCK 3.4} & 2 & 14 & 0.483 & 0.117 & 2.86 & 1.381 \\
\hline & 3 & 5 & 0.246 & 0.045 & 2.86 & 0.704 \\
\hline & 4 & 0 & & & & \\
\hline & 5 & 0 & & & & \\
\hline \multirow[t]{4}{*}{ WOL } & 2 & 8 & 0.415 & 0.146 & 3.26 & 1.353 \\
\hline & 3 & 15 & 0.208 & 0.090 & 3.26 & 0.678 \\
\hline & 4 & 10 & 0.149 & 0.074 & 3.26 & 0.486 \\
\hline & 5 & 4 & 0.088 & 0.015 & 3.26 & 0.287 \\
\hline
\end{tabular}

aData derived from W.E. Ricker, "Growth in Length and Weight," Chap. 9, pp. 203-233, in Computation and Interpretation of Biological Statistics of Fish Populations, Bulletin 191, Department of the Environment, Fisheries and Marine Service, Ottowa, 1975.

${ }^{b} \mathrm{BFK}=$ Brushy Fork kilometer; WCK $=$ White Oak Creek kilometer.

Represents the last annulus of growth. For example, a year class of 2 represents fish which have completed 2 years of growth.

${ }^{d} \mathbf{N}=$ number of fish analyzed.

Mean of the difference in the natural logarithm of the initial and final length (in millimeters) for the last complete year of growth. This is the instantaneous rate of increase in length.

$f_{\text {s.d. }}=$ standard deviation.

Slope of the linear regression between length and weight based on all fish at each site, as calculated by the PROC GLM procedure of SAS (SAS Institute, Inc. SAS User's Guide: Statistics, Version 5 Edition. SAS Institute, Inc., Cary, North Carolina, 1985).

${ }^{h}$ Product of the stope and instantaneous growth rate, which equals the true growth rate for the last year of growth for that age class.

(WCK 3.9, WCK 2.9, and fall sample at WCK 5.1), did not show significantly lower condition factors for any species. In fact, individuals in these areas often had relatively high condition factors, suggesting that they are transient individuals that can survive in less than optimal environments and utilize the available resources. Finally, it was generally noted that at sites where density was high, condition factors were low. 
For the bluegill and redbreast sunfish, two cases were found where significant differences in condition existed between sites. In the spring sample, bluegill condition factors at WCK 2.3 were significantly lower than at WCK 3.4 (Table G-11), indicating possible spawning site differences or an absence of spawning adults at WCK 2.3 (due to its proximity to WOL). In the fall sample, the redbreast sunfish population at WCK 2.3 had a significantly higher mean condition factor than the population at WCK 3.4, with no apparent causal factor (Table G-12). These observations were not consistent with the data for other species at these sites at these times. The significance of data on condition factors must be considered with some caution because they can be relatively insensitive to environmental conditions or nutritional status (Loar et al. 1985b).

\subsection{Fish Kills}

During 1987 two reportable fish kills occurred in the WOC watershed. Although neither wis jurged to be insignificant at the time of detection, one was later attributed to a natural phenomenon, and the other was possibly related to an ethylene glycol spill.

The first incident was a shad die-off, first observed by DEMC staff in early February 1987 in WOL. Concern over the numbers of dead or dying fish led to the initiation of a routine survey that was continued for several weeks as a precautionary measure. Over a period of 7 weeks, more than 1600 dead shad (principally gizzard shad) and various other species were collected by DEMC and ESD staff in routine surveys of the lake (Appendix H). Water quality sampling and surveys of WOC above WOL failed to identify a specific problem. Die-offs of shad in late winter are common occurrences in local TVA reservoirs. A survey of a nearby reservoir (Ft. Loudoun) revealed a similar die-off of shad on March 14, 1986. The effect on the WOL shad population was not significant, because they remained extremely abundant in the subsequent surveys (Appendix F, Table F-1).

A second fish kill was observed on August 12, 1987, in WOC below the weir at WCK 2.65, again by personnel from the DEMC at ORNL. The dead fish that were collected included six decomposed bluegill and one "minnow." This discovery was associated in time with a spill of $3808 \mathrm{~L}$ (1006 gal) of ethylene glycol in the vicinity of the 4500 area of ORNL (near WCK 4.5). Numerous live fish that appeared to be unaffected were observed in the area (WCK 2.5 to WCK 5.0) by DEMC personnel. Surveillance by DEMC and ESD staff during the spill, and subsequent monitoring of its passage out of the WOC system, failed to reveal any additional mortality.

\section{Conclusions}

This report presents the results from the second year of studies designed to characterize the fish populations of the WOC watershed. In general, the data gathered in 1987 support trends first observed in 1985-86 (Loar et al. 1992). One general factor that influenced the data collected in 1987 was the drought conditions present during much of the year. Rainfall in 1987 was substantially below normal (Sect. 2.1), and several upstream sites were dry, which affected fish distributions and may have increased densities.

Data on species richness in WOC watershed indicated little change during 1987. The total number of species within WOC proper in 1987 (15) was similar to the number in 
1986 (16), and, considering the number of additional species in the WOL and ESD pond areas (13) available for colonization, it appears to be relatively stable. Richness at sites above the weir at WCK 2.65 showed increases due to the spread of opportunistic species, such as the fathead minnow.

Analyses of the trophic structure of the fish populations indicated that most sites had simple communities with few herbivores, and only a few sites supported piscivores (top predators). The communities were dominated by tolerant species; intolerant species were mostly limited to upstream reference sites or the larger sites in close proximity to WOL. The ability of intolerant species to provide an additional measure of change in WOC in the future appears limited, primarily because of the absence of a possible access route from better water quality sources in the Clinch River drainage. Overall, the fauna of WOC watershed, and especially of WOC proper, appears to be depauperate in comparison with such local streams as EFPC and Bear Creek (Ryon and Loar 1988); this is particularly noticeable in terms of pollution-intolerant taxa, such as Notropis, Catostomidae, and Percidae.

Population density and biomass values for 1987 supported some trends noticed in 1985-86. Data at FFK 0.2 and WCK 3.9, for example, reinforced the trends observed during the initial year of characterization; significant impacts were evident at these two sites. The areas of highest biomass and density in 1985-86 (FFK 0.4 and WCK 5.1) were again the highest in 1987. Biomass and density at these two sites were as much as four times higher than in other area streams, and may be related to nutrient enrichment (see Sect. 2.2.4). However, unlike 1985-86 levels, density and biomass at WCK 5.1 showed a substantial decline during the fall sampling period in 1987. Some portion of this decrease may be due to the drought or an undetected effluent discharge above WCK 5.1.

The trend of decreasing fish abundance in lower Melton Branch observed in 1985-86 was reversed in 1987. Following low values in the first two sampling periods at MEK 0.6, MEK 1.4, and MEK 2.1, a dramatic increase in fish density and biomass was observed at MEK 0.6 in the fall. This increase may reflect some compression of the fish population because of low flows but also indicates a successful spawning season during the summer of 1987. The recovery represented by this spawning corresponds well with the shutdown of the HFIR facility in November 1986 and suggests that, with normal flow, recovery may extend to all of Melton Branch.

Another area that showed a change from 1985-86 was WCK 2.9. This was an area of fluctuating density and biomass, but in 1987 a more stable population was evident. Density values were more consistent, and biomass values were three to ten times greater in 1987 than in 1986, due, in large part, to the establishment of a resident breeding population of fathead minnows and larger adult centrarchids. If this pattern continues, an improvement at this site is suggested; however, if the improvement is to be considered significant, then the expansion of other species (e.g. largemouth bass) into this area should also occur.

The biomass and density of individual species remained similar to those observed in the first year of sampling. Blacknose dace was the dominant species, although redbreast 
and bluegill sunfish, as well as creek chubs, were other significant species. The fathead minnow and stoneroller expanded their distribution and abundance.

Evaluations of growth and condition also supported the findings of 1985-86. Condition factors of all species in 1987 again were significantly higher in the spring sampling period. This represents spawning preparation as well as winter mortality of some young-of-the-year, but little more could be determined from the condition factors, even in the larger centrarchid species. Between-site comparisons did not show a pattern among impacted sites that paralleled the biomass, density, and richness data.

Two growth evaluations were performed for ı edbreast and bluegill sunfish collected in 1987. Population growth was estimated for both species, as was done in 1986, but it failed to show a significant pattern in mean weight per age class between WOC and the reference stream (Brushy Fork).

The other growth evaluation, mean instantaneous growth, presented a different picture. For redbreast sunfish the reference site had consistently better growth than the WOC sites, and little difference was noted between WOC sites. For bluegill initial growth was better in WOC, but, at older ages, fish in Brushy Fork demonstrated better sustained growth. One noticeable aspect of the growth curves was the lack of older age classes in WOL and WOC sunfish in comparison with Brushy Fork. This may be only a consequence of sample size, but a similar lack of older age classes was noted by Krumholz (1956) for bluegill in WOL. Although no explanation can be given for the differences in the two growth evaluations, more credence is associated with the estimation of the instantaneous growth rate because it avoids size-selective mortality biases (Ricker 1975, Gutreuter 1987).

\subsubsection{Future Studies}

A variety of approaches and short-term experimental studies will be implemented in 1988-89 to assess the impacts on the fish populations of WOC watershed and to identify specific sources and areas of impact. As a first step, the routine, quantitative monitoring of the density, biomass, and richness of the fish communities in WOC watershed will be conducted twice annually (spring and fall). Age determination and growth rate computation will be based on scales collected in the fall. Qualitative sampling will be limited to stream areas not previously sampled, with added emphasis on monitoring the spread or establishment of a breeding population of brook stickleback in lower Northwest Tributary and vegetated areas of streams.

To help evaluate the role of habitat differences in explaining differences in community composition between sites, each site will be characterized by substrate, bank vegetation, cover, flow, and other variables by use of a standard procedure. Additional analytical techniques for interpreting existing data will also be employed. The Index of Biotic Integrity, for example, may provide additional insights into the magnitude of the impacts on fish communities at different sites (Karr et al. 1986). Production will be estimated using the procedure of Garman and Waters (1983), and a statistical evaluation of data on fish growth rate will be conducted. 
As part of the growth evaluation, a validation program will be developed for the age determinations from scale analyses. This will involve analyzing otoliths and scales from sunfish collected in the bioaccumulation and the bioindicator monitoring programs (Sects. 4.0 and 5.0 respectively) and determining the degree of correspondence.

\subsection{INTERPRETATION OF BIOTIC CHANGES}

\subsubsection{Introduction}

The growing data base of information on the fish and benthic invertebrate communities of WOC watershed (Loar et al. 1981, Loar et al. 1992, Sects. 6.1 and 6.2; and Sects. 6.1 and 6.2 of this report) demonstrates that, although conditions have improved somewhat since 1980 and have remained more or less stable since the present program of sampling began in 1985, some stream reaches continue to show adverse impacts on the biota. These impacts are shown most convincingly by the continuing low biomass and low numbers of species at sites such as lower Fifth Creek (FFK 0.2) and WOC adjacent to the main ORNL complex (WCK 3.9).

Interpretation of the differences in the biotic communities in different reaches of WOC watershed, and of how these communities change through time, requires an understanding not only of biomass and diversity but also of the specific types of organisms that make up the community. The basis for this understanding is a knowledge of the types of organisms (not necessarily the exact species) that would occur naturally in streams of the size and condition of those in WOC watershed, as well as the biomass and diversity of organisms found in similar natural streams. "Improvement" of conditions in a stream could result in either an increase or a decrease in biomass or diversity, as well as a change in the types of species found in the stream. A thorough understanding of a variety of different reference sites is also necessary in order to understand the changes that are expected.

The objective of this study (Subtask $4 c$ of the BMAP, as discussed in Loar et al. 1991 ) is to develop a methodology, based on ecological theory and data from a large number of appropriate reference streams within the region, that will allow evaluation of (1) the ecological conditions of the various sites in WOC watershed and (2) the significance of changes in those conditions that occur following implementation of remedial actions.

\subsubsection{Methods}

The first stage of this study has been to assemble a data base that will help place the WOC watershed in a regional context and allow each site to be compared with streams of similar size and structure that have been less severely affected by human activity. No single stream can serve as an adequate reference (or control), because every stream differs in some way from every other. However, a regional data base developed from a large number of streams can help detect general patterns of community structure that would not be obvious from a study of only a few streams.

In the past year, a data base of fish community structure (in the form of a SAS data set) was completed in collaboration with Dr. David Etnier, University of Tennessee, and 
analysis was initiated. The principal source of data is a series of TVA studies of streams and rivers of the Tennessee Valley region ( 7 river systems with a total of 107 sites studied between 1968 and 1972). In addition tc the numbers and biomass of fish, the data base now includes measures of stream size, str, cture, and water quality. Measurements of watershed area, stream gradient, etc., were taken from a complete set of TVA 15-min quadrangles that was acquired for this study. These physiographic data allow basic comparisons between stream reaches that have not been thoroughly characterized by "on the ground" studies.

The current data base will be supplemented in the future with additional comparable data from the University of Tennessee Baseline Stream Survey of 20 sites conducted in 1981 (Etnier et al. 1983); data on small watersheds in the Cumberland Plateau assembled by G. A. Vaughn, The University of Tennessee Department of Zoology; and a compilation of data from the Powell River system assembled by the Tennessee Cooperative Fishery Unit at Tennessee Technological University.

In addition to comparisons of biomass and diversity, the data base allows comparisons of streams based on functional guilds of fish; that is, fish that consume different types of food and/or obtain their food in different physical areas of the stream (e.g., bottom feeders vs surface feeders). This classification of fish functional guilds (Table 6-17) was developed by Dr. David Etnier and allows comparisons of streams regardless of the particular species that may or may not occur in them.

\subsubsection{Results and Discussion}

Comparison of streams is always problematical because of the many ways in which they can differ (e.g., width, depth, flow volume, current velocity, water quality, temperature). Streams similar in one set of parameters may differ in other critical parameters that make them noncomparable. Stream order (relative position in a hierarchy of tributary streams) has long been used as a standard for comparability. However, even streams of the same order (e.g., $2^{\circ}$ streams formed by the junction of two unbranched tributaries) can vary greatly in size from one region to another, depending on the annual precipitation and thus their volume of flow. An alternative standard for comparison of streams is watershed area, which provides a better indication of flow rates and patterns than does stream order (Hughes and Omernik 1983).

To illustrate some of the general patterns in the TVA fish data base, streams were compared on the basis of watershed area and stream gradient. Together these two parameters characterize a wide range of stream conditions. Although there is significant correlation between watershed area and stream gradient (i.e., rivers with large watersheds tend to have much lower gradients than streams with smaller watersheds), there is sufficient variation for these two parameters to form a useful two-dimensional system in which to classify streams.

In all of the following graphs, each site is plotted in two-dimensional space based on the log of the watershed area at the sampling point and the log of the stream gradient ( $\times 10,000$ for convenience of scaling) at the sampling point. Each site is represented by a circle whose size is scaled to indicate the magnitude of a particular parameter (e.g., biomass or diversity) at that site in relation to all other sites on the graph. In all graphs 
Table 6-17. Functional classification of fish species collected from White Oak Creek in August-September 1986

Feeding guild

Species

1. Herbivores

1. Detritivores

2. Periphyton scrapers

3. Periphyton and midwater planktivore

4. Macrophytes and invertebrates

II. Insectivores

5. Midwater planktivore/ insectivores

6. Midwater/surface insectivore

Fathead minnow (Pimephales notatus)

Stoneroller (Campostoma anomalum)

Mosquitofish (Gambusia affinis)

Bluegill (Lepomis macrochirus)

7. Benthic insectivore

Banded sculpin (Cottus carolinae)

Blacknose dace (Rhinichthys atratulus)

Redbreast sunfish (Lepomis auritus)

Rock bass (Ambloplites rupestris)

Warmouth (Lepomis gulosus)

8. Benthic insectivore/

molluscivore

III. Piscivores

9. Midwater piscivore/ insectivore

10. Ambush piscivore

11. Pursuit piscivore

Largemouth bass (Micropterus salmoides)

12. Piscivore/scavenger/ insectivore

Yellow bullhead (Ictalurus natalis)

IV. Parasites

13. Parasite

Source: D. A. Etnier, Department of Zoology, The University of Tennessee, personal communication, 1986. 
the TVA sites from seven river systems (Buffalo, Duck, Emory, Flint, Powell, Sequatchie, and Upper Little Tennessee) are represented by thin circles, and sites from WOC are represented by thick circles with site labels. The data presented for the WOC sites were collected in August-September 1986 (Loar et al. 1992). One problem with use of the current data base for evaluation of the WOC watershed sites is the small number of reference sites with drainage areas as small as most of the sites on WOC and its tributaries.

\subsubsection{General Patterns in the Tennessee Valley Region}

One of the major trends in stream community structure is a decrease in the number of fish species in smaller high-gradient streams (Fig. 6-13). This trend is expected based on the greater number of habitats that are found in larger streams because, in general, species diversity is positively correlated with habitat heterogeneity. There also seems to be an effect of stream gradient on species number. For streams of relatively small watershed area (10-100 ha), the maximum number of species found at sites with similar areas is highest at intermediate stream gradients and decreases at sites with lower and higher gradients. This is consistent with predictions based on a dynamic equilibrium model of community structure (Huston 1979). Because the entire WOC watershed is small $(13.3 \mathrm{ha})$, the maximum number of species that would be expected is relatively low. For the WOC sites shown in Fig. 6-13, the number of species collected in August-September 1986 is at the low end of the range that would be expected in streams with those particular gradients and watershed areas.

With regard to total fish biomass among the TVA sites, the highest values are found in streams of intermediate watershed area (30-300 ha) (Fig. 6-14). Explanations for this pattern are likely to include increased nutrient input from larger watersheds, increased sunlight reaching the stream surface in wider streams, and water with higher clarity and higher oxygen content than large rivers. Biomass in streams the size of WOC sites is generally quite low, but biomass in some of the WOC sites (WCK 3.4 and WCK 5.1) appears unusually high for streams of this size, indicating possible nutrient enrichment.

Many other aspects of community structure can be evaluated in this same manner, some of which are discussed in the following section. A more detailed analysis of this data base will be prepared during the coming year.

\subsubsection{Patterns in the Guild Structure of WOC Sites}

The biomass of each trophic guild in a natural stream depends, in part, on the resources available to that guild. The relative biomass of different trophic guilds changes with stream size as relative resource levels change. For example, the relative proportion of the herbivorous periphyton scraper guild is highest in intermediate-sized streams (Fig. 6-15), where low turbidity and high insolation are likely to favor periphyton growth. In contrast, the relative proportion of midwater/surface insectivores increases with decreasing stream size (Fig. 6-16). The trophic guild structure of WOC sites can be evaluated in relation to the trophic structure of similar streams.

\footnotetext{
In relation to the site with the highest number of fish species.
} 


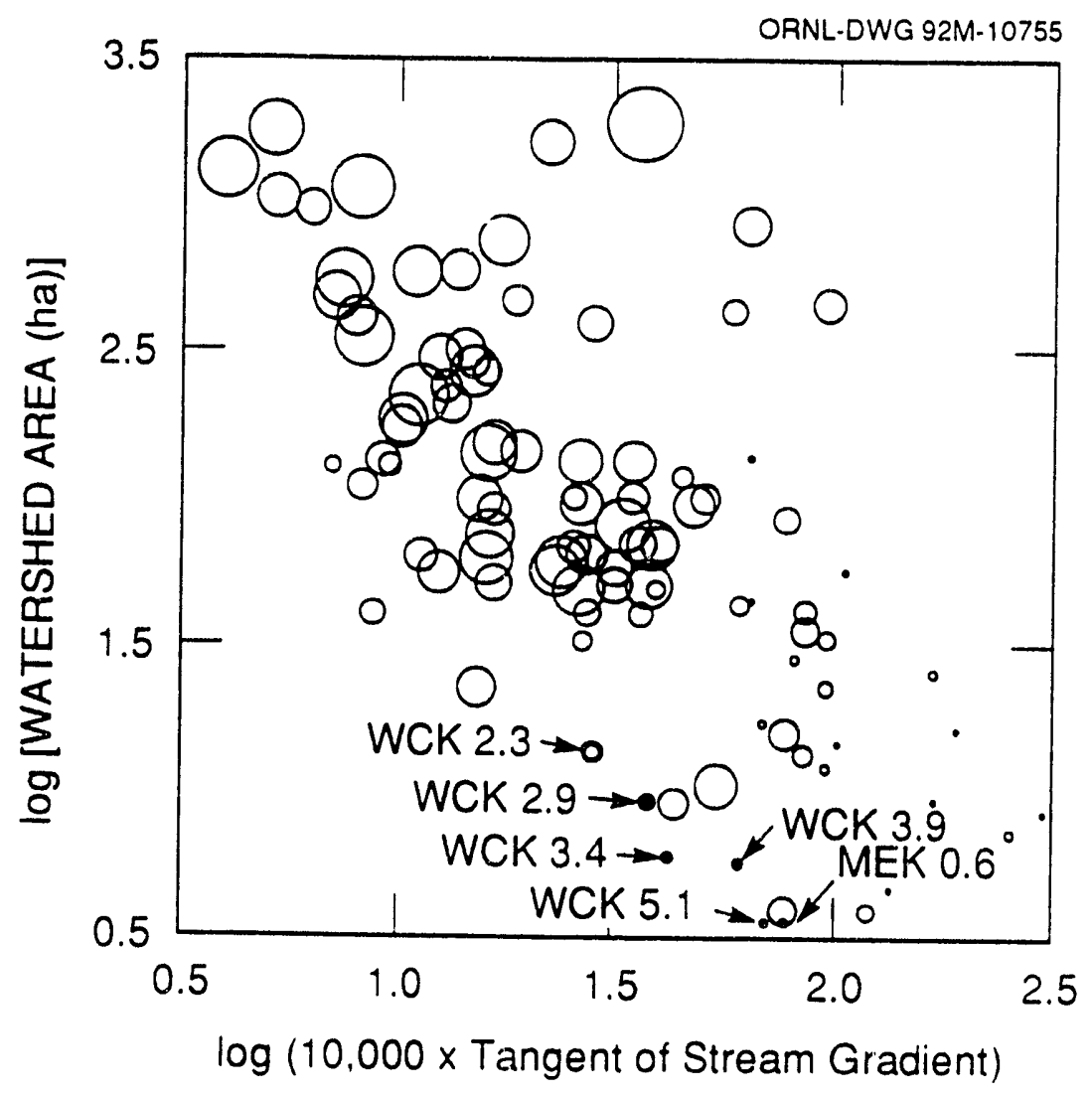

Fig. 6-13. Relative number of fish species at sites in the Tennessee Valley regional data bese and at White Oak Creek sites, August-September 1986 . Each circle is scaled in size with relation to the site with the highest number of fish species, so the number of fish species per site decreases proportionally with decreasing circle size. Sites on WOC are drawn with heavy lines and labeled. MEK = Melton Branch kilometer; WCK = White Oak Creek kilometer. 


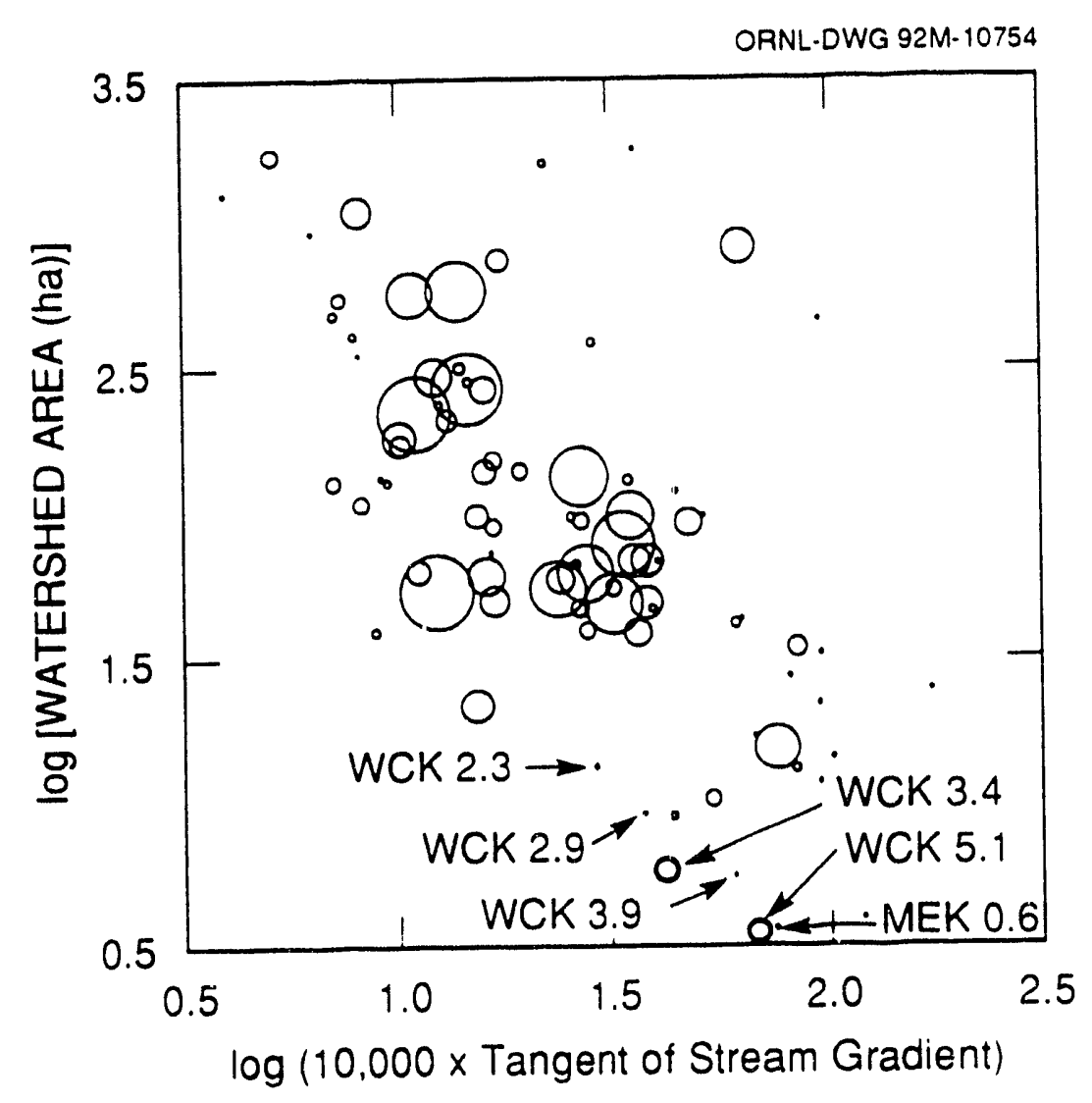

Fig 6-14. Relative fish wet weight at sites in the Tennessec Valley regional data bese and at White Oak Creek (WOC) sites, August-September 1986. Circles are scaled with relation to the site with the greatest total fish wet weight, so the total fish weight per site decreases proportionally with decreasing circle size. Sites on WOC are drawn with heavy lines and labeled. MEK = Melton Branch kilometer; WCK = White Oak Creek kilometer. 
ORNL-DWG 92M-10739

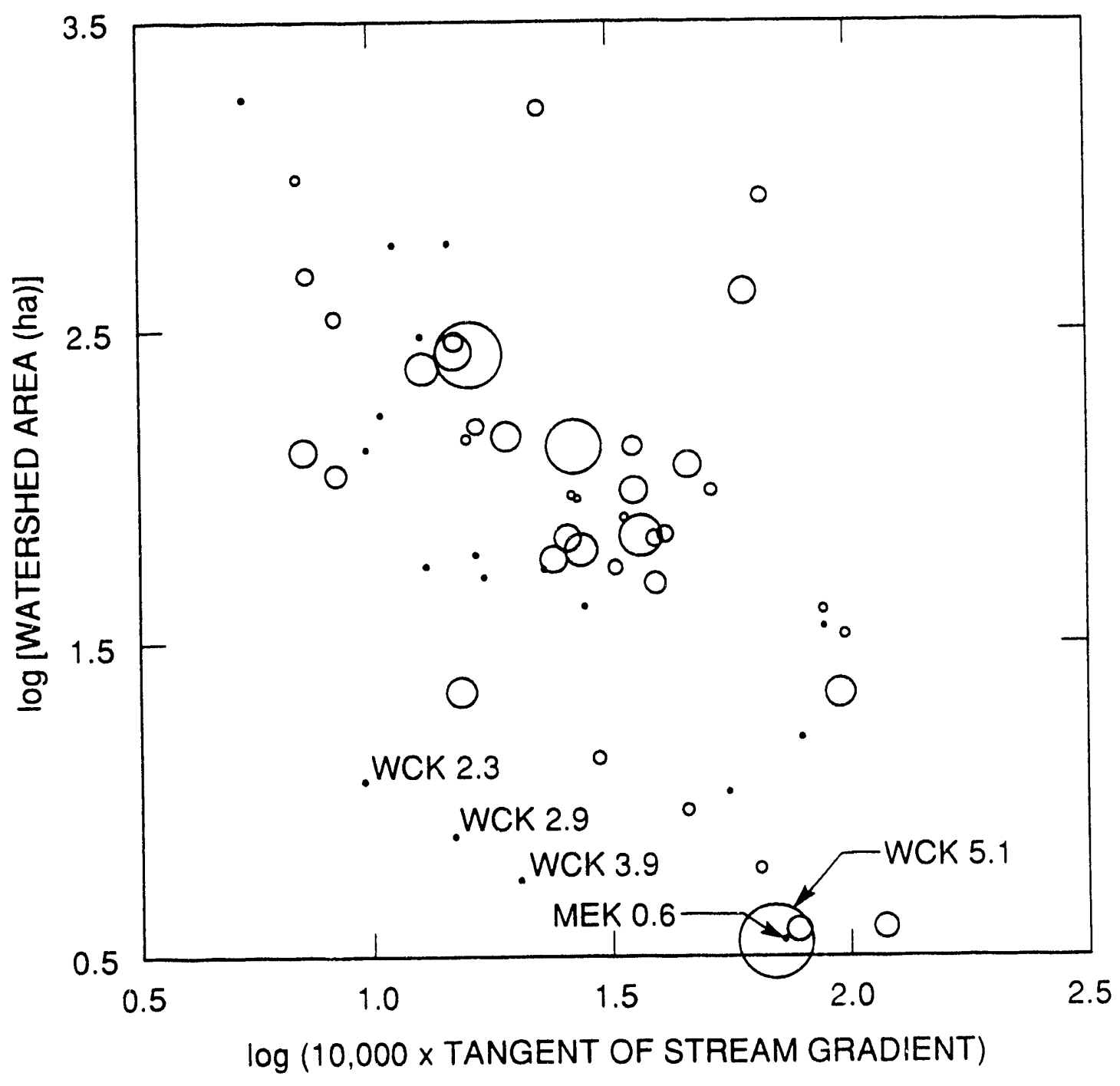

Fig 6-15. Relative proportion of the periphyton scraper guild to total fish population at sites in the Teanescee Valley regional data base and at White Oak Creek (WOC) sites,

August-September 1986 . The relative proportion is calculated as the total weight of all fish in the guild divided by the total weight of all fish. Circles are scaled with relation to the proportion of periphyton scrapers at that site. Thus, the proportion of guild members per site decreases in direct relation to circle size. Sites on WOC are drawn with heavy lines and labeled. MEK = Melton Branch kilometer; WCK = White Oak Creek kilometer. 
ORNL-DWG 92M-10740

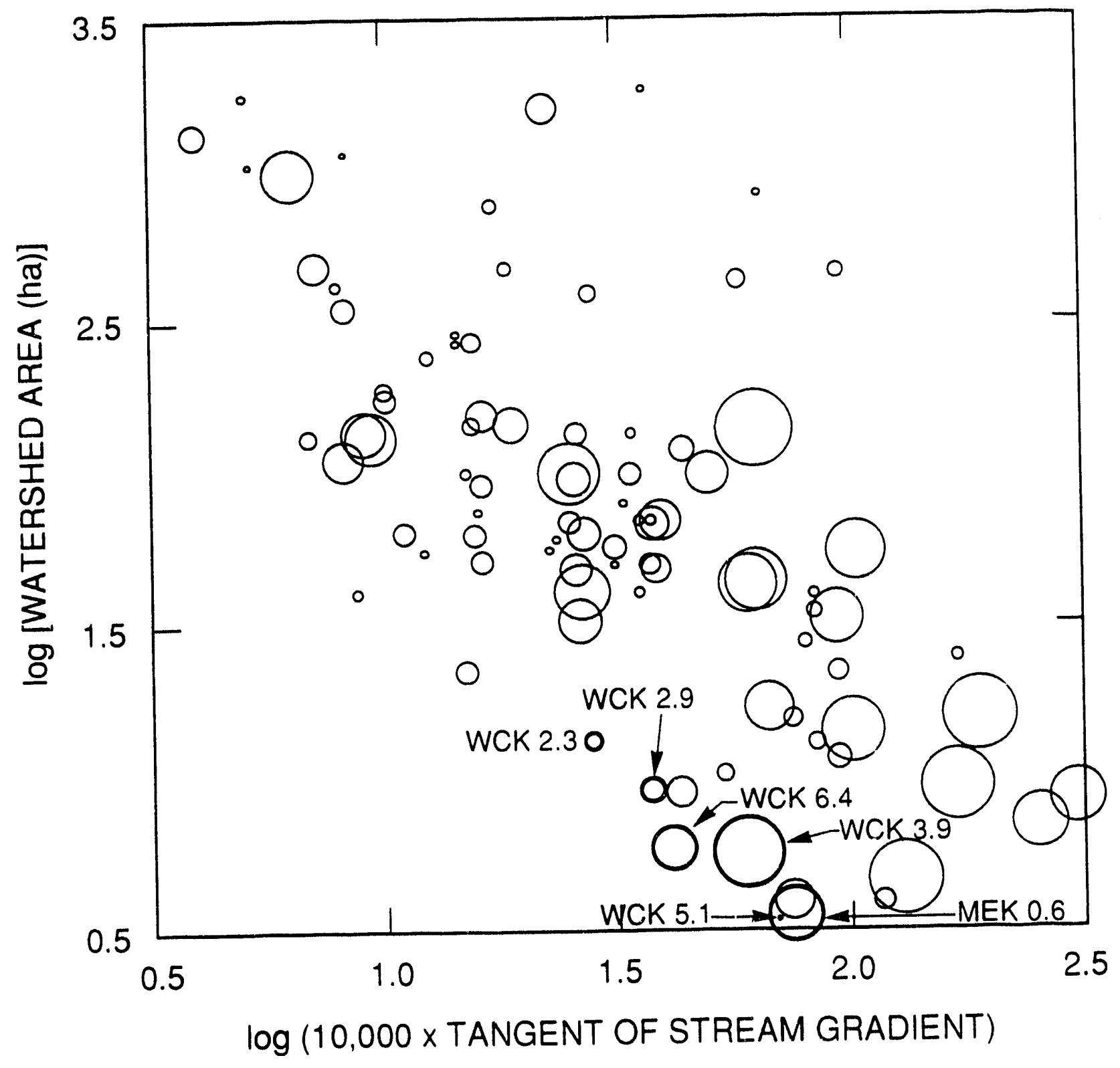

Fig 6-16. Relative proportion of the midwater/surface insectivore guild at sites in the Tennessee Valley regional data base and at White Oak Creek (WOC) sites, August-September 1986. The relative proportion is calculated as described in Fig. 6-15, and circles are scaled in size with relation to the proportion of midwater/surface insectivores at that site. Thus, the proportion of guild members per site decreases in direct relation to circle size. Sites on WOC are drawn with heavy lines and labeled. MEK $=$ Melton Branch kilometer; WCK $=$ White Oak Creek kilometer. 
The midwater/surface insectivore guild at most WOC sites appears to be within the range of relative ${ }^{*}$ abundances found in other streams of the same size (Figs. 6-16 and 6-17). This guild is represented by three species in WOC.

The periphyton scraper guild (Figs. 6-15 and 6-18) seems to be over-represented in terms of biomass at WCK 5.1 because of the abundance of the central stoneroller, which is the only member of this guild found in WOC. Ordinarily, very low relative* abundance would be expected for the central stoneroller at sites of this size, which is consistent with the low abundance of the species at most WOC sites.

The benthic insectivore guild, represented by five species in WOC, is present in relative" proportions consistent with other streams of the same size (Figs. 6-19 and 6-20). The high relative abundance of this guild in the highest-gradient sites (WCK 6.8, FCK 0.1, FCK 0.8, and FFK 1.0) is difficult to evaluate because currently there are no sites this small in the data base.

The high relative abundance of the fathead minnow at NTK 0.3 (Loar et al. 1992, Tables E-3 and E-6), which is classified as a detritivore, results in a very high representation of this guild at this site (Figs. 6-21 and 6-22). In the sites in the regional data base, the relative abundance of detritivores is generally quite low, with the maximum found in a large low-gradient river, where detritus levels would be expected to be high (Fig. 6-21). The ecological role of this invading species in WOC requires further study.

A more detailed analysis of guild structure in WOC and the regional data base will be prepared as a separate report during the coming year.

\subsubsection{Future Studies}

Efforts for the coming year will focus on adding more small (<5-ha) watersheds to the data base to provide a better basis for assessment of the smallest watersheds in the WOC system. Additional data will come from the Powell River data base completed by Tennessee Technological University. The University of Tennessee studies mentioned earlier and some additional sampling of small reference watersheds in the local area were also used as sources.

A complete, detailed analysis and interpretation of the data base, focusing on diversity and guild structure, will be prepared in the form of a peer-reviewed publication. In addition, patterns of seasonal and year-to-year variation in the guild structure of WOC sites and reference sites will be analyzed to allow comparison of the community dynamics at different sites, rather than simply the single-sample comparisons allowed by the present data base.

Work on a simulation model of stream communities will continue in collaboration with the ESD Stream Recycling and Resilience Project funded by the National Science Foundation.

"In relation to the site with the highest number of fish species. 
ORNL-DWG 92M-10741

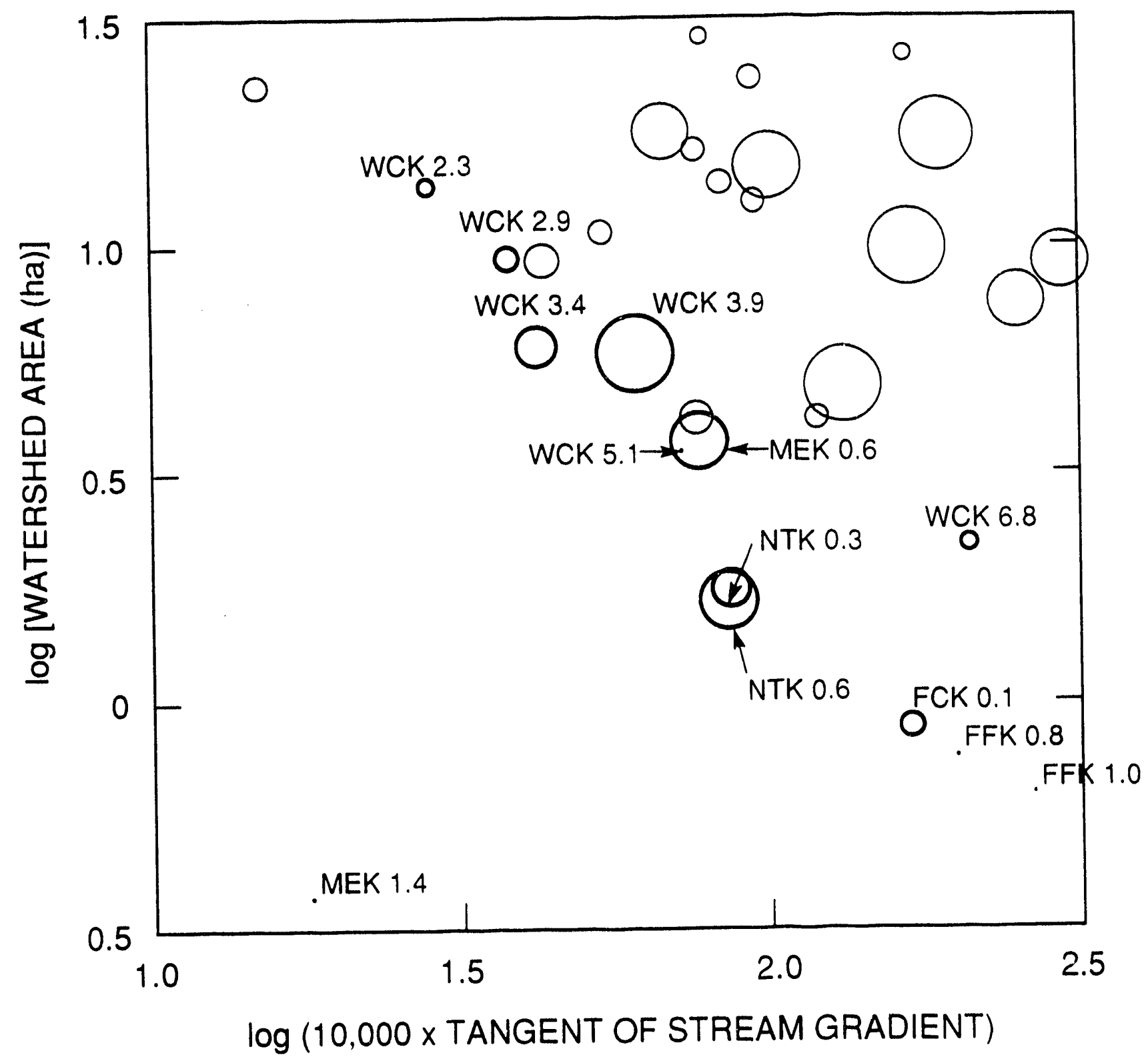

Fig. 6-17. Relative proportion of the midwater/surface insectivore guild at sites in the Tennessece Valley regional data base and at White Oak Creek (WOC) sites, August-September 1986 (rescaled ares). The axes have been rescaled to show the smaller WOC sites. Circles are scaled in size with relation to the proportion of midwater/surface insectivores at that site. Thus, the proportion of guild members per site decreases in direct relation to circle size. Sites on WOC are drawn with heavy lines and labeled. 
ORNL-DWG $92 M-10742$

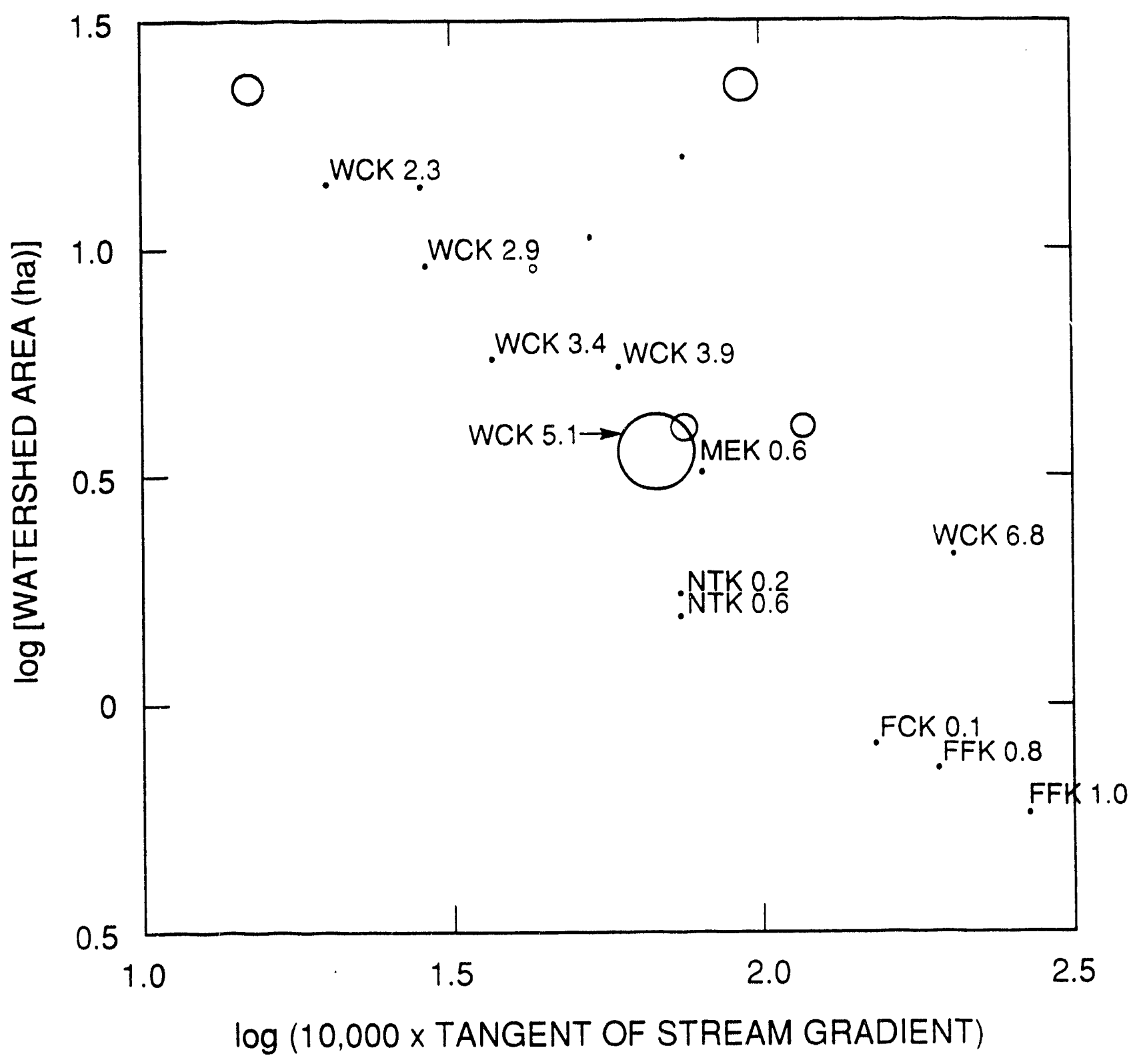

Fig 6-18. Relative proportion of the periphyton scraper guild at sites in the Tennessee Valley regional data base and at White Oak Creek (WOC) sites, August-September 1986 (rescaled ares). The axes have been rescaled to show the smaller WOC sites. Circles are scaled in size with relation to the proportion of periphyton scrapers at that site. Thus, the proportion of guild members per site decreases in direct relation to circle size. Sites on WOC are drawn with heavy lines and labeled. 
ORNL-DWG 92M-10743

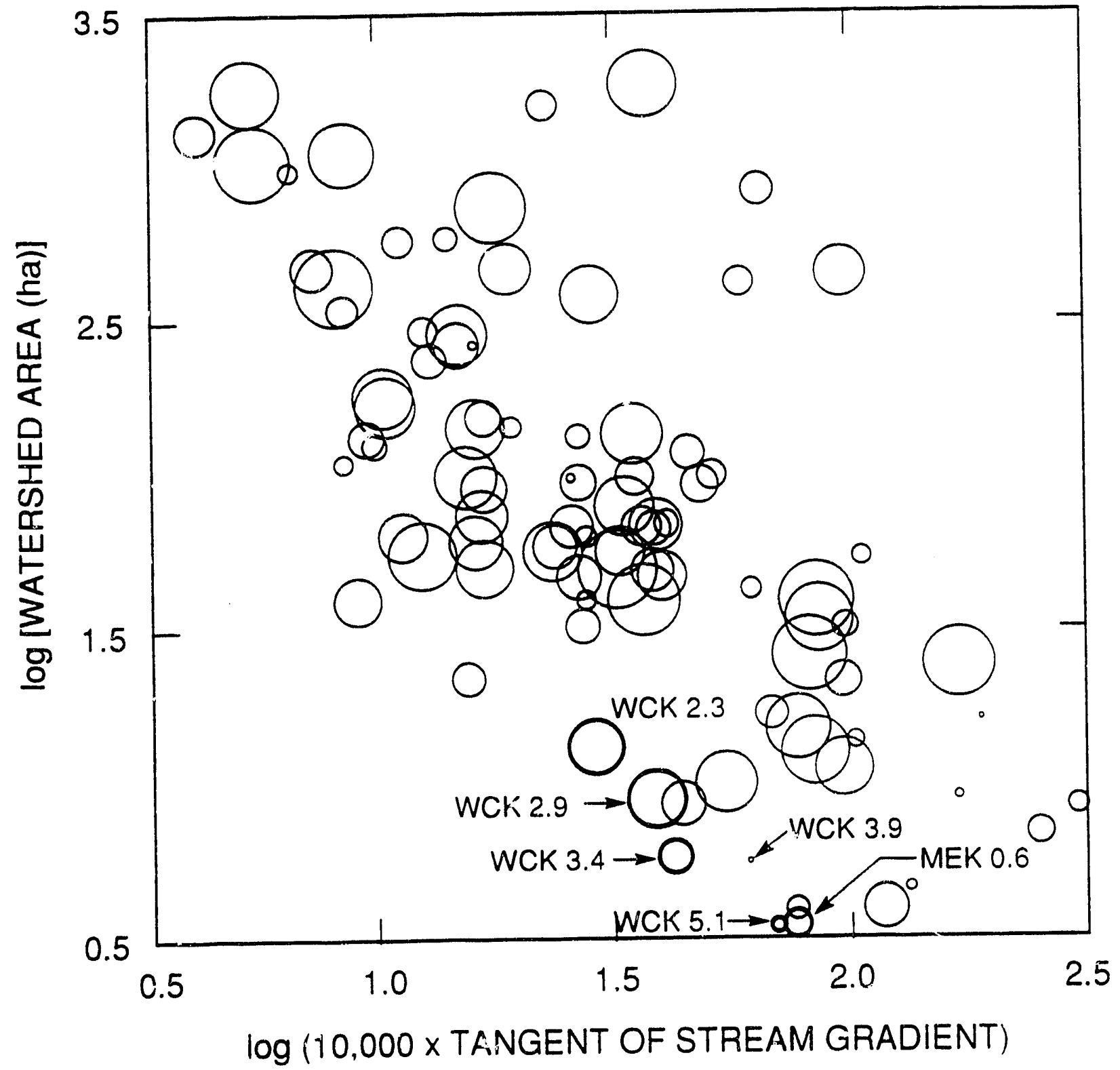

Fig. 6-19. Relative proportion of the benthic insectivore guild at sites in the Tennessee Valley regional data bese and at White Cak Creek (WOC) sites, August-September 1986. The relative proportion is calculated as the total weight of all fish in the guild divided by the total weight of all fish. Circles are scaled in size with relation to the proportion of benthic insectivores at that site. Thus, the proportion of guild members per site decreases in direct relation to circle size. Sites on WOC are drawn with heavy lines and labeled. 


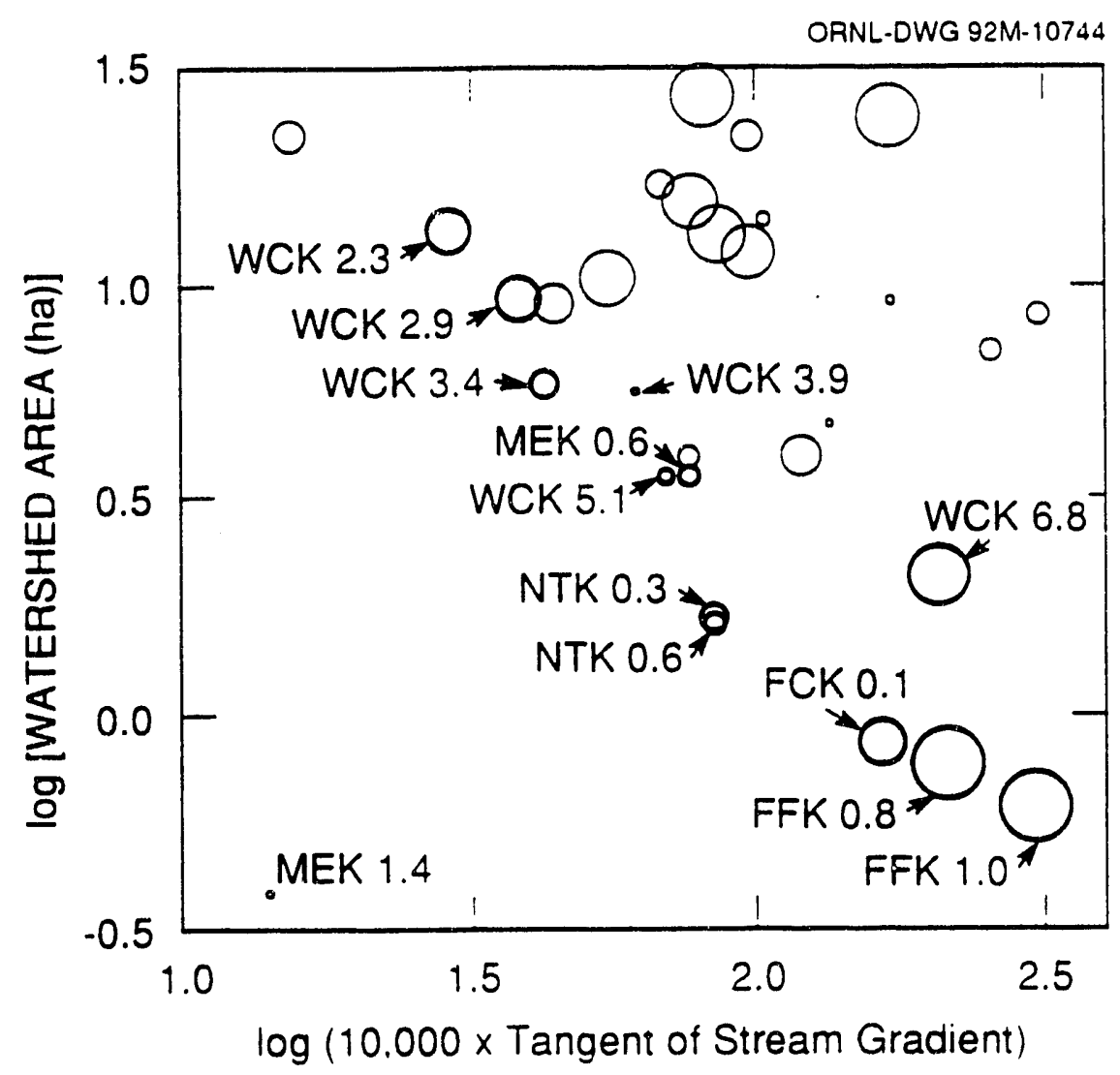

Fig. 6-20. Relative proportion of the benthic insectivore guild at sites in the Tennessee Valley regional data base and at White Oak Creek (WOC) sites, August-September 1986 (rescaled ares). The axes have been rescaled to show the smaller WOC sites. Circles are scaled in size with relation to the proportion of benthic insectivores at that site. Thus, the proportion of guild members per site decreases in direct relation to circle size. Sites on WOC are drawn with heavy lines and labeled. 


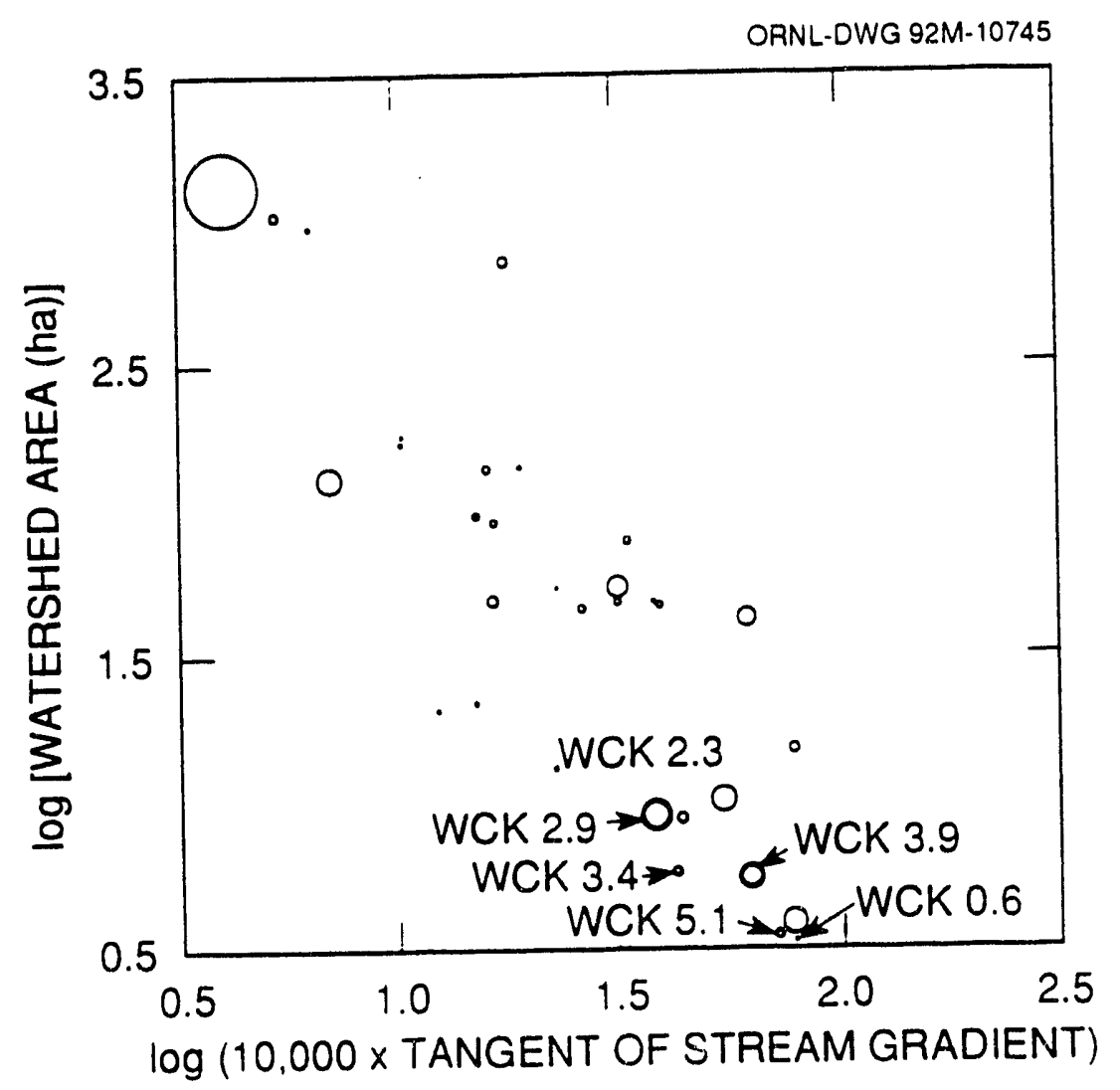

Fig 6-21. Reintive proportion of the detritivore guild at sites in the Tennesece Valley regional data bese and at White Oak Creek (WOC) sites, Angust-September 1986. The relative proportion is calculated as the total weight of all fish in the guild divided by the total weight of all fish. Circles are scaled in size with relation to the proportion of detritivores at that site. Thus, the proportion of guild members per site decreases in direct relation to circle size. Sites on WOC are drawn with heavy lines and labeled. 


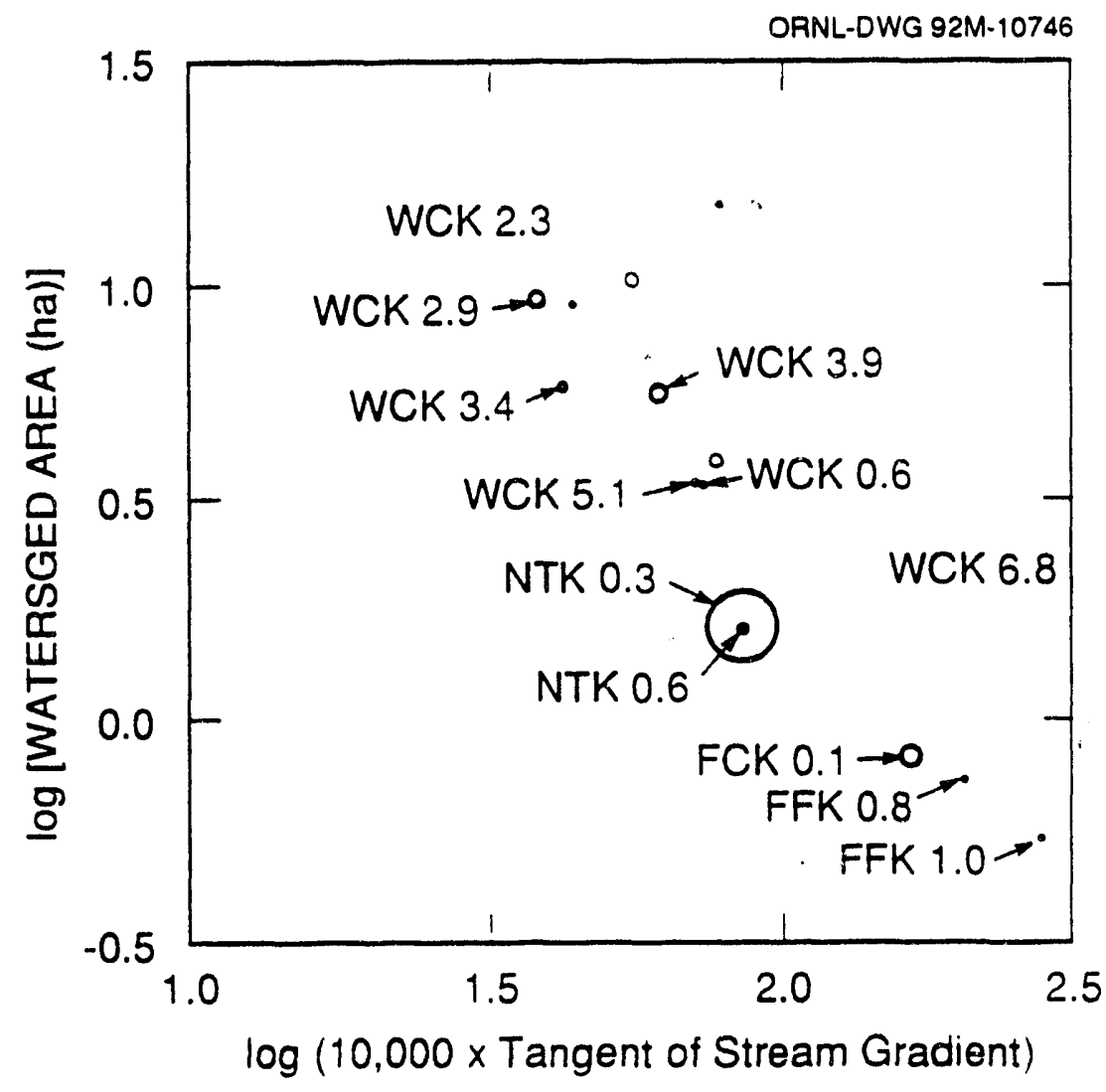

Fig 6-22. Relative proportion of the detritivore guild at sites in the Tennescee Valley regional data base and at White Oak Creek (WOC) sites, August-September 1986 (rescaled ares). The axes have been rescaled to show the smaller WOC sites. Circles are scaled in size with relation to the proportion of detritivores at that site. Thus, the proportion of guild members per site decreases in direct relation to circle size. Sites on WOC are drawn with heavy lines and labeled. 


\section{ASSESSMENT OF CONTAMINANTS IN THE TERRESTRIAL ENVIRONMENT}

Terrestrial biota can serve as important indicators of chemical contamination in terrestrial systems because toxicant exposures are integrated by the animals over time and space. Wildlife can be used to forecast potentially adverse biological impacts of environmental toxicants and as sentinels to show changes in concentrations of chemicals on a long-term basis. They can also serve as indicators of chemical concentrations in other compartments in the environment (Clark et al. 1988). Despite these advantages of wildlife monitoring, there are practical drawbacks that must be addressed in order to implement biomonitoring in terrestrial ecosystems.

Development of an effective biological monitoring program for the terrestrial environment presents special difficulties not encountered in aquatic environs. Fewer data exist on contaminant types, amounts, and sources for the terrestrial environment near ORNL, and much of the available data for radionuclides were obtained many years ago; thus, they are not reliable indicators of current levels of contamination. The slower movement of contaminants in soils compared with that in air and water, as well as the greater potential for spatial variation of contaminant concentrations in soils, complicates the task of surveying large land areas. Sampling must be conducted more intensively within a given area, and sources or hot spots cannot be readily tracked from flow patterns as in aquatic systems. Screening for contaminants is further complicated by the fact that chemicals present in soils may not reach either surface or ground waters in sufficient concentrations to be detected during routine water quality surveys. In addition, organic contaminants with high sorption coefficients $\left(\mathrm{K}_{\mathrm{p}}\right)$ in soil may not be found in surrounding waters, yet may still be available to terrestrial biota to produce toxic effects.

While methods for biological monitoring in aquatic environments have been intensively studied and extensively developed over the past decades (Roop and Hunsaker 1985, Bergman et al. 1986), standard procedures and approaches for terrestrial biomonitoring do not exist. The techniques of wildlife and population biology are not suitable for establishing toxicological effects of contaminants on natural populations of animals because they are too time-consuming, expensive, and typically yield equivocal results due to the high variability inherent in the measurements. In addition, terrestrial animals are generally more difficult to sample and handle than aquatic species. Whereas most aquatic animals can be obtained by electroshocking, seining, and netting, most terrestrial species must be trapped at a much lower success rate. Furthermore, the handling and transport of wild animals to the laboratory can be difficult and pose hazards of disease and bodily injury to workers. Nonetheless, biomonitoring for contaminants in the terrestrial environment offers a cost-effective means to obtain information on the scope of chemical contamination in the ORNL environs.

Studies to monitor contaminant levels in small mammals (Task 5) were modified in scope and continued during the second year of the ORNL BMAP. The objectives of this task of BMAP are (1) to document what radioactive and organic contaminants are present in elevated levels in the terrestrial environment at ORNL, (2) to examine the potential for mobility and availability of these contaminants to terrestrial biota, and (3) to select the 
appropriate organisms and monitoring approaches for more-detailed biological monitoring as needed (Loar et al. 1991). Included within the last objective is a continuation from 1986 of Subtask 5a (Part 4) on the use of freshwater turtles as indicators of environmental contamination. The turtles included in this subtask are found both on land and in water and did not, therefore, fall exclusively into any of the other biomonitoring tasks designated by ecosystem type. Inclusion of the turtle studies in Task 5 was somewhat arbitrary and was more a function of who had the expertise to conduct the studies than of where the turtles spend the largest percentage of their time.

\subsection{SMALL MAMMALS AS BIOLOGICAL MONTTORS OF ENVIRONMENTAL CONTAMINANTS}

\subsubsection{Introduction}

Effective environmental management requires knowledge of the transport and fate of contaminants in natural systems (Wren 1986). Small mammals can serve as indicators of the presence and bioavailability of contaminants, and selected monitoring species can be used to measure the accumulation of contaminants. Furthermore, knowledge of food habits and habitat may indicate pathways of contaminants to organisms.

Small mammals have frequently been used to monitor the presence of metals and other contaminants in the environment either directly, by residue analysis, or indirectly, by measurement of biochemical parameters. Biomonitoring is essential for determining bioavailability and resultant biological effects under natural conditions. Small mammals can be particularly effective biomonitors of soil contaminants if the species used are abundant, easily caught, do not migrate long distances, have a widespread distribution, and have generalized food habits (Beardsley et al. 1978). Ideal biomonitors are in equilibrium with the environment and show a graded response to a range of pollution.

Monitoring of small mammals can be used as a cost-effective survey of contaminated sites and as a means of routinely monitoring uncontaminated sites. Such monitoring can also provide evidence of contaminant impact on biota and be used to establish priorities for remedial action. In areas that have been established as uncontaminated where there is a potential for contamination via accidental releases or migration of contaminants, small mammals can be routinely monitored over long periods of time. Since the presence of a contaminant does not necessarily involve risk to humans, evidence of impact on biota, as determined by biochemical parameter changes and tissue residues, will help to establish the need for remedial action.

Tissue residue and biochemical analyses can provide needed information on contaminant exposure over an animal's home range. Such data may give an indication of the exposure history of the organism and are the best kind of data to indicate the bioavailability of contaminants. Thus, bioavailability, coupled with information on food habits and habitats, permits inferences on the route of transfer for chemical contaminants to biota. 
There are several potentially serious problems with biological monitoring in terrestrial systems. In many cases reference sites ecologically similar to contaminated sites are not available for comparative purposes. When suitable reference sites are found, the species composition at both sites may not be the same. In addition, the best species for monitoring, as indicated by preliminary studies, may be rare or not present at both sites. After selection of one or more indicator species, individual variation within species may be great, especially if the contaminated area is small and contains few animals. Trapping can be a labor-intensive exercise requiring that traps be checked daily. In addition, the biological significance of endpoints may be unknown. The presence of tissue residues or a change in biochemical parameters does not necessarily signify detrimental effects either to individuals or populations. Finally, the relationship of endpoints to exposure cannot always be determined. In the laboratory a known dose produces a specific level of response, but in the field the dose is unknown, and the time period over which exposure has occurred is likewise usually impossible to determine.

Extensive aquatic and groundwater monitoring studies were previously undertaken to determine the extent and impact of chemical contaminants in the ORNL environs (Boyle et al. 1982). In addition, contaminants in sediments in the vicinity of the Y-12 Plant were characterized (Hoffman et al. 1984) and provided information for selection of reference sites. From these preliminary studies, mercury, ${ }^{90} \mathrm{Sr}$, and several organic compounds, including benzo $[a]$ pyrene $(\mathrm{B}[a] \mathrm{P})$, were shown to be present in the soil at several sites.

No terrestrial biomonitoring studies have been conducted in the ORNL environs in recent years. Biomonitoring of small mammals was undertaken as an alternative to extensive soil sampling and chemical analyses, especially because of the large area involved and the lack of information on the extent of contamination in the ORNL terrestrial environment. In the studies for the present reporting period, small mammals were collected and analyzed primarily for mercury and ${ }^{90} \mathrm{Sr}$. Preliminary analyses of PCBs were conducted during 1987. Contaminant levels in soil and vegetation were either measured or obtained from field studies reported by others.

\subsubsection{Materials and Methods}

\subsubsection{Study sites}

White Oak Creek The floodplain of WOC provided the primary sampling area for small mammals. The stream flows through the ORNL complex into WOL, a settling basin for radionuclides, before entering the Clinch River. Discharges from several settling ponds contaminated with radionuclides $\left({ }^{90} \mathrm{Sr},{ }^{137} \mathrm{Cs}\right.$, and $\left.{ }^{60} \mathrm{Co}\right)$ enter the stream at several locations. The stream flows near several SWSAs and trenches (Fig. 2-2), where contaminated runoff and groundwater from these areas can enter WOC.

Two weirs are present on WOC downstream of the main plant area and serve as convenient references for designating locations of sampling sites. The areas above the weirs are characterized by low-lying flat fields covered with grassy vegetation. At the point where WOC enters WOL, the vegetation consists of shrubs with a canopy of boxelder (Acer negundo) and willow (Salix sp.). Animals were trapped on the floodplain near WCK 2.1 (the point where WOC enters WOL), near the weir at WCK 2.7 (NPDES 
station X14), and above the weir at Melton Valley Drive (WCK 3.4) during the spring and summer of 1987.

Solid Radioactive Waste Storage/Disposal Area 4. SWSA 4 encompasses an area of -10 ha just south of the main plant area (Fig. 2-2). Between 1951 and 1959, it was used as a low-level radioactive disposal site for wastes generated both on- and off-site (Melroy et al. 1986). Trenches and auger holes were used for disposal of the wastes. Alphaemitting wastes were covered with concrete, and the beta- and gamma-emitting wastes were covered with a natural soil cover (Lomenick and Cowser 1961). The burial ground was covered with uncontaminated fill and closed in 1959. It is now maintained as a grassy field. A bank covered with brush and trees separates SWSA 4 from a small tributary of WOC.

During periods of rain or high water table, the trenches at SWSA 4 fill up and overflow, creating surface contamination. This effect is referred to as the bathtub effect, and the seeps are referred to as "bathtub seeps." According to recent studies (Melroy et al. 1986), as much as $150,000 \mathrm{~Bq} / \mathrm{kg}$ dry weight of ${ }^{90} \mathrm{Sr}$ is present in the surface soil. Ground- level Geiger-Muller (GM) survey meter readings taken at the intersections of a 4-m grid pattern ranged up to 25,000 counts per minute (Fig. 7-1) (Garten and Lomax 1987). Small mammals were trapped in the area of the bathtub seeps during the spring and summer of 1987 to determine whether radionuclides were taken up by resident fauna and whether the site could be one of the sources of ${ }^{90} \mathrm{Sr}$ and ${ }^{137} \mathrm{Cs}$ in deer. SWSA 4 also served as a reference area for the mercury-contaminated site.

East Fork Poplar Creek EFPC, which originates at the Y-12 Plant, was selected as a reference site for comparison with animals collected from the ORNL environs. It is the receiving stream for industrial effluent from the Y-12 Plant and may receive wastes as it flows through a commercial area of Oak Ridge. The stream is $23.7 \mathrm{~km}$ in length from New Hope Pond, a waste settling pond at the east end of the Y-12 Plant, to its confluence with Poplar Creek. For much of its length, EFPC flows through the City of Oak Ridge. Near EFK 17-18, the floodplain is low and the creek floods periodically, depositing sediment. The floodplain at this point is abundantly vegetated with sneezeweed (Helenium autumnale), jewelweed (Impatiens capensis), and grasses (Sorgum halepense). A stand of boxelder borders an old field on the floodplain. Animals were trapped at this site during 1986 and 1987.

EFPC was contaminated with mercury released from the Y-12 Plant, where it had been used in a lithium-separation process. From 1950 to 1963, 1080 metric tons $(1,000,000 \mathrm{~kg})$ could not be accounted for at the plant (Bashor and Turri 1986). It is estimated that $80,000 \mathrm{~kg}$ may be present in the floodplain (R.R. Turner, ORNL, personal communication, 1986). Sample analyses by researchers at Oak Ridge Associated Universities indicate that most of the mercury is present as inorganic salts (Bashor and Turri 1986).

Benzo[a]pyrene is also present in the floodplain (Hoffman et al. 1984); and, although its source is unknown, $\mathrm{B}[a] \mathrm{P}$ concentrations are high in the floodplain adjacent to the $\mathrm{Y}$ 12 Plant and decrease with distance downstream. Radionuclides are present at extremely low levels and, according to Hoffman et al. (1984), can be excluded from consideration as 


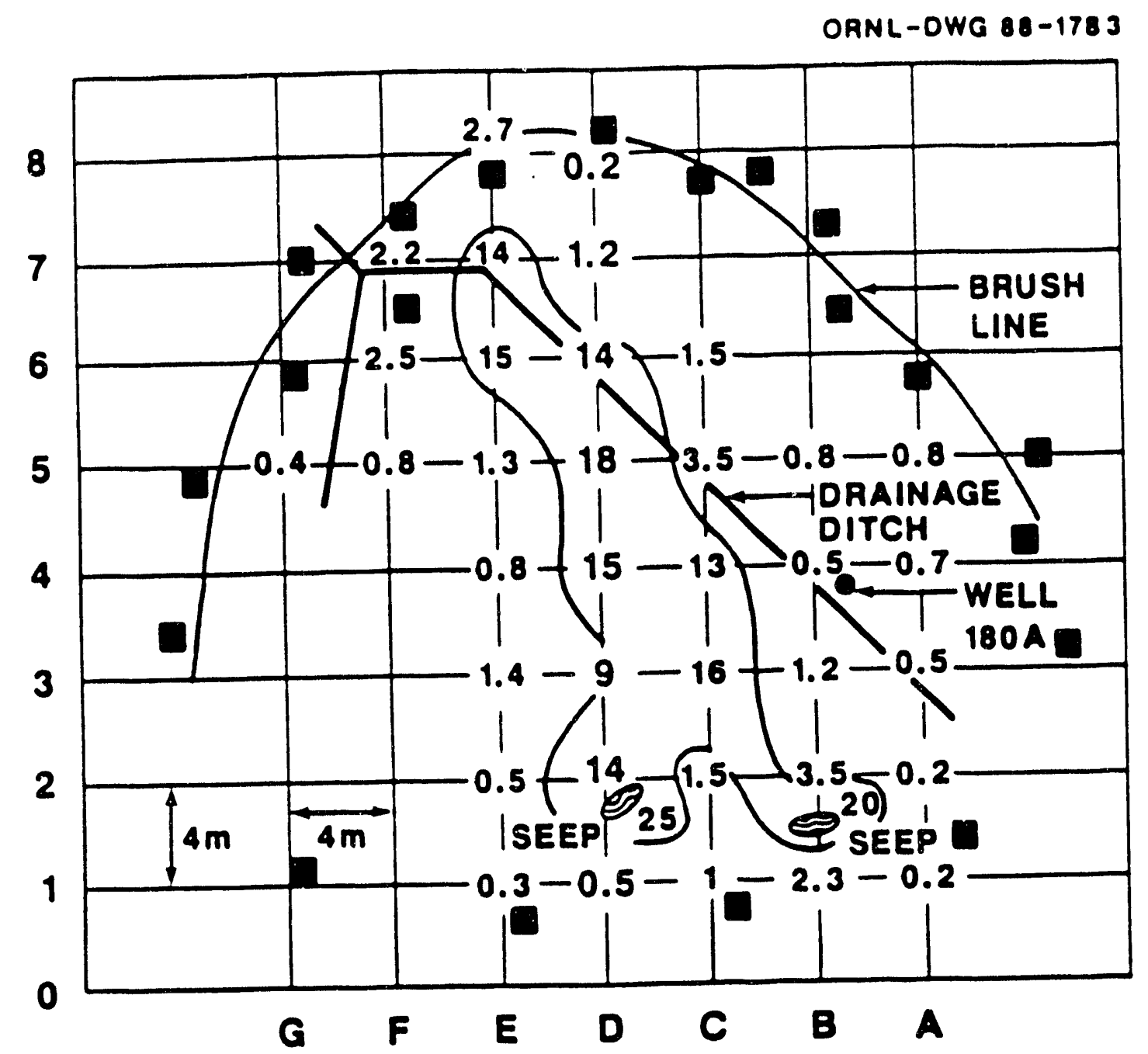

Fig 7-1. Grid pattern for solid radioactive waste storage/disposal area (SWAS) 4, showing the bathtub seeps and the location of small mammal traps (indicated by squares). 
important contaminants. Thus, the EFPC floodplain provided an excellent negative control for radionuclides in small mammals and a positive control for mercury and $B[a] P$.

\subsubsection{Trapping of small mammals}

Small mammals were trapped using $23 \times 8 \times 8 \mathrm{~cm}$ Sherman live traps baited with sunflower seeds and/or fish. All traps were checked each morning, and trapped animals were transported to the laboratory, where they were identified to species and weighed. Selected tissues were analyzed for mercury, ${ }^{90} \mathrm{Sr}$, and PCBs.

\subsubsection{Soil sampling}

Surface soil samples $(0-3 \mathrm{~cm})$ were collected at trap locations at all sites. At EFPC, samples were also taken with a soil corer at depths up to $40 \mathrm{~cm}$. (Deposits of metallic mercury were visible in the cores at a depth of $20-40 \mathrm{~cm}$.) Sampling points were noted by trap location or by coordinates relative to a permanent marker at the site. Soils were analyzed for mercury and $\mathrm{B}[a] \mathrm{P}$ to supplement previously reported evaluations of $\mathrm{B}[\mathrm{a}] \mathrm{P}$ in mammals (Loar et al. 1992).

\subsubsection{Analytical methods}

Benzo[a]pyrene. Soil samples were collected at all study sites and air dried, sieved (2-mm mesh), and composited before extraction. In preliminary studies $\mathrm{B}[\mathrm{a}] \mathrm{P}$ and other organics in soil and vegetation from the EFPC site were determined by the ACD at ORNL. Subsequent extractions and analyses were conducted in our laboratory using the following procedures.

Benzo[a]pyrene was extracted from soil by Soxhlet extraction according to EPA Method 3540 (EPA 1982). Soil samples of $5 \mathrm{~g}$ each were mixed with $5 \mathrm{~g}$ of anhydrous sodium sulfate (to absorb water) and $5 \mathrm{~g}$ of Ottawa sand (to permit good solvent percolation), placed in an extraction thimble, and extracted using $150 \mathrm{~mL}$ of methylene chloride. The extract was reduced in volume to $1 \mathrm{~mL}$ on a rotnevaporator (Buchi Rotovapor-R).

Because colored contaminants were present in the extract, a cleanup step was developed to clarify the samples as follows. During cleanup the solvent was changed to cyclohexane, and organics were extracted into dimethyl sulfoxide and reextracted into clean cyclohexane followed by two water washes. Most of the interfering colored contaminants remained in the original cyclohexane. The samples were dried with sodium sulfate, concentrated, filtered through silica columns (Waters Silica Sep-Paks), and dried further under a stream of nitrogen. The samples were then dissolved in $1 \mathrm{~mL}$ of $100 \%$ methanol, filtered, and injected into a high-pressure liquid chromatograph (Perkin-Elmer Series 4) coupled with a fluorescence spectrometer (Perkin-Elmer LS-4). Samples were eluted with $100 \%$ methanol; detector settings were $355 \mathrm{~nm}$ excitation and $410 \mathrm{~nm}$ emission.

Initial extractions using ${ }^{14} \mathrm{C}$-labeled $\mathrm{B}[a] \mathrm{P}$ showed that percentage of recovery was poor. Since $\mathrm{B}[a] \mathrm{P}$ appears to be strongly sorbed to soils, extractions were carried out for a longer period than prescribed in the EPA method, and different solvents were tested. 
Organic carbon contents of the soils were also determined to establish its influence on $\mathrm{B}[a] \mathrm{P}$ extractability. For the latter analyses, each soil was initially prepared by grinding to a fine powder using a high-speed grinder (Janke and Kunkel, Cincinnati, Ohio). Next, 1 g of Iron Chip Accelerator (LECO Brand) and $1 \mathrm{~g}$ of Copper Metal Accelerator (WACO Brand) were added to a baking crucible. The crucible was tared, and $\sim 0.8 \mathrm{~g}$ of soil was added. The contents were mixed thoroughly, placed in a LECO HF 20 Induction Furnace, and ignited. The total carbon content was analyzed by a LECO WR 12. Carbon Determinator. Triplicate samples of composite soils were analyzed from each site.

Mercury. Air-dried soil samples and fresh kidneys from small mammals were analyzed for total mercury by the ACD laboratory at ORNL. Samples were wet digested in nitric and perchloric acids and analyzed as a cold vapor by atomic absorption spectroscopy.

Because the levels of mercury in tissue were unknown before analysis and literature searches indicated that they may be very low, kidney samples from several animals of the same species collected at EFPC (the positive reference site) were pooled to provide a sample weight of $1 \mathrm{~g}$. When the first results indicated that mercury levels were extremely high compared with the detection limit of $40 \mathrm{ng} / \mathrm{g}$, individual kidneys of a pair were submitted separately. Kidneys from laboratory-reared mice were analyzed to obtain background mercury concentrations.

905r. Hind limbs and crania of sacrificed animals were cleaned of muscle tissue, dried overnight at $100^{\circ} \mathrm{C}$, and ashed at $900^{\circ} \mathrm{C}$. Weights of wet, dried, and ashed samples were recorded. The bone samples were ground, successively digested in $4 M$ hydrochloric and $8 \mathrm{~N}$ nitric acid, dried, cleared with $30 \%$ hydrogen peroxide, and then dissolved in plastic vials containing $20 \mathrm{~mL}$ of water and a few drops of hydrochloric acid. Samples were counted for Cerenkov radiation in a Packard Tri-Carb Scintillation Spectrometer (Model 3002). Bones from laboratory-reared mice and blank samples served as controls.

\subsubsection{PCBs}

PCBs in whole liver and brain of small mammals were analyzed by the ACD laboratory. The procedure utilized Soxhlet extraction with methylene chloride as the solvent. Analysis was by packed column GC/ECD. Brain and liver tissue, rather than fat tissue, were used because wild animals were found to have too little fat for analyses.

\subsubsection{Results}

\subsubsection{Small mammal species}

Seven different species of small mammals were captured along WOC, at SWSA 4, and along EFPC (Table 7-1). The white-footed mouse, Peromyscus leucopus, was the most common species trapped and was present at all locations.

\subsubsection{Benzo[a]pyrene}

Analyses of composite soils showed that $\mathrm{B}[a] \mathrm{P}$ was present at all three sampling locations (Table 7-2). The highest concentration was found at EFK 17.4 (70 ng/g, dry wt); 
Table 7-1. Species and number of small mammals trapped at different study sites during 1986-1987

Scientific name

Number collected

East Fork Poplar Creek Floodplain (near EFK 17.4)

Peromyscus leucopus (White-footed mouse)

Blarina brevicauda (Shorttail shrew)

Sigmodon hispidus (Cotton rat)

White Oak Creek Floodplain (near WCK 2.1)

Peromyscus leucopus (White-footed mouse)

White Oak Creek Floodplain (near WCK 2.7)

Peromyscus leucopus (White-footed mouse)

White Oak Creek Floodplain (near WCK 3.4)

Peromyscus leucopus (White-footed mouse)

Sigmodon hispidus (Cotton rat)

Reithrodontomys humulis (Eastern harvest mouse)

Solid Radioactive Waste Storage/Disposal Area 4

Peromyscus leucopus (White-footed mouse)

Blarina brevicauda (Shorttail shrew)

Sigmodon hispidus (Cotton rat)

Reithrodontomys humulis (Eastern harvest mouse)

Microtus pinetorum (Pine vole)

3

Tamias striatus (Eastern chipmunk)

2

Mus musculus (House mouse)

Table 7-2. Benzo[a]pyrene concentrations in soil at the East

Fork Poplar Creek Aloodplain near EFK 17.4, White Oak

Creek Aloodplain near WCK 2.1, and Solid

Radioactive Waste Storage/Disposal

Area 4 (SWSA 4)

Site

Concentration $^{a}$

(ng/g)

EFK 17.4

WCK 2.1

70

SWSA 4

5

35

-Values represent the mean of duplicate analyses of a single composite sample. 
lower concentrations were present at SWSA 4 and WCK 2.1. That some of the small mammals trapped on the EFPC floodplain tested positively for $B[a] P$ (based on $B[a] P$ adducts to hemoglobin), while those from the WOC floodplain and SWSA 4 were negative (Loar et al. 1992), suggests that a soil concentration of $B[a] P>35 \mathrm{ng} / \mathrm{g}$ is needed to elicit a positive response for uptake of $\mathrm{B}[a] \mathrm{P}$ by small mammals.

\subsubsection{Mercury}

Mercury concentrations in the soil from the EFPC floodplain averaged $348 \mu \mathrm{g} / \mathrm{g}$ in the top $3 \mathrm{~cm}$ (Table 7-3) and $1675 \mu \mathrm{g} / \mathrm{g}$ at a depth of $20-40 \mathrm{~cm}$. Concentrations were lower along WOC, averaging from $0.8 \mu \mathrm{g} / \mathrm{g}$ at WCK 2.7 to $7.0 \mu \mathrm{g} / \mathrm{g}$ at WCK 3.4, and were lowest at the reference site (SWSA 4). Residues of mercury were detected in kidneys of all mammals collected at the study sites (Table 7-3). The highest concentrations of mercury were found in mammals trapped on the EFPC floodplain. Concentrations in the shorttail shrew, Blarina brevicauda, ranged from 21 to $73 \mu \mathrm{g} / \mathrm{g}$, wet wt. Concentrations in small $P$. leucopus, the only species trapped at all sites, and the cotton rat, Sigmodon hispidus, from the EFPC floodplain were $1.5 \mu \mathrm{g} / \mathrm{g}$ and $1.9 \mu \mathrm{g} / \mathrm{g}$, respectively, compared with $\leq 0.5 \mu \mathrm{g} / \mathrm{g}$ for both species at WCK 3.4 and SWSA 4. The standard deviation of the mean was large (from $41 \%$ up to $106 \%$ of the mean) for all field-collected species. The mean concentration in laboratory mice fed laboratory chow was $0.02 \mu \mathrm{g} / \mathrm{g}(n=4)$. Concentrations for individual animals collected at each site are listed in Appendix I.

\subsubsection{4 ${ }^{90} \mathrm{Sr}$}

All small mammals from SWSA 4 and the WOC floodplain had detectable concentrations of ${ }^{90} \mathrm{Sr}$ in bone tissue (Table 7-4). At SWSA 4, the highest concentrations were found in the Eastern harvest mouse, Reithrodontomys humulis, (mean: $71.5 \mathrm{~Bq} / \mathrm{g}$, dry wt of bone; range: $10.0-281 \mathrm{~Bq} / \mathrm{g}$ ). This species was captured in the grass immediately adjacent to the seeps. Concentrations were high for S. hispidus trapped at both SWSA 4 and WCK 3.4 (26.5 and $20.7 \mathrm{~Bq} / \mathrm{g}$ respectively) and for B. brevicauda trapped at SWSA 4 $(23.5 \mathrm{Bg} / \mathrm{g})$. ${ }^{90} \mathrm{Sr}$ was present in low concentrations in $P$. leucopus and $R$. humulis trapped at the WOC sites. The standard deviation of the mean was large in all cases. Concentrations were close to background in animals from EFPC. Concentrations in laboratory-raised mice averaged the same as distilled water blanks and blanks taken through the entire analytical procedure (12 counts/min). Concentrations for individual animals collected at each site are listed in Appendix J.

\subsubsection{PCB6}

Only three $P$. leucopus, two trapped at WCK 2.1 and one trapped at SWSA 4, and two laboratory control mice were analyzed for PCB-1254 and PCB-1260 (Table 7-5). Except for PCB-1260 in the liver $(2.1 \mu \mathrm{g} / \mathrm{g})$ of $P$. leucopus from WCK 2.1, concentrations in brain and liver tissue of the field-collected specimens were similar to those of the control mice. 
Table 7-3. Mencury concentrations found in soil and kidncy. tissue of small mammals collected on the East Fork Poplar Creek floodplain near EFK 17.4;" White Oak Creek Aoodplain, and Solid Radioactive Waste Storage/Disposal Area 4 (SWSA 4)

Soil samples expressed as micrograms per gram dry weight; tissue samples expressed as micrograms per gram, wet weight

\begin{tabular}{|c|c|c|c|c|}
\hline $\begin{array}{l}\text { Collection } \\
\text { site }^{a}\end{array}$ & $\begin{array}{l}\text { Peromyscus } \\
\text { leucopus }\end{array}$ & $\begin{array}{c}\text { Blarina } \\
\text { brevicauda }\end{array}$ & $\begin{array}{l}\text { Sigmodon } \\
\text { hispidus }\end{array}$ & Soil \\
\hline EFK 17.4 & $\begin{array}{l}1.5 \pm 1.6^{b} \\
(11)\end{array}$ & $\begin{array}{l}47.2 \pm 19.3^{b} \\
(5)\end{array}$ & $\begin{array}{l}1.9 \\
(1)\end{array}$ & $\begin{array}{l}348 \\
(2)\end{array}$ \\
\hline WCK 3.4 & $\begin{array}{l}0.27 \\
(1)\end{array}$ & $\mathrm{ND}^{c}$ & $\begin{array}{l}0.5 \pm 0.3 \\
(3)\end{array}$ & $\begin{array}{l}7.0 \\
(2)\end{array}$ \\
\hline WCK 2.7 & $\begin{array}{l}0.4 \pm 0.2 \\
(5)\end{array}$ & ND & ND & $\begin{array}{l}0.8 \pm 0.5 \\
(3)\end{array}$ \\
\hline WCK 2.1 & $\begin{array}{l}0.2 \pm 0.2 \\
(9)\end{array}$ & ND & ND & $\begin{array}{l}2.6 \pm 0.8 \\
(3)\end{array}$ \\
\hline SWSA 4 & $\begin{array}{l}0.5 \pm 0.4 \\
(8)\end{array}$ & $\begin{array}{l}0.9 \pm 0.6 \\
(3)\end{array}$ & $\begin{array}{l}0.1 \\
(1)\end{array}$ & $\begin{array}{l}0.2 \pm 0.1 \\
(6)\end{array}$ \\
\hline
\end{tabular}

${ }^{a}$ EFK $=$ East Fork kilometer; $\mathbf{W C K}=$ White Oak Creek kilometer; SWSA $=$ Solid Radioactive Waste Storage/Disposal Area.

'Significantly different from the reference site (SWSA 4) (Student's t-test, $p=0.05$ ).

'No data available.

Note: Values are the mean \pm 1 s.d. (sample size in parentheses).

\subsubsection{Discussion}

\subsubsection{Benzo[a]pyrene}

Although $\mathrm{B}[a] \mathrm{P}$ is nearly ubiquitous in terrestrial ecosystems (Edwards 1983), uptake by vegetation is usually low. In a literature review Edwards (1983) found that concentration ratios $(B[a] P$ in vegetation: $B[a] P$ in soil) ranged from 0.0001 to 0.33 . In the present study, $\mathrm{B}[a] \mathrm{P}$ was found in the soil at all three study sites. The highest concentration was found at EFPC ( $70 \mathrm{ng} / \mathrm{g}$ ), but this concentration was low compared to highly contaminated areas cited by Edwards (up to $191 \mu \mathrm{g} / \mathrm{g}$ ). Low concentrations of a $B[a] P$ metabolite were found in some species of mammals collected at this site (Loar et al. 1992). None of the animals collected at WOC had detectable quantities of the $B[a] P$ metabolite. The low concentrations in the soil near WOC $(5 \mu \mathrm{g} / \mathrm{g})$ and the absence of uptake by small mammals inhabiting the area indicate that $\mathrm{B}[\mathrm{a}] \mathrm{P}$ is not a contaminant of concern at SWSA 4 or along WOC. 
Table 7-4. Strontium-90 concentrations (expressed as becquerels per gram dry $w$ ) in bone of small mammals collected from Solid Radioactive Waste Storage/Disposal Area 4 (SWSA 4),

the floodplain of Xzivic Oak Creek, and the Aloodplain of East Fork Poplar Creek near BFK 17.4

Values are mean \pm 1 s.d. (sample size in parentheses)

\begin{tabular}{|c|c|c|c|c|}
\hline Collection & $\begin{array}{l}\text { Piromyscus } \\
\text { leucopus }\end{array}$ & $\begin{array}{c}\text { Reithrodontomys } \\
\text { humulis }\end{array}$ & $\begin{array}{c}\text { Blarina } \\
\text { brevicauda }\end{array}$ & $\begin{array}{l}\text { Sigmodon } \\
\text { hispidus }\end{array}$ \\
\hline SWSA 4 & $\begin{array}{l}12.7 \pm 24.4 \\
(14)\end{array}$ & $\begin{array}{l}71.5 \pm 117 \\
(5)\end{array}$ & $\begin{array}{l}23.5 \pm 35.6 \\
(3)\end{array}$ & $\begin{array}{l}26.5 \pm 35.6 \\
(2)\end{array}$ \\
\hline WCK $5:$ & $\begin{array}{l}0.6 \\
(1)\end{array}$ & $\begin{array}{l}0.9 \\
(1)\end{array}$ & ND & $\begin{array}{l}20.7 \pm 20.9 \\
\text { (3) }\end{array}$ \\
\hline WCK 2.7 & $\begin{array}{l}1.6 \pm 1.2 \\
(5)\end{array}$ & ND & ND & ND \\
\hline WCK 2.1 & $\begin{array}{l}1.6 \pm 1.5 \\
(9)\end{array}$ & ND & ND & ND \\
\hline EFK 17.4 & $\begin{array}{l}<0.04 \\
(6)\end{array}$ & ND & $\begin{array}{l}<0.4 \\
(3)\end{array}$ & ND \\
\hline
\end{tabular}

-SWSA = Solid Radioactive Waste Storage/Disposal Area; WCK = White Oak Creek kilometer, EFK = East Fort Poplar Creek kilometer.

ND $=$ no data available.

\subsubsection{Mercury}

Mercury burdens in terrestrial mammals are generally related to diet and are reported to be lower in herbivores than in carnivores (NRC 1978). According to Wren (1986) mercury concentrations are biomagnified within terrestrial food chains and the highest levels of mercury (up to $40 \mathrm{\mu g} / \mathrm{g}$, wet wt of tissue) have been found in seed-eating birds and mammalian predators in areas where mercury-containing fungicides were widely used as seed disinfectants. Mercury does nut appear to concentrate in plants; concentrations are usually $<0.5 \mu \mathrm{g} / \mathrm{g}$ fresh weight plant tissue in control areas and up to $3.5 \mu \mathrm{g} / \mathrm{g}$ over cinnabar deposits (Shacklette 1970).

Releases of mercury into EFPC have contaminated the creek and its floodplain with concentrations as high as $2100 \mu \mathrm{g} / \mathrm{g}$ having been measured in the floodplain (C. S. Gist, ORAU, unpublished data). Mercury concentrations in plants ranged from 0.00058 to $0.31 \mu \mathrm{g} / \mathrm{g}$ with an average value of $0.05 \mathrm{\mu g} / \mathrm{g}$ in vegetables grown along EFPC (Bashor and Turri 1986). 
Table 7-5. PCB concentrations (expressed as micrograms per gram fresh wt) in brain and liver of laboratory control mice and Peromyscus leucopus trapped at the White Oak Creek floodplain (WCK 21) and Solid Radioactive Waste Storage/Disposal Area (SWSA 4)

Values are mean and range (in parentheses); $N=$ number of samples

\begin{tabular}{lccc}
\hline Site/Tissue & $N$ & PCB-1254 & PCB-1260 \\
\hline & & Control & \\
Brain & 2 & $0.35(0.18-0.52)$ & $0.07(0.02-0.12)$ \\
Liver & 2 & $0.13(0.07-0.18)$ & $0.03(0.02-0.04)$ \\
& & WCK 2.1 & $0.22(0.20-0.23)$ \\
Brain & 2 & $0.21(0.10-0.31)$ & $2.1(0.91-3.3)$ \\
Liver & 2 & $<0.05$ & \\
& & SWSA 4 & 0.09 \\
Brain & 1 & 0.41 & 0.12 \\
Liver & 1 & 0.22 & \\
\hline
\end{tabular}

Nore: WCK $=$ White Oak Creek kilometer; SWSA = Solid Radioactive Waste Storage/Disposal Area.

Although no documentation was found of the presence of mercury in WOC soils, analyses of soils and small mammals showed that mercury is present on the floodplain. Mercury may have been released into WOC from ORNL and/or from burial grounds used for nonradioactive waste (Boyle et al. 1982). Concentrations of mercury in floodplain soils ranged from $0.8 \mu \mathrm{g} / \mathrm{g}$, dry wt at a site where there is little flooding to $7.0 \mu \mathrm{g} / \mathrm{g}$, dry wt at a site where the floodplain is low and wet. For soils in general the mercury content is reported to average $0.3 \mu \mathrm{g} / \mathrm{g}$ (Lisk 1972), although the natural trace metal content of soils varies, depending both on the rocks from which the soil was formed and weathering conditions. The mercury concentration at SWSA 4 averaged $0.2 \mu \mathrm{g} / \mathrm{g}$, dry wt and provided a suitable noncontaminated reference site for mercury analysis in mammals.

In this study, the highest concentrations of mercury were found in B. brevicauda collected from the EFPC floodplain. The shrew is carnivorous, with a diet of earthworms, insects, and occasionally mice. Its position in the food chain and its food habits, particularly the ingestion of soil-containing earthworms, make it vulnerable to the accumulation of mercury. $P$. leucopus, a seed eater, and $S$. hispidus, a herbivore, had much lower concentrations of mercury in kidney tissue. For both of these species, tissue mercury concentrations were significantly lower in animals from SWSA 4 than they were in those trom the EFPC floodplain; however, no other species was abundant enough at the EFPC site to make statistical comparisons on a species-by-species basis. 


\subsubsection{Strontium-90}

The bathtub effect at the southwestern corner of SWSA 4 has contaminated this area with ${ }^{90} \mathrm{Sr}$. Concentrations of ${ }^{90} \mathrm{Sr}$ in soil at this location ranged from 44 to $150 \mathrm{~Bq} / \mathrm{g}$, dry wt $(1,000$ to $4,000 \mathrm{pCi} / \mathrm{g}$ ) (Melroy et al. 1986) and fescue, the dominant vegetation at the site, averaged $37 \mathrm{~Bq} / \mathrm{g}$, dry wt (1,000 pCi/g) (Garten and Lomax 1987). No previous data on ${ }^{90} \mathrm{Sr}$ concentrations in soil and vegetation along WOC were found. At two sites along EFPC, one above and one below the present trapping area, ${ }^{90} \mathrm{Sr}$ in soil averaged less than $8 \times 10^{-3} \mathrm{~Bq} / \mathrm{g}$ (Hoffman et al. 1984).

Animals accumulate ${ }^{90} \mathrm{Sr}$, a bone-seeking radionuclide, through dietary intake (Klusek 1987). At SWSA 4, the highest concentration was present in bone tissue of $R$. humulis, which feeds mainly on seeds found in the fescue grass that it inhabits; four of the five individuals were collected in the grass immediately adjacent to the seeps. Concentrations were high in some individuals of all species caught at this site, but there was considerable intraspecies variation, probably reflecting the overlap of the home ranges with contaminated and uncontaminated areas.

P. leucopus was the most common species caught along WOC, but concentrations of ${ }^{90} \mathrm{Sr}$ were low. Of the three $S$. hispidus collected, all within a few meters of each other, adjacent to the creek (WCK 3.4), two had ${ }^{90} \mathrm{Sr}$ concentrations of 14.5 and $44.0 \mathrm{~Bq} / \mathrm{g}$, while the other had a much lower concentration $(3.6 \mathrm{~Bq} / \mathrm{g})$. The only $P$. leucopus collected at this site was trapped about $50 \mathrm{~m}$ from the creek and had a very low concentration in bone $(0.6 \mathrm{~Bq} / \mathrm{g})$. At EFPC, values for the six $P$. leucopus and the three shrews averaged the same as the background count (12 counts/min).

\subsubsection{Summary}

Overall, terrestrial biological monitoring studies using small mammals as indicator species provided information on the presence and impact of on-site contaminants at ORNL. The studies focused on mercury, ${ }^{90} \mathrm{Sr}$, and benzo $[a]$ pyrene. Results of soil analyses for $\mathrm{B}[a] \mathrm{P}$ and blood analyses of mammals for $\mathrm{B}[a] \mathrm{P}$ metabolites indicated that this contaminant does not exceed background levels at ORNL and can be excluded from further consideration.

Mercury concentrations in kidneys of all small mammals collected along WOC were below the tissue concentration of $1.1 \mu \mathrm{g} / \mathrm{g}$ proposed by Eisler (1987) as producing adverse effects. Interpretation of the results is limited, however, because only $P$. leucopus, a species shown at other sites to be a poor indicator of mercury bioaccumulation, was trapped at two of the WOC sites. Analyses of soil along the creek indicate the presence of mercury (up to $7 \mathrm{\mu g} / \mathrm{g}$ ). Additional trapping to collect more species is needed. Results of trapping near the Y-12 Plant (EFPC), where soil is contaminated with mercury (up to $2100 \mathrm{\mu g} / \mathrm{g}$ ), showed that only one species, $B$. brevicauda, was a good indicator of mercury contamination (mean concentration in kidney $=47.2 \mu \mathrm{g} / \mathrm{g}$ ). P. leucopus and $S$. hispidus from the EFPC floodplain had only slightly elevated concentrations of mercury in kidney tissue $(1.5 \mu \mathrm{g} / \mathrm{g}$ and $1.9 \mu \mathrm{g} / \mathrm{g}$ respectively), indicating these species are poor sentinels for this contaminant. 
All small mammals trapped at SWSA 4 had ${ }^{90} \mathrm{Sr}$ concentrations in bone that were elevated above background levels, indicating that ${ }^{90} \mathrm{Sr}$ from the burial trenches is available to the small mammals inhabiting the site. Highest levels were found in $R$. humulis (up to $281 \mathrm{~Bq} / \mathrm{g}$ ) which inhabits and feeds on the ${ }^{90} \mathrm{Sr}$-contaminated grass. The small home range of these mammals ( $<0.5 \mathrm{ha}$ ) make them ideal monitors for identifying specific areas of seepage. Larger mammals, such as deer, show ${ }^{90} \mathrm{Sr}$ contamination and uptake at ORNL (Garten and Lomax 1987), but their home range is too large to pinpoint areas of active radionuclide seepage.

All mammals collected along WOC had ${ }^{90} \mathrm{Sr}$ concentrations in bone that were elevated above background levels. However, $P$. leucopus, the most abundant species, was a poor biomonitor, having only slightly elevated concentrations. $S$. hispidus captured near the creek in a wet area subject to flooding, appeared to be the best indicator species.

\subsection{FRESHWATER TURTLES AS INDICATORS OF CONTAMINATED ENVIRONMENTS}

\subsection{Introduction}

A variety of organisms have been used to monitor contaminants in aquatic systems. Long-lived species, such as freshwater turtles, which are often found in close association with lake sediments, may offer advantages as a substitute or a supplement to fish species that are frequently used in biological monitoring programs. Both organic and inorganic contaminants have been reported in turtles, including PCBs (Helwig and Hora 1983, Olafsson et al. 1983, Bryan et al. 1987), organochlorine pesticides (Punzo et al. 1979, Hall 1980) and radionuclides (Brungs 1967, Holcomb 1971, Jackson et al. 1974, Peters 1986, Scott et al. 1986). To address the importance of species selection in monitoring programs, two freshwater turtle species occupying different ecological niches were selected for comparison of their abilities to accumulate a variety of sedimentassociated contaminants. A biochemical technique for field monitoring was also evaluated as a nonspecific indicator of toxicant exposure in turtles.

The influence of habitat and food preference on the concentration of contaminants in freshwater turtles is being determined by comparing data from two species of turtles found in WOL. The yellow-bellied slider (Pseudemys scripta), a pond turtle that feeds primarily on vegetation as an adult, is being compared with a carnivorous species more closely associated with sediments. The numerous attempts made to collect the sediment-dwelling Eastern spiny soft-shell turtle (Trionyx spiniferus spiniferus) from WOL during the spring and summer of 1987 met with little success. As a consequence, the common snapping turtle (Chelydra serpentina) was substituted for the soft-shell turtle in order to evaluate the influence of sediment contact and food habits on body burdens of chemical contaminants. Data presented in this report focus on yellow-bellied sliders collected during the 1987 field season. 


\subsection{Study Sites}

Two study sites were selected: WOL and the Bearden Creek embayment on Melton Hill Reservoir. The dominant radionuclides found in WOL are ${ }^{90} \mathrm{Sr}$, ${ }^{137} \mathrm{Cs}$ and ${ }^{60} \mathrm{Co}$, all of which have been detected in the lake biota (Oakes et al. 1982). Mercury and PCBs are also present in WOL (Hoffman et al. 1984) and have been detected in fish (Loar et al. 1992). The origin of the mercury contamination in the lake is unknown, and both past and present discharges from ORNL may be sources of PCBs in WOL.

An uncontaminated marshy embayment of Bearden Creek located east of ORNL served as the reference site for this study. Preliminary studies showed that the embayment is relatively free of the contaminants under investigation and provides suitable habitats for a variety of turtle species. The Bearden Creek embayment is located approximately $5.25 \mathrm{~km}$ from WOL.

\subsubsection{Materials and Methods}

\subsubsection{Field techniques and animal dissection}

Pseudemys scripta was trapped from WOL and Bearden Creek embayment from July 23 through September 18, 1987. Hoop nets and 0.6-cm wire-mesh funnel traps were baited with either rainbow trout or pork liver and placed in water approximately $60 \mathrm{~cm}$ deep. Traps were set overnight and checked each morning.

Turtles from WOL that were marked and released during the 1985 and 1986 field seasons were weighed when recaptured and returned alive at the recapture site. Locations of the recaptured animals were noted and used as incidental data on the movement of the species within the lake.

A total of six male and six female, unmarked yellow-bellied sliders were collected from each site and returned to the laboratory for dissection. Individuals were sacrificed by injecting 2.5 to $7.0 \mathrm{~mL}$ of a $10 \%$ solution of tricaine methane sulfonate, an anesthetic, into the neck before decapitation with a table-top cable cutter. Individuals were immediately dissected and a section of liver was removed and placed on ice for DNA analysis. Samples of muscle, bone and carapace were retained for ${ }^{90} \mathrm{Sr}$ determinations. Kidney and muscle samples were removed for mercury analysis, and sections of muscle and liver were saved for ${ }^{137} \mathrm{Cs}$ and ${ }^{60} \mathrm{Co}$ determinations. A sample of fat was also removed from each animal for PCB analysis. Information on the food habits of $P$. scripta was obtained by examination of the gastrointestinal (GI) tract contents.

\subsubsection{Radionuclide counting and analysis}

${ }^{137} \mathrm{Cs}$ and ${ }^{60} \mathrm{Co}$ were measured in frozen muscle samples using a Packard NaI auto gamma scintillation spectrometer. Samples designated for ${ }^{90} \mathrm{Sr}$ analysis were ashed and acid digested for Cerenkov counting (Larsen 1981, Lauchli 1969) using a Packard liquid scintillation spectrometer. The samples were also counted in $15.2-\times 15.2-\mathrm{cm}^{2} \mathrm{NaI}$ detectors with a $3.81-\times 7.62-\mathrm{cm}^{2}$ well to record levels of any interfering gamma emitters so appropriate corrections could be made when necessary. 


\subsection{Mercury analysis}

The concentrations of mercury in the muscle and kidney tissue of the turtles were determined at the ACD/ORNL laboratory. The protocol included acid digestion of 1-g (wet weight) samples followed by the addition of stannous chloride to reduce the mercury. Total organic and inorganic mercury content was determined by cold vapor atomic adsorption spectrophotometry.

\subsubsection{PCB analysis}

Fat samples from $P$. scripta were analyzed for PCBs in the ACD/ORNL laboratory by first extracting the PCBs from 10-g samples (frozen until analysis) via Soxhlet extraction and then using packed column GC/ECD to separate and quantify the PCBs.

\subsubsection{Assessment of DNA damage}

DNA damage was used as a biochemical indicator of nonspecific exposure to genotoxic chemicals. The method was used to compare the ratios of the single-stranded as well as double-stranded DNA content for turtles collected from WOL and the Bearden Creek embayment. Genotoxic agents such as radiation can induce DNA damage, which is measured as enhanced single-stranded breaks (Swenberg et al. 1976, Erikson et al. 1980).

DNA isolated from liver samples of field-collected turtles was examined for damage by means of an alkaline unwinding technique followed by a spectrofluorometric assay. The technique has been tested on different tissue cells and organisms as a means of exploring damage to the DNA molecule caused by gamına radiation, $x$-rays, and other genotoxic agents (Ahnstrom and Erixon 1973, Rydberg 1975, Sheridan and Huang 1977, Kanter and Schwartz 1982, Daniel et al. 1985). The alkaline unwinding assay was used as modified by L. R. Shugart at ORNL. DNA isolated from turtle liver was denatured, and estimates of single strandedness were made using Hoechst dye 33528 (Cesarone et al. 1979, Kanter and Schwartz 1982, Downs and Wilfinger 1983) and a fluorescent spectrometer (Perkin-Elmer L-S).

\subsection{Results}

\subsubsection{Turtle ranges from mark-recapture data}

Recapture data for marked $P$. scripta are presented Table 7-6. These data showed that individual sliders traveled an average distance of approximately $100 \mathrm{~m}$ within a year (Fig. 7-2). Because it is likely that the sliders move throughout the lake, it is reasonable to use existing data on average concentrations of contaminants in lake water and sediments as indicators of turtle exposures rather than obtaining data from the precise point of capture for each animal.

\subsection{Food habits}

Examination of the GI contents of $P$. scripta from WOL and Bearden Creek embayment showed that turtles from the two sites had similar diets. Vegetation comprised 
Table 7-6. Mark-recapture data for yellow-bellied slider turtles (Psendemos scripta) from White Oak Lake

A total of 15 turtles were marked and released

\begin{tabular}{lccc}
\hline $\begin{array}{c}\text { Date of } \\
\text { capture/recapture }\end{array}$ & $\begin{array}{c}\text { Whole body } \\
\text { wet weight } \\
(\mathrm{g})\end{array}$ & Sex & $\begin{array}{c}\text { Estimated distance } \\
\text { traveled } \\
(\mathrm{m})\end{array}$ \\
\hline $6 / 18 / 86$ & 197 & $\mathrm{~F}$ & \\
$7 / 21 / 86$ & 274 & & 84 \\
$9 / 12 / 85$ & $\mathrm{NR}$ & $\mathrm{F}$ & \\
$7 / 21 / 86$ & 140 & & $<3$ \\
$9 / 12 / 85$ & $\mathrm{NR}$ & $\mathrm{F}$ & 213 \\
$7 / 21 / 86$ & 222 & $\mathrm{M}$ & \\
$9 / 12 / 85$ & $\mathrm{NR}$ & & 76 \\
$7 / 21 / 86$ & 260 & & 267 \\
$9 / 3 / 87$ & 364 & & $<3$ \\
$9 / 11 / 87$ & 353 & $\mathrm{M}$ & \\
$6 / 25 / 86$ & 404 & & 73 \\
$9 / 10 / 87$ & 456 & & \\
\hline
\end{tabular}

Note: $\mathbf{N R}=$ not recorded

94\% and $87 \%$ of the volume of the GI tract in turtles from WOL and Bearden Creek respectively (Table 7-7 and Appendix K, Tables K-1 and K-2). Thus, P. scripta appears to be an opportunistic feeder, consuming primarily vegetation in the water column and on the surface. Evidence of opportunism included the presence of fruits, seed heads, and algae in the GI tracts. Cicadas (Homoptera:Cicadidae) were the dominant insect type found in the GI tracts of $P$. scripta at Bearden Creek. The 17-year cicadas (Magicicada sp.) emerged in mass during the summer, and a large number of insects were probably floating on the surface of the water and were consumed. Very little detritus and mud were found in the GI tracts of the turtles from either site. Contact with contaminated sediment via ingestion is expected to be less in this species than in turtles that are primarily scavengers.

\subsubsection{Radionuclide concentrations}

Muscle samples taken from the $P$. scripta collected from WOL and Bearden Creek embayment were gamma counted to determine ${ }^{137} \mathrm{Cs}$ and ${ }^{60} \mathrm{Co}$ concentrations (Tables K-3 and $\mathrm{K}-4$ ). Differences in the concentration of radionuclides in turtles from the two sites (Table 7-8) were not statistically significant (Student's t-test) because of the large standard deviations of both data sets. 

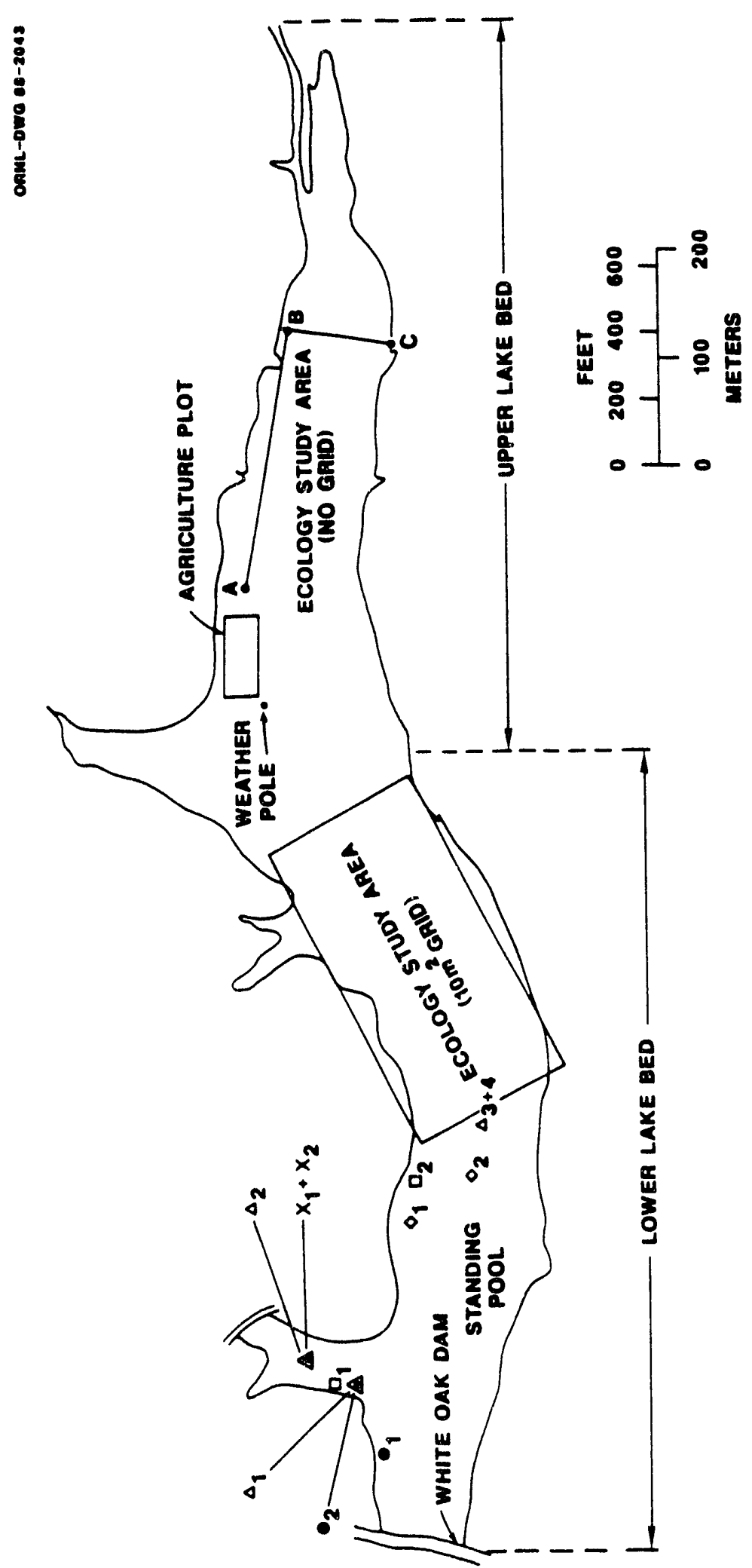

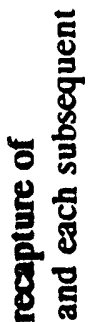

里跑

5

量

प

5

8 을

量

.

荬

政

点。

8

을

놀

․ㅗㅇ

岛

क

8

8 要

\&

요을

照

응

물

息

8

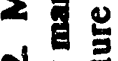

고을

홍

总 
Table 7-7. Mean percentage volume of different food types in the gastrointestinal tract of yellowbellied slider turtles (Pseudemys scripta) collected from July through September 1987

\begin{tabular}{lcccccc}
\hline Collection site & $N$ & Fish & Insects & Vegetation & Detritus & Mud and rocks \\
\hline White Oak Lake & 12 & 0.1 & 0.5 & 93.7 & 5.6 & 0.1 \\
$\begin{array}{l}\text { Bearden Creek } \\
\text { embayment }\end{array}$ & 12 & 3.0 & 8.5 & 86.5 & 2.0 & 0.0 \\
\hline
\end{tabular}

Note: $N=$ number of samples.

Table 7-8. Concentrations of ${ }^{157} \mathrm{Cs}$ and ${ }^{4} \mathrm{Co}$ (expressed as becquerels per gram wet weight) in muscle tissue of yellow-bellied slider turtles (Pseudemys scripta)

Values are the mean \pm 1 s.d.

\begin{tabular}{lccr}
\hline Collection site & ${ }^{137} \mathrm{Cs}$ & ${ }^{60} \mathrm{Co}$ & $N$ \\
\hline White Oak Lake & $7.29 \times 10^{1} \pm 2.36 \times 10^{2}$ & $5.14 \times 10^{-2} \pm 1.62 \times 10^{-1}$ & 12 \\
$\begin{array}{l}\text { Bearden Creek } \\
\text { embayment }\end{array}$ & $1.27 \times 10^{-2} \pm 1.51 \times 10^{-2}$ & $1.57 \times 10^{-3} \pm 3.38 \times 10^{-3}$ & 12 \\
\hline
\end{tabular}

Note: $N=$ number of samples.

Two turtles from WOL had ${ }^{137} \mathrm{Cs}$ concentrations that greatly exceeded those of the remaining 10 turtles. A male turtle collected on August 11, 1987, had concentrations of ${ }^{137} \mathrm{Cs}$ and ${ }^{60} \mathrm{Co}$ in muscle of $822 \mathrm{~Bq} / \mathrm{g}$ and $0.57 \mathrm{~Bq} / \mathrm{g}$ wet wt respectively. Bone from this individual also contained ${ }^{85} \mathrm{Sr}(4.44 \mathrm{~Bq} / \mathrm{g}$ wet $\mathrm{wt})$. Because ${ }^{85} \mathrm{Sr}$ is not known to be present in WOL, it is likely that the turtle migrated from the Old Hydrofracture Pond near Melton Branch; the pond was spiked with ${ }^{85} \mathrm{Sr}$ in March 1987 (O. M. Sealand, ORNL, personal communication, February 1988). The Old Hydrofracture Pond is located approximately $2.5 \mathrm{~km}$ from the point of capture in WOL and is the only known environmental source of ${ }^{85} \mathrm{Sr}$ within the area.

A second male turtle collected from the lake on July 27,1987 , contained $48.8 \mathrm{~Bq} / \mathrm{g}$, wet wt, of ${ }^{137} \mathrm{Cs}$ in muscle. ${ }^{60} \mathrm{Co}$ was not detected in the muscle, nor was ${ }^{85} \mathrm{Sr}$ detected in the bone. A Dixon statistical test for determining outliers indicated that the ${ }^{137} \mathrm{Cs}$ concentration was significantly different $(p<0.01)$ from levels detected in the remaining ten turtles. The mean ${ }^{137} \mathrm{Cs}$ concentration of $5.33 \times 10^{-1} \pm 1.59 \times 10^{-1} \mathrm{~Bq} / \mathrm{g}$, wet wt in 
these 10 turtles was significantly higher than the concentration in the 12 turtles from Bearden Creek embayment (Student's t-test, $p=0.01$ ). The mean concentrations of ${ }^{60} \mathrm{Co}$ in turtles from the two sites were not significantly different. Nonetheless, these two turtles were not deleted from the data set since they were in fact captured in WOL and constituted a portion of the sample of turtles within the lake.

Bone and carapace samples from five $P$. scripta were compared for ${ }^{90} \mathrm{Sr}$ (Table 7-9). Concentrations found in bone were similar to those in the carapace. Levels detected in bone ranged from 2.31 to $4830 \mathrm{~Bq} / \mathrm{g}$ wet wt. Although the data suggested a possible difference between ${ }^{90} \mathrm{Sr}$ body burdens in male and female turtles, the difference could be explained by the immigration of male turtles to WOL from a more highly contaminated area.

${ }^{90} \mathrm{Sr}$ determinations were also made on bone samples from four $P$. scripta collected from Bearden Creek embayment. Concentrations ranged from nondetectable levels to $0.28 \mathrm{~Bq} / \mathrm{g}$, wet wt (Table 7-10). Mean ${ }^{90} \mathrm{Sr}$ concentrations in the bone of turtles from the two sites differed by four orders of magnitude (Table 7-11). The low levels of ${ }^{90} \mathrm{Sr}$ in Bearden Creek embayment provide evidence that this area is not contaminated with radionuclides.

${ }^{90} \mathrm{Sr}$ concentrations in the shells of a $C$. serpentina and a $T$. spiniferus spiniferus collected from WOL on August 8,1986, were determined for comparison with the $P$. scripta data. The ${ }^{90} \mathrm{Sr}$ concentrations in the carapace of $C$. serpentina and the plastron of $T$. spiniferus spiniferus were 5.86 and $1.61 \mathrm{~Bq} / \mathrm{g}$ wet wt, respectively.

\subsubsection{Mercury}

Data on total mercury concentrations in kidney and muscle of $P$. scripta from WOL and Bearden Creek embayment are summarized in Table 7-12. (Concentrations in individual turtles are listed in Tables K-5 and K-6.) Although the concentration in muscle of turtles from WOL was significantly higher than that in turtles from Bearden Creek embayment (Student's t-test, $p<0.05$ ), mean concentrations in muscle of turtles from both sites were low $(<0.1 \mu \mathrm{g} / \mathrm{g}$ wet $\mathrm{wt})$. The concentration of mercury in the kidney of turtles from WOL averaged $0.64 \pm 1.11 \mu \mathrm{g} / \mathrm{g}$ wet wt and was significantly higher than the concentration in turtles from Bearden Creek embayment (Student's t-test, $p<0.10$ ). Like radionuclides, mercury concentrations were highest in turtles that appeared to immigrate to WOL. When these individuals were excluded from the data set, the mean concentration decreased to $0.19 \pm 0.04 \mu \mathrm{g} / \mathrm{g}$ wet $\mathrm{wt}$, but the statistical significance of the difference between the two sites was unchanged. The total mercury concentration in the kidney of a $T$. spiniferus spiniferus from WOL was $0.75 \mu \mathrm{g} / \mathrm{g}$ wet wt and within the range of concentrations found in $P$. scripta.

\subsubsection{PCBs}

Initial determinations of PCB concentrations in turtles from WOL were made on fat samples from two P. scripta and four T. spiniferus spiniferus (Table 7-13). Both species were found to have PCB-1254 and PCB-1260. In addition, fat tissue from a $P$. scripta 
Table 7-9. Strontium-90 concentrations (expressed as becquerels per gram wet weight) in the bone and carapace of yellow-bellied slider turtles (Pseudemss scripta) from White Oak Lake

Concentrations in picocuries per gram wet wt, in parentheses

\begin{tabular}{lclll}
\hline $\begin{array}{l}\text { Capture } \\
\text { date }\end{array}$ & Sex & $\begin{array}{c}\text { Whole body } \\
\text { wet wt } \\
(\mathrm{g})\end{array}$ & Bone & Carapace \\
\hline $7 / 27 / 87$ & $\mathrm{M}$ & 989 & $\begin{array}{l}1.42 \times 10^{2} \\
(3,842)\end{array}$ & $\begin{array}{l}1.41 \times 10^{2} \\
(3,794)\end{array}$ \\
$7 / 27 / 87$ & $\mathrm{~F}$ & 1,865 & $\begin{array}{l}2.92 \times 10^{1} \\
(789)\end{array}$ & $\begin{array}{l}4.24 \times 10^{1} \\
(1,145)\end{array}$ \\
$7 / 27 / 87$ & $\mathrm{~F}$ & 619 & $\begin{array}{l}1.04 \times 10^{1} \\
(280)\end{array}$ & $\begin{array}{l}1.24 \times 10^{1} \\
(334)\end{array}$ \\
$8 / 11 / 87$ & $\mathrm{M}$ & 932 & $\begin{array}{l}4.79 \times 10^{3} \\
(129,303)\end{array}$ & $\begin{array}{l}4.04 \times 10^{3} \\
(109,084)\end{array}$ \\
$8 / 12 / 87$ & & 1,820 & $\begin{array}{l}2.31 \times 10^{\circ} \\
(62.4)\end{array}$ & $\begin{array}{l}1.65 \times 10^{\circ} \\
(44.5)\end{array}$ \\
\hline
\end{tabular}

Table 7-10. Strontium-90 concentrations (expressed as becquerels per gram wet weight) in bone of yellow-bellied slider turtles (Pseudemys scripta) from Bearden Creek embayment

Concentrations in picocuries per gram wet wt, in parentheses

\begin{tabular}{lccc}
\hline $\begin{array}{l}\text { Capture } \\
\text { date }\end{array}$ & Sex & $\begin{array}{c}\text { Whole body } \\
\text { wet weight } \\
(\mathrm{g})\end{array}$ & $9 \mathrm{Sr}$ \\
\hline $8 / 31 / 87$ & $\mathrm{M}$ & 435 & 0.12 \\
$9 / 1 / 87$ & $\mathrm{M}$ & & $(3.31)$ \\
$9 / 1 / 87$ & F & 412 & $\mathrm{ND}$ \\
$9 / 1 / 87$ & & 2865 & 0.28 \\
\hline
\end{tabular}

${ }^{\mathrm{a}} \mathrm{ND}=$ Not detected $($ detection limit $=0.033 \mathrm{~Bq} / \mathrm{g})$ 
Table 7-11. Strontium-90 concentrations (expressed as becquerels per gram wet weight) in bone of yellow-bellied slider turtles (Pseudemys scripia)

$$
N=\text { number of samples }
$$

\begin{tabular}{lcc}
\hline $\begin{array}{l}\text { Collection } \\
\text { site }\end{array}$ & Mean \pm 1 s.d. & $N$ \\
\hline $\begin{array}{l}\text { White Oak Lake } \\
\begin{array}{l}\text { Bearden Creek } \\
\text { embayment }\end{array}\end{array}$ & $990 \pm 2120$ & 5 \\
\hline
\end{tabular}

Table 7-12. Total mercury concentrations (in micrograms per gram wet weight) in yellow-bellied slider turtles (Pseudemys scripta)

$$
N=\text { number of samples }
$$

\begin{tabular}{llll}
\hline & & \multicolumn{2}{c}{ Mean \pm 1 s.d. } \\
\cline { 4 - 4 } $\begin{array}{l}\text { Collection } \\
\text { site }\end{array}$ & $N$ & Kidney & Muscle \\
\hline White Oak Lake & $12(6 \mathrm{M}, 6 \mathrm{~F})$ & $0.64 \pm 1.11$ & $0.10 \pm 0.13$ \\
& $6(\mathrm{~F})$ & $0.18 \pm 0.03$ & $0.05 \pm 0.02$ \\
& $6(\mathrm{M})$ & $1.11 \pm 1.55$ & $0.15 \pm 0.18$ \\
Bearden Creek & $12(6 \mathrm{M}, 6 \mathrm{~F})$ & $0.12 \pm 0.13$ & $0.03 \pm 0.03$ \\
embayment & $6(\mathrm{~F})$ & $0.09 \pm 0.13$ & $0.03 \pm 0.04$ \\
& $6(\mathrm{M})$ & $0.15 \pm 0.13$ & $0.03 \pm 0.02$ \\
\hline
\end{tabular}

collected from Bearden Creek on September 1, 1987, had $0.01 \mu \mathrm{g} / \mathrm{g}$ wet wt of PCB-1254 and $72 \mu \mathrm{g} / \mathrm{g}$ wet $w t$ of PCB-1260. These data are inadequate to speculate on the relative concentrations of PCBs at the two sites or on differences in PCB concentrations in the turtles inhabiting the sites.

\subsubsection{DNA-damage assessment}

The double-stranded DNA alkaline unwinding assay was conducted on liver samples from $P$. scripta from both sites. The mean percent double-stranded DNA value obtained using this technique was $\mathbf{8 7 . 7 \%}$ for Bearden Creek embayment turtles and $\mathbf{4 9 . 2 \%}$ for WOL turtles (Table 7-14). A Student's t-test showed these values to be significantly different at $p<0.001$. The DNA of $P$. scripta from WOL contained approximately 4.5 times the number of breaks found in the DNA of turtles from Bearden Creek embayment. 
Table 7-13. PCB concentrations (expressed as micrograms per gram wet weight) in fat tissue of turtles from White Oak Lake

\begin{tabular}{llll}
\hline & $\begin{array}{l}\text { Date of } \\
\text { capture }\end{array}$ & PCB-1254 & PCB-1260 \\
\hline Species & $7 / 27 / 87$ & $<0.01$ & 49 \\
$\begin{array}{l}\text { Yellow-bellied slider } \\
\text { (Pseudemys scripta) }\end{array}$ & $8 / 11 / 87$ & 45 & 69 \\
Eastern spiny soft- & $9 / 10 / 87$ & 82 & 86 \\
shell (Trionyx & $8 / 7 / 86$ & $62^{a}$ & $77^{a}$ \\
spiniferus spiniferus) & $8 / 8 / 86$ & $45^{a}$ & $52^{a}$ \\
& $7 / 21 / 86$ & $60^{a}$ & $72^{a}$ \\
\hline
\end{tabular}

aData reported by the ACD/ORNL laboratory to be of uncertain reliability.

Table 7-14. Percentage of double-stranded (ds) decaxribonucleic acid (DNA) in liver samples from yellow-belliod slider turtles (Pseudemys scripta)

S.E. = One standard error of the mean

\begin{tabular}{|c|c|c|c|c|}
\hline \multirow[b]{2}{*}{ Site of capture } & \multicolumn{3}{|c|}{$\%$ ds DNA } & \multirow{2}{*}{$\begin{array}{l}\text { Relative number of } \\
\text { breaks per alkaline } \\
\text { unwinding unit }\end{array}$} \\
\hline & Mean & S.E. & $\mathbf{N}$ & \\
\hline White Oak Lake & 49.16 & 4.28 & 12 & 4.49 \\
\hline Bearden Creek embayment & 87.73 & 3.06 & 12 & 1.0 \\
\hline
\end{tabular}

\subsection{Discussion}

The ability of $P$. scripta to accumulate contaminants from an aquatic environment was evidenced by the elevated concentrations of mercury, PCBs, and radionuclides detected in the animals. Turtles from WOL contained higher mercury and ${ }^{90} \mathrm{Sr}$ concentrations than did turtles from Bearden Creek embayment, the reference site, and preliminary data indicate the presence of PCBs in turtles from both sites. Additional data are needed on $\mathrm{PCB}$ residues in turtles from both sites before conclusions can be reached on the presence or bioavailability of this contaminant.

Results of the alkaline unwinding assay provided evidence that $P$. scripta in WOL have a higher frequency of DNA breaks than do turtles inhabiting the Bearden Creek embayment. While elevated DNA breakage is recognized as indicative of exposure to 
genotoxic agents, interpretation of these findings is not unambiguous. The nonspecificity of the alkaline unwinding assay is both a strength and a weakness. The strength is that DNA damage can be detected in a field population without knowing the specific agent producing the effect, but the inability to implicate a specific cause from measurement of the symptoms of exposure prohibits identifying the causative agent at a specific site. One of the merits of biological monitoring, however, is that the condition of a resident population of plants or animals can be used to survey improvement or deterioration of the environment at a specific site, or to compare resident populations with those at reference sites. Although the alkaline unwinding assay for DNA breakage indicated that $P$. scripta in WOL are subjected to a greater genotoxic load than $P$. scripta inhabiting nearby Bearden Creek embayment, the cause of this genetic damage is unknown.

Concentrations of contaminants measured in $P$. scripta can also be compared with published data on fish collected from the same site. Total mercury concentrations in muscle tissue of sunfish (Lepomis auritus and L. macrochirus) from WOL in December 1986 ranged from $0.14-0.52 \mu \mathrm{g} / \mathrm{g}$ wet wt with a mean value of $0.16 \mu \mathrm{g} / \mathrm{g}$ (Loar et al. 1992). Although these concentrations are lower than the mean concentration of mercury detected in the kidneys of the turtles $(0.64 \pm 1.11 \mu \mathrm{g} / \mathrm{g}$ wet $\mathrm{wt})$, the amount detected in turtle muscle $(0.1 \pm 0.13 \mu \mathrm{g} / \mathrm{g}$ wet $w t)$ is below that found in sunfish. Like many metals, mercury has an affinity for kidney tissue. Because data on mercury residues in kidneys of WOL fish were not available for comparison, it can only be speculated that mercury accumulation does not differ much between $P$. scripta and sunfish. Differences, however, may exist in the concentration and retention of mercury in the kidneys of the two species.

Mean ${ }^{137} \mathrm{Cs}$ and ${ }^{60} \mathrm{Co}$ concentrations in muscle of $P$. scripta from WOL were 72.9 and $0.05 \mathrm{~Bq} / \mathrm{g}$ wet wt respectively. The mean concentration of ${ }^{137} \mathrm{Cs}$ for eight species of fish collected in the lake during May 1987 was $0.39 \mathrm{~Bq} / \mathrm{g}$ wet wt (Sect. 8.1), at least two orders of magnitude below the mean concentration found in turtles from the same lake. The mean concentration of ${ }^{60} \mathrm{Co}$ reported in these fish was $0.02 \mathrm{~Bq} / \mathrm{g}$ wet wt, approximately $0.03 \mathrm{~Bq} / \mathrm{g}$ less than the average concentration detected in turtle muscle.

The mean concentration of ${ }^{90} \mathrm{Sr}$ in the bone of $P$. scripta from WOL was almost three times higher than the mean concentration in bone of three fish species from the same lake. The mean ${ }^{90} \mathrm{Sr}$ concentration in fish was $0.37 \mathrm{~Bq} / \mathrm{g}$ wet wt (Sect. 8.1) compared to a mean concentration in turtles of $0.99 \mathrm{~Bq} / \mathrm{g}$ wet wt.

$P$. scripta feed primarily on vegetation, either within the water column or on the surface of the water, suggesting that exposure to contaminants is largely by ingestion of plant material and water. $P$. scripta move throughout WOL and, like fish, are exposed to contaminants within a large area of the lake.

Movement of turtles from other radioactively contaminated ponds into WOL may have occurred. The presence of ${ }^{85} \mathrm{Sr}$ in one particular turtle indicated that it traveled approximately $2.5 \mathrm{~km}$ from a radioactive settling pond (Old Hydrofracture Pond 3514) to the marshy cove of WOL. These data also indicate that turtles can move from other contaminated sites (e.g., Ponds 3513 and 3524) into the lake and may also move from the lake to offsite areas, thus increasing the exposure of humans who consume them. The data also demonstrate that $P$. scripta may be a useful monitor of the contaminants in 
WOL. Concentrations of contaminants detected in the turtles from WOL were greater than those found in turtles from the reference site and in most instances exceeded concentrations measured in fish collected from WOL. DNA damage in WOL turtles, as measured by the alkaline unwinding assay, exceeded that in turtles from Pearden Creek embayment.

\subsection{FUTURE STUDIES}

Future studies will be conducted in the following areas:

1. Analyses for PCBs will be made for the small mammal and turtle tissues that have been preserved for this purpose. (Liver. brain, and fat samples were stored during the course of animal dissections for the studies reported herein.) Additional samples will be processed as needed to develop data on the ${ }^{\prime} \mathrm{CB}$ body burdens of these animals, which were collected from SWSA 4 and the WOC floodplain.

2. The data on small mammals will be supplemented with analyses of animals trapped during the 1988 season. These and all existing data on contaminants in small mammals will be used to formulate a guidance document for routine monitoring of small mammals in the ORNL environs. The document will include recommendations for sites, species, a d contaminants to be included in routine biomonitoring.

3. Both the usefuiness of turtles in a biomonitoring plan an 1 the potential merit of the DNA alkaline unwinding ass $\%$ as a nonspecific indicator of genotoxic stress to natural populations will be subjected to further evaluation. The studies presented herein for yellow-bellied sliders ( $P$. scripta) will be completed and compared with results from studies of the snapping turtle ( $C$. serpentina). This comparison of two species from the same sites (WOL and Bearden Creek embayment) will give a berter evaluation of the general applicability and validity of the tests used than will a simple repetition of the same studies on $P$. nigra for yet another season. Data on contaminant body burdens and diet (from analyses of gut contents) will also be collected on $C$. serpentina for comparison with similar data on $P$. scripta. Results are expected to reveal higher levels of contamination in $C$. serpentina because this species has greater contact with sediments than $P$. scripta. 


\section{RADIOECOLOGY OF WHITE OAK LAKE}

The purpose of the radioecological studies on WOL is to determine whether exposure to contaminants is significant enough to warrant remedial actions under current conditions or under hypothesized loss of institutional control. To accomplish this task it is necessary to have reasonably accurate estimates of concentrations and inventories of contaminants in the principal biotic and abiotic compartments of the WOL ecosystem. The report includes an estimate of the inventories of radionuclides in the various compartments of the WOL ecosystem (Sect. 8.1); a report on the waterfowl associated with ORNL waste ponds (Sect. 8.2); a preliminary screening analysis of WOL for nonradioactive pollutants (Sect. 8.3); a study of the biomass and concentrations of contaminants in the aquatic macrophytes (Sect. 8.4); and radionuclides in fish from WOC (Sect. 8.5).

\subsection{RADIONUCLIDES IN THE WHITE OAK LAKE ECOSYSTEM}

Before potential remedial actions can be evaluated for WOL, a reliable estimate is needed of the quantity of hazardous materials in the biotic and abiotic compartments of the lake ecosystem. To obtain these estimates, measurements of the concentration of radionuclides in each compartment, together with estimates of the mass of each compartment, were used to calculate the quantity of radioactivity in the various compartments of the lake ecosystem.

Three radionuclides, ${ }^{137} \mathrm{Cs},{ }^{60} \mathrm{Co}$, and ${ }^{90} \mathrm{Sr}$, comprise most of the radioactivity in WOL (Loar et al. 1992). In this report, estimates of the quantity of radioactivity in the different compartments will be limited to these radionuclides. The WOL ecosystem as defined here is approximately 5.3 ha (Appendix F). It is the impoundment or standing pond behind WOL dam, not including areas formerly covered by water, which also contain quantities of the same radionuclides. In this study, estimates were made of the quantities of ${ }^{137} \mathrm{Cs},{ }^{60} \mathrm{Co}$, and ${ }^{90} \mathrm{Sr}$ in fish, invertebrates, emergent macrophytes, sediment, and water.

\subsubsection{Fishes}

Fish in WOL were sampled in May 1987 to esimate the size of the populations and to obtain an average weight of each species (see App indix $F$ for a description of the study). The species collected from the lake and the as erage concentration of ${ }^{137} \mathrm{Cs},{ }^{60} \mathrm{Co}$, and ${ }^{90} \mathrm{Sr}$ in each species are listed in Table 8-1. In most cases, ten fish each of the eight species with the highest biomass in WOL (Table F-1) were analyzed for ${ }^{137} \mathrm{Cs}$ and ${ }^{60} \mathrm{Co}$, and five fish each of three species (bluegill, largemouth bass, and gizzard shad) were analyzed for ${ }^{90} \mathrm{Sr}$. Other species were also analyzed for ${ }^{90} \mathrm{Sr}$, but the results are not complete. The average concentration of ${ }^{90} \mathrm{Sr}$ for these three species was used to estimate the concentration in the other species. The estimated size of the population and average weight for each species as well as the quantity of the radionuclides in each population are shown in Table 8-2. 
Table 8-1. Whole body concentrations of ${ }^{137} \mathrm{Cs},{ }^{4} \mathrm{Co}$, and ${ }^{4} \mathrm{Sr}$ (expressed in becquerels per kilogram wet $w t$ ) in fish collected from White Oak Lake in May 1987

Values are the mean \pm s.d.; $\mathrm{N}=10$ for ${ }^{137} \mathrm{Cs}$ and ${ }^{60} \mathrm{Co}$ and $\mathrm{N}=5$ for ${ }^{90} \mathrm{Sr}$

\begin{tabular}{lllc}
\hline Species & ${ }^{137} \mathrm{Cs}$ & ${ }^{60} \mathrm{Co}$ & ${ }^{90} \mathrm{Sr}$ \\
\hline Bluegill (Lepomis macrochirus) & & & \\
Carp (Cyprinus carpio) & $340 \pm 80$ & $26 \pm 9$ & $520 \pm 140$ \\
Gizzard Shad (Dorosoma cepedianum) & $219 \pm 130$ & $37 \pm 11$ & NA \\
Largemouth Bass (Micropterus salmoides) & $\mathbf{4 8 0} \pm 90$ & $44 \pm 7$ & $370 \pm 360$ \\
Redbreast Sunfish (Lepomis auritus) & $600 \pm 580$ & $22 \pm 15$ & $230 \pm 120$ \\
Redear Sunfish (Lepomis microlophus) & $290 \pm 46$ & $15 \pm 6$ & NA \\
Warmouth (Lepomis gulosus) & $220 \pm 120$ & $11 \pm 4$ & NA \\
& & & NA \\
\hline
\end{tabular}

NA $=$ not analyzed.

Table 8-2 Estimated total number of each species, mean weight (expressed in grams), and quantity of ${ }^{137} \mathrm{Cs}$, ${ }^{4} \mathrm{Co}$, and ${ }^{3 r}$ in the fish population of White Oak Lake

\begin{tabular}{|c|c|c|c|c|c|}
\hline \multirow[t]{2}{*}{ Species } & \multirow[t]{2}{*}{$\begin{array}{l}\text { Estimated } \\
\text { number }\end{array}$} & \multirow{2}{*}{$\begin{array}{c}\text { Mean } \\
\text { weight } \\
\text { ( } \pm 1 \text { s. d.) }\end{array}$} & \multicolumn{3}{|c|}{ Inventory (kBq) } \\
\hline & & & ${ }^{137} \mathrm{Cs}$ & ${ }^{60} \mathrm{Co}$ & ${ }^{90} \mathrm{Sr}$ \\
\hline Bluegill & 17,363 & $32 \pm 0.76$ & 188 & 14 & 292 \\
\hline Carp & 600 & $780 \pm 77$ & 103 & 17 & 178 \\
\hline Gizzard shad & 13,233 & $36 \pm 1.5$ & 226 & 21 & 177 \\
\hline Golden shiner & 360 & $34 \pm 6$ & 4.1 & 0.4 & 6 \\
\hline Largemouth bass & 575 & $352 \pm 22$ & 193 & 4.4 & 47 \\
\hline Redbreast sunfish & 207 & $189 \pm 17$ & 24 & 0.7 & 15 \\
\hline Redear sunfish & 1,568 & $77 \pm 5.8$ & 35 & 1.8 & 46 \\
\hline Warmouth & 975 & $36 \pm 4.4$ & 7.8 & 0.4 & 13 \\
\hline Total & & & $\begin{array}{r}781 \\
(21.1 \mu \mathrm{Ci})\end{array}$ & $\begin{array}{c}60.7 \\
(1.6 \mu \mathrm{Ci})\end{array}$ & $\begin{array}{r}77.3 \\
(20.9 \mu \mathrm{Ci})\end{array}$ \\
\hline
\end{tabular}




\subsubsection{Invertebrates}

Bimonthly samples were collected from WOL to obtain an estimate of the biomass and the concentration of radionuclides in benthic invertebrates. A $3375-\mathrm{cm}^{3}$ sediment sample was taken, and the invertebrates were picked from the sample. The majority of the invertebrates were chironomids, chaoborines (phantom midges), and annelid species. More detailed information on sampling methods and results are presented in Sect. 6.1.2 and Sect. 6.1.3, respectively, of this report. After the invertebrates were separated from the sediment, composite samples were analyzed for ${ }^{137} \mathrm{Cs}$ and ${ }^{60} \mathrm{Co}$. (No attempt was made to clear the gut before analyzing for radionuclides.) The organisms contained an average of $4200 \mathrm{~Bq} / \mathrm{kg}$ of ${ }^{137} \mathrm{Cs}$ and $950 \mathrm{~Bq} / \mathrm{kg}$ of ${ }^{60} \mathrm{Co}$. Analyses for ${ }^{90} \mathrm{Sr}$ have not been completed for these samples. The average number of organisms per sample ( \pm 1 s.d.) was $38 \pm 20$, and the mean weight per individual was $0.90 \mathrm{mg}$. Snails, clams, and crayfish, which were limited in number, were not included in the sample but will be analyzed separately (Sect. 8.6.1). The estimated number and biomass of benthic organisms in the WOL ecosystem and the calculated inventories of ${ }^{137} \mathrm{Cs}$ and ${ }^{60} \mathrm{Co}$ in the benthic invertebrate compartment are given in Table 8-3.

Table 8-3. Estimated numbers, biomass, and inventories of ${ }^{137} \mathrm{Cs}$ and ${ }^{5} \mathrm{Co}$ in benthic invertebrates in White Oak Lake

\begin{tabular}{llll}
\hline $\begin{array}{l}\text { Number of } \\
\text { organisms }\end{array}$ & $\begin{array}{c}\text { Biomass } \\
(\mathrm{kg}, \text { wet wt) }\end{array}$ & ${ }^{137} \mathrm{Cs}$ & ${ }^{60} \mathrm{Co}$ \\
\hline $8.2 \times 10^{7}$ & $7.9 \times 10^{1}$ & $3.2 \times 10^{5}$ & $7.5 \times 10^{4}$ \\
\hline
\end{tabular}

The estimated biomass for invertebrates in WOL is for organisms in the upper $15 \mathrm{~cm}$ of the sediment. Because some benthic invertebrates are often found at depths greater than $15 \mathrm{~cm}$, the estimated biomass in Table 8-3 and thus the quantity of radionuclides in this compartment of the lake may be somewhat underestimated. Future samples will be taken at greater depths to obtain a more accurate estimate of the biomass.

\subsubsection{Macrophytes}

Aquatic macrophytes often comprise a high percentage of the biomass of aquatic ecosystems. Since macrophytes have relatively high concentration ratios for many radionuclides, they can be important in the retention and remobilization of radionuclides. Emergent macrophytes cover an area of WOL estimated to be about 1.71 ha (Sect. 8.4). In previous years, populations of submerged and floating macrophytes were also abundant in WOL; however, in 1987 they were observed to have very limited distribution and were in poor condition. Therefore biomass and radionuclide analyses were not conducted on submergent and floating macrophytes. The inventories of radionuclides in the macrophyte compartment of the WOL ecosystem is thus estimated only for emergent macrophytes. A 
more comprehensive study of the macrophytes in WOL is described in Sect. 8.4, which also includes the methods used to estimate biomasses and to determine the concentrations of radionuclides. The estimated biomasses and concentrations of radionuclides in the emergent macrophytes in WOL are given in Table 8-4.

Table 8-4. Estimated biomass and inventories of radionuclides in the emergent macrophytes of White Oak Lake

\begin{tabular}{llccc}
\hline Species & $\begin{array}{c}\text { Biomass } \\
(\mathrm{kg}, \text { dry wt) }\end{array}$ & ${ }^{137} \mathrm{CS}$ & ${ }^{60} \mathrm{Co}$ & \multicolumn{3}{c}{ Inventory $(\mathrm{kBq})$} \\
\cline { 3 - 5 } & & & & \\
\hline $\begin{array}{c}\text { Cattail } \\
\quad \text { (Typha) }\end{array}$ & $2.5 \times 10^{3}$ & $1.2 \times 10^{6}$ & $3.3 \times 10^{5}$ & $7.5 \times 10^{6}$ \\
$\begin{array}{c}\text { Bulrush } \\
\text { (Scirpus) }\end{array}$ & $4.3 \times 10^{3}$ & $4.5 \times 10^{6}$ & $5.4 \times 10^{5}$ & $1.0 \times 10^{7}$ \\
$\begin{array}{l}\text { Grasses } \\
\text { Total }\end{array}$ & $2.3 \times 10^{3}$ & $2.7 \times 10^{6}$ & $2.1 \times 10^{5}$ & $5.7 \times 10^{6}$ \\
\hline
\end{tabular}

\subsubsection{Water and Sediment}

The amount of ${ }^{137} \mathrm{Cs},{ }^{60} \mathrm{Co}$, and ${ }^{90} \mathrm{Sr}$ in the water compartment of WOL at any given time depends both upon the volume of water and the concentrations of each radionuclide in the water. Both of these variables fluctuate with the flow rate and the release rate of contaminants. For comparison with the biota, an area of 5.3 ha was used for the lake surface. One of the major uncertainties in this estimate is the depth of water in the lake, which has not been measured for many years and has changed considerably because of sedimentation. Based on the available information, an average water depth of $1 \mathrm{~m}$ was estimated. The average concentration of ${ }^{137} \mathrm{Cs},{ }^{60} \mathrm{Co}$, and ${ }^{90} \mathrm{Sr}$ for unfiltered water sampled at the dam was used to estimate the total amount of each radionuclide in the water (Table 8-5).

Reliable estimates of the inventory of radionuclides in the sediment of WOL have not been made in recent years because of insufficient information on the concentrations of radionuclides as a function of depth. In order to compare the biotic and abiotic compartments of the ecosystem, an estimate of ${ }^{137} \mathrm{Cs}$, ${ }^{60} \mathrm{Co}$, and ${ }^{90} \mathrm{Sr}$ in sediment was made using data from three core samples taken from the lower, middle, and upper end of the lake (T. W. Doyle and F. G. Taylor, ORNL, personal communication, 1986). These three radionuclides comprise most of the radioactivity in WOL. Although small quantities of other radionuclides, including some actinides, are known to have accumulated in the sediments, they are not included in this estimate because the small quantities in the lake 
Table 8-5. Estimated inventories of ${ }^{17} \mathrm{Cs}$, ${ }^{4} \mathrm{Co}$, and ${ }^{4} \mathrm{Sr}$ (expressed in becquerels) in the abiotic and biotic compartments of White Oak Lake

NA $=$ Not available

\begin{tabular}{llll}
\hline Compartment & ${ }^{137} \mathrm{Cs}$ & ${ }^{60} \mathrm{Co}$ & ${ }^{90} \mathrm{Sr}$ \\
\hline Fish & $7.8 \times 10^{5}$ & $6.1 \times 10^{4}$ & $7.7 \times 10^{5}$ \\
Benthic invertebrates & $3.2 \times 10^{5}$ & $7.5 \times 10^{4}$ & $\mathrm{NA}$ \\
Emergent macrophytes & $8.4 \times 10^{6}$ & $1.1 \times 10^{6}$ & $2.3 \times 10^{7}$ \\
Sediment & $1.2 \times 10^{13}$ & $3.2 \times 10^{11}$ & $5.1 \times 10^{11}$ \\
Water & $2.1 \times 10^{8}$ & $1.6 \times 10^{7}$ & $2.7 \times 10^{8}$ \\
Total & $1.2 \times 10^{13}$ & $3.2 \times 10^{11}$ & $5.1 \times 10^{11}$ \\
& $(324 \mathrm{Ci})$ & $(8.6 \mathrm{Ci})$ & $(13.8 \mathrm{Ci})$ \\
\hline
\end{tabular}

and their relatively low concentration factors in biota make them difficult to measure accurately.

The lake was estimated to have an area of $5.3 \mathrm{ha}$, and the contaminated sediment estimated to extend to a depth of $68 \mathrm{~cm}$. The average concentration of ${ }^{137} \mathrm{Cs},{ }^{60} \mathrm{Co}$, and ${ }^{90} \mathrm{Sr}$ in the three cores was used to estimate the amount of each radionuclide in the sediment (Table 8-5). In the past, the size of the standing pond behind the dam has been greater than 5.3 ha; however, for a current comparison with the biotic compartments, only sediment of the present standing pond (5.3 ha) was considered. (Nevertheless, an estimate of the radionuclides in the former lake bed should be assessed for remedial action purposes.)

\subsubsection{Summary}

Estimated quantities of ${ }^{137} \mathrm{Cs},{ }^{60} \mathrm{Co}$, and ${ }^{90} \mathrm{Sr}$ in the biotic and abiotic compartments of WOL are summarized in Table 8-5. As expected, the sediment compartment, which represented more than $99 \%$ of the activity, overwhelms all other compartments. The total radioactivity for the compartments analyzed in the 5.3 ha lake was $346 \mathrm{Ci}$. Of the measured radioactivity, ${ }^{137} \mathrm{Cs}$ made up $93.5 \%$, while the remainder was ${ }^{90} \mathrm{Sr}(4.0 \%)$ and ${ }^{60} \mathrm{Co}(2.5 \%)$. The radioactivity that is available for direct human consumption, excluding inadvertent ingestion of sediment, is in water, macrophytes, and fish. Of the radioactivity in the compartments other than sediment, $92-96 \%, 3-7 \%$, and $0.3-0.4 \%$ are contained in water, macrophytes and fish, respectively, depending on the radionuclide considered. 
Between 0.2 and $0.4 \%$ of the radioactivity was in the benthic invertebrate compartment, but the organisms considered here are not usually consumed by humans. Limited information is currently available on macroinvertebrates (clams, snails, and crayfish) and amphibians (turtles and frogs) which are consumed by humans, but it was not included in this analysis because quantitative data on the populations in WOL are not yet available. General observations and previous sampling of these macroinvertebrates indicate that they are not abundant in the lake, and the inventory of radioactivity in these compartments would be much less than in the fish compartment. However, all food-chain pathways leading to humans, including macroinvertebrates, were considered in a previous study that investigated the potential food chain pathways to humans (Loar et al. 1992).

Comparing the radionuclide concentration in the different compartments of the WOL ecosystem demonstrates the importance of sediments in the cycling of radionuclides in aquatic ecosystems, regardless of whether the sediments serve as a sink or as a long-term source from which radionuclides can be remobilized and become available to aquatic food chains. For this reason, a reliable estimate of the quantity of radionuclides in sediment and an assessment of the potential for remobilization is needed before different remedial action proposals for WOL can be fully evaluated.

\subsection{WATERFOWL POPULATIONS ASSOCIATED WITH ORNL LAKES AND PONDS}

\subsubsection{Introduction}

A long-standing question, which has never been satisfactorily answered, is the extent to which waterfowl act as important vectors of radionuclides in the food chain utilized by human populations. Waterfowl utilize ORNL waste disposal ponds and settling basins and thus are capable of accumulating radionuclides and other contaminants. After these waterfowl migrate from ORR, they may be harvested and consumed by hunters. It has generally been assumed that most of the waterfowl that frequent ORNL ponds are transient and that the amount of radioactivity they accumulate in their tissue for such a short residency at one of the waste ponds is insignificant. Another assumption is that the number of waterfowl that frequent these contaminated ponds is so small that the probability of a hunter harvesting more than one bird that has spent some time on these ponds is very small. However, increased attention to the question concerning contaminated waterfowl has arisen as a result of recent deer hunts on ORR in which some animals were confiscated because the screening level for radioactivity in their tissues was exceeded. Further, an increase in the local Canada goose population has resulted in some of these ponds serving as nesting areas. As a result, a study was initiated to determine (1) the resident and migratory population of waterfowl that utilize ORNL waste disposal ponds and settling basins and (2) the concentrations of radionuclides in samples of waterfowl taken from these areas.

\subsection{Materials and Methods}

Censusing of the waterfowl on the ORNL reservation was initiated in October 1987. Dr. J. T. Tanner, an ornithologist from the University of Tennessee, was subcontracted to 
advise on procedures for obtaining a census of the populations and methods of data analysis for population estimates.

Eleven locations were identified as areas of potential use by migratory waterfowl or which might serve as nesting areas. The locations and approximate size of these areas are given in Table 8-6. The grids in which these ponds, waste basins, and quarries are located were taken from map S-16A of the Oak Ridge Area (TVA, December 1987). The approximate distance in kilometers from these areas to the ORNL administration building $(4500 \mathrm{~N})$ is also given in Table 8-6. These aquatic systems range in surface area from 0.07 ha for the Old Hydrofracture Facility Pond to 5.3 ha for WOL.

Table 8-6. Location and approximate size of water bodies near Oak Ridge National Laboratory that are being censused to estimate resident and migratory populations of waterfowl

\begin{tabular}{llccc}
\hline & $\begin{array}{c}\text { Estimated } \\
\text { size } \\
\text { (ha) }\end{array}$ & $\begin{array}{c}\text { Distance } \\
\text { from Bldg. } \\
4500 \text { N } \\
\text { Site }\end{array}$ & $\begin{array}{c}\text { Map } \\
(\mathbf{S - 1 6 A}) \\
\text { grid }\end{array}$ & $\begin{array}{c}\text { Creek } \\
\text { km }\end{array}$ \\
\hline Kerr Hollow Quarry & 1.6 & 9.6 & F14 & \\
Roger's Quarry & 3.7 & 7.3 & F13 & \\
Swan Pond & 1.4 & 0.3 & F8 & \\
Melton Branch Weir & 0.4 & 1.5 & G7 & 0.2 \\
Hydrofracture pond (7852 A) & 0.07 & 1.1 & G7 & \\
White Oak Creek Weir & 0.07 & 1.3 & G7 & 2.6 \\
White Oak Creek & 0.12 & 1.6 & G7 & $2.0-2.6$ \\
White Oak Lake & 5.3 & 2.3 & G6 & $0.9-2.0$ \\
Storage pond (P7821) & 0.3 & 2.6 & G6 & \\
Waste ponds (P3513) & 0.8 & 0.5 & F8 & \\
HFIR pond & 0.08 & 1.6 & G8 & \\
\hline
\end{tabular}

A weekly census of the waterfowl populations was conducted at each of the sites listed in Table 8-6. Waterfowl counts were also recorded when sites were visited for other reasons. The list of waterbirds as well as waterfowl that have been observed at one or more of these sites is given in Table 8-7.

With the exception of Swan Pond (SP), all of the aquatic systems listed in Table 8-6 have received contaminants from the Oak Ridge facilities. Contaminants released into Kerr Hollow Quarry (Q1) and Roger's Quarry (Q2) are nonradioactive, and no known radioactive or nonradioactive contaminants have been released into Swan Pond. 
Table 8-7. List of waterfowl and waterbirds that hrve been observed at various water bodies near Oak Ridge National Laboratory

\begin{tabular}{ll} 
Common Name & Scientific Name \\
\hline American black duck & Anas rubripes \\
American coot & Fulica americana \\
Belted kingfisher & Megaceryle alcyon \\
Black-crowned night-heron & Nycticorax nycticorax \\
Canada goose & Branta canadensis \\
Gadwall & Anas strepera \\
Great blue heron & Ardea herodias \\
Green-backed heron & Butorides striatus \\
Hooded merganser & Lophodytes cucullatus \\
Killdeer & Charadrius vociferus \\
Mallard & Anas platyrhynchos \\
Pied-billed grebe & Podilymbus podiceps \\
Ring-billed gull & Larus delawarensis \\
Ring-neck duck & Aythya collaris \\
Wood duck & Aix sponsa \\
\hline
\end{tabular}

Ducks were collected from WOL in December 1987 using hoop traps baited with corn. Whole-body gamma counts of the ducks were made using an Intrinsic Germanium solid state detector. The ducks were dissected and the following organs and tissues analyzed for gamma radioactivity: feathers, feet, gastrointestinal tract, liver, breast tissue, crop and stomach contents. Samples of bone were obtained for ${ }^{90} \mathrm{Sr}$ analysis.

\section{Results and Discussion}

The average numbers of waterfowl observed for all 11 sites and for WOL and SP from October 1987 through January 1988 are shown in Fig. 8-1. Waterfowl were not observed on sites Q1, Q2, the Hydrofracture pond (7852A), or HFIR pond (HFIR-P) during this time (Table 8-6); most of the waterfowl were observed either on WOL or SP. Because commercial food is often provided to the SP waterfowl, it appears to have a more stable resident population with only a few migratory birds frequenting the pond. While WOL does not appear to have a large resident population, apparently it has many more migratory birds than does SP.

The mean concentrations of ${ }^{137} \mathrm{Cs}$ and ${ }^{60} \mathrm{Co}$ in the whole body and in various tissues of seven mallard ducks captured at WOL in December 1987 are given in Table 8-8; 


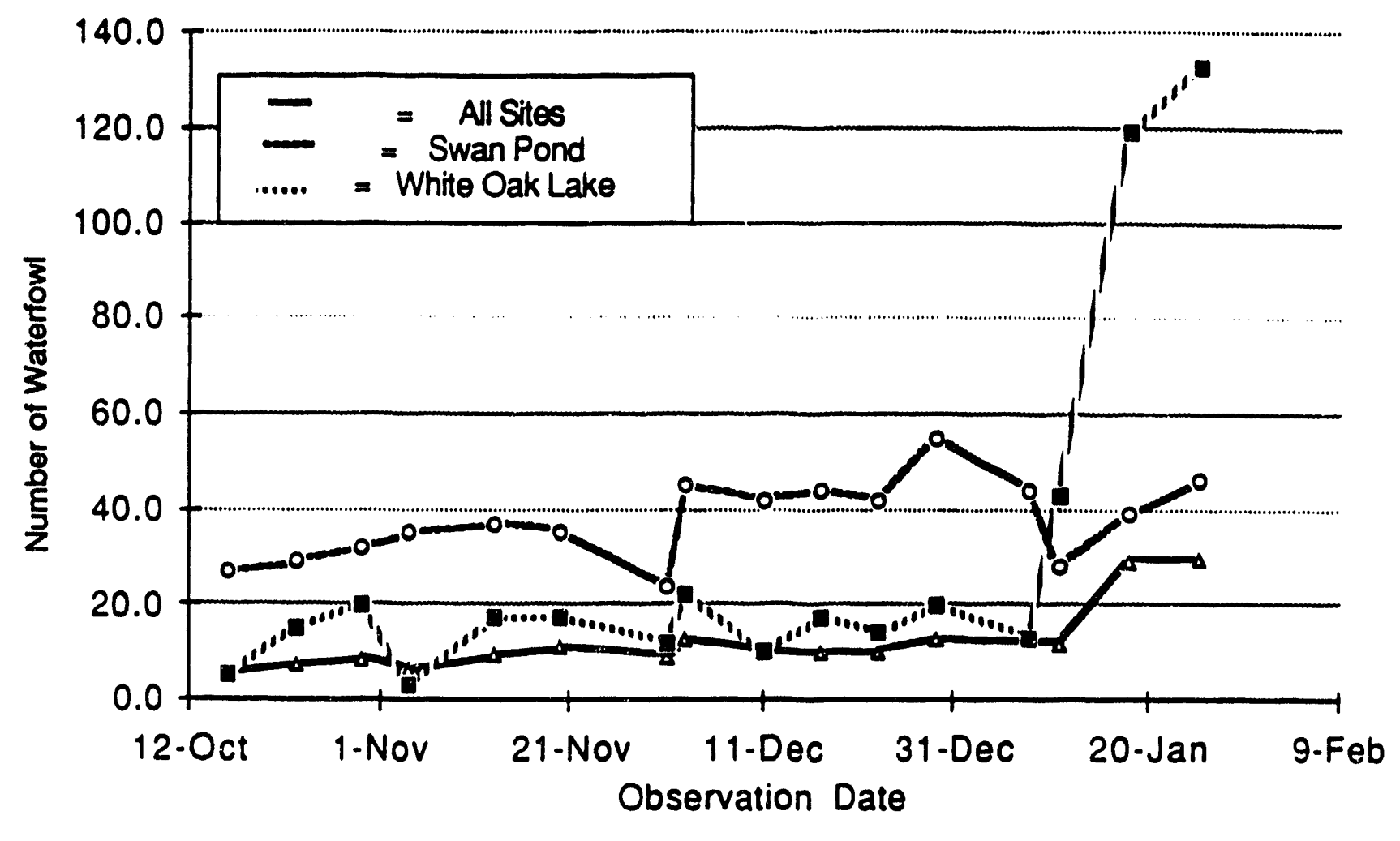

Fig 8-1. Average number of waterfow per site $(N=11)$ and total number of waterfow observed at the White Oak Lake and Swan Pond sites, October 1987-January 1988. 
Table 88. Mean concentrations ( \pm 1 s. d) of ${ }^{17} \mathrm{Cs}$ and ${ }^{4} \mathrm{Co}$ (expressed as beoquerels per kilogram wet wt) in mallard ducks collected from White Oak Lake in December 1987

$$
(\mathrm{ND}=\text { not detectable })
$$

\begin{tabular}{lccc}
$\begin{array}{l}\text { Whole Body, } \\
\text { Organs, } \\
\text { Tissues }\end{array}$ & $\begin{array}{c}\text { Number of ducks } \\
\text { analyzed }\end{array}$ & ${ }^{137} \mathrm{Cs}$ & ${ }^{60} \mathrm{Co}$ \\
\hline Whole body & 7 & $260 \pm 56$ & $18 \pm 4.1$ \\
Feathers & 5 & $382 \pm 100$ & $36 \pm 9.6$ \\
Feet & 4 & $619 \pm 200$ & $59 \pm 56$ \\
Liver & 7 & $59 \pm 27$ & $9.3^{\circ}$ \\
Heart & 7 & $55 \pm 24$ & $\mathrm{ND}$ \\
Breast muscle & 7 & $141 \pm 70$ & $\mathrm{ND}$ \\
GI tract & 5 & $110 \pm 70$ & $17 \pm 13$ \\
\hline
\end{tabular}

- Only one had detectable ${ }^{\infty} \mathrm{Co}$.

muscle and bone are in the process of being analyzed for ${ }^{90} \mathrm{Sr}$. The highest concentrations of ${ }^{137} \mathrm{Cs}$ and ${ }^{60} \mathrm{Co}$ were found on the feet and the feathers and appear to be the result of external contamination from lake water and sediment. The breast muscle tissue, or the portion normally consumed by humans, contained an average of $141 \mathrm{~Bq} / \mathrm{kg}$ of ${ }^{137} \mathrm{Cs}$. However, ${ }^{60} \mathrm{Co}$ was not detected in this tissue, suggesting that the ducks were resident on the lake for only a short time.

The average weight of the mallard ducks collected was approximately $1 \mathrm{~kg}(2.2 \mathrm{lb})$. Assuming that one of these ducks was harvested by a hunter immediately after it left WOL and the entire amount of muscle tissue, approximately $40 \%(400 \mathrm{~g})$ of the total weight of the waterfowl, was consumed by an individual, the resulting committed effective equivalent dose is estimated to be $0.001 \mathrm{mSv}(0.1 \mathrm{mrem})$. Because these ducks were probably migratory individuals that had spent only a short time on WOL, higher concentrations of radionuclides would be expected in resident waterfowl or in waterfowl that had spent a longer period of time on the lake.

Some of the holding ponds that receive radioactive effluents from ORNL have higher concentrations of radionuclides in sediment and water than does WOL. In the past, these ponds have served as nesting sites for Canada geese, and the concentration of ${ }^{137} \mathrm{Cs}$ measured in the muscle tissue sampled from these waterfowl was almost three orders of magnitude higher than that observed in the mallard ducks from WOL (Martin Marietta 
Energy Systems 1987). For this reason, the sizes of the resident and migratory populations of waterfowl that frequent the more highly contaminated sites will be determined, and the concentrations of radionuclides in these populations will be measured.

\subsection{PREILIMINARY SCREENING OF NONRADIOLOGICAL CONTAMINANTS IN WHITE OAK LAKE}

\subsubsection{Introduction}

A preliminary screening analysis was conducted for the nonradioactive contaminants in WOL. The analysis considered several of the food-chain pathways reported previously in the screening exercise performed for radionuclides (Loar et al. 1992). The purpose of a screening exercise in a contaminated environment is to identify contaminants of potential concern from the standpoint of protecting human health. Equally important is the identification of contaminants that are present at such low levels that they need to be considered further. Such analyses are important because the results can be used to (1) identify where additional site characterization, data collection, and/or research are needed and (2) assist in making decisions regarding remedial actions.

The approach taken for screening nonradioactive contaminants is similar to that used for radionuclides (Loar et al. 1992) in that the screening analysis involves the use of conservatively biased calculational procedures that are unlikely to underestimate the actual exposure to humans. If calculated exposures do not approach or exceed specified limits or established health standards, individual contaminants can be screened out and given a low priority for future consideration. Contaminants that approach or exceed established limits are designated as warranting further evaluation or investigation.

In this study a screening analysis was conducted for metals and organic contaminants for which recent measurements have been made in WOL media. A previous screening exercise for metals and organic compounds in WOL (Hoffman et al. 1984) included a large number of organic compounds but was referenced to concentrations of contaminants in sediments only.

\subsection{Exposure pathways}

In the present analysis the screening has been performed for a scenario in which the lake is maintained at its current pool size and contaminant inventories, and the public is allowed free access to it and the surrounding environs. The aquatic food-chain pathway includes consumption of water, fish, and aquatic plants. Aquatic plants, namely Elodea and cattails, are considered as potential sources of exposure; however, their actual use as a food source from WOL would probably be negligible. The potential human exposure pathways considered in the screening of metals and organic pollutants in WOL are listed under aquatic and terrestrial food-chain pathways in Table 8-9. As conditions exist in WOL today, the aquatic food-chain pathways, with the exception of fish, would be of little significance as a source of contamination. 
Table 8-9. Potential White Oak Lake sources of metak and organic contaminants to humans via the ingestion pathway

\begin{tabular}{ll}
\hline Aquatic & Terrestrial \\
\hline Fish & Beef \\
Clams & Milk \\
Aquatic plants & Vegetables \\
Water & \\
\hline
\end{tabular}

The terrestrial food-chain pathway considered for screening purposes includes consumption of vegetables grown on either the drained lake bed or floodplain and beef and milk from animals grazing on the floodplain or lake bed. This screening analysis did not consider external exposure (i.e., by means of inhalation) to metals and organic pollutants. The annual consumption rates used in this screening analysis for aquatic and terrestrial foods are listed in Table 8-10. The consumption rates used are the same as those in the previous screening exercise for radionuclides (Loar et al. 1992).

Table 8-10. Estimates of consumption rates of aquatic and terrestrial foods used in screening White Oak Lake contaminants

\begin{tabular}{lc}
\hline $\begin{array}{l}\text { Pathway } \\
\text { component }\end{array}$ & $\begin{array}{c}\text { Consumption } \\
\text { rate } \\
\text { (kg/year) }\end{array}$ \\
\hline Water & $730^{\circ}$ \\
Aquatic plants & $20^{\circ}$ \\
Fish & $7.3^{b}$ \\
Beef & $100^{\circ}$ \\
Milk & $300^{\circ}$ \\
Vegetables & $200^{\circ}$ \\
\hline
\end{tabular}

-National Council on Radiation Protection (NCRP) (1986). Screening techniques for determining compliance with environmental standards: Releases of radionuclides to the atmosphere, NCRP Commentary No. 3, Bethesda, Maryland.

bMartin Marietta Energy Systems (1985). Environmental monitoring report, U.S. Department of Energy Oak Ridge facilities, calendar year 1984. ORNL-6209. Oak Ridge National Laboratory, Oak Ridge, Tennessee. 


\subsubsection{Methods}

\section{Data Base}

Concentrations of metals and organic pollutants in fish and macrophytes were obtained from analyses of samples collected from WOL during 1987. Data used for metals in sediment are the average concentrations from the most recent sediment core samples taken from WOL (T. W. Doyle and F. G. Taylor, Oak Ridge National Laboratory, personal communication, 1987). Concentrations of many of the pollutants in sediment were less than the detection limit for the analytical procedure employed and therefore are reported (albeit conservatively) as the detection limit. Metals and organic pollutants in water are the 1987 monthly averages obtained from the NPDES monitoring program (Table 2-5). Concentrations of contaminants in water, fish, macrophytes, and soils used in the present screening analysis are listed in Tables 8-11 through 8-16. (The floodplain soil concentrations were assumed to be the same as the sediment concentration.)

For the terrestrial food-chain components, concentrations of metals in vegetables grown on the floodplain and in milk and beef from animals consuming forage vegetation grown on the floodplain or drained lake bed were derived from mathematical models. Model calculations were based on conservative default values from concentration ratios (micrograms per kilogram of pollutant in dry or fresh weight vegetation to micrograms per kilogram dry weight soil) and transfer coefficients (the fraction of contaminant ingested daily by a herbivore that can be measured per unit mass of animal product or that is secreted in milk when at steady-state conditions). Although the calculated values may deviate from measured values, this is expected to result in an overestimation of the actual concentrations.

\section{Screening Levels}

The allowable daily intakes (ADIs) for human exposure to noncarcinogenic toxic chemicals used in the present screening exercise are presented in Table 8-17 and were obtained from Hoffman et al. (1984). The ADI is the intake of a toxicant (measured in micrograms per day) that is not anticipated to result in any adverse effects after chronic exposure to the general population, including sensitive subgroups. There is no acceptable threshold limit for carcinogenic chemicals. In developing water quality criteria, EPA utilized the intake associated with specific risk over a human lifetime (usually $10^{-5}$ ) to establish acceptable levels of exposure to carcinogens (Hoffman et al. 1984). In the present screening exercise, as in Hoffman et al. (1984), the term ADI was used to represent an allowable intake for both carcinogens and noncarcinogens.

The technique employed for this screening exercise is the ratio of the calculated average intake (AI) (which is the consumption rate of the food-chain component multiplied by the concentration of the contaminant in the foodstuff) to the ADI. When the ratio of $\mathrm{AI}: \mathrm{ADI}$ is significantly less than unity, the contaminant is designated as having a low priority for further consideration. When this ratio is $\geq 1$, the contaminant is designated as one that warrants further investigation. $A$ factor of 10 is included in the screening level to account for the summed risk from several contaminants with ratios $<1$ (individually) but that may be $>1$ in aggregate. 
Table 8-11. Comparison of the average intake (AI) of metaks and organic compounds from drinking water with the allowable drily intake (ADI)

\begin{tabular}{lcccc}
\hline Metal/Organic & $\begin{array}{c}\text { Concentration } \\
(\mu \mathrm{g} / \mathrm{L})\end{array}$ & $\begin{array}{c}\mathrm{AI} \\
(\mu \mathrm{d} / \mathrm{d})\end{array}$ & $\begin{array}{c}\text { ADI } \\
(\mu \mathrm{g} / \mathrm{d})\end{array}$ & $\begin{array}{c}\text { Ratio } \\
\text { AI:ADI }\end{array}$ \\
\hline Metals & & & & \\
$\quad$ Arsenic & $<6.00 \mathrm{E}+01$ & $1.20 \mathrm{E}+02$ & $4.00 \mathrm{E}-02$ & $3.00 \mathrm{E}+03$ \\
Cadmium & $<7.00 \mathrm{E}+00$ & $1.40 \mathrm{E}+01$ & $5.74 \mathrm{E}+01$ & $2.44 \mathrm{E}-01$ \\
Chromium & $<3.70 \mathrm{E}+01$ & $7.40 \mathrm{E}+01$ & $1.00 \mathrm{E}+02$ & $7.40 \mathrm{E}-01$ \\
Copper & $<1.60 \mathrm{E}+01$ & $3.20 \mathrm{E}+01$ & $2.00 \mathrm{E}+03$ & $1.60 \mathrm{E}-02$ \\
Lead & $<7.00 \mathrm{E}+00$ & $1.40 \mathrm{E}+01$ & $1.00 \mathrm{E}+02$ & $1.40 \mathrm{E}-01$ \\
Manganese & $1.30 \mathrm{E}+02$ & $2.60 \mathrm{E}+02$ & $5.00 \mathrm{E}+02$ & $5.20 \mathrm{E}-01$ \\
Mercury & $<8.00 \mathrm{E}-02$ & $1.60 \mathrm{E}-01$ & $2.35 \mathrm{E}+01$ & $6.81 \mathrm{E}-03$ \\
Nickel & $<3.60 \mathrm{E}+01$ & $7.20 \mathrm{E}+01$ & $2.94 \mathrm{E}+02$ & $2.45 \mathrm{E}-01$ \\
Silver & $<5.00 \mathrm{E}+00$ & $1.00 \mathrm{E}+01$ & $1.60 \mathrm{E}+01$ & $6.25 \mathrm{E}-01$ \\
Zinc & $4.80 \mathrm{E}+01$ & $9.60 \mathrm{E}+01$ & $1.00 \mathrm{E}+04$ & $9.60 \mathrm{E}-03$ \\
& & & & \\
Organics & $<5.00 \mathrm{E}+00$ & $1.00 \mathrm{E}+01$ & $2.60 \mathrm{E}+02$ & $5.00 \mathrm{E}-02$ \\
Bromodichloromethane & $<5.00 \mathrm{E}+00$ & $1.00 \mathrm{E}+01$ & $4.75 \mathrm{E}+03$ & $2.11 \mathrm{E}-03$ \\
Chloroform & $<5.00 \mathrm{E}-01$ & $1.00 \mathrm{E}+00$ & $2.20 \mathrm{E}+02$ & $4.55 \mathrm{E}-03$ \\
PCBs & $<1.00 \mathrm{E}+00$ & $2.00 \mathrm{E}+00$ & $7.00 \mathrm{E}+06$ & $2.86 \mathrm{E}-07$ \\
Phenols & $<5.00 \mathrm{E}+00$ & $1.00 \mathrm{E}+01$ & $5.70 \mathrm{E}+04$ & $1.75 \mathrm{E}-04$ \\
Trichloroethene & & & & \\
\hline
\end{tabular}

Table 8-12 Comparison of the average intake (AI) of metals and polychlorinnted biphenyts (PCBs) through the fish food-chain pathway with the allowable daily intake (ADI)

\begin{tabular}{lcccc}
\hline Metal/Organic & $\begin{array}{c}\text { Concentration } \\
(\mu \mathrm{g} / \mathrm{L})\end{array}$ & $\begin{array}{c}\mathrm{AI} \\
(\mu \mathrm{g} / \mathrm{d})\end{array}$ & $\begin{array}{c}\text { ADI } \\
(\mu \mathrm{g} / \mathrm{d})\end{array}$ & $\begin{array}{c}\text { Ratio } \\
\text { AI:ADI }\end{array}$ \\
\hline Fish & & & & \\
$\quad$ Antimony & $<3.85 \mathrm{E}+00$ & $7.70 \mathrm{E}+01$ & $2.94 \mathrm{E}+02$ & $2.62 \mathrm{E}-01$ \\
Arsenic & $<2.82 \mathrm{E}+00$ & $5.64 \mathrm{E}+01$ & $4.00 \mathrm{E}-02$ & $1.41 \mathrm{E}+03$ \\
Beryllium & $<5.50 \mathrm{E}-02$ & $1.10 \mathrm{E}+00$ & $2.00 \mathrm{E}-01$ & $5.50 \mathrm{E}+00$ \\
Chromium & $<1.13 \mathrm{E}+00$ & $2.20 \mathrm{E}+01$ & $1.00 \mathrm{E}+02$ & $2.26 \mathrm{E}-01$ \\
Lead & $<5.65 \mathrm{E}+00$ & $1.13 \mathrm{E}+02$ & $1.00 \mathrm{E}+02$ & $1.13 \mathrm{E}+00$ \\
Silver & $<1.40 \mathrm{E}+00$ & $2.80 \mathrm{E}+01$ & $1.60 \mathrm{E}+01$ & $1.75 \mathrm{E}+00$ \\
Nickel & $<1.69 \mathrm{E}+00$ & $3.38 \mathrm{E}+01$ & $2.94 \mathrm{E}+0$ & $1.15 \mathrm{E}-01$ \\
Cadmium & $<1.40 \mathrm{E}-01$ & $2.80 \mathrm{E}+00$ & $5.74 \mathrm{E}+01$ & $4.88 \mathrm{E}-02$ \\
Copper & $<5.90 \mathrm{E}-01$ & $1.18 \mathrm{E}+01$ & $2.00 \mathrm{E}+03$ & $5.90 \mathrm{E}-03$ \\
Selenium & $<5.65 \mathrm{E}+00$ & $1.13 \mathrm{E}+02$ & $2.30 \mathrm{E}+01$ & $4.91 \mathrm{E}+00$ \\
Ziac & $8.54 \mathrm{E}+00$ & $1.71 \mathrm{E}+02$ & $1.00 \mathrm{E}+04$ & $1.71 \mathrm{E}-02$ \\
Mercury & $1.60 \mathrm{E}-01$ & $3.20 \mathrm{E}+00$ & $2.35 \mathrm{E}+01$ & $1.36 \mathrm{E}-01$ \\
PCBs & $<6.60 \mathrm{E}-01$ & $1.325+01$ & $2.20 \mathrm{E}-01$ & $6.00 \mathrm{E}+01$ \\
Cams & & & & \\
PCBs & $1.40 \mathrm{E}+00$ & $6.90 \mathrm{E}+00$ & $2.20 \mathrm{E}-01$ & $3.14 \mathrm{E}+01$ \\
\hline
\end{tabular}


Table 8-13. Comparison of the average intake (AI) of metals and polychlorinated biphenyls (PCB) through the aquatic plant food-chain pathway with the allowable daily intake (ADI)

\begin{tabular}{lcccc}
\hline Metal & $\begin{array}{c}\text { Concentration } \\
(\mu \mathrm{g} / \mathrm{L})\end{array}$ & $\begin{array}{c}\text { AI } \\
(\mu \mathrm{g} / \mathrm{d})\end{array}$ & $\begin{array}{c}\text { ADI } \\
(\mu \mathrm{g} / \mathrm{d})\end{array}$ & $\begin{array}{c}\text { Ratio } \\
\text { AI:ADI }\end{array}$ \\
\hline Antimony & $<4.60 \mathrm{E}+00$ & $2.52 \mathrm{E}+02$ & $2.94 \mathrm{E}+02$ & $8.57 \mathrm{E}-01$ \\
Arsenic & $<2.50 \mathrm{E}+00$ & $1.37 \mathrm{E}+02$ & $4.00 \mathrm{E}-02$ & $3.43 \mathrm{E}+03$ \\
Beryllium & $<5.00 \mathrm{E}-02$ & $2.74 \mathrm{E}+00$ & $2.00 \mathrm{E}-01$ & $1.37 \mathrm{E}+01$ \\
Cadmium & $1.14 \mathrm{E}+00$ & $6.25 \mathrm{E}+01$ & $5.74 \mathrm{E}+01$ & $1.09 \mathrm{E}+00$ \\
Chromium & $6.70 \mathrm{E}+00$ & $3.67 \mathrm{E}+02$ & $1.00 \mathrm{E}+02$ & $3.67 \mathrm{E}+00$ \\
Copper & $2.60 \mathrm{E}+00$ & $1.42 \mathrm{E}+02$ & $2.00 \mathrm{E}+03$ & $7.12 \mathrm{E}-02$ \\
Lead & $<4.60 \mathrm{E}+00$ & $2.52 \mathrm{E}+02$ & $1.00 \mathrm{E}+02$ & $2.52 \mathrm{E}+00$ \\
Nickel & $<4.30 \mathrm{E}+00$ & $2.36 \mathrm{E}+02$ & $2.94 \mathrm{E}+02$ & $8.01 \mathrm{E}-01$ \\
Silver & $<1.40 \mathrm{E}+00$ & $7.67 \mathrm{E}+01$ & $1.60 \mathrm{E}+01$ & $4.80 \mathrm{E}+00$ \\
Zinc & $2.20 \mathrm{E}+01$ & $1.21 \mathrm{E}+03$ & $1.00 \mathrm{E}+04$ & $1.21 \mathrm{E}-01$ \\
& & & & \\
PCBs & & & $2.20 \mathrm{E}-01$ & $7.45 \mathrm{E}+01$ \\
Milfoil & $3.00 \mathrm{E}-01$ & $1.64 \mathrm{E}+01$ & $2.20 \mathrm{E}-01$ & $1.47 \mathrm{E}+02$ \\
Elodea & $5.90 \mathrm{E}-01$ & $3.23 \mathrm{E}+01$ & & \\
\hline
\end{tabular}

Table 8-14. Comparison of the average intake (AI) of metals through the beef food-chain pathway with the allowable daily intake (ADI)

\begin{tabular}{lccccc}
\hline Metal & $\begin{array}{c}\text { Soil } \\
\text { concentration } \\
(\mu \mathrm{g} / \mathrm{L})\end{array}$ & $\begin{array}{c}\text { Food } \\
\text { concentration } \\
(\mu \mathrm{g} / \mathrm{g})\end{array}$ & $\begin{array}{c}\mathrm{AI} \\
(\mu \mathrm{g} / \mathrm{d})\end{array}$ & $\begin{array}{c}\text { ADI } \\
(\mu \mathrm{g} / \mathrm{d})\end{array}$ & $\begin{array}{c}\text { Ratio } \\
\text { AI:ADI }\end{array}$ \\
\hline Antimony & $<1.72 \mathrm{E}+02$ & $1.07 \mathrm{E}-01$ & $2.94 \mathrm{E}+01$ & $2.94 \mathrm{E}+02$ & $1.00 \mathrm{E}-01$ \\
Arsenic & $<1.24 \mathrm{E}+02$ & $6.19 \mathrm{E}+00$ & $1.70 \mathrm{E}+00$ & $4.00 \mathrm{E}-01$ & $4.24 \mathrm{E}+00$ \\
Beryllium & $<4.40 \mathrm{E}+00$ & $5.49 \mathrm{E}-03$ & $1.50 \mathrm{E}+00$ & $2.00 \mathrm{E}-01$ & $7.52 \mathrm{E}+00$ \\
Chromium & $6.83 \mathrm{E}+02$ & $1.02 \mathrm{E}+01$ & $2.80 \mathrm{E}+03$ & $1.00 \mathrm{E}+02$ & $2.80 \mathrm{E}+01$ \\
Lead & $<4.10 \mathrm{E}+01$ & $3.68 \mathrm{E}-02$ & $1.01 \mathrm{E}+01$ & $1.00 \mathrm{E}+02$ & $1.01 \mathrm{E}-01$ \\
Silver & $<2.25 \mathrm{E}+01$ & $1.40 \mathrm{E}+00$ & $3.85 \mathrm{E}+02$ & $1.60 \mathrm{E}+01$ & $2.40 \mathrm{E}+01$ \\
Nickel & $4.47 \mathrm{E}+01$ & $2.23 \mathrm{E}-01$ & $6.11 \mathrm{E}+01$ & $2.94 \mathrm{E}+02$ & $2.08 \mathrm{E}-01$ \\
Cadmium & $<4.60 \mathrm{e}+00$ & $2.01 \mathrm{E}-02$ & $5.50 \mathrm{E}+00$ & $5.74 \mathrm{E}+01$ & $9.59 \mathrm{E}-02$ \\
Copper & $<1.14 \mathrm{E}+02$ & $1.15 \mathrm{E}+01$ & $3.16 \mathrm{E}+03$ & $2.00 \mathrm{E}+03$ & $1.58 \mathrm{E}+00$ \\
Selenium & $<4.60 \mathrm{E}+02$ & $2.87 \mathrm{E}+02$ & $7.86 \mathrm{E}+04$ & $2.30 \mathrm{E}+01$ & $3.42 \mathrm{E}+03$ \\
Zinc & $<4.15 \mathrm{E}+02$ & $5.18 \mathrm{E}+02$ & $1.42 \mathrm{E}+05$ & $1.00 \mathrm{E}+04$ & $1.42 \mathrm{E}+01$ \\
Mercury & $2.60 \mathrm{E}+00$ & $3.24 \mathrm{E}-01$ & $8.89 \mathrm{E}+01$ & $2.35 \mathrm{E}+01$ & $3.78 \mathrm{E}+00$ \\
& & & & & \\
\hline
\end{tabular}


Table 8-15. Comparison of the average intake (AI) of metals through the milk food-chain pathway with the allowable daily intake (ADI)

\begin{tabular}{lccccc}
\hline Metal & $\begin{array}{c}\text { Soil } \\
\text { concentration } \\
(\mu \mathrm{g} / \mathrm{L})\end{array}$ & $\begin{array}{c}\text { Food } \\
\text { concentration } \\
(\mu \mathrm{g} / \mathrm{g})\end{array}$ & $\begin{array}{c}\mathrm{AI} \\
(\mu \mathrm{g} / \mathrm{d})\end{array}$ & $\begin{array}{c}\text { ADI } \\
(\mu \mathrm{g} / \mathrm{d})\end{array}$ & $\begin{array}{c}\text { Ratio } \\
\text { AI:ADI }\end{array}$ \\
\hline Antimony & $<1.72 \mathrm{E}+02$ & $1.43 \mathrm{E}-02$ & $1.18 \mathrm{E}+01$ & $2.94 \mathrm{E}+02$ & $4.00 \mathrm{E}-02$ \\
Arsenic & $<1.24 \mathrm{E}+02$ & $4.13 \mathrm{E}-02$ & $3.39 \mathrm{E}+01$ & $4.00 \mathrm{E}-02$ & $8.48 \mathrm{E}+02$ \\
Beryllium & $<4.40 \mathrm{E}+00$ & $2.93 \mathrm{E}-06$ & $2.41 \mathrm{E}-03$ & $2.00 \mathrm{E}-01$ & $1.20 \mathrm{E}-02$ \\
Chromium & $6.83 \mathrm{E}+02$ & $9.09 \mathrm{E}-01$ & $7.47 \mathrm{E}+02$ & $1.00 \mathrm{E}+02$ & $7.47 \mathrm{E}+00$ \\
Lead & $<4.10 \mathrm{E}+01$ & $1.84 \mathrm{E}-02$ & $1.51 \mathrm{E}+01$ & $1.00 \mathrm{E}+02$ & $1.51 \mathrm{E}-01$ \\
Silver & $<2.25 \mathrm{E}+01$ & $3.74 \mathrm{E}+00$ & $3.08 \mathrm{E}+03$ & $1.60 \mathrm{E}+01$ & $1.92 \mathrm{E}+02$ \\
Nickel & $4.47 \mathrm{E}+01$ & $1.49 \mathrm{E}-01$ & $1.22 \mathrm{E}+02$ & $2.94 \mathrm{E}+02$ & $4.16 \mathrm{E}-01$ \\
Cadmium & $<4.60 \mathrm{E}+00$ & $1.53 \mathrm{E}-01$ & $1.26 \mathrm{E}+02$ & $5.74 \mathrm{E}+01$ & $2.19 \mathrm{E}+00$ \\
Copper & $<1.14 \mathrm{E}+02$ & $3.41 \mathrm{E}+00$ & $2.81 \mathrm{E}+03$ & $2.00 \mathrm{E}+03$ & $1.40 \mathrm{E}+00$ \\
Selenium & $<4.60 \mathrm{E}+02$ & $3.83 \mathrm{E}+01$ & $3.15 \mathrm{E}+04$ & $2.30 \mathrm{E}+01$ & $1.37 \mathrm{E}+03$ \\
Zinc & $<4.15 \mathrm{E}+02$ & $6.91 \mathrm{E}+01$ & $5.68 \mathrm{E}+04$ & $1.00 \mathrm{E}+04$ & $5.68 \mathrm{E}+00$ \\
Mercury & $2.60 \mathrm{E}+00$ & $2.16 \mathrm{E}-02$ & $1.78 \mathrm{E}+01$ & $2.35 \mathrm{E}+01$ & $7.57 \mathrm{E}-01$ \\
& & & & & \\
\hline
\end{tabular}

Table 8-16. Comparison of the average intake (AN) of metals through the vegetable food-chain pathway with the allowable daily intake (ADI)

\begin{tabular}{lccccc}
\hline Metal & $\begin{array}{c}\text { Soil } \\
\text { concentration } \\
(\mu \mathrm{g} / \mathrm{L})\end{array}$ & $\begin{array}{c}\text { Food } \\
\text { concentration } \\
(\mu \mathrm{g} / \mathrm{g})\end{array}$ & $\begin{array}{c}\mathrm{AI} \\
(\mu \mathrm{g} / \mathrm{d})\end{array}$ & $\begin{array}{c}\text { ADI } \\
(\mu \mathrm{g} / \mathrm{d})\end{array}$ & $\begin{array}{c}\text { Ratio } \\
\text { AI:ADI }\end{array}$ \\
\hline Antimony & $<1.72 \mathrm{E}+02$ & $1.72 \mathrm{E}+00$ & $9.42 \mathrm{E}+02$ & $2.94 \mathrm{E}+02$ & $3.21 \mathrm{E}+00$ \\
Arsenic & $<1.24 \mathrm{E}+02$ & $1.12 \mathrm{E}+01$ & $6.12 \mathrm{E}+03$ & $4.00 \mathrm{E}-02$ & $1.53 \mathrm{E}+05$ \\
Beryllium & $<4.40 \mathrm{E}+00$ & $1.76 \mathrm{E}-02$ & $9.64 \mathrm{E}+00$ & $2.00 \mathrm{E}-01$ & $4.82 \mathrm{E}+01$ \\
Chromium & $6.83 \mathrm{E}+02$ & $6.83 \mathrm{E}+00$ & $3.74 \mathrm{E}+03$ & $1.00 \mathrm{E}+02$ & $3.74 \mathrm{E}+01$ \\
Lead & $<4.10 \mathrm{E}+01$ & $4.10 \mathrm{E}-01$ & $2.25 \mathrm{E}+02$ & $1.00 \mathrm{E}+02$ & $2.25 \mathrm{E}+00$ \\
Silver & $<2.25 \mathrm{E}+01$ & $4.50 \mathrm{E}+00$ & $2.47 \mathrm{E}+03$ & $1.60 \mathrm{E}+01$ & $1.54 \mathrm{E}+02$ \\
Nickel & $4.47 \mathrm{E}+01$ & $2.24 \mathrm{E}+00$ & $1.22 \mathrm{E}+03$ & $2.94 \mathrm{E}+02$ & $4.17 \mathrm{E}+00$ \\
Cadmium & $<4.60 \mathrm{E}+00$ & $2.30 \mathrm{E}+00$ & $1.26 \mathrm{E}+03$ & $5.74 \mathrm{E}+01$ & $2.20 \mathrm{E}+01$ \\
Copper & $<1.14 \mathrm{E}+02$ & $5.70 \mathrm{E}+00$ & $3.12 \mathrm{E}+03$ & $2.00 \mathrm{E}+03$ & $1.56 \mathrm{E}+00$ \\
Selenium & $<4.60 \mathrm{E}+02$ & $4.60 \mathrm{E}+01$ & $2.52 \mathrm{E}+04$ & $2.30 \mathrm{E}+01$ & $1.10 \mathrm{E}+03$ \\
Zinc & $<4.15 \mathrm{E}+02$ & $1.66 \mathrm{E}+02$ & $9.10 \mathrm{E}+04$ & $1.00 \mathrm{E}+04$ & $9.10 \mathrm{E}+00$ \\
Mercury & $2.60 \mathrm{E}+00$ & $7.80 \mathrm{E}-01$ & $4.27 \mathrm{E}+02$ & $2.35 \mathrm{E}+01$ & $1.82 \mathrm{E}+01$ \\
\hline
\end{tabular}


Table 8-17. Allowable daily intake of metals and organics used for screening analysis

Metal/organic
Allowable daily intake

$(\mu \mathrm{g} / \mathrm{d})$

\begin{tabular}{ll} 
Metals & \\
Antimony & $2.94 \mathrm{E}+02$ \\
Arsenic & $4.00 \mathrm{E}-02$ \\
Beryllium & $2.00 \mathrm{E}-01$ \\
Cadmium & $5.74 \mathrm{E}+01$ \\
Chromium & $1.00 \mathrm{E}+02$ \\
Copper & $2.00 \mathrm{E}+03$ \\
Lead & $1.00 \mathrm{E}+02$ \\
Manganese & $5.00 \mathrm{E}+02$ \\
Mercury & $2.35 \mathrm{E}+01$ \\
Nickel & $2.94 \mathrm{E}+02$ \\
Selenium & $2.30 \mathrm{E}+01$ \\
Silver & $1.60 \mathrm{E}+01$ \\
Zinc & $1.00 \mathrm{E}+04$ \\
& \\
Organics & \\
Bromodichloromethane & $2.00 \mathrm{E}+02$ \\
Chloroform & $4.75 \mathrm{E}+03$ \\
Phenols & $7.00+06$ \\
Trichloroethene & $5.70 \mathrm{E}+04$ \\
& \\
PCBs & $2.20 \mathrm{E}-01$ \\
\hline
\end{tabular}

Source: F.O. Hoffman, B.G. Blaylock, C.C. Travis, K.L. Daniels, E.L. Etnier, K.E. Cowser, and C.W. Weber. 1984. Preliminary screening of contaminants in sediments. ORNL/TM-9370. Oak Ridge National Laboratory, Oak Ridge, Tennessee.

\subsubsection{Results}

Comparisons of $\mathrm{AI}$ with $\mathrm{ADI}$ for the aquatic and terrestrial food-chain pathways considered for WOL are given in Tables 8-11 through 8-16. Concentrations for most of the contaminants measured in soil and food-chain components were less than the limits of detection for the chemical analysis used; therefore, the detection limits were taken as the concentration of the contaminant. Using the detection limit for the concentration of the contaminant in the screening analysis and using conservative assumptions in the screening calculations, in most cases, resulted in AI:ADI ratios that exceeded unity.

Metals and organic compounds warranting further consideration, and the pathways under which they were screened, are listed in Table 8-18. The contaminants are listed under each food-chain pathway from the highest to the lowest AI:ADI ratio. All metals 
that were considered in the screening exercise for the vegetable pathway had ratios exceeding unity. The conservative default values of the concentration ratios used for vegetables in the model to estimate metal concentrations in vegetation, and the soil concentrations that were based on sediment values, may explain why all the metals screened in this pathway exceed unity. This exercise demonstrates that additional analyses are needed to properly quantify metals in the floodplain soils.

Table 8-18. Metals and organic compounds warranting further consideration

\begin{tabular}{llllll}
\hline Water & Fish & Aquatic plants & Beef & Milk & Vegetables \\
\hline Metaks & & & & \\
& & & & \\
$\mathrm{As}(3000)$ & $\mathrm{As}(1410)$ & $\mathrm{As}(3430)$ & $\mathrm{As}(42,400)$ & $\mathrm{Se}(1370)$ & $\mathrm{As}(153,000)$ \\
$\mathrm{Cr}(0.7)$ & $\mathrm{Be}(5.5)$ & $\mathrm{Be}(13.7)$ & $\mathrm{Se}(3420)$ & $\mathrm{As}(848)$ & $\mathrm{Se}(1100)$ \\
$\mathrm{Mn}(0.5)$ & $\mathrm{Se}(4.9)$ & $\mathrm{Ag}(4.8)$ & $\mathrm{Cr}(28)$ & $\mathrm{AG}(192)$ & $\mathrm{Ag}(154)$ \\
$\mathrm{Ag}(0.3)$ & $\mathrm{Ag}(1.8)$ & $\mathrm{Cr}(3.7)$ & $\mathrm{Ag}(24)$ & $\mathrm{Cr}(7.5)$ & $\mathrm{Be}(48)$ \\
$\mathrm{Ni}(0.2)$ & $\mathrm{Pb}(1.1)$ & $\mathrm{Pb}(2.5)$ & $\mathrm{Zn}(14)$ & $\mathrm{Zn}(5.7)$ & $\mathrm{Cr}(37)$ \\
$\mathrm{Cd}(0.2)$ & $\mathrm{Sb}(0.3)$ & $\mathrm{Cd}(1.1)$ & $\mathrm{Be}(7.5)$ & $\mathrm{Cd}(2.2)$ & $\mathrm{Cd}(22)$ \\
$\mathrm{Pb}(0.01)$ & $\mathrm{Cr}(0.2)$ & $\mathrm{Sb}(0.9)$ & $\mathrm{Hg}(3.8)$ & $\mathrm{Cu}(1.4)$ & $\mathrm{Hg}(18)$ \\
& $\mathrm{Hg}(0.1)$ & $\mathrm{Ni}(0.8)$ & $\mathrm{Cu}(1.6)$ & $\mathrm{Hg}(0.8)$ & $\mathrm{Zn}(9.1)$ \\
& $\mathrm{Ni}(0.1)$ & $\mathrm{Zn}(0.1)$ & $\mathrm{Ni}(0.2)$ & $\mathrm{Ni}(0.4)$ & $\mathrm{Ni}(4.2)$ \\
& $\mathrm{PCBs}(3.14)^{\circ}$ & & $\mathrm{Pb}(0.1)$ & $\mathrm{Pb}(0.2)$ & $\mathrm{Sb}(3.2)$ \\
& & & $\mathrm{Cu}(1.6)$ & $\mathrm{Sb}(0.1)$ & $\mathrm{Pb}(2.3)$ \\
& & & & &
\end{tabular}

Organics

$\operatorname{PCBs}(60) \quad \operatorname{PCBs}(147)$

${ }^{a}$ In clams.

Note: Contaminants are listed for each food-chain pathway from highest to lowest AI:ADI ratio (in parentheses).

Arsenic was the only metal that warranted further consideration for all pathways. For screening purposes, ADI for arsenic is exceedingly small because it is considered to be a carcinogen; therefore, whenever present in the environment, arsenic will usually exceed $\mathrm{ADI}$ in every food-chain pathway. Arsenic had the highest AI:ADI ratios in all food-chain pathways except milk, where it was replaced by selenium.

Only the organic contaminants that were measured in the different pathways were included in this screening analysis. Six organics were measured in water, while fish and aquatic plants were analyzed for PCBs only. Concentrations of organics were not available for screening the terrestrial food-chain pathways and were not considered in 
modeling the terrestrial pathways because default concentrations and transfer coefficients for organics were not available in the literature.

The AI:ADI ratio would undoubtedly be reduced in the terrestrial food-chain pathways if direct measurements were available for these components instead of the conservative concentration ratios and transfer coefficients from sediment to vegetation that must be used. In addition, the concentrations of contaminants in soil were based on the average of only three sediment core samples. Because site characterization data for metals and organics are poor, it is difficult to perform a meaningful screening exercise on these pathways. Therefore, more reliable measurements of contaminant concentrations must be obtained on the floodplain soils and sediments before a defensible evaluation of the contamination of the WOL ecosystem can be made.

Results of the terrestrial food-chain pathway analyses indicate that the vegetable pathway is the most sensitive of the pathways for screening metal contaminants. Likewise, the most sensitive aquatic pathway for metals and organics involved consumption of aquatic plants. However, it should be emphasized that in actuality the consumption of aquatic plants from WOL is a highly unlikely pathway. These results also indicate that, for screening purposes, more than one food-chain pathway should be considered, unless the most sensitive pathway is selected. If only one pathway is analyzed and it is not the most sensitive one, then the screening procedure should be conservative enough to account for any pathways.

\subsection{ROLE OF AQUATIC MACROFLORA IN THE RADIOECOLOGY OF WHITE OAK LAKE}

\subsubsection{Introduction}

Aquatic macrophytes are a salient feature of shallow lentic systems, such as WOL. As a result of their physiological activities and physical structure, these plants may have significant influences on the retention, remobilization, transport, and food-chain entry of contaminants that enter and/or accumulate within WOL. Large stands of emergent macrophytes (cattails and bulrushes) populate shallow regions, including those adjacent to contaminant-bearing surface water inflows. Rooted submersed plants have been observed to occupy much of the lake bottom in past years (B. G. Blaylock, ORNL, personal observation, June 1987), and could potentially colonize almost the entire lake bottom in substantial densities. Spring and fall blooms of floating plants (e.g., duckweeds) are also a common occurrence on WOL.

In addition to their ecological roles, the physical presence of these plants affects the transport of particulates within and out of the lake and consequently influences the dynamics of radionuclides associated with these particulates. The physiological activities of these plants affect radionuclide dynamics indirectly through their influences on the physicochemical environment, and directly through active uptake and adsorption of radionuclides and their subsequent losses as macrophyte-related dissolved and particulate substances. Organisms grazing on the epiphytic coating on macrophyte surfaces and those consuming detritus of macrophyte origin may incorporate the macrophyte-associated 
radionuclides. The reliance of rooted macrophytes on the sediment for nutrients is well established. However, the extent to which macrophytes may remobilize ${ }^{137} \mathrm{Cs}$, ${ }^{60} \mathrm{Co}$, and ${ }^{90} \mathrm{Sr}$ contained in the sediment is unknown. A real potential exists for the continued remobilization of sediment-radionuclides by macrophytes long after radionuclide inputs to the lake have ceased. The subsequent release of these contaminants to the water column could constitute a long-term source of contaminant entry into the water column. The magnitude and significance of such actions remains to be evaluated.

Efforts in 1987 addressed several basic issues: (1) determining the distribution, biomass, and species composition of the macroflora in WOL; (2) determining the radionuclide concentrations in the various macrophytes; and (3) investigating the sources of macrophyte-associated radionuclides, and the dynamics and fate of the macrophyteassociated radionuclide pools.

\subsubsection{Methods}

On September 8 and 15, 1987, the emergent vegetation in WOL was surveyed using landmarks and existing markers from previous studies. This survey was confined to the major stands occurring at the upper end of the lake (Fig. 8-2). The data were then compared with an aerial photograph taken in early 1987 that clearly showed the extent of the emergent plant zone. From this information, a map of the emergent macrophyte distribution was constructed. A total of 12 vegetation samples and 8 soil samples were collected in the emergent macrophyte zone at the time of the survey. The above-ground portions of the emergent plants from 12 randomly selected $0.25-\mathrm{m}^{2}$ plots were cut with garden shears and taken to the laboratory. At each site a 4-cm-diameter, $25-\mathrm{cm}$-long, soil core was also collected. The plants from each sample were separated by species, and the wet weight of the plants was determined. (Live and dead leaves were not separated.) A gamma scan of a subsample was performed, after which the dry weight of the subsample was also determined. The wet:dry weight ratio of the subsample was then used to calculate the dry weight of the entire sample. Samples of Typha leaves and Scirpus stems from 5 plots each (randomly selected from the 12 samples) were submitted for ${ }^{90} \mathrm{Sr}$ determination. Five samples of Typha leaves and five samples of Scirpus stems were also submittad for ICP analysis. A sample of "standard pine needles" (NBS standard reference material \#1575) was also submitted as part of the QA-QC program. The radionuclide and mineral content of the soil cores from each plot will be determined in order to evaluate the relationship between soil characteristics and macrophyte radionuclide content.

The open water region of WOL was surveyed for submersed macrophytes in late August 1987. For this survey, a weighted garden rake attached to a line was pulled behind a rowboat to collect submersed macrophytes; however, no samples were collected due to the scarcity of submersed vegetation and the poor condition of that encountered. Samples of benthic filamentous algae and submersed rooted macrophytes were collected from WOL during a later survey on October 15, 1987.

Because few submersed and floating aquatic macrophytes were found in WOL during the survey, samples of these plants were collected from populations at the weirs on WOC (WCK 2.65 and WCK 3.41), at Melton Branch (MEK 0.16), and at a site just above 


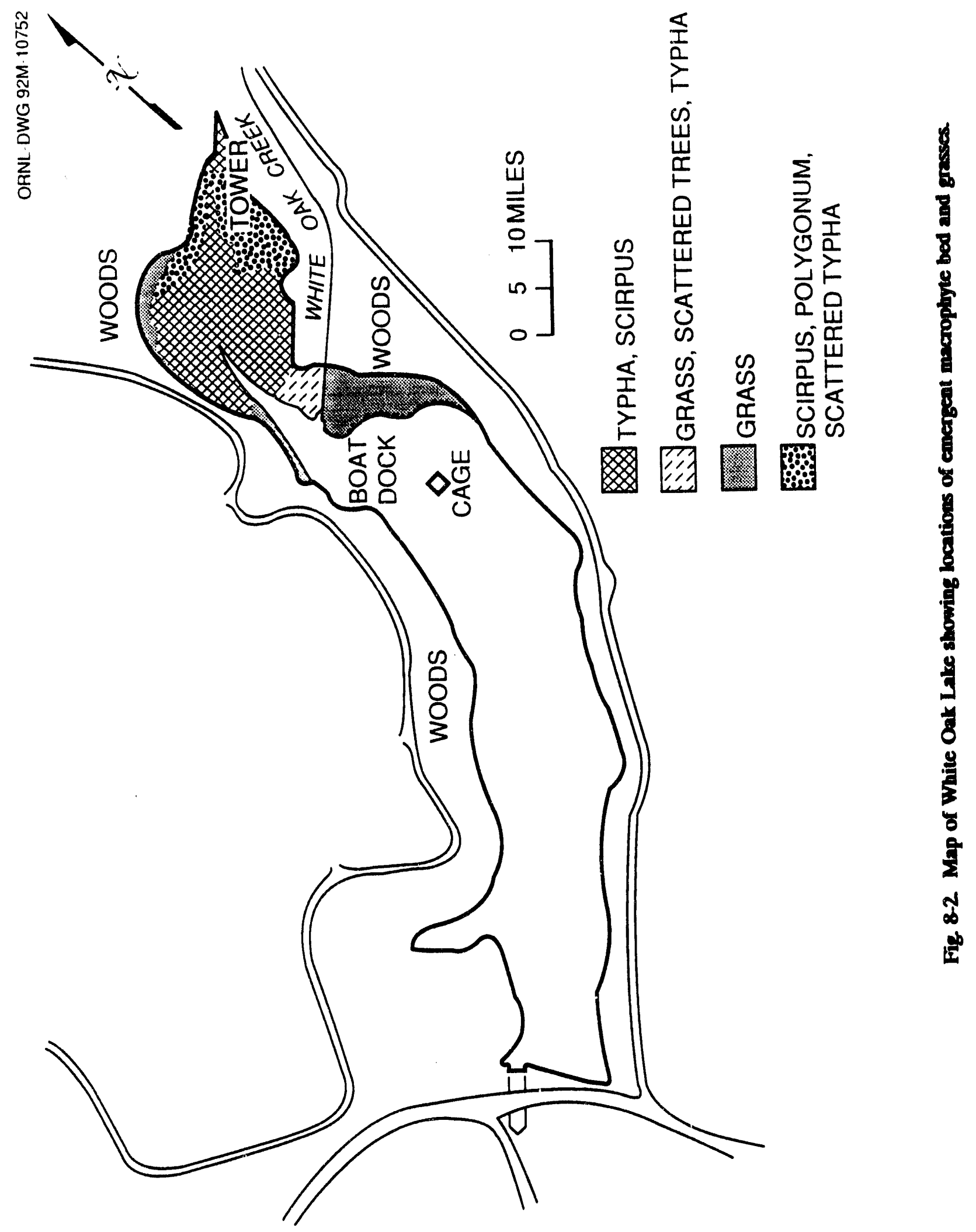


WOL. Gamma scans, ${ }^{90} \mathrm{Sr}$ determination, and ICP scans were conducted for these plant samples as described above.

\subsubsection{Results and Discussion}

The emergent macrophyte community occupying the shallow region at the north end of the lake was composed primarily of Typha latifolia (cattail), Scirpus sp. (bulrush), Polygonum sp. (smart weed), and various grasses (Fig. 8-2). The emergent macrophytes covered $\sim 1.71$ ha or $-16 \%$ of the lake surface area. Average above-ground biomass in this region was $-535 \mathrm{~g}$ of dry weight per square meter, which was dominated by Scirpus (Table 8-19). The total emergent macrophyte standing crop in mid-September 1987 was $-9.2 \times 10^{3} \mathrm{~kg}$ dry wt.

Above-ground portions of Scirpus and the grasses had higher concentrations of ${ }^{137} \mathrm{Cs}$ than did those of the Typha; however, concentrations of ${ }^{60} \mathrm{Co}$ were similar for all three types of plants (Table 8-19). All plants had greater concentrations of ${ }^{137} \mathrm{Cs}$ than ${ }^{60} \mathrm{Co}$. Concentrations of ${ }^{90} \mathrm{Sr}$ were similar for Typha and Scirpus, and similar to or greater than the concentration of ${ }^{137} \mathrm{Cs}$ (Table 8-19). Grass samples were not analyzed for ${ }^{90} \mathrm{Sr}$.

Five samples of the above-ground portion of Typha and Scirpus were submitted for ICP analysis. With the exception of low phosphorus concentrations, perhaps reflecting the inclusion of standing dead stems, the concentrations of the major minerals were fairly typical for these species (Table 8-20).

The survey of WOL for submersed and floating macrophytes during August 1987 found only scattered stems of Myriophyllum spicatum (Eurasian water milfoil) and Elodea canadensis in shallow water $(<0.5-\mathrm{m}$ depth). The plants had a thick coating of epiphyton and were in very poor condition, having spindly stems with few leaves. Due to the scant populations (1 or 2 stems per square meter) present in limited areas, no biomass samples were collected. Similarly, the poor condition of these plants precluded the collection of plant material for radionuclide analysis.

During October 1987, a few stems of Myriophyllum were found in a screened enclosure at mid-lake, and mats of filamentous green algae covered the bottom of a shallow bay on the west side of the lake adjacent to the boat ramp (Fig. 8-2). Samples of these plants were collected and scanned for gamma emitters. Cesium-137 and ${ }^{60} \mathrm{Co}$ were the only gamma emitters found. The concentrations of ${ }^{137} \mathrm{Cs}$ and ${ }^{60} \mathrm{Co}$ were 74.9 and $5.96 \mathrm{Bg} / \mathrm{g}$ dry weight, respectively, for the Myriophyllum stems and 10.2 and $1.37 \mathrm{~Bq} / \mathrm{g}$ dry weight, respectively, for the filamentous algae (Table 8-21). Data for Elodea collected from the mid-lake enclosure in 1976 (B. G. Blaylock, ORNL, unpublished data) averaged 29.1 and $175.6 \mathrm{~Bq} / \mathrm{g}$ dry weight of ${ }^{137} \mathrm{Cs}$ and ${ }^{60} \mathrm{Co}$ respectively. Filamentous algae in the enclosure in 1976 averaged 48.0 and $98.5 \mathrm{~Bq} / \mathrm{g}$ dry weight for ${ }^{137} \mathrm{Cs}$ and ${ }^{60} \mathrm{Co}$ respectively. The differences in the concentrations of ${ }^{137} \mathrm{Cs}$ and ${ }^{10} \mathrm{Co}$ found for samples collected during 1976 and 1987 may reflect physiological differences in plant species, the poor condition of plants during 1987 , or differences in the availability of ${ }^{137} \mathrm{Cs}$ and ${ }^{60} \mathrm{Co}$ in WOL between 1976 and 1987. 
Table 8-19. Biomass and radionuclide concentration for emergent Macrophytes collected from White Oak Lake during September 1987

\begin{tabular}{|c|c|c|c|c|}
\hline Species & Biomass & ${ }^{137} \mathrm{Cs}$ & ${ }^{60} \mathrm{Co}$ & ${ }^{90} \mathrm{Sr}$ \\
\hline $\begin{array}{l}\text { Typha } \\
\text { s.d. } \\
\text { Range }\end{array}$ & $\begin{array}{c}147.8 \\
\pm 110.6 \\
(26.5-388)\end{array}$ & $\begin{array}{c}0.47(12.8) \\
\pm 0.16 \\
0.17-0.78\end{array}$ & $\begin{array}{c}0.13(3.5) \\
\pm 0.09 \\
0.03-0.37\end{array}$ & $\begin{array}{c}3.0(81) \\
\pm 1.2 \\
1.8-5.0\end{array}$ \\
\hline $\begin{array}{l}\text { Scirpus } \\
\text { s.d. } \\
\text { Range }\end{array}$ & $\begin{array}{c}251.3 \\
\pm 105.5 \\
(31.7-401.8)\end{array}$ & $\begin{array}{c}1.06(28.6) \\
\pm 0.95 \\
0.20-3.6\end{array}$ & $\begin{array}{c}0.12(3.4) \\
\pm 0.07 \\
0.03-0.25\end{array}$ & $\begin{array}{c}2.4(66) \\
\pm 1.7 \\
1.2-5.8\end{array}$ \\
\hline $\begin{array}{c}\text { Grasses } \\
\text { s.d. } \\
\text { Range }\end{array}$ & $\begin{array}{c}136.3 \\
\pm 70.4 \\
(12.1-246.7)\end{array}$ & $\begin{array}{c}1.23(33.3) \\
\pm 0.43 \\
0.60-2.11\end{array}$ & $\begin{array}{c}0.09(2.4) \\
\pm 0.03 \\
0.04-0.14\end{array}$ & NA \\
\hline Total & 535.4 & & & \\
\hline
\end{tabular}

Note: Values represent the mean \pm 1 s.d. and range. Biomass values are above-ground biomass (gram dry weight per square meter) in the emergent macrophyte zone. Concentrations of ${ }^{137} \mathrm{Cs}$ and ${ }^{60} \mathrm{Co}$ are measured in becquerels per gram dry weight. Sample sizes were: biomass $(N=12),{ }^{137} \mathrm{Cs}$ and ${ }^{60} \mathrm{Co}(N=6)$, and ${ }^{9} \mathrm{Sr}(N=5)$. NA = not analyzed. Values in parentheses are picocuries per gram dry weight.

Because few submersed plants and no floating plants were found in WOL during 1987, plants were collected from WOC and Melton Branch. Substantial populations of the macrophytes common in WOL occur above the weirs on WOC and Melton Branch. Samples of these plants and those occurring farther upstream were collected during July and August 1987 in order to evaluate intersite differences in radionuclide concentrations. Plants from WOC had greater concentrations of ${ }^{137} \mathrm{Cs}$ but lower concentrations of ${ }^{60} \mathrm{Co}$ compared with plants from Melton Branch (Table 8-21), reflecting the radionuclide concentrations in the discharges from these systems. Of the plants collected, Myriophyllum, Elodea, and Potamogeton sp. are rooted submersed species that can accumulate minerals from either the water column or the sediment. The filamentous algae, the moss, and Lemna (duck weed) are not rooted and so accumulate materials exclusively from the water column. In addition to differences in access to the sediment mineral pool, these plants represent a great diversity of plant types (autotrophic protist, bryophyte, and angiosperm respectively) and thus are likely to differ physiologically. At the WOC weir at WCK 2.65, the rooted plants had higher concentrations of ${ }^{137} \mathrm{Cs}$ and ${ }^{60} \mathrm{Co}$ than the filamentous algae (Table 8-21). Concentrations of ${ }^{90} \mathrm{Sr}$ were similar for all plants at this site. The Myriophyllum and the moss collected further upstream (WCK 3.4) seemed to have greater concentrations of ${ }^{137} \mathrm{Cs}$ and ${ }^{60} \mathrm{Co}$ in comparison with plants at WCK 2.65. The concentrations of ${ }^{137} \mathrm{Cs}$ and ${ }^{60} \mathrm{Co}$ were similar for Myriophyllum samples collected at WCK 3.4 and in WOL (Table 8-21). Concentrations of ${ }^{90} \mathrm{Sr}$ were similar for plants at WCK 2.65 and WCK 3.4 (Table 8-21). 
Tuble 8-20. Concentrations of selected elements in the stems of Typha and Scipus from White Oat Late

Concentrations are expressed as parts per million dry wt, values $=$ the mean \pm 1 s.d., $N=5$

\begin{tabular}{|c|c|c|}
\hline Elements & Typha & Scirpus \\
\hline Al & $216 \pm 251$ & $252 \pm 94$ \\
\hline B & $7.96 \pm 0.94$ & $4.84 \pm 2.02$ \\
\hline $\mathbf{B a}$ & $28.2 \pm 14.3$ & $52.8 \pm 11.1$ \\
\hline $\mathrm{Ca}$ & $16600 \pm 1744$ & $5880 \pm 1123$ \\
\hline Co & $1.14 \pm 0.33$ & $1.26 \pm 0.36$ \\
\hline $\mathrm{Cr}$ & $6.72 \pm 5.45$ & $11.3 \pm 3.5$ \\
\hline $\mathrm{Cu}$ & $2.58 \pm 0.47$ & $2.76 \pm 0.88$ \\
\hline $\mathrm{Fe}$ & $305 \pm 352$ & $310 \pm 69$ \\
\hline $\mathbf{K}$ & $10320 \pm 2897$ & $4920 \pm 1690$ \\
\hline Mg & $1780 \pm 256$ & $890 \pm 114$ \\
\hline $\mathbf{M n}$ & $1524 \pm 669$ & $882 \pm 172$ \\
\hline $\mathrm{Na}$ & $22800 \pm 748$ & $181 \pm 80$ \\
\hline $\mathbf{N i}$ & $4.28 \pm 3.10$ & $5.06 \pm 1.64$ \\
\hline $\mathbf{P}$ & $1820 \pm 306$ & $1228 \pm 321$ \\
\hline Sr & $24.6 \pm 4.6$ & $11.6 \pm 0.5$ \\
\hline $\mathrm{Zn}$ & $22.0 \pm 3.3$ & $35.4 \pm 8.8$ \\
\hline
\end{tabular}

Rooted plants (Potamogeton) at the Melton Branch weir (MEK 0.16) had higher concentrations of ${ }^{60} \mathrm{Co}$ than did nonrooted plants (Lemna and filamentous algae) (Table 8-21). Concentrations of ${ }^{137} \mathrm{Cs}$ were low for all plants in Melton Branch, and ${ }^{90} \mathrm{Sr}$ concentrations were similar for all plants at MEK 0.16. Moss collected farther upstream on Melton Branch (MEK 0.6) had very high concentrations of ${ }^{60} \mathrm{Co}$, about $346 \mathrm{~Bq} / \mathrm{g}$ dry wt. 
Table 8-21. Redionuclide concentrations (expreseed as becquerels per gram dry wt) in submersed and foating aquatic macrophytes in White Oak Lake, White Oak Creek, and Melton Branch during 1987

\begin{tabular}{lllll}
\hline Site/date & Species & ${ }^{137} \mathrm{Cs}$ & ${ }^{60} \mathrm{Co}$ & \\
\hline White Oak Lake & & & \\
$(10 / 15)$ & Myriophyllum & $74.9(2024)$ & $5.96(161)$ & NA \\
& filamentous algae & $1.37(37)$ & NA
\end{tabular}

WCK 2.65

(7/13)

$\begin{array}{llll}\text { Myriophyllum } & 40.7(1100) & 2.93(79.2) & 0.95(25.7) \\ \text { Elodea } & 57.7(1560) & 3.92(106) & 1.40(37.8) \\ \text { filamentous algae } & 15.3(413) & 1.03(27.8) & 1.40(37.8)\end{array}$

WCK 3.4

Myriophyllum

moss

MEK 0.16

$(7 / 13)$

(7/24)

$$
\begin{aligned}
& \text { Lemna } \\
& \text { filamentous algae } \\
& \text { Potamogeton }
\end{aligned}
$$

MEK 0.6
83.1(2246)

4.96(134)

$1.40(37.8)$

84.5(2285)

8.77(237)

$0.55(14.9)$

Note: Values are for single determinations. All data for above-ground biomass only. Values not shown were below the detection limit. NA $=$ not analyzed. Values in parentheses are expressed as picocuries per gram dry wt. WCK $=$ White Oak Creek kilometer; MEK = Melton Branch kilometer.

In general, rooted plants had higher concentrations of ${ }^{137} \mathrm{Cs}$ and ${ }^{60} \mathrm{Co}$ than did nonrooted plants. Concentrations of ${ }^{90} \mathrm{Sr}$ were similar for both rooted and nonrooted species, although the bryophytes had lower concentrations of ${ }^{90} \mathrm{Sr}$ than the other plants. Interestingly, concentrations of total $\mathrm{Sr}$ in the moss samples were similar to those in other species (Table 8-22). 


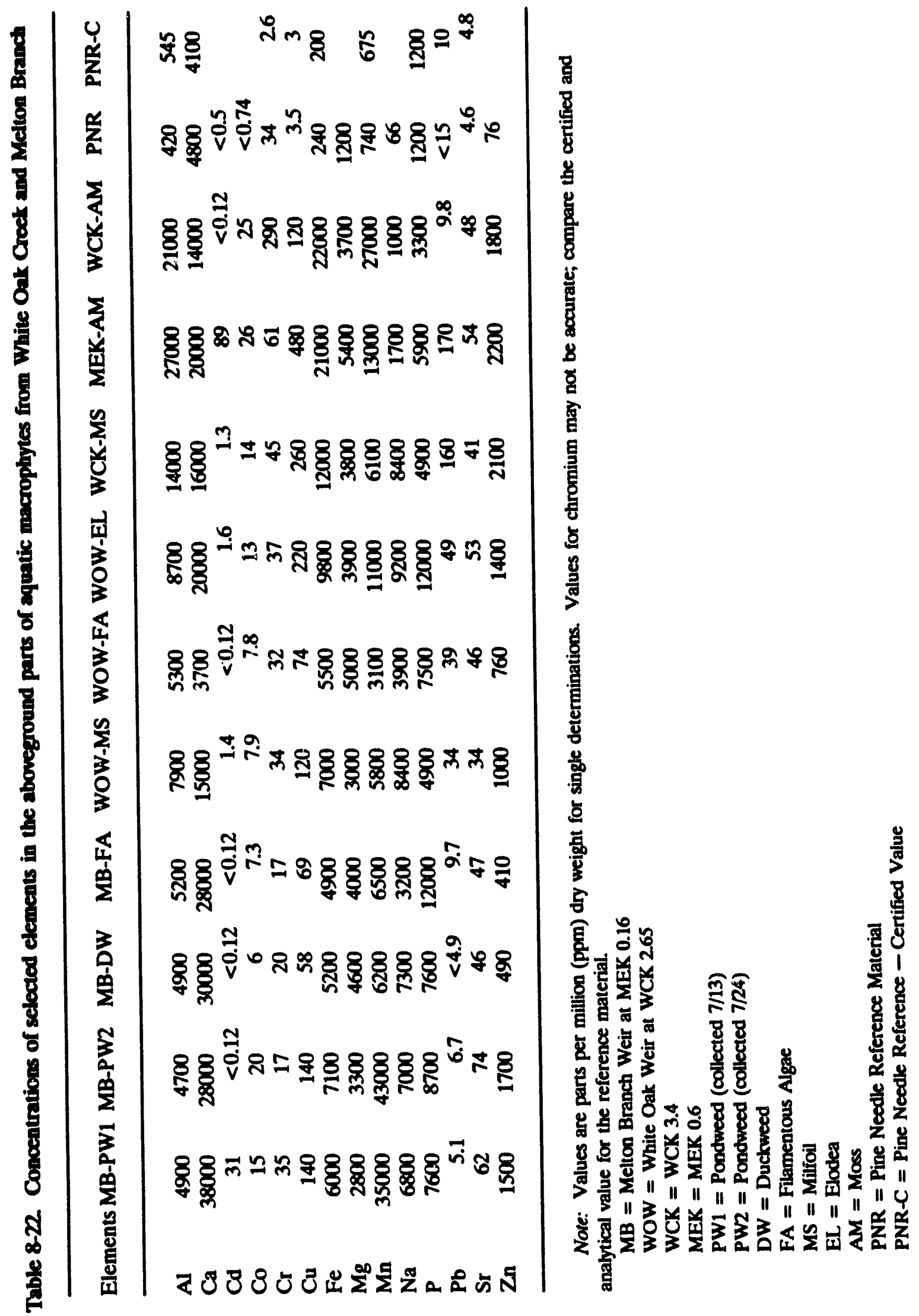


Results of the ICP analysis (Table 8-22) showed differences in the mineral composition of the plants collected from different locations. Myriophyllum collected upstream (WCK 3.4) had higher concentrations of $\mathrm{Al}, \mathrm{Co}, \mathrm{Cu}, \mathrm{Fe}, \mathrm{P}, \mathrm{Pb}$, and $\mathrm{Zn}$ compared with Myriophyllum collected at the WOC weir. Rooted plants had higher concentrations of copper and zinc than did the duckweed or filamentous algae. Bryophytes are well known for their ability to accumulate metals. The aquatic mosses at MEK 0.6 were enriched in $\mathrm{Cd}, \mathrm{Co}, \mathrm{Cu}, \mathrm{Pb}$, and $\mathrm{Zn}$. The data for chromium presented in Table 8-22 may be in error because the certified value for the pine needle reference material was more than an order of magnitude lower than the analytically determined values. The cause for this discrepancy has not yet been resolved.

\subsubsection{Summary}

The emergent macrophyte community in WOL, consisted primarily of Typha latifolia (cattail), Scirpus sp. (bulrush), Polygonum sp. (smart weed), and various grasses. These plants covered about 1.71 ha, or about $16 \%$ of the lake surface area, with an average above-ground biomass of about $535 \mathrm{~g} / \mathrm{m}^{2}$ dry wt in this region. Although the lake has the potential and has been reported to support extensive stands of submersed and floating species in the past, few were encountered during 1987. Rooted submersed plants collected from the lake were in poor condition but had substantial concentrations of ${ }^{137} \mathrm{Cs}$ and ${ }^{60} \mathrm{Co}$, indicating that plants growing in WOL may serve as sources of contaminant entry into the aquatic food chain or as sources of contaminants for downstream transport. Because few submersed or floating plants were found in WOL this year, samples of plants previously found in the lake were collected from WOC and Melton Branch above the lake. Plants collected from WOC and Melton Branch also had concentrations of ${ }^{137} \mathrm{Cs}$, ${ }^{60} \mathrm{Co}$, and ${ }^{90} \mathrm{Sr}$ in the range of $10^{\circ}$ to $10^{2} \mathrm{~Bq} / \mathrm{g}$ dry wt.

Emergent plants had lower concentrations of ${ }^{137} \mathrm{Cs}$ and ${ }^{60} \mathrm{Co}$ than did other macrophytes; however, concentrations of ${ }^{90} \mathrm{Sr}$ were fairly similar for all macrophytes. The concentrations of the various radionuclides in the macrophytes reflected the concentrations at the site of collection. Differences in the radionuclide concentrations for different species collected from the same site were apparent. Currently it is not known to what extent these differences reflect the remobilization of sediment-associated radionuclides or merely reflect differences in physiology among species. Further, during this initial survey no effort was made to determine whether the various radionuclides were organically or inorganically bound or whether they were incorporated within the plant or merely associated with plant surfaces. The dynamics and fate of the macrophyteassociated radionuclide pools are also of interest but were not addressed in this initial survey.

The results of this survey indicated that macrophytes growing in WOL have substantial concentrations of radionuclides; and that given the potential for colonization, biomass turnover, and the translocation of radionuclides from the sediment to the aboveground parts of the plants, the aquatic macrophytes could become a major source of radionuclides in WOL. Clearly more information is needed concerning (1) the extent of remobilization of sediment-associated radionuclides by aquatic macrophytes, (2) the fate of the macrophyte-associated radionuclide pools (food-chain entry, downstream transport, 
sedimentation), and (3) the influence of these plants (physical, physicochemical and physiological) on the radionuclide dynamics in WOL.

\subsection{RADIONUCLIDES IN FISH IN WHITE OAK CREEK}

\subsubsection{Introduction}

Weirs constructed on WOC for environmental monitoring purposes have created habitats for populations of sunfish that did not exist previously. The purpose of this study was to determine if levels of radionuclides found in fish from WOL were representative of the degree of contamination found in fish from WOC and tributaries. Data on the accumulation and partitioning of ${ }^{137} \mathrm{Cs}$ were also of interest in Task 2 of the BMAP because ${ }^{137} \mathrm{Cs}$ is a particle-associated contaminant whose transport and accumulation in this system should have much in common with the behavior of mercury and PCBs, contaminants in WOC that also are highly particle associated.

\section{5 .2 Methods}

Levels of ${ }^{137} \mathrm{Cs}$ were determined in sunfish samples that had been collected and freeze-dried for metals analyses as part of Task 2 of BMAP (Sect. 4.1). Freeze-dried fish samples were counted by the ORNL ACD using a GeLi crystal scintillation spectrometer.

\subsubsection{Results}

Relatively high levels of ${ }^{137} \mathrm{Cs}$ were found in fish from reaches of WOC upstream from WOL in comparison with fish from WOL or WOC embayment (Table 8-23). Concentrations of ${ }^{137} \mathrm{Cs}$ in fish from the site with the highest mean concentration (WCK 2.9) were approximately 10 times the level found in the same species from WOL. Although fish from Melton Branch also contained elevated levels of ${ }^{137} \mathrm{Cs}$, the levels were about a factor of $\mathbf{1 0}$ lower than that observed in fish from WOC near the main ORNL complex. Northwest Tributary contained a mixture of highly contaminated individuals and fish with much lower levels of ${ }^{137} \mathrm{Cs}$. This pattern is consistent with the movement of fish into this site from nearby reaches of WOC. Metu ury contamination in fish at this site also exhibited a similar pattern of highly variable concentrations (Table D-1). The overall pattern of ${ }^{137} \mathrm{Cs}$ in fish from the WOC system agreed with findings of earlier investigations (Spalding and Cerling 1979), which showed that the main ORNL complex is the major source of ${ }^{137} \mathrm{Cs}$ to WOC and tributaries, and the Melton Valley facilities and SWSAs are of secondary importance.

\subsection{FUTURE STUDIES}

\subsection{Radionuclides in the White Oak Lake Ecosystem}

The task of estimating the quantity of radionuclides in the various compartments of the WOL ecosystem is near completion. Still to be completed are measurements of the biomass and concentrations of ${ }^{137} \mathrm{Cs},{ }^{60} \mathrm{Co}$, and ${ }^{90} \mathrm{Sr}$ in the periphyton, zooplankton, and 
Table 8-23. Levels of ${ }^{137} \mathrm{Cs}$ (measured in becquerels per kilogram dry weight) in sunfishe from the White Oak Creek system, December 1986

\begin{tabular}{lccc}
\hline Site & Mean \pm 1 s.d. & Range & N \\
\hline WCK 3.5 & $21600 \pm 2200$ & $18000-25000$ & 8 \\
WCK 2.9 & $29800 \pm 9100$ & $21000-45000$ & 8 \\
WCK 2.3 & $13600 \pm 8400$ & $7000-30000$ & 8 \\
WOL & $3011 \pm 1200$ & $2100-6000$ & 9 \\
WCK 0.9 & $1500 \pm 600$ & $560-2700$ & 8 \\
MEK 0.2 & $2900 \pm 600$ & $2300-4000$ & 5 \\
NTK 0.2 & $8400 \pm 11400$ & $140-25000$ & 8 \\
\hline
\end{tabular}

Includes bluegill (Lepomis macrochirus) and redbreast sunfish ( $L$ auritus).

Note: WCK = White Oak Creek kilometer, WOL = White Oak Lake; MEK = Melton Branch kilometer; NTK $=$ Northwest Tributary kilometer.

phytoplankton compartments. Additional samples of invertebrates will be collected and analyzed to obtain a better estimate of the invertebrate biomass with depth in sediment, and an attempt will be made to estimate the clam, snail, and crayfish populations in WOL.

A reliable estimate of the quantity of radionuclides in WOL ecosystem will not be available until a comprehensive core sampling program is completed and better estimates of the volume and concentration of radionuclides in the sediments are obtained. (Core sampling of the lake sediments is not included in the present task because it will be conducted as part of the Remedial Investigation on WOC and WOL under the corrective action requirements of the Resource Conservation and Recovery Act [Sect. 3004 (u)].) In addition, a complete inventory of the radionuclides in the WOL ecosystem requires estimates of the quantity of radioactivity in the surrounding floodplain of the lake and estimates of the biomass and the concentration of radionuclides in flora and fauna on the floodplain.

\subsection{Waterfowi Populatic v Associated with ORNL Lakes and Ponds}

The census of waterfowl that frequent impoundments near ORNL will continue for the purpose of estimating the numbers of resident and migratory populations inhabiting these areas. Additional waterfowl will be collected and analyzed for radionuclides and other environmental contaminants. Emphasis will be placed on samplijg waterfowl from the resident populations and obtaining birds from other areas for a comparison with ORR sites. 
A study will be initiated to determine whether WOL serves as a refuge for migratory waterfowl or whether most of the birds that inhabit the lake are local residents. The study will compare population patterns for WOL with migratory patterns observed by the Tennessee Wildlife Resource Agency's waterfowl aerial census of East Tennessee reservoirs, ponds, and streams, especially Watts Bar and Melton Hill reservoirs and the Clinch River.

Another study will be initiated to establish whether the resident populations that inhabit waste disposal ponds, which serve as nesting areas primarily for wood ducks and Canada geese, produce offspring that join the local flocks of waterfowl, which can be harvested by hunters. The approach in this study will be to tag nesting geese and their offspring from these areas and determine their movement patterns. Nesting boxes will be used to facilitate the collection of wood ducks and their offspring for sampling and tagging. The local Audubon Society will be asked to participate in reporting the sightings of tagged waterfowl.

\subsubsection{Preliminary Screening of Contaminants in White Oak Lake}

The screening analysis for radionuclides and other contaminants in the entire WOL ecosystem is near completion. These analyses have pointed out the areas where additional environmental measurements are needed. When more reliable data, based on additional sampling, become available, the various food-chain pathways should again be screened and the results incorporated into a single report.

\subsubsection{Role of Aquatic Macroflora in the Radioecology of White Oak Lake}

Macrophytes are a potential important biological pool for radionuclides in aquatic ecosystems and can influence the fate and food-chain entry of these contaminants. Therefore, investigations will be conducted during 1988 to evaluate the processes of sediment remobilization and $\mathrm{fa}^{*}$. of ${ }^{137} \mathrm{Cs}$, ${ }^{90} \mathrm{Sr}$, and ${ }^{60} \mathrm{Co}$ as influenced by aquatic macrophytes in WOL. The seasonal dynamics of the aquatic macroflora in WOL, WOC, and Melton Branch will be characterized to assess the role of macrophyte beds as sources or sinks for suspended contaminants and to determine the ability of these beds to intercept, retain, and enhance the deposition of radionuclides. The functional role of macrophytes in the remobilization of ${ }^{137} \mathrm{Cs}$, ${ }^{90} \mathrm{Sr}$, and ${ }^{60} \mathrm{Co}$ from the sediments and subsequent fate of macrophyte-associated radionuclides will be determined, emphasizing entry into the aquatic food-chain and downstream transport. Field studies will primarily be used to achieve these objectives; and, where applicable, laboratory studies will be employed to provide better resolution of specific processes.

The results of these investigations will elucidate the functional role of aquatic macrophytes in the accumulation, persistence, and dynamics of radionuclides within the WOL ecosystem and the extent to which changes in system parameters (e.g., plant biomass, production, turnover and distribution, sediment and water quality, and environmental conditions) influence their fate. These data will be used in conjunction with data on the biomass and radionuclide concentrations of the WOL biota to build a linear, donor-controlled, mass balance model of the dynamics of these contaminants based on the functional role of sediments and macrophytes in food web interactions. 


\subsubsection{Radionuclides in Fish from White Oak Creek}

Weirs constructed on WOC for environmental monitoring purposes have created habitats for populations of sunfish that did not exist previously. As a result, limited populations of sunfish have developed that have much higher concentrations of ${ }^{137} \mathrm{Cs}$ in their tissues than in those found in WOL fish. In Task 2 of BMAP, these fish are being monitored for metals and organic pollutants. Samples collected as part of Task 2 of BMAP will continue to be analyzed for ${ }^{137} \mathrm{Cs}$ and ${ }^{60} \mathrm{Co}$. An effort will be made to correlate concentrations of these contaminants in fish with changes in waste treatment systems (e.g., planned modifications in PWTP). In addition, consideration will be given to determining the size of the sunfish population that now exists in WOC. 


\section{CONTAMINANT TRANSPORT, DISTRIBUTION, AND FATE IN THE CLINCH RIVER-WATTS BAR RESERVOIR SYSTEM}

\subsection{INTRODUCTION}

Waste disposal activities on ORR have introduced contaminants into local streams that ultimately drain into the Clinch River-Watts Bar Reservoir system. The focus of this BMAP task is on (1) scoping the extent of contamination within the sediments of Watts Bar Reservoir; (2) quantifying the physical, chemical, and biological processes that affect the transport, distribution, and fate of contaminants in the river-reservoir system; and (3) establishing a baseline of information for assessing the effectiveness of remedial actions undertaken at the DOE facilities on the ORR. To accomplish these objectives, four subtasks are being addressed that involve an interdisciplinary combination of literature review, simulation modeling, field sampling, and laboratory analysis (Fig. 9-1).

\subsection{LITERATURE REVIEW AND SYNTHESIS}

Available data on the fate of contaminants discharged from ORR to the Clinch River are being reviewed, integrated, and synthesized. To date, existing data on releases of ${ }^{137} \mathrm{Cs}$, other radionuclides, and mercury, along with available information on the concentrations of these contaminants in the sediments of the Clinch River and reservoirs downstream have been examined. This data review indicated that most of the previous sampling was focused on the Clinch River and that a need existed for a thorough sampling of Watts Bar Reservoir sediments. Additionally, long-term water quality data sets are being identified that can be used to calibrate and verify the river-reservoir contaminant transport model (Sect. 9.3).

\subsection{CONTAMINANT TRANSPORT AND FATE SIMULATION MODEL}

A working version of a branched, two-dimensional (longitudinal and vertica.') simulation model of the Clinch River-Watts Bar Reservoir system was developed. This river-reservoir model is complementary to the Clinch River Dispersion Model and supplementary to ongoing Emergency Response System modeling efforts. Flood control operations and hydroelectric power generation at Norris and Melton Hill dams on the Clinch River, Fort Loudoun Dam on the Tennessee River, and at Watts Bar Dam result in a complex hydrodynamic regime in Watts Bar Reservoir. Therefore, a two-dimensional transport model is necessary for short-term and long-term forecasting of contaminant transpurt, distribution, fate, and effects in this river-reservoir system.

In the working model, the reservoir is divided into 52 segments, with up to 10 vertical layers per segment (Fig. 9-2), through which water is routed based on inflow and outflow rates, segment morphometry, and temperature-density relationships. The Tennessee and Emory Rivers are divided into 3- to 5-mile segments. The Clinch River is divided into 


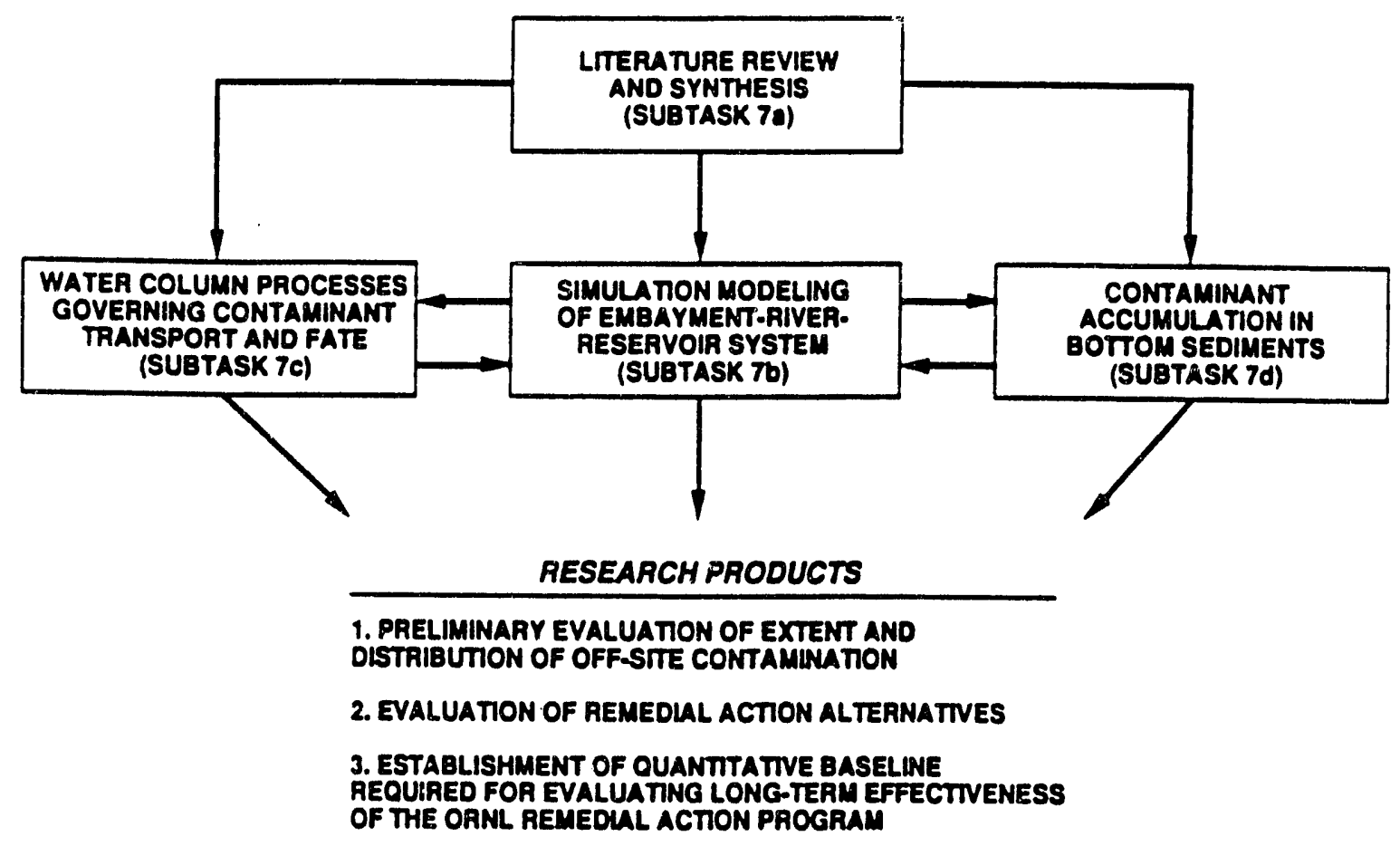

Fig 9-1. Linkages between subtosts and research products. 
(a)

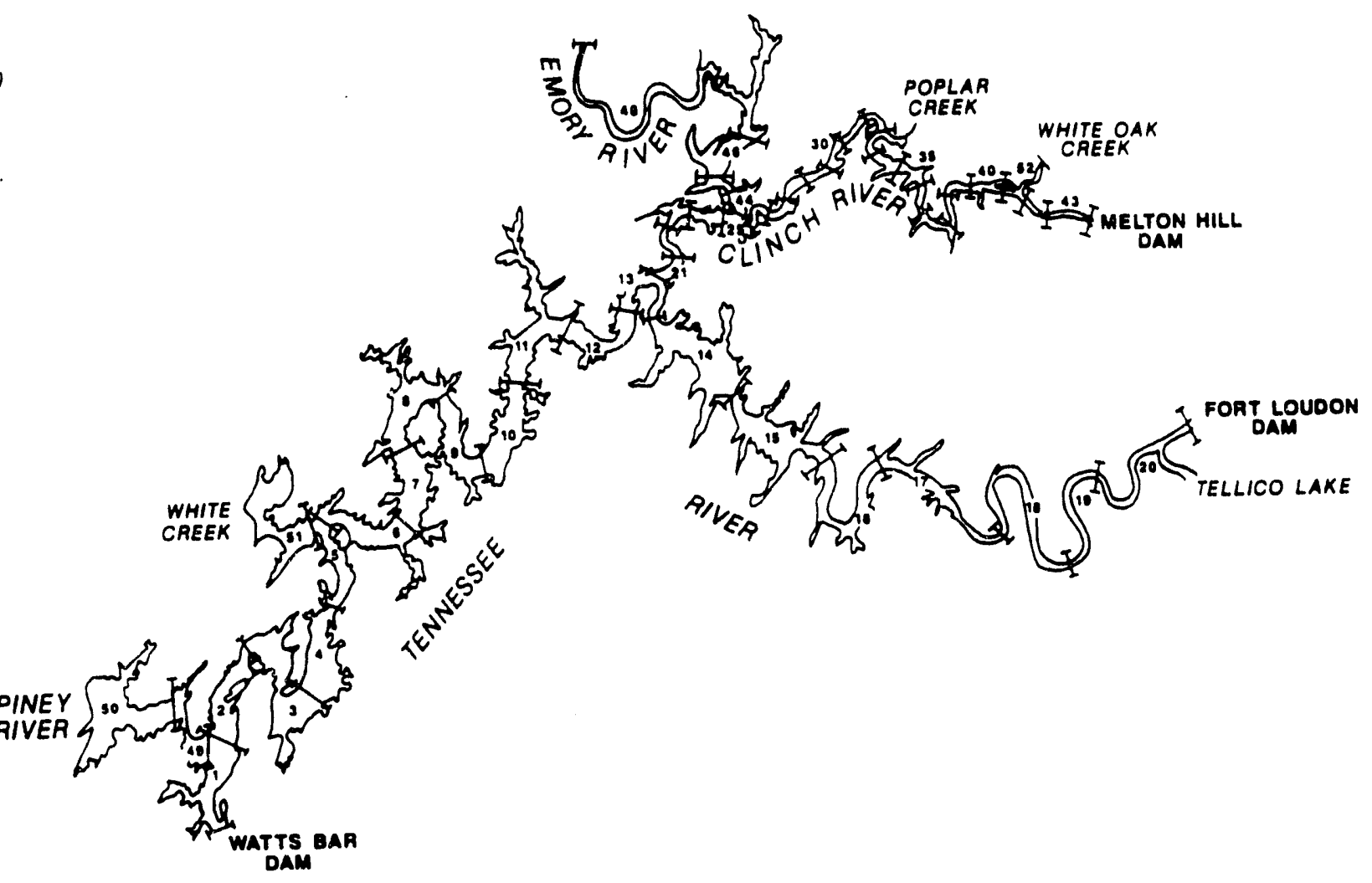

(b)

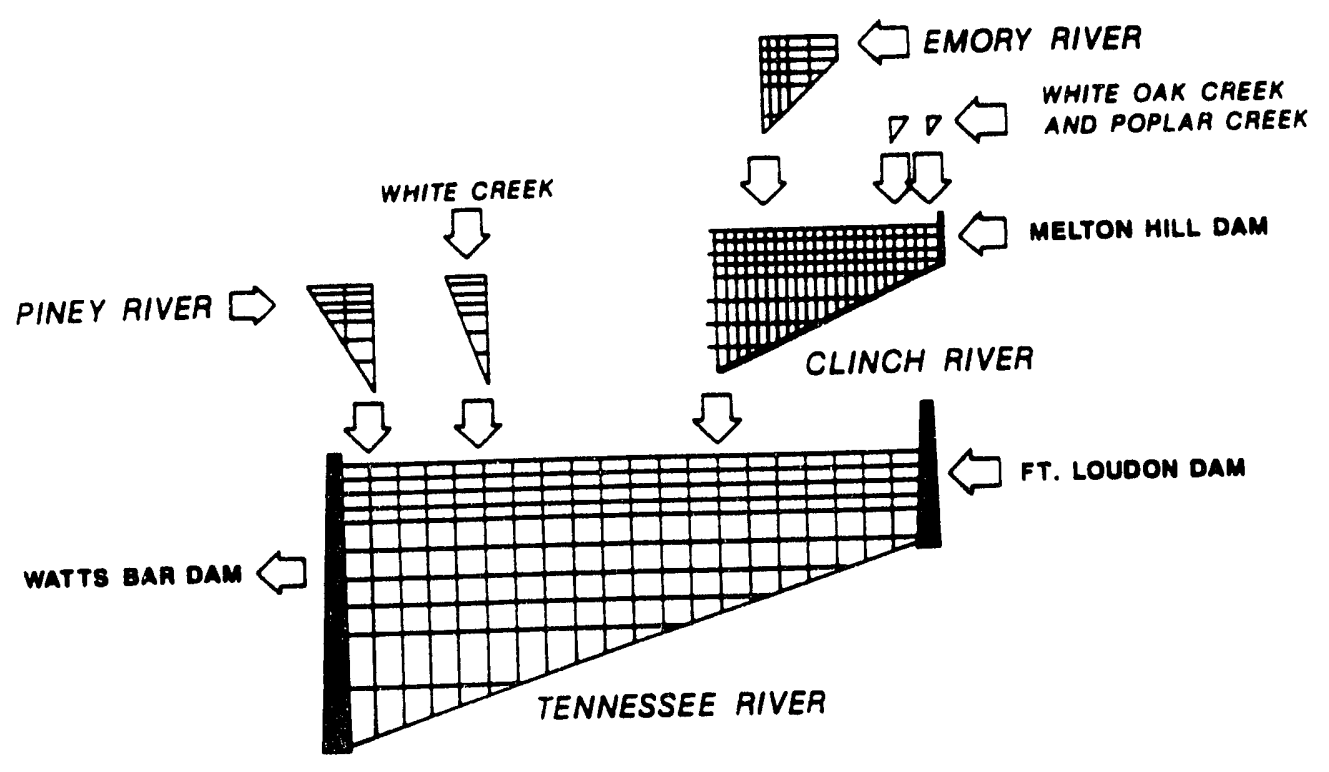

Fig 9-2. Basic structure of the Clinch River-Watts Bar Reservoir contaminant transport simulation model. The river-reservoir system is divided into 52 segments longitudinally (a), with up to 10 vertical layers per segments (b). Water and waterborne contaminants are routed through the model segments as dictated by inflow and outflow rates, segment morphometry, and water temperature-density relationships. 
1-mile segments to allow a more detailed simulation of the flow and mixing patterns immediately downstream of WOC and Poplar Creek. The working model includes the effects of wedge storage created on the Clinch River during peaking-power releases from Melton Hill Dam and of the flushing of the WOC and Poplar Creek embayments as river elevation fluctuates during peaking-power cycles.

Inflow and outflow data reported in the 1961-62 Clinch River Study were used to parameterize the working model and to conduct model runs to assess the effects of different hydropower operating conditions on the hydrodynamic transport of water-borne material (e.g., a contaminant release or "dye" in the model output, see Fig. 9-3). Results of these initial model runs indicated that the ability to integrate the effects of rapidly varying flow regimes, as provided by the transport model, was essential for interpreting contaminant transport and distribution patterns and for predicting contaminant concentrations downstream. Additional existing data sets and the results of ongoing field monitoring (see Sect. 9.4) will be used to further calibrate the model and to validate its predictive capability.

\subsection{BIOGEOCHEMICAL PROCESSES GOVERNING CONTAMINANT TRANSPORT AND FATE}

Some contaminants and radionuclides, such as ${ }^{3} \mathrm{H},{ }^{90} \mathrm{Sr}$, and ${ }^{131} \mathrm{I}$, are relatively soluble in freshwater systems; consequently their transport and biogeochemical fate are mediated by water mass movements and biological uptake from the water phase. However, most contaminants (e.g., PCBs, $\mathrm{Hg}$, ${ }^{60} \mathrm{Co},{ }^{137} \mathrm{Cs}$, and ${ }^{239,240} \mathrm{Pu}$ ) are chemically and biologically reactive and rapidly become associated with particles in freshwater systems. Consequently, the transport and biogeochemical fate of these contaminants are primarily governed by particle dynamics.

Limnological monitoring was conducted at stations located along a longitudinal transect from Melton Hill Dam to Watts Bar Dam to quantify the flow regime, thermal stratification, relative water column stability, suspended particle concentrations, and phytoplankton biomass. These measurements are being employed to determine specifically the conditions affecting contaminant transport, distribution, and fate in the Clinch River-Watts Bar Reservoir system and to provide the field data necessary for the calibration and validation of the contaminant transport model described in Sect. 9.3.

Surface water temperatures fluctuate little between CRK 35, located immediately below Melton Hill Dam, and CRK 7.5, located just upstream from the mouth of the Emory River, regardless of the season of the year (Fig. 9-4a). However, inflows from the Emory River and the effluent from the Kingston Steam Plant (CRK 4.2) significantly increase water temperatures. Clinch River water velocities showed the opposite tendency, as expected; highest velocities occurred at CRK 35 with velocities decreasing with distance downstream. Large changes in flow rates occur daily. For example, surface water velocities, measured July 14,1987, increased from $15 \mathrm{~cm} / \mathrm{s}$ to $140 \mathrm{~cm} / \mathrm{s}$ at CRK 33.5 as a result of peaking-power releases from Melton Hill Dam (Table 9-1). 


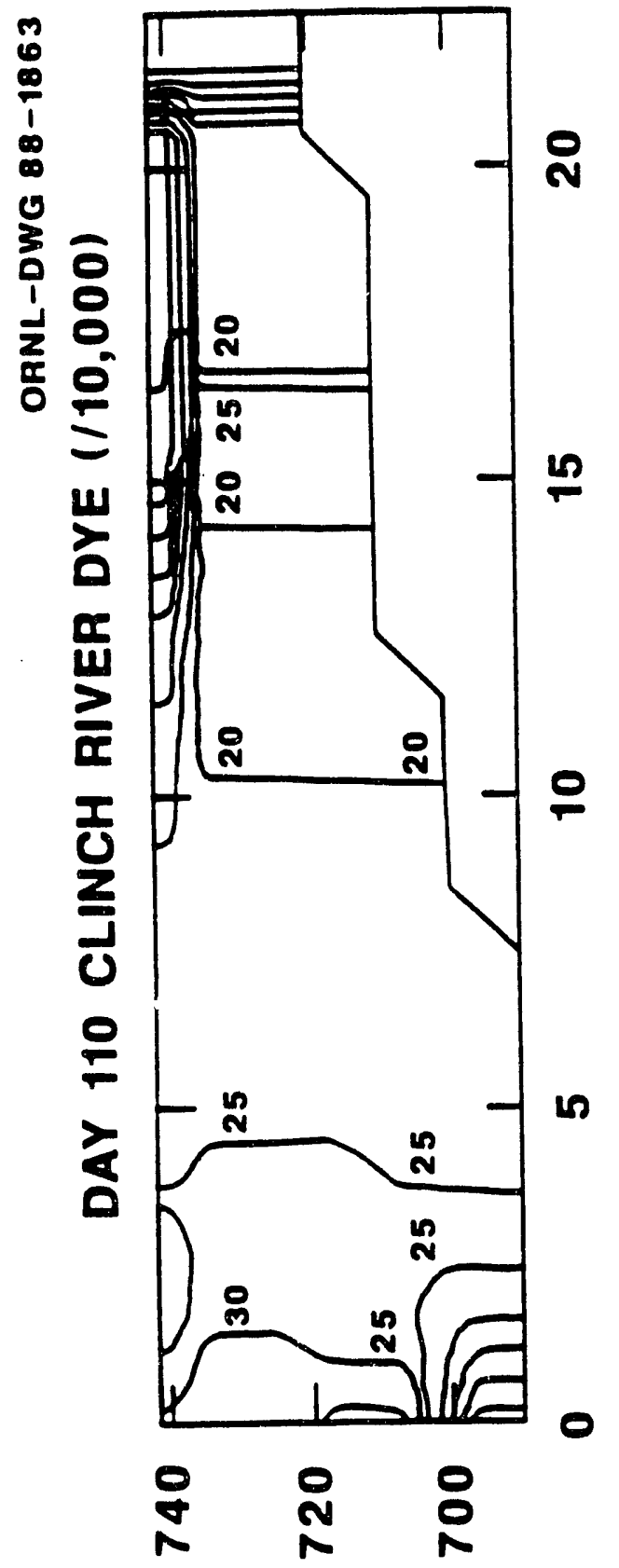

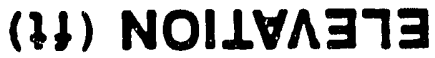

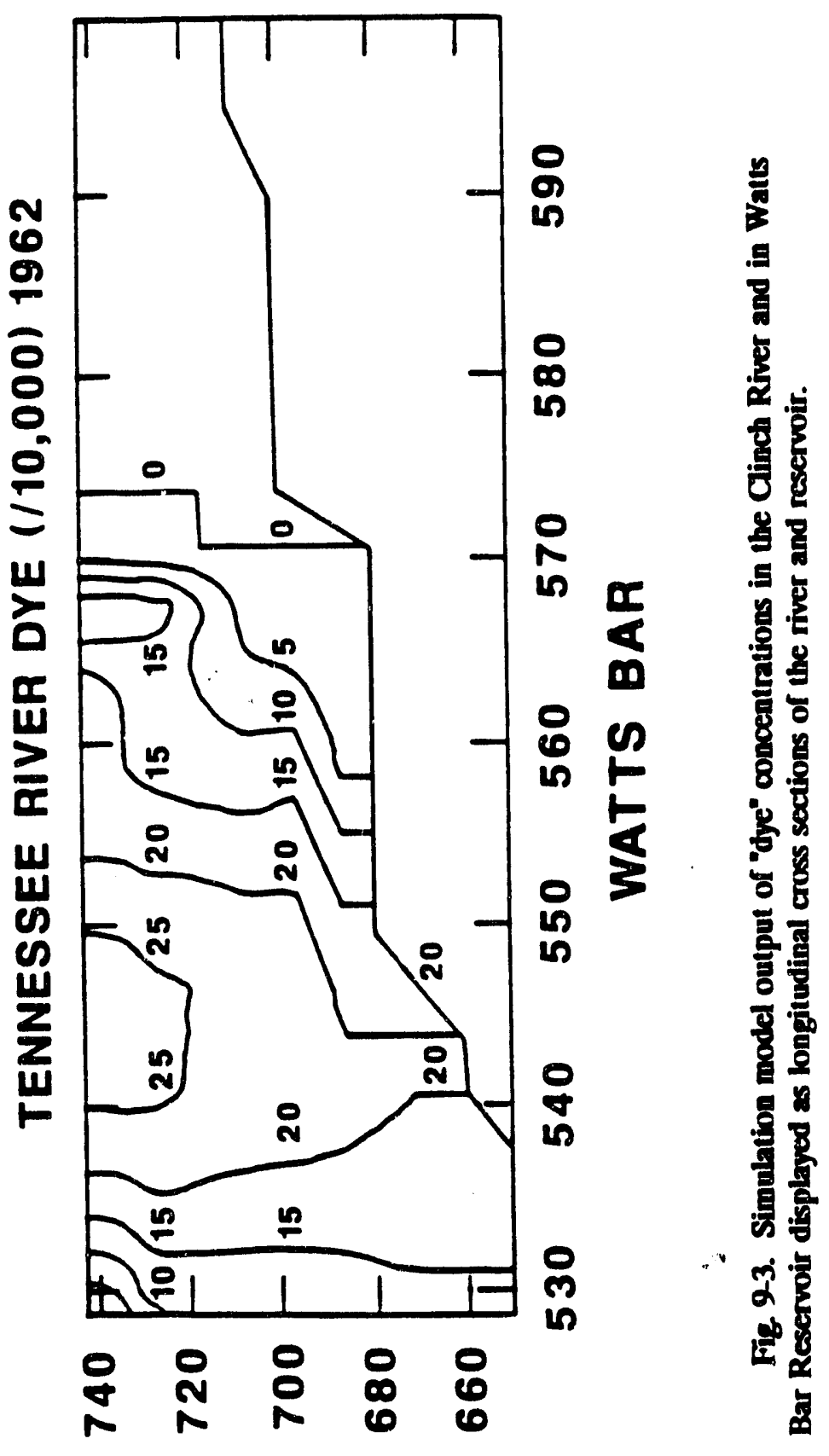

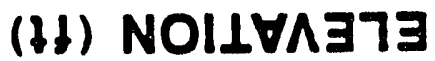



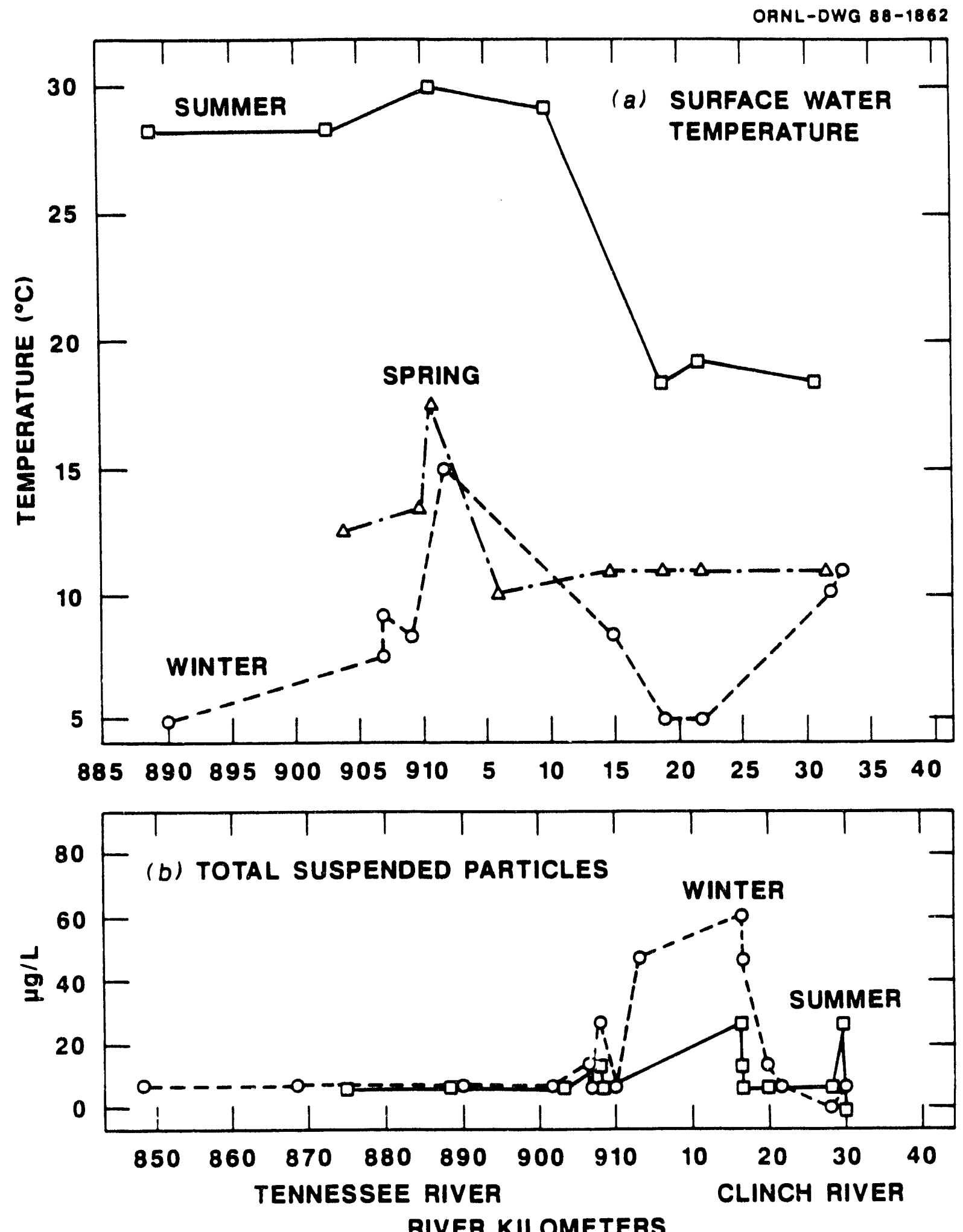

Fig 9-4. Surface water temperatures (a) and total suspended particle concentrations (b) in the lower Clinch River and Watts Bar Reservoir in the spring ( $\Delta)$, sumwer $(\square)$, and winter $(0)$. 
Table 9-1. Surface water velocities (measured in centimeters per second) in the lower Clinch River, 1987

\begin{tabular}{lccr}
\hline Site & Date & Time & Velocity \\
\hline CRK 2.4 & 07 July 1987 & $10: 15$ & \\
CRK 7.2 & 07 July 1987 & $11: 00$ & 8.2 \\
CRK 14.2 & 07 July 1987 & $11: 38$ & 14.9 \\
CRK 19.2 & 07 July 1987 & $12: 00$ & 4.9 \\
CRK 22.7 & 07 July 1987 & $12: 40$ & 19.0 \\
CRK 33.4 & 07 July 1987 & $13: 17$ & 30.0 \\
& & & 45.0 \\
CRK 19.2 & 14 July 1987 & $11: 20$ & 13.9 \\
CRK 22.7 & 14 July 1987 & $10: 48$ & 12.1 \\
CRK 31.8 & 14 July 1987 & $12: 15$ & 80.2 \\
CRK 33.4 & 14 July 1987 & $10: 10$ & 15.7 \\
CRK 33.4 & 14 July 1987 & $12: 43$ & 140.1 \\
& & & \\
\hline
\end{tabular}

Phytoplankton biomass (as reflected by chlorophyll-a concentrations in $\mu \mathrm{g} / \mathrm{L}$ ) increased with distance downstream, although there was little change in the chlorophyll- $a$ concentration within riverine portions of the Clinch River. Total suspended particle (TSP) concentrations (expressed in milligrams per liter) were low between CRK 35 and CRK 22 but increased markedly in association with input from Poplar Creek (CRK 19) and the Emory River (CRK 7.2) (Fig. 9-4b). Concentrations of TSP decreased in the upper portion of Watts Bar Reservoir as a result of particle sedimentation and dilution from the Tennessee River.

The relative importance of TSP versus phytoplankton for contaminant sorption is distinctly seasonal, especially from CRK 33.5 to CRK 4. Particle production by algae in riverine portions of the Clinch River provides a small quantity of the suspended particles available for sorption during most of the year. However, suspended sediments from storm runoff (occurring primarily from November through March) enter this section of the Clinch River from several sources, primarily WOC and Poplar Creek, and supply the majority of suspended particles available for sorption interactions in the river. Particle sedimentation removes most of the suspended sediment load from the water column in the upper portion of Watts Bar Reservoir, and phytoplankton-produced particles then become important for contaminant sorption and removal by sedimentation.

To quantify contaminant sorption rates onto suspended matter and contaminant removal rates from the water column by settling partisles, the partitioning of particle-reactive contaminants between aqueous and particulate phases was investigated by conducting field experiments with naturally occurring ${ }^{7} \mathrm{Be}$ (53.3-d half-life). Beryllium-7 enters aquatic systems as a dissolved constituent of rain water and, consequently, each rainstorm acts as a natural spiking event to the river-reservoir system. Rates of ${ }^{7} \mathrm{Be}$ sorption were determined by measuring changes in the amount of dissolved and particle- 
bound ${ }^{7} \mathrm{Be}$ after major precipitation (input) events. About $800 \mathrm{~L}$ of water was collected from $1 \mathrm{~m}$ below the water surface. Suspended particulate matter was removed by continuous-flow centrifugation. Dissolved ${ }^{7} \mathrm{Be}$ was concentrated and removed from the water phase by coprecipitation with $\mathrm{Fe}(\mathrm{OH})_{3}$. Radionuclide concentrations in the suspended matter and in the water phase $\left[\mathrm{Fe}(\mathrm{OH})_{3}\right.$ precipitate] were analyzed by gamma spectrometry.

Results indicate that the rate of ${ }^{7} \mathrm{Be}$ sorption onto suspended matter is -10 to $20 \%$ per day (Fig. 9-5), and that the average particle-to-water distribution coefficient for ${ }^{7} \mathrm{Be}$ is about $1 \times 10^{5}$. The length of time that $\mathrm{Be}$ remained in the water column before removal by settling particles ranged from -5 to 15 days. Because the particle-to-water distribution coefficient for ${ }^{7} \mathrm{Be}$ is similar to values determined for other particle-reactive contaminants, such as ${ }^{137} \mathrm{Cs},{ }^{60} \mathrm{Co},{ }^{239,240} \mathrm{Pu}, \mathrm{Hg}$, and $\mathrm{PCBs}$ in freshwater reservoir systems, these results indicate that most of the particle-reactive contaminants discharged into the Clinch River-Watts Bar Reservoir system are already sorbed or will sorb onto suspended particles, settle from the water column, and accumulate in the reservoir sediments.

\subsection{CONTAMINANT ACCUMULATION IN BOTTOM SEDIMENTS}

It is well established that reservoirs trap riverborne particles, nutrients, and contaminants, and that they are sites of rapid sediment and contaminant accumulation (Olsen et al. 1981, Turner et al. 1985). The objective of this subtask is to estimate the total inventory of ${ }^{137} \mathrm{Cs}$ that has accumulated in the sediments of Watts Bar Reservoir. Radiocesium was chosen because (1) its primary source is ORNL; (2) its history of release from WOL is reasonably well documented; (3) it is rapidly sorbed to riverborne suspended matter and consequently serves as a tracer for the transport and accumulation patterns of a wide variety of other particle-reactive contaminants, such as $\mathrm{Hg}, \mathrm{Pu}$, and $\mathrm{PCBs}$; and (4) it is easy to measure by gamma spectrometry.

The distribution of ${ }^{137} \mathrm{Cs}$ was determined in 187 surface sediment samples and 61 sediment cores collected within the Clinch River-Watts Bar Reservoir System. Two types of coring devices were used to obtain sediment profiles: a gravity corer and a vibracorer. The free-fall gravity corer (Wildco KB) was equipped with a plastic liner which is $120 \mathrm{~cm}$ in length and $4.7 \mathrm{~cm}$ in diameter. The corer was attached to a cable on a reel and allowed to free-fall during descent. This coring device was primarily used in water that was $>5-\mathrm{m}$ deep. Upon retrieval, the plastic liner containing the sediment was capped and then removed from the core barrel. The core was extruded from the liner and sectioned into either 2- or 4-cm depth increments. These sections were then saled into labeled aluminum cans and returned to the laboratory for radionuclide analysis.

The vibracore consisted of a vibrating head attached to an aluminum irrigation pipe, typically $7.2 \mathrm{~cm}$ in diameter. The vibrating head allowed for greater penetration of the core pipe by thixotropic action. Sediment penetration by vibracoring is usually much greater than that achieved by gravity coring. Because pipe lengths greater than the depth of water column were required in this operation, vibracores were only collected in areas where the water was $<5 \mathrm{~m}$ deep. After penetration into ine sediment, the top of the core was plugged and the entire core pipe was brought to the surface. The bottom was then 


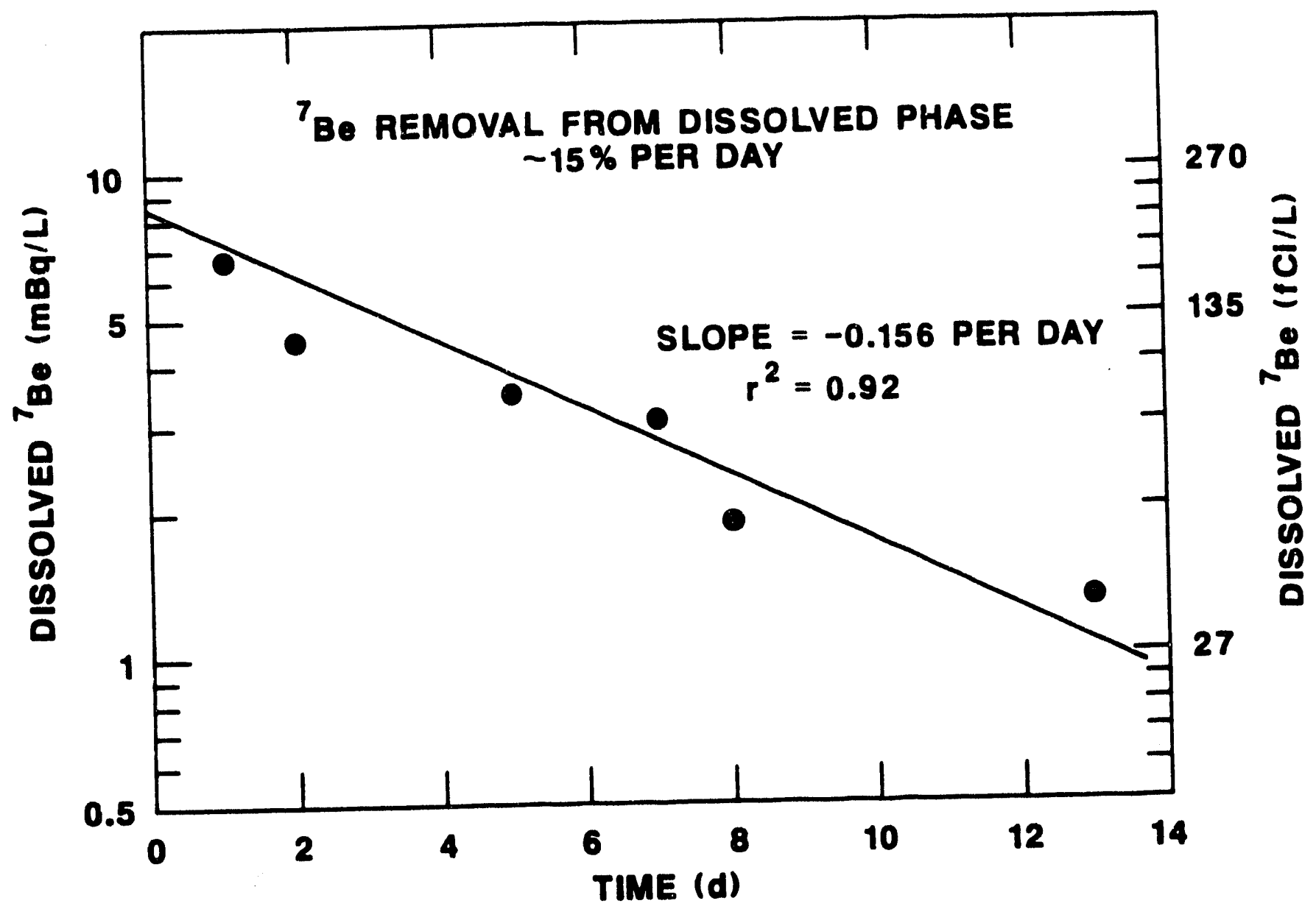

Fig 9-5. Dissolved 'Be concentrations messured in Melton Hill Reservoir samples collected in a time series after a major rainstorm ('Be-input) cvent. These results indicate that the sorption rate for particle-reactive contaminants is about $15 \% / d$. 
plugged and the excess core pipe was removed for easier handling and sediment extrusion. After extrusion, the sediment core was sectioned into either 2- or 4-cm depth increments and sealed into a labeled aluminum can as described previously.

The surface-sediment samples were used to develop a map of the sedimentary characteristics (Fig. 9-6) and to identify sites best suited for sediment coring. The sediment coring sites are identified in Fig. 9-7. The vertical distribution of ${ }^{137} \mathrm{Cs}$ in Watts Bar Reservoir sediment cores is strongly correlated with the historical record of ${ }^{137} \mathrm{Cs}$ discharges from WOL, exhibiting a large subsurface peak coincident with the draining of WOL in the mid 1950s (Fig. 9-8). The depth of this subsurface peak and the thickness of ${ }^{137} \mathrm{Cs-contaminated} \mathrm{sediment} \mathrm{vary} \mathrm{with} \mathrm{the} \mathrm{rate} \mathrm{of} \mathrm{sediment} \mathrm{accumulation.} \mathrm{In} \mathrm{areas} \mathrm{of}$ rapid sediment accumulation, such as in the upper portion of the reservoir and along the old river channel, the highest ${ }^{137} \mathrm{Cs}$ concentrations occur at sediment depths as great as $1.5 \mathrm{~m}$. In areas of slower sediment accumulation, maximum levels of ${ }^{137} \mathrm{Cs}$ occur very near the sediment surface.

The total burden of ${ }^{137} \mathrm{Cs}$ in Watts Bar Reservoir sediments was estimated by measuring the inventory of ${ }^{137} \mathrm{Cs}$ in each sediment core (Table 9-2) and integrating these data over the entire reservoir using a Geographic Information System (GIS) and ARC:INFO software package. Logistically, the reservoir surface area (from the City of Kingston to Watts Bar Dam) was subdivided into polygons on the basis of (1) proximity to the mouth of the Clinch River, (2) sedimentary characteristics, and (3) the ${ }^{137} \mathrm{Cs}$ concentration in surface-sediment samples (Fig. 9-9). $A{ }^{137} \mathrm{Cs}$ inventory was then calculated for each polygonal area. In areas where no sediment cores were collected, the ${ }^{137} \mathrm{Cs}$ inventory was estimated as an average calculated from the inventories of cores collected within the same vicinity and with the same sedimentary characteristics. Preliminary results from this GIS integration indicate that about $1.07 \times 10^{13} \mathrm{~Bq}(290 \mathrm{Ci})$ of ${ }^{137} \mathrm{Cs}$ reside in the sediments of Watts Bar Reservoir (Fig. 9-9). A decay-corrected total of $1.24 \times 10^{13} \mathrm{~Bq}(335 \mathrm{Ci})$ of ${ }^{137} \mathrm{Cs}$ are estimated to have been released from WOL into the Clinch River since 1949 , which indicates that about $85 \%$ of the ${ }^{137} \mathrm{Cs}$ released from White Oak Dam has been trapped within the sediments of Watts Bar Reservoir. The remaining $15 \%$ may reflect error in the estimate, uncertainty in the ${ }^{137} \mathrm{Cs}$ release history, or may indicate the amount of ${ }^{137} \mathrm{Cs}$ that has either been trapped within floodplain areas of the Clinch River and WOC embayment or transported downstream past Watts Bar Dam.

A variety of other contaminants, such as $\mathrm{Hg}, \mathrm{Pu}$, and $\mathrm{PCBs,}$ also associate with particles when discharged into river-reservoir systems; therefore, the measured ${ }^{137} \mathrm{Cs}$ distributions serve as a cost-effective indicator of the accumulation patterns of other contaminants. Additional sampling and analyses will be required in the future to document the inventories of other contaminants (metals, organics, and radionuclides) in the reservoir sediments, but the number and resultant costs will be greatly reduced by using ${ }^{137} \mathrm{Cs}$ to screen samples prior to other, more costly, contaminant analyses. 


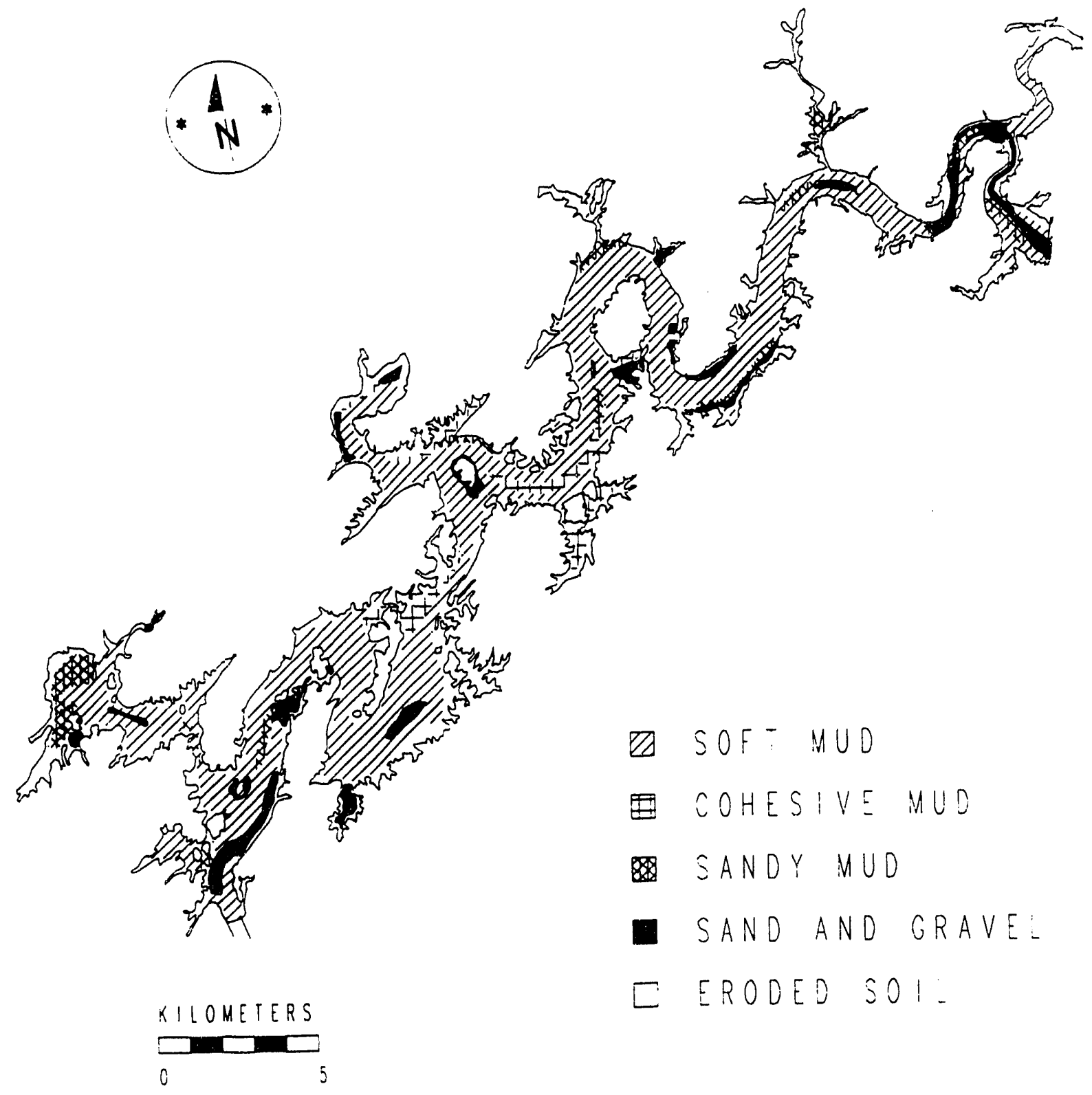

Fig. 9-6. A map illustrating the sedimentary characteristics in Watts Bar Reservoir. Total surface area $=119.4 \mathrm{~km}^{2}$. 
ORNL-DWG 88-8991

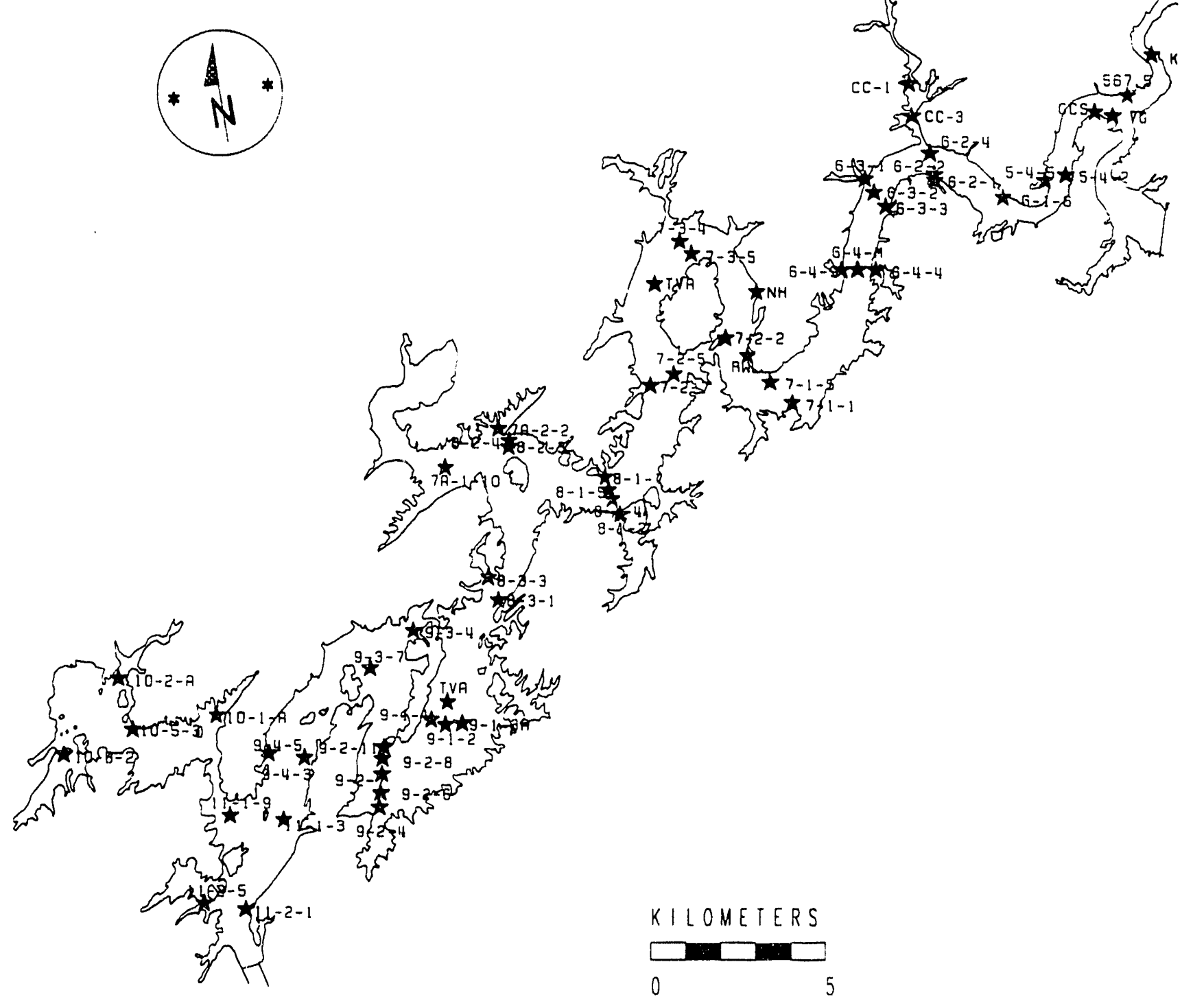

Fig 9-7. A map of the sediment core locations in Watts Bar Reservoir. 
OANL-DWO De-1732

ANNUAL ${ }^{137}$ CS DISCHARGE FROM WOL

SEDIMENT PROFILE CORE 567.5

CI (DECAY CORRECTED)
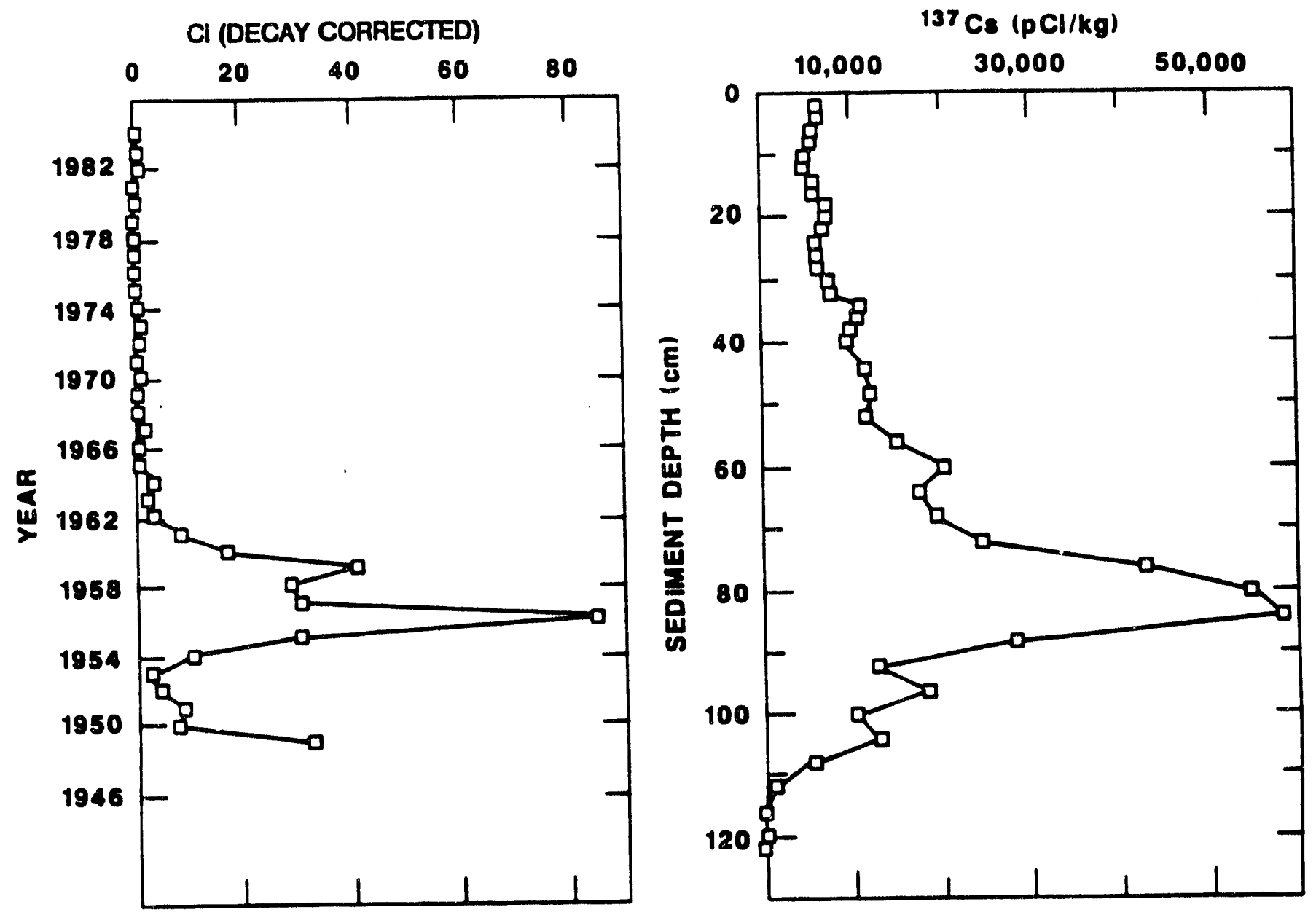

Fig 98. A graph illustrating the discharge history of ${ }^{17} \mathrm{C}$ s from White Oak Lake (WOL) and a typical ${ }^{17} \mathrm{CS}$ profile in the sediments of Watts Bar Reservoir. The large subsurface peak in sediment ${ }^{137} \mathrm{Cs}$ profile at $84 \mathrm{~cm}$ is coincident with the draining of WOL in mid-1950s. 
Table 9-2. Cesium-137 inventories in Watts Bar Reservoir sediment

\begin{tabular}{|c|c|c|c|}
\hline \multirow[b]{2}{*}{ Location } & \multirow[b]{2}{*}{ Collection date } & \multicolumn{2}{|c|}{ Total ${ }^{137} \mathrm{Cs}$} \\
\hline & & $\mathrm{Bq} / \mathrm{cm}^{2}$ & $\mathrm{pCi} / \mathrm{cm}^{2}$ \\
\hline Core KCP-A & April 29, 1987 & 58.7 & 1587 \\
\hline Core TN 567.5 & August 22, 1986 & 36.5 & 986 \\
\hline G COURSE SLEW & August 22, 1986 & 2.2 & 59 \\
\hline 7th GREEN SLEW & August 22, 1986 & 5.5 & 148 \\
\hline Core 5-4-5 & August 27, 1986 & 30.5 & 825 \\
\hline Core $5-4-2$ & August 27, 1986 & 0.6 & 15 \\
\hline Core 6-1-6 & September 9, 1986 & 15.1 & 407 \\
\hline Core 6-2-1 & September 9, 1986 & 26.5 & 716 \\
\hline GCore 6-2-2 & September 9, 1986 & $>6.9$ & $>186$ \\
\hline GCore 6-2-4 & September 17,1986 & $>8.1$ & $>218$ \\
\hline CANEY CR \#1 & September 17,1986 & 3.4 & 91 \\
\hline CANEY CR \#3 & September 19,1986 & 4.1 & 111 \\
\hline Core 6-3-1 & September 24,1986 & 11.6 & 314 \\
\hline GCore 6-3-2 & October 3,1986 & $>17.5$ & $>474$ \\
\hline Core 6-3-3 & September 17,1986 & 20.1 & 542 \\
\hline Core 6-4-4 & September 29,1986 & 20.1 & 544 \\
\hline GCore 6-4-M & September 29, 1986 & $>14.9$ & $>404$ \\
\hline GCore 6-4-9 & September 29,1986 & 3.8 & 104 \\
\hline Core 7-1-1 & October 3,1986 & 11.5 & 310 \\
\hline GCore 7-1-5 & October 10,1986 & $>11.5$ & $>311$ \\
\hline ROCKWOOD LAND & July 22,1986 & 3.1 & 85 \\
\hline NEW HOPE & July 22, 1986 & 0.1 & 4 \\
\hline GCore 7-2-2 & October 10,1986 & $>16.1$ & $>436$ \\
\hline GCore 7-2-5 & October 10,1986 & $>18.8$ & $>508$ \\
\hline GCore 7-2-7 & October 10,1986 & $>7.6$ & $>205$ \\
\hline GCore 7-3-4 & October 10,1986 & $>23.5$ & $>634$ \\
\hline Core 7-3-5 & October 15,1986 & 16.3 & 440 \\
\hline GCore 8-1-2 & October 17,1986 & 5.8 & 158 \\
\hline GCore 8-1-4 & October 17, 1986 & $>23.2$ & $>627$ \\
\hline GCore 8-1-5 & October 17, 1986 & 6.0 & 163 \\
\hline GCore 8.1-7 & October 17, 1986 & 6.7 & 180 \\
\hline GCore 8-2-3 & October 17, 1986 & 12.7 & 343 \\
\hline GCore 8-2-4 & October 17, 1986 & 0.4 & 12 \\
\hline GCore 7A-1-10 & January 15, 1987 & 4.6 & 124 \\
\hline GCore 7A-2-2 & January 15,1987 & $>5.7$ & $>153$ \\
\hline GCore 8-3-1 & January 15,1987 & $>10.0$ & $>271$ \\
\hline GCore 8-3-3 & January 15,1987 & 5.0 & 134 \\
\hline GCore 9-1-1 & February 12,1987 & 9.8 & 266 \\
\hline GCore 9-1-2 & February 12,1987 & $>18.7$ & $>505$ \\
\hline GCore 9-1-3A & February 12,1987 & 0.2 & 6 \\
\hline GCore 9-2-4 & September 10,1987 & 0.04 & 1 \\
\hline GCore 9-2-6 & September 10,1987 & $>15.9$ & $>431$ \\
\hline
\end{tabular}


Table 9-2 (continued)

\begin{tabular}{|c|c|c|c|}
\hline \multirow[b]{2}{*}{ Location } & \multirow[b]{2}{*}{ Collection date } & \multicolumn{2}{|c|}{ Total ${ }^{137} \mathrm{Cs}$} \\
\hline & & $\mathrm{Bq} / \mathrm{cm}^{2}$ & $\mathrm{pCi} / \mathrm{cm}^{2}$ \\
\hline GCore 9-2-7 & September 10,1987 & 11.0 & 298 \\
\hline GCore 9-2-8 & September 10,1987 & 8.9 & 240 \\
\hline GCore 9-2-11 & September 10,1987 & 0.2 & 5 \\
\hline GCore 9-3-4 & July 9,1987 & 12.6 & $>341$ \\
\hline GCore 9-3-7 & July 9, 1987 & 12.5 & 339 \\
\hline GCore 9-4-3 & July 23,1987 & 20.6 & 556 \\
\hline GCore $9-4-5$ & July 23,1987 & $>4.5$ & $>122$ \\
\hline GCore $10-1-2$ & June 4, 1987 & 4.0 & 108 \\
\hline GCore 10-2-A & June 18, 1987 & 0.8 & 21 \\
\hline GCore 10-3-2 & June 4, 1987 & 0.3 & 9 \\
\hline GCore $10-5-3$ & June 18,1987 & 0.8 & 22 \\
\hline GCore 11-1-3 & June 25,1987 & 9.3 & 250 \\
\hline GCore 11-1-9 & June 25,1987 & 10.7 & 289 \\
\hline GCore 11-2-1 & July 29,1987 & 14.7 & 397 \\
\hline GCore $11-2-5$ & July 29,1987 & 11.3 & 306 \\
\hline \multicolumn{4}{|c|}{ FALLOUT ${ }^{137}$ Cs INVENTORY } \\
\hline$(1950-1987)$ & 0.4 & 10 & \\
\hline
\end{tabular}

\subsection{FUTURE STUDIES}

The ORNL Remedial Action Program support for this task will be terminated upon initiation of the RCRA facility investigation (RFI) that specifically addresses offsite contamination of surface waters. Although contingent upon approval of the RFI Workplan by the EPA and TDHE, the offsite RFI is scheduled to begin early in FY 1989. At that time, the future work described here will be integrated into the larger scope of the RFI effort.

Future studies will be conducted in five areas: (1) the use of a two-dimensional flow model to integrate data on flow, particle dynamics, and contaminant concentrations and to predict contaminant transport, distribution, bioavailability, and retention in various portions of the Clinch River-Watts Bar Reservoir system; (2) additional collection and analysis of samples in other areas of concern (such as embayments along the Clinch River, including WOC and Poplar Creek); (3) continued use of the GIS system to delineate contaminant distributions and to identify offsite areas that have the greatest potential for exposing biota to contaminated sediments; (4) application of geochemical-diffusion and biophysical-mixing models to quantify the chemical, biological, and physical processes resulting in the release of contaminants from the sediments back into the water column; and (5) additional sampling and analyses in reservoirs that are linked to Watts Bar (Norris, Melton Hill, Ft. Loudoun, and Chickamauga) to document all contaminant sources and background levels. 


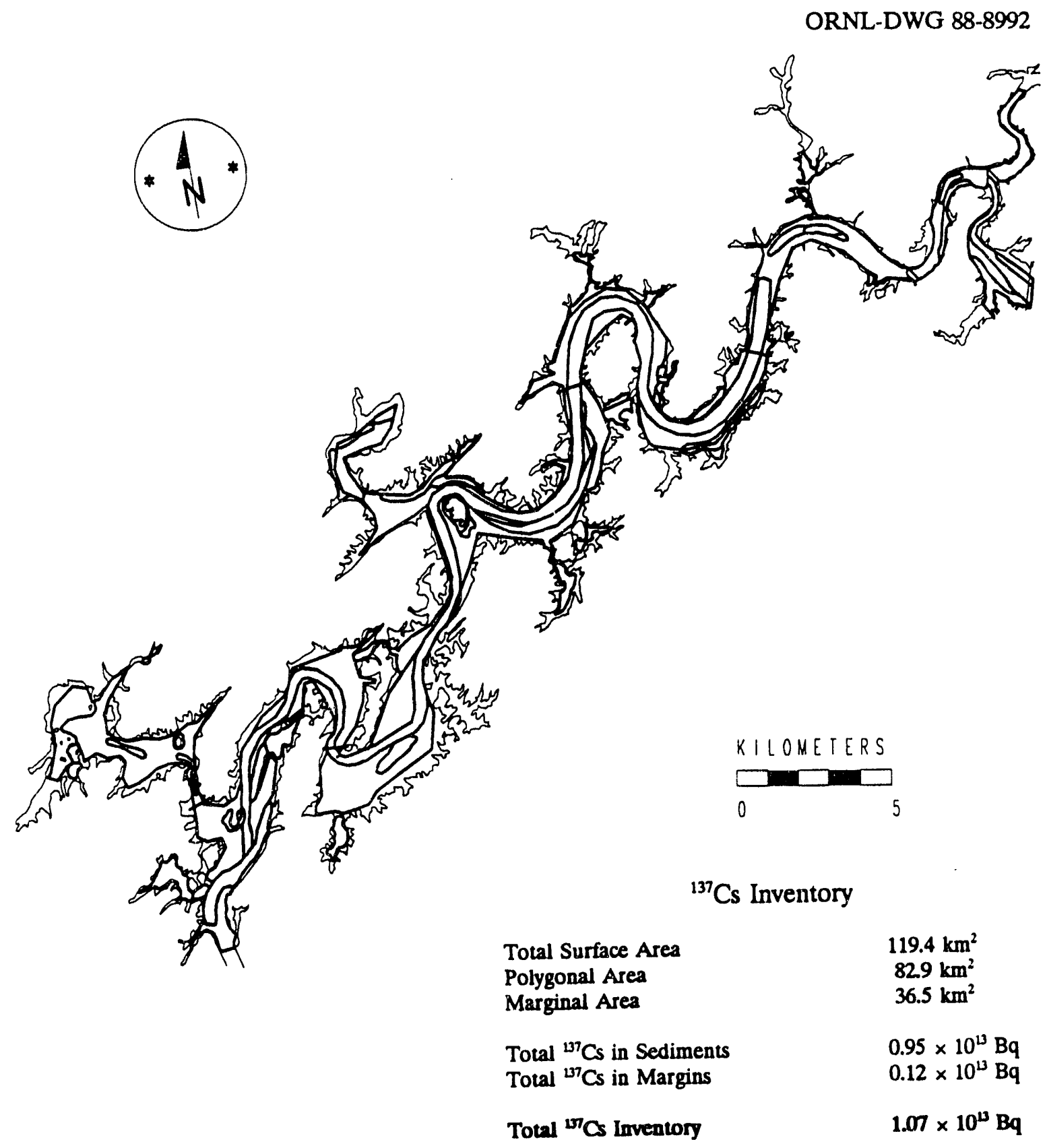

Fig 9-9. A map showing the polygonal areas used by the Geographic Information System to determine the total burden of ${ }^{137} \mathrm{Cs}$ in Watts Bar Reservoir sediments. The polygonal areas were delineated on the basis of (1) proximity to the mouth of the Clinch River, (2) sedimentary characteristics, and (3) ${ }^{137} \mathrm{Cs}$ concentration in the surface sediment samples. 


\section{ABATEMENT PROGRAM}

In several areas, efforts to abate aquatic toxicity have been and will continue to be focused on management initiatives. These areas include the following: (1) minimization of chlorine and ethylene glycol concentrations in surface streams; (2) implementation of monitoring plans that are designed to locate sources that contribute PCBs and mercury to surface streams, to characterize the sources, and to develop remedial measures; (3) improvements to existing underground wastewater piping systems, including relining and rerouting pipelines, to enhance control of ORNL wastewater streams; (4) secondary containment and/or diking of tanks containing hazardous or toxic substances, and of transformer oils; and (5) enhanced interface activity between ORNL DEMC personnel and operational and construction personnel in the field, on an individual, site-specific basis.

\subsection{CHLORINE REDUCTION}

Large cooling towers at ORNL continue to receive special attention through NPDES sampling. Although not indicative of a problem, the use of chlorine during warm months warrants sampling of blowdown before release to the receiving stream. Although the NPDES permit requires only quarterly sampling, chlorine is always checked, and if levels are not below $0.2 \mathrm{ppm}$, the blowdown is not discharged. The DEMC has provided guidance on several projects involving maintenance of existing cooling towers and installation of new cooling systems to ensure that chlorine discharges to ORNL streams are either prevented or are kept at levels that are as low as are reasonably achievable (ALARA).

It has become evident that chlorine is or has the potential to be the principal source of toxicity to aquatic life in ORNL streams. A study is being considered to install a system of instream chlorine monitors. The accumulation of real time data could be related to stream conditions and correlated to possible episodic events. The value of such a system will be assessed.

Because the potable water system at ORNL has a chlorine content of approximately $1.8 \mathrm{ppm}$, there is always the potential for toxic levels in the stream. Water pipeline leaks and breaks have been the source of problems in the past and most likely will continue to be a potential problem. In order to deal with this problem, two aerators have been purchased. The intent is to be prepared to place an aerator anywhere in the stream where chlorine levels are high and, through dissipation, reduce the chlorine level. This equipment provides for quick abatement of a problem.

\subsection{ETHYLENE GLYCOL,}

There have been numerous leaks and breaks in the ethylene glycol cooling system at ORNL, particularly in the 4500 area, during the past year. The ethylene glycol chilling system is approximately 40 years old, and the problem can be attributed to the age of the system. The presence of ethylene glycol in the streams enhances microbial growth and 
reduces the oxygen level in the stream. A contract has been given to the Chemistry Division to find a substitute for ethylene glycol through the combined efforts of the Plant and Equipment, Environmental Compliance and Health Protection, Engineering, and Environmental Sciences divisions. The study is in the preliminary phase. The purchase and use of the aforementioned aerators will also help reduce the effect of ethylene glycol in the streams.

\subsection{TANK DIKING}

In the past there have been occasions when storage tanks have leaked, and the potential exists for the contents of the tank to reach ORNL receiving streams. All aboveground tanks storing hazardous or toxic chemicals in volumes greater than $208 \mathrm{~L}$ (55 gal), including transformers, have been evaluated. A list is being developed to determine a schedule for the diking or diking improvements for each tank. The first phase of the project will include a prioritization of tanks, based on the toxicity of the contents, to assure secondary containment.

\subsection{PCBMERCURY MONITORING}

Efforts are continuing on the PCB and mercury monitoring plans. Areas of ORNL that contribute higher concentrations of mercury have been tentatively identified. A preliminary study of ORNL contributions of PCBs to surface streams is underway. Reporting schedules for progress on the plans have been established, and regular reporting of results has been initiated.

\subsection{WASTEWATER PIPING}

Projects to reroute wastewater piping from the 1500 and 2000 areas of ORNL to the 3518 Acid Neutralization Facility are underway and scheduled for completion in November 1988 . This will provide monitoring plus neutralization capability for these waste streams.

\subsection{FIELD INTERFACE ACTIVITIES}

In the past, the potential existed for contaminants to reach ORNL streams because of construction activities or for the streams to be adversely affected by sedimentation due to surface runoff associated with construction activities. Recently, efforts to control and inspect construction activities have greatly increased. The Field Interface Staff (FIS) of DEMC conducts a field assessment of construction activities conducted by ORNL and ORNL contractors to detect and prevent potential environmental problems and to determine compliance with environmental laws and regulations. This activity includes onsite monitoring of construction activities as well as interfacing with a wide range of people involved with these projects. Each activity is monitored to determine potential environmental problems. If problems are identified, members of the FIS work with those 
involved to address the environmental concern. This activity is also closely associated with emergency response at ORNL and has been a primary factor in preventing spills from reaching the receiving streams. 


\section{LITERATURE CITED}

Adams, S. M., and R. B. McLean. 1985. Estimation of largemouth bass, Micropterus salmoides Lacepede, growth using the liver-somatic index and physiological variables. J. Fish Biol. 26:111-126.

Adams, S. M., C. A. Burtis, and J. J. Beauchamp. 1985. Integrated and individual biochemical responses of rainbow trout (Salmo gairdneri) to varying durations of acidification stress. Comp. Biochem. Physiol. 82C:301-310.

Adams, S. M., J. J. Beauchamp, and C. A. Burtis. 1988. A multivariate approach tor evaluating responses of fish to chronic pollutant stress. Marine Environmental Research 24:223-226.

Ahnstrom, G., and K. Erixon. 1973. Radiation-induced strand breakage in DNA from mammalian cells: Strand separation in alkaline solution. Inter. J. Rad. Biol. 23:285-289.

Alexopoulos, C. J. 1962. Introductory Mycology, (2nd ed). John Wiley \& Sons, Inc., New York.

Allain, C. C., L. S. Poon, C. S. G. Chan, W. Richmond, and P. C. Fu. 1974. Enzymatic determination of total serum cholesterol. Clin. Chem. 20:470-475.

APHA (American Public Health Association). 1985. Standard Methods for the Evaluation of Water and Wastewater, 16th ed. American Public Health Association, Washington, D.C.

Barron, M. G., and I. R. Adelman. 1984. Nucleic acid, protein content, and growth of larval fish sublethally exposed to various toxicants. Can. J. Fish. Aquat. Sci. 41:141-150.

Bashor, B. S., and P. A. Turri. 1986. A method for determining an allowable concentration of mercury in soil. Arch. Environ. Contam. Toxicol. 15:435-438.

Beardsley, A. M. J. Vagg, P. H. T. Beckett, and B. F. Sansom. 1978. Use of the field vole (M. aegrestis) for monitoring potentially harmful elements in the environment. Environ. Pollut. 16:65-71.

Beck, W. M., Jr. 1977. Environmental requirements and pollution tolerance of common freshwater Chironomidae. EPA-600/4-77-024. Environmental Monitoring and Support Laboratory, U.S. Environmental Protection Agency, Cincinnati, Ohio.

Becker, G. C. 1983. Fishes of Wisconsin. University of Wisconsin Press, Madison, Wisconsin. 
Berger, J. O., and D. A. Berry. 1988. Statistical analysis and the illusion of objectivity. American Scientist 76:159-165.

Bergman, H. L., R. A. Kimerle, and A. W. Maki. 1986. Environmental hazard Assessment of Effluents. Pergamon Press, Inc., New York.

Bligh, E. G., and W. J. Dyer. 1959. A rapid method of total lipid extraction and purification. Can. J. Biochem. Physiol. 8:911-917.

Boyle, J. W., R. Blumberg, S. J. Cotter, G. S. Hill, C. R. Kerley, R. H. Ketelle, R. L. Kroodsma, D. W. Lee, R. C. Martin, R. D. Roop, D. N. Secora, W. P. Staub, and R. E. Thoma. 1982. Environmental analysis of the operation of the Oak Ridge National Laboratory (X-10 Site). ORNL-5870. Oak Ridge National Laboratory, Oak Ridge, Tennessee.

Bradford, M. M. 1976. A rapid and sensitive method for the quantification of microgram quantities of protein using the principle of protein-dye binding. Anal. Biochem. 72:248-254.

Brungs, W. A. Jr. 1967. Distribution of cobalt-60, zinc-65, strontium-85, and cesium-137 in a freshwater pond. U.S. Department of Health, Education, and Welfare, National Center for Radiological Health, Rockville, Maryland.

Bryan, A. M., P. G. Olafsson, and W. B. Stone. 1987. Disposition of low and high environmental concentrations of PCBs in snapping turtle tissues. Bull. Environ. Contam. Toxicol. 38:1000-1005.

Bucolo, G., and H. David. 1973. Quantitative determination of serum triglycerides by the use of enzymes. Clin. Chem. 19:476-482.

Bulow, F. J. 1970. RNA-DNA ratios as indicators of recent growth rates of a fish. J. Fish. Res. Board Can. 27:2343-2349.

Burtis, C. A., W. F. Johnson, J. C. Mailen, J. B. Overton, T. O. Tiffany, and M. B. Watsky. 1973. Development of an analytical system based around a miniature fast analyzer. Clin. Chem. 19:895-903.

Callahan, M. A., M. W. Slimak, N. W. Gabel, I. P. May, C. F. Fowler, J. R. Freed, P. Jennings, R. L. Durfee, F. C. Whitmore, B. Maestri, W. R. Mabey, B. R. Holt, and C. Gould. 1979. Water related fate of 129 priority pollutants, Volume II: Halogenated aliphatic hydrocarbons, halogenated esters, monocyclic aromatics, phthalate esters, polycyclic aromatic hydrocarbons, nitrosamines, and miscellaneous compounds. EPA-440/4-79-029b.

Carlander, K. D. 1981. Caution on the use of the regression method of back-calculating lengths from scale measurements. Fisheries 6:2-4. 
Carlander, K. D. 1982. Standard intercepts for calculating lengths from scale measurements for some centrarchid and percid fishes. Trans. Amer. Fish. Soc. 111:332-336.

Carle, F. S., and M. R. Strub. 1978. A new method for estimating population size from removal data. Biometrics 34:621-630.

Cerling, T. E., and B. P. Spalding. 1982. Distribution and relationship of radionuclides to streambed gravels in a small watershed. Environ. Geol. 4:99-116.

Cesarone, C. F., C. Bolognesi, and L. Santi. 1979. Improved microfluorometric DNA determination in biological material using 33258 Hoechst. Anal. Biochem. 100:188-197.

Chambers, J. E. 1979. Induction of microsomal mixed-function oxidase system components in striped mullet by short-term exposure to crude oil. Toxicol. Lett. 4:227-230.

Clark, T., K. Clark, S. Patterson, D. Mackay, and R. J. Norstrom. 1988. Wildlife monitoring, modeling, and fugacity. Environ. Sci. Technol. 22:120-127.

Cole, G. A. 1983. Textbook of Limnology, 3rd ed. C. V. Mosby Company, Si. Louis, Missouri.

Cooper, E. L. 1983. Fishes of Pennsylvania and the Northeastern United States. Pennsylvania State University Press, University Park, Pennsylvania.

Daniel, F. B., D. L. Haas, and S. M. Pyle. 1985. Quantitation of chemically induced DNA strand breaks in human cells via an alkaline unwinding assay. Anal. Biochem. 144:390-402.

DEM (Department of Environmental Management). 1986a. Environmental surveillance data report for the second quarter of 1986. ORNL/M-173. Oak Ridge National Laboratory, Oak Ridge, Tennessee.

Downs, R., and W. Wilfinger. 1983. Fluorometric quantification of DNA in cells and tissue. Anal. Biochem. 131:538-547.

Dycus, D. L., and G. D. Hickman. 1987. PCB levels in fish from Fort Loudoun Reservoir-1985. TVA/ONRED/AWR-88/8. Tennessee Valley Authority, Office of Natural Resources and Economic Development, Knoxville, Tennessee.

Edgar, D. E. 1978. An analysis of infrequent hydrologic events with regard to existing streamflow monitoring capabilities in White Oak Creek watershed. ORNL/TM-6542. Oak Ridge National Laboratory, Oak Ridge, Tennessee.

Edwards, N. T. 1983. Polycyclic aromatic hydrocarbons (PAHs) in the terrestrial environment-a review. J. Environ. Qual. 12(4):427-441. 
Egan, B. Z., N. E. Lee, C. A. Burtis, J. Y. Kao, and J. M. Holland. 1983. Use of laser-excited fluorescence to measure mixed function oxidase activity. Clin. Chem. 29:1616-1619.

Eisler, R. 1987. Mercury hazards to fish, wildlife, and invertebrates: a synoptic review. Report 85(1.10), U.S. Fish and Wildlife Service, Patuxent Wildlife Research Center, Laurel, Maryland.

Elliott, J. M. 1977. Some methods for the statistical analysis of benthic invertebrates. Sci. Publ. No. 25. Freshwater Biological Association, Ambleside, England.

Elwood, J. W., J. J. Beauchamp, and C. P. Allen. 1980. Chromium levels in fish from a lake chronically contaminated with chromates from cooling towers. Int. J. Environ. Stud. 14:289-298.

EPA (U.S. Envi:onmental Protection Agency). 1976. Quality criteria for water. EPA-440/9-76-023. U.S. Environmental Protection Agency, Washington, D.C.

EPA (U.S. Environmental Protection Agency). 1980a. Water quality criteria for toxic substances. Fed. Regist. 45: 79318-79379.

EPA (U.S. Environmental Protection Agency). 1980b. Interim methods for the sampling and analysis of priority pollutants in sediments and fish tissues. EPA 600/4-81-055. Environmental Monitoring and Support Laboratory, U.S. Environmental Protection Agency, Cincinnati.

EPA (U.S. Environmental Protection Agency). 1982. Test methods for evaluating solid waste: Physical/chemical methods. SW-846. U.S. Environmental Protection Agency, Washington, D.C.

EPA (U.S. Environmental Protection Agency). 1983. Methods for chemical analysis of water and wastes. EPA-600/4-79-020. Environmental Monitoring and Support Laboratory, U.S. Environmental Protection Agency, Cincinnati.

EPA (U.S. Environmental Protection Agency). 1986. Authorization to discharge under the National Pollutant Discharge Elimination System and Fact Sheet. Permit No. TN0002941, Oak Ridge National Laboratory (X-10). U.S. Environmental Protection Agency, Atlanta.

ERDA (Energy Research and Development Administration). 1975. Preliminary Draft Environmental Analysis - Oak Ridge Operations, Vol. VI, Sect. 2.5.5. Mimeo.

Erikson, L. C., R. Osieka, N. A. Sharkey, and K. W. Kohn. 1980. Measurement of DNA damage in unlabeled mammalian cells analyzed by alkaline elution and a fluorometric DNA assay. Anal. Biochem. 106:169-174. 
Etnier, D. A., D. L. Bunting, W. O. Smith, and G. A. Vaughn. 1983. Tennessee Baseline Stream Survey. Research Report No. 95, Tennessee Water Resources Research Center, The University of Tennessee, Knoxville, Tennessee.

Evaldi, R. D. 1986. Streamflow and specific conductance data for Bear Creek, August 13, 1985, the Oak Ridge Reservation. Tennessee. Open-File Report 85-682. U.S. Geological Survey, Knoxville, Tennessee.

Everhart, W. H., A. W. Eipper, and D. W. Youngs. 1975. Principles of Fishery Science. Cornell University Press, Ithaca, New York.

Fabacher, D. L., and P. C. Baumann. 1985. Enlarged livers and hepatic microsomal mixed function oxidase components in tumor bearing brown bullheads from a chemically contaminated river. Environ. Toxicol. Chem. 4:703-710.

FDA (U.S. Department of Agriculture Food and Drug Administration). 1984a. Action level for methylmercury in fish. Fed. Regist. 49:45663.

FDA (U.S. Department of Agriculture Food and Drug Administration). 1984b. Polychlorinated biphenyls in fish and shellfish: Reduction of tolerances, final decision. Fed. Regist. 49:21514-21520.

Filbin, G. J., and R. A. Hough. 1984. Extraction of ${ }^{14} \mathrm{C}$-labeled photosynthate from aquatic plants with dimethyl sulfoxide (DMSO). Limnol. Oceanogr. 29:426-428.

Freeman, H. C., and D. R. Idler. 1973. Effects of corticosteroids on liver transaminases in two salmonids, the rainbow trout (Salmo gairdneri) and the brook trout (Salvelinus fontinalis). Gen. Comp. Endocrin. 20:69-75.

Garman, G. C., and T. F. Waters. 1983. Use of the size-frequency (Hynes) method to estimate annual production of a stream fish population. Can. J. Fish. Aquat. Sci. 40:2030-2034.

Garten, C. T., Jr., and R. D. Lomax. 1987. Strontium-90 contamination in vegetation from radioactive waste seepage areas at $\mathrm{ORNL}$, and theoretical calculations of ${ }^{90} \mathrm{Sr}$ accumulation by deer. ORNLTM-10453. Oak Ridge National Laboratory, Oak Ridge, Tennessee.

Giddings, J. M., A. J. Steward, R. V. O'Neill, and R. H. Gardner. 1983. An efficient algal bioassay based on short-term photosynthetic response. pp. 445-459. IN W. E. Bishop, R. D. Cardwell, and B. B. Heidolph (eds.), Aquatic Toxicology and Hazard Assessment: Sixth Symposium. ASTM STP 802. American Society for Testing and Materials, Philadelphia.

Greeson, P. E., T. A. Ehlke, G. A. Irwin, B. W. Lium, and K. V. Slack. 1977. Methods for collection and analysis of aquatic biological and microbiological samples. Book 5 , Chapt. A4. IN Techniques of Water-Resources Investigations of the United States Geological Survey. U.S. Government Printing Office, Washington, D.C. 
Gutreuter, S. 1987. Considerations for estimation and interpretation of annual growth rates. pp. 115-126. IN R. C. Summerfelt and G. E. Hall (eds.), Age and Growth of Fish. Iowa State University Press, Ames, Iowa.

Haines, T. A. 1973. An evaluation of RNA-DNA ratio as a measure of long-term growth in fish populations. J. Fish. Res. Board Can. 30:195-199.

Hall, R. J. 1980. Effects of environmental contaminants of reptiles: A review. Special Scientific Report-Wildlife No. 228. U.S. Department of the Interior, Fish and Wildlife Service.

Harvey, H. R., and J. S. Patton. 1981. Solvent focusing for rapid and sensitive quantification of total lipids on chromarods. Anal. Biochem. 116:313-316.

Haynes, G. J., et al. 1989. Gender-dependent problems in toxicity tests with Ceriodaphnia dubia. Bull. Environ. Contam. Toxicol. 43:271-279.

Healey, F. P., and L. L. Hendzel. 1980. Physiological indicators of nutrient deficiency in lake phytoplankton. Can. J. Fish. Aquat. Sci. 37:4/2-453.

Heidinger, R. C., and S. D. Crawford. 1977. Effect of temperature and feeding rate on the liver-somatic index of the largemouth bass, Micropterus salmoides. J. Fish. Res. Board Can. 34:633-638.

Helwig, D. D., and M. E. Hora. 1983. Polychlorinated biphenyl, mercury, and cadmium concentrations in Minnesota snapping turtles. Bull. Environ. Contam. Toxicol. 30:186-190.

Hile, R. 1936. Age and growth of the cisco, Leucichthys artedi (LeSeur), in the lakes of the northeastern highlands, Wisconsin. U.S. Bur. Fish. Bull. 48:211-317.

Hinton, D. E., and J. A. Couch. 1984. Pathological measures of marine pollution effects. pp. 7-32. IN H. H. Harris (ed.), Concepts in Marine Pollution Measurements. Maryland Sea Grant College, University of Maryland, College Park, Maryland.

Hoffman, F. O., B. G. Blaylock, C. C. Travis, K. L. Daniels, E. L. Etnier, K. E. Cowser, and C. W. Weber. 1984. Preliminary screening of contaminants in sediments. ORNL/TM-9370. Oak Ridge National Laboratory, Oak Ridge, Tennessee.

Holcomb, C. M. 1971. Occurrence of radionuclides in the exoskeleton of turtles. pp. 385-389. IN D. J. Nelson (ed.), Proceedings of the Third National Symposium on Radioecology. May 10-12, 1971. Oak Ridge, Tennessee.

Horning, W. B., and C. I. Weber. 1985. Short-term methods for estimating the chronic toxicity of effluents and receiving waters to freshwater organisms. EPA/600/4-85/014. U.S. Environmental Protection Agency, Cincinnati. 
Hotchkiss, R. D. 1955. The biological role of the deoxypentose nucleic acids. pp. 435-473. IN E. Chargaff and J. N. Davidson (eds.), The Nucleic Acids: Chemistry and Biology. Academic Press, New York.

Huckabee, J. W., and B. G. Blaylock. 1973. Transfer of mercury and cadmium from terrestrial to aquatic ecosystems. pp. 125-160. IN S. K. Dhar (ed.), Metal Ions in Biological Systems, Vol. 40. Advances in Experimental Medicine and Biology. Plenum Press, New York.

Hughes, R. M., and J. M. Omernik. 1983. An alternative for characterizing stream size. pp. 87-101. IN T. D. Fontaine, III and S. M. Bartell (eds.), Dynamics of Lotic Ecosystems. Ann Arbor Science, Ann Arbor.

Huston, M. A. 1979. A general hypothesis of species diversity. Am. Nat. 113:81-101.

Hynes, H. B. N. 1960. The Biology of Polluted Waters. University of Toronto Press, Toronto.

Jackson, C. C., Jr., C. H. Holcomb, S. Kleinbergs-Krisans, and M. M. Jackson. 1974. Variation in strontium-90 exoskeletal burdens of turtles (Reptilia: Testudines) in South Eastern United States. Herpetologica 30:406-409.

Jeffery, S. W., and G. F. Humphrey. 1975. New spectrophotometric equations for determining chlorophylls $a, b, c_{1}$ and $c_{2}$ in higher plants, algae, and natural phytoplankton. Biochem. Physiol. Pflanz. 167:191-194.

Kanter, P. M., and H. S. Schwartz. 1982. A fluorescence enhancement assay for cellular DNA damage. Molec. Pharmacol. 22:145-151.

Karr, J. R. 1981. Assessment of biotic integrity using fish communities. Fisheries 6:21-27.

Karr, J. R. 1987. Biological monitoring and assessment: A conceptual framework. Environ. Manag. 11:249-256.

Karr, J. R., K. D. Fausch, P. L. Angermeier, P. R. Yant, and I. J. Schlosser. 1986. Assessing biological integrity in running waters: A method and its rationale. Spec. Pub. 5. Illinois Natural History Survey, Champaign.

Kasten, J. L. 1986. Resource Management Plan for the Oak Ridge Reservation, Vol. 21: Water Conservation Plan for the Oak Ridge Reservation. ORNL/ESH-1/V21. Oak Ridge National Laboratory, Oak Ridge, Tennessee.

Klusek, C. S. 1987. Strontium-90 in food and bone from fallout. J. Environ. Qual. 16:195-199. 
Krumholz, L. A. 1954. An ecological survey of White Oak Creek, 1950-1953. ORO-587, Vol. 1. U.S. Atomic Energy Commission, Division of Technical Information, Oak Ridge, Tent، ssee.

Krumholz, L. A. 1956. Observations un the fish populations of a lake contaminated by radioactive wastes. Bull. Am. Mus. Nat. Hist. 110(4):281-367.

Larsen, I. L. 1981. Strontium-90 determinations by Cerenkov radiation counting for well monitoring at Oak Ridge National Laboratory. ORNL/TM-7760. Oak Ridge National Laboratory, Oak Ridge, Tennessee.

Lauchli, A. 1969. Radioassay for B-emitters in biological materials using Cerenkov radiation. Int. J. Appl. Radiat. Isot. 20:265-270.

Lisk, D. J. 1972. Trace metals in soils, plants, and animals. Adv. Agron. 24:267-325.

Loar, J. M. (ed.). 1992. First Annual Report on the Y-12 Plant Biological Monitoring and Abatement Program. ORNL/TM-10722. Oak Ridge National Laboratory, Oak Ridge, Tennessee.

Loar, J. M., J. A. Solomon, and G. F. Cada. 1981. Technical background information for the ORNL Environmental and Safety Report, Vol. 2: A description of the aquatic ecology of White Oak Creek watershed and the Clinch River below Melton Hill Dam. ORNL/TM-7509/V2. Oak Ridge National Laboratory, Oak Ridge, Tennessee.

Loar, J. M., M. J. Sale, G. F. Cada, D. K. Cox, R. M. Cushman, G. K. Eddlemon, J. L. Elmore, A. J. Gatz, Jr., P. Kanciruk, J. A. Solomon, and D. S. Vaughn. 1985. Application of habitat evaluation models in southern Appalachian trout streams. ORNL/TM-9323. Oak Ridge National Laboratory, Oak Ridge, Tennessee.

Loar, J. M., S. M. Adams, B. G. Blaylock, H. L. Boston, M. A. Huston, B. L. Kimmel, C. R. Olsen, J. G. Smith, G. R. Southworth, A. J. Stewart, and B. T. Walton. 1991. Biological Monitoring Plan and Abatement Program for White Oak Creek watershed and the Clinch River. ORNL/TM-10370. Oak Ridge National Laboratory, Oak Ridge, Tennessee.

Loar, J. M., S. M. Adams, B. G. Blaylock, H. L. Boston, M. A. Huston, B. L. Kimmel, J. T. Kitchings, C. R. Olsen, M. G. Ryon, J. G. Smith, G. R. Southworth, A. J. Stewart, B. T. Walton, H. Amano, C. T. Garten, and L. J. Meyers. 1992. First annual report on the ORNL Biological Monitoring and Abatement Program. ORNL/TM-10399. Oak Ridge National Laboratory, Oak Ridge, Tennessee.

Lomenick, T. F., and K. E. Cowser. 1961. Status report on evaluation of solid waste disposal at ORNL: Part 2. ORNL-3182, Health Physics Div., Oak Ridge National Laboratory, Oak Ridge, Tennessee. 
Lowe, T. P., T. W. May, W. G. Brumbaugh, and D. A. Kane. 1985. National Contaminant Biomonitoring Program: Concentrations of seven elements in freshwater fish, 1978-1981. Arch. Environ. Contam. Toxicol. 14:363-388.

Mackay, A. P. 1977. Growth and development of larval Chironomidae. Oikos 28:270-275.

Mackay, D. 1988. On low, very low, and negligible concentrations. Environ. Toxicol. Chem. 7:1-3.

Mackay, D., W. Y. Shiu, J. Billington, and G. L. Huang. 1983. Physical chemical properties of polychlorinated biphenyls. pp. 59-69. IN D. Mackay, S. Patterson, S. J. Eisenreich, and M. S. Simmons (eds.), Physical Behavior of PCBs in the Great Lakes. Ann Arbor Science Publishers, Ann Arbor.

Martin Marietta Energy Systems, Inc. 1983. Environmental and effluent analysis manual. Martin Marietta Energy Systems, Inc., Oak Ridge, Tennessee.

Martin Marietta Energy Systems, Inc. 1985. Environmental monitoring report, U.S. Department of Energy Oak Ridge facilities, calendar year 1984. ORNL-6209. Oak Ridge National Laboratory, Oak Ridge, Tennessee.

Martin Marietta Energy Systems, Inc. 1987. Environmental surveillance of the U.S. Department of Energy Oak Ridge Reservation and surrounding environs during 1986, Vol. 2: Data presentation. ESH-1/V2. Martin Marietta Energy Systems, Inc., Oak Ridge, Tennessee.

Mattsoff, L, and A. Oikari. 1987. Acute hyperbilirubinaemia in rainbow trout (Salmo gairdneri) caused by resin acids. Comp. Biochem. Physiol. 88C:263-268.

McCabe, G. P., Jr. 1975. Computations for variable selection in discriminant analysis. Technometrics 17:103-109.

McMaster, W. M. 1963. Geologic map of the Oak Ridge Reservation, Tennessee. ORNL/TM-713. Oak Ridge National Laboratory, Oak Ridge, Tennessee.

McMaster, W. M. 1967. Hydrologic data for the Oak Ridge area, Tennessee. U.S. Geological Survey Water-Supply Paper No. 1839-N. U.S. Government Printing Office, Washington, D.C.

McMaster, W. M., and H. D. Waller. 1965. Geology and soils of White Oak Creek basin, Tennessee. ORNL/TM-1108. Oak Ridge National Laboratory, Oak Ridge, Tennessee.

Melroy, L. A., D. D. Huff, and N. D. Farrow. 1986. Characterization of the near-surface radionucude contamination associated with the bathtub effect at Solid Waste Storage Area 4, Oak Ridge National Laboratory, Tennessee. ORNL/TM-10043. Oak Ridge National Laboratory, Oak Ridge, Tennessee. 
Minshall, G. W. 1978. Autotrophy in stream ecosystems. Bioscience 28:767-771.

Mount, D. I., and T. J. Norberg. 1984. A seven-day life-cycle cladoceran toxicity test. Environ. Toxicol. Chem. 3:425-434.

NCCLS (National Committee for Clinical Laboratory Standards). 1979. NCCLS Approved Standards: ACS-1 Specification for standardized protein solution (Bovine serum albumin), 2nd ed. National Committee for Clinical Laboratory Standards, Villanova, Pennsylvania.

NCRP (National Council on Radiation Protection). 1986. Screening techniques for determining compliance with environmental standards: Releases of radionuclides to the atmosphere, NCRP Commentary No. 3, Bethesda, Maryland.

Niimi, A. J., and B. G. Oliver. 1983. Biological half-lives of polychlorinated biphenyl (PCB) congeners in whole fish and muscle of rainbow trout (Salmo gairdneri). Can. J. Fish. Aquat. Sci. 40:1388-1394.

NOAA (National Oceanic and Atmospheric Administration). 1985. Local climatological data: Monthly summaries for January-December 1985 , Oak Ridge, Tennessee. National Climatic Data Center, Asheville, North Carolina.

NOAA (National Oceanic and Atmospheric Administration). 1986. Local climatological data: Monthly summaries for January-December 1986, Oak Ridge, Tennessee. National Climatic Data Center, Asheville, North Carolina.

NOAA (National Oceanic and Atmospheric Administration). 1987a. Local climatological data: 1986 annual summary with comparative data, Oak Ridge, Tennessee. National Climatic Data Center, Asheville, North Carolina.

NOAA (National Oceanic and Atmospheric Administration). 1987b. Local climatological data: Monthly summaries for January-November 1987, Oak Ridge, Tennessee. National Climatic Data Center, Asheville, North Carolina.

Norberg, T. J., and D. I. Mount. 1985. A new fathead minnow (Pimephales promelas) subchronic toxicity test. Environ. Toxicol. Chem. 4:711-718.

NRC (National Research Council). 1978. An assessment of mercury in the environment. National Academy of Sciences, Washington, D.C.

Oakes, T. W., B. A. Kelley, W. F. Ohnesorge, J. S. Eldridge, J. C. Bird, K. E. Shanks, and F. S. Tsakeres. 1982. Technical background information for the ORNL Environmental and Safety Report, Vol. 4: White Oak Lake and Dam. ORNL-5681. Oak Ridge National Laboratory, Oak Ridge, Tennessee.

Olafsson, P. G., A. M. Bryan, B. Bush, and W. Stone. 1983. Snapping turtles-a biological screen for PCBs. Chemosphere 12:1524-1532. 
Olsen, C. R., I. L. Larsen, N. H. Cutshall, J. F. Donoghue, O. P. Bricker, and H. J. Simpson. 1981. Reactor-released radionuclides in Susquehanna River sediments. Nature 294:242-245.

Omura, T., and R. Sato. 1964. The carbon monoxide-binding pigment of liver microsomes. J. Biol. Chem. 239:2370-2378.

Palumbo, A. V., P. J. Mulholland, and J. W. Elwood. 1987. Extraction with DMSO to simultaneously measure periphyton photosynthesis, chlorophyll, and ATP. Limnol. Oceanogr. 32:(2)464-471.

Payne, J. F., and W. R. Penrose. 1975. Induction of aryl [benzo(a)pyrene] hydrocarbon hydroxylase in fish by petroleum. Bull. Environ. Contam. Toxicol. 14:112-116.

Peters, E. L. 1986. Radiocesium kinetics in the yellow-bellied turtle (Pseudemys scripta). M. S. Thesis. University of Georgia, Athens.

Peterson, J. I., and D. S. Young. 1968. Evaluation of the hexokinase/glucose-6-phosphate dehydrogenase method of determining glucose in urine. Anal. Biochem. 23:301-316.

Pflieger, W. L 1975. The Fishes of Missouri. Missouri Department of Conservation, Missouri.

Phillips, A. H., and R. G. Langdon. 1962. Hepatic triphosphopyridine nucleotide-cyt-c reductase isolation, characterization, and kinetic studies. J. Biol. Chem. 237:2652-2660.

Pielou, E. C. 1977. Mathematical Ecology. John Wiley and Sons, New York.

Platts, W. S., W. F. Megahan, and G. W. Minshall. 1983. Methods for evaluating stream, riparian, and biotic conditions. U.S. Forest Service General Technical Report INT138. Intermountain Forest and Range Experimental Station, Ogden, Utah.

Poels, C. L. M., M. A. Van Der Gaag, and J. F. J. Van De Kerkhoff. 1980. An investigation into the long-term effects of Rhine water on rainbow trout. Water Res. 14:1029-1035.

Power, M. E., W. J. Matthews, and A. J. Stewart. 1985. Grazing minnows, piscivorous bass, and stream algae: Dynamics of a strong interaction. Ecology 66:1448-1456.

Punzo, F., J. Lavaglia, D. Lohr, and P. A. Dahm. 1979. Organochlorine insecticide residues in amphibians and reptiles from Iowa and lizards from the southwestern United States. Bull. Environ. Contam. Toxicol. 21:842-848.

Rhodes, L., E. Casillas, B. McKnight, W. Gronlund, M. Myers, P. Olson, and B. McCain. 1985. Interactive effects of cadmium, polychlorinated biphenyls, and fuel oil on experimentally exposed English sole (Parophyrys vetulus). Can. J. Fish. Aquat. Sci. 42:1870-1880. 
Ricker, W. E. 1975. Growth in length and in weight. Chap. 9, pp. 203-233. IN Computation and Interpretation of Biological Statistics of Fish Populations. Bulletin 191. Department of the Environment, Fisheries and Marine Service, Ottawa.

Roche Diagnostic Systems. 1986. Reagent for total protein. Roche Diagnostic Systems Information Package, Item 44903 \& 44313. Nutley, New Jersey.

Roop, R. D., and C. T. Hunsaker. 1985. Biomonitoring for toxic control in NPDES permitting. J. Water Pollut. Control Fed. 57:271-277.

Rydberg, B. 1975 . The rate of strand separation in alkali of DNA or irradiated mammalian cells. Radiat. Res. 61:274-287.

Ryon, M. G., and J. M. Loar. 1988. A checklist of fishes on the Department of Energy Oak Ridge Reservation. J. Tenn. Acad. Sci. 58(4):97-102.

SAS (SAS Institute, Inc.). 1985a. SAS User's Guide: Basies, Version 5 Edition. SAS Institute, Inc., Cary, North Carolina.

SAS (SAS Institute, Inc.). 1985b. SAS User's Guide: Statistics, Version 5 Edition. SAS Institute, Inc., Cary, North Carolina.

Scandinavian Committee on Enzymes. 1974. Recommended methods for the determination of four enzymes in blood. Scand. J. Clin. Lab. Invest. 33:291-300.

Scott, D. E., F. W. Wicker, and J. W. Gibbons. 1986. Effect of season on the retention of ${ }^{137} \mathrm{Cs}$ and ${ }^{90} \mathrm{Sr}$ by the yellow-bellied slider turtle (Pseudemys scripta). Can. J. Zool. 64:2850-2853.

Seal, H. 1968. Multivariate Statistical Analysis for Biologists. Methuen and Co., London.

Seber, G. A. F. 1973. The Estimation of Animal Abundance. Hafner Press, New York.

Selby, D. A. J. M. Ihnat, and J. J. Messer. 1985. Effects of subacute cadmium exposure on a hardwater mountain stream microcosm. Water Res. 19:645-655.

Shacklette, H. T. 1970. Mercury content of plants. U.S. Geological Survey Professional Paper 713:35-36. U.S. Government Printing Office, Washington, D.C.

Sheppard, J. D. 1974. Storm runoff in the vicinity of Oak Ridge, Tennessee. ORNL/TM-4662. Oak Ridge National Laboratory, Oak Ridge, Tennessee.

Sheridan, R. B., and P. C. Huang. 1977. Single stranded breakage and repair in eukaryotic DNA as assayed by S1 nuclease. Nuc. Acid Res. 4:299-318.

Sherwood, C. B., and J. M. Loar. 1987. Environmental data for the White Oak Creek/White Oak Lake watershed. ORNL/TM-10062. Oak Ridge National Laboratory, Oak Ridge, Tennessee. 
Shoaf, W. T., and B. W. Lium. 1976. Improved extraction of chlnrophyll $a$ and $b$ from algae using dimethyl sulfoxide. Limnol. Oceanogr. 21:926-928.

Silbergeld, E. K. 1974. Blood glucose: A sensitive indicator of environmental stress in fish. Bull. Environ. Contam. Toxicol. 11:20-25.

Slooff, W., C. F. Van Kreijl, and A. J. Baars. 1983. Relative liver weights and xenobiotic-metabolizing enzymes of fish from polluted surface waters in the Netherlands. Aquat. Toxicol. 4:1-14.

Smith, J. G., L. A. Kszos, G. R. Southworth, J. M. Loar, M. G. Ryon, and S. M. Adams. 1992. First Annual Report on the ORGDP Biological Monitoring and Abatement Program. Y/TS-886. Oak Ridge National Laboratory, Oak Ridge, Tennessee.

Smith, P. W. 1979. The Fishes of Illinois. University of Illinois Press, Urbana, Illinois.

Spalding, B. P., and T. E. Cerling. 1979. Association of radionuclides with streambed sediments in White Oak Creek Watershed. ORNL/TM-6895. Oak Ridge National Laboratory, Oak Ridge, Tennessee.

Steel, R. G. D., and J. H. Torrie. 1960. Principles and Procedures of Statistics with Special Reference to the Biological Sciences. McGraw-Hill, Inc., New York.

Stegeman, J. J. 1981. Polynuclear aromatic hydrocarbons and their metabolism in the marine environment. pp. 1-47. IN H. V. Gelboin and P. O. P. Ts'o (eds.), Polycyclic Hydrocarbons and Cancer. Academic Press, New York.

Stewart, A. J. 1988. Alkalinity dynamics in a hard-water prairie-margin stream. Arch. Hydrobiol 112:335-350.

Strickland, J. D. H., and T. R. Parsons. 1972. A Practical Handbook of Seawater Analysis. Fisheries Research Board of Canada, Ottawa.

Stueber, A. M., D. A. Webster, I. L. Munro, N. D. Farrow, and T. G. Scott. 1981. An investigation of radionuclide release from Solid Waste Disposal Area 3, Oak Ridge National Laboratory. ORNL/TM-7323. Oak Ridge National Laboratory, Oak Ridge, Tennessee.

Swenberg, J. A., G. L. Petzold, and P. R. Harbach. 1976. In vitro DNA damage/alkaline elution assay for predicting carcinogenic potential. Biochem. Biophys. Res. Comm. 72(2):732-738.

Swingle, H. S. 1952. Farm pond investigations in Alabama. J. Wildl. Manage. 16:243-249.

Tietz, N. W. 1986. Textbook of Clinical Chemistry. W. B. Saunders, Co., Philadelphia, Pennsylvania. 
Travis, C. C., F. O. Hoffman, B. G. Blaylock, K. L. Daniel, C. S. Gist, and C. W. Weber. 1986. Preliminary review of TVA fish sampling and analysis report. Report of Task Group Five to Oak Ridge Task Force. Mimeo.

Turner, R. R., C. R. Olsen, and W. J. Wilcox, Jr. 1985. pp. 329-338. Environmental fate of $\mathrm{Hg}_{\mathrm{g}}$ and ${ }^{137} \mathrm{Cs}$ discharged from Oak Ridge facilities. IN D. D. Hemphill (ed.), Trace substances in Environmental Health-XVII, University of Missouri, Columbia, Missouri.

TVA (Tennessee Valley Authority). 1985a. Instream Contaminant Study, Task 2: Sediment characterization, Vol. I. Report to U.S. Department of Energy, Oak Ridge Operations Office. Tennessee Valley Authority, Office of Natural Resources and Economic Development, Knoxville, Tennessee.

TVA (Tennessee Valley Authority). 1985b. Instream Contaminant Study, Task 2: Sediment characterization, Vol. II-Appendices. Report to U.S. Department of Energy, Oak Ridge Operations Office. Tennessee Valley Authority, Office of Natural Resources and Economic Development, Knoxville, Tennessee.

TVA (Tennessee Valley Authority). 1985c. Instream Contaminant Study, Task 4: Fish sampling and analysis. Report to U.S. Department of Energy, Oak Ridge Operations Office. Tennessee Valley Authority, Office of Natural Resources and Economic Development, Knoxville, Tennessee.

TVA (Tennessee Valley Authority). 1986. Instream Contaminant Study, Task 5: Summary Report. Report to U.S. Department of Energy, Oak Ridge Operations Office. Tennessee Valley Authority, Office of Natural Resources and Economic Development, Knoxville, Tennessee.

Volchok, H. L., and G. A. Planque (eds). 1982. SR-01: Radiochemical strontium-90. pp. E-SR-01-01 through E-SR-01-29. IN EML Procedure Manual (HASL-300), 26th ed. Environmental Measurements Laboratory, U.S. Department of Energy, New York.

Ward, J. V., and J. A. Stanford. 1979. Ecological factors controlling stream zoobenthos with emphasis on thermal modification of regulated streams. pp. 35-55. IN J. V. Ward and J. A. Stanford (eds.), The Ecology of Regulated Streams. Plenum Press, New York.

Weber, C. I. (ed.). 1973. Biological field and laboratory methods for measuring the quality of surface waters and effluents. EPA-670/4-73-001. National Environmental Research Center, U.S. Environmental Protection Agency, Cincinnati.

Wiederholm, T. 1984. Responses of aquatic insects to environmental pollution. pp. 508-557. IN: V. H. Resh and D. M. Rosenberg (eds.), The Ecology of Aquatic Insects. Praeger Publishers, New York.

Williams, D. D., and H. B. N. Hynes. 1976. The recolonization mechanisms of stream benthos. Oikos 27:265-272. 
Winner, R. W., M. W. Boesel, and M. P. Farrell. 1980. Insect community structure as an index of heavy-metal pollution in lotic ecosystems. Can. J. Fish. Aquat. Sci. 37:647-655.

Wren, C. D. 1986. Mammals as biological monitors of environmental metal levels. Environ. Monit. Assess. 6:127-144.

Zar, J. H. 1984. Biostatistical Analysis. Prentice-Hall, Inc., Englewood Cliffs, New Jersey. 


\section{APPENDIX A}

MEAN CONCENTRATIONS OF SELECTED WATER QUALTTY PARAMETERS MEASURED AT THE PERIPHYTON SAMPLING SITES, AUGUST-DECEMBER 1986 


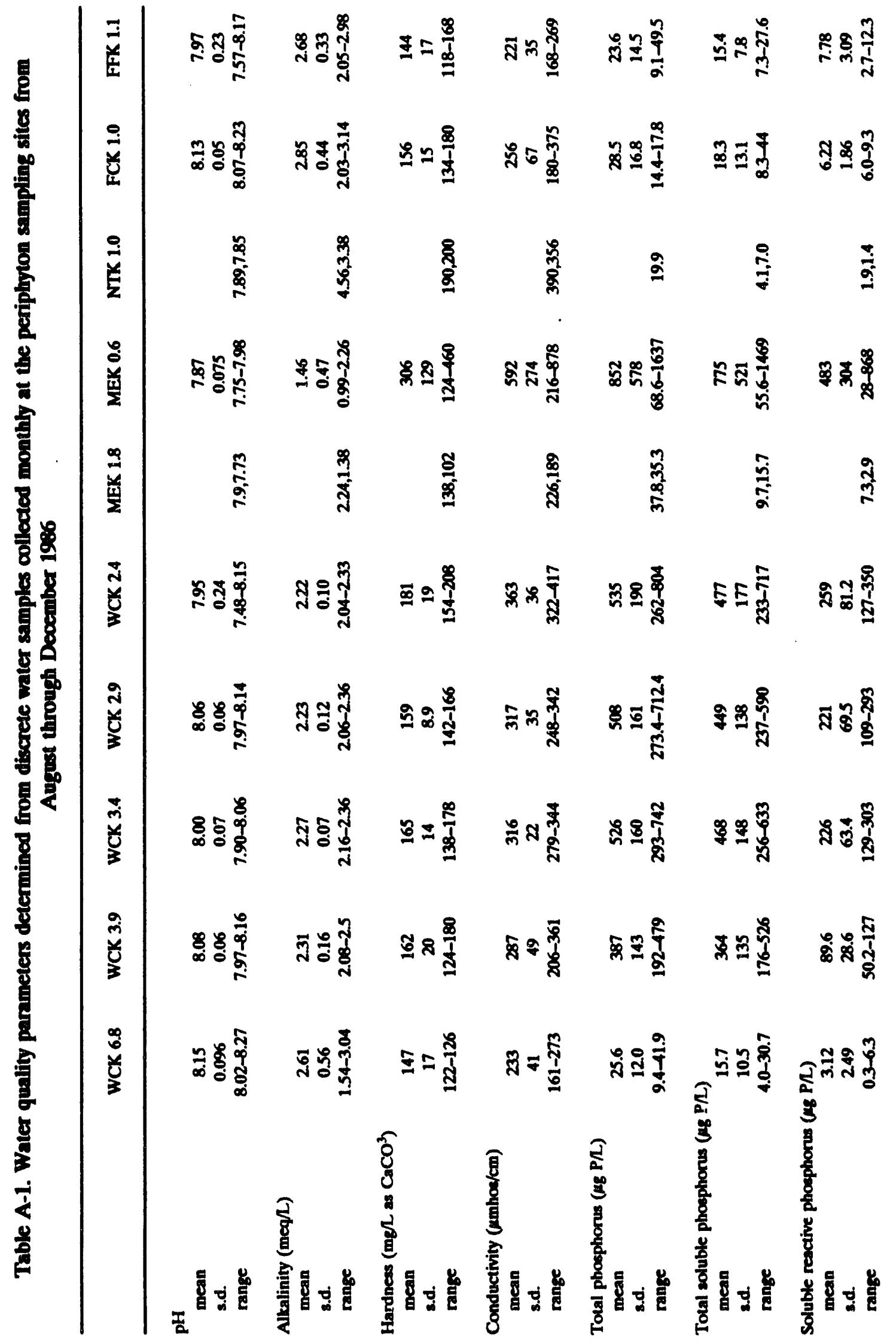




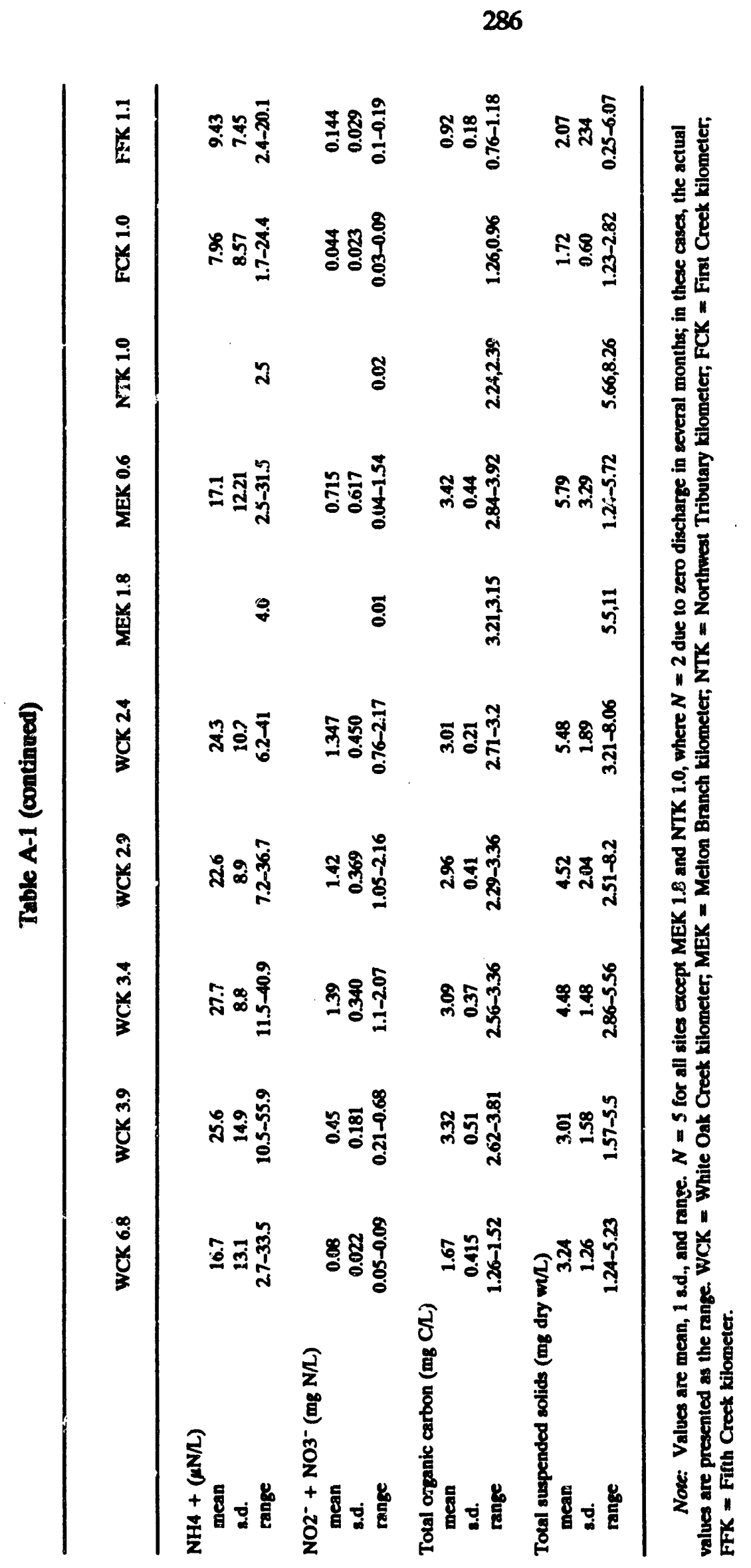




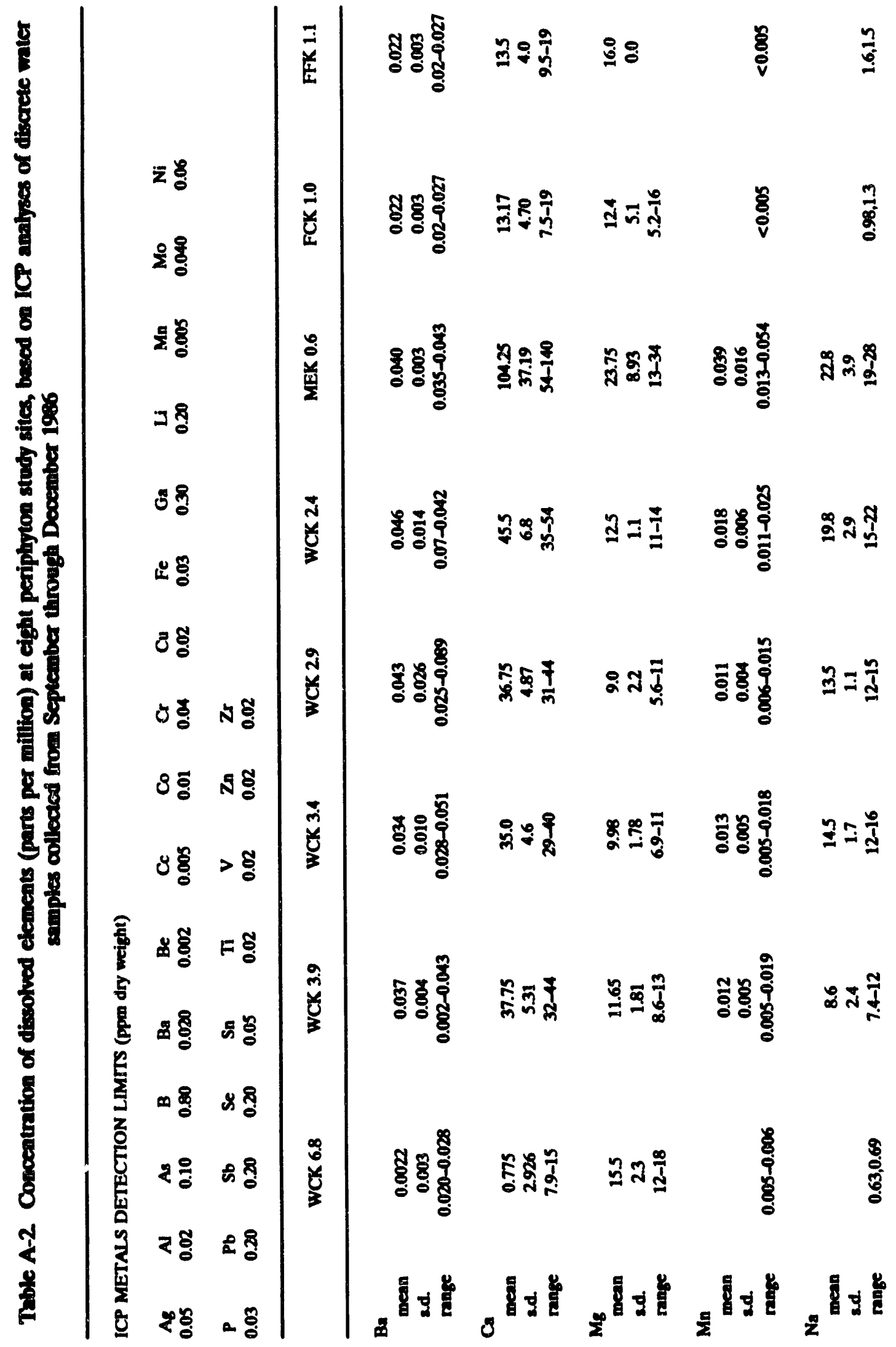




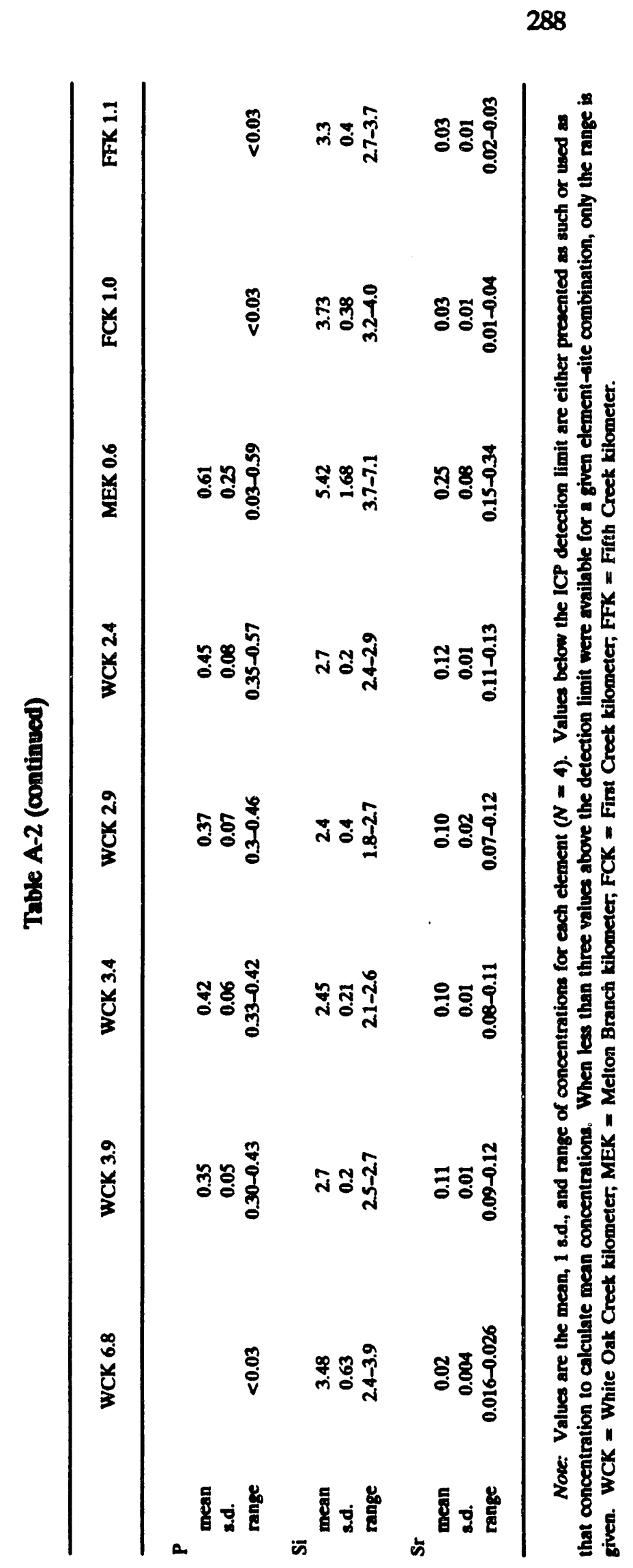


APPENDIX B

MONTHLY ESTIMATES OF PERIPHYTON BIOMASS AND CARBON INCORPORATION RATES

APRIL 1986-DECEMBER 1987 


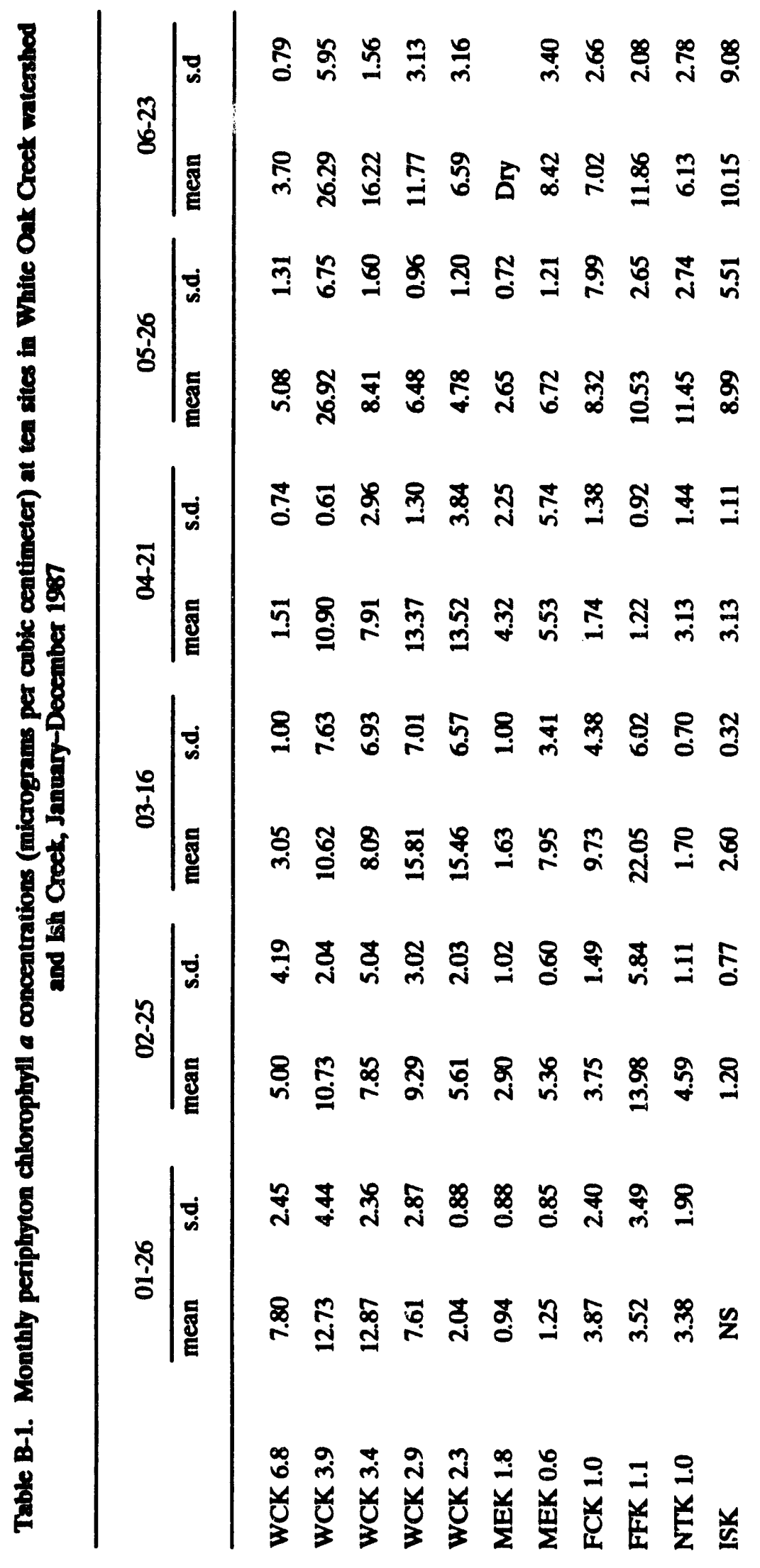




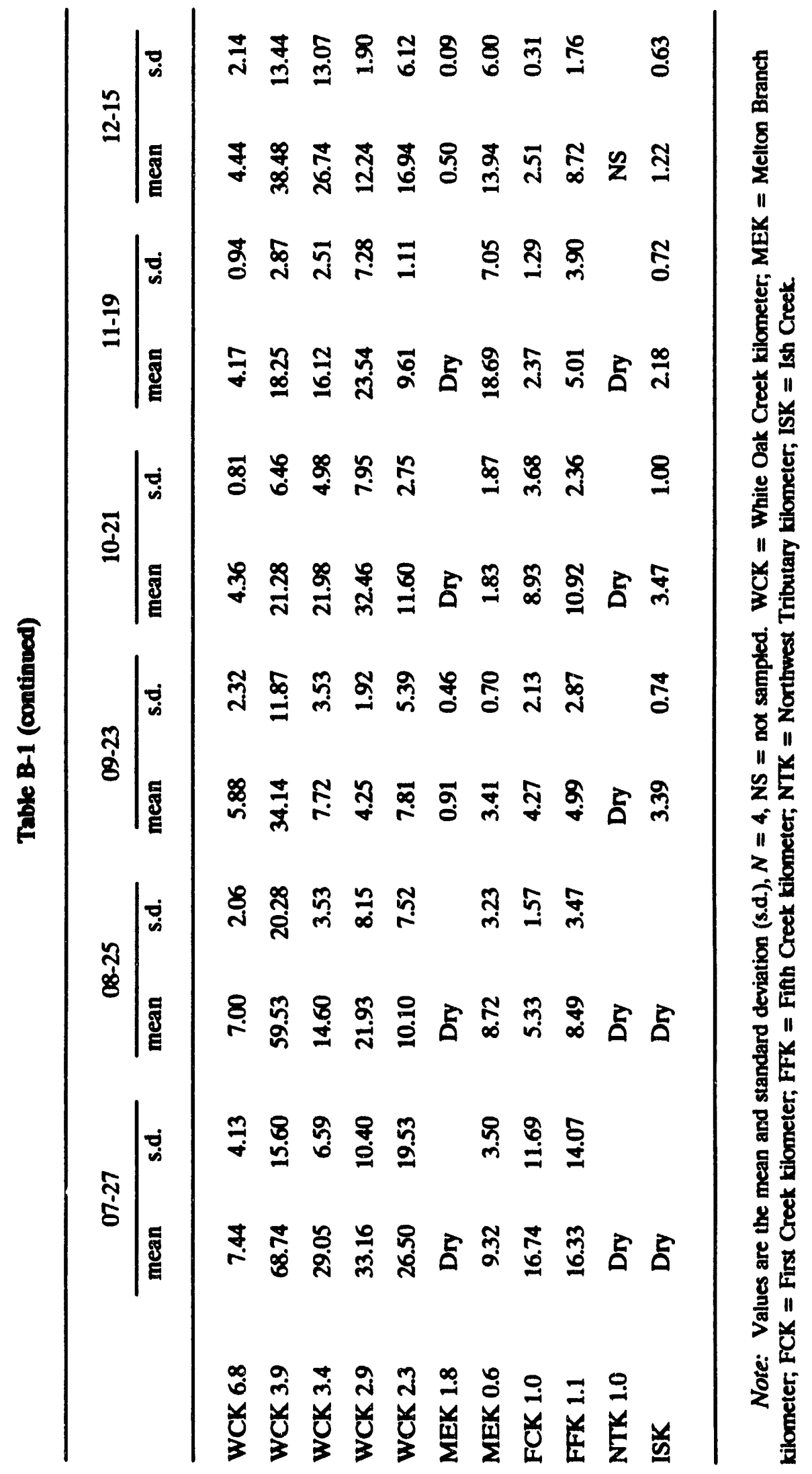




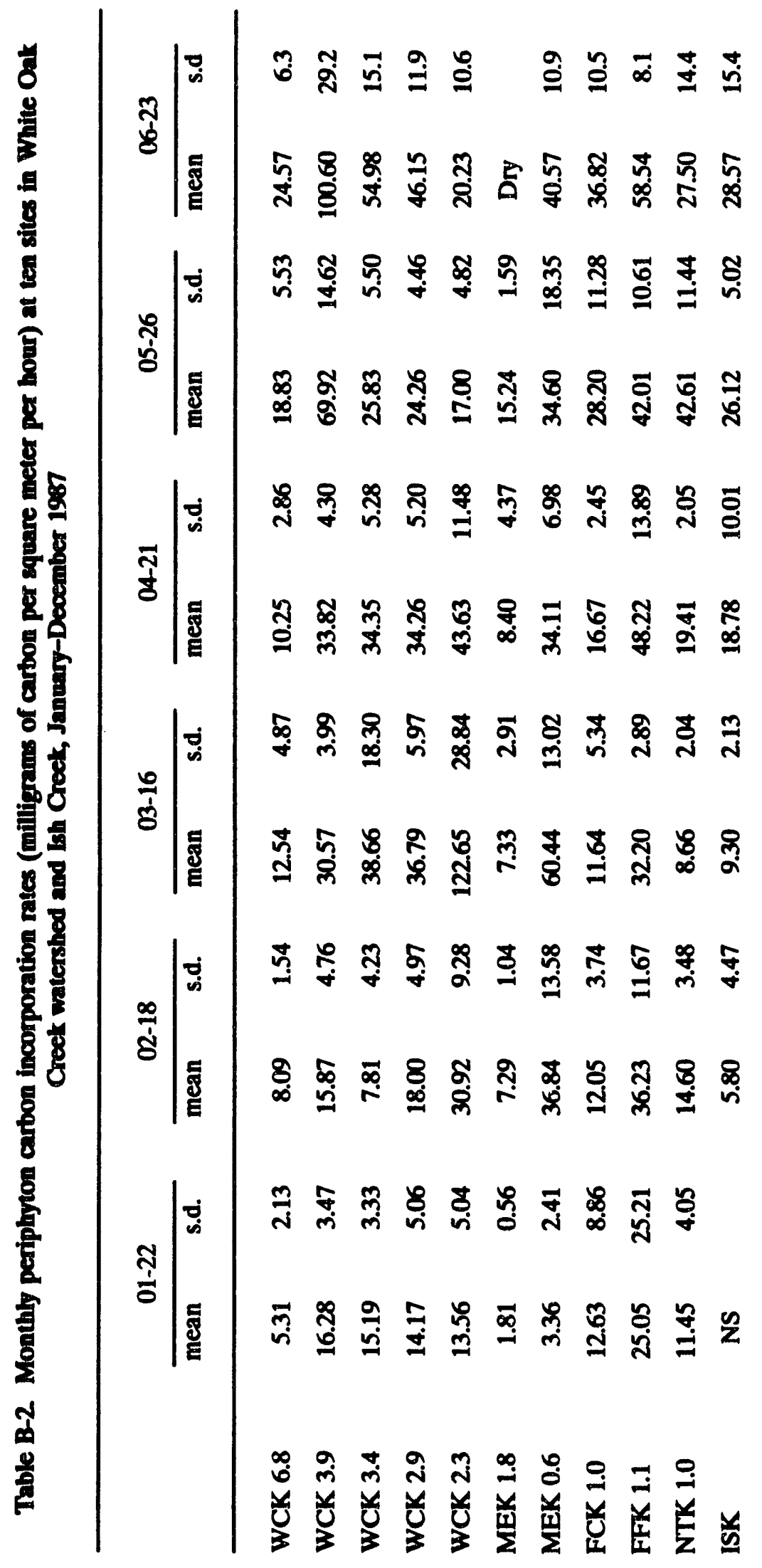




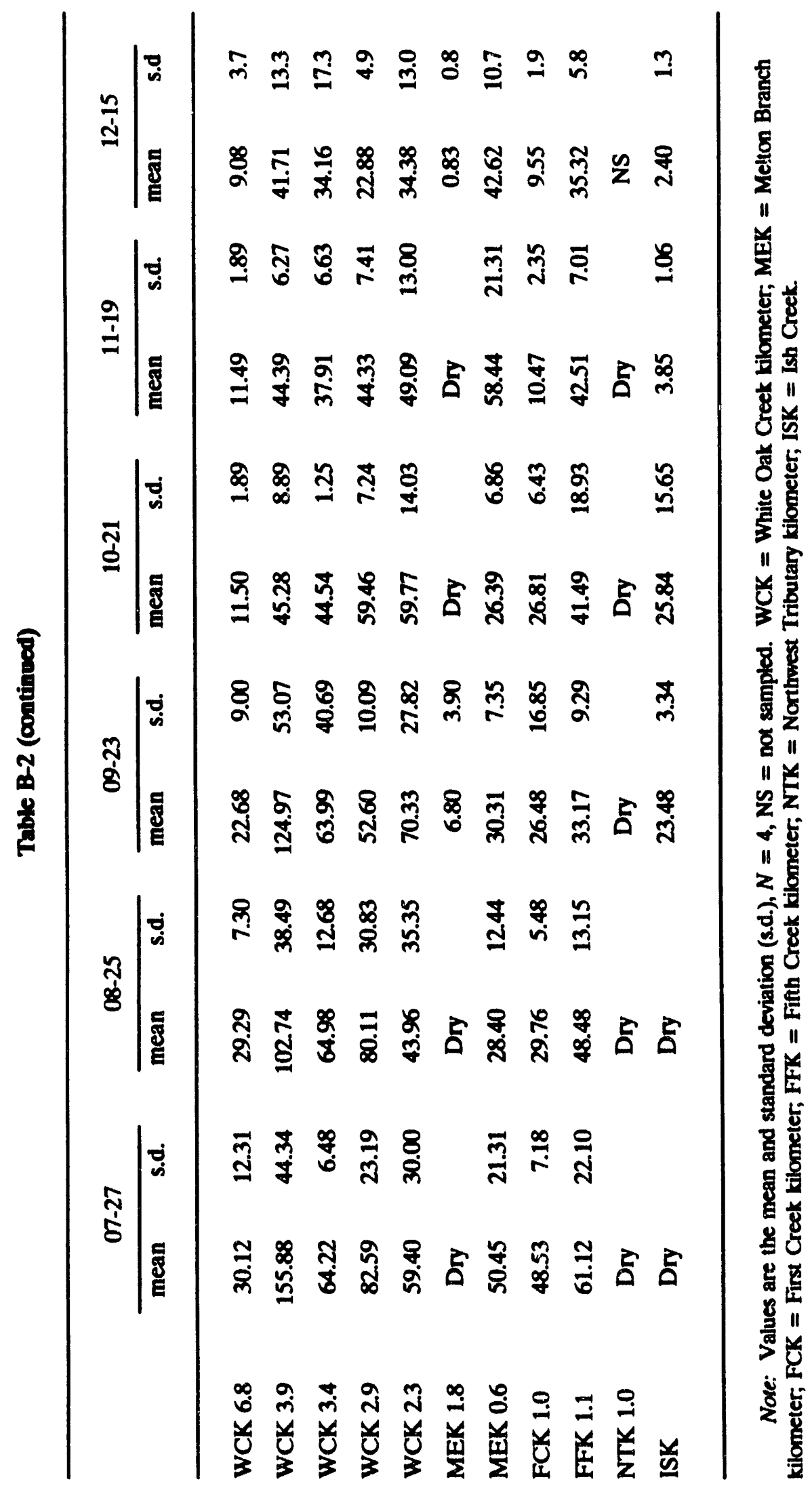


APPENDIX C

\section{RESULTS OF QAVC ANALYSES OF MERCURY, POLYCHLORINATED BIPHENYLS, AND ORGANICS IN FISH SAMPLES}




\section{APPENDIX C}

\section{RESULTS OF QAVQC ANALYSES OF MERCURY, POLYCHLORINATED BIPHENYLS, AND ORGANICS IN FISH SAMPLES}

\section{C.1 MERCURY}

Eight pairs of blind duplicate samples were analyzed for mercury and showed a relatively low degree of variation; the mean coefficient of variation (CV) between sample pairs was $6 \%$ with a mean standard deviation (s.d.) of $0.02 \mathrm{ppm}$. The mean difference between duplicate samples was $0.01 \mathrm{ppm}$. The multiple analyses of mercury in Environmental Protection Agency (EPA) reference fish $(n=4)$ agreed well with the expected value, averaging $2.46 \pm 0.17 \mathrm{ppm}$ (mean \pm s.d.) compared with an expected value of $2.52 \mathrm{ppm}$; the average recovery was $97 \pm 7 \%$. Split duplicate fish samples analyzed for mercury by the ORNL Analytical Chemistry Division (ACD) and the U.S. EPA Environmental Services Laboratory in Athens, Georgia, were in good agreement. Fish analyzed by Oak Ridge National Laboratory (ORNL) averaged 1.10 ppm mercury, while those analyzed by the EPA lab averaged $1.17 \mathrm{ppm}$. The mean difference between individual samples analyzed by EPA and ORNL $(0.06 \mathrm{ppm})$ did not differ significantly from zero $(p=>0.05)$, and a CV $=10 \%$ and s.d. $=0.11 \mathrm{ppm}$ were similar to values observed for duplicate analyses within the ORNL lab. Mercury levels in sunfish from the uncontaminated reference site (Hinds Creek) were typical of background levels in stream fish, averaging $0.09 \pm 0.03 \mathrm{ppm}(n=11)$.

\section{C2 OTHER METALS}

Four pairs of blind duplicate samples were analyzed for metals, and relatively low variation was observed for those metals exceeding detection limits. Mean CVs for CD, $\mathrm{Pb}, \mathrm{Se}$, and $\mathrm{Zn}$ were $44,34,46$, and $10 \%$ respectively; mean s.d.s were $0.02,0.01,0.11$, and $0.65 \mathrm{ppm}$ respectively. The relatively high CVs are due in large part to the very low concentrations of metals in these samples. Results of analyses of reference tissues indicated good recoveries and quantitation of the metals (Table C-1).

\section{C.3 PCBS}

The results of polychlorinated biphenyl (PCB) analyses of ten pairs of blind duplicate catfish samples were somewhat more variable than the results of mercury analyses, as is generally the case. The mean difference and s.d. between duplicates was $0.01 \pm 0.28 \mathrm{ppm}$, with a mean CV of $15 \%$. The variabilities in the measurement of PCB-1254 and PCB-1260 were similar. With mean differences between duplicates of 0.12 and $0.11 \mathrm{ppm}$ respectively, s.d.s were 0.19 and $0.18 \mathrm{ppm}$ and the mean CVs were 25 and $37 \%$ respectively. Samples of uncontaminated catfish were spiked at 1 ppm each of PCB-1254 
Table C-1. Analyses of reference tiksue for metak (units are expressed in parts per million, dry weight)

\begin{tabular}{|c|c|c|c|c|c|}
\hline Metal & Found & Expected & Sample & Mean $\%$ recovery \pm s.d. & Range \\
\hline Ag & $\begin{array}{l}0.86 \\
0.82 \\
0.84 \\
0.88 \\
0.06 \\
0.06\end{array}$ & 0.06 & Bovine liver & $97 \pm 3$ & $92-100$ \\
\hline As & $\begin{array}{l}11.9 \\
10.9 \\
11.8\end{array}$ & 13.4 & Oyster & $86 \pm 4$ & $81-89$ \\
\hline Cd & $\begin{array}{l}3.2 \\
3.3 \\
3.3 \\
3.5 \\
0.15\end{array}$ & 0.16 & Oyster & $95 \pm 3$ & $91-100$ \\
\hline $\mathrm{Cu}$ & $\begin{array}{c}2.3 \\
177 \\
62 \\
63 \\
57 \\
61\end{array}$ & $\begin{array}{c}2.2 \\
193 \\
63\end{array}$ & $\begin{array}{l}\text { Fish } \\
\text { Bovine liver } \\
\text { Oyster }\end{array}$ & $97 \pm 5$ & $90-105$ \\
\hline $\mathrm{Cr}$ & $\begin{array}{l}0.49 \\
0.76 \\
0.68 \\
0.53\end{array}$ & $\begin{array}{l}0.58 \\
0.69\end{array}$ & $\begin{array}{l}\text { Fish } \\
\text { Oyster }\end{array}$ & $92 \pm 15$ & $77-110$ \\
\hline $\mathrm{Hg}$ & $\begin{array}{l}2.30 \\
2.60 \\
2.61 \\
2.31\end{array}$ & 2.52 & Fish & $97 \pm 7$ & $92-104$ \\
\hline $\mathbf{N i}$ & $\begin{array}{l}1.0 \\
1.0 \\
0.7 \\
1.2 \\
1.4\end{array}$ & 1.0 & Oyster & $106 \pm 26$ & $70-140$ \\
\hline $\mathrm{Pb}$ & $\begin{array}{l}0.46 \\
0.45 \\
0.54 \\
0.31 \\
0.33 \\
0.36\end{array}$ & 0.34 & $\begin{array}{l}\text { Oyster } \\
\text { Bovine liver }\end{array}$ & $99 \pm 8$ & $91-113$ \\
\hline
\end{tabular}


Table C-1 (continued)

\begin{tabular}{|c|c|c|c|c|c|}
\hline Metal & Found & Expected & Sample & Mean \% recovery \pm s.d. & Range \\
\hline Se & $\begin{array}{l}2.1 \\
2.1 \\
2.5 \\
2.3\end{array}$ & 2.1 & Oyster & $107 \pm 9$ & $100-119$ \\
\hline $\mathbf{Z n}$ & $\begin{array}{r}43 \\
854 \\
848 \\
127\end{array}$ & $\begin{array}{r}44 \\
852 \\
130\end{array}$ & $\begin{array}{l}\text { Fish } \\
\text { Oyster } \\
\text { Bovine liver }\end{array}$ & $99 \pm 1$ & $98-100$ \\
\hline
\end{tabular}

Note: Sample types were as follows: Oyster, freeze-dried oyster tissue (National Bureau of Standards \# 1566); Fish, freeze-dried fish tissue (EPA trace metals in fish, U.S. EPA, Cincinnati); Bovine Itver, freeze. dried bovine liver (National Bureau of Standards $\# 1577$ ).

and PCB-1260 and analyzed along with fish samples. Mean recoveries averaged $106 \pm$ $16 \%$ for total PCBs, and $107 \pm 13 \%$ and $106 \pm 21 \%(n=7)$ for PCB-1254 and PCB-1260 respectively. Samples of PCB-cnescaminated carp and channel catfish were homogenized and split for analysis by the ACD/ORNL laboratory and the EPA Environmental Services Laboratory, Athens, Georgia. Mean levels of total PCBs, PCB-1254, and PCB-1260 did not differ significantly in the five samples analyzed by the two laboratories $(p>0.05)$, but the results obtained by the ORNL lab were somewhat higher, averaging $1.35 \pm 0.88$ vs $0.94 \pm 0.34,0.52 \pm 0.55$ vs $0.40 \pm 0.19$, and $0.83 \pm 0.66$ vs $0.51 \pm 0.28 \mathrm{ppm}$ for total PCBs, PCB-1254, and PCB-1260 respectively. The variability between duplicate samples analyzed by ORNL and EPA was similar to the variability between duplicates analyzed at ORNL, with a mean s.d. between duplicates of $0.39,0.21$, and $0.24 \mathrm{ppm}$ and a mean CV of $30 \%$, $61 \%$, and $28 \%$ for total PCBs, PCB-1254, and PCB-1260 respectively. Samples of catfish from an uncontaminated site (commercial fish farm) were used as analytical controls; these exhibited very low levels of total PCBs, averaging $0.04 \pm 0.02 \mathrm{ppm}$ ( $n=8$ samples from four fish).

Because these data were to be compared with data collected in 1986 to ascertain the presence of any year-to-year changes, archived samples of catfish collected and analyzed in 1986 were reanalyzed along with the fish collected in 1987. Results of the re-analysis of these samples differed little, averaging $1.40 \pm 0.75$ and $1.25 \pm 0.53 \mathrm{ppm}(n=8)$ in 1986 and 1987 respectively. The mean difference in PCBs between sample pairs was $0.15 \pm$ $0.33 \mathrm{ppm}(\mathrm{CV}=27 \%)$. Variabilities in the measurement of PCB-1254 and PCB-1260 were similar; mean differences between sample pairs were $0.06 \pm 0.22$ and $0.09 \pm 0.13$ ppm respectively; CVs were $29 \%$ and $27 \%$ respectively. The t-test comparisons of mean PCBs, PCB-1254, and PCB-1260 between samples analyzed in 1986 and 1987 indicated no significant difference $(p>0.05)$. 


\section{C.4 ORGANICS SCREENING ANALYSES}

Uncontaminated fish and clam samples were spiked with a mixture of six priority pollutants [PCB-1254, PCB-1260, di- $n$-butylphthalate, 2-ethylhexylphthalate, pyrene, and benzo(a)pyrene] and analyzed to ensure that these contaminants would be recovered and quantified in the extraction, clean-up, and gas chromatographic analysis. Recoveries of PCB-1254 and PCB-1260 averaged $79 \pm 17 \%(n=5)$, while recoveries of the phthalates and polycyclic aromatic hydrocarbons (PAHs) were lower. The recovery of di-n-butylphthalate and 2-ethylhexylphthalate averaged $50 \pm 10 \%$ and $46 \pm 16 \%$, respectively, and that of pyrene and benzo(a)pyrene averaged $30 \pm 2 \%$ and $34 \pm 6 \%$, respectively ( $n=3$ for each substance). The split samples analyzed for PCBs by ORNL and EPA by packed column gas chromatography with electron capture detectors (GC/ECD) were also analyzed by the capillary column procedure used in the screening of organics. The capillary column results compared poorly with the packed column analyses, averaging only $0.20 \pm 0.05 \mathrm{ppm}$ PCBs as compared with $0.94 \pm 0.34$ and $1.35 \pm 0.88 \mathrm{ppm}$ PCBs in the same samples analyzed by EPA and ORNL respectively. The reasons for this large difference are not known; it is unlikely, however, that such poor recoveries occurred in the sunfish analyses reported in Sect. 4.1.3.2, since the levels of PCBs reported in those samples by capillary column analyses were similar to the levels found at those sites in 1987 when fish samples were analyzed by packed column GC/ECD.

The organics screening analyses did not detect any of the sought-for compounds (except PCBs) in fish or clam samples from the reference streams. One clam sample at a reference site was reported to contain $1.9 \mathrm{ppm}$ PCBs, but its companion sample (a second sample from the same group of clams) reported PCBs below detection limits. Two samples from this same group of clams were also analyzed by packed column GC/ECD and were found to contain PCB levels typical of uncontaminated sites. 


\section{APPENDIẌ D}

CONCENTRATIONS OF CONTAMINANTS IN AQUATIC BIOTA FROM WHITE OAK CREEK AND TRIBUTARIES, WHITE OAK LAKE, AND THE CLINCH RIVER NOVEMBER 1986-AUGUST 1987 
Table D-1. Metals in sunfish from White Oak Creek and tributaries and White Oak Lake

Metal content expressed as parts per million (micrograms per gram) wet weight

\begin{tabular}{|c|c|c|c|c|c|c|c|c|c|c|c|c|}
\hline Site & Darce & $S p^{b}$ & Sex $x$ & $\mathbf{N}$ & Weight & Lengthe & $\mathrm{Hg}_{\mathbf{g}}$ & $\mathrm{Cd}$ & $\mathrm{Cu}$ & $\mathbf{P b}$ & se & $\mathbf{Z n}$ \\
\hline WCK 3.5 & $11 / 25 / 86$ & Bluegill & & 7119 & 143.8 & 18.5 & 0.16 & 0.021 & $<0.46$ & $<0.02$ & 0.48 & 5.1 \\
\hline WCK 3.5 & $11 / 2 \% / 86$ & Bluegill & & 7159 & 123.8 & 18.0 & 0.26 & 0.006 & $<0.42$ & $<0.02$ & 0.30 & 6.5 \\
\hline WCK 3.5 & $11 / 25 / 86$ & Bluegill & & 7275 & 253.4 & 23.0 & 0.52 & 0.010 & $<0.38$ & $<0.02$ & 0.27 & 5.5 \\
\hline WCK 3.5 & $11 / 25 / 86$ & Bluegill & & 7175 & 119.0 & 18.0 & 0.22 & 0.007 & $<0.46$ & $<0.02$ & 0.53 & 5.8 \\
\hline WCK 3.5 & $11 / 25 / 86$ & Bluegill & & 7197 & 161.1 & 18.7 & 0.14 & 0.009 & $<0.46$ & 0.03 & 0.35 & 9.0 \\
\hline WCK 3.5 & $11 / 25 / 86$ & Bluegill & & 7595 & 47.7 & 13.4 & 0.20 & 0.060 & $<0.46$ & $<0.02$ & 0.30 & 7.1 \\
\hline WCK 3.5 & $11 / 25 / 86$ & Bluegill & & 7597 & 67.6 & 14.8 & 0.21 & 0.002 & $<0.44$ & 0.13 & 0.24 & 6.4 \\
\hline WCK 3.5 & $11 / 25 / 86$ & Bluegill & & 8128 & 125.2 & 18.3 & 0.26 & 0.079 & $<0.44$ & $<0.02$ & 0.40 & 5.5 \\
\hline WCK 2.9 & $12 / 11 / 86$ & Bluegill & $\mathbf{M}$ & 7519 & 49.9 & 14.2 & 0.38 & 0.010 & $<0.38$ & $<0.02$ & 0.38 & 8.4 \\
\hline WCK 29 & $12 / 11 / 86$ & Redbreast & $\mathbf{M}$ & 9023 & 139.2 & 19.6 & 0.46 & 0.016 & 0.40 & $<0.02$ & 0.44 & 5.8 \\
\hline WCK 2.9 & $12 / 11 / 86$ & Redbreast & $\mathbf{M}$ & 9024 & 167.7 & 20.3 & 0.48 & 0.006 & $<0.40$ & $<0.02$ & 0.75 & 4.2 \\
\hline WCK 2.9 & $12 / 11 / 86$ & Redbreast & $\mathbf{M}$ & 9025 & 157.9 & 20.0 & 0.37 & 0.006 & $<0.40$ & $<0.02$ & 0.32 & 6.4 \\
\hline WCK 2.9 & $12 / 11 / 86$ & Redbreast & $\mathbf{F}$ & 9029 & 85.3 & 16.6 & 0.58 & 0.008 & $<0.40$ & 0.05 & 0.52 & 7.6 \\
\hline WCK 29 & $12 / 11 / 86$ & Bluegill & $\mathbf{M}$ & 7538 & 93.0 & 16.6 & 0.30 & 0.006 & 0.53 & 0.03 & 0.75 & 5.9 \\
\hline WCK 2.9 & $12 / 11 / 86$ & Bluegill & $\mathbf{M}$ & 7539 & 93.9 & 16.7 & 0.40 & 0.004 & 0.65 & $<0.02$ & 0.50 & 6.5 \\
\hline WCK 2.9 & $12 / 11 / 86$ & Bluegill & $\mathbf{M}$ & 7554 & 137.1 & 19.3 & 0.52 & 0.006 & $<0.40$ & 0.07 & 0.38 & 6.0 \\
\hline WCK 2.3 & 02/03/87 & Bluegill & $\mathbf{M}$ & 0008 & 58.0 & 15.1 & 0.40 & 0.029 & 0.70 & 0.05 & 0.23 & 9.4 \\
\hline WCK 2.3 & $02 / 03 / 87$ & Redbreast & $\mathbf{M}$ & 0015 & 78.9 & 17.1 & 0.66 & 0.009 & $<0.36$ & $<0.02$ & 0.18 & 5.9 \\
\hline WCK 2.3 & 02/03/87 & Redbreast & $\mathbf{M}$ & 0016 & 54.0 & 15.1 & N.D. & 0.036 & $<0.42$ & 0.05 & 0.16 & 5.5 \\
\hline WCK 23 & $02 / 03 / 87$ & Bluegill & $\mathbf{M}$ & 0067 & 49.8 & 14.4 & 0.20 & 0.019 & $<0.42$ & 0.04 & 0.14 & 6.3 \\
\hline WCK 2.3 & $02 / 03 / 87$ & Pivegill & $\mathbf{M}$ & 0077 & 162.5 & 21.5 & 0.73 & 0.010 & $<0.32$ & 0.02 & $<0.08$ & 12.3 \\
\hline WCK 2.3 & $02 / 03 / 87$ & Redbreast & $\mathbf{M}$ & 0081 & 55.5 & 15.5 & 0.50 & 0.006 & $<0.40$ & $<0.02$ & 0.20 & 7.0 \\
\hline WCK 2.3 & $02 / 03 / 87$ & Bluegill & $\mathbf{M}$ & 0088 & 68.6 & 15.4 & 0.43 & 0.005 & $<C .34$ & $<0.02$ & 0.17 & 6.3 \\
\hline WCK 2.3 & 02/03/87 & Redbreast & $\mathbf{M}$ & 0104 & 42.6 & 13.5 & 0.38 & 0.030 & 0.34 & 0.05 & 0.26 & 5.2 \\
\hline WCK 2.3 & $02 / 03 / 87$ & Redbreast & $\mathbf{M}$ & 0106 & 68.9 & 16.8 & 0.64 & N.D. & N.D. & N.D. & N.D. & N.D. \\
\hline WOL & $12 / 05 / 86$ & Bluegiii & $\mathbf{M}$ & 6904 & 55.6 & 14.3 & N.D. & 0.044 & $<0.40$ & $<0.04$ & 0.25 & 4.8 \\
\hline WOL & $12 / 05 / 86$ & Bluegill & $\mathbf{M}$ & 6933 & 65 & 15 & 0. & 0.013 & $<0.20$ & $<0$ & 0.32 & 5.9 \\
\hline WOL & $1: 05 / 86$ & Bluegill & $\mathbf{M}$ & 6950 & 113.1 & 17.7 & 0.09 & 0.020 & $<0.20$ & $<0.04$ & 0.34 & 4.2 \\
\hline WOL & $1<05 / 86$ & Bluegill & $\mathbf{M}$ & 6968 & 61.4 & 14.5 & 0.09 & 0.010 & $<0.40$ & $<0.04$ & 0.13 & 4.9 \\
\hline WOL & $12 / 05 / 86$ & Bluegill & $\mathbf{M}$ & 6997 & 56.3 & 14.7 & 0.11 & 0.015 & $<0.20$ & $<0.0 .3$ & 0.32 & 4.6 \\
\hline WOL & $12 / 05 / 86$ & Bluegill & $\mathbf{M}$ & 9037 & 101.8 & 17.3 & 0.07 & 0.048 & $<0.40$ & 0.21 & 0.36 & 4.6 \\
\hline WOL & $12 / 05 / 86$ & Redbreast & $\mathbf{M}$ & 9042 & 60 & 15.0 & 0.35 & 0.054 & $<0.20$ & $<0.04$ & 0.40 & 6.2 \\
\hline WOL & $12 / 05 / 86$ & Redbreast & $\mathbf{M}$ & 9043 & 68.7 & 15.3 & 0.18 & N.D. & N.D. & N.D. & N.D. & N.D. \\
\hline WOL & $12 / 05 / 86$ & Redbreast & $\mathbf{M}$ & 9045 & 85.0 & 17.0 & 0.27 & 0.044 & $<0.40$ & $<0.04$ & 0.25 & 4.8 \\
\hline WCK 0.9 & 02/23/87 & & $\mathbf{M}$ & 0010 & & & & & $<0$ & $<0$ & & 6.6 \\
\hline WCK 0.9 & $02 / 23 / 87$ & Bluegill & $\mathbf{M}$ & 0027 & 76 . & 16.0 & 0.06 & 0.007 & $<0.36$ & $<0$. & 0.18 & 5.2 \\
\hline WCK 0.9 & 02/23/87 & Bluegill & $\mathbf{F}$ & 0033 & 33.1 & 12.4 & 0.05 & 0.009 & $<0.36$ & $<0.02$ & 0.29 & 5.2 \\
\hline WCK 0.9 & $02 / 23 / 87$ & Redbreast & $\mathbf{M}$ & 0037 & & 13. & & 0.006 & $<0.40$ & 0.0 & 0.28 & 6.6 \\
\hline WCK 0.9 & $02 / 23,87$ & Redbreast & $\mathbf{F}$ & 0046 & 59 & 15.0 & 0.08 & 0.016 & 0.62 & 0.03 & 0.28 & 6.2 \\
\hline WCK 0.9 & $02 / 23 / 87$ & Bluegill & F & 0074 & 49.4 & 14.2 & 0.08 & 0.021 & $<0.38$ & $<0.02$ & 0.23 & 5.7 \\
\hline WCK 0.9 & $02 / 23,87$ & Bluegill & $\mathrm{F}$ & 0079 & 41.1 & 12.9 & 0.08 & 0.051 & $<0.38$ & $<0.02$ & 0.10 & 5.9 \\
\hline WCK 0.9 & $02 / 23 / 87$ & Bluegill & F & 0105 & 32.3 & 12.2 & 0.07 & 0.034 & $<0.36$ & $<0.02$ & 0.16 & 4.7 \\
\hline
\end{tabular}


Table D-1 (continued)

\begin{tabular}{|c|c|c|c|c|c|c|c|c|c|c|c|c|}
\hline Site & Date & $\mathbf{S p} \mathbf{p}^{b}$ & Sex & $\mathbf{N}$ & Weight & Lengthe & $\mathbf{H g}$ & $\mathrm{Cd}$ & $\mathrm{Cu}$ & $\mathbf{P b}$ & Se & $\mathbf{Z n}$ \\
\hline MEK 0.2 & $12 / 04 / 86$ & Bluegill & $\mathbf{M}$ & 9034 & 42.2 & 13.5 & N.D. & 0.016 & $<0.40$ & $<0.04$ & 0.40 & 6.7 \\
\hline MEK 0.2 & $12 / 04 / 86$ & Bluegill & $\mathbf{M}$ & 9035 & $\mathbf{3 0 . 0}$ & 12.0 & 0.11 & 0.024 & $<0.40$ & $<0.04$ & 0.42 & 7.6 \\
\hline MEK 0.2 & $12 / 04 / 86$ & Bluegiil & $\mathbf{M}$ & 9036 & 82.2 & 16.1 & 0.08 & 0.051 & 0.32 & $<0.04$ & 0.34 & 6.1 \\
\hline MEK 0.2 & $12 / 04 / 86$ & Bluegill & $\mathbf{M}$ & 9038 & 24.0 & 11.2 & 0.11 & 0.049 & $<0.40$ & $<0.04$ & 0.25 & 5.9 \\
\hline MEK 0.2 & $12 / 04 / 86$ & Bluegill & $\mathbf{M}$ & 7469 & 27.1 & 11.7 & 0.11 & 0.034 & $<0.40$ & $<0.04$ & 0.29 & 5.7 \\
\hline MEK 0.2 & $02 / 05 / 87$ & Bluegill & I & 0017 & 12.0 & 9.4 & 0.14 & N.D. & N.D. & N.D. & N.D. & N.D. \\
\hline MEK 0.2 & $02 / 05 / 87$ & Redbreast & $\mathbf{M}$ & 0051 & 51.0 & 14.4 & 0.20 & N.D. & N.D. & N.D. & N.D. & N.D. \\
\hline MEK 0.2 & 02/05/87 & Bluegill & $\mathbf{M}$ & 0071 & 28.7 & 12.0 & 0.10 & N.D. & N.D. & N.D. & N.D. & N.D. \\
\hline MEK 0.2 & 02/05/87 & Redbreast & I & 0075 & 12.0 & 9.6 & 0.13 & N.D. & N.D. & N.D. & N.D. & N.D. \\
\hline MEK 0.2 & $02 / 05 / 87$ & Bluegill & I & 0085 & 9.5 & 8.5 & 0.14 & N.D. & N.D. & N.D. & N.D. & N.D. \\
\hline NTK 0.2 & $12 / 11 / 86$ & Bluegill & $\mathbf{M}$ & 6905 & 111.2 & 17.6 & 0.19 & 0.023 & 0.29 & $<0.04$ & 0.61 & 6.1 \\
\hline NTK 0.2 & $12 / 11 / 86$ & Bluegill & $\mathbf{M}$ & 6927 & 93.8 & 18.0 & 0.27 & 0.039 & 0.24 & 0.03 & 0.41 & 5.1 \\
\hline NTK 0.2 & $12 / 11 / 86$ & Bluegill & $\mathbf{F}$ & 6985 & 106.2 & 17.8 & 0.30 & 0.022 & $<0.20$ & $<0.04$ & 0.31 & 5.1 \\
\hline NTK 0.2 & $12 / 11 / 86$ & Bluegill & $\mathbf{M}$ & 7576 & 117.3 & 19.0 & 0.32 & 0.013 & $<0.20$ & $<0.04$ & 0.36 & 4.7 \\
\hline NTK 0.2 & $12 / 11 / 86$ & Bluegill & $\mathbf{M}$ & 7577 & 67.1 & 15.4 & 0.19 & 0.023 & $<0.20$ & $<0.04$ & 0.32 & 4.2 \\
\hline NTK 0.2 & $12 / 11 / 86$ & Bluegill & $\mathbf{F}$ & 7579 & 67.0 & 15.4 & 0.29 & 0.006 & $<0.20$ & $<0.04$ & 0.38 & 4.2 \\
\hline NTK 0.2 & $12 / 11 / 86$ & Bluegill & $\mathbf{M}$ & 7592 & 38.3 & 13.4 & 0.29 & 0.068 & 0.22 & 0.07 & 0.40 & 7.4 \\
\hline NTK 0.2 & $12 / 11 / 86$ & Bluegill & $M$ & 7598 & 108.4 & 17.4 & 0.26 & 0.017 & $<0.20$ & $<0.04$ & 0.48 & 4.4 \\
\hline
\end{tabular}

WCK = White Oak Creek kilometer; WOL = White Oak Lake; MEK = Melton Branch kilometer, NTK = Northwest Tributary kilometer; N.D. = no data available.

'Species include bluegill sunfish (Lepomis macrochinus) and redbreast sunfish (Lepomis auritus).

$\mathbf{M}=$ male; $\mathbf{F}=$ female; $I$ = immature.

${ }^{d}$ Fish weight, measured in grams.

Total fish length, measured in centimeters.

Note: The following metals were below the detection limit (ppm) in all samples:

$\mathrm{Sb}-<0.12$
$\mathrm{As}-<0.06$
$\mathrm{Be}-<0.04$
$\mathrm{Cr}-<0.1$
$\mathrm{Li}-<0.4$
$\mathrm{Ni}-<1.0$
$\mathrm{Ag}-<0.6$
$\mathrm{Th}-<0.1$

Cr was detected in three samples (No. $9038=0.10 \mathrm{ppm}$; No. $7469=0.14 \mathrm{ppm}$; No. $6950=0.14 \mathrm{ppm}$ ).

$\mathrm{Ni}$ was detected in one sumple (No. $7592=1.3 \mathrm{ppm}$ ). 
Table D-2 Organic contaminants in sunfish from White Oak Creek and tributaries and White Oak Lake

\begin{tabular}{|c|c|c|c|c|c|c|c|c|c|c|}
\hline Site & Date & $\mathbf{S p}^{b}$ & Sex & $\mathbf{N}$ & Weight ${ }^{c}$ & Length ${ }^{d}$ & $1254^{e}$ & $1260^{\circ}$ & PCB & Other" \\
\hline WCK 3.5 & $11 / 25 / 86$ & Bluegill & $\mathbf{M}$ & 7117 & 94.7 & 16.4 & $<0.1$ & $<0.1$ & $<0.2$ & BLD \\
\hline WCK 3.5 & $11 / 25 / 86$ & Bluegill & & 7119 & 143.8 & 18.5 & $<0.1$ & $<0.1$ & $<0.2$ & BLD \\
\hline WCK 3.5 & $11 / 25 / 86$ & Bluegill & $\mathbf{M}$ & 7157 & 241.7 & 22.6 & $<0.1$ & $<0.1$ & $<0.2$ & BLD \\
\hline wCK 3.5 & $11 / 25 / 86$ & Bluegill & $\mathbf{F}$ & 7173 & 81.9 & 16.3 & $<0.1$ & $<0.1$ & $<0.2$ & BLD \\
\hline WCK 3.5 & $11 / 25 / 86$ & Bluegill & & 7175 & 119.0 & 18.0 & $<0.1$ & $<0.1$ & $<0.2$ & BLD \\
\hline WCK 3.5 & $11 / 25 / 86$ & Bluegill & & 7197 & 161.1 & 18.7 & $<0.1$ & $<0.1$ & $<0.2$ & BLD \\
\hline WCK 3.5 & $11 / 25 / 86$ & Bluegill & $\mathbf{M}$ & 7593 & 64.0 & 14.5 & 4.0 & 0.8 & 4.8 & BLD \\
\hline WCK 3.5 & $11 / 25 / 86$ & Bluegill & & 8128 & 125.2 & 18.3 & 2.7 & 0.5 & 3.2 & BLD \\
\hline WCK 2.9 & $12 / 11 / 86$ & Redbreast & $\mathbf{M}$ & 7537 & 52.8 & 14.0 & $<0.2$ & $<0.2$ & $<0.4$ & BLD \\
\hline WCK 29 & $12 / 11 / 86$ & Redbreast & $\mathbf{M}$ & 7538 & 93.0 & 16.6 & $<0.1$ & $<0.1$ & $<0.2$ & BLD \\
\hline WCK 2.9 & $12 / 11 / 86$ & Bluegill & $\mathbf{M}$ & 7554 & 137.1 & 19.3 & 3.4 & 0.5 & 3.9 & BLD \\
\hline WCK 2.9 & $12 / 11 / 86$ & Bluegill & $\mathbf{M}$ & 7557 & 162.4 & 20.4 & 1.1 & 0.2 & 1.3 & BLD \\
\hline WCK 2.9 & $12 / 11 / 86$ & Redbreast & $\mathbf{M}$ & 7558 & 201.9 & 21.2 & 1.9 & $<0.1$ & 1.9 & BLD \\
\hline WCK 2.9 & $12 / 11 / 86$ & Redbreast & $\mathbf{M}$ & 7559 & 73.6 & 16.5 & 1.6 & $<0.1$ & 1.6 & BLD \\
\hline WCK 2.9 & $12 / 11 / 86$ & Bluegill & $\mathbf{M}$ & 9023 & 139.2 & 19.6 & 0.3 & $<0.1$ & 0.3 & BLD \\
\hline WCK 2.9 & $12 / 11 / 86$ & Bluegill & $\mathbf{M}$ & 9025 & 157.9 & 20.0 & 1.9 & $<0.1$ & 1.9 & BLD \\
\hline WCK 2.3 & 02/03/87 & Redbreast & $\mathbf{M}$ & 0007 & 40.6 & 13.3 & 4.7 & $<0.2$ & 4.7 & BLD \\
\hline WCK 2.3 & $02 / 03 / 87$ & Bluegill & $\mathbf{F}$ & 0012 & 43.1 & 13.6 & 1.3 & $<0.2$ & 1.3 & BLD \\
\hline WCK 2.3 & $02 / 03 / 87$ & Redbreast & $\mathbf{M}$ & 0016 & 54.0 & 15.1 & 0.8 & 0.3 & 1.1 & BLD \\
\hline WCK 2.3 & $02 / 03 / 87$ & Bluegill & & 0020 & 42.7 & 13.5 & 2.7 & $<0.2$ & 2.7 & BLD \\
\hline WCK 2.3 & $02 / 03 / 87$ & Bluegill & $\mathbf{F}$ & 0073 & 55.0 & 14.8 & 2.0 & 0.2 & 2.0 & BLD \\
\hline WCK 2.3 & $02 / 03 / 87$ & Bluegill & $\mathbf{M}$ & 0077 & 162.5 & 21.5 & 2.5 & 3.3 & 5.8 & BLD \\
\hline WCK 2.3 & $02 / 03 / 87$ & Redbreast & $\mathbf{M}$ & 0106 & 68.9 & 16.6 & 0.2 & $<0.2$ & 0.2 & BLD \\
\hline WCK 2.3 & $02 / 03 / 87$ & Redbreast & $\mathbf{F}$ & 0107 & 49.5 & 13.9 & 1.3 & $<0.2$ & 1.3 & BLD \\
\hline WOL & $12 / 05 / 86$ & Bluegill & $\mathbf{M}$ & 6904 & 55.6 & 14.3 & $<0.1$ & $<0.1$ & $<0.2$ & BLD \\
\hline WOL & $12 / 05 / 86$ & Bluegill & $\mathbf{M}$ & 6922 & 65.7 & 15.5 & $<0.1$ & $<0.1$ & $<0.2$ & BLD \\
\hline WOL & $12 / 05 / 86$ & Bluegill & $\mathbf{M}$ & 6950 & 113.1 & 17.7 & $<0.1$ & $<0.1$ & $<0.2$ & BLD \\
\hline WOL & $12 / 05 / 86$ & Bluegill & $\mathbf{M}$ & 9037 & 101.8 & 17.3 & $<0.1$ & $<0.1$ & $<0.2$ & BLD \\
\hline WOL & $12 / 05 / 86$ & Bluegill & $\mathbf{M}$ & 9039 & 71.7 & 15.8 & $<0.1$ & $<0.1$ & $<0.2$ & BLD \\
\hline WOL & $12 / 05 / 86$ & Redbreast & $\mathbf{M}$ & 9042 & 60.6 & 15.0 & $<0.2$ & $<0.2$ & $<0.4$ & BLD \\
\hline WOL & $12 / 05 / 86$ & Redbreast & $\mathbf{M}$ & 9043 & 68.7 & 15.3 & 1.5 & $<0.2$ & 1.5 & BLD \\
\hline YOL & $12 / 05 / 86$ & Redbreast & $\mathbf{M}$ & 9045 & 113.1 & 17.7 & 1.4 & $<0.2$ & 1.4 & BLD \\
\hline WCK 0.9 & $02 / 23 / 87$ & Bluegill & $\mathbf{M}$ & 0010 & 55.6 & 13.9 & 1.0 & $<0.2$ & 1.0 & BLD \\
\hline WCK 0.9 & $02 / 23 / 87$ & Bluegill & $\mathbf{M}$ & 0021 & 38.2 & 12.5 & 0.49 & $<0.1$ & 0.49 & $\overline{B L D}$ \\
\hline WCK 0.9 & 02/23/87 & Redbreast & $\mathbf{M}$ & 0037 & 40.4 & 13.3 & $<0.2$ & $<0.2$ & $<0.4$ & BLD \\
\hline WCK 0.9 & $02 / 23 / 87$ & Redbreast & $\mathbf{F}$ & 0057 & 68.1 & 15.0 & 0.3 & $<0.1$ & 0.3 & BLD \\
\hline WCK 0.9 & $02 / 23 / 87$ & Bluegill & F & 0074 & 49.4 & 14.2 & 1.1 & $<0.2$ & 1.1 & BLD \\
\hline WCK 0.9 & 02/23/87 & Bluegill & F & 0090 & 34.3 & 12.1 & 0.81 & $<0.1$ & 0.81 & BLD \\
\hline WCK 0.9 & $02 / 23 / 87$ & Bluegill & $\mathbf{F}$ & 0101 & 71.4 & 15.2 & 0.65 & $<0.1$ & 0.65 & BLD \\
\hline WCK 0.9 & $02 / 23 / 87$ & Bluegill & $\mathbf{M}$ & 0113 & 55.3 & 14.6 & 0.73 & $<0.1$ & 0.73 & BLD \\
\hline MEK 0.2 & $12 / 04 / 86$ & Bluegill & $\mathbf{M}$ & 9033 & 22.9 & 11.0 & 1.1 & $<0.2$ & 1.1 & BLD \\
\hline MEK 0.2 & $12 / 04 / 86$ & Bluegill & $\mathbf{M}$ & 9034 & 42.2 & 13.5 & 2.3 & 0.5 & 28 & BLD \\
\hline MEK 0.2 & $12 / 04 / 86$ & Bluegill & $\mathbf{M}$ & 9036 & 82.2 & 16.1 & $<0.1$ & $<0.1$ & $<0.2$ & BLD \\
\hline
\end{tabular}


Table D-2 (continued)

\begin{tabular}{lllllrrrrrr}
\hline Site & Date & Sp $^{b}$ & Sex & N & Weight $^{c}$ & Length $^{d}$ & $1254^{e}$ & 1260 & PCB $^{s}$ & Other $^{h}$ \\
\hline NTK 0.2 & $12 / 11 / 86$ & Bluegill & M & 6927 & 93.8 & 18.0 & $<0.1$ & $<0.1$ & $<0.2$ & BLD \\
NTK 0.2 & $12 / 11 / 86$ & Bluegill & F & 6939 & 106.2 & 17.8 & $<0.1$ & $<0.1$ & $<0.2$ & BLD \\
NTK 0.2 & $12 / 11 / 86$ & Bluegill & F & 7575 & 75.7 & 16.5 & $<0.1$ & $<0.1$ & $<0.2$ & BLD \\
NTK 0.2 & $12 / 11 / 86$ & Bluegill & M & 7576 & 117.3 & 19.0 & $<0.1$ & $<0.1$ & $<0.2$ & BLD \\
NTK 0.2 & $12 / 11 / 86$ & Bluegill & F & 7594 & 52.6 & 14.3 & $<0.2$ & $<0.2$ & $<0.4$ & BLD \\
NTK 0.2 & $12 / 11 / 86$ & Bluegill & M & 7598 & 108.4 & 17.4 & $<0.1$ & $<0.1$ & $<0.2$ & BLD \\
NTK 0.2 & $12 / 11 / 86$ & Bluegill & M & 7599 & 30.5 & 12.5 & $<0.1$ & $<0.1$ & $<0.2$ & BLD \\
\hline
\end{tabular}

'WCK = White Oak Creek kilometer; WOL = White Oak Lake; MEK = Melton Branch kilometer, NTK = Northwest Tributary kilometer. Numerical value is the distance from the reference point to the mouth of the stream.

'Species include bluegill sunfish (Lepomis macrochinus) and redbreast sunfish (Lepomis auritus).

Tish weight, measured in grams.

Total fish length, measured in centimeters.

$1254=$ PCB-1254 (Arochlor-1254) in fish axial muscle, parts per million (micrograms per gram) wet weight.

$f_{1260}=$ PCB-1260 (Arochlor-1260) in fish axial muscle, parts per million (micrograms per gram) wet weight.

PCB = Total PCB (sum of PCB-1254 and PCB-1260) in fish axial muscle, parts per million (micrograms per gram) wet weight.

${ }^{h}$ Fish analyzed for pesticides and PCBs at all sites; high-performance liquid chromatography (HPLC) for polycyclic aromatic hydrocarbons (PAHs) at WCK 3.5, WCK 2.9, NTK 0.2, WOL, and MEK 0.2; and gas chromatographic/mass spectrometric (GCMS) at WCK 2.3 and WCK 0.9.

Note: BLD $=$ Below limit of detection. 
Table D-3. Organic contaminants in caged clams (Corbicula fuminea)

A. Polychlorinated Biphenyls (PCBs) by Packed Column Gas Chromatography (ppm wet wt)

\begin{tabular}{llllll} 
Sample & Site & Exposure & PCB-1254 & PCB-1260 & PCB $^{d}$ \\
\hline MS23 & WCK 3.5 & $7 / 15-8 / 17 / 87$ & 0.18 & $<0.01$ & 0.18 \\
MS24 & WCK 3.5 & $7 / 15-8 / 17 / 87$ & 0.15 & $<0.01$ & 0.15 \\
MS33 & WCK 2.6 & $7 / 15-8 / 17 / 87$ & 1.5 & $<0.01$ & 1.5 \\
MS34 & WCK 2.6 & $7 / 15-8 / 17 / 87$ & 1.5 & $<0.01$ & 1.5 \\
MS43 & MEK 0.2 & $7 / 15-8 / 17 / 87$ & 0.06 & 0.02 & 0.08 \\
MS44 & MEK 0.2 & $7 / 15-8 / 17 / 87$ & 0.13 & 0.01 & 0.14 \\
WOL3 & WOL & $7 / 15-8 / 17 / 87$ & 1.3 & 0.02 & 1.3 \\
WOL4 & WOL & $7 / 15-8 / 17 / 87$ & 1.4 & 0.02 & 1.4 \\
BR3 & Bull Run & $7 / 15-8 / 17 / 87$ & 0.05 & 0.01 & 0.06 \\
BR4 & Bull Run & $7 / 15-8 / 17 / 87$ & 0.02 & 0.02 & 0.04
\end{tabular}

B. Organics by Capillary Column gas chromatography with electron capture detectors (GC/ECD and gas chromatography/mass spectrometry (GCMS)

\begin{tabular}{lllcccc} 
Sample & Site & Exposure & PCB-1254 & PCB-1260 & PCB $^{\circ}$ & $\begin{array}{c}\text { Other } \\
\text { organicse }\end{array}$ \\
MS21 & WCK 3.5 & $7 / 15-8 / 17 / 87$ & $\begin{array}{l}\text { Sample lost in extraction/clean-up } \\
\text { MS22 }\end{array}$ & WCK 3.5 & $7 / 15-8 / 17 / 87$ & Sample lost in extraction/clean-up \\
MS31 & WCK 2.6 & $7 / 15-8 / 17 / 87$ & 2.0 & 0.8 & 2.8 & BLD \\
MS32 & WCK 2.6 & $7 / 15-8 / 17 / 87$ & $<0.2$ & $<0.2$ & $<0.4$ & BLD \\
MS41 & MEK 0.2 & $7 / 15-8 / 17 / 87$ & 1.7 & $<0.2$ & 1.9 & BLD \\
MS42 & MEK 0.2 & $7 / 15-8 / 17 / 87$ & 1.5 & $<0.2$ & 1.5 & BLD \\
WOL1 & WOL & $7 / 15-8 / 17 / 87$ & $<0.2$ & $<0.2$ & $<0.4$ & BLD \\
WOL2 & WOL & $7 / 15-8 / 17 / 87$ & 0.77 & $<0.2$ & 0.77 & BLD \\
BR1 & Bull Run & $7 / 15-8 / 17 / 87$ & 1.7 & $<0.2$ & 1.7 & BLD \\
BR2 & Bull Run & $7 / 15-8 / 17 / 87$ & $<0.2$ & $<0.2$ & $<0.4$ & BLD \\
\hline
\end{tabular}

-WCK = White Oak Creek kilometer, MEK = Melton Branch kilometer; WOL = White Oak Lake.

${ }^{b} 1254=$ PCK-1254 (Arochlor-1254) in soft tissue, parts per million (micrograms per gram).

${ }^{c} 1260$ = PCK-1260 (Arochlor-1260) in soft tissue, parts per million (micrograms per gram).

Total PCBs (sum of PCB-1254 and PCB-1260) in soft tissue, parts per million (micrograms per gram) wet weight.

Pesticides and halogenated compounds, GC/MS organics.

Note: BLD $=$ Below limit of detection. 
Table D-4. Detection limits of organic compounds (given in parts per million wet weight)

Measured by capillary column GC/MS, capillary column GC/ECD, and HPLC with fluorescence detection

\section{Capillary Column GCMS}

Phenol

$<1.0$

Bis(2-chloroethyl)ether

$<1.0$

2-Chlorophenol

$<1.0$

1,3-Dichlorobenzene

$<1.0$

1,4-Dichlorobenzene

$<1.0$

Benzyl alcohol

$<1.0$

1,2-Dichlorobenzene

$<1.0$

2-Methylphenol

$<1.0$

Bis(2-chlorodisopropyl)ether

$<1.0$

4-Methylphenol

$<1.0$

$\mathrm{N}$-Nitroso-di-N-propylamine

$<1.0$

Hexachloroethane

$<1.0$

Nitrobenzene

$<1.0$

Isophorone

$<1.0$

2-Nitrophenol

2,4-Dimethylphenol

Benzoic acid

$<1.0$

$<1.0$

Bis(2-chloroethoxy)methane

$<2.0$

2,4-Dichlorophenol

$<1.0$

1,2,4-Trichlorobenzene

$<1.0$

Naphthalene

$<1.0$

4-Chloroaniline

$<1.0$

Hexachlorobutradiene

$<1.0$

4-Chloro-3-methylphenol

$<1.0$

2-Methylnaphthalene

$<1.0$

Hexachlorocyclapentadiene

$<1.0$

2,4,6-Trichlorophenol

$<1.0$

2,4,5-Trichlorophenol

$<1.0$

2-Chloronaphthalene

$<2.0$

2-Nitroaniline

$<1.0$

Dimethylphthalate

$<2.0$

Acenaphthalene

$<1.0$

3-Nitroaniline

$<1.0$

Acenaphthene

2,4-Dinitrophenol

Nitrophenol

Dibenzofuran

$<2.0$

$<1.0$

$<2.0$

2,4-Dinitrotoluene

$<2.0$

2,6-Dinitrotoluene

$<1.0$

Diethylphthalate

$<1.0$

$<1.0$

$<1.0$ 
Table D-4 (continued)

Detection limit

4-Chlorophenyl-phenylether

Fluorene

$<1.0$

4-Nitroaniline

$<2.0$

4,6-Dinitro-2-methylphenol

$<2.0$

$N$-Nitrosodiphenylamine

$<1.0$

4-Bromophenyl-phenylether

$<1.0$

Hexachlorobenzene

$<1.0$

Pentachlorophenol

$<2.0$

Phenanthrene

$<1.0$

Anthracene

$<1.0$

Di- $N$-butylphthalate

$<1.0$

Fluoranthene

$<1.0$

Pyrene

$<1.0$

Butylbenzylphthalate

$<1.0$

3,3-Dichlorobenzidene

$<2.0$

Benz[a]anthracene

$<1.0$

Bis(2-ethylhexyl)phthalate

$<1.0$

Chrysene

$<1.0$

Di-N-octylphthalate

$<1.0$

Benzo[b]fluoranthene

$<1.0$

Benzo[k]fluoranthene

$<1.0$

Benzo[a]pyrene

$<1.0$

Indeno[ $[1,2,3-c d]$ pyrene

$<1.0$

Dibenz $[a, h]$ anthracene

$<1.0$

Benzo $[g, h, i]$ perylene

$<1.0$

Capillary Column GC/ECD

Alpha-BHC

Beta-BHC

$<0.005$

Delta-BHC

$<0.005$

Gamma-BHC

$<0.005$

Heptachlor

$<0.005$

Aldrin

$<0.005$

Heptachlor epoxide

$<0.005$

Endosulfan I

$<0.005$

Dieldrin

$<0.005$

4,4'-DDE

$<0.01$

Endrin

$<0.01$

Endosulfan II

$<0.01$

4,4'-DDD

$<0.01$

Endosulfan sulfate

$<0.01$

4,4'-DDT

$<0.01$

Endrin ketone

$<0.01$

Methoxychlor

$<0.01$

Alpha chlordane

$<0.05$

$<0.05$ 
Table D-4 (continued)

\begin{tabular}{|c|c|}
\hline Compound & Detection limit \\
\hline $\begin{array}{l}\text { Gamma chlordane } \\
\text { Toxaphene } \\
\text { PCB-1016 } \\
\text { PCB-1221 } \\
\text { PCB-1232 } \\
\text { PCB-1242 } \\
\text { PCB-1248 } \\
\text { PCB-1254 } \\
\text { PCB-1260 }\end{array}$ & $\begin{array}{l}<0.05 \\
<0.1 \\
<0.05 \\
<0.05 \\
<0.05 \\
<0.05 \\
<0.05 \\
<0.1 \\
<0.1\end{array}$ \\
\hline \multicolumn{2}{|c|}{ HPLC' with fluorescence detection } \\
\hline $\begin{array}{l}\text { Naphthalene } \\
\text { Acenaphthene } \\
\text { Fluorene } \\
\text { Phenanthrene } \\
\text { Anthracene } \\
\text { Fluoranthene } \\
\text { Pyrene } \\
\text { Benz }[a] \text { anthracene } \\
\text { Benzo }[b] \text { fluoranthene } \\
\text { Benzo }[k] \text { fluoranthene } \\
\text { Benzo }[a] \text { pyrene } \\
\text { Dibenz }[a, h] \text { anthracene } \\
\text { Benzo }[g, h, i] \text { perylene } \\
\text { Indeno }[1,2,3-c d] \text { pyrene }\end{array}$ & $\begin{array}{l}<0.2 \\
<0.05 \\
<0.2 \\
<0.05 \\
<0.2 \\
<0.02 \\
<0.03 \\
<0.02 \\
<0.02 \\
<0.02 \\
<0.02 \\
<0.02 \\
<0.02 \\
<0.04\end{array}$ \\
\hline
\end{tabular}

Detection limit in 10-g tissue sample. Sample weights varied between 5 and $10 \mathrm{~g}$; mean \pm s.d. was $8.5 \pm$ $1.7 \mathrm{~g}$.

${ }^{6} \mathrm{GC} / \mathrm{MS}=$ gas chromatography/mass spectrometry.

${ }^{\circ} \mathrm{GC} / E C D=$ gas chromatography with electron capture detectors.

${ }^{d}$ HPLC $=$ high-performance liquid chromatography. 
Table D-5. Concentrations of polychlorinated biphenyls (PCBs) and "Sr in catfish and giveard shad from lower Melton Hill Reservoir, Fort Loudon Reservoir, White Oak Lake, White Oak Creek embayment, the Clinch River near ORNL, and reference sites

\begin{tabular}{|c|c|c|c|c|c|c|c|c|c|c|c|}
\hline Site & Type $^{b}$ & Date & $S p^{c}$ & Sexd & $\begin{array}{l}\text { Sample } \\
\text { number }\end{array}$ & $W_{g t}{ }^{2}$ & Lgth $f$ & PCB & $1254^{h}$ & $1260^{\circ}$ & ${ }^{0} \mathrm{Sr}$ \\
\hline WOL & $\mathbf{R}$ & $7 / 16 / 87$ & Y. Bull & $\mathbf{F}$ & WOL-1 & 328 & 28.8 & 0.46 & 0.11 & 0.35 & 4400 \\
\hline WOL & $\mathbf{R}$ & $7 / 17 / 87$ & Y. Bull & $\mathbf{F}$ & WOL-2 & 460 & 32.7 & 0.79 & 0.28 & 0.514 & 300 \\
\hline WOL & $\mathbf{R}$ & $7 / 17 / 87$ & Y. Bull & $\mathbf{M}$ & WOL-3 & 306 & 31.0 & 0.84 & 0.23 & 0.61 & 6600 \\
\hline WOL & $\mathbf{R}$ & $7 / 21 / 87$ & Y. Bull & $\mathbf{F}$ & WOL-4 & 223 & 26.4 & 0.41 & 0.06 & 0.35 & 3700 \\
\hline WOL & $\mathbf{R}$ & $7 / 22 / 87$ & Y. Bull & $\mathbf{F}$ & WOL-5 & 463 & 31.4 & 2.50 & 0.80 & 1.70 & 5000 \\
\hline WCK 0.3 & $\mathbf{R}$ & $7 / 14 / 87$ & Ch. Cat & $\mathbf{M}$ & WCK-1 & 545 & 39.4 & 0.57 & 0.14 & 0.43 & 240 \\
\hline WCK 0.3 & $\mathbf{R}$ & $7 / 15 / 87$ & Ch. Cat & $\mathbf{M}$ & WCK-2 & 2160 & 60.0 & 1.83 & 0.03 & 1.80 & 210 \\
\hline WCK 0.3 & $\mathbf{R}$ & $7 / 15 / 87$ & Ch. Cat & $\mathbf{M}$ & WCK-3 & 1010 & 48.2 & 1.28 & 0.68 & 0.60 & 1100 \\
\hline WCK 0.3 & $\mathbf{R}$ & $7 / 16 / 87$ & Ch. Cat & $\mathbf{M}$ & WCK-4 & 1315 & 54.5 & 1.61 & 0.99 & 0.62 & 250 \\
\hline WCK 0.3 & $\mathbf{R}$ & $7 / 24 / 87$ & Ch. Cat & $\mathbf{F}$ & WCK-5 & 2450 & 61.5 & 2.13 & 1.40 & 0.73 & 24 \\
\hline WCK 0.3 & $\mathbf{R}$ & $7 / 27 / 87$ & Ch. Cat & $\mathbf{M}$ & WCK-6 & 690 & 46.1 & 1.40 & 0.10 & 1.30 & 410 \\
\hline WCK 0.3 & $\mathbf{R}$ & $7 / 29 / 87$ & Ch. Cat & $\mathbf{F}$ & WCK-7 & 821 & 45.7 & 3.28 & 0.68 & 2.60 & 390 \\
\hline WCK 0.3 & $\mathbf{R}$ & $8 / 03 / 87$ & Ch. Cat & $\mathbf{M}$ & WCK-8 & 242 & 33.2 & 0.61 & 0.14 & 0.47 & 180 \\
\hline CRK 34.8 & $8 R$ & $8 / 07 / 87$ & Ch. Cat & $\mathbf{M}$ & CRU-1 & 2420 & 58.8 & 3.00 & 1.10 & 1.90 & 260 \\
\hline CRK 34.8 & $\mathbf{R}$ & $8 / 14 / 87$ & Ch. Cat & $\mathbf{F}$ & CRU-2 & 1640 & 56.5 & 1.23 & 0.13 & 1.10 & 47 \\
\hline CRK 34.8 & $8 R$ & $8 / 20 / 87$ & Ch. Cat & $\mathbf{M}$ & CRU-3 & 615 & 41.2 & 0.83 & 0.60 & 0.23 & 770 \\
\hline CRK 32.2 & $2 R$ & $7 / 21 / 87$ & Ch. Cat & $\mathbf{F}$ & CRD-1 & 2260 & 57.3 & 0.81 & 0.29 & 0.52 & 34 \\
\hline CRK 32.2 & $2 R$ & $7 / 24 / 87$ & Ch. Cat & $\mathbf{F}$ & CRD-2 & 2735 & 62.5 & 4.70 & 1.90 & 2.80 & 800 \\
\hline CRK 32.2 & $2 R$ & $7 / 24 / 87$ & Ch. Cat & $\mathbf{M}$ & CRD-3 & 820 & 46.2 & 0.85 & 0.21 & 0.64 & 250 \\
\hline CRK 32.2 & $2 \mathrm{R}$ & $7 / 24 / 87$ & Ch. Cat & $\mathbf{F}$ & CRD 4 & 830 & 45.5 & 0.76 & 0.18 & 0.58 & 13 \\
\hline CRK 32.2 & $2 R$ & $7 / 24 / 87$ & Ch. Cat & $\mathbf{F}$ & CRD-5 & 540 & 41.5 & 3.41 & 0.01 & 3.40 & 52 \\
\hline CRK 32.2 & $2 R$ & $8 / 04 / 87$ & Ch. Cat & $\mathbf{M}$ & CRD-6 & 1170 & 51.5 & 0.92 & 0.57 & 0.35 & 57 \\
\hline CRK 322 & $2 R$ & $8 / 05 / 87$ & Ch. Cat & $\mathbf{M}$ & CRD.7 & 850 & 45.8 & 0.51 & 0.25 & 0.26 & 44 \\
\hline CRK 32.2 & $2 R$ & $\mathbf{8} / 05 / 87$ & Ch. Cat & $\mathbf{F}$ & CRD-8 & 810 & 45.7 & 0.90 & 0.24 & 0.66 & 16 \\
\hline CEC & C & $7 / 15 / 87$ & Ch. Cat & $\mathbf{M}$ & CEC-1 & 780 & 44.5 & 0.03 & 0.02 & 0.01 & 8 \\
\hline CEC & C & $7 / 15 / 87$ & Ch. Cat & $\mathbf{F}$ & CEC-2 & 607 & 38.7 & 0.03 & 0.02 & 0.01 & 0 \\
\hline CEC & C & $7 / 15 / 87$ & Ch. Cat & $\mathbf{M}$ & CEC-3 & 1245 & 49.5 & 0.04 & 0.03 & 0.01 & 20 \\
\hline CEC & C & $7 / 15 / 87$ & Ch. Cat & $\mathbf{M}$ & CEC-4 & 1500 & 55.1 & 0.03 & 0.03 & $<0.01$ & 9 \\
\hline MHL & $\mathbf{R}$ & $8 / 04 / 87$ & Ch. Cat & $\mathbf{M}$ & MHL-1 & 3160 & 63.5 & 1.05 & 0.60 & 0.45 & 0 \\
\hline MHL & $\mathbf{R}$ & $8 / 14 / 87$ & Ch. Cat & & MHL-2 & $3050^{k}$ & & 0.80 & 0.43 & 0.37 & \\
\hline MHL & $\mathbf{R}$ & $\mathbf{8} / 18 / 87$ & Ch. Cat & $\mathbf{F}$ & MHL-3 & 1840 & 56.4 & 0.87 & 0.32 & 0.55 & 10 \\
\hline MHL & $\mathbf{R}$ & $8 / 18 / 87$ & Ch. Cat & $\mathbf{M}$ & MHL-4 & 1000 & 48.3 & 0.26 & 0.07 & 0.19 & 27 \\
\hline MFIL & $\mathbf{R}$ & $8 / 18 / 87$ & Ch. Cat & $\mathbf{M}$ & MHL-5 & 590 & 41.3 & 0.43 & 0.19 & 0.24 & 8 \\
\hline MHL & $\mathbf{R}$ & 8/18/87 & Ch. Cat & $\mathbf{M}$ & MHL-6 & 290 & 32.8 & 0.23 & $<0.01$ & 0.23 & 16 \\
\hline MHL & $\mathbf{R}$ & 8/19/87 & Ch. Cat & $\mathbf{F}$ & MHL-7 & 1110 & 50.8 & 2.0 & 1.00 & 1.00 & 0 \\
\hline FLD & $\mathbf{R}$ & $8 / 06 / 87$ & Bl. Cat & $\mathbf{F}$ & FLD-1 & 4990 & 76.0 & & & & \\
\hline FLD & $\mathbf{R}$ & $8 / 12 / 87$ & Ch. Cat & $\mathbf{M}$ & FLD-2 & 450 & 40.0 & 0.42 & 0.04 & 0.38 & \\
\hline FLD & $\mathbf{R}$ & $8 / 12 / 87$ & Ch. Cat & $\mathbf{F}$ & FLD-3 & 1090 & 48.1 & 5.00 & 2.10 & 290 & \\
\hline FLD & $\mathbf{R}$ & $8 / 12 / 87$ & Ch. Cat & $\mathbf{F}$ & FLD-4 & 870 & 44.8 & 2.05 & 0.45 & 1.60 & \\
\hline FLD & $\mathbf{R}$ & $8 / 12 / 87$ & Ch. Cat & $\mathbf{M}$ & FLD-5 & 1670 & 56.5 & 1.23 & 0.13 & 1.10 & \\
\hline FLD & $\mathbf{R}$ & $8 / 12 / 87$ & Ch. Cat & $\mathbf{M}$ & FLD-6 & 800 & 47.2 & 0.92 & 0.57 & 0.35 & \\
\hline
\end{tabular}


Table D-5 (continued)

\begin{tabular}{|c|c|c|c|c|c|c|c|c|c|c|c|}
\hline Sitea & Type $^{b}$ & Date & $S p^{f}$ & Sext & $\begin{array}{l}\text { Sample } \\
\text { number }\end{array}$ & Wgt & Lgth' & $\mathrm{PCB}^{\mathrm{S}}$ & $1254^{h}$ & $1260^{\circ}$ & ${ }^{*} \mathrm{~S} \mathrm{~s}$ \\
\hline $\begin{array}{l}\text { FLD } \\
\text { FLD } \\
\text { FLD }\end{array}$ & $\begin{array}{l}\mathbf{R} \\
\mathbf{R} \\
\mathbf{R}\end{array}$ & $\begin{array}{l}8 / 12 / 87 \\
8 / 12 / 87 \\
8 / 12 / 87\end{array}$ & $\begin{array}{l}\text { Ch. Cat } \\
\text { Ch. Cat } \\
\text { Ch. Cat }\end{array}$ & $\begin{array}{l}\mathbf{M} \\
\mathbf{F} \\
\mathbf{M}\end{array}$ & $\begin{array}{l}\text { FLD-7 } \\
\text { FLD-8 } \\
\text { FLD-9 }\end{array}$ & $\begin{array}{l}1160 \\
380 \\
727\end{array}$ & $\begin{array}{l}50.0 \\
36.2 \\
45.2\end{array}$ & $\begin{array}{l}3.33 \\
1.09 \\
1.13\end{array}$ & $\begin{array}{l}0.53 \\
0.44 \\
0.32\end{array}$ & $\begin{array}{l}2.80 \\
0.65 \\
0.81\end{array}$ & \\
\hline $\begin{array}{l}\text { MHL } \\
\text { MHL } \\
\text { MHL }\end{array}$ & $\begin{array}{l}\mathbf{F} \\
\mathbf{F} \\
\mathbf{F}\end{array}$ & $\begin{array}{l}8 / 20 / 87 \\
8 / 20 / 87 \\
8 / 20 / 87\end{array}$ & $\begin{array}{l}\text { Grshad } \\
\text { Grshad } \\
\text { Grshad }\end{array}$ & $\begin{array}{l}\text { C } \\
\text { C } \\
\text { C }\end{array}$ & $\begin{array}{l}\text { MHL-A } \\
\text { MHL-B } \\
\text { MHL-C }\end{array}$ & & & $\begin{array}{l}0.66 \\
0.33 \\
0.33\end{array}$ & $\begin{array}{l}0.41 \\
0.10 \\
0.14\end{array}$ & $\begin{array}{l}0.25 \\
0.23 \\
0.19\end{array}$ & $\begin{array}{r}14 \\
10 \\
0\end{array}$ \\
\hline $\begin{array}{l}\text { CRK } 32.2 \\
\text { CRK } 32.2 \\
\text { CRK } 32.2\end{array}$ & $\begin{array}{ll}2 & F \\
2 & F \\
2 & F\end{array}$ & $\begin{array}{l}8 / 20 / 87 \\
8 / 20 / 87 \\
8 / 20 / 87\end{array}$ & $\begin{array}{l}\text { Grshad } \\
\text { Gzshad } \\
\text { Grshad }\end{array}$ & $\begin{array}{l}\text { C } \\
\text { C } \\
\text { C }\end{array}$ & $\begin{array}{l}\text { CRD-A } \\
\text { CRD-B } \\
\text { CRD-C }\end{array}$ & & & $\begin{array}{l}0.71 \\
0.64 \\
0.60\end{array}$ & $\begin{array}{l}0.15 \\
0.49 \\
0.38\end{array}$ & $\begin{array}{l}0.56 \\
0.15 \\
0.22\end{array}$ & $\begin{array}{r}220 \\
22 \\
31\end{array}$ \\
\hline $\begin{array}{l}\text { WCK } 0.3 \\
\text { WCK } 0.3 \\
\text { WCK } 0.3\end{array}$ & $\begin{array}{l}F \\
F \\
F\end{array}$ & $\begin{array}{l}8 / 20 / 87 \\
8 / 20 / 87 \\
8 / 20 / 87\end{array}$ & $\begin{array}{l}\text { Gzshad } \\
\text { Gzshad } \\
\text { Gzshad }\end{array}$ & $\begin{array}{l}\text { C } \\
\text { C } \\
\text { C }\end{array}$ & $\begin{array}{l}\text { WCK-A } \\
\text { WCK-B } \\
\text { WCK-C }\end{array}$ & & & $\begin{array}{l}1.81 \\
2.5 \\
4.8\end{array}$ & $\begin{array}{l}1.10 \\
1.4 \\
3.2\end{array}$ & $\begin{array}{l}0.71 \\
1.1 \\
1.6\end{array}$ & $\begin{array}{l}350 \\
520 \\
320\end{array}$ \\
\hline
\end{tabular}

-WOL = White Oak Lake; WCK $=$ White Oak Creek kilometer; CRK = Clinch River kilometer; CEC refers to a commercial cattish farm; MHL $=$ Melton Hill Lake; FLD $=$ Fort Loudon Dam (Fort Loudon Reservoir). See also Fig. 4.1 for site identification.

'Sample types classed as R (regular), C (control), and F (food organisms).

'Species include yellow bulihead (Y. Bull) (Ictalurus natalis), channel catish (Ch. Cat) (Ictalurus punctarus), and gizzard shad (Grshad) (Dorosoma cepedianum).

$d \mathbf{M}=$ male; $F=$ female; $C=$ composite sample (both sexes).

Fish weight, measured in grams.

Total fish length, measured in centimeters.

Total PCBs (sum of PCB-1254 and PCB-1260) in fish axial muscle, parts per million (micrograms per gram) wet weight.

"PCB-1254 (Arochlor-1254) in fish axial muscle, parts per million (micrograms per gram) wet weight.

'PCB-1260 (Arochlor-1260) in fish axial muscle, parts per million (micrograms per gram) wet weight.

iStrontium-90 in cattish vertebrae, bequerels per kilogram dry weight.

Tail missing; fish partially eaten by turtles. 
APPENDIX E

CHECKLIST OF BENTHIC MACROINVERTEBRATE TAXA FROM WHTTE OAK CREEK WATERSHED

MAY 1986-APRIL 1987 


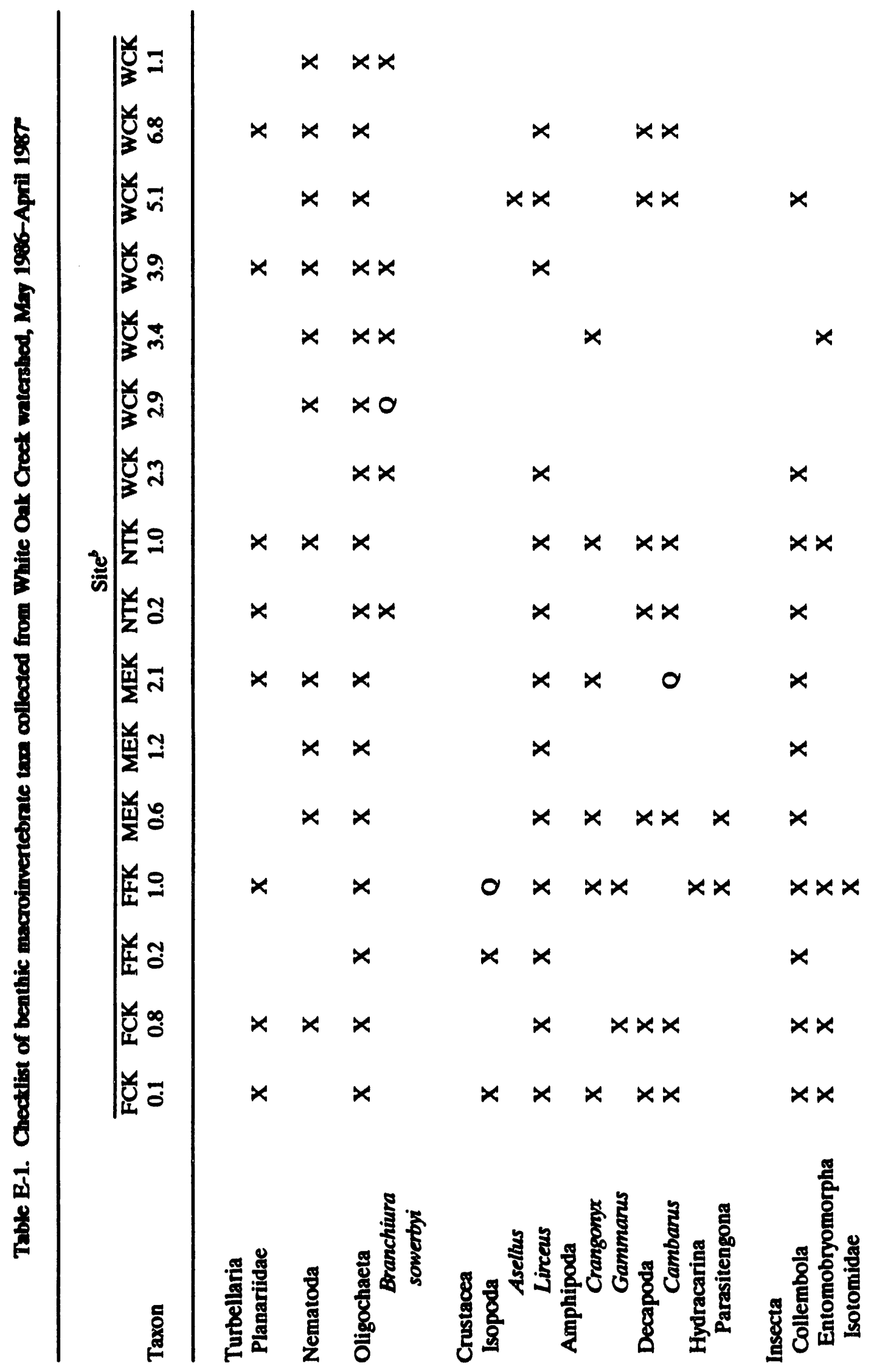


316

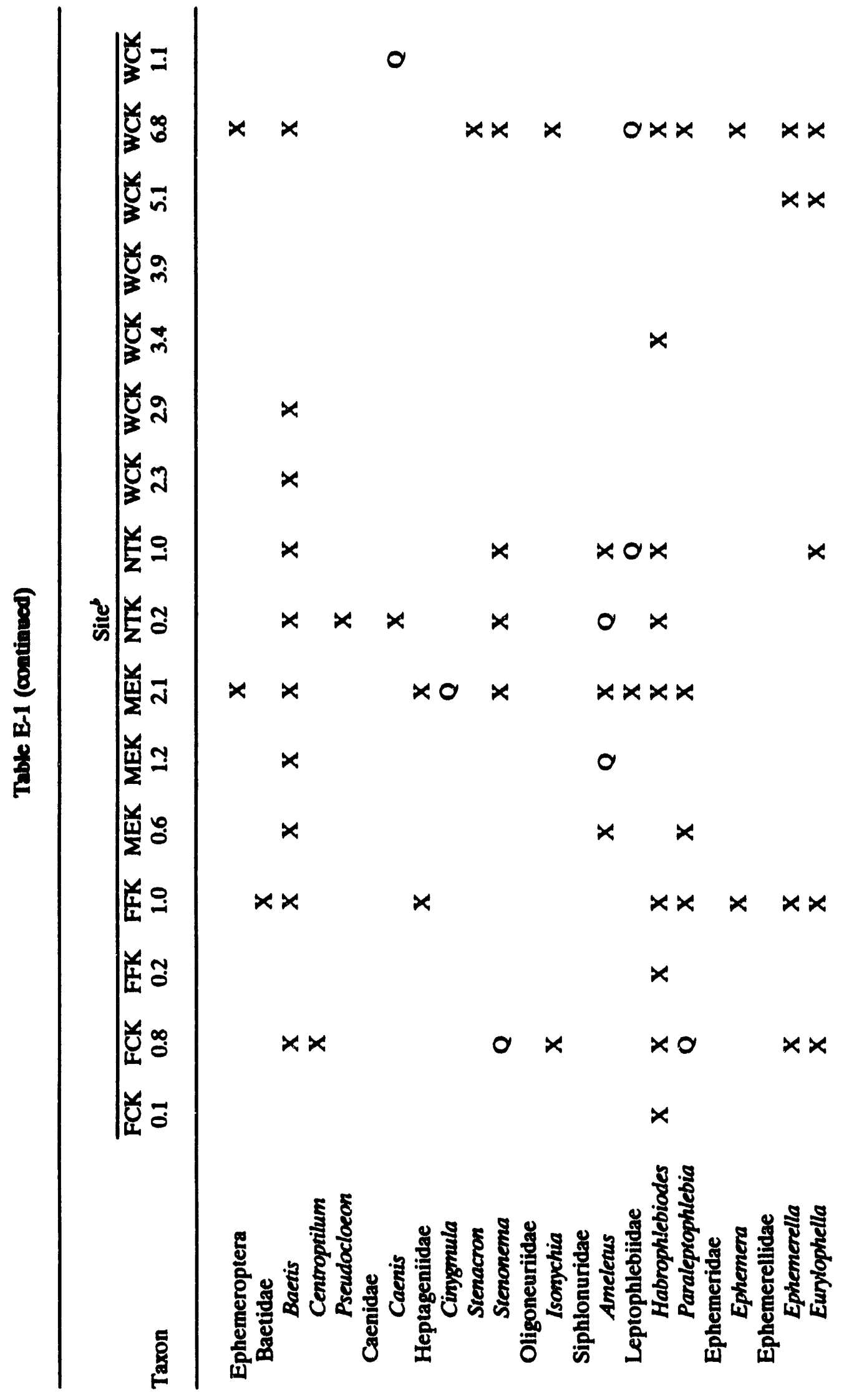




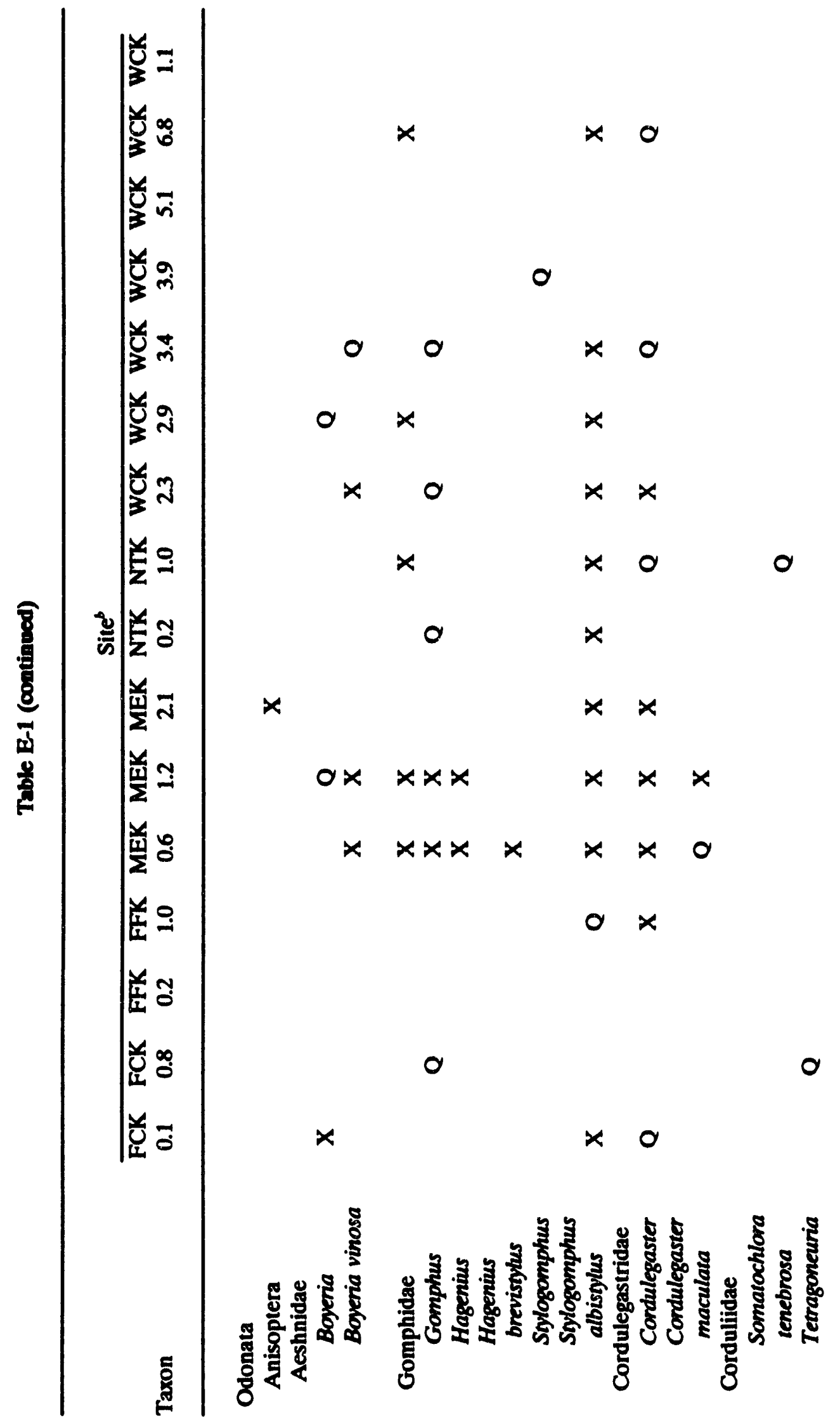




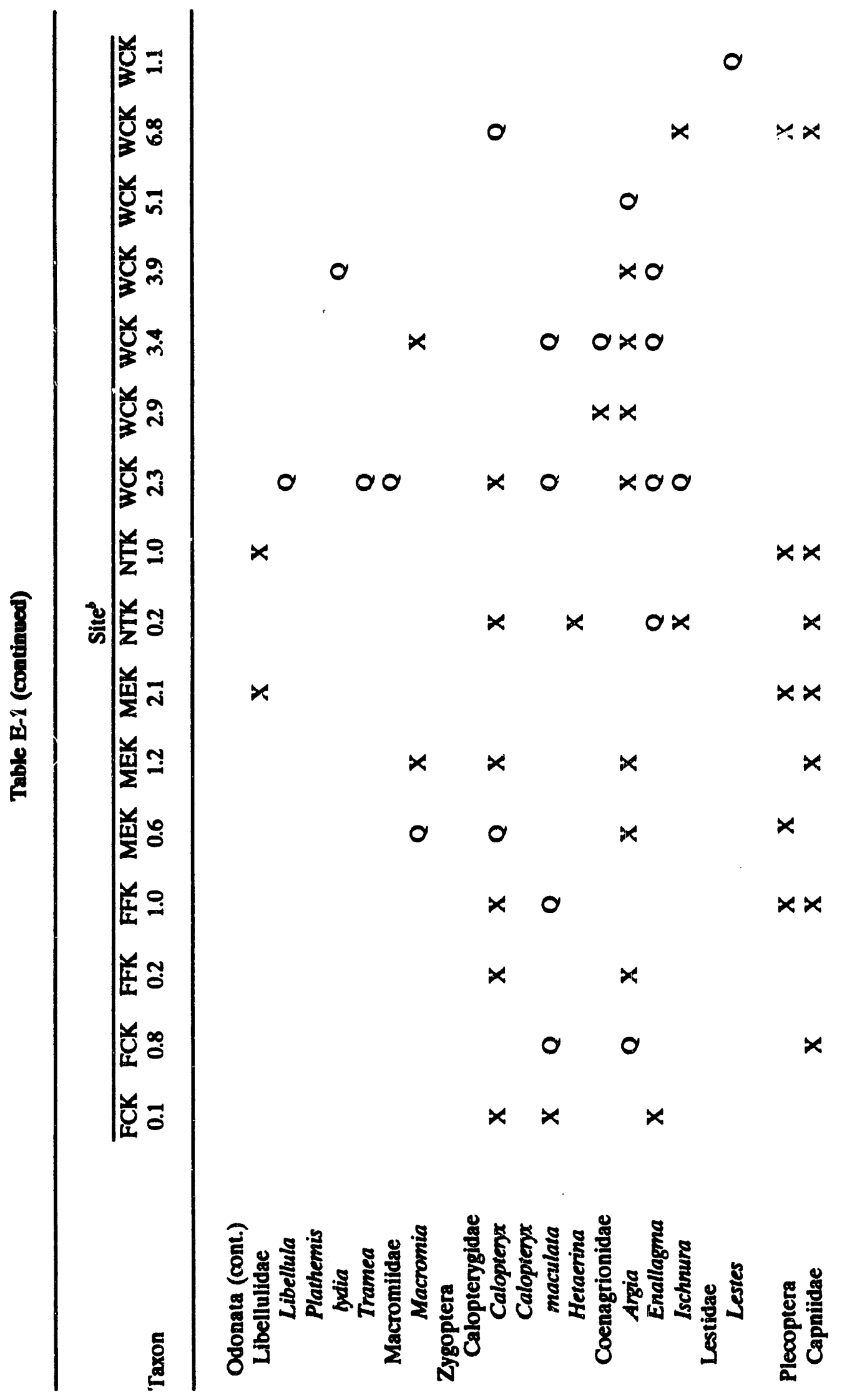




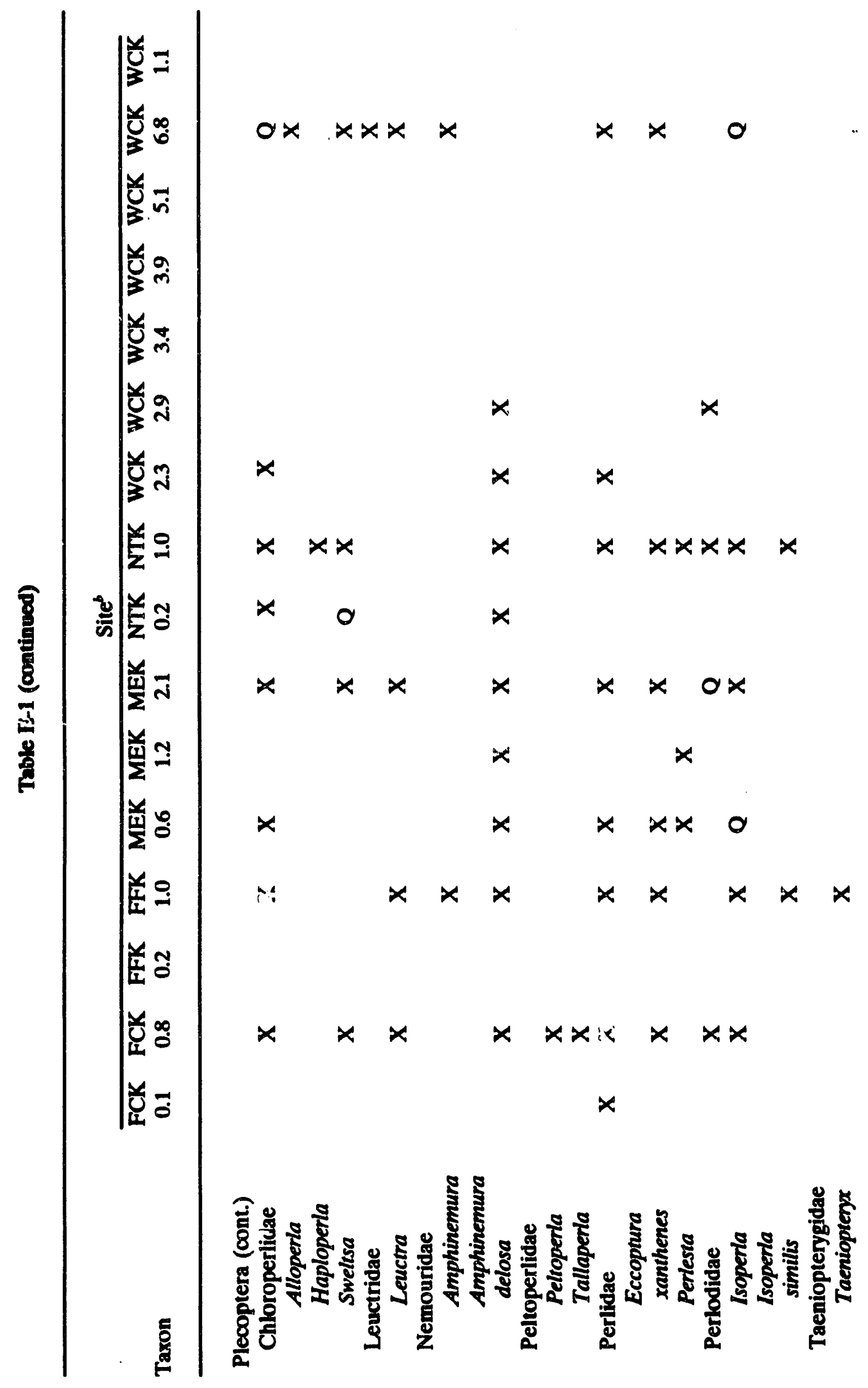




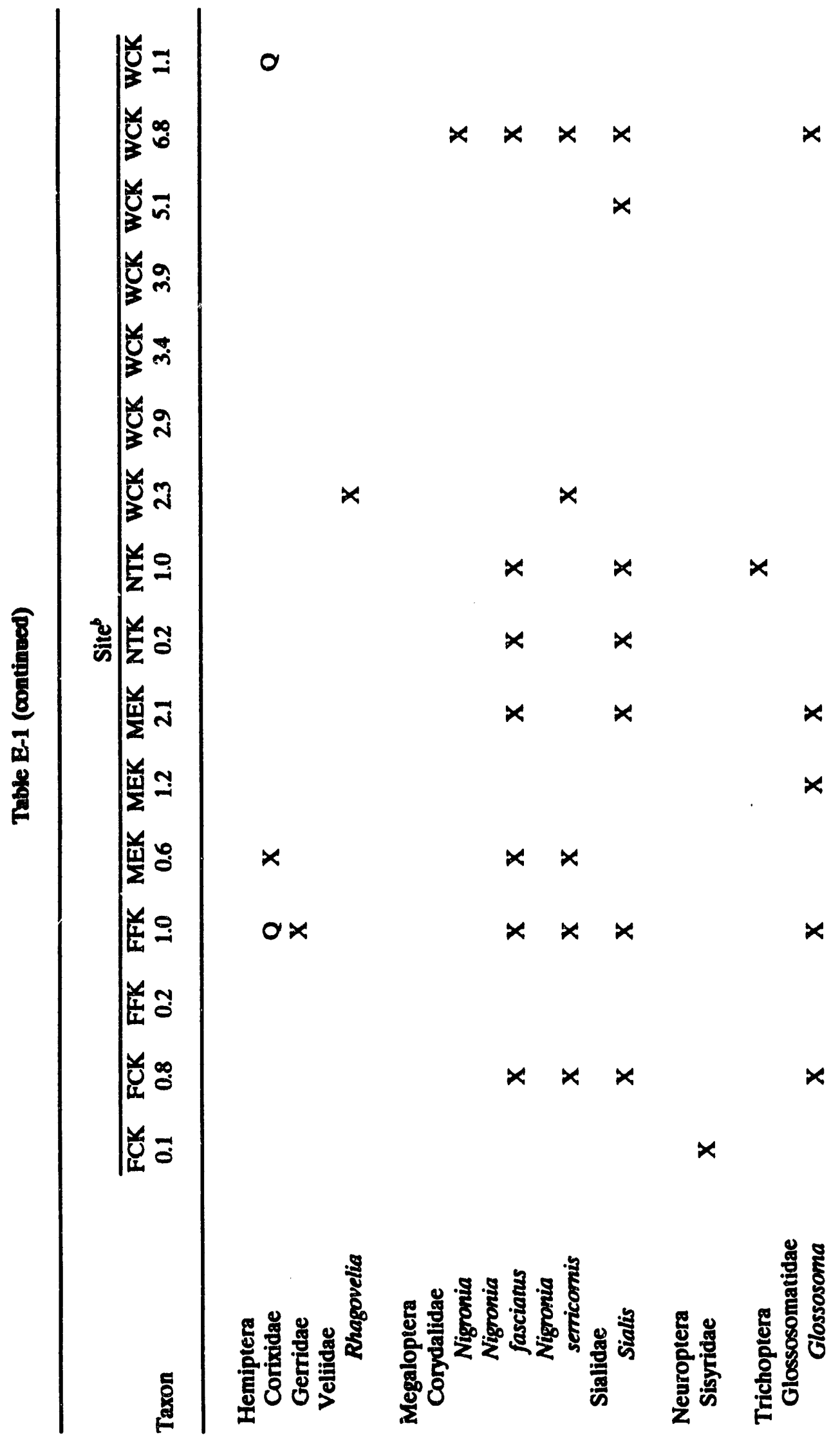




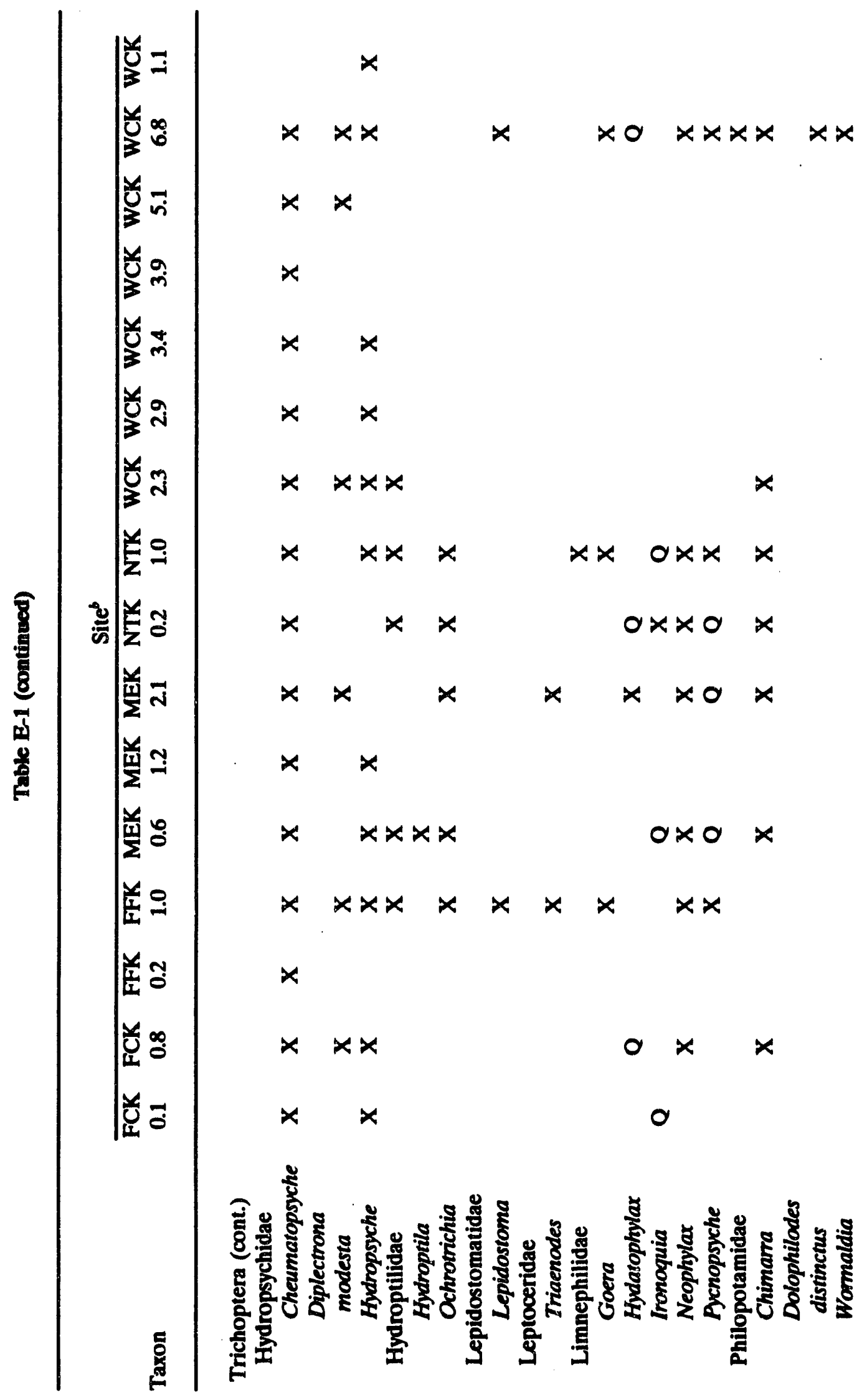




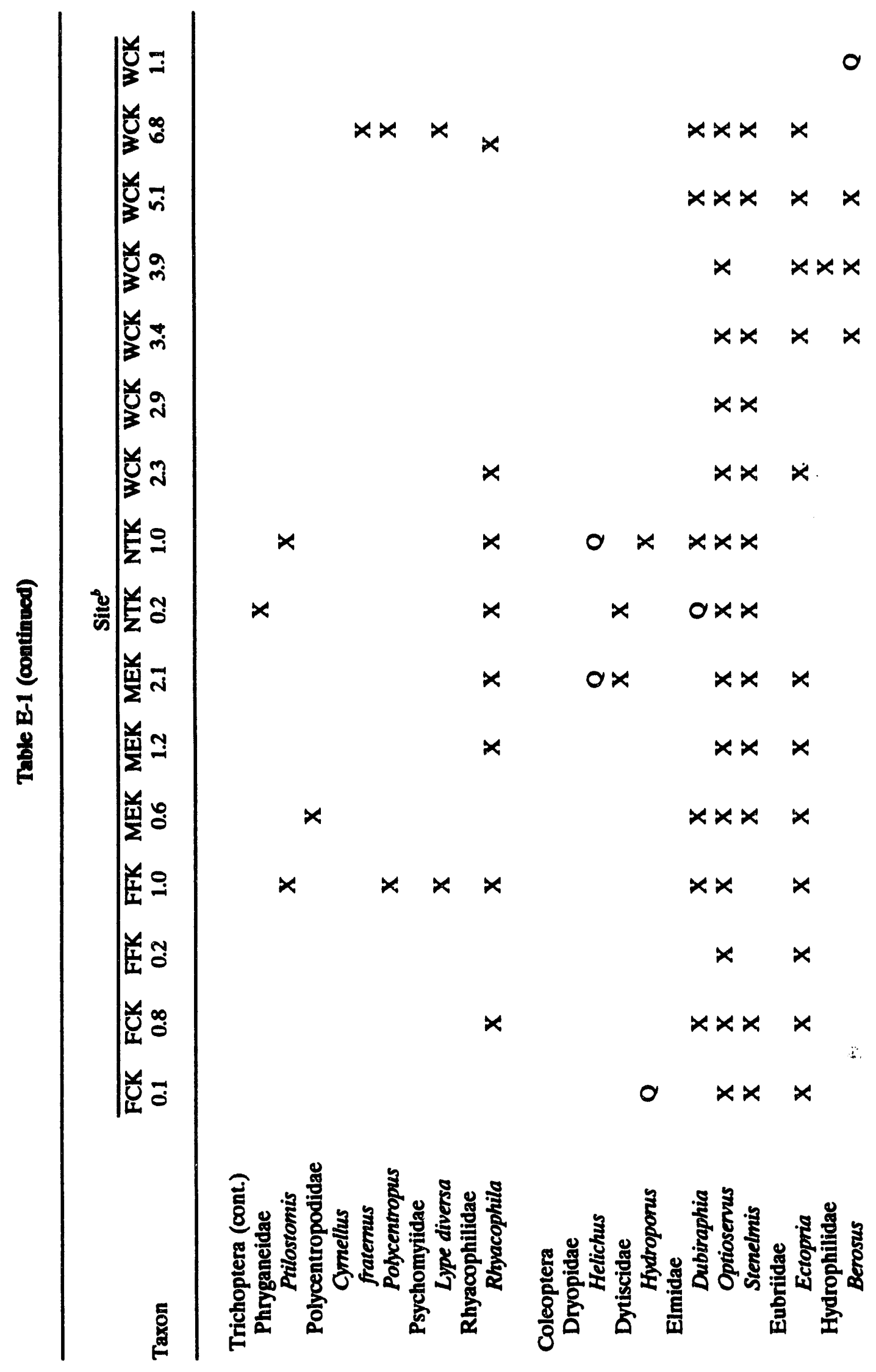




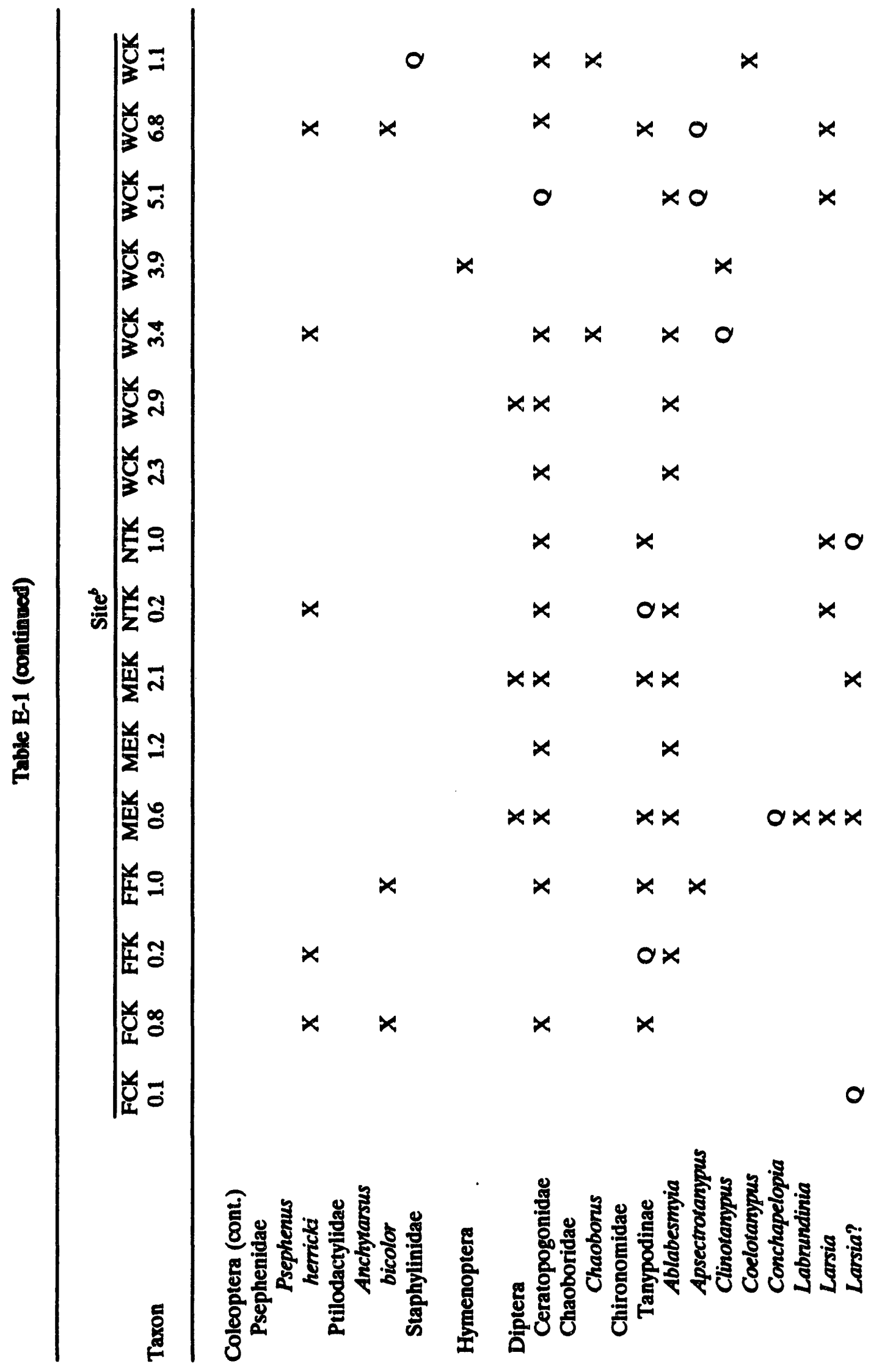




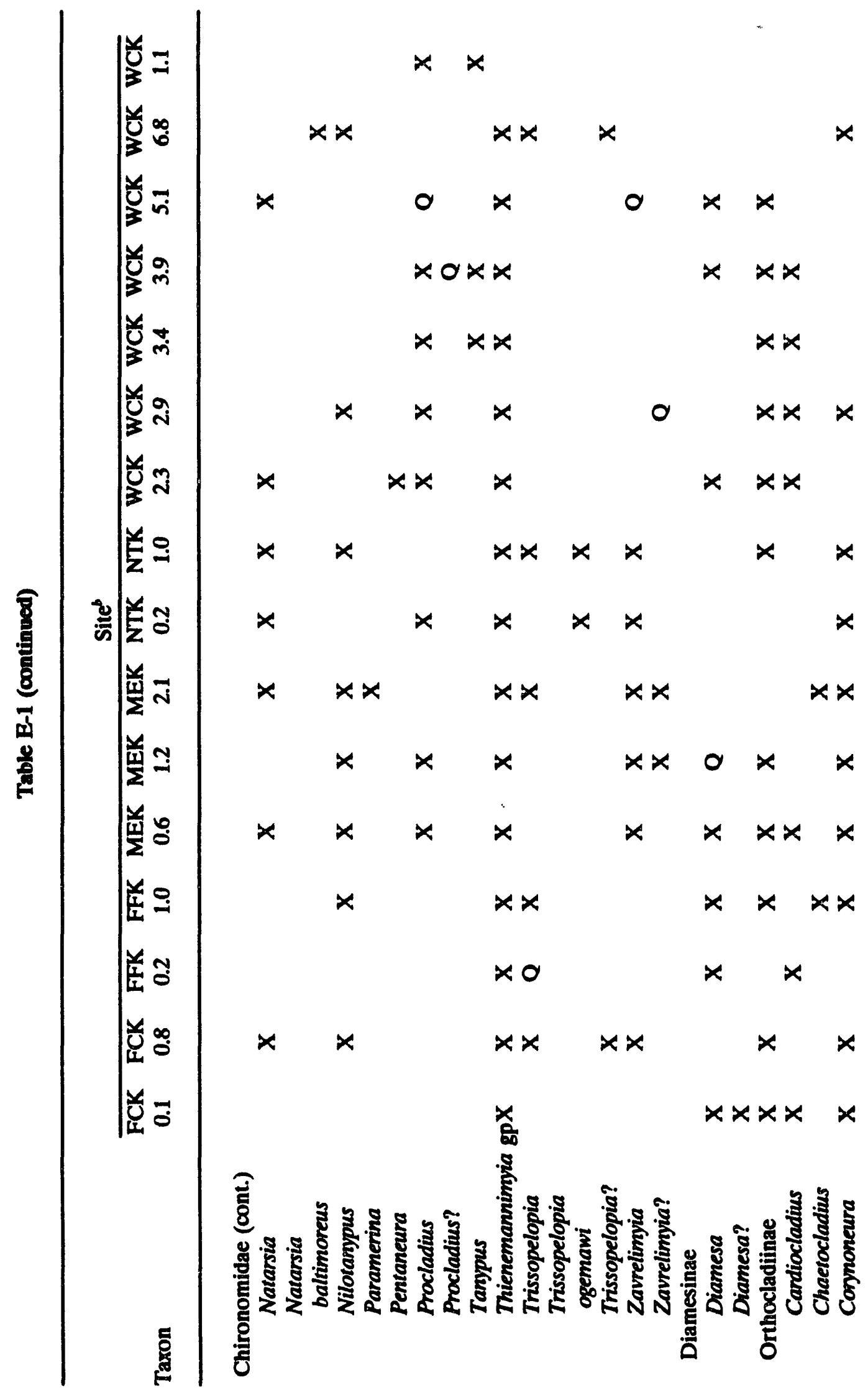




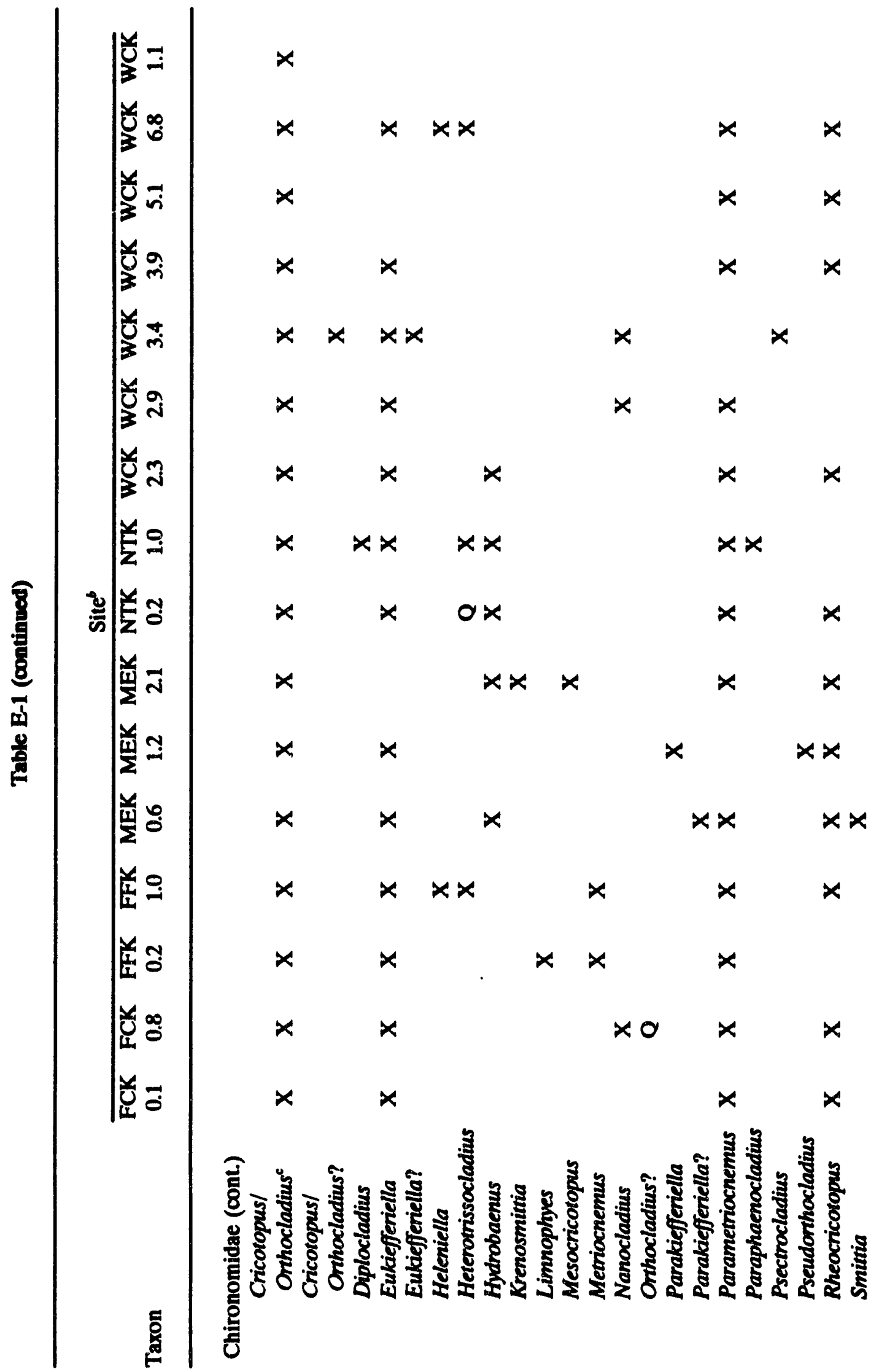




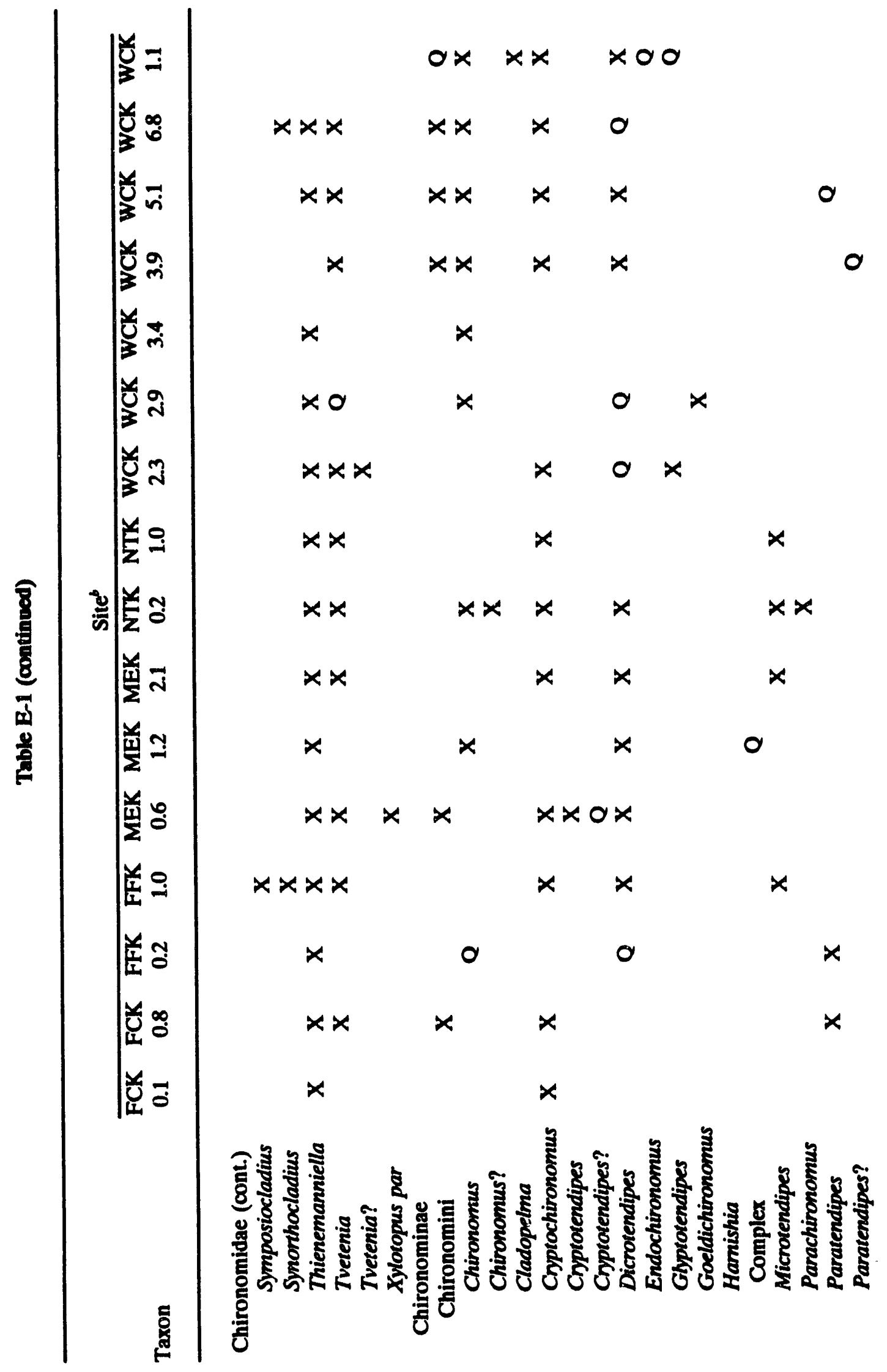




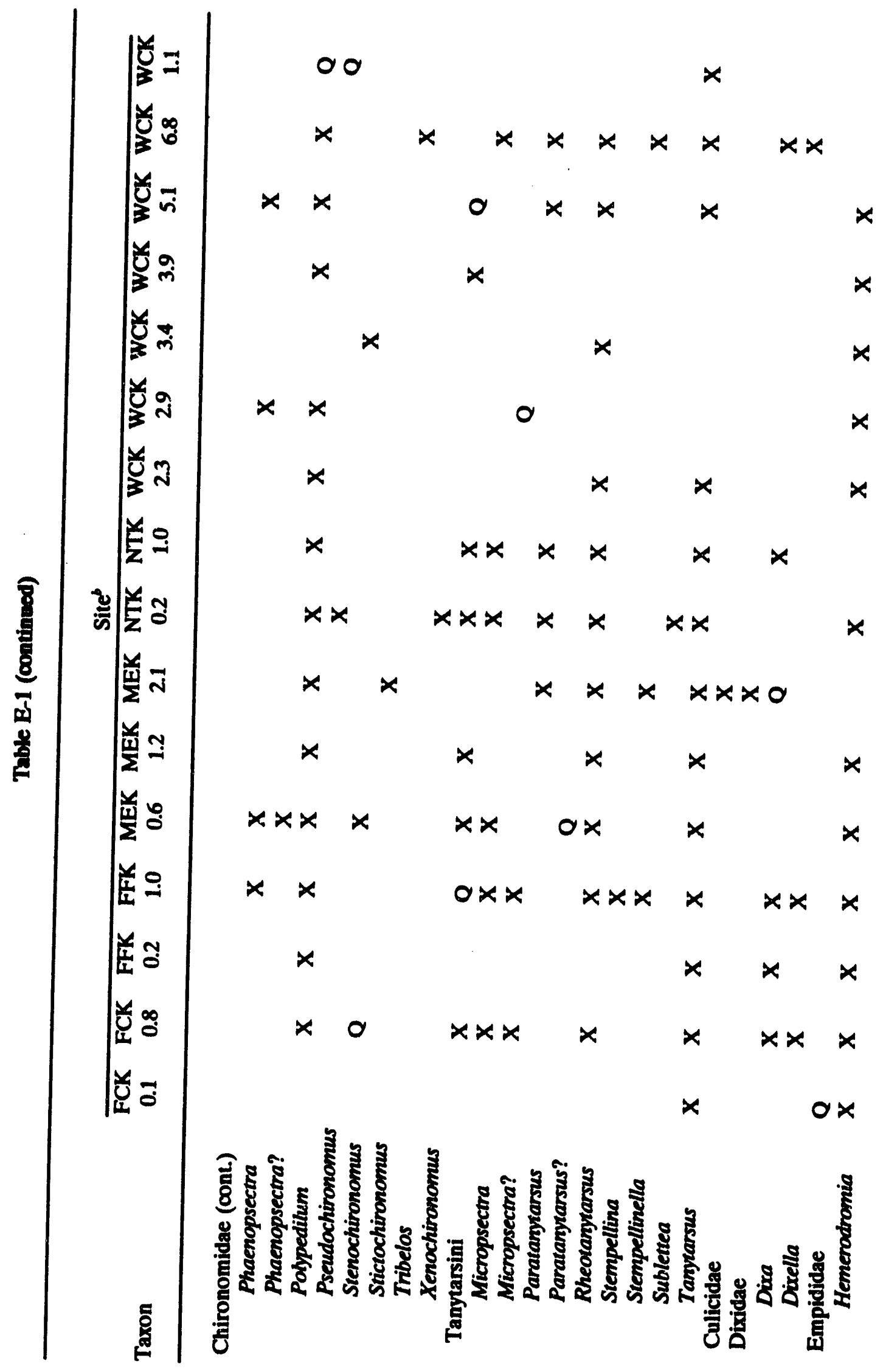




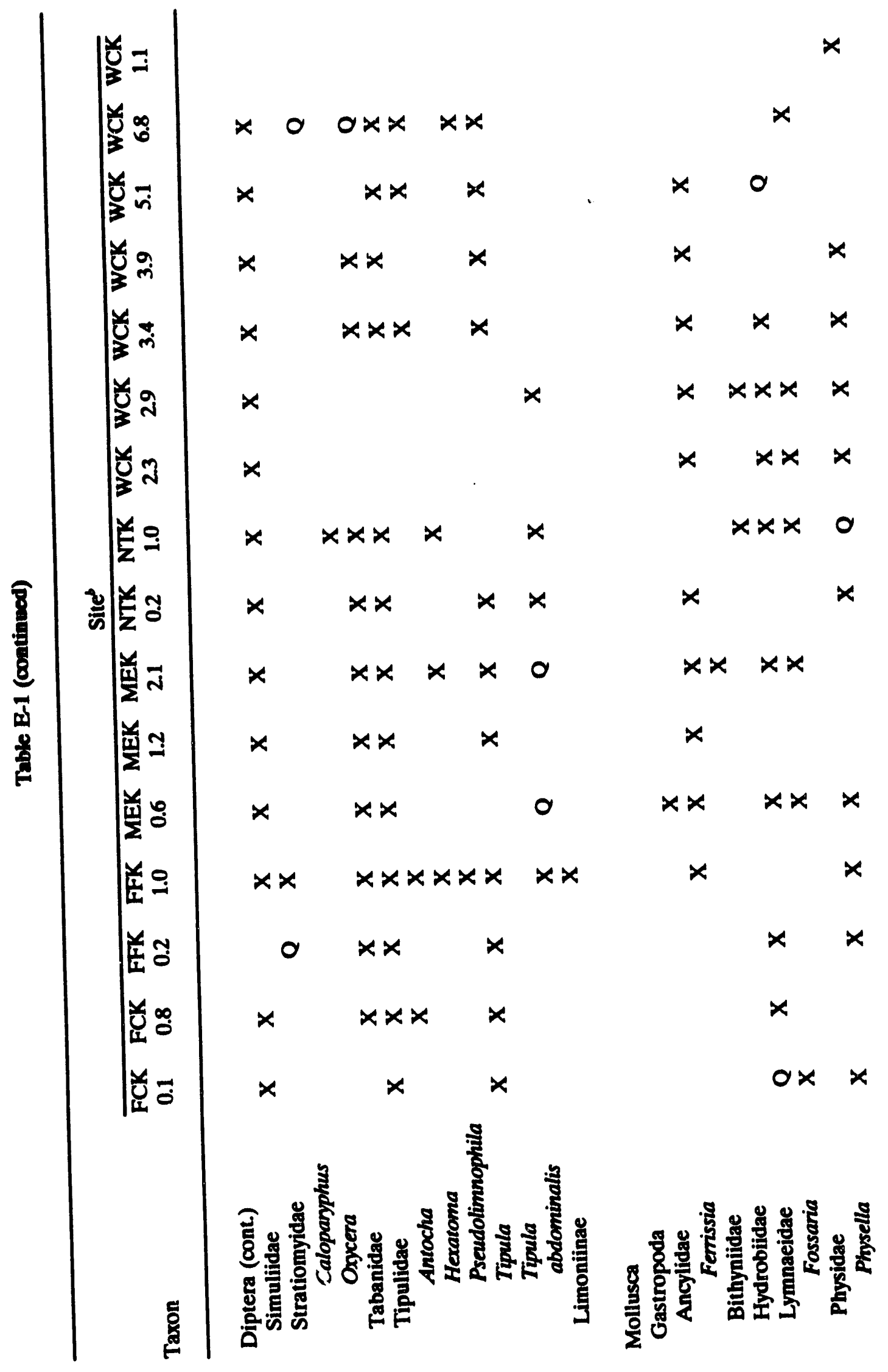




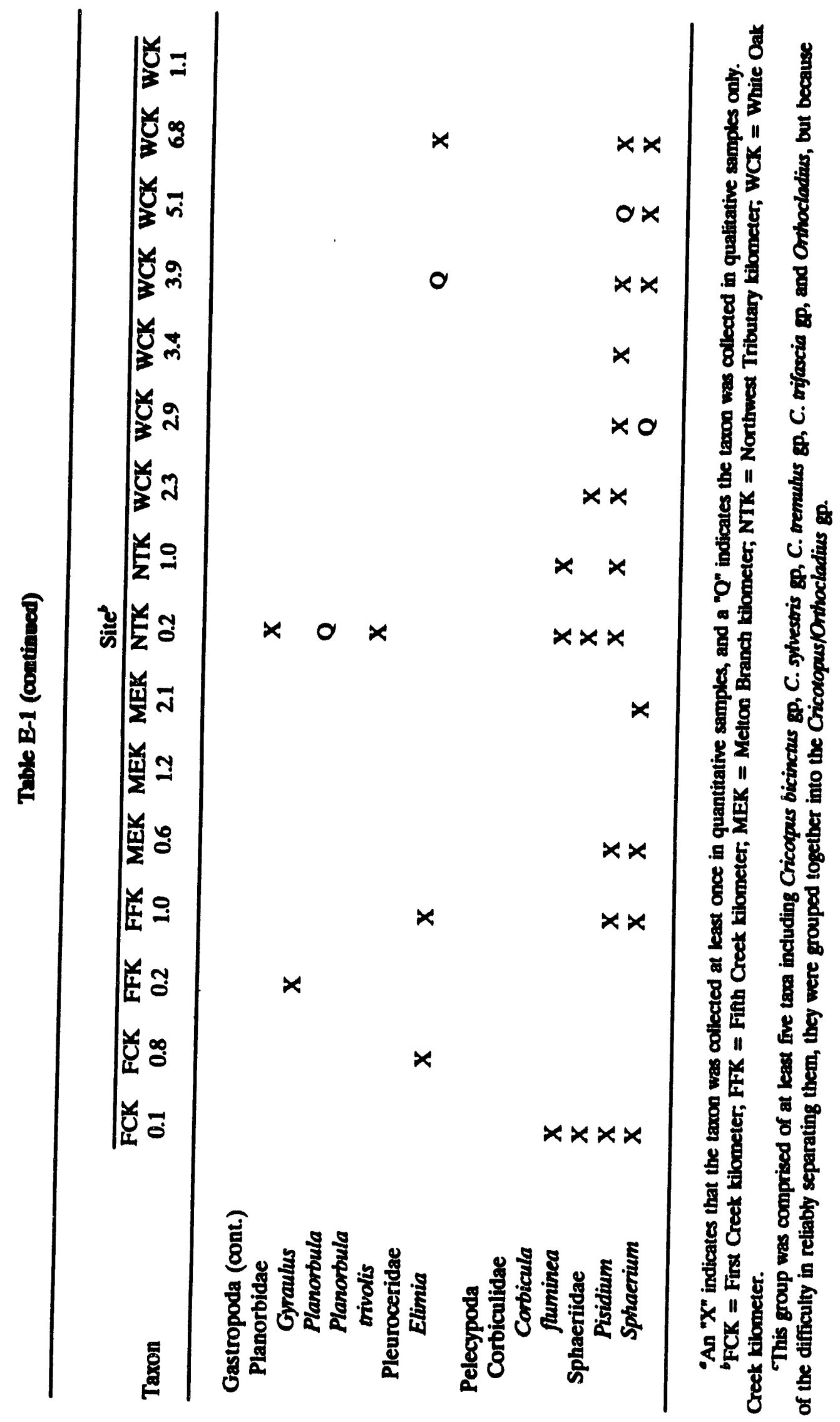


APPENDIX F

FISH POPULATION AND BIOMASS ESTIMATES OF WHITE OAK LAKE 


\section{APPENDIX F}

\section{FISH POPULATION AND BIOMASS ESTIMATES OF WHITE OAK LAKE}

\section{INTRODUCTION}

WOL has functioned as a settling basin for ORNL radioactive effluents for over four decades. As a result, radionuclides and other contaminants have accumulated in the sediment and biota. Fish inhabiting WOL are exposed to environmental irradiation not only from external sources, such as water and radioactive sediment, but also from internal sources as a result of consuming food that has accumulated radionuclides (Krumholz 1956). The quantity of fish and quantity of radioactivity they contain would be an essential component in the assessment of alternatives for remedial actions.

In May 1987, a standing crop estimate of the prevalent fish populations in WOL was conducted to (1) determine the distribution, biomass, and species composition of the fish community of WOL; (2) provide baseline fish population data in order to be able to evaluate any future actions affecting WOL; (3) provide supporting data for determining the radionuclide concentrations in the various fish species; and (4) evaluate methods for assessing fish populations in shallow lentic systems such as WOL.

\section{F.1 METHODS}

A mark and recapture, Petersen ratio was employed to estimate fish populations (Everhart et al. 1975). This was augmented by a Schnabel procedure that allows for multiple marking and recapture periods (Seber 1973). The two methods produce similar estimates and both rely on the same principle. A sample of fist. is collected, marked, and released. At a later time a second "recapture" sample is taken that includes both marked and unmarked fish. It is assumed that the proportion of marked fish recovered (R) to the total number of fish in the recapture sample (C) is the same as the proportion of the total number of marked fish released $(\mathrm{M})$ is to the total population $(\hat{N})$,

$$
\frac{M}{\hat{N}}=\frac{R}{C} \text { or } \hat{N}=M C / R \text {. }
$$

The Schnabel method provides for multiple marking and recapture periods using all accumulated data for one estimate. This method assumes that no mortality occurs during the series of releases and recaptures. During the course of the WOL population estimate, however, mortality occurred and was carefully adjusted for. At the end of each of the $5 \mathrm{~d}$ in which fish were marked and released, and for $2 \mathrm{~d}$ thereafter, the entire shoreline of the WOL was examined for dead fish. Fish were marked by clipping a specific fin to correspond to a specific collection date. Dead fish with a clipped fin could thus be identified and subtracted from the number of fish marked on that day. These mortality-adjusted daily values were summed to provide the total number of marked fish 
available for recapture $(M)$. The mortality adjustments could be readily applied to the Petersen ratio estimates, but not to the Schnabel method.

All mortality did not occur quickly but was spread over a period of several days. This made it difficult to adjust the number of marked fish available in WOL for each set of releases and recaptures that took place during the time period the fish were dying. The Petersen method allows time for marked and unmarked fish to mix before a recapture. In this study, $4 \mathrm{~d}$ elapsed before a single-day recapture effort was initiated, thus allowing sufficient time for decomposing fish to float to the surface where they were collected, examined for marks, and used to make appropriate adjustments in the pool of available marked fish. Because the Schnabel method assumes no mortality, and corrections for mortality could only be made for the Petersen estimate, the most reliable method in this case was the Petersen ratio. The Schnabel method was used because a population estimate could be calculated at the end of each successive marking run in which previously marked fish were recovered. In this way, an apprcximation of the total number of fish in the population could be obtained and used to determine whether an adequate number of fish had been marked to yield a reliable estimate of the population by the Petersen method.

Sampling was conducted with a Smith-Rooi type IV, boat-mounted electrofisher with pulsed DC current and one or two booms. Prior to sampling, WOL was divided into quadrants, and each quadrant was sampled thoroughly for 30 to $60 \mathrm{~min}$. Daily fish collections started in the northeast quadrant and proceeded in a clockwise direction until each quadrant had been sampled twice. For processing, two boats containing personnel and processing equipment were towed from quadrant to quadrant. A single electrofishing boat was used during the marking runs, and an additional electrofishing boat was used during the single-day recapture period.

Fish were identified to species, weighed, measured, marked with a fin-clip, and released in the same quadrant in which they had been collected. In order to facilitate rapid processing of many fish, fish were $n$ o longer weighed after 20 individuals of a species within a 2-cm-length class had been weighed. Weights for the remaining individuals were estimated from a length-weight regression developed from the WOL data. The five collection days represented the multiple marking and recapture periods that constituted the data base for the Schnabel population estimates. After a 4-d hiatus, an intensive 1-d recapture effort was made with the goal of capturing 1500 fish. Fish collected during the recapture run were not weighed or measured, but were identified by species, examined for fin-clips, and then placed in one of two large floating cages. Large carp and predators, such as largemouth bass (Micropterus salmoides) and spotted gar (Lepisosteus osseus), were held in one cage and the remaining species in the other. In this manner, processed fish were separated from the remainder of the fish in the lake and were not included in any following collections, thus meeting a condition required for the application of the Petersen ratio or "point census" method.

The area of WOL was determined by use of a planimeter and an aerial photograph taken in July 1987, less than two : nonths after completion of the population survey. The scale of the photograph (1:400) was determined by measuring between known points on th. map. A small portion of WOL that included the mouth of WOC and the water at the 
upper end of the lake was too shallow for the electrofishing boat. Therefore, this area was partitioned off by use of a block net. Thus, the total area of WOL is slightly greater than the area $(5.26 \mathrm{ha})$ sampled for the calculation of fish biomass.

\section{F2 RESULTS AND DISCUSSION}

During the marking runs, significant numbers (in decreasing order of abundance) of bluegill, gizzard shad, largemouth bass, redear sunfish, common carp, redbreast sunfish, and warmouth sunfish were collected. Much smaller numbers of an additional 11 species were also collected (Table F-1). The list of the most abundant species changes when the estimated population size $(\hat{N})$ is used to rank the species (in descending order of abundance): bluegill sunfish, gizzard shad, redear sunfish, largemouth bass, carp, golden shiner, and redbreast sunfish. When $(\hat{N})$ is used to calculate biomass $(\hat{N} \times$ mean weight per individual), the relative ranking based on decreasing biomass is carp, gizzard shad, bluegill sunfish, largemouth bass, redear sunfish, warmouth, redbreast sunfish, and golden shiners. Golden shiners, redear sunfish, and warmouth sunfish had a very broad (95\%) confidence interval about the population estimate.

Based on the biomass of the above eight species, a reasonable trophic level pyramid can be constructed by assigning the largemouth bass the role of top predator, the remaining centrarchids to an intermediate level, and the common carp, gizzard shad, and golden shiner to the lowest level. The biomass of these three trophic levels are 233, 810, and $1778 \mathrm{~kg}$ respectively. From a bioenergetic point of view, these numbers are reasonable, thus lending support to the validity of the estimated population values. The Schnabel and Petersen ratio estimates produced similar results. The total fish community estimates ( \pm 1 s.d., all species combined) were $20,426 \pm 2,820$ and $23,345 \pm 2,745$ for the Schnabel and Petersen ratios respectively.

Estimates of fish standing crops were determined from biomass estimates and the area of the lake $(5.26 \mathrm{ha})$. The estimated total biomass for all species was $536.6 \mathrm{~kg} / \mathrm{ha}$. Standing crop estimates for individual species are given in Table F-1.

The fish populations of WOL will certainly change through time. Most small impoundments become increasingly eutrophic over time, with a shallow profile and greater primary productivity. These trends may enhance production and diversity for a time. In May 1987, WOL had an estimated standing crop of $198 \mathrm{~kg} / \mathrm{ha}$ for largemouth bass and other centrarchids. This is within the range of production (37-339 kg/ha) observed by Swingle (1952) for a series of fertilized ponds in Alabama that had been stocked with largemouth bass and various combinations of other centrarchids. The standing crop of largemouth bass and bluegill in WOL in 1953 was estimated by Krumholz (1956) to be $259 \mathrm{~kg} / \mathrm{ha}$. If siltation continues and littoral vegetation and plankton populations become more abundant, the resulting heavy organic content of the lake may change habitat conditions and alter fish production and species composition. The 1987 fish population estimates will provide a basis for comparison with any future changes in the fish populations of WOL. In combination with information on the concentrations of radionuclides in fishes from WOL, the standing crop estimates obtained in this study were used to calculate the total radionuclide content of the fish community component of the WOL ecosystem (Sect. 8.1). 


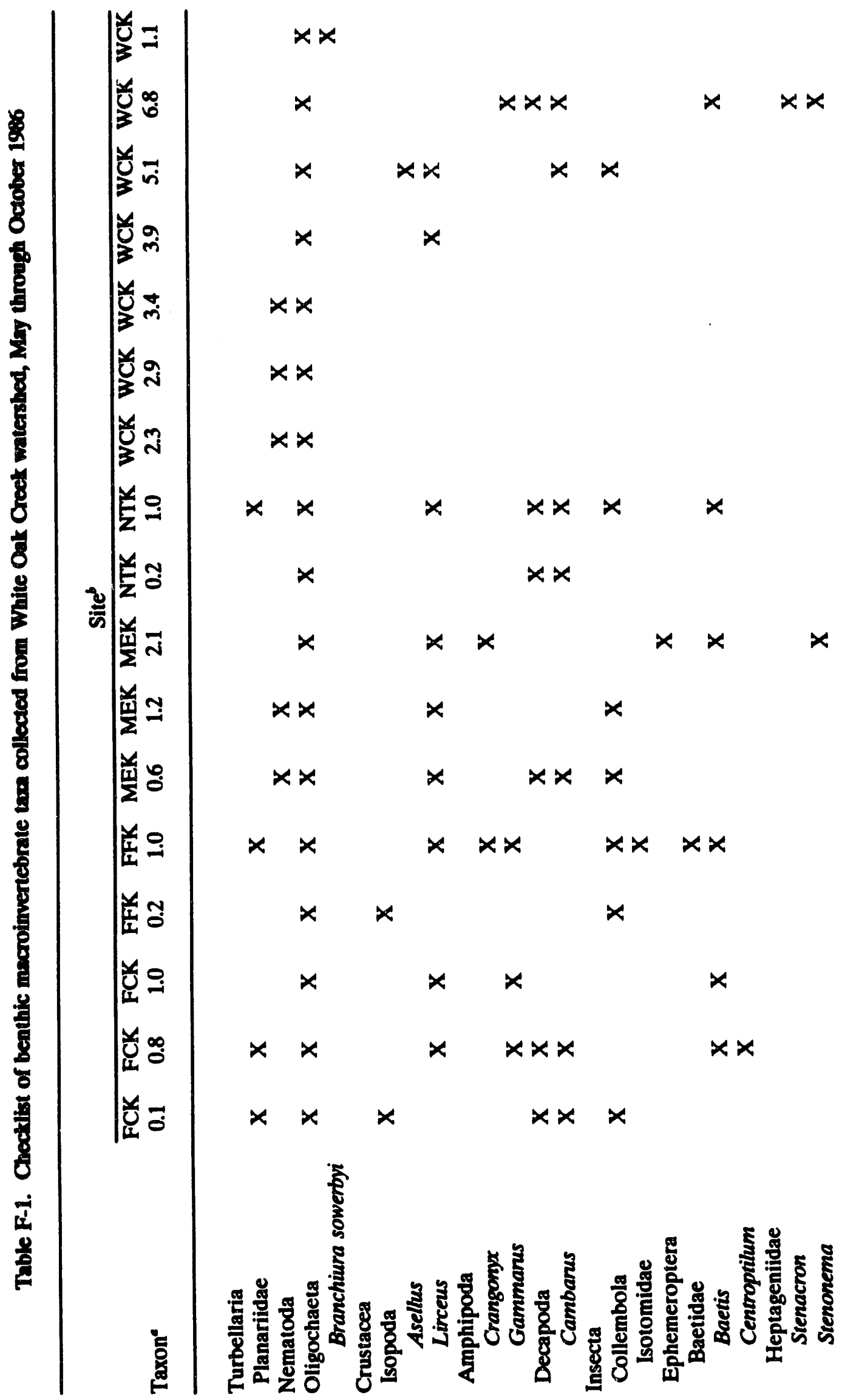




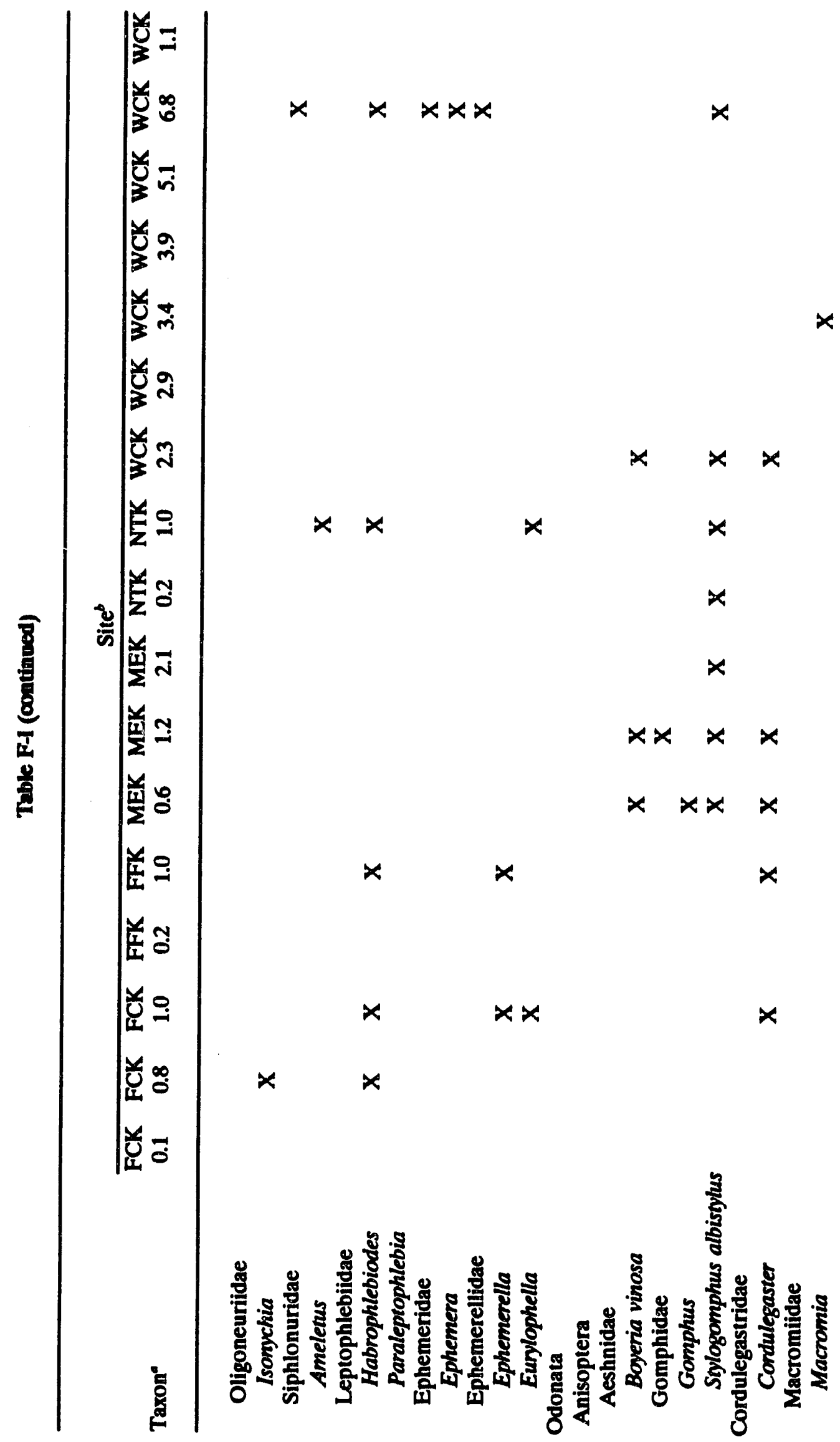




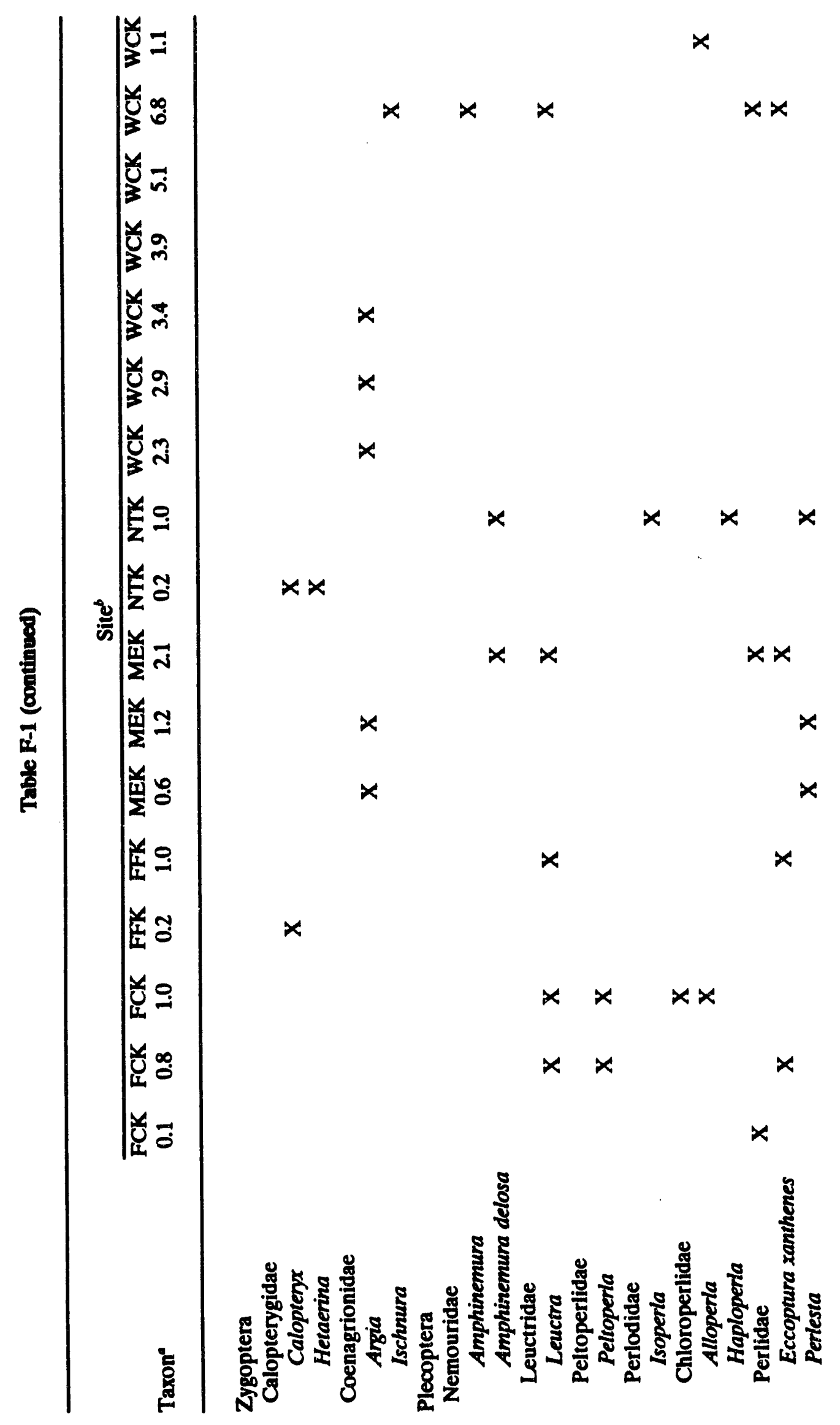




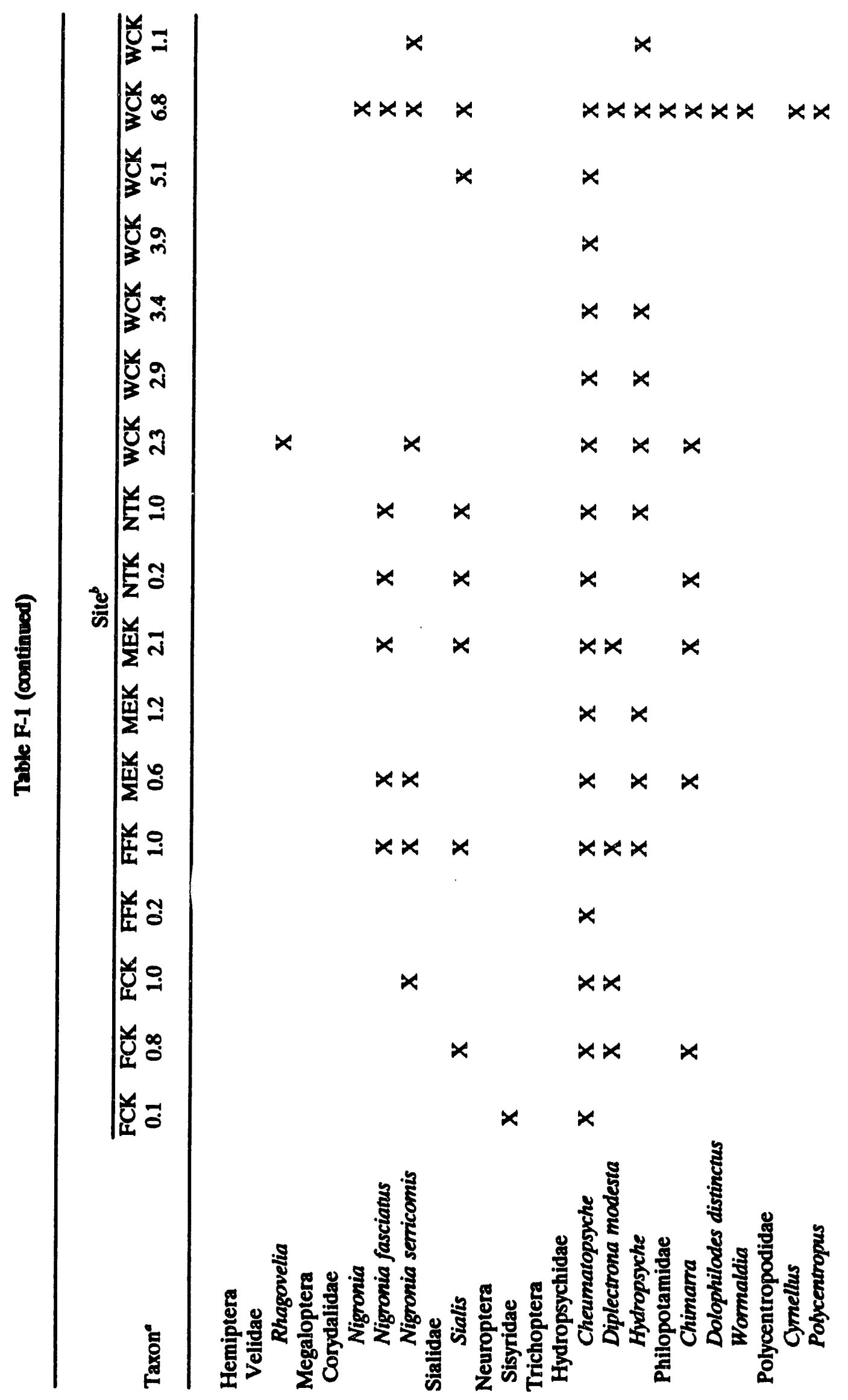




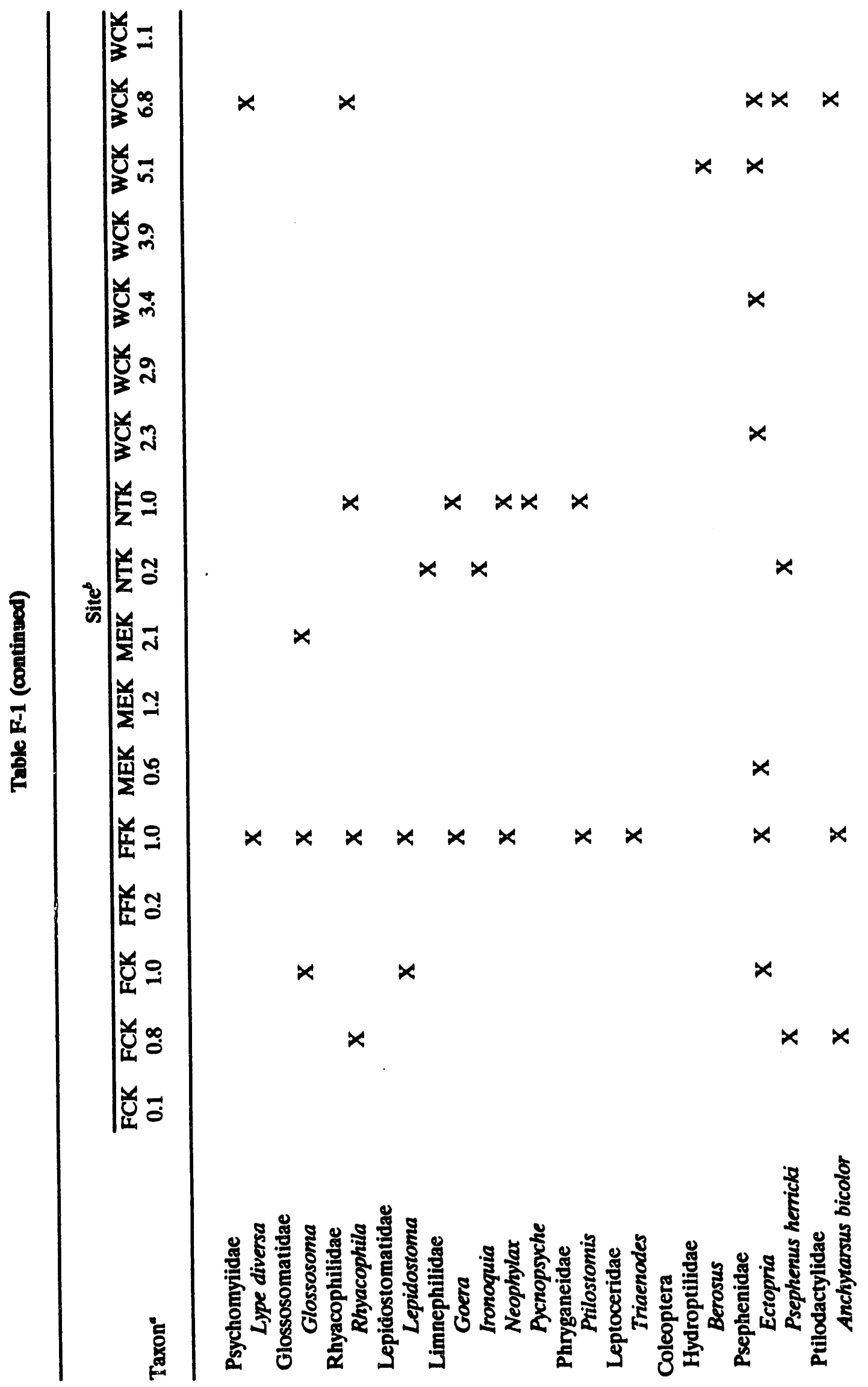




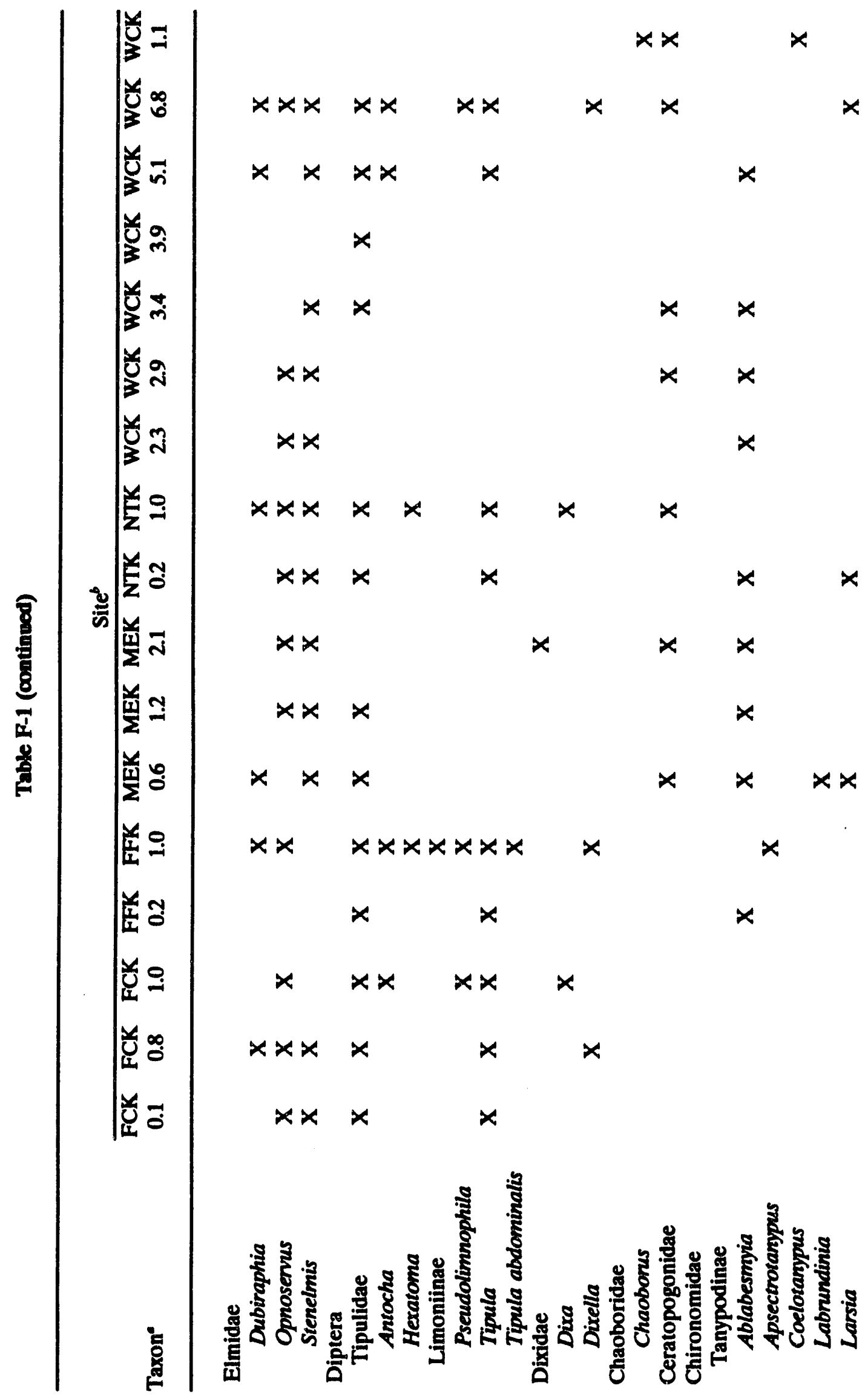




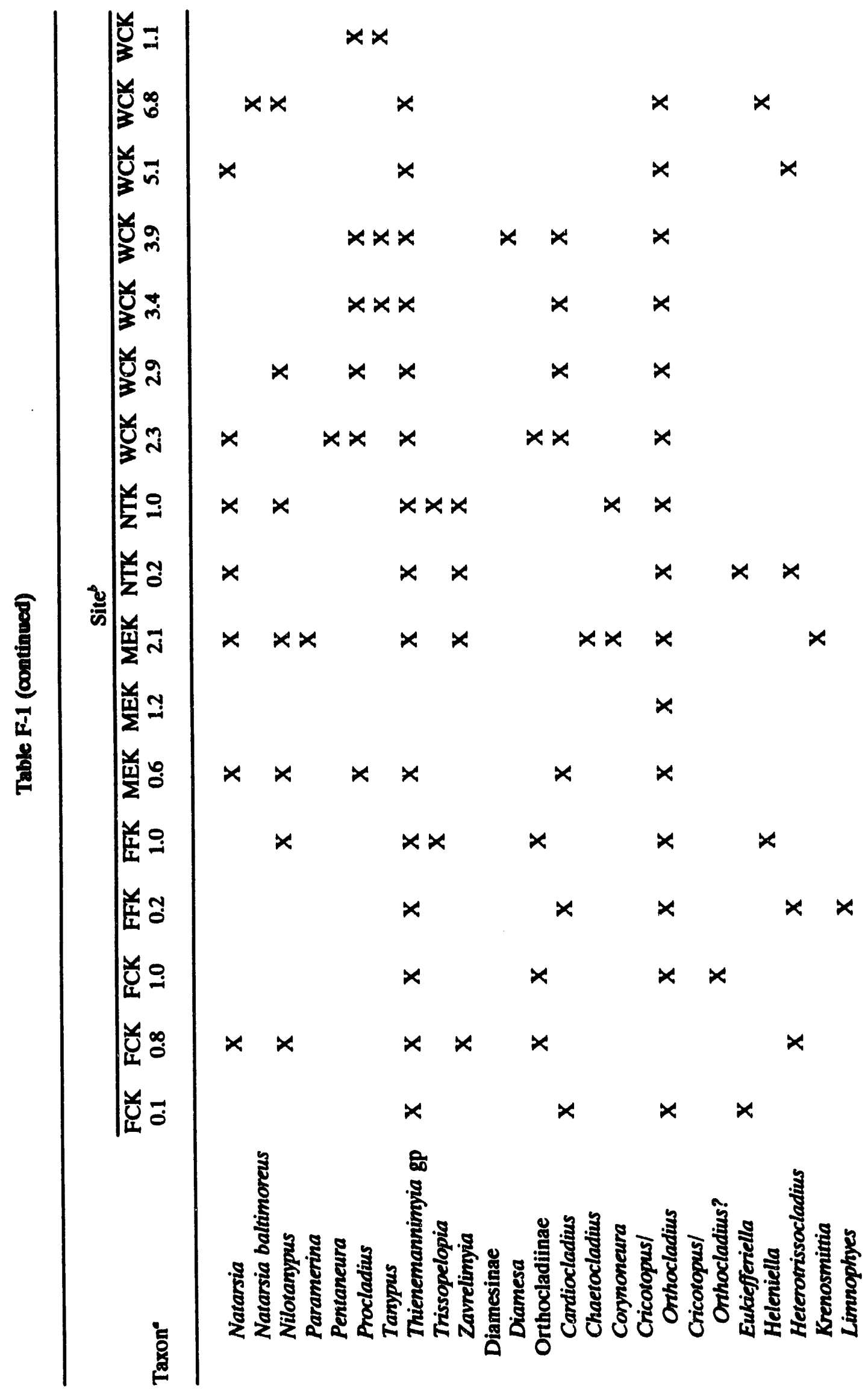




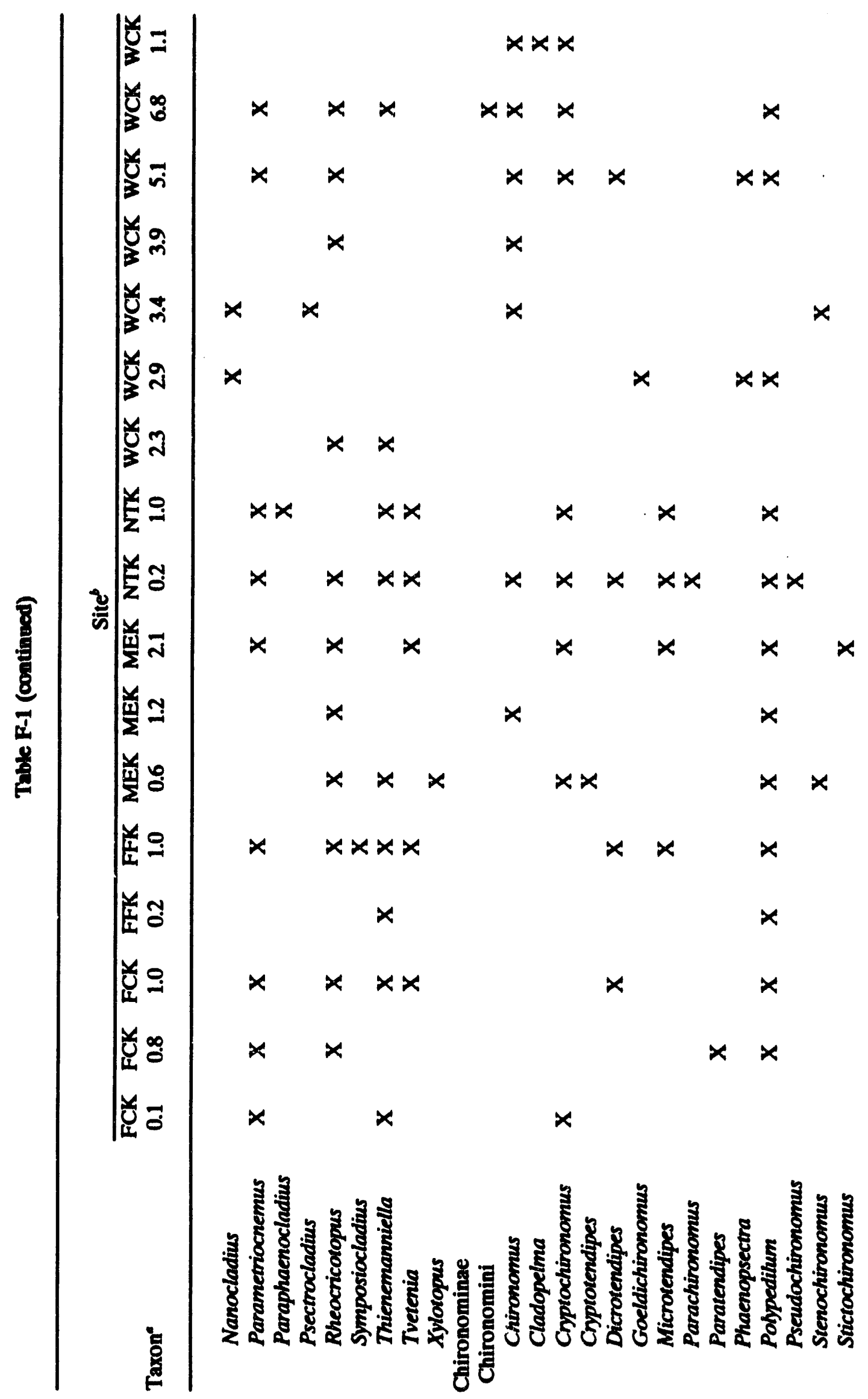




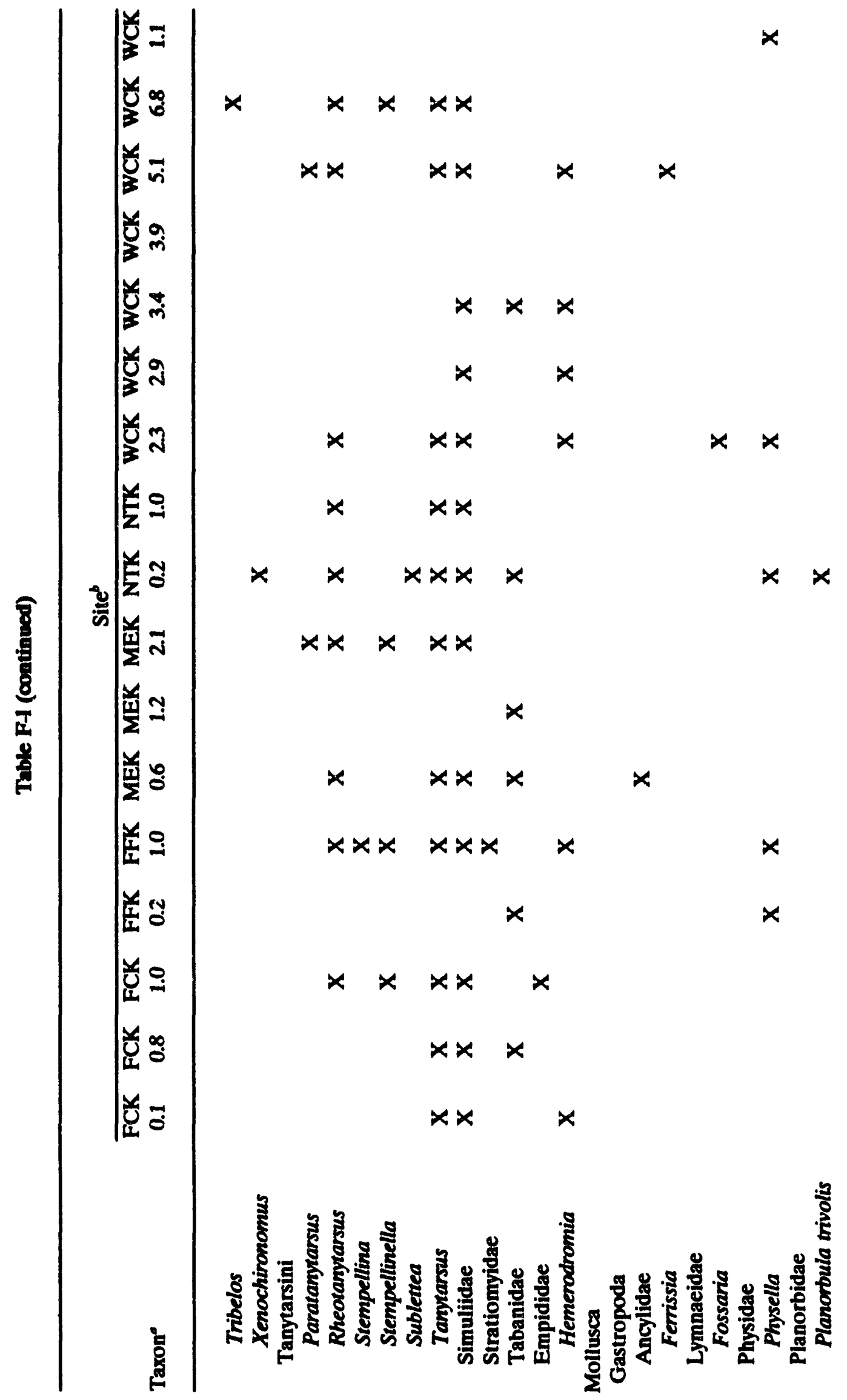




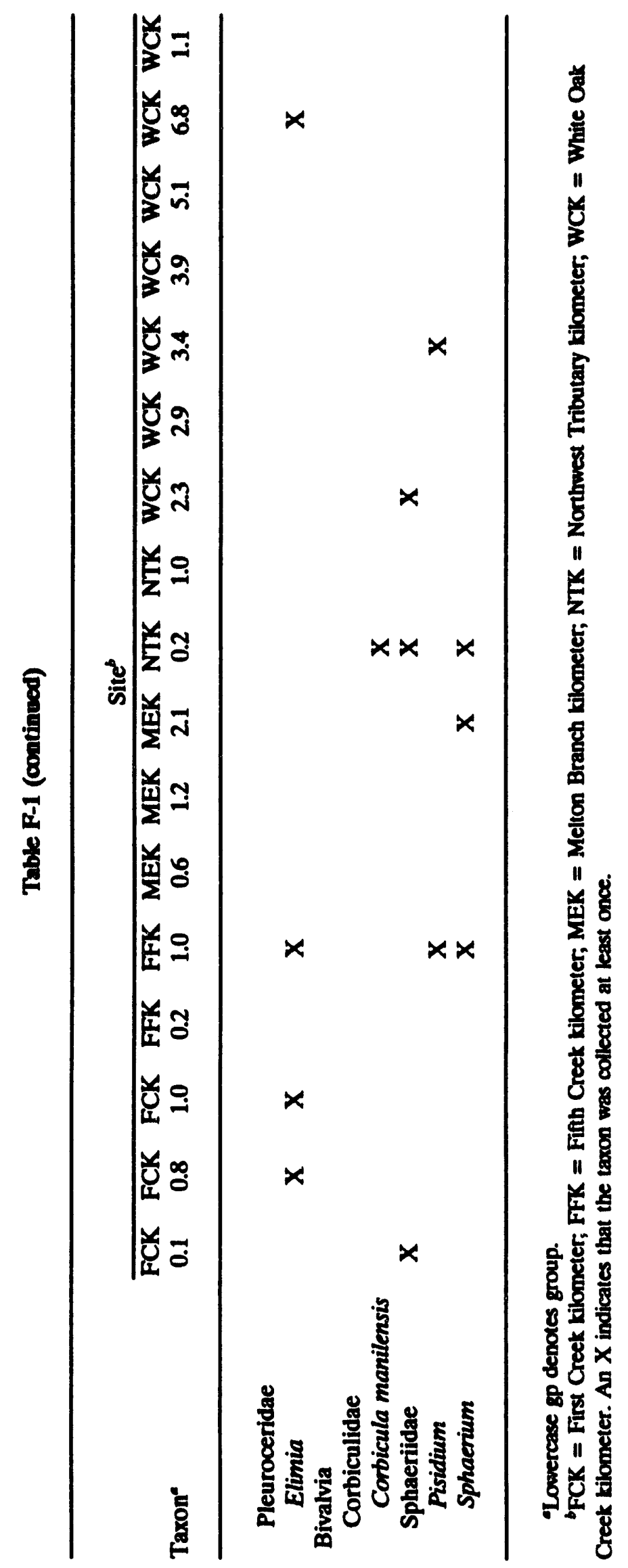


APPENDIX G

FISH DENSITY, BIOMASS, AND CONDITION FACTOR DATA COLLECTED IN WHITE OAK CREEK WATERSHED, JANUARY-DECEMBER 1987 


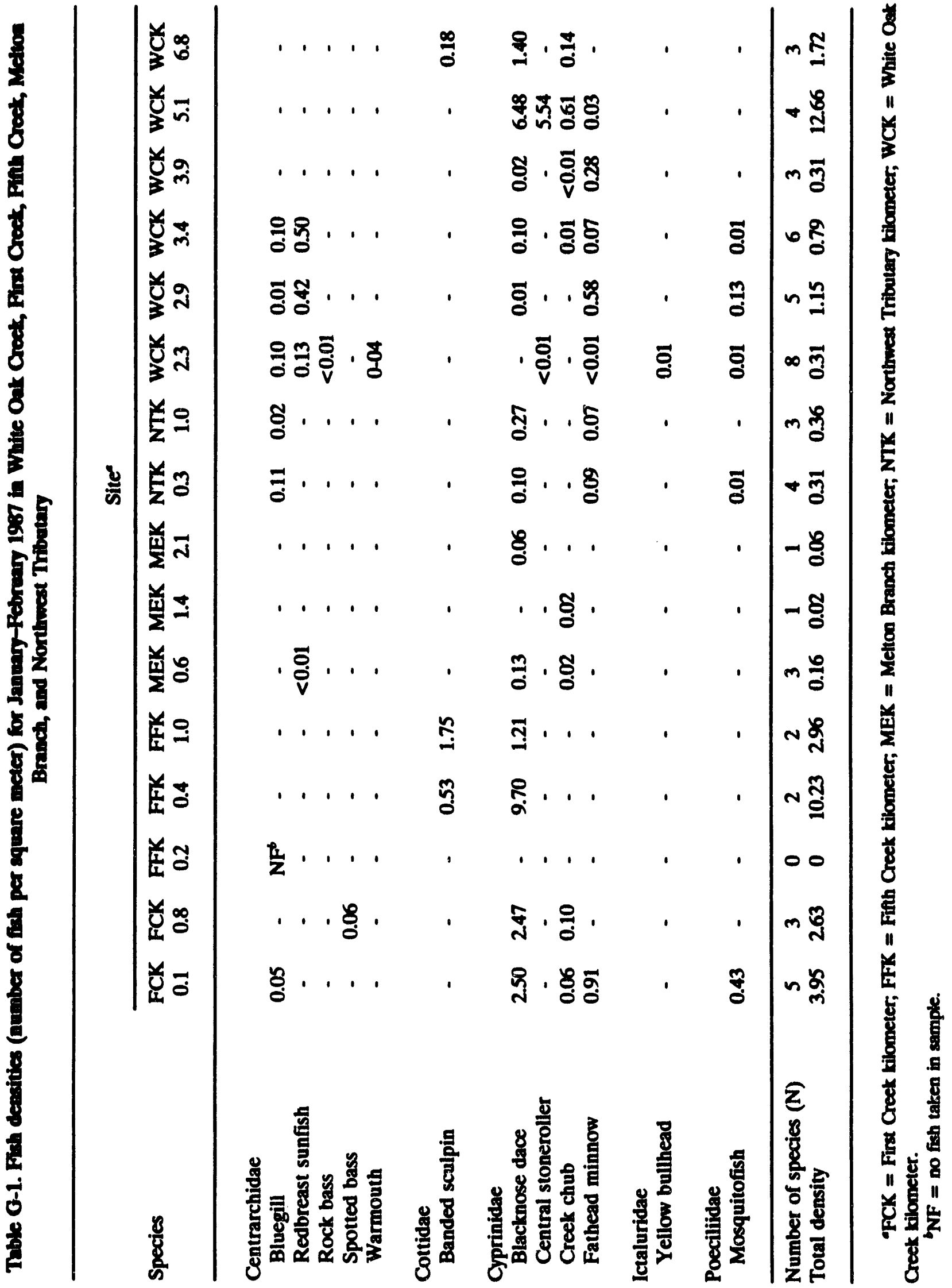




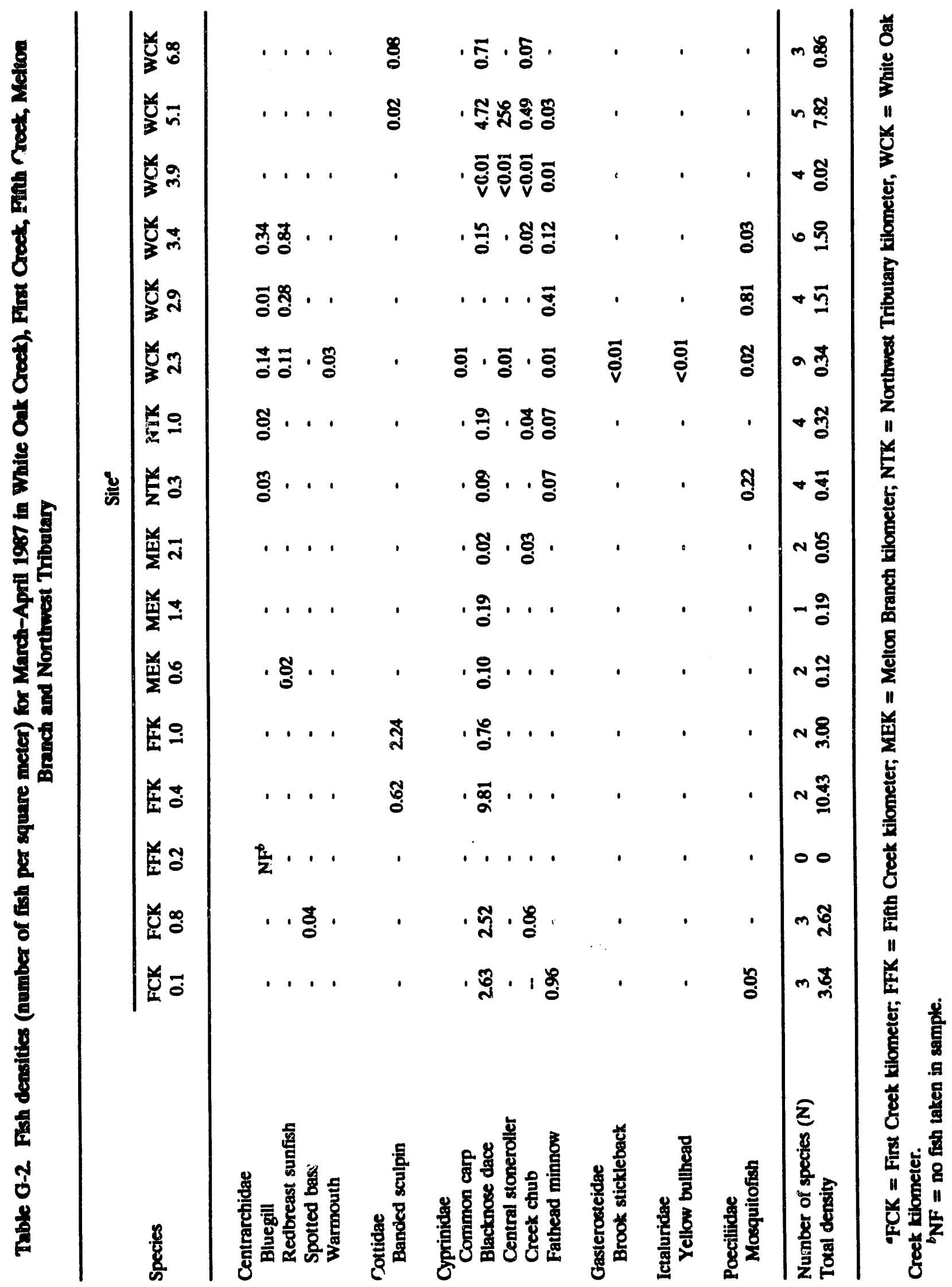




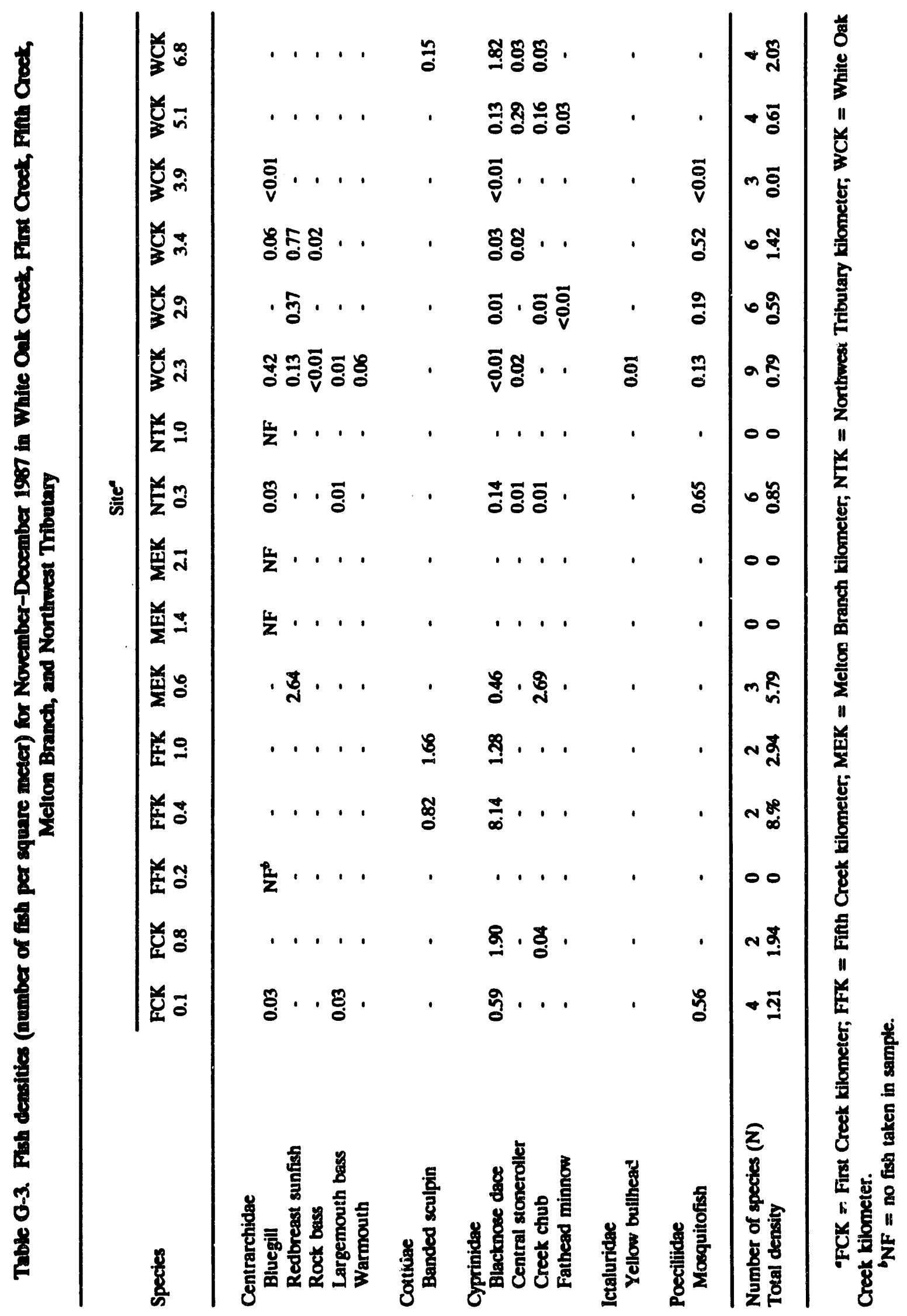




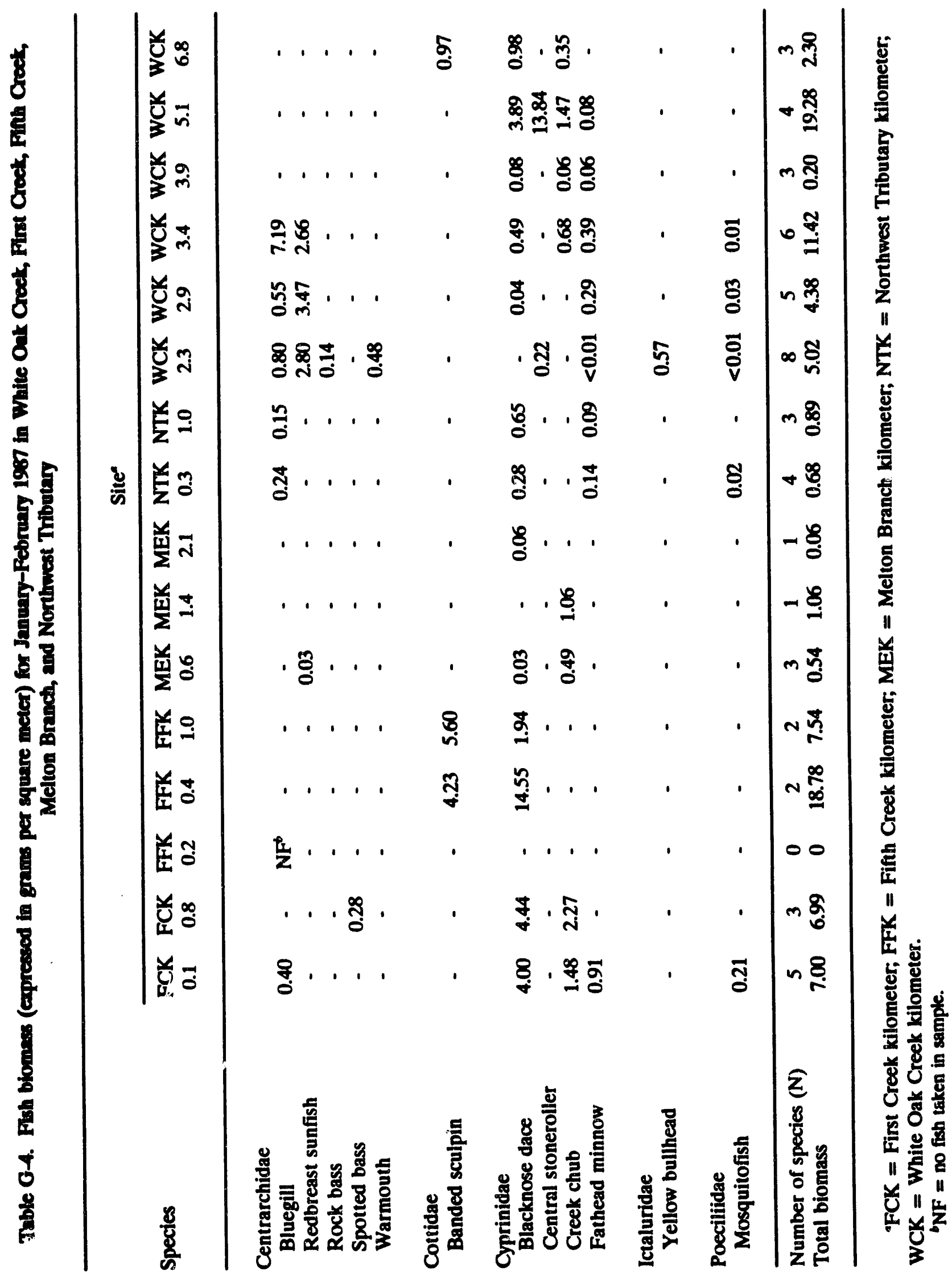




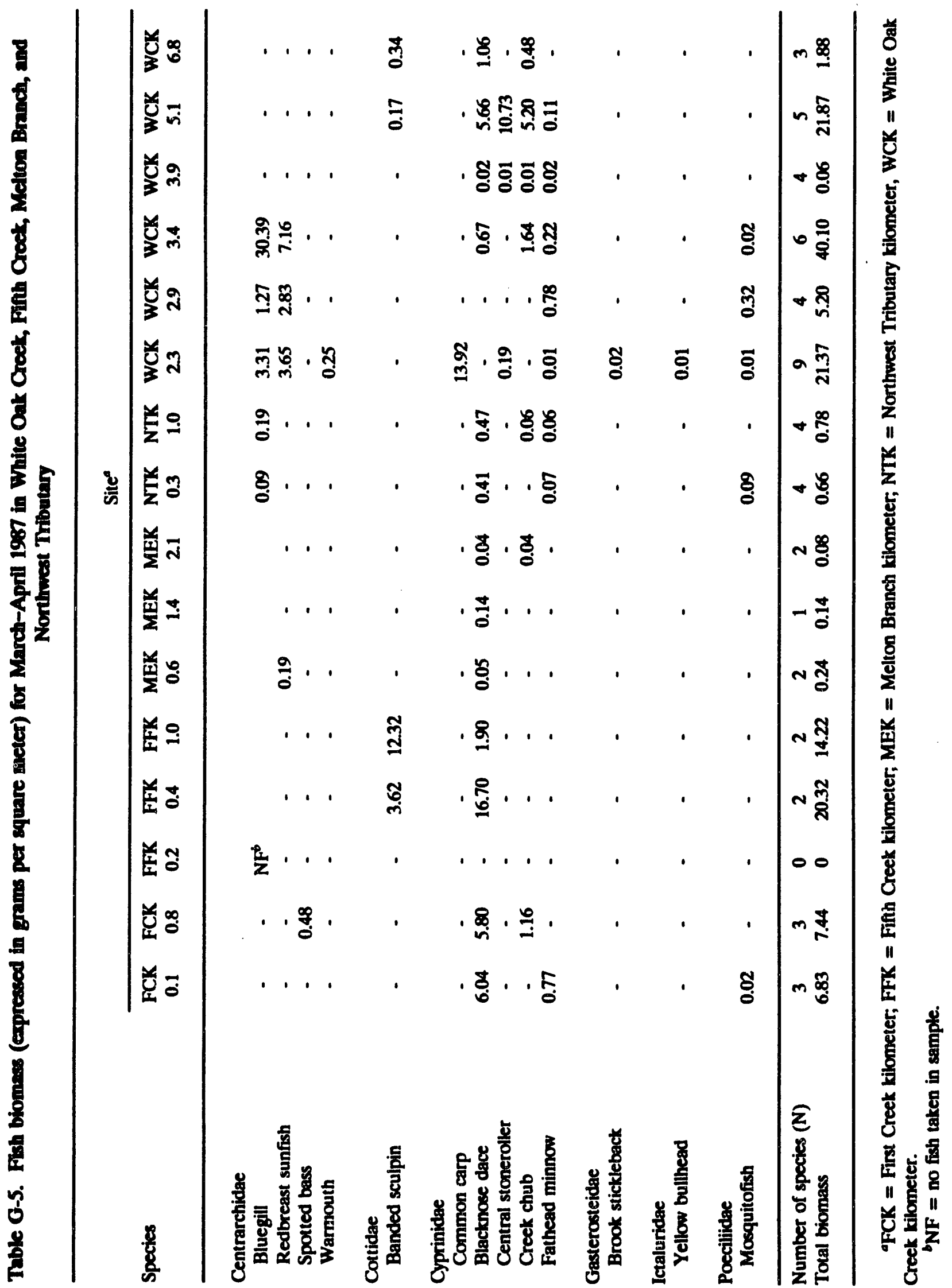




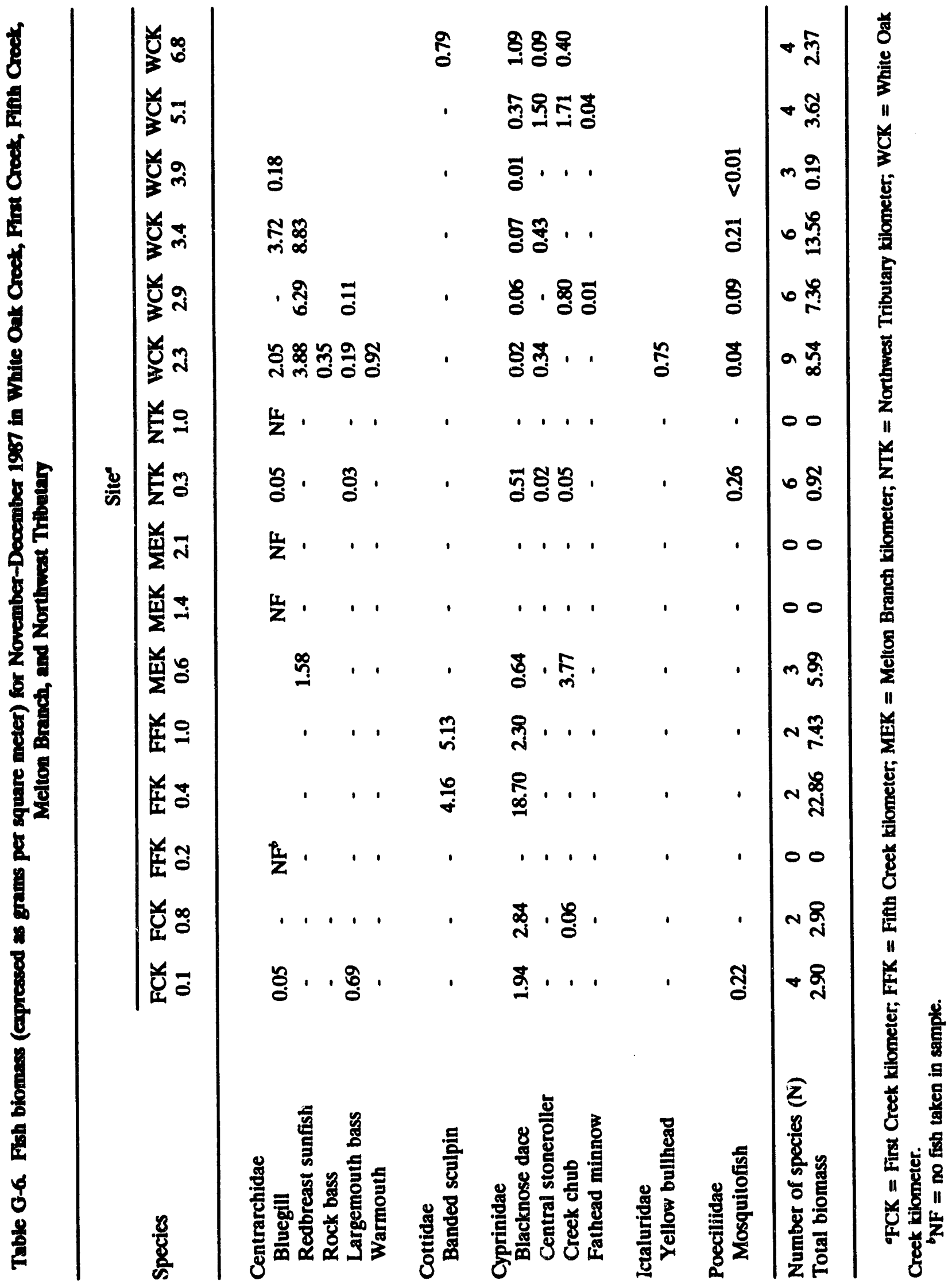


Table G-7. Comparison between sampling periods for sites on White Oak Creek, First Creek, Fifh Creek, Melton Branch, and Northwest Tributary of mean condition factors (K) of fish species collected in January-December 1987

\begin{tabular}{|c|c|c|c|c|c|c|}
\hline Site & & egill & & & lbreast sun & \\
\hline FCK 0.1 & $\begin{array}{c}\text { Wint } \\
\mathrm{n}=3^{b} \\
(1.46)\end{array}$ & $\begin{array}{c}\text { Fall } \\
n=11 \\
(1.45)\end{array}$ & & & & \\
\hline MEK 0.6 & & & & $\begin{array}{l}\text { Sprng } \\
\mathbf{n}=3 \\
(1.96)\end{array}$ & $\begin{array}{l}\text { Wint } \\
n=2 \\
(1.62)\end{array}$ & $\begin{array}{c}\text { Fall } \\
\mathrm{n}=68 \\
(1.57)\end{array}$ \\
\hline NTK 0.3 & $\begin{array}{l}\text { Sprng } \\
n=4 \\
(1.54)\end{array}$ & $\begin{array}{c}\text { Wint } \\
\mathrm{n}=14 \\
(1.16)\end{array}$ & $\begin{array}{c}\text { Fall } \\
\mathrm{n}=5 \\
(1.16)\end{array}$ & & & \\
\hline WCK 2.3 & $\begin{array}{c}\text { Fall } \\
\mathbf{n}=102 \\
(1.77)\end{array}$ & $\begin{array}{c}\text { Sprng } \\
\mathrm{n}=50 \\
(1.72)\end{array}$ & $\begin{array}{c}\text { Wint } \\
n=49 \\
(1.38)\end{array}$ & $\begin{array}{c}\text { Sprng } \\
\mathbf{n}=49 \\
(1.96)\end{array}$ & $\begin{array}{c}\text { Fall } \\
n=56 \\
(1.68)\end{array}$ & $\begin{array}{c}\text { Wint } \\
\mathrm{n}=55 \\
(1.66)\end{array}$ \\
\hline WCK 2.9 & $\begin{array}{l}\text { Sprng } \\
n=3 \\
(2.29)\end{array}$ & $\begin{array}{l}\text { Wint } \\
n=4 \\
(1.73)\end{array}$ & & $\begin{array}{c}\text { Sprng } \\
n=108 \\
(1.93)\end{array}$ & $\begin{array}{c}\text { Wint } \\
\mathbf{n}=107 \\
(1.69)\end{array}$ & $\begin{array}{c}\text { Fall } \\
n=111 \\
(1.64)\end{array}$ \\
\hline WCK 3.4 & $\begin{array}{c}\text { Sprng } \\
n=62 \\
(1.97)\end{array}$ & $\begin{array}{c}\text { Wint } \\
\mathrm{n}=20 \\
(1.71)\end{array}$ & $\begin{array}{c}\text { Fall } \\
\mathrm{n}=10 \\
(1.57)\end{array}$ & $\begin{array}{c}\text { Sprng } \\
\text { n = 112 } \\
(1.95)\end{array}$ & $\begin{array}{c}\text { Wint } \\
\mathrm{n}=81 \\
(1.65)\end{array}$ & $\begin{array}{c}\text { Fall } \\
\mathrm{n}=119 \\
(1.55)\end{array}$ \\
\hline
\end{tabular}

${ }^{\circ}$ FCK $=$ First Creek kilometer; MEK = Melton Branch kilometer; NTK = Northwest Tributary kilometer; WCK $=$ White Oak Creek kilometer.

${ }^{b}$ Number $(n)$ of fish measured and weighed.

Values connected by the same line are not significantly different $(p>0.05)$, based on Tukey's studentized range test.

Wint = fish collected in January-February; Sprng = fish collected in March-April; Fall = fish collected in November-December. 


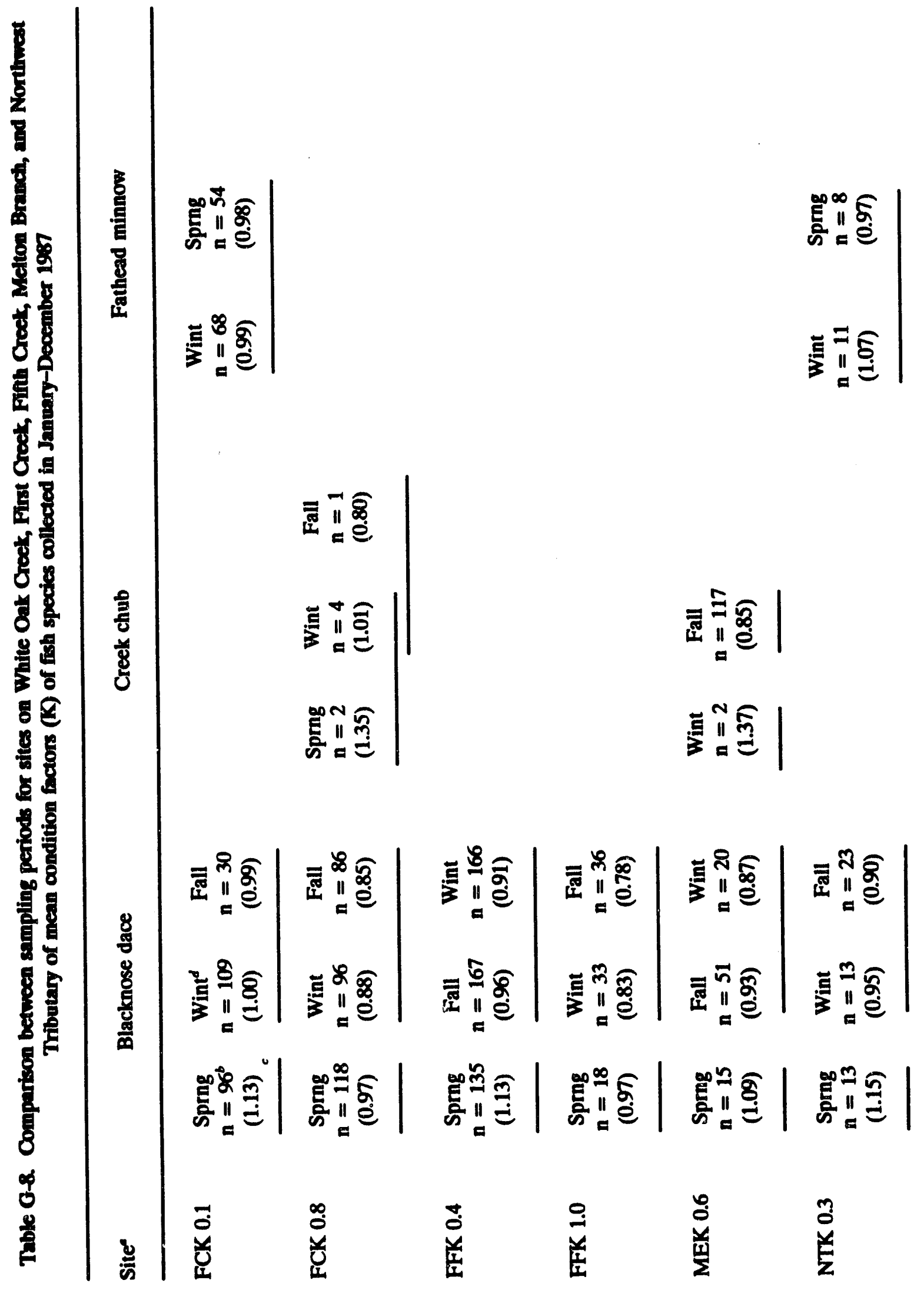




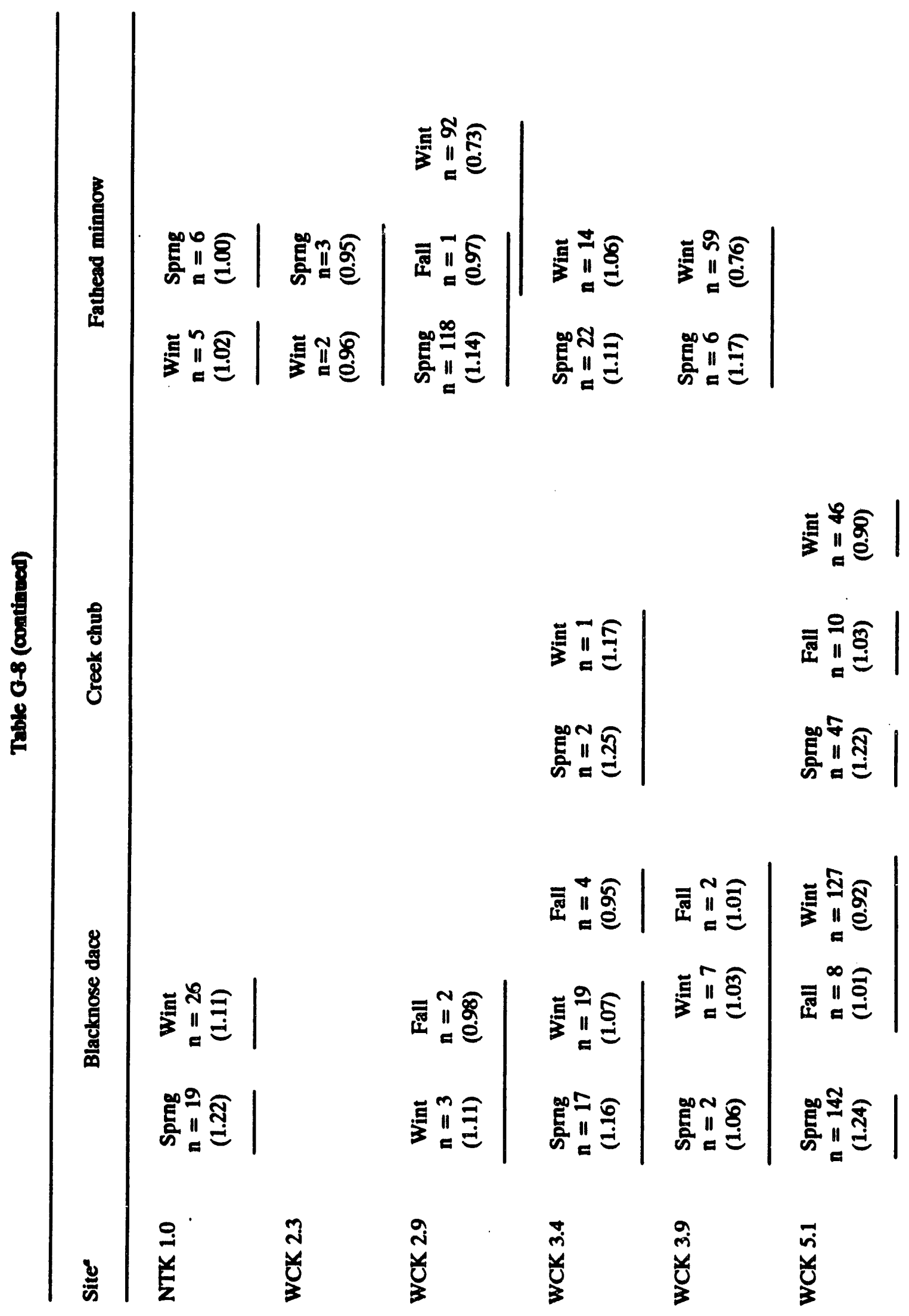




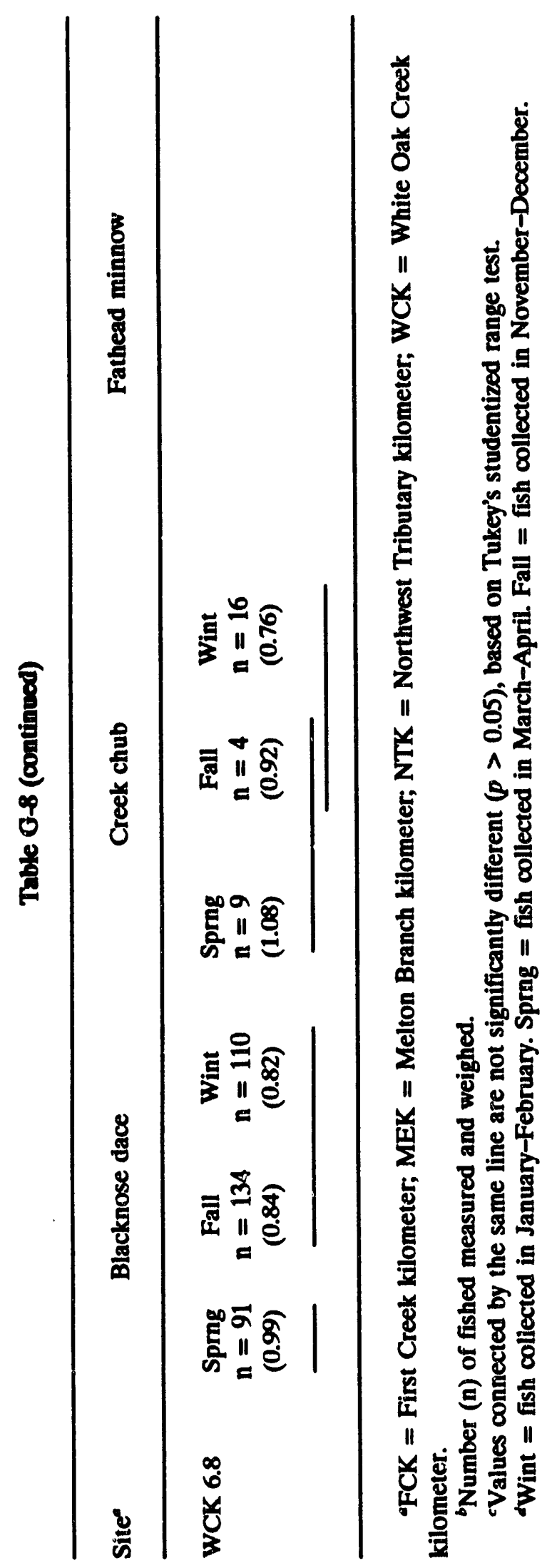




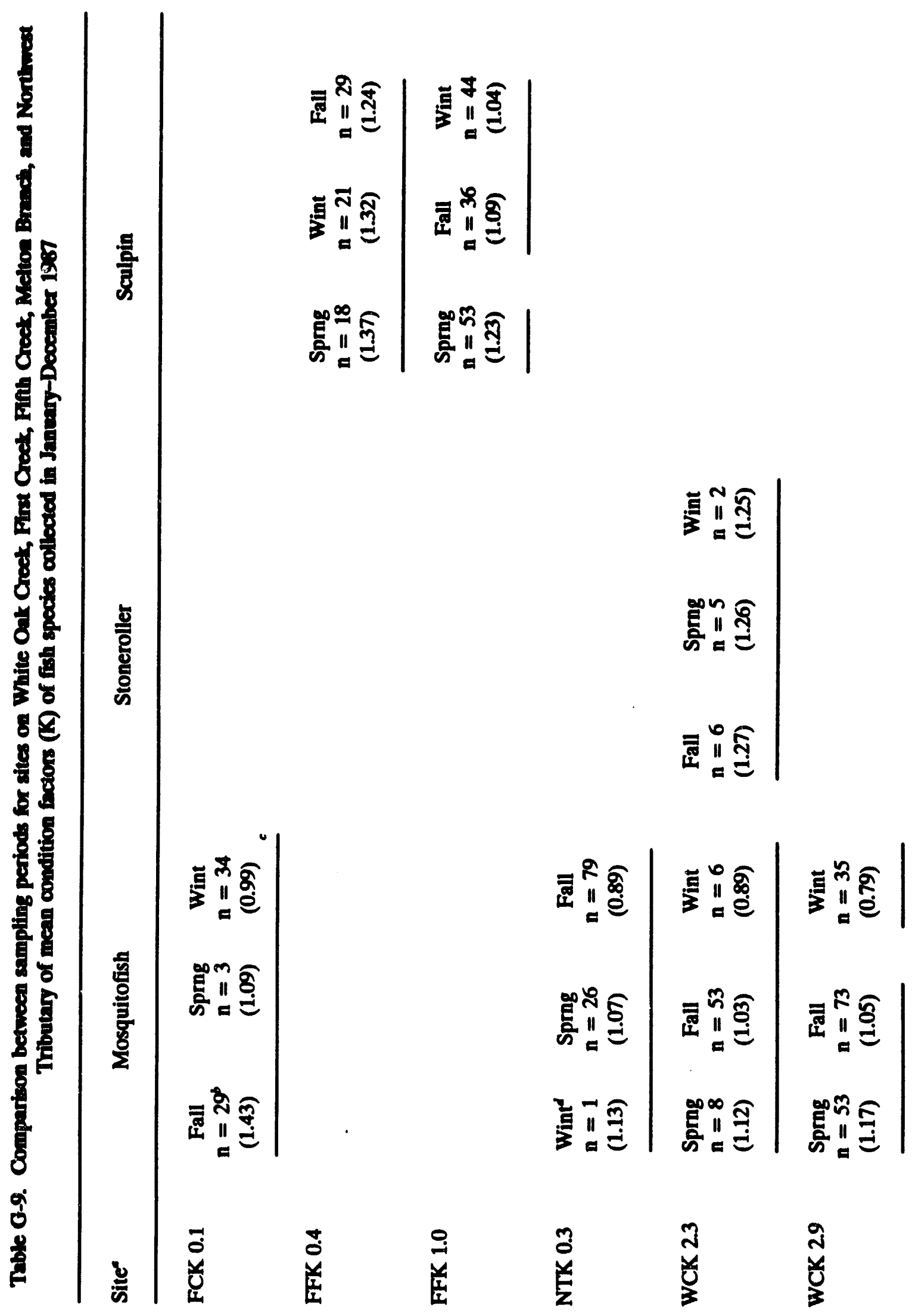




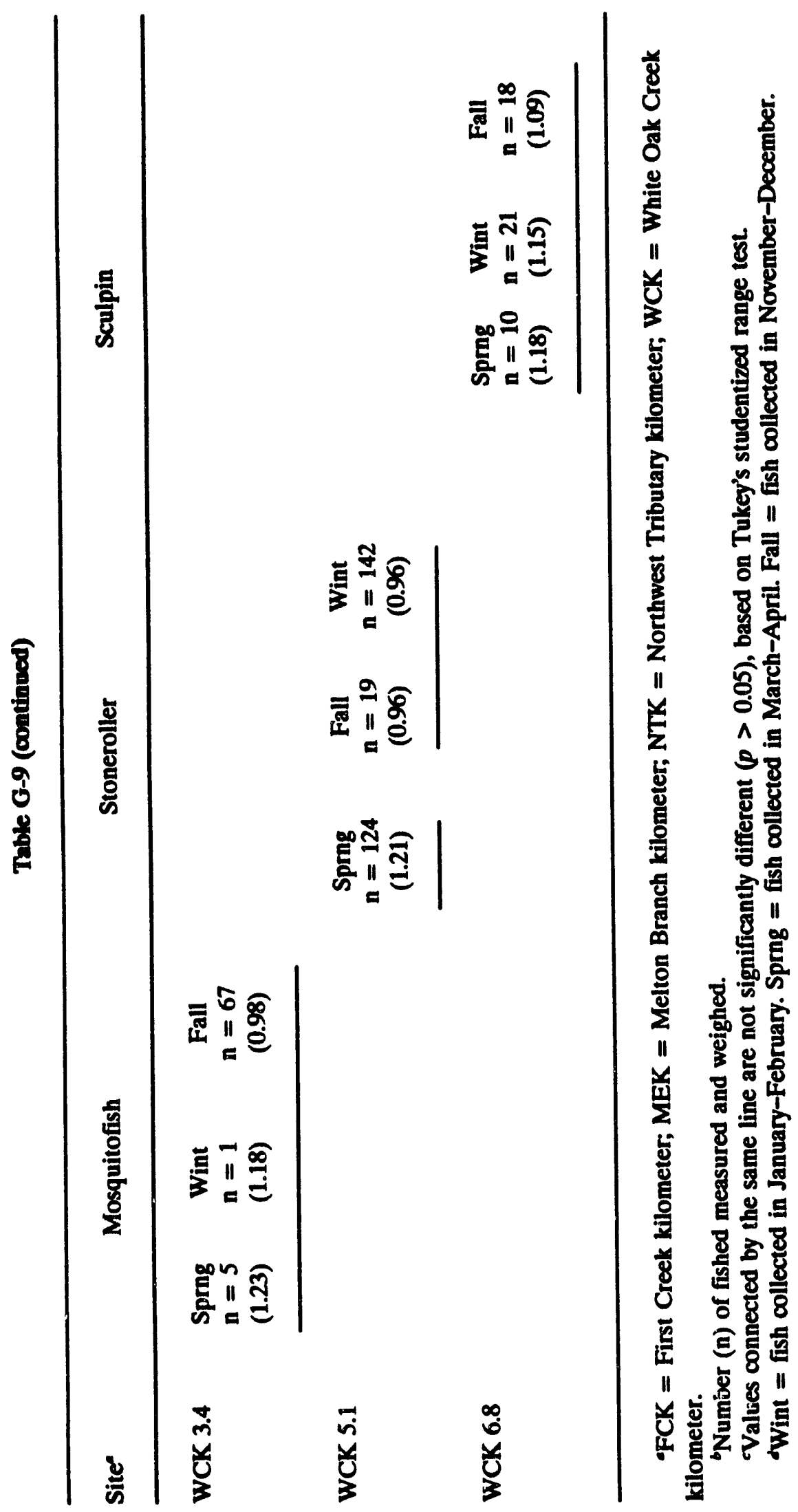




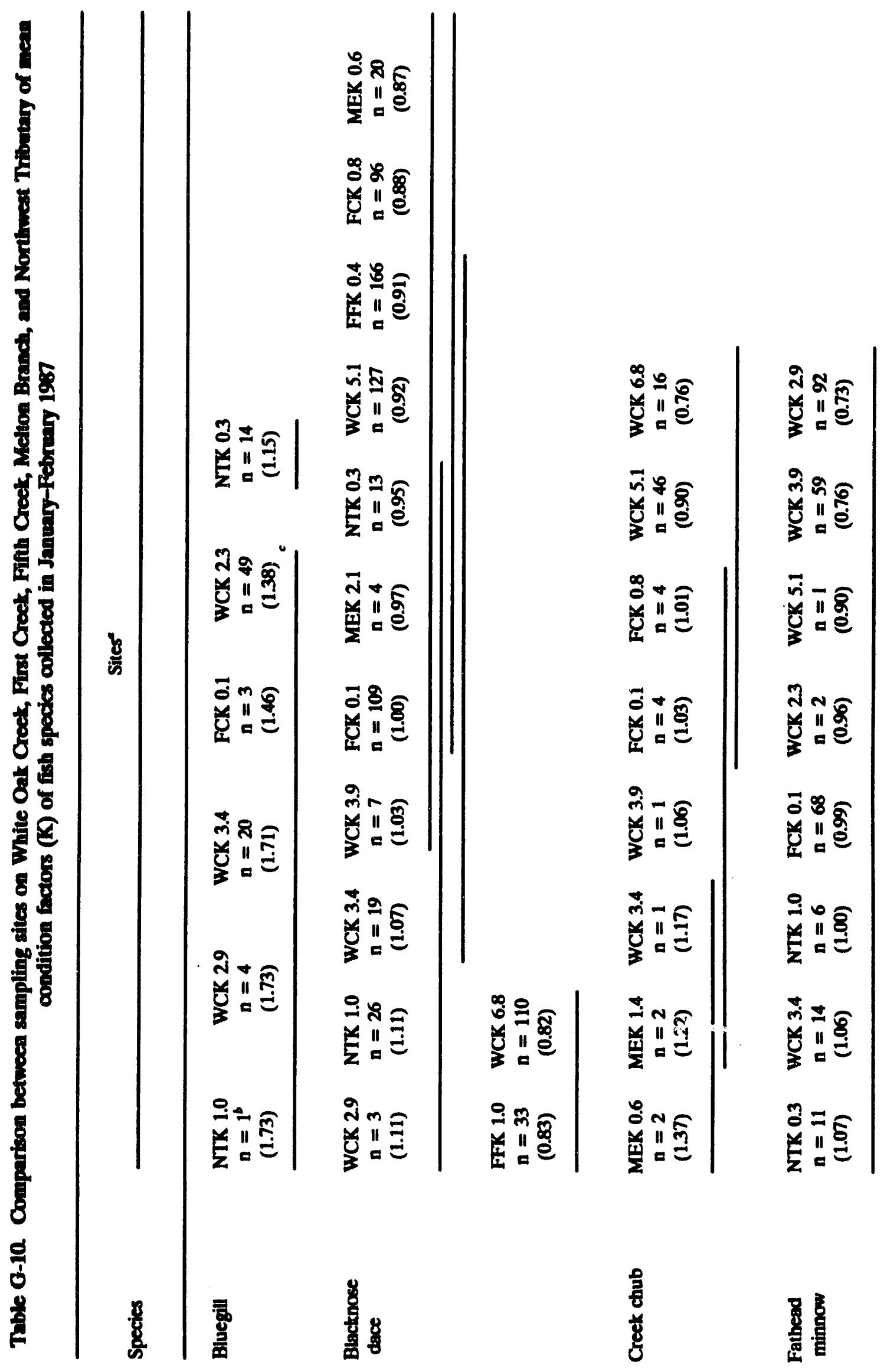




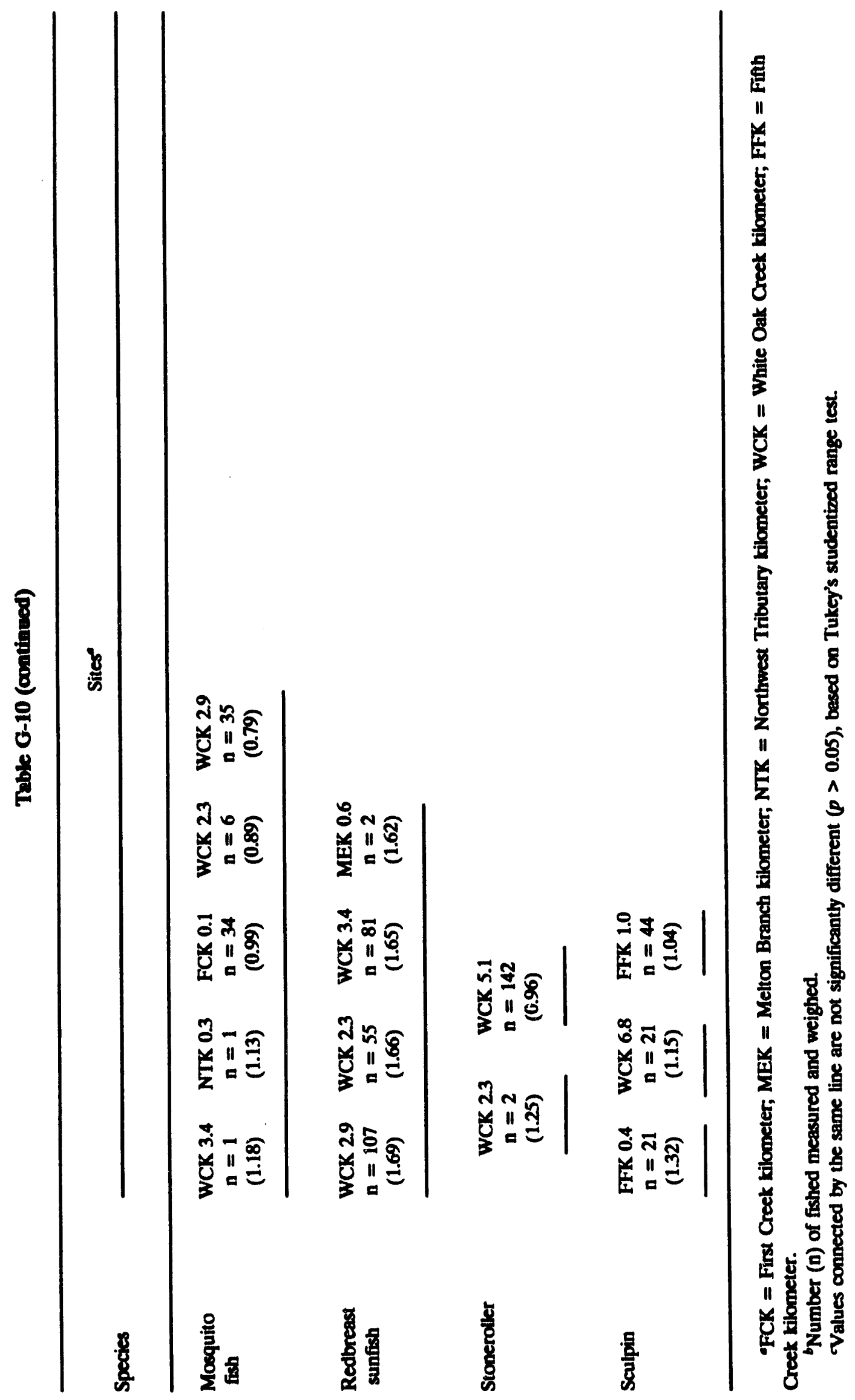




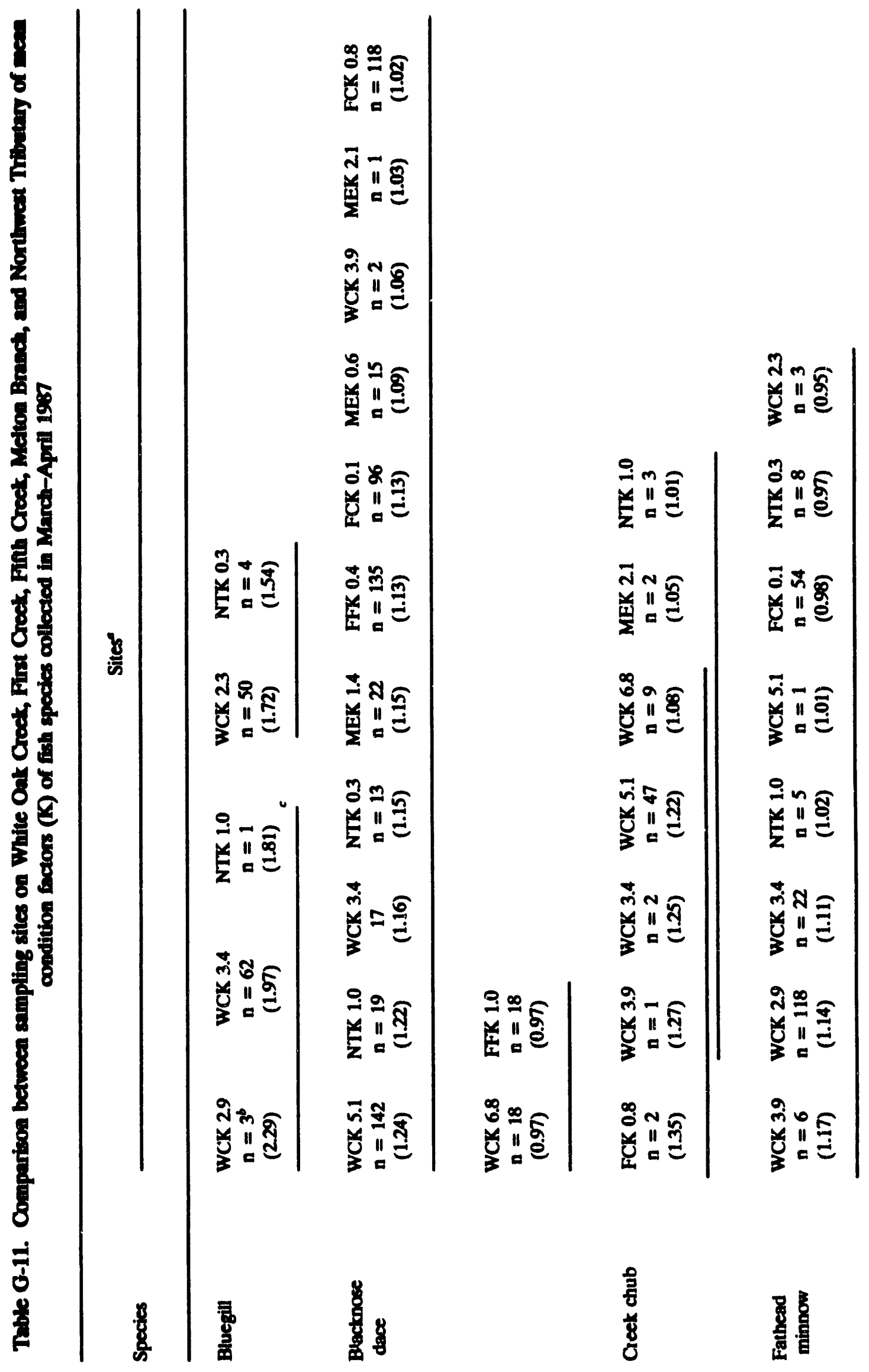




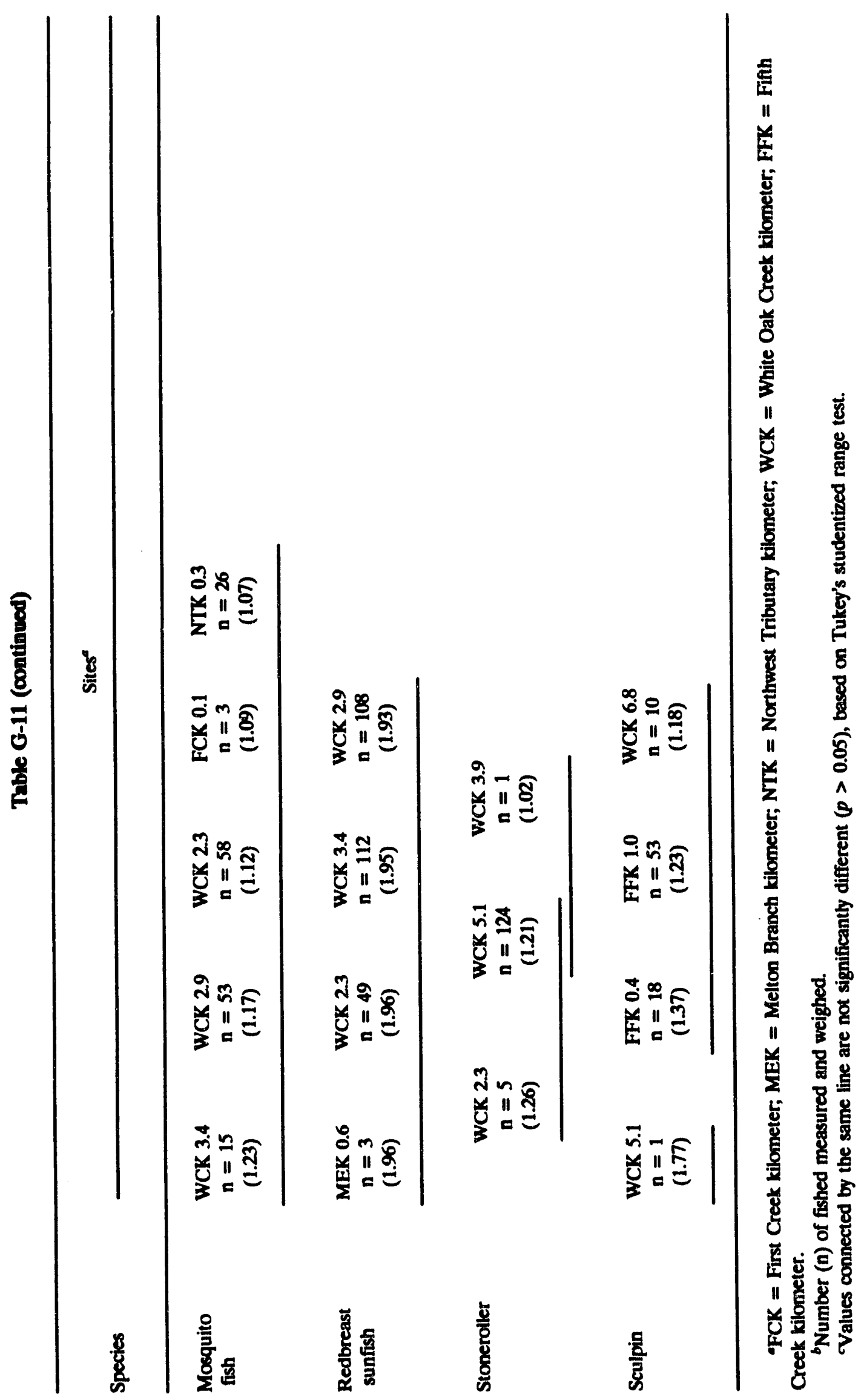




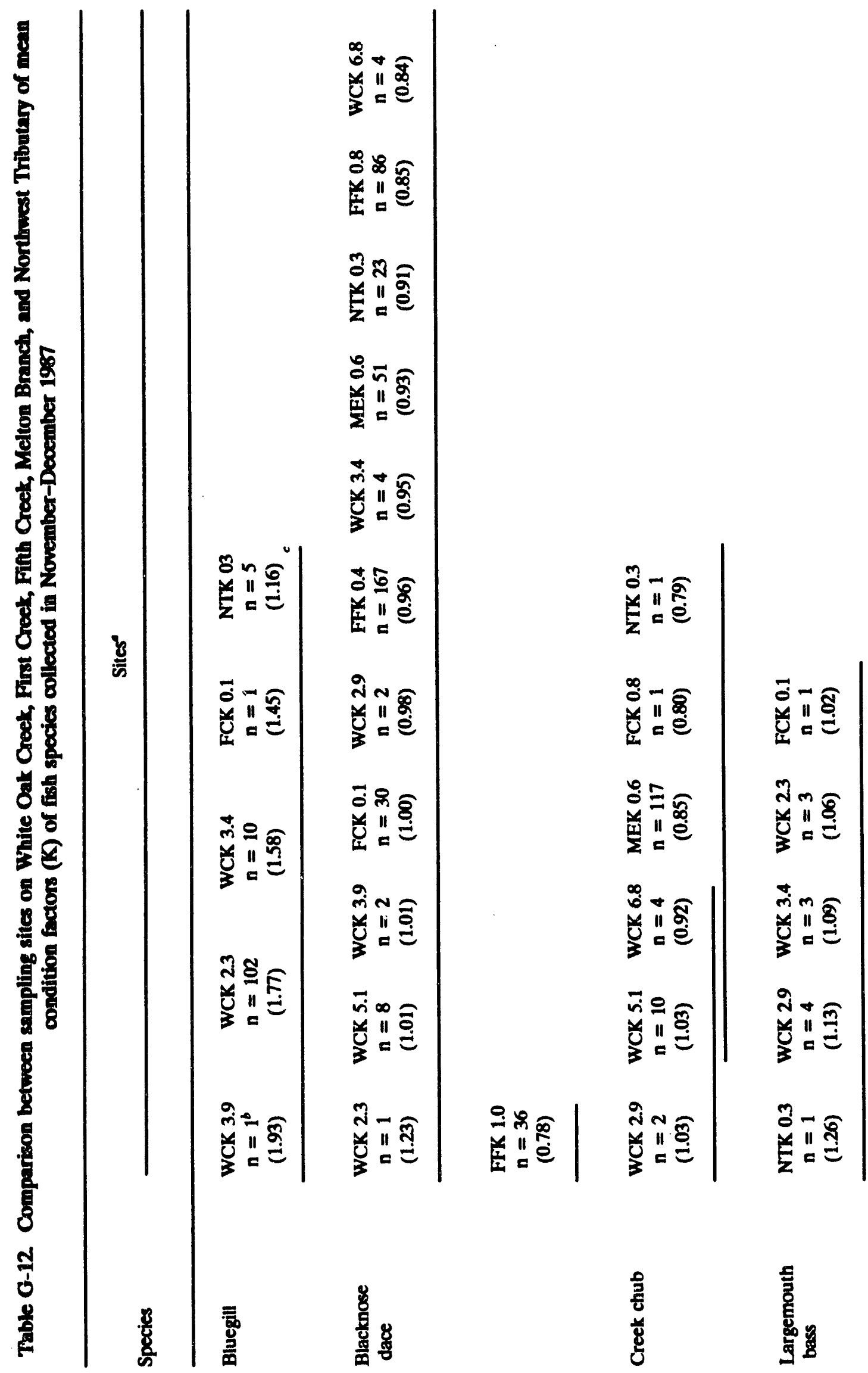




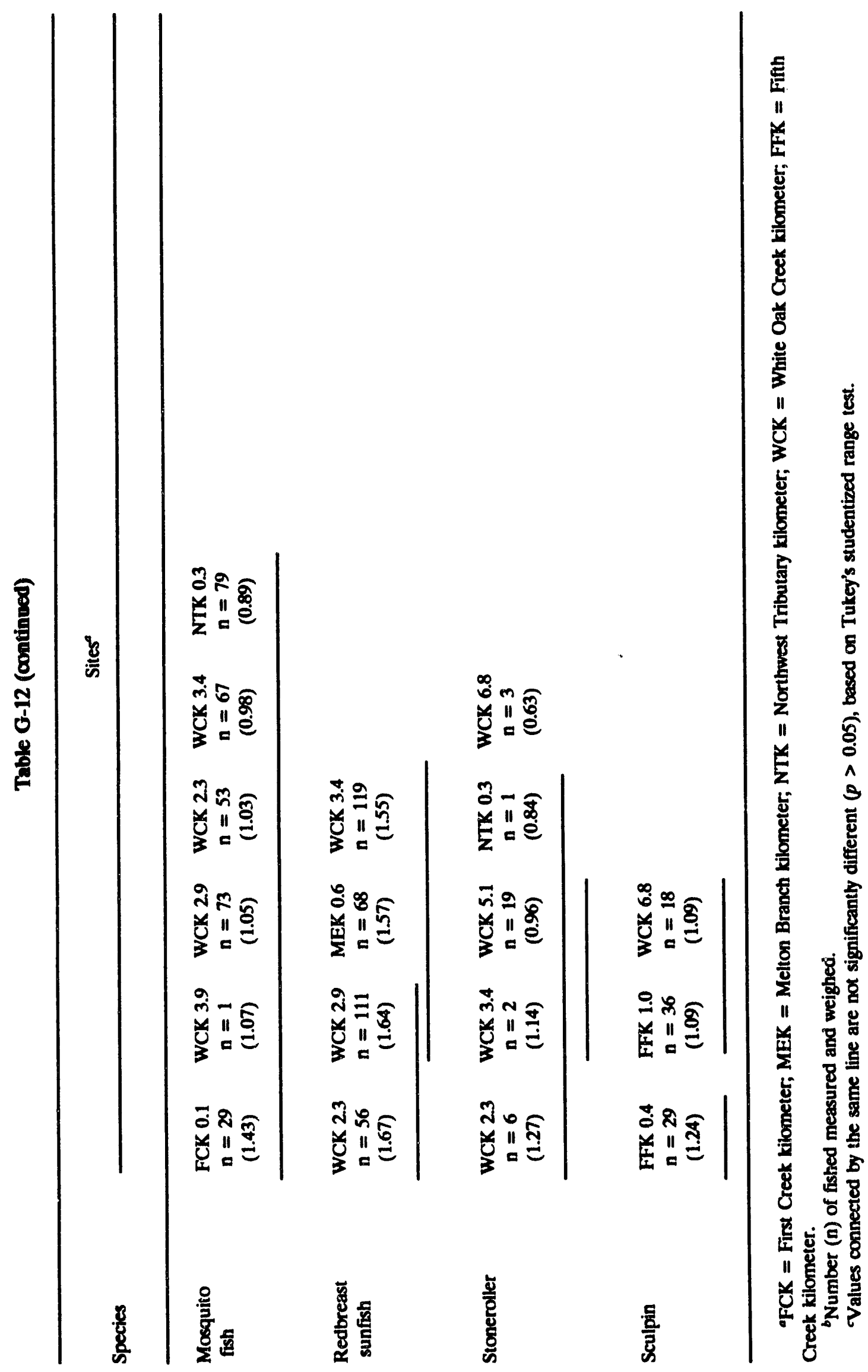


APPENDIX H

FISH COLLECTED IN SURVEYS OF WHITE OAK LAKE DURING A WINTER DIE-OFF OF GIZZARD SHAD, 1987 


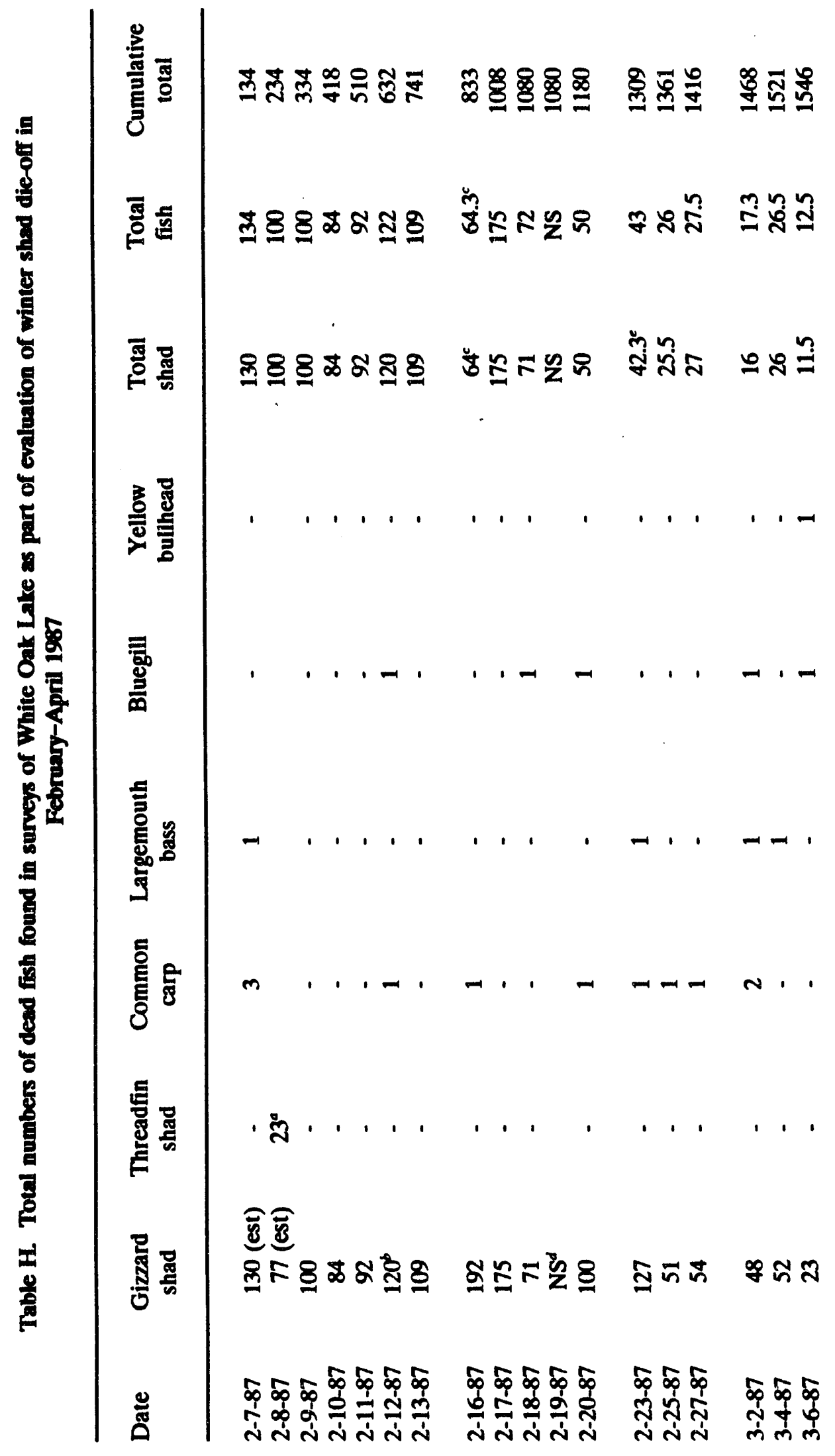




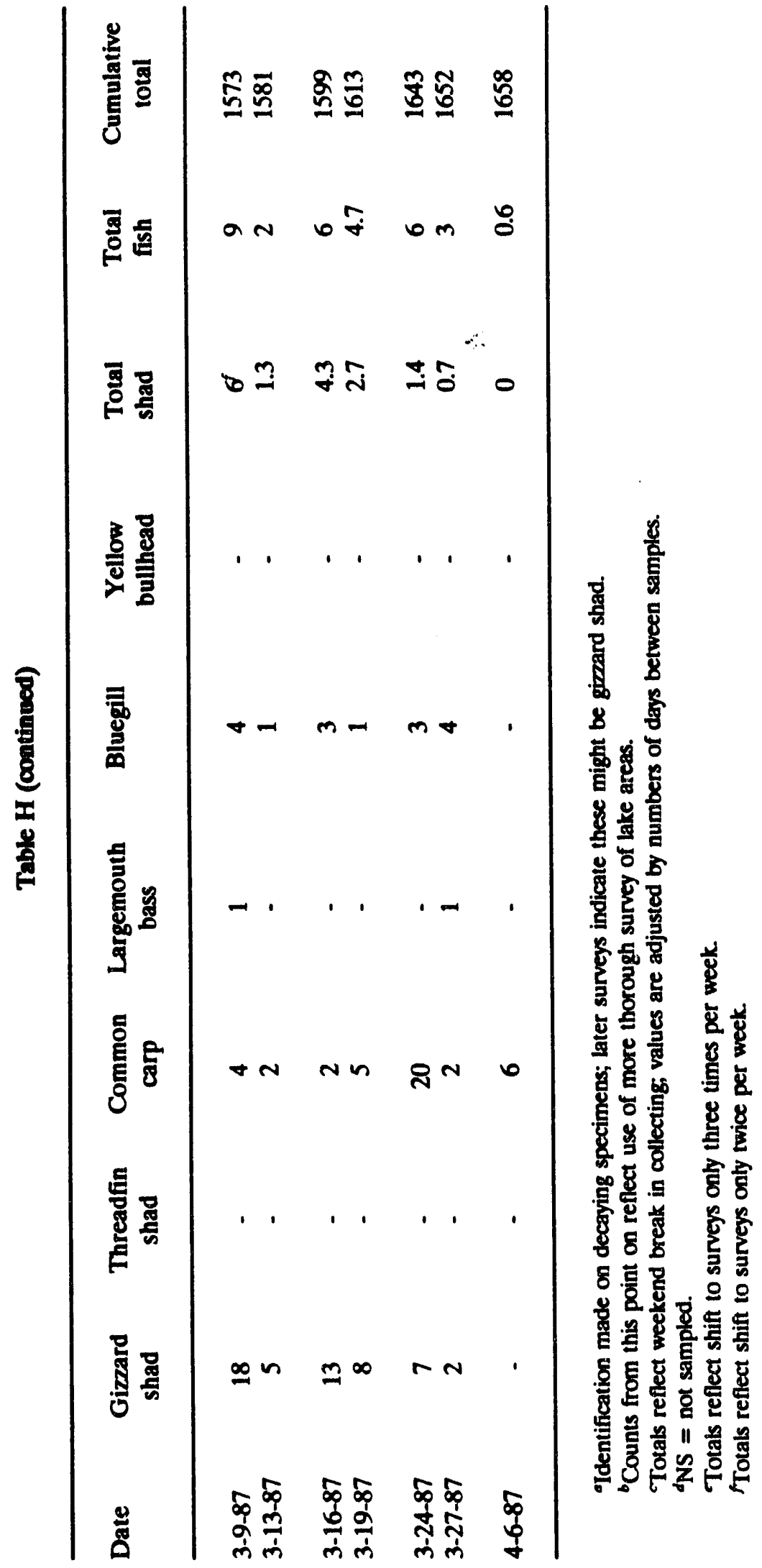




\section{APPENDIX I}

\section{MERCURY CONCENTRATIONS IN KIDNEYS OF SMALL MAMMALS}


Table I. Mercury concentrations in kidney tissue of individual animak and in soil from the White Oak Creek ficodplain, Solid Radionctive Waste Disposal/Storage Area 4, and the Bast Fort Poplar Creek foodplain near EFK 17.4

\begin{tabular}{|c|c|c|c|}
\hline Site & Species & Specimen & $\begin{array}{c}\mathrm{Hg} \\
\text { ( } \mu \mathrm{g} / \mathrm{g} \text { wet } \mathrm{wt})\end{array}$ \\
\hline
\end{tabular}

WCK 2.1

\section{Small mammal data}

$\begin{array}{lll}\text { Peromyscus leucopus } & (7-16 \mathrm{~A}) & 0.38 \\ \text { Peromyscus leucopus } & (7-16 \mathrm{C}) & 0.15 \\ \text { Peromyscus leucopus } & (7-16 \mathrm{E}) & 0.27 \\ \text { Peromyscus leucopus } & (7-16 \mathrm{I}) & 0.25 \\ \text { Peromyscus leucopus } & (7-16 \mathrm{~J}) & 0.17 \\ \text { Peromyscus leucopus } & (7-21 \mathrm{D}) & 0.18 \\ \text { Peromyscus leucopus } & (7-22 \mathrm{H}) & 0.13 \\ \text { Peromyscus leucopus } & (7-22 \mathrm{I}) & 0.08 \\ \text { Peromyscus leucopus } & (7-23 \mathrm{~B}) & 0.26\end{array}$

WCK 3.4

Sigmodon hispidus

(7-21B) $\quad 0.63$

Reithrodontomys humulis $\quad$ (7-21A) $\quad 0.42$

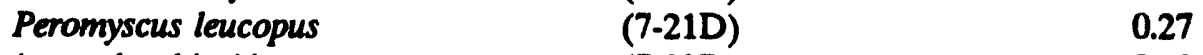

$\begin{array}{lll}\text { Sigmodon hispidus } & \text { (7-22B) } & 0.10\end{array}$

$\begin{array}{lll}\text { Sigmodon hispidus } & \text { (7-22A) } & 0.74\end{array}$

WCK 2.7

Peromyscus leucopus

(7-21A) $\quad 0.35$

Peromyscus leucopus

(7-21C) 0.62

Peromyscus leucopus

(7-21F) $\quad 0.20$

Peromyscus leucopus

(7-22A)

0.26

Peromyscus leucopus

(7-22F)

0.41

SWSA 4

Peromyscus leucopus

(S,5-27S,0,5,5-28Q

Peromyscus leucopus

S,5-290)

0.39

Microtus pinetorum

(S,5-29P,S,6-4V,I,T)

1.33

Peromyscus leucopus

$\left(S_{4} 5-29 E, S, 6-10 J\right)$

0.06

Peromyscus leucopus

(S.7-14U)

0.60

Peromyscus leucopus

(S,7-12W)

0.22

Peromyscus leucopus

0.48

Peromyscus leucopus

(S $7-17 R)$

0.15

Reithrodontomys humulis

0.24

Blarina brevicauda

(S,7-16V)

0.32

Mus musculus

(S,7-22D,H)

0.36

Tamias striatus

(S,7-22F)

0.04

Tamias striatus

(S,7-21K)

0.36

Peromyscus leucopus

$\left(S_{4} 7-28 T\right)$

0.05

$\left(\mathrm{S}_{4} 7-21 \mathrm{BB}\right) \quad 0.55$ 
Table I (continued)

\begin{tabular}{|c|c|c|c|}
\hline Site $^{\infty}$ & Species & Specimen & $\begin{array}{c}\mathrm{Hg} \\
(\mu \mathrm{g} / \mathrm{g} \text { wet wt) }\end{array}$ \\
\hline & Sigmodon hispidus & $\left(\mathrm{S}_{4} 7-22 \mathrm{BB}\right)$ & 0.36 \\
\hline & Reithrodontomys humulis & $\left(S_{4} 9-23 E\right)$ & 0.27 \\
\hline & Blarina brevicauda & $(\mathrm{S}, 9-23 \mathrm{~F})$ & 0.96 \\
\hline & Sigmodon hispidus & $(\mathrm{S}, 9-24 \mathrm{~K})$ & 0.10 \\
\hline & Blarina brevicauda & $\left(\mathrm{S}_{4} 9-24 \mathrm{~N}\right)$ & 1.52 \\
\hline \multicolumn{4}{|c|}{ EFPC floodplain } \\
\hline & Peromyscus leucopus & (E8 3A) & 0.60 \\
\hline & Peromyscus leucopus & (E8-3B) & 0.51 \\
\hline & Peromyscus leucopus & (E8-4A) & 5.6 \\
\hline & Peromyscus leucopus & (E8-4B) & 3.1 \\
\hline & Peromyscus leucopus & (E8-5B) & 0.62 \\
\hline & Blarina brevicauda & (E8-5A) & 57. \\
\hline & Peromyscus leucopus & (E8-14A,E8-5A, & \\
\hline & & E8-6A,E8-5B) & 0.78 \\
\hline & Blarina brevicauda & $\begin{array}{l}\text { (E8-15A,E8-15C, } \\
7 / 24 / 86 . D O A ~ 10 / 16 / 85)\end{array}$ & 21 \\
\hline & Sigmodon hispidus & (E8-15B) & 1.9 \\
\hline & Peromyscus leucopus & $(E 8-6 x, 7,3)$ & 1.94 \\
\hline & Peromyscus leucopus & (E8-7(11),E8-13(6) & 1.08 \\
\hline & Peromyscus leucopus & $(\mathrm{E} 8-13(2), \mathrm{E} 8-13(27)$ & 0.97 \\
\hline & Peromyscus leucopus & $(\mathrm{E} 9-27(21 \mathrm{~A}),(27))$ & 0.70 \\
\hline & Peromyscus leucopus & (E9-26(6),(E-10-15) & 0.82 \\
\hline & Blarina brevicauda & (E9-14) & 73. \\
\hline & Blarina brevicauda & (E9-15A) & 42. \\
\hline & Blarina brevicauda & (E9-14B) & 43. \\
\hline
\end{tabular}

Soil concentrations (top $3 \mathrm{~cm})$

$\mathrm{Hg}$

( $\mu g / g$ dry wt)

WCK 2.1

Trap A (iron stake) $\quad 3.5$

Trap E (well) 2.3

$\begin{array}{ll}\text { Trap I } & 2.0\end{array}$

WCK 3.4

$\begin{array}{ll}\text { Trap A } & 6.6\end{array}$

$\begin{array}{ll}\text { Trap B } & 7.3\end{array}$

WCK 2.7

$\begin{array}{ll}\text { Trap A } & 0.34 \\ \text { Trap B } & 0.89 \\ \text { Trap C } & 1.3\end{array}$


Table I (continued)

\begin{tabular}{|c|c|c|}
\hline Site $^{\infty}$ & Specimen & $\begin{array}{c}\mathrm{Hg} \\
(\mu \mathrm{g} / \mathrm{g} \text { dry wt) }\end{array}$ \\
\hline \multicolumn{3}{|c|}{ Solid Radioactive Waste Disposal/Storage Area 4} \\
\hline & & 0.32 \\
\hline & & 0.28 \\
\hline & & 0.15 \\
\hline & & 0.17 \\
\hline & stake) & 0.09 \\
\hline & & 0.24 \\
\hline \multicolumn{3}{|c|}{ EFPC } \\
\hline & & $\begin{array}{r}348 . \\
1665 .\end{array}$ \\
\hline
\end{tabular}

${ }^{a}$ WCK $=$ White Oak Creek kilometer, SWSA = Solid Radioactive Waste Disposal/Storage Area; EFPC = East Fork Poplar Creek; EFK = East Fork Poplar Creek kilometer. 


\section{APPENDIX J}

STRONTIUM-90 CONCENTRATIONS IN BONE OF SMALL MAMMALS 
Table J. Strontium-90 concentrations in bone of individual animals trapped at Solid Radioactive Waste Storage/Disposal Area 4, White Oak Creek, and the Bast Fork Poplar Creek foodplain near BFK 17.4

\begin{tabular}{lc}
\hline Site & $\stackrel{90 \mathrm{Sr}}{\text { Species }} \quad$ (Bq/kg dry wt) \\
\hline
\end{tabular}

Laboratory Control mouse (5 samples)

n.d.

SWSA-4 (bathtub. seeps)

Peromyscus leucopus (S,5-270)

Peromyscus leucopus (S,5-27S)

$5.67 \times 10^{3}$

$1.64 \times 10^{3}$

Peromyscus leucopus (S,5-28Q)

$3.97 \times 10^{3}$

Tamins striatus $\left(\mathrm{S}_{4}, 5-28 \mathrm{~T}\right)$

Microtus pinetorum $(\mathrm{S}, 5-29 \mathrm{E})$

$8.91 \times 10^{3}$

Peromyscus leucopus (S,5-290)

$1.45 \times 10^{3}$

Tamias striatus $(\mathbf{S}, 5-29 \mathrm{~S})$

$3.81 \times 10^{3}$

Peromyscus leucopus (S,5-29?)

$0.95 \times 10^{3}$

Reithrodontomys humulis (S,6-4D)

$4.29 \times 10^{3}$

$10.43 \times 10^{3}$

Peromyscus leucopus (S,6-4V)

$0.85 \times 10^{3}$

Peromyscus leucopus (S,6-4I)

$1.56 \times 10^{3}$

Peromyscus leucopus (S,6-4T)

Reithrodontomys humulis (S,6-10B)

$2.34 \times 10^{3}$

Microtus pinetorum (S,6-10J)

$40.04 \times 10^{3}$

Peromyscus leucopus $\left(S_{4} 7-14 U\right)$

$31.81 \times 10^{3}$

Peromyscus leucopus (S,7-14W)

$3.85 \times 10^{3}$

Peromyscus leucopus (S $7-16 \mathrm{~V}$ )

$3.40 \times 10^{3}$

$1.20 \times 10^{3}$

Peromyscus leucopus (S7-17R)

$48.76 \times 10^{3}$

Peromyscus leucopus ( $\left.S_{4} 7-17 \mathrm{U}\right)$

$9.88 \times 10^{3}$

Mus musculus $\left(\mathrm{S}_{1} 7-21 \mathrm{~K}\right)$

$1.29 \times 10^{3}$

Peromyscus leucopus (S 7-21BB)

$86.11 \times 10^{3}$

Reithrodontomys humulis (S,7-22D)

$16.00 \times 10^{3}$

Blarina brevicauda (S 7-22F)

Reithrodontomys humulis $\left(\mathrm{S}_{4} 7-22 \mathrm{H}\right)$

$3.90 \times 10^{3}$

Sigmodon hispidus ( $\left.\mathrm{S}_{4} 7-22 \mathrm{BB}\right)$

$10.17 \times 10^{3}$

$1.33 \times 10^{3}$

Reithrodontomys humulis (S,9-23E)

Blanina brevicauda (S,9-23F)

Sigmodon hispidus (S,9-24K)

$280.76 \times 10^{3}$

$4.99 \times 10^{3}$

Blarina brevicauda (S,9-24N)

$51.64 \times 10^{3}$

$61.72 \times 10^{3}$

WCK 2.1

Peromyscus leucopus (7-16A)

$0.19 \times 10^{3}$

Peromyscus leucopus (7-16C)

$1.60 \times 10^{3}$

Peromyscus leucopus (7-16E)

$1.08 \times 10^{3}$

Peromyscus leucopus (7-16I)

$2.49 \times 10^{3}$

Peromyscus leucopus (7-16J)

$4.69 \times 10^{3}$

Peromyscus leucopus (7-21D)

$2.15 \times 10^{3}$

Peromyscus leucopus (7-22H)

$0.14 \times 10^{3}$

Peromyscus leucopus (7-22I)

$0.75 \times 10^{3}$

Peromyscus leucopus (7-23B)

$1.22 \times 10^{3}$ 
Table J (continued)

\begin{tabular}{|c|c|c|}
\hline Site & Species & $\begin{array}{c}{ }^{20} \mathrm{Sr} \\
\mathrm{Bq} / \mathrm{kg} \text { dry wt }\end{array}$ \\
\hline WCK & $\begin{array}{l}\text { Reithrodontomys humulis (7-21A) } \\
\text { Sigmodon hispidus (7-21B) } \\
\text { Peromyscus leucopus (7-21D) } \\
\text { Sigmodon hispidus (7-22A) } \\
\text { Sigmodon hispidus (7-22B) }\end{array}$ & $\begin{array}{r}0.93 \times 10^{3} \\
14.46 \times 10^{3} \\
0.62 \times 10^{3} \\
3.58 \times 10^{3} \\
44.06 \times 10^{3}\end{array}$ \\
\hline WCK & $\begin{array}{l}\text { Peromyscus leucopus (7-21A) } \\
\text { Peromyscus leucopus (7-21C) } \\
\text { Peromyscus leucopus (7-21F) } \\
\text { Peromyscus leucopus (7-22A) } \\
\text { Peromyscus leucopus (7-22F) }\end{array}$ & $\begin{array}{l}1.36 \times 10^{3} \\
1.36 \times 10^{3} \\
1.43 \times 10^{3} \\
0.32 \times 10^{3} \\
3.66 \times 10^{3}\end{array}$ \\
\hline EFPC & $\begin{array}{l}\text { Peromyscus leucopus [E8-6(x)] } \\
\text { Peromyscus leucopus [E8-6(11)] } \\
\text { Peromyscus leucopus (E8-3A) } \\
\text { Peromyscus leucopus (E8-3B) } \\
\text { Peromyscus leucopus (E8-4A) } \\
\text { Peromyscus leucopus (E8-4B) } \\
\text { Blarina brevicauda (E8-5A) } \\
\text { Peromyscus leucopus (E8-5B) } \\
\text { Blarina brevicauda (E9-14A) } \\
\text { Blarina brevicauda (E9-15A) } \\
\text { Blarina brevicauda (E9-15B) }\end{array}$ & $\begin{array}{l}\text { n.d. } \\
0.02 \times 10^{3} \\
0.05 \times 10^{3} \\
\text { n.d. } \\
\text { n.d. } \\
\text { n.d. } \\
\text { n.d. } \\
\text { n.d. } \\
0.44 \times 10^{3} \\
\text { n.d. }\end{array}$ \\
\hline
\end{tabular}

-SWSA = Solid Radioactive Waste Storage/Disposal Area; WCK = White Oak Creek kilometer (WCK 2.1 is at the junction of White Oak Creek and White Oak Lake); EFPC = East Fork Poplar Creek; EFK = East Fork Poplar Creek kilometer.

Note: n.d. = not detectable. 


\section{APPENDIX K}

FOOD HABITS, CONTAMINANT CONCENTRATIONS $\left({ }^{\circ} \mathrm{COBALT}\right.$, ${ }^{137}$ CESIUM, AND MERCURY), AND PERCENTAGE OF DOUBLE-STRANDED DNA LEVELS IN YELLOW-

BELLIED SLIDER TURTLES (Pseudemys scripta) FROM WHITE OAK LAKE AND BEARDEN CREEK EMBAYMENT 


$$
\text { . }
$$


Table K-1. Food habits of yellow-bellied slider turtles (Psendemys scripta) collected from White Oat Late

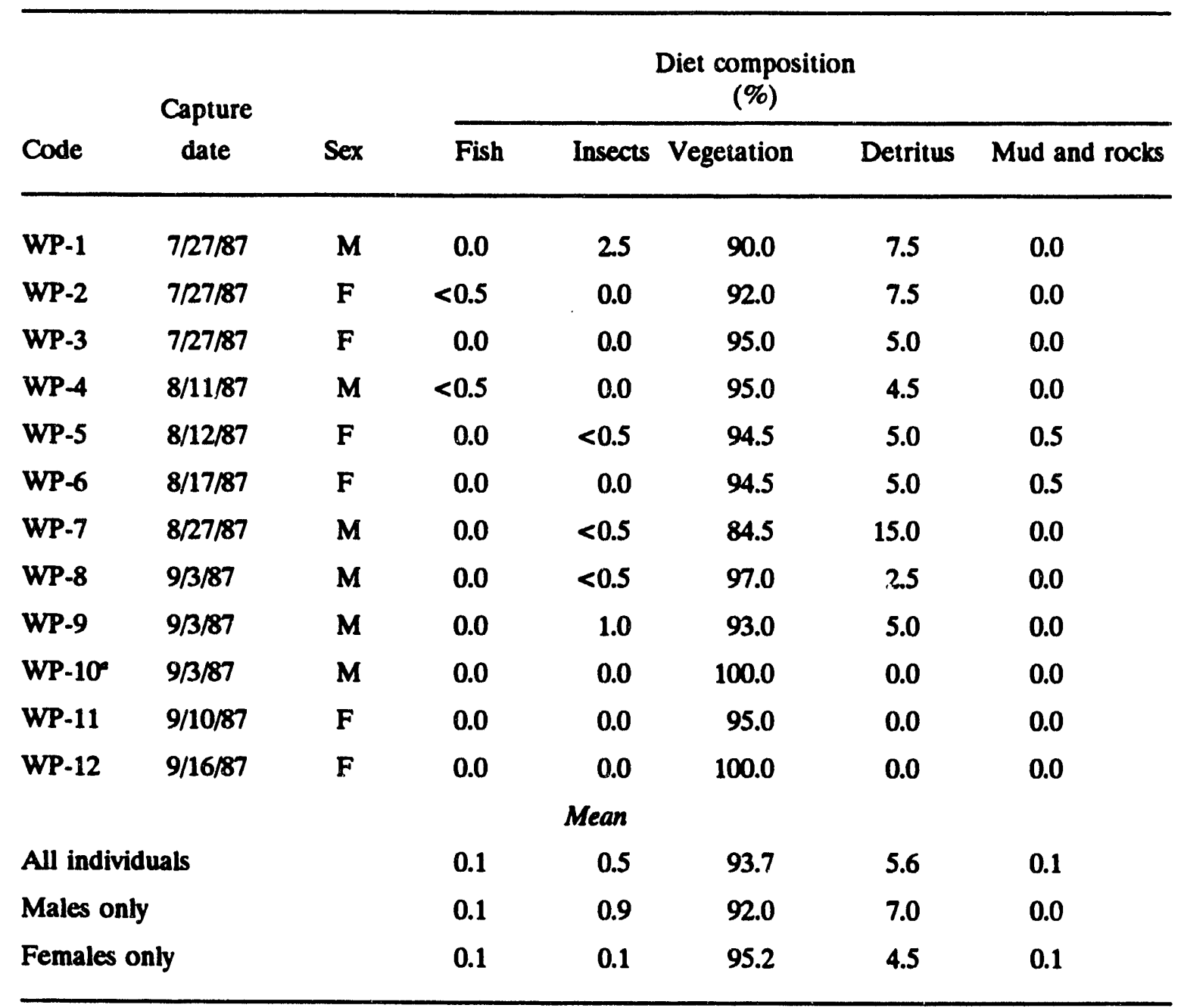

aEmpty GI tract not included in calculations. 
Table K-2 Food habits of yellow-bellied slider turtles (Psendengs scripta) collected from Bearden Creek embayment

\begin{tabular}{|c|c|c|c|c|c|c|c|c|}
\hline \multirow[b]{2}{*}{ Code } & \multirow{2}{*}{$\begin{array}{c}\text { Capture } \\
\text { date }\end{array}$} & \multirow[b]{2}{*}{ Sex } & \multicolumn{6}{|c|}{$\begin{array}{c}\text { Diet composition } \\
(\%)\end{array}$} \\
\hline & & & Fish & Insects & Vegetation & Detritus & Mud and rocks & Crayfish \\
\hline BP-2 & $8 / 31 / 87$ & $\mathbf{M}$ & 0.0 & 0.5 & 97.5 & 2.0 & 0.0 & 0.0 \\
\hline BP-3 & 9/1/87 & $\mathbf{M}$ & 0.0 & 75.0 & 24.0 & 1.0 & 0.0 & 0.0 \\
\hline BP-4 & 9/1/87 & $\mathbf{F}$ & 0.0 & 0.0 & 100.0 & 0.0 & 0.0 & 0.0 \\
\hline BP-5 & $9 / 1 / 87$ & $\mathbf{F}$ & 0.0 & 0.5 & 97.0 & 2.0 & 0.0 & $<0.5$ \\
\hline BP-6 & $9 / 14 / 87$ & $\mathbf{M}$ & 0.0 & 1.0 & 98.0 & 1.0 & 0.0 & 0.0 \\
\hline BP-7 & $9 / 14 / 87$ & $\mathbf{M}$ & 0.0 & 0.0 & 98.0 & 2.0 & 0.0 & 0.0 \\
\hline BP-8 & $9 / 14 / 87$ & $\mathbf{M}$ & 0.0 & 20.0 & 79.5 & $<0.5$ & 0.0 & 0.0 \\
\hline BP-9 & 9/15/87 & $\mathbf{M}$ & 0.0 & 0.0 & 99.0 & $<0.5$ & $<0.5$ & 0.0 \\
\hline BP-10 & 9/15/87 & $\mathbf{F}$ & 2.5 & 0.0 & 87.5 & 10.0 & 0.0 & 0.0 \\
\hline Bre-11 & $9 / 16 / 87$ & $\mathbf{F}$ & 14.0 & 0.0 & 85.5 & 0.5 & 0.0 & 0.0 \\
\hline BP-12 & $9 / 17 / 87$ & $\mathbf{F}$ & 0.0 & 5.0 & 94.5 & 0.5 & 0.0 & 0.0 \\
\hline \multirow[t]{2}{*}{ BP-13 } & $9 / 18 / 87$ & $\mathbf{F}$ & 20.0 . & 0.5 & 77.0 & 2.5 & 0.0 & 0.0 \\
\hline & \multicolumn{8}{|c|}{ Mean } \\
\hline \multicolumn{3}{|c|}{ All individuals } & 3.0 & 8.5 & 86.5 & 2.0 & 0.0 & 0.0 \\
\hline \multicolumn{3}{|c|}{ Males only } & 0.0 & 16.1 & 82.7 & 1.2 & 0.0 & 0.0 \\
\hline \multicolumn{3}{|c|}{ Females only } & 6.1 & 1.0 & 90.3 & 2.6 & 0.0 & 0.0 \\
\hline
\end{tabular}


Table K-3. "Co and ${ }^{15} \mathrm{Cs}$ activity in muscle tissue of yellow-bellied slider turtles (Prendenoys scripta) collected from White Oak Lake

\begin{tabular}{|c|c|c|c|c|c|}
\hline Turtle & Date & $\begin{array}{l}\text { Whole body } \\
\text { wet wt } \\
\text { (g) }\end{array}$ & Sex & $\begin{array}{c}{ }^{137} \mathrm{Cs} \\
(\mathrm{Bq} / \mathrm{kg})\end{array}$ & $\begin{array}{c}{ }^{60} \mathrm{Co} \\
(\mathrm{Bq} / \mathrm{kg})\end{array}$ \\
\hline Wp-1 & $7 / 27 / 87$ & 989 & Male & $\begin{array}{c}4.88 \times 10^{4} \\
(1320)^{\circ}\end{array}$ & $\begin{array}{l}\text { n.d. } \\
\text { n.d. }\end{array}$ \\
\hline Wp-2 & $7 / 27 / 87$ & 1865 & Female & $\begin{array}{c}4.4 \times 10^{2} \\
(11.9)\end{array}$ & $\begin{array}{l}\text { n.d. } \\
\text { n.d. }\end{array}$ \\
\hline Wp-3 & $7 / 27 / 87$ & 619 & Female & $\begin{array}{c}5.4 \times 10^{2} \\
(14.6)\end{array}$ & $\begin{array}{l}\text { n.d. } \\
\text { n.d. }\end{array}$ \\
\hline$w p-4$ & $8 / 11 / 87$ & 932 & Male & $\begin{array}{c}8.22 \times 10^{5} \\
(22,200)\end{array}$ & $\begin{array}{c}5.66 \times 10^{2} \\
(15.3)\end{array}$ \\
\hline Wp-5 & $8 / 12 / 87$ & 1820 & Female & $\begin{array}{c}2.16 \times 10^{2} \\
(5.84)\end{array}$ & $\begin{array}{l}\text { n.d. } \\
\text { n.d. }\end{array}$ \\
\hline Wp-6 & $8 / 17 / 87$ & 1687 & Female & $\begin{array}{c}4.48 \times 10^{2} \\
(12.1)\end{array}$ & $\begin{array}{l}\text { n.d. } \\
\text { n.d. }\end{array}$ \\
\hline Wp-7 & $8 / 27 / 87$ & 419 & Male & $\begin{array}{c}6.22 \times 10^{2} \\
(16.8)\end{array}$ & $\begin{array}{l}\text { n.d. } \\
\text { n.d. }\end{array}$ \\
\hline Wp-8 & $9 / 3 / 87$ & 369 & Male & $\begin{array}{c}5.18 \times 10^{2} \\
(14.0)\end{array}$ & $\begin{array}{c}41.1 \\
(1.11)\end{array}$ \\
\hline Wp-9 & 9/3/87 & 351 & Male & $\begin{array}{c}8.03 \times 10^{2} \\
(21.7)\end{array}$ & $\begin{array}{l}\text { n.d. } \\
\text { n.d. }\end{array}$ \\
\hline Wp-10 & 9/3/87 & 834 & Male & $\begin{array}{c}6.11 \times 10^{2} \\
(16.5)\end{array}$ & $\begin{array}{l}\text { n.d. } \\
\text { n.d. }\end{array}$ \\
\hline Wp-11 & $9 / 10 / 87$ & 2750 & Female & $\begin{array}{c}6.70 \times 10^{2} \\
(18.1)\end{array}$ & $\begin{array}{l}\text { n.d. } \\
\text { n.d. }\end{array}$ \\
\hline Wp-12 & $9 / 16 / 87$ & 1487 & Female & $\begin{array}{c}4.48 \times 10^{2} \\
(12.1)\end{array}$ & $\begin{array}{l}\text { n.d. } \\
\text { n.d. }\end{array}$ \\
\hline
\end{tabular}

Values in parenthesis reported as $\mathrm{pCi/g}$ wet weight.

Nore: n.d. $=$ nondetectable. 
Table K4. "Co and ${ }^{\mathrm{E}} \mathrm{Cs}$ concentrations in muscle tissue of yellow-bellied slider (Psendemys scripta) collected from Bearden Creek embayment

\begin{tabular}{|c|c|c|c|c|c|}
\hline Turtle & Date & $\begin{array}{l}\text { Whole body } \\
\text { wet wt } \\
\text { (g) }\end{array}$ & Sex & $\begin{array}{c}{ }^{137} \mathrm{Cs} \\
(\mathrm{Bq} / \mathrm{kg})\end{array}$ & $\begin{array}{l}{ }^{\infty} \mathrm{Co} \\
(\mathrm{Bq} / \mathrm{kg})\end{array}$ \\
\hline Bp-2 & $8 / 31 / 87$ & 435 & Male & $\begin{array}{c}17.4 \\
(0.47)\end{array}$ & $\begin{array}{c}2.22 \\
(0.06)\end{array}$ \\
\hline Bp-3 & $9 / 1 / 87$ & 412 & Male & $\begin{array}{c}5.55 \\
(0.15)\end{array}$ & $\begin{array}{l}\text { n.d. } \\
\text { n.d. }\end{array}$ \\
\hline Bp-4 & 9/ 1/87 & 2865 & Female & $\begin{array}{c}5.55 \\
(0.15)\end{array}$ & $\begin{array}{c}2.96 \\
(0.08)\end{array}$ \\
\hline Bp-5 & 9/ 1/87 & 834 & Female & $\begin{array}{l}\text { n.d. } \\
\text { n.d. }\end{array}$ & $\begin{array}{l}\text { n.d. } \\
\text { n.d. }\end{array}$ \\
\hline Bp-6 & $9 / 14 / 87$ & 1079 & Male & $\begin{array}{l}\text { n.d. } \\
\text { n.d. }\end{array}$ & $\begin{array}{c}0.42 \\
(0.011)\end{array}$ \\
\hline Bp-7 & $9 / 14 / 87$ & 477 & Male & $\begin{array}{c}12.9 \\
(0.35)\end{array}$ & $\begin{array}{l}\text { n.d. } \\
\text { n.d. }\end{array}$ \\
\hline Bp-8 & $9 / 14 / 87$ & 1162 & Male & $\begin{array}{c}12.2 \\
(0.33)\end{array}$ & $\begin{array}{l}\text { n.d. } \\
\text { n.d. }\end{array}$ \\
\hline Bp-9 & $9 / 15 / 87$ & 746 & Male & $\begin{array}{c}20.7 \\
(0.56)\end{array}$ & $\begin{array}{l}\text { n.d. } \\
\text { n.d. }\end{array}$ \\
\hline Bp-10 & $9 / 15 / 87$ & 1312 & Female & $\begin{array}{c}8.89 \\
(0.24)\end{array}$ & $\begin{array}{c}1.48 \\
(0.04)\end{array}$ \\
\hline Bp-11 & $9 / 16 / 87$ & 1350 & Female & $\begin{array}{c}6.66 \\
(0.18)\end{array}$ & $\begin{array}{c}11.8 \\
(0.32)\end{array}$ \\
\hline Bp-12 & $9 / 17 / 87$ & 1101 & Female & $\begin{array}{c}6.29 \\
(0.17)\end{array}$ & $\begin{array}{l}\text { n.d. } \\
\text { n.d. }\end{array}$ \\
\hline Bp-13 & 9/18/87 & 642 & Female & $\begin{array}{c}56.2 \\
(1.52)\end{array}$ & $\begin{array}{l}\text { n.d. } \\
\text { n.d. }\end{array}$ \\
\hline
\end{tabular}

-Values in parenthesis reported as $\mathrm{pCi} / \mathrm{g}$ wet weight.

Note: n.d. $=$ nondetectable. 
Table K-5. Total mercury concentrations in tissues of yellow-bellied slider turtles (Pseudernys scripta) collected from White Oak Lake

\begin{tabular}{|c|c|c|c|c|}
\hline $\begin{array}{l}\text { Capture } \\
\text { date }\end{array}$ & Sex & $\begin{array}{l}\text { Whole body } \\
\text { wet weight } \\
\text { (g) }\end{array}$ & Tissue & $\begin{array}{c}\text { Total } \mathrm{Hg} \\
(\mu \mathrm{g} / \mathrm{g} \text { wet } \mathrm{wt})\end{array}$ \\
\hline $7 / 27 / 87$ & $\mathbf{M}$ & 989 & $\begin{array}{l}\text { Kidney } \\
\text { Muscle }\end{array}$ & $\begin{array}{l}4.00 \\
0.48\end{array}$ \\
\hline $7 / 27 / 87$ & $\mathbf{F}$ & 1865 & $\begin{array}{l}\text { Kidney } \\
\text { Muscle }\end{array}$ & $\begin{array}{l}0.15 \\
0.14\end{array}$ \\
\hline $7 / 27 / 87$ & $\mathbf{F}$ & 619 & $\begin{array}{l}\text { Kidney } \\
\text { Muscle }\end{array}$ & $\begin{array}{l}0.14 \\
0.04\end{array}$ \\
\hline $8 / 11 / 87$ & $\mathbf{M}$ & 932 & $\begin{array}{l}\text { Kidney } \\
\text { Muscle }\end{array}$ & $\begin{array}{l}1.81 \\
0.25\end{array}$ \\
\hline $8 / 12 / 87$ & F & 1820 & $\begin{array}{l}\text { Kidney } \\
\text { Muscle }\end{array}$ & $\begin{array}{l}0.18 \\
0.05\end{array}$ \\
\hline $8 / 17 / 87$ & $\mathbf{F}$ & 1687 & $\begin{array}{l}\text { Kidney } \\
\text { Muscle }\end{array}$ & $\begin{array}{l}0.17 \\
0.03\end{array}$ \\
\hline $8 / 27 / 87$ & $\mathbf{M}$ & 419 & $\begin{array}{l}\text { Kidney } \\
\text { Muscle }\end{array}$ & $\begin{array}{l}0.15 \\
0.04\end{array}$ \\
\hline $9 / 3 / 87$ & $\mathbf{M}$ & 369 & $\begin{array}{l}\text { Kidney } \\
\text { Muscle }\end{array}$ & $\begin{array}{l}0.24 \\
0.07\end{array}$ \\
\hline $9 / 3 / 87$ & $\mathbf{M}$ & 351 & $\begin{array}{l}\text { Kidney } \\
\text { Muscle }\end{array}$ & $\begin{array}{l}0.27 \\
0.05\end{array}$ \\
\hline 9/3/87 & $\mathbf{M}$ & 834 & $\begin{array}{l}\text { Kidney } \\
\text { Muscle }\end{array}$ & $\begin{array}{l}0.19 \\
0.02\end{array}$ \\
\hline $9 / 10 / 87$ & $\mathbf{F}$ & 2750 & $\begin{array}{l}\text { Kidney } \\
\text { Muscle }\end{array}$ & $\begin{array}{l}0.18 \\
0.04\end{array}$ \\
\hline 9/16/87 & $\mathbf{F}$ & 1487 & $\begin{array}{l}\text { Kidney } \\
\text { Muscle }\end{array}$ & $\begin{array}{l}0.23 \\
0.04\end{array}$ \\
\hline
\end{tabular}


Table K-6. Total mercury concentrations in tissues of yellow-bellied slider turtles (Psendenys scripta) collected from Bearden Creek embayment

\begin{tabular}{|c|c|c|c|c|}
\hline $\begin{array}{l}\text { Capture } \\
\text { date }\end{array}$ & Sex & $\begin{array}{l}\text { Whole body } \\
\text { wet weight } \\
\text { (g) }\end{array}$ & Tissue & $\begin{array}{c}\text { Total } \mathrm{Hg} \\
(\mu g / g \text { wet } w t)\end{array}$ \\
\hline $8 / 31 / 87$ & $\mathbf{M}$ & 435 & $\begin{array}{l}\text { Kidney } \\
\text { Muscle }\end{array}$ & $\begin{array}{l}0.16 \\
0.02\end{array}$ \\
\hline 9/1/87 & $\mathbf{M}$ & 412 & $\begin{array}{l}\text { Kidney } \\
\text { Muscle }\end{array}$ & $\begin{array}{l}0.11 \\
0.04\end{array}$ \\
\hline 9/1/87 & . $\mathbf{F}$ & 2865 & $\begin{array}{l}\text { Kidney } \\
\text { Muscle }\end{array}$ & $\begin{array}{l}0.36 \\
0.10\end{array}$ \\
\hline 9/1/87 & $\mathbf{F}$ & 834 & $\begin{array}{l}\text { Kidney } \\
\text { Muscle }\end{array}$ & $\begin{array}{l}0.04 \\
0.01\end{array}$ \\
\hline $9 / 14 / 87$ & $\mathbf{M}$ & 1079 & $\begin{array}{l}\text { Kidney } \\
\text { Muscle }\end{array}$ & $\begin{array}{l}0.40 \\
0.06\end{array}$ \\
\hline $9 / 14 / 87$ & $\mathbf{M}$ & 477 & $\begin{array}{l}\text { Kidney } \\
\text { Muscle }\end{array}$ & $\begin{array}{l}0.05 \\
0.01\end{array}$ \\
\hline $9 / 14 / 87$ & $\mathbf{M}$ & 1162 & $\begin{array}{l}\text { Kidney } \\
\text { Muscle }\end{array}$ & $\begin{array}{l}0.15 \\
0.02\end{array}$ \\
\hline $9 / 15 / 87$ & $\mathbf{M}$ & 746 & $\begin{array}{l}\text { Kidney } \\
\text { Muscle }\end{array}$ & $\begin{array}{l}0.05 \\
0.02\end{array}$ \\
\hline $9 / 15 / 87$ & $\mathbf{F}$ & 1312 & $\begin{array}{l}\text { Kidney } \\
\text { Muscle }\end{array}$ & $\begin{array}{l}0.08 \\
0.02\end{array}$ \\
\hline $9 / 16 / 87$ & $\mathbf{F}$ & 1350 & $\begin{array}{l}\text { Kidney } \\
\text { Muscle }\end{array}$ & $\begin{array}{l}0.04 \\
0.01\end{array}$ \\
\hline $9 / 17 / 87$ & $\mathbf{F}$ & 1101 & $\begin{array}{l}\text { Kidney } \\
\text { Muscle }\end{array}$ & $\begin{array}{l}0.03 \\
0.01\end{array}$ \\
\hline 9/18/87 & $\mathbf{F}$ & 642 & $\begin{array}{l}\text { Kidney } \\
\text { Muscle }\end{array}$ & $\begin{array}{l}0.01 \\
0.002\end{array}$ \\
\hline
\end{tabular}


Table K-7. Percentage double-stranded (ds) DNA in liver samples obtained from yellow-belliec slider turtles (Psendenos scripta) collixted from White Oak Lake and

Bearden Creek embayment

\begin{tabular}{|c|c|c|c|c|}
\hline $\begin{array}{l}\text { Specimen } \\
\text { code }\end{array}$ & $\begin{array}{l}\text { Collection } \\
\text { site }^{\infty}\end{array}$ & Date & Sex & $\begin{array}{c}\text { ds DNA } \\
(\%)\end{array}$ \\
\hline WP-1 & WOL & $7 / 27 / 87$ & $\mathbf{M}$ & 56.4 \\
\hline WP-2 & WOL & $7 / 27 / 87$ & $F$ & 84.8 \\
\hline WP-3 & WOL & $7 / 27 / 87$ & $\mathbf{F}$ & 27.7 \\
\hline WP-4 & WOL & $8 / 11 / 87$ & $\mathbf{M}$ & 56.5 \\
\hline WP-5 & WOL & $8 / 12 / 87$ & $\mathbf{F}$ & 43.7 \\
\hline WP-6 & WOL & $8 / 17 / 87$ & F & 56.4 \\
\hline WP-7 & WOL & $8 / 27 / 87$ & $\mathbf{M}$ & 56.4 \\
\hline WP-8 & WOL & $9 / 3 / 87$ & $\mathbf{M}$ & 39.9 \\
\hline WP-9 & WOL & 9/3/87 & $\mathbf{M}$ & 46.6 \\
\hline WP-10 & WOL & $9 / 3 / 87$ & $\mathbf{M}$ & 48.8 \\
\hline WP-11 & WOL & $9 / 10 / 87$ & $\mathbf{F}$ & 40.3 \\
\hline WP-12 & WOL & $9 / 16 / 87$ & F & 32.7 \\
\hline BP-2 & BCE & $8 / 31 / 87$ & $\mathbf{M}$ & 100 \\
\hline BP-3 & BCE & 9/1/87 & $\mathbf{M}$ & 100 \\
\hline BP-4 & BCE & 9/1/87 & $\mathbf{F}$ & 96.0 \\
\hline BP-5 & BCE & 9/1/87 & $\mathbf{F}$ & 98.6 \\
\hline BP-6 & BCE & $9 / 14 / 87$ & $\mathbf{M}$ & 93.6 \\
\hline BP-7 & BCE & 9/14/87 & $\mathbf{M}$ & 91.2 \\
\hline BP-8 & BCE & $9 / 14 / 87$ & $\mathbf{M}$ & 88.8 \\
\hline BP-9 & BCE & $9 / 15 / 87$ & $\mathbf{M}$ & 78.0 \\
\hline BP-10 & BCE & $9 / 15 / 87$ & $\mathbf{F}$ & 81.7 \\
\hline BP-11 & BCE & $9 / 16 / 87$ & F & 67.7 \\
\hline BP-12 & BCE & $9 / 17 / 87$ & F & 79.7 \\
\hline BP-13 & BCE & $9 / 18 / 87$ & $\mathbf{F}$ & 77.4 \\
\hline
\end{tabular}

'WOL = White Oak Lake; BCE $=$ Bearden Creek Embayment. 


\section{INTERNAL DISTRIBUTION}

1-2. S. M. Adams

3. T. L. Ashwood

4. R. D. Bailey

5. B. G. Blaylock

6. H. L. Boston

7. G. F. Cada

8. S. W. Christensen

9. R. B. Cook

10. D. K. Cox

11. H. R. Gaddis

12. M. L. Frank

13. C. W. Gehrs

14. S. G. Hildebrand

15-24. R. L. Hinzman

25. D. D. Huff

26. M. A. Huston

27. B. L. Kimmel

28. L. A. Kszos

29. A. J. Kuhaida

30. J. R. Lawson

31. J. M. Loar

32. J. B. Murphy

33. C. E. Nix

34. F. R. O'Donnell
35-36. P. T. Owen

37. M. J. Peterson

38. M. G. Ryon

39. E. M. Schilling

40. J. A. Shaakir-Ali

41. L. R. Shugart

42. J. G. Smith

43. G. R. Southworth

44. A. J. Stewart

45. S. S. Talmage

46. J. R. Trabalka

47. R. R. Turner

48. C. K. Valentine

49. L. D. Voorhees

50. B. T. Walton

51. J. A. Watts

52. S. H. Welch

53-67. ESD Library

68. ER Document Management Center

69-70. Laboratory Records Department

71. Laboratory Records-RC

72. ORNL Patent Office

73. ORNL Y-12 Technical Library

\section{EXTERNAL DISTRIBUTION}

74. S. M. Appellanis, University of Puerto Rico, San Juan, PR 00931

75. K. M. Charko, Bechtel National, Inc., RI/FS Team, Wing B, P.O. Box 350, Oak Ridge, TN 37831

76. J. W. Chason, Science Applications International Corp., 301 Laboratory Road, Oak Ridge, TN 37831

77. W. D. Crumby, Automated Sciences Group, Inc., 800 Oak Ridge Turnpike, Oak Ridge, TN 37831

78. J. F. Franklin, Bloedel Professor of Ecosystem Analysis, College of Forest Resources, University of Washington, Anderson Hall (AR-10), Seattle, WA 98195

79. W. Goldsmith, Lee Wan \& Associates, 120 S. Jefferson Circle, Oak Ridge, TN 37831

80. R. C. Harriss, Institute for the Study of Earth, Oceans, and Space, Science and Engineering Research Building, University of New Hampshire, Durham, NH 03824

81. M. V. Huq, Connecticut Department of Environmental Protection, Hamden, CT 06514 
82. B. D. Jimenez, University of Puerto Rico, San Juan, PR 00931

83. G. Y. Jordy, Director, Office of Program Analysis, Office of Energy Research, ER-30, G-226, U.S. Department of Energy, Washington, DC 20545

84. D. Martinez, U.S. Fish and Wildlife Service, 222 S. Houston, Suite A, Tulsa, OK 74127

85. L. J. Meyers-Schone, Frankfurter, STR 63A, 6080 Gross-Gerau, Germany

86. D. A. Mohrbacher, Advanced Sciences, Inc., 165 Mitchell Road, Oak Ridge, TN 37830

87. C. R. Olsen, Department of Energy, Environmental Sciences Division, Office of Health and Environmental Research, ER-74, Washington, DC 20585

88. R. H. Olsen, Vice President for Research, University of Michigan, Medical Science Building II, \#5605, 1301 East Catherine Street, Ann Arbor, MI 48109-0620

89. A. Patrinos, Director, Environmental Sciences Division, Office of Health and Environmental Research, ER-74, U.S. Department of Energy, Washington, DC 20585

90. R. C. Sleeman, Department of Energy Oak Ridge Field Office, P.O. Box 2001, Oak Ridge, TN 37831

91. J. G. Stout, University of Cincinnati, Cincinnati, OH 45202

92. A. E. Waters, Breedlove, Dennis \& Associates, Inc., Winter Park, FL 32789

93. F. J. Wobber, Environmental Sciences Division, Office of Health and Environmental Research, ER-74, U.S. Department of Energy, Washington, DC 20585

94. Office of Assistant Manager for Energy Research and Development, Department of Energy Oak Ridge Field Office, P.O. Box 2001, Oak Ridge, TN 37831-8600

95-96. Office of Scientific and Technical Information, P.O. Box 62, Oak Ridge, TN 37831 

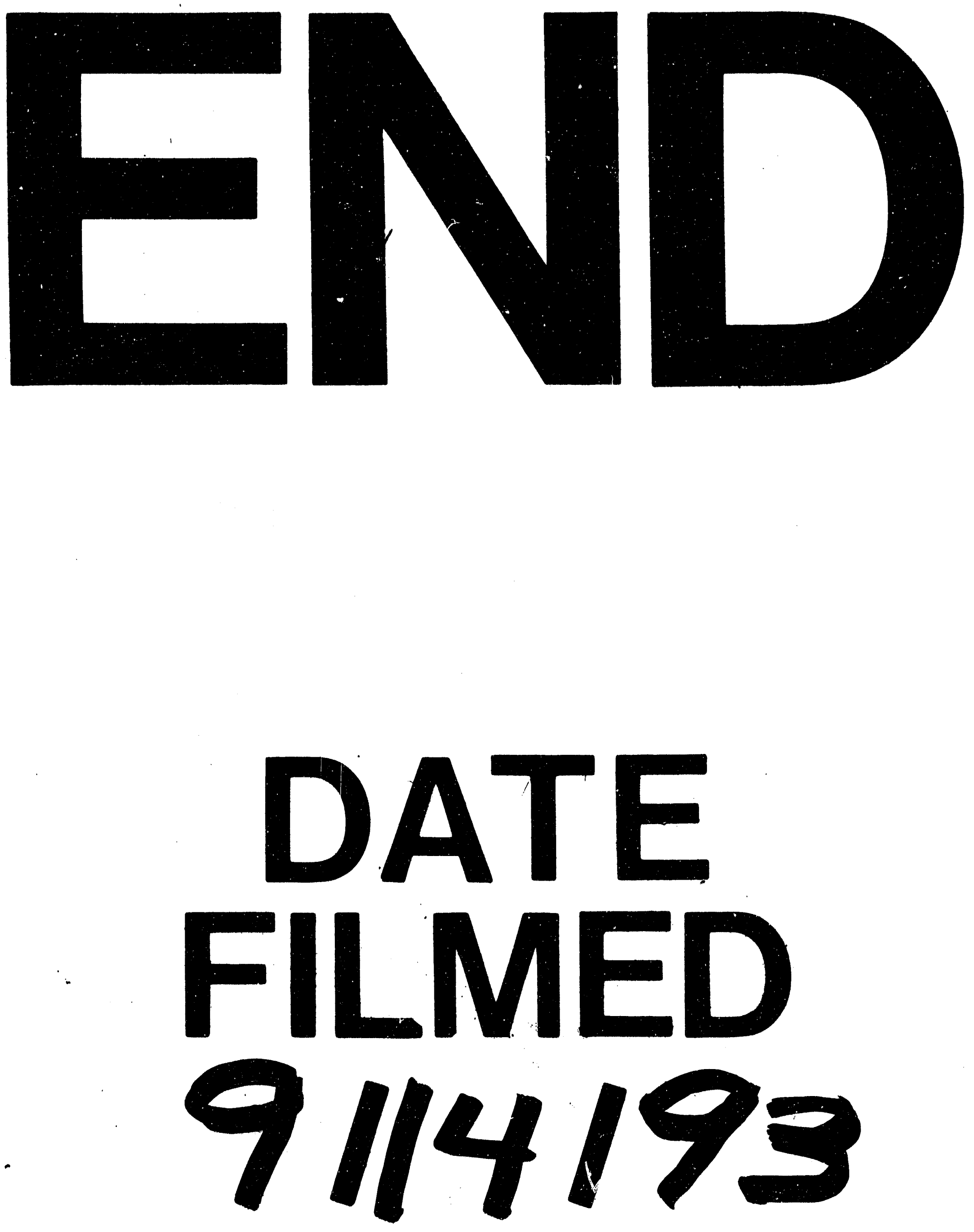